UNIVERSIDADE DE SÃO PAULO

INSTITUTO DE GEOCIÊNCIAS

\title{
EVOLUÇÃO TECTÔNICA DA MARGEM ATIVA NEOPROTEROZÓICA DO ORÓGENO GONDWANA OESTE NA PROVÍNCIA BORBOREMA (NE-BRASIL)
}

\author{
Carlos Eduardo Ganade de Araujo \\ Orientador: Prof. Dr. Umberto Giuseppe Cordani
}

TESE DE DOUTORAMENTO

Programa de Pós-Graduação em Geoquímica e Geotectônica

SÃO PAULO

2014 


\section{Agradecimentos}

Ao orientador desta Tese, Prof. Umberto G. Cordani meus profundos agradecimentos por acreditar neste projeto, me orientar e me ensinar a como se portar cientificamente, pela liberdade, e por abrir TODAS as portas necessárias para a realização desta pesquisa. Ao Prof. Miguel A. S. Basei pelo companheirismo e orientação indispensável na zirconologia. Ao Prof. Roberto F. Weinberg pela orientação nos migmatitos e granitóides, por estar sempre aberto e solicito a uma boa discussão geológica e por ser um incentivador de novas ideias científicas. Aos Profs. Daniela Rubatto e Joerg Hermman por me ensinarem que a geocronologia não é somente a busca de uma idade. Ao Prof. Renaud Caby por compartilhar comigo todo seu conhecimento geológico do NE do Brasil e suas correlações africanas. Ao Prof. Yao Agboussomondé pela aventura na coleta de amostras no Togo e Benin. Aos Profs. Jean-Jacques Peucat e René-Pierre Ménot pelos zircões extras das rochas de alta-P do Togo. Ao Prof. Ian Williams por me mostrar as facetas do SHRIMP e ao Richard Armstrong pelo auxílio nas análises isotópicas de oxigênio. A todo staff do CPGeo por me aturarem nesses quatro anos, em especial ao Walter Sproesser (U-Pb), Kei Sato (U-Pb), Izabel Ruiz (Nd-Sr) e Vasco Loios, este ultimo por me ensinar com destreza a arte da separação mineral. Ao Mauricio de Souza pelos mounts sem bolhas. Ao Serviço Geológico do Brasil por possibilitar meu desenvolvimento técnico-científico, e em especial ao Maurílio Vasconcelos por facilitar sempre o meu caminho. A Prof. Renata Schmitt, sempre a primeira a visualizar os produtos desta pesquisa. Ao Prof. Ticiano S. dos Santos por me apresentar a esplêndida Geologia da Província Borborema. Aos Profs. Roberto Xavier e Asit Choudhuri por me iniciarem ao questionamento e ação científica. Ao Prof. Wagner Amaral pelas discussões sobre os retroeclogitos do Ceará. Aos amigos Thaís Hyppolito e Vinicius T. Meira por me ajudarem e me escutarem nos momentos de dúvida. A família Basei e a Luana Florisbal por me oferecerem um lar na maior cidade da América do Sul. A FAPESP por financiar esta pesquisa 2005/58688-1 e 2012/00071-2. Ao CNPq por me financiar no exterior 246206/2012-8. Ao projeto UFRJ/CENPES 013850 por financiar o transporte das amostras do Togo para o Brasil. 
Para minha querida mãe (in memorian), que partiu durante esta etapa de minha vida. 


\section{Resumo}

O Orógeno Gondwana Oeste (OGO), sugerido nesta Tese, é uma faixa linear que se estende por mais de 5000 $\mathrm{km}$ do atual noroeste da África ao Brasil Central. Perspectivas modernas e tradicionais sugerem que este Orógeno resultou do consumo e fechamento do Oceano Goiás-Faruriano que culminou na colisão continentecontinente envolvendo os crátons Amazônico/Oeste Africano contra os crátons São Francisco/Congo e Saariano. Nesta Tese foi investigada a evolução crustal de um importante setor do OGO no noroeste da Província Borborema (NE-Brasil), assim como em outras áreas no Togo e Mali, utilizando-se de uma estratégia coerente. A geocronologia U-Pb em zircões de rochas siliciclásticas e ígneas indicam a existência de uma margem convergente de longa duração (de até 350 m.y.) associada ao consumo do Oceano Goiás-Faruriano. $\mathrm{Na}$ área investigada, particularmente no NE do Brasil no Domínio Ceará Central, o magmatismo associado a esta convergência pode ser dividido em três principais períodos: i) um período inicial constituído essencialmente por magmatismo de arco juvenil em ca. 880-800 Ma que continua até $650 \mathrm{Ma}$, como evidenciado indiretamente por zircões detríticos de depósitos sin-orogênicos, ii) um estágio de arco maturo em ca. 660-630 Ma caracterizado por rochas magmáticas hibridas entre crosta e manto e iii) anatexia crustal em 625-618 Ma que continua até $600 \mathrm{Ma}$. A longa evolução do OGO e o sincronismo do metamorfismo de ultra-alta pressão UAP no NE do Brasil, Togo e Mali indicam que a subducção continental e, portanto, a colisão continental ocorreu simultaneamente por pelo menos $2500 \mathrm{~km}$ durante o período Ediacariano (620-610 Ma). Nesta Tese propõem-se que o desenvolvimento da Província Borborema entre 620 a 570 Ma resultou da interação de dois eventos colisionais distintos. A Colisão I ao longo do OGO ocorreu há ca. 620-610 Ma como resultado da colisão entre o Bloco Parnaíba, como parte dos crátons Amazônico/Oeste Africano, contra o embasamento antigo da Província a leste. A zona de sutura associada a esta colisão foi reativada por uma zona transformante dextral (o Lineamento Transbrasiliano), permitindo a aproximação da Província Borborema e sua subsequente colisão contra o cráton São Francisco em ca. 590-580 Ma, marcando a Colisão II ao longo do Orógeno Sergipano. A interação dos esforços de leste relacionados com a Colisão I com os esforços de norte relacionados a endentação cratônica em uma litosfera espessa gerou uma trama extensa de zonas de cisalhamento direcionais que contribuíram para a extrusão da Província na direção nordeste. Nesta Tese, também foi considerado que o sincronismo do metamorfismo UAP (620-610 Ma) por pelo menos $2500 \mathrm{~km}$ no OGO registra o primeiro indício de subducção continental na escala do Orógeno Himalaiano e o consequente surgimento de Megamontanhas no registro geológico. A formação destas Megamontanhas ca. 40 m.y. antes da explosão da Vida no período Ediacariano tem a idade ideal para providenciar, por meio da erosão, os sedimentos (nutrientes) que são considerados necessários para a evolução da Vida. Finalmente, a evolução do OGO indica que o supercontinente Gondawa já estava formado desde o Oeste da África ao Brasil Central, dificultando a hipótese da chegada tardia do cráton Amazônico/Oeste Africano e assim a existência de um amplo Oceano Cambriano como previamente proposto. 


\begin{abstract}
The Neoproterozoic West Gondwana Orogen (WGO), suggested in this Thesis, is a linear belt that extended for more than $5000 \mathrm{~km}$ from nowadays northwest Africa to Central Brazil. Traditional views suggest that this orogen resulted from the consumption and closure of the Goiás-Pharusian Ocean that culminated in a continent-continent collision involving mainly the conjoined Amazon and West African cratons against the São Francisco-Congo and Saharan cratons. In this Thesis it has been investigated the crustal evolution of an important sector of the WGO in NE-Brazil at the northwestern portion of the Borborema Province as well as in some areas of Africa in Togo and Mali using a coherent approach. U-Pb Zircon geochronology of siliciclastic and igneous rocks indicates a long-lived convergent tectonics (up to $400 \mathrm{~m} . \mathrm{y}$ ) related to the comsumption of the Goiás-Pharusian Ocean. In the studied, particularly in NE- Brazil in the Ceára Central Domain, convergentrelated magmatism can be divided into three main periods: i) an early period comprising essentially juvenile arc magmatism at ca. 880-800 Ma and continuing to $650 \mathrm{Ma}$ as evidenced indirectly by detrital zircons from synorogenic deposits, ii) a more mature arc period at ca. 660-630 Ma characterized by hybrid mantle-crustal magmatic rocks, and iii) crustal anatexis at 625-618 Ma continuing until ca. 600 Ma. Protracted tectonic evolution in the WGO and synchronicity of UHP metamorphism in NE-Brazil, Togo and Mali indicate that continental subduction, and hence continental collision, occurred simultaneously over at least $2500 \mathrm{~km}$ during the Ediacaran period (620-610 Ma). Here, it has been proposed that Borborema Province development from 620 to $570 \mathrm{Ma}$ resulted from two discrete collisional events. Collision I, along the WGO, took place at ca. 620$610 \mathrm{Ma}$ as the result of collision between the Parnaíba Block, as the forefront of the much larger AmazonianWest Africa Craton, and the old basement of the Borborema Province. The suture zone related to this collision was reactivated by a dextral transform zone (the Transbrasiliano Lineament), allowing the Borborema Province to approach and collide against the São Francisco Craton in the south at ca. 590-580 Ma marking collision II along the Sergipano Orogen. The combined stresses related to eastward push from collision I and northward push from the cratonic indentation onto a thickened lithosphere gave rise to an extensive network of strike-slip shear zones across the Province forcing its northeastward extrusion. It has bee also considered here that synchronicity of UHP metamorphism (620-610 Ma) over at least $2500 \mathrm{~km}$ in WGO records the first Himalayan-scale deep-continental subduction and the consequent appearance of Megamountains in the geological record. The formation of these Megamountains ca. 40 m.y. before the explosion of Life in the Late Ediacaran is perfectly timed to deliver by erosion the sediments (nutrients) that have been deemed necessary for Life evolution. Finally, evolution of the WGO indicate that the Gondwana supercontinent was already assembled from West Africa to Central Brazil, precluding the late arrive of the Amazon-West African craton and hence the existence of a large Cambrian Ocean as proposed earlier.
\end{abstract}




\section{Índice}

\section{Gapítulo 1: Introdução}

1.1. Objetivos

1.2. Estrutura da Tese

1.3. Referencias

Capítulo 2: $O$ zircão e sua versatilidade

2.1. Geocronologia U-Th-Pb em zircão

2.2. Imageamento de domínios complexos em zircões - catodoluminescência (CL)

2.3. Datação U-Th-Pb em zircões detríticos

2.4. Determinação de isótopos de Hf em zircão

2.5. Combinação dos métodos U-Pb e Lu-Hf em zircão detrítico 15

2.6. Isótopos de Oxigênio em zircão 17

2.7. Elementos traços e terras raras (ETR) em zircão 17

2.8. Conexão entra a idade e padrões ETR em rochas de alto grau $\quad 18$

2.9 Referencias

Gapítulo 3: Arcabouço geológico

3.1 O Orógeno Gondwana Oeste

3.2 A Província Borborema

3.2.1 O Domínio Médio Coreaú

3.2.2 O Domínio Geará Central

3.2.2.1 Registro arqueano e associações do embasamento paleoproterozóico 23

3.2.2.2 Supracrustais de idade proterozóica (neoproterozóica?) 24

3.2.2.3 Complexos granito-migmatíticos de idade Neoproterozóica 26

3.2.2.4 Granitogenese pós-colisional 26

3.2.2.5 Calhas tardi-brasilianas e o início da sedimentação da Bacia do Parnaíba 27

3.3 Referencias 28

Capítulo 4: Procedimentos analíticos 31

4.1. Geoquímica

4.2. Geocronologia U-Pb em zircão 31

4.2.1 Imageamento dos zircões por Catodoluminescência (CL) 31

4.2.2 A método U-Th-Pb por SHRIMP 31

4.2.3 O método U-Th-Pb por ICP-MS

4.3. Isótopos de $\mathrm{Sr}-\mathrm{Nd} \quad 34$

4.4. Isótopos de Hf em zircão (LA-MG-ICP-MS) 34

4.5. Isótopos de O em zircão (SHRIMP) 34

4.6. Química mineral 35

4.6.1. Zircão e rutilo (LA-ICP-MS) 35

4.6.2. Outros silicatos (EMP)

4.7 Referencias $\quad 35$

Gapítulo 5: U-Pb detrital zircon provenance of metasedimentary rocks from the Ceará Central and Médio Coreaú Domains, Borborema Province, NE-Brazil: Tectonic implications for a long-lived Neoproterozoic active continental margin

5.2.1 The Médio Coreaú Domain (MCD) 39 
5.2.2 The Ceará Central Domain (CGD) 41

5.2.3 The Jaíbaras Trough 42

5.3. Sampling and analytical procedures 43

5.3.1 Sampling strategy

5.3.2 Sample preparation $\quad 43$

5.3.3. CL imaging and U-Pb geochronology 43

$\begin{array}{ll}\text { 5.4. Results } & 44\end{array}$

5.4.1 CL images

$\begin{array}{ll}\text { 5.4.2 U-Pb ages of detrital zircons } & 44\end{array}$

$\begin{array}{ll}\text { 5.5. Discussion } & 48\end{array}$

$\begin{array}{ll}\text { 5.5.1 Metamorphism } & 48\end{array}$

5.5.2 Detrital zircon provenance patterns 49

$\begin{array}{ll}5.3 \text { Potential source areas } & 50\end{array}$

5.5.4 Tectonic implications: A long-lived continental margin? 57

5.6. Conclusions $\quad 59$

5.7. References

Capítulo 6: Tracing Neoproterozoic subduction in the Borborema Province (NE- Brazil): clues from U-Pb geochronology and $\mathrm{Sr}-\mathrm{Nd}-\mathrm{Hf}-\mathrm{O}$ isotopes on granitoids and migmatites

6.1. Introduction

6.2. Geological setting: the Ceará Central Domain 73

6.2.1. The Tamboril-Santa Quitéria Complex 74

6.2.1.1. Lagoa Caíçara unit 76

$\begin{array}{ll}\text { 6.2.1.2. Boi Unit } & 77\end{array}$

6.2.1.3. Santa Quitéria Unit $\quad 77$

$\begin{array}{lr}\text { 6.2.1.4. Tamboril Unit } & 78\end{array}$

\begin{tabular}{l} 
6.3. Analytical Procedures \\
\hline 69
\end{tabular}

6.4. Results

6.4.1. Zircon SHRIMP U-Pb ages, zircon O-Hf and whole-rock Nd-Sr isotopes 81

6.4.1.1. Lagoa Caíçara unit 81

6.4.1.2. Boi Unit $\quad 85$

6.4.1.3. Santa Quitéria unit 85

6.4.1.4. Tamboril Unit $\quad 87$

6.4.2. Zircon SHRIMP O isotopes in detrital zircons 89

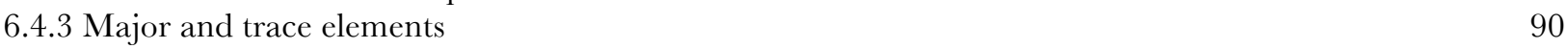

$\begin{array}{ll}\text { 6.4.3.1. Lagoa Caíçara unit } & 90\end{array}$

$\begin{array}{ll}\text { 6.4.3.2. Boi unit } & 91\end{array}$

6.4.3.3. Santa Quitéria unit 91

$\begin{array}{ll}\text { 6.4.3.4. Tamboril unit } & 91\end{array}$

\begin{tabular}{l} 
6.5. Discussion \\
\hline 63
\end{tabular}

6.5.1. Magmatic Evolution 93

6.5.1.1 Early 880-800 Ma juvenile arc-related magmatism 93

6.5.1.2 Mature Andean-type arc magmatism: ca. 660-630 Ma 96

6.5.1.3. Reworking of arc rocks: the 620-610 Ma crustal anatexis event 98

6.5.1.4. Bracketing collision time 99

6.6. From a juvenile to mature arc setting and terminal collision 101

$\begin{array}{lr}\text { 6.7. Conclusions } & 103\end{array}$

$\begin{array}{lr}\text { 6.8. References } & 105\end{array}$

Capítulo 7: Extruding the Borborema Province (NE-Brazil): a two-stage Neoproterozoic collision process

7.2. The West Gondwana Orogen: the 620-600 Ma Collision I 
7.3. The Sergipano Orogen: the 590-570 Ma collision II 118

7.4. Extrusion Tectonics (ca. 590-570 Ma) 119

7.5. Transbrasiliano-Kandi Strike-Slip Belt: A Neoproterozoic Transform Plate Boundary? 120

$\begin{array}{ll}\text { 7.6. Conclusion } & 123\end{array}$

$\begin{array}{lr}\text { 7.7. References } & 123\end{array}$

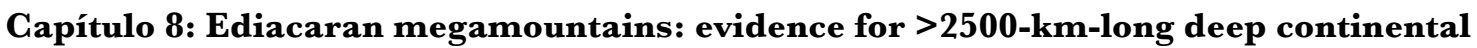
subduction in the West Gondwana Orogen

$\begin{array}{lr}\text { 8.1. Introduction } & 128\end{array}$

8.2 The West Gondwana Orogen (WGO) 129

8.3 Deep subduction in the West Gondwana Orogen 130

8.4 Timing of deep continental subduction 132

8.5 The West Gondwana megamountains and implications for the Ediacaran Earth 135

8.6. Appendix: Analytical methods 136

$\begin{array}{lr}\text { 8.7. References } & 138\end{array}$

Capítulo 9: The significance of the Transbrasiliano- Kandi tectonic corridor for the amalgamation of West Gondwana

9.1. Introduction $\quad 142$

9.2. Geotectonic Setting of West Gondwana 144

9.3. Closure of the Goiás-Pharusian Ocean 145

9.4. The Borborema Province and the Trans-Saharan belt 146

9.5. The Brasília Belt, the Goiás Magmatic Arc and the Paraguay Belt 149

9.6. Ediacaran/Cambrian Tectonic Evolution in Southern West Gondwana 153

$\begin{array}{lr}\text { 9.7. Conclusion } & 156\end{array}$

$\begin{array}{lr}\text { 9.8. References } & 157\end{array}$

Capítulo 10: Was there an Ediacaran Glymene Ocean in Central South America?

10.1. Introduction $\quad 163$

10.2. Closure of the Goiás-Pharusian Ocean 164

10.3. Ediacaran and Cambrian oceanic subduction in southern South America 167

10.4. Extensional-type post-tectonic episodes along the Transbrasiliano Lineament 169

10.5. Was there an Ediacaran Clymene Ocean in Central South America? 173

10.5.1. Amazonian-São Francisco-Congo collision along the Transbrasiliano Megashear 173

10.5.2. The Bassarides, Rokelides, Araguaia, and Gurupi belts 174

10.5.3. The Corumbá - Arroyo del Soldado Epicontinental Sea 177

10.5.4 - Significance of the Puga Paleomagnetic Pole 178

10.5.5. The Pampean Ocean and its northern continuation 179

$\begin{array}{lr}\text { 10.6. Conclusions } & 180\end{array}$

$\begin{array}{lr}10.7 \text { References } & 181\end{array}$

$\begin{array}{ll}\text { Capítulo 11: Conclusões finais } & 187\end{array}$

ANEXOS

ANEXO I (resultados U-Th-Pb LA-ICP-MS em zircões detríticos)

ANEXO II (resultados U-Th-Pb SHRIMP em zircões ígneos)

ANEXO III (resultados U-Th-Pb SHRIMP em zircões metamórficos)

ANEXO IV (resultados Lu-Hf LA-ICP-MS em zircões ígneos)

ANEXO V (resultados ${ }^{18} \mathrm{O} / 16 \mathrm{O}$ SHRIMP em zircões ígneos)

ANEXO VI (resultados de Elementos Terras Raras LA-ICP-MS em zircões metamórficos e ígneos ) 
ANEXO VII (resultados de Elementos Traços LA-ICP-MS em rutilo)

ANEXO VIII (resultados de química mineral em granada, onfacita e fengita)

ANEXO IX (resultados de Sr-Nd TIMS em granitóides)

ANEXO X (resultados de geoquímica de granitóides) 


\section{Lista de Figuras}

Figura 1.1 - Principais cratons, blocos formadores e assembleias lito-tectônicas do Orógeno Godwana Oeste. O Orógeno, que se estende por mais de $5000 \mathrm{~km}$ da Algéria ao Brasil central desenvolvido a partir do consumo e fechamento do Oceano Goiás-Farusiano durante o Neoproterozóico entre 950-630 Ma, culminando na colisão continental das principais massas continentais em 620-610 Ma. As flechas negras indicam os nomes regionais dos setores orogênicos do Neoproterozóico, unificados aqui no Orógeno Gondwana Oeste. O retângulo laranja indica a posição da principal área de estudo na Província Borborema. As estrelas laranjas indicam a localização das amostras de rochas de alta-pressão investigadas nesta Tese.

Figura 2.1 - A. Diagrama Concórdia de Wheterill (1956). Modificado de Harley \& Kelly (2007).

Figura 2.3 - Acima: imagens de catodoluminescência (CL) de zircões provenientes da localidade de Jack Hills, mostrando spots analisados para ETR, isótopos de oxigênio e geocronologia U-Th-Pb. (extraído de Cavosie et al., 2006). Abaixo: imagens de catodoluminescência (CL) em zircões submetidos a condições metamórficas eclogíticas, com inclusões de onfacita e coesita (extraído de Liu et al., 2008).

Figura 2.4 - A. Evolução hipotética da razão ${ }^{176} \mathrm{Hf} /{ }^{177} \mathrm{Hf}$ versus tempo para o (BSE) bulk silicate earth, manto empobrecido $(\mathrm{DM})$, para dois reservatórios crustais e para o zircão. B. Os mesmos reservatórios representados em termos do parâmetro Épsilon Hf versus tempo. A idade U-Pb no zircão data sua cristalização (3), a idade de Lu-Hf de residência crustal é uma estimativa do tempo decorrido da extração deste domínio crustal do manto empobrecido até a cristalização do zircão hospedado neste domínio. G. Trends evolutivos hipotéticos para o manto empobrecido $(\mathrm{DM})$ e proto-crosta com valor da razão ${ }^{176} \mathrm{Lu} /{ }^{177} \mathrm{Hf}$ de 0,009 com parâmetro CHUR de Toft \& Albarèbe (1997), (extraído e modificado de Scherer et al., 2007).

Figura 3.1 - Contexto geológico da área de estudo (a partir de De Wit et al. 2008, Cavalcante, 1999; Delgado et al., 2003; Cavalcante et al., 2003), compilação geocronológica baseada em Osako et al. (2008).

Figura 4.1 - Ilustração comparativa entre as cavidades geradas pelas técnicas SHRIMP e LA-ICP-MS (modificado de Patchett \& Samson, 2005).

Figura 5.1 - Geological setting of the Ceará Central and Médio Coreaú domains and sample site location (modified from Cavalcante et al. 2003, de Araujo et al. 2010a and De Wit et al. 2008).

Figura 5.2 - Selected CL images and spot placement from the analyzed zircons.

Figura 5.3 - Concordia (right) and relative age probability (left) diagrams for selected zircons analyzed in this study.

Figura 5.4 - A. Relative age probability diagram comparing ages of detrital zircon grains from samples of the Médio Coreaú and Ceará Central Domains. B. Cumulative age density distribution diagram comparing ages of detrital zircon grains from samples of the Médio Coreaú (MCD) and Ceará Central Domains (CCD). TSQgmC - Tamboril-Santa Quitéria granitic-migmatitic Complex.

Figura 5.5 - Tectonic model for the Neoproterozoic to Cambrian evolution in the Ceará Central and Médio Coreaú Domains of the Borborema Province. A. Wide oceanic setting in an early arc stage with inactive precursors arcs (Cariris Velhos) and intraoceanic arcs in Central Brazil and Africa. B. Narrowing of the oceanic domain and development of some extensional settings inboard of the eastern (present day position) plate. C. Continental collision and development of the Tamboril-Santa Quitéria granitic-migmatitic Complex and strike-slip shear zones of the Transbraliliano-Kandi Shear System. D. Late orogenic stage related with the development of extensional setting (Jaíbaras Trough) arguably associated with the collapse of the orogen. ACAmazonian Craton, WAC- West African Craton, SFC-São Francisco Craton. 
Figura 6.1 - Main cratonic blocks and mobile belts of the West Gondwana (modified from De Wit et al., 2008) and the Borborema Province and its main sub-divisions.

Figura 6.2 - Geological map and structure of the northern portion of the Tamboril-Santa Quitéria Complex and its neighbouring units.

Figura 6.3 - Field aspects of the studied rocks from the Lagoa Caíçara unit. A. Stromatic metatexite after a $833 \pm 6$ Ma tonalitic protolith (sample DKE-221) with hornblende-bearing leucosomes, interpreted to result from water-fluxed melting. B. Stromatic metatexite after a $650 \pm 5$ Ma mafic tonalite (sample DKE-200A). C. $632 \pm 5$ Ma biotite gneiss with injected leucocratic veins parallel to the gneissic foliation (sample DKE-269). D. Metatexite after a $627 \pm 5$ biotite orthogneiss (sample DKE-231).

Figura 6.4 - Field aspects of the studied rocks from the Boi and Santa Quitéria units. A. $648 \pm 5$ Ma quartzdiorite of the Boi Unit injected by felsic quartz-feldspathic material (Sample DKE-277). B. $638 \pm 5$ porphyritic monzogranites of the Santa Quitéria unit with mafic enclaves exhibiting crystal-transfer structures (Sample DKE211). C. Coeval Santa Quitéria monzogranite with mafic dioritic rocks showing crystal-transfer structures (arrows). J. Syn-plutonic dikes of diorites cutting through the Santa Quitéria porphyritic monzogranite.

Figura 6.5 - Field aspects of the studied rocks from Tamboril unit. A. Composite outcrop of patchy metatexite after a $882 \pm 7 \mathrm{Ma}$ granodioritic orthogneiss (schollen) embedded in a $618 \pm 5$ granitic diatexite of Tamboril unit within Lagoa Caíçara unit (Sample DKE-273A and B). B. Raft of a 663 77 Ma granodioritic orthogneiss embedded in a granitic host close to the contact between Santa Quitéria and Tamboril units (Sample $D K E-170)$. G. Folded stromatic metatexite tonalite to diorite (Boi unit) injected by crustal granitic veins of Tamboril unit (Sample DKE-125). D. Characteristic flow banding defined by schlieren diatexite of the Tamboril unit. E. Characteristic schollen diatexite of the Tamboril unit. F. Hornblende-bearing leucosomes in diatexite of Tamboril unit.

Figura 6.6 - Cathodoluminescence images from zircons selected for U-Pb geochronology and $\mathrm{Hf}-\mathrm{O}$ isotopic investigation.

Figura 6.7- U-Pb Whetheril Concordia diagrams for the investigated samples.

Figura 6.8 - A. $\mathrm{K}_{2} \mathrm{O}$ versus $\mathrm{SiO}_{2}$ diagram of Peccerillo and Taylor (1976), showing that granitoids are high-K calc-alkaline to shoshonitic in nature. B. A/NK vs. ASI diagram modified from Shand (1947). C. Rb versus $\mathrm{Ta}+\mathrm{Yb}$ tectonic discrimination diagram of Pearce et al. (1984). D. Th/Hf versus Ta/Hf discrimination diagram between continental active margins and within plate volcanic zones of Shandl and Gorton (2002).

Figura 6.9 - REE and spider diagrams for granitoid rocks of the protolith of granitoids and migmatites from Tamboril-Santa Quitéria Complex. Primitive mantle and Chondrite normalized values from McDonough and Sun (1995) and Sun and McDonough (1989), respectively.

Figura 6.10 - A. Variations of $\delta^{18} \mathrm{O}$ values with age for zircons from protolith of granitoids and migmatites from Tamboril-Santa Quitéria Complex. B. Schematic diagram for Lu-Hf isotopic evolution vs. U-Pb age for zircons from protolith of of granitoids and migmatites from Tamboril-Santa Quitéria Complex.

Figura 6.11 - A. Relationship between zircon $\varepsilon \mathrm{Hf}(t)$ and whole-rock $\varepsilon \mathrm{Nd}(t)$ for protolith of granitoids and migmatites from Tamboril-Santa Quitéria Complex. Mantle and crust arrays are from to Vervoort et al. (1999). B. $\varepsilon \mathrm{Nd}(\mathrm{t})$ vs. $\varepsilon \mathrm{Sr}(\mathrm{t})$ diagram protolith of granitoids and migmatites from Tamboril-Santa Quitéria Complex. The line separating materials derived from upper (high positive $\varepsilon \mathrm{Sr}$ ) to lower crust (low positive $\varepsilon \mathrm{Sr}$ ) have been proposed by DePaolo and Wasserburg (1979).

Figura 6.12 - Schematic illustration of the water-fluxed melting of the juvenile protoliths. Hf budget in the melt is mainly controlled by high initial $(176 \mathrm{Hf} / 177 \mathrm{Hf})$ of the juvenile arc-related protoliths, thus yielding a melt with high initial $\left({ }^{176} \mathrm{Hf} /{ }^{177} \mathrm{Hf}\right)$. Nd budget is controlled by the mixing of juvenile protoliths and crustal 
contaminants yielding neutral $\varepsilon \mathrm{Nd}$ signatures in the melt. Water-fluxed melting of the juvenile protoliths are indicated by the lack of anhydrous peritetic phases in the melt, as well as by high $\delta^{18} \mathrm{O}$ signatures.

Figura 6.13 - A. Comparison between zircon ages acquired from the granitoids of the Tamboril-Santa Quitéria in this study versus detrital zircons from the back arc and fore arc basins from Ceará Complex (data from the detrital zircons from Ganade de Araujo, 2012). B. Summary of magmatic ages of the granitiod rocks of the Tamboril-Santa Quitéria Complex.

Figura 6.14 - Sketch tectonic model for Neoproterozoic tectonic evolution for the continental convergent margin of Ceará Central Domain. A. Early subduction stage in an extensional setting, due to old oceanic lithosphere subduction and juvenile magmatism accretion on a stretched continental margin. B. Continuous subduction with development of extensinal back-arc basins with associated magmatism and both arc- and continental-derived detritus. C. Compressive arc-setting and development of the Santa Quitéria arc. D. Terminal collision with subduction of stretched continental crust to the west of the Santa Quiteria arc and subduction of the stretched continental crust (e.g. back-arc basin) to the east of the Santa Quitéria arc. Collisional metamorphism on both sides of the arc are evidenced by (U)HP-eclogite rocks of Forquilha (Santos et al., 2009; Santos et al., 2013; Ganade de Araujo, submitted) and Itataia HP eclogites (Castro, 2004). E. Postcollision extension and exhumation of the (U)HP and HP rocks.

Figura 7.1 - Position of cratons, blocks, Brasiliano Neoproterozoic orogens and Neoproterozoic to Cambrian fold and thrust belts in Brazil (modified from Alkmim et al., 2001). Cratons in the inset: AM: Amazonian, WA: West Africa, SF: São Francisco, C: Congo, S: Saharan “metacraton".

Figura 7.2 - Temporal and spatial distribution of granitoid rocks in the Borborema Province. The figure depicts a systematic younging of arc-related pre-collisional magmatism from north to south across the Province, as well as in the timing of metamorphism. Arc magmatism ends at ca. $630 \mathrm{Ma}$ in the NW-section of the province but starts at ca. $630 \mathrm{Ma}$ in the south (Fetter et al., 2003; Oliveira et al., 2010). Whilst the most voluminous magmatism is centred around $580 \mathrm{Ma}$ across the entire Province, the timing of collisional magmatism in each region varies: $620 \mathrm{Ma}$ in the NW section of the Province, along the trend of the Transbrasiliano Lineament and 590-570 Ma in the south, along the Sergipano Orogen, contemporaneous with peak magmatism in the Province. Ar-Ar cooling ages also show the same systematic decreasing age pattern from the site of collision I in the Ceará Central Domain to the site of collision II in the Sergipano Belt, but suggest final cooling was established only at $c a .500 \mathrm{Ma}$, which is interpreted to indicate the end of collisional deformation. Voluminous magmatism during development of the shear zones at ca. 590-560 Ma has dominant lithospheric mantle affinities (Neves et al., 2000; Guimarães et al., 2004) possibly related to delamination of the orogenic crustal root after thickening promoted by collision I (Ganade de Araujo, 2011). Ar-Ar ages also indicate slow colling rate with continuous heat supply until the Cambrian (Monié et al., 1997; Corsini et al., 1998; Hollanda et al., 2010). References for ages are listed in table 1.

Figura 7.3 - Simplified Neoproterozoic tectonic evolution of the Borborema Province and adjoining regions. A. Position of main tectonic components of the region in the pre-collision I stage (ca. 800-650 Ma), based on Caby (1989), Pimentel and Fuck (1992), Brito Neves et al. (2000), Berger et al. (2011), Ganade de Araujo et al. (2012a,b), including the Cariris Velhos extensional event (Neves, 2003). The Parnaíba Block is inferred from geophysical evidence (de Castro et al., 2003) and is separated from the Amazonian-West-African Craton by the Gurupi and Araguaia volcano-sedimentary belts (Klein et al., 2005; Moura et al., 2008). Opening of the Sergipano Basin (>800 Ma) and continued rifting (ca. 700-640 Ma) separating the PEAL from the rest of the São Francisco-Congo Craton (Oliveira et al., 2010). B. Collision I (ca. 620-610 Ma) in the west, leading to the West Gondwana Orogen marked by HP and UHP metamorphism and anatexis of continental crust (BernardGriffiths et al., 1991; Agbossoumonde et al., 2001; Jahn et al., 2008; Fetter et al., 2003; Santos et al., 2009) and arc magmatism at the Sergipano Orogen due to initiation of subduction (Oliveira et al., 2010). C. Collision II (ca. 590-570 Ma) resulting from the closure of the Sergipano-Oubanguides Ocean and leading to thrusting of sedimentary rocks onto the craton, and development of inboard orogenic basins in the Borborema Province (e.g., Van Schmus et al., 2003), and syn-collisional magmatism (Bueno et al., 2009; Oliveira et al., 2010). Inversion of the Gurupi and Araguaia basins (Klein et al., 2005; Moura et al., 2008). D. Final craton indentation and northeastward extrusion stage (ca. 580-550 Ma) with development of major shear zones (Neves 
et al., 2012, Archanjo et al., 2013) emanating from the main Transbrasiliano-Kandi Strike-Slip Belt. White arrows: direction of mass escape. Dashed line: shore line.

Figura 7.4 - Extrusion of Borborema Province. A. Simple squeezing model that requires sinistral movement of the Transbrasiliano shear zone after collision II. B. Squeezing and anticlockwise internal block rotation due to ductile deformation of the Borborema Province allowing northeast escape and dextral movement on the Transbrasiliano shear zone. C. Estimated orientations of 2-D strain axes for the different domains illustrating their counter-clockwise rotation from southeast to northwest. Borborema Province scale block rotation (black thick arrow) and domain-scale rotations (solid black arrows) illustrating east and northeast mass escape. Straight red gray arrows: relative movement direction at ca. 590-570 Ma. Straight green arrows: mass escape direction at ca. 590-570 Ma.

Figura 8.1 - A. Main cratons and tectonic blocks involved in the formation of the collisional West Gondwana Orogen. B. Spatial distribution of HP and UHP rocks and main lithotectonic assemblages in the 5000-km-long collisional orogen. C. Temporal distribution of the main lithotectonic units along each sector of the orogen together with main global events. Sr-isotope values for sea water after Veizer (1989) and pO2 after Canfield et al. (2007). Timing of pre-collision geological events are mostly based on Pimentel (1992), Caby (1989), Caby (2003), Ganade de Araujo et al. (2012).

Figura 8.2 - Photomicrographs (polarized light) of the investigated samples. Eclogites from Mali and Togo exhibit phase equilibria among garnet (grt), omphacite (omph), phengite (phe) and rutile (rt). Retrogressed eclogites from NE-Brazil have abundant amphibole (amph), garnet and simplectic clinopyroxene (cpx) plagioclase (pl) resulting from the breakdown of former omphacite. In this sample rutile is often rimed by titanite (ttn).

Figura 8.3 - Pressure-temperature diagram comparing P-T paths (dashed curves are inferred) for the HPUHP terranes from Mali, Togo and NE-Brazil. Peak metamorphic conditions are discussed in the text and data are available in the electronic appendix. No geothermobarometric information is available for the retrograde P$\mathrm{T}$ path in Mali, but petrographic (Caby, 1994) and geochronological (Jahn et al., 2001) evidence suggests rapid exhumation without passing through the granulite field. Geothermobarometric data from Lato terrane (Agbossoumondé et al., 2001) indicate a retrograde path through granulite facies (1.0-0.8 $\mathrm{GPa}$ and $700-750{ }^{\circ} \mathrm{C}$ ) and later amphibolite facies $\left(0.6-0.4 \mathrm{GPa}\right.$ and $\left.500-600^{\circ} \mathrm{C}\right)$. Minimum calculated P-T condition from NE-Brazil for the retrogression $\left(1.7 \mathrm{GPa}\right.$ and $\left.770^{\circ} \mathrm{C}\right)$ was followed by a granulitic stage $\left(1.4 \mathrm{GPa}\right.$ and $\left.870^{\circ} \mathrm{C}\right)$ and then an amphibolitic stage at $\left(0.5-0.75 \mathrm{GPa}\right.$ and $530-700^{\circ} \mathrm{C}$ ) (Santos et al., 2009).

Figura 8.4 - Left: Wetherill Concordia plots of the U-Pb zircon data. Ellipse colours reflect zircon growth domains as defined by zoning and REE composition. Grey ellipse represents the Concordia age. Right: Internal structure of the zircons revealed by cathodoluminescence and rare earth element (REE) composition (chondrite-normalised patterns) for each zircon type.

Figura 9.1 - Crustal building blocks for the amalgamation of Gondwana, after the closing of the GoiásPharusian and Mozambique oceans. Location of the Iapetus Ocean between SW Gondwana, Laurentia and Baltica, and location of the Proto-Pacific Ocean before the onset of the subduction of the Pacific Plate.

Figura 9.2 - Major tectonic elements related to West Gondwana at about 800 - $900 \mathrm{Ma}$ ago, prior to the final amalgamation. Cratons: AM = Amazonian; $\mathrm{CO}=$ Congo; $\mathrm{KA}=$ Kalahari; LAU - Laurentia; RP = Rio de La Plata; SF = São Francisco; SM = Sahara metacraton; WA = West African. Smaller cratonic fragments: BO = Borborema; GO = Goiás Central Massif; LA = Luiz Alves; PA = Paranapanema; $\mathrm{PB}=$ Parnaiba; $\mathrm{PP}=$ Pampia. Intra-oceanic magmatic arcs: $\mathrm{A}=$ Amalaoulaou; $\mathrm{G}=$ Goiás; $\mathrm{I}=\mathrm{Iskel} ; \mathrm{K}=$ Kabyé; $\mathrm{T}=$ Tilemsi. Adapted from Cordani et al. (2013).

Figura 9.3 - Outline of the Transbrasiliano-Kandi mega-shear zone in a late Paleozoic pre-drift reconstruction of South America and Africa, with the relative position of cratons, cratonic fragments and lateProterozoic- Cambrian mobile belts. Adapted from Cordani et al. (2013). 
Figura 9.4 - Geological correlations between northeastern South America and north-western Africa, in a late Paleozoic pre-drift reconstruction.

Figura 9.5 - Main tectonic elements within the Borborema and Tocantins provinces and the Parnaíba Basin, in South America, in the vicinity of the Transbrasiliano Lineament.

Figura 10.1- Major tectonic elements related to West Gondwana, prior to the final amalgamation. Major cratons: $\mathrm{AM}=$ Amazonian; $\mathrm{CO}=$ Congo; $\mathrm{KA}=$ Kalahari; $\mathrm{RP}=$ Rio de La Plata; $\mathrm{SF}=$ São Francisco; $\mathrm{SM}=$ Sahara Metacraton; WA $=$ West African. Smaller cratonic fragments: $\mathrm{AA}=$ Arequipa-Antofalla; $\mathrm{BO}=$ Borborema; $\mathrm{GO}=$ Goiás Central Massif; LA = Luiz Alves; $\mathrm{PA}=$ Paranapanema; $\mathrm{PB}=$ Parnaiba; $\mathrm{PP}=$ Pampia. Intra-oceanic magmatic arcs: A = Amalaoulaou; $\mathrm{G}=$ Goiás; I = Iskel; K = Kabyé; T = Tilemsi.

Figura 10.2 - Outline of the Transbrasiliano-Kandi mega-shear zone in a pre-drift reconstruction of South America and Africa. The suggested position of the Cambrian suture proposed by Tohver et al. (2012) is indicated. Phanerozoic covers are omitted.

Figura 10.3 - Geological correlations between north-eastern South America and north-western Africa, in a pre-drift reconstruction. The location of specific tectonic features mentioned in the text are indicated: HP and UHP metamorphic units of Neoproterozoic age; extensional early Paleozoic basins; and basement mantled domes within the Araguaia Belt.

Figura 10.4 - Geotectonic interpretation of the south-eastern part of South America. It includes cratonic units (Amazonian, Rio de La Plata, Paranapanema and Luiz Alves), allochthonous terranes (Arequipa-Antofalla, Famatina, Cuyania South America during the Paleozoic and the tectonic units of the Pampean orogeny: the eastern Pampean ranges and the Puncoviscana Tract. Phanerozoic covers are omitted. Tectonic features related to the Transbrasiliano Lineament.

Figura 10.5 - Late Neoproterozoic geotectonic features of eastern South America. The location of the proposed suture resulting from the closure of a supposed Ediacaran/Cambrian Clymene Ocean is indicated.

\section{Lista de Tabelas}

Tabela 2.1 - Principais características químicas/isotópicas do zircão e suas aplicações, segundo Harley \& Kelly (2007).

Tabela 2.2 - Aspectos morfológicos do zircão e suas respectivas interpretações (modificado de Silva, 2006).

Tabela 6.1 - Localization and units of the investigated samples from the Tamboril-Santa Quitéria Complex.

Tabela 6.2 - Summary of the main isotopic features of the investigated samples.

Tabela 7.1 - Summary of main U-Pb and Ar-Ar ages available for the Borborema Province. 
Carlos E. Ganade de Araujo - Tese de Doutorado - Universidade de São Paulo Capítulo 1 - Introdução

\section{Introdução}

A presente Tese de Doutorado foi realizada no âmbito do Programa de Pós-Graduação em Geoquímica e Geotectônica do Instituto de Geociências da Universidade de São Paulo (IGc-USP). De forma geral, a temática da Tese foi inicialmente discutida com o intuito de entender a evolução crustal da área adjacente ao Lineamento Transbrasiliano no nordeste brasileiro, particularmente no norte do estado do Ceará. Durante a evolução da pesquisa sentiu-se a necessidade de expandir a abrangência do estudo em direção a contraparte africana no Togo, Benin e Mali no sentindo de entender e correlacionar as rochas de alto grau (e.g. eclogitos) que ocorrem alinhadas ao longo de uma importante zona de sutura do supercontinente Gondwana.

O Orógeno Gondwana Oeste (fig. 1.1), sugerido nesta Tese, inclui todas as áreas orogênicas Panafricanas/Brasilianas que ocorrem ao longo do Lineamento Transbrasiliano-Kandi, que se estende por mais de $5000 \mathrm{~km}$ lineares da Algéria ao Brasil Central. Este orógeno resultou do consumo e fechamento do Oceano Goiás-Farusiano (Caby, 2003; Kroener and Cordani, 2003), que culminou na colisão continental envolvendo os crátons Amazônico/Oeste África, São Francisco-Congo e o metacráton Saara. A ocorrência de elementos indicativos de zonas de subducção e colisão continental (e.g. ofiolitos; arcos intra-oceânicos, arcos continentais, metamorfismo de alta e ultra-alta pressão; prismas acrescionários) ao longo das adjacências do Lineamento Transbrasiliano-Kandi levou muitos pesquisadores a interpretar esta estrutura como uma grande zona sutural (e.g. Caby, 1989, Kroener \& Cordani, 2003, Cordani et al., 2003a, Cordani et al., 2003b, Ganade de Araujo \& Santos, 2008, entre outros), ou mais precisamente, como proposto aqui, uma estrutura desenvolvida dentro da dinâmica colisional Neoproterozóica no Orógeno Gondwana Oeste, semelhante ao sistema de falhas e zonas de cisalhamentos desenvolvidas durante a colisão e escape lateral entre a Índia e Eurásia no Cenozóico.

O Orógeno registra em toda sua extensão um longo período de convergência ( $>$ que 400 m.y) condizente com o desenvolvimento de diversos arcos intraoceânicos e continentais que são hoje preservados dentro da zona colisional fóssil profundamente erodida (Pimentel and Fuck, 1992; Caby, 2003; Berger et al., 2011; Ganade de Araujo et al., 2012). As principais assembleias petrotectônicas entre as regiões cratônicas envolvidas na colisão estão representadas por margens passivas, arcos juvenis, arcos continentais tardios e sequencias supracrustais sin-orogênicas. Os detritos da erosão das montanhas resultantes da colisão no orógeno estão hoje depositados em bacias molássicas e do tipo foreland, e o final da atividade orogênicas é estabelecido em ca. 540-500 Ma com base nas idades dos granitóides pós-colisionais dispostos ao longo do orógeno (Affaton et al., 2000; Caby, 2003; Pimentel et al., 2011; Ganade de Araujo et al., 2012; Castro et al. 2012).

Desde a definição do termo "Pan-Africano" (Kennedy, 1964) para designar eventos termo-tectônicos de idade Neoproterozóica-Cambriana na África, e seu termo equivalente na América do Sul, o "Brasiliano", inúmeros cinturões orogenéticos foram batizados com nomes regionais. A faixa de idade Neoproterozóica que se estende ao longo do importante Lineamento Transbrasiliano-Kandi (Caby, 1989), da Algéria até o Brasil Central, foi segmentada em diversos setores, províncias e blocos tectônicos. Na África, a faixa Dahomey no Togo e Benin (e.g. Affaton et al., 1991), e Hoggar na Algéria e Mali (Caby, 2003) são geralmente agrupadas no Orógeno Trans-Saariano (Caby, 1989; Trompette, 1994). No Brasil, a Província Borborema (Brito Neves et al., 2000) na parte nordeste do país e a Província Tocantins (Pimentel et al., 2000) em sua porção Central são agrupadas nos Orógenos Brasilianos. Nesta Tese, todas as províncias geológicas mencionadas acima foram agrupadas em um só orógeno, batizado aqui de o Orógeno Gondwana Oeste (fig 1.1). No Brasil, o orógeno abarca o limite oeste da Província Borborema e parte norte da Faixa Brasília. 
Há muito tempo, as correlações geológicas entre o nordeste brasileiro e noroeste africano tem sido utilizadas como fonte de informações na reconstrução da paleogeografia do Gondwana Oeste (Almeida \& Black, 1968; Torquato \& Cordani, 1981; Brito Neves et al., 2001; De Wit et al., 2008a). A correlação entre a Província Borborema e sua expressão na contraparte africana representada pelos domínios Trans-Saarianos, Nigerianos e pelas faixas orogênicas África Central-Oubanguides, no que Tromp alte (1994) designa de Província Nordeste do Brasil/Centro Oeste Africana têm sido alvo correspondente no exercício da correlação (Caby, 1989; Arthaud et al., 2008; Santos et al., 2008a).
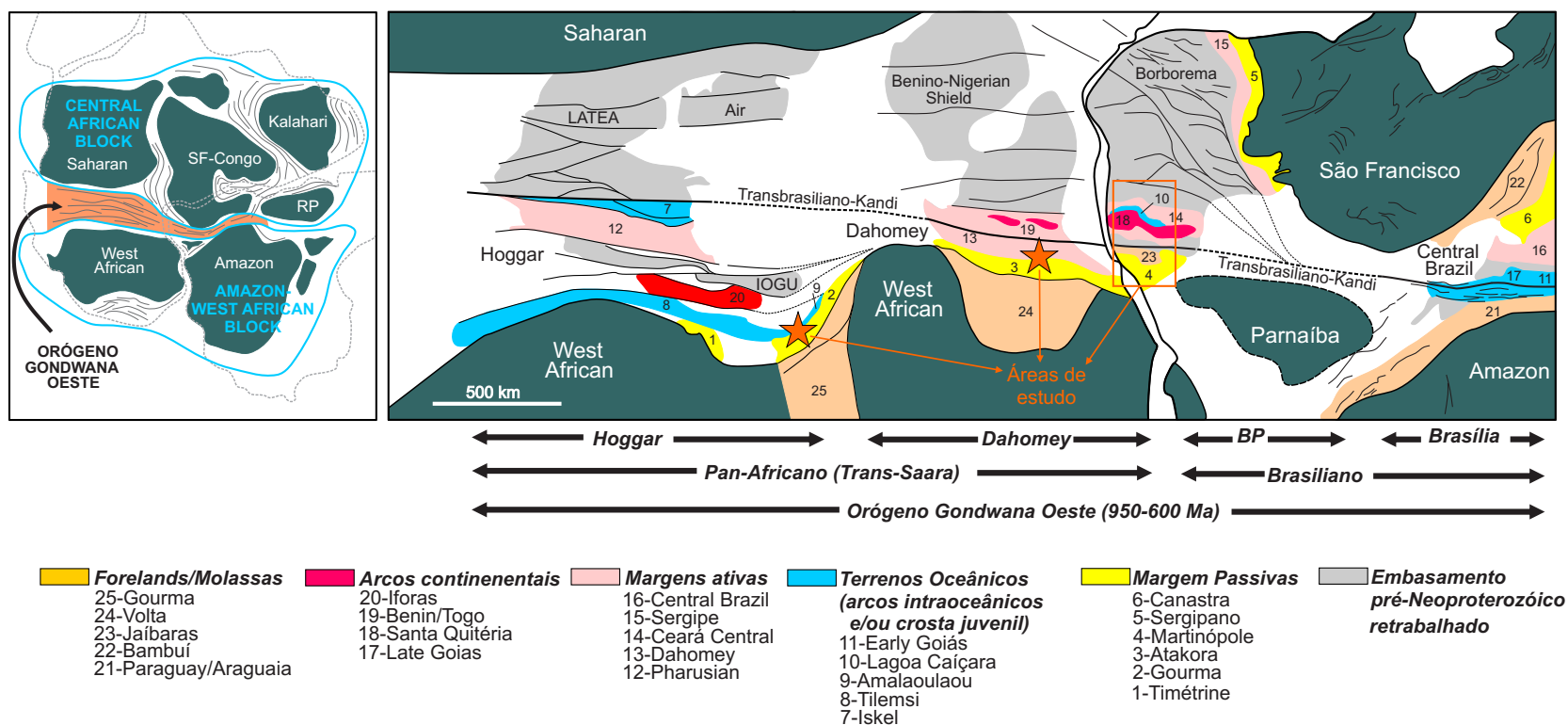

Figura 1.1 - Principais crátons, blocos formadores e assembleias lito-tectônicas do Orógeno Godwana Oeste. O Orógeno, que se estende por mais de $5000 \mathrm{~km}$ da Algéria ao Brasil central desenvolvido a partir do consumo e fechamento do Oceano Goiás-Farusiano durante o Neoproterozóico entre 950-630 Ma, culminando na colisão continental das principais massas continentais em 620-610 Ma. As flechas negras indicam os nomes regionais dos setores orogênicos do Neoproterozóico, unificados aqui no Orógeno Gondwana Oeste. O retângulo laranja indica a posição da principal área de estudo na Província Borborema. As estrelas em laranja indicam a localização das amostras de rochas de alta-pressão investigadas nesta Tese.

O noroeste da Província Borborema, principal área de estudo desta Tese, configura uma região chave na evolução do Gondwana Oeste, no que De Wit et al. (2008b) denomina de um dos piercing points na correlação pré-deriva entre a África e Brasil. Localizada no nordeste do Brasil, a Província Borborema foi originalmente descrita e definida por Almeida et al. $(1977,1981)$ como uma complexa região de domínios tectonoestratigráficos, fortemente afetada pelo(s) evento(s) tectônico(s) de idade Neoproterozóica. Compreendendo uma área de aproximadamente $450.000 \mathrm{~km}^{2}$, esta província foi finalmente estruturada, por volta de 0.6-0.58 Ga, pela convergência dos crátons Amazônico-São Luiz-Oeste Africano e São Francisco-Congo, com a participação do bloco Parnaíba, na intitulada colagem Brasiliana/Pan-Africana, que culminou na formação da parte oeste do supercontinente Gondwana (Trompette, 1994; Brito Neves \& Cordani, 1991).

Por tratar-se de uma região chave dentro da dinâmica orogênica do Neoproterozóico a área de estudo foi amplamente investigada do ponto de vista geocronológico e isotópico para fornecer subsídios ao entendimento e suas respectivas correlações ao longo do Orógeno Gondwana Oeste. 


\subsection{Objetivos}

O objetivo essencial da presente Tese foi entender os eventos tectônicos associados a evolução Neoproterozóica da margem do Orógeno Gondwana Oeste no nordeste do Brasil, bem como estabelecer uma ordem cronológica dos mesmos. A ferramenta escolhida para tal tarefa foi a Geologia Isotópica fortemente aliada com as relações observadas em campo. O sistema U-Th-Pb em zircão e as demais versatilidades petrológicas oferecidas por esta fase mineral foi o ponto mais explorado nesta Tese.

No nordeste do Brasil foram utilizados mapas em andamento ou já confeccionados na escala 1.100000, pelo Serviço Geológico do Brasil. Para a coleta das amostras foram realizadas diversas campanhas de campo no nordeste do Brasil, que contou com o apoio logístico do Serviço Geológico do Brasil. Para coleta de amostras em unidades equivalentes na África (especialmente relacionadas ao metamorfismo de alto grau, p.e. eclogitos), foi realizada uma campanha de campo de 20 dias no Togo e Benin. Ainda, nesta Tese algumas amostras provenientes da região do Gourma, no Mali, também foram investigadas. Essas amostras foram coletadas pelo pesquisador Renaud Caby em 1981 e cedidas ao doutorando durante sua estada na França na Université de Montpellier II. Vale ressaltar aqui, que na atual conjuntura política essas amostras são de grande valor científico, pois tratam-se de das rochas de ultra-alta pressão mais antigas da Terra (Janh et al., 2001), e a região onde afloram é hoje inacessível devido presença de conflitos armados.

As análises laboratoriais foram em grande parte realizadas no Centro de Pesquisas Geocronológicas (CPGeo) do IGc/USP. Uma outra leva de analises foi realizada na Research School of Earth Sciences da Australian National University em Camberra, na Austrália.

A forma de abordagem no noroeste da Província Borborema foi dividida em três grandes linhas principais que incluem: i) a sedimentação, ii) o magmatismo e iii) metamorfismo. Esta ultima linha com particular foco na determinação das idades do pico do metamorfismo de alta/ultra-alta pressão no Brasil e África.

i) sedimentação: dentro da linha da sedimentação o objetivo foi entender a proveniência, por meio da datação $\mathrm{U}-\mathrm{Pb}$ dos zircões detríticos, que compõem as rochas sedimentares (hoje metamorfizadas em graus diversos) associadas ao desenvolvimento da margem passiva do Oceano Goiás-Farusiano no nordeste do Brasil bem como bacias marginais relacionadas ao desenvolvimento de arcos Neoproterozóicos, e ainda aquelas associadas embasamento Paleoproterozóico. As principais unidades investigadas no noroeste da Província compõem parte das rochas siliciclásticas dos domínios Médio Coreaú e Geará Central.

ii) magmatismo: nesta linha o objetivo essencial foi o de estabelecer o timing e fontes das rochas magmáticas relacionadas ao consumo do Oceano Goiás-Farusiano no nordeste do Brasil, bem como o retrabalhamento das mesmas durante a colisão continental que se seguiu. Além dos aspectos geocronológicos U-Pb em zircão das diferentes linhagens magmáticas que compõem o magmatismo foram empregadas técnicas traçadoras de fontes (em rocha total), corriqueiramente utilizadas em estudos de petrologia de granitóides, tais como isótopos de $\mathrm{Sr}$ e $\mathrm{Nd}$, combinados com aqueles obtidos diretamente dos zircões, tais como isótopos de Hf e O. A unidade litoestratigráfica investigada nesta linha restringiu-se ao Complexo ígneo-anatético Tamboril-Santa Quitéria localizado no Domínio Ceará Central da Província Borborema.

iii) metamorfismo: nesta linha, novamente a geocronologia $\mathrm{U}-\mathrm{Pb}$ em zircão foi a principal ferramenta utilizada com o objetivo de estabelecer a idade do pico metamórfico de alta pressão e ultra-alta pressão em amostras de eclogitos ao longo do Orógeno Gondwana Oeste no nordeste do Brasil (zona eclogítica Forquilha definida por 
Santos et al., 2009), Togo (eclogitos do Monte Lato, Agbossoumondé et al., 2001) e Mali (eclogitos de ultraalta pressão mais antigos da Terra; Jahn et al., 2001). Ressalta-se que a geocronologia U-Pb em zircão foi aliada a composição química dos mesmos zircões no que se constitui em um moderno ramo da investigação geocronológica chamado de petrocronologia. Nesta linha foram investigadas ainda as condições de $\mathrm{P}$ e T aos quais esses eclogitos foram submetidos, por meio da química mineral das fases de pico metamórfico, difusibilidade de Zr em rutilo e Ti em zircão.

\subsection{Estrutura da Tese}

Com a euforia acadêmica do publish or perish (publique ou padeça) (The Economist, 19 de outubro de 2013) na busca de melhores índices pessoais e institucionais a publicação de artigos científicos vem sendo incentivada em todos os âmbitos acadêmicos, incluindo as apresentações de teses de doutoramento. Esta nova condição traz vantagens e desvantagens. A vantagem é de gerar teses concisas e objetivas, de certa forma impactantes. A busca por periódicos de alto impacto, em que os artigos são revisados (peer-reviewed) por dois a três especialistas, apuram a qualidade da Tese e testam a fidedignidade dos dados analíticos. A desvantagem é de que uma dada Tese pode terminar em um apanhado de artigos desconexos da temática central proposta pela pesquisa. Outra desvantagem é a repetição de itens que devem ser descritos em todos os artigos, como por exemplo o contexto geológico da pesquisa. Contudo, a principal desvantagem surge da pressa, pois dados científicos necessitam de tempo para serem digeridos apropriadamente.

Seguindo esta nova tendência a presente Tese está estruturada sob a forma de seis artigos científicos publicados ou em processo de submissão/revisão em revistas internacionais indexadas. Após aos quatro primeiros capítulos que versam sobre a apresentação da pesquisa, o zircão e suas aplicações, introdução sobre o contexto geológico e metodológico, os resultados são apresentados em seis capítulos que relatam suas implicações dentro do contexto do Domínio Ceará Central, da Província Borborema e do supercontinente Gondwana. Os dois últimos capítulos trazem novas perspectivas aliadas a ideias já tradicionais em relação a evolução Neoproterozóica do Gondwana Oeste no Brasil e África. As opiniões expressadas nestes dois últimos artigos foram fruto do trabalho em colaboração com outros pesquisadores levadas adiantes pelo orientador desta Tese.

No capitulo 5, o artigo "U-Pb detrital zircon provenance of metasedimentary rocks from the Ceará Central and Médio Coreaú Domains, Borborema Province, NE-Brazil: Tectonic implications for a long-lived Neoproterozoic active continental margin"apresenta dados de proveniência sedimentar das bacias de margem passiva e ativa associadas ao desenvolvimento do Orógeno Gondwana Oeste no Domínio Ceará Central da Província Borborema. O mesmo capítulo ja encontra-se publicado no periódico internacional Precambrian Research.

No capitulo 6, que versa sobre o registro magmático relacionado ao consumo do Oceano Goiás-Farusiano o artigo "Tracing Neoproterozoic subduction in the Borborema Province (NE- Brazil): clues from U-Pb geochronology and Sr-Nd-Hf-O isotopes on granitoids and migmatites" traz informações geocronológicas e isotópicas do sistema de subducção relacionado à evolução da margem ativa Neoproterozóica do Orógeno Gondwana Oeste no Domínio Ceará Central. O presente capítulo encontra-se em revisão em no periódico científico internacional indexado Lithos.

No capitulo 7 são discutidas as implicações da colisão Ediacarana na Província Borborema por meio do artigo "Extruding the Borborema Province: a two-stage collision process". Neste capítulo é proposto um novo modelo para evolução da Província Borborema com base em duas colisões distintas. No modelo, a interação destas 
duas colisões em conjunto com a endentação do Craton São Francisco, no sul da Província, teriam levado ao desenvolvimento do sistema de zonas de cisalhamentos pelas quais a extrusão da Província teria ocorrido. O mesmo modelo interpreta o importante Lineamento Transbrasiliano como um limite de placas transformante durante o Neoproterozóico. O presente capítulo encontra-se publicado no periódico internacional Terra Nova.

O capitulo 8 apresenta informações geocronológicas sobre o metamorfismo colisional ao longo do Orógeno Gondwana Oeste no artigo "Ediacaran megamountains: evidence for $\mathbf{2 5 0 0 - k m - l o n g}$ deep continental subduction in the West Gondwana Orogen". Neste capítulo é demostrado que a colisão continental que procedeu em decorrência do fechamento do Oceano Goiás-Farusiano foi sincrônica ao longo de pelo menos $2.500 \mathrm{~km}$, resultando numa cadeia montanhosa de magnitude equivalente aos Himalaias no período Ediacarano. As implicações desta extensa cadeia de montanhas para o desenvolvimento da Vida na Terra são também discutidas neste capítulo. O presente capítulo encontra-se em revisão em no periódico científico internacional indexado Nature Communications.

O capitulo 9 traz uma ampla revisão do Orógeno Gondwana Oeste ao longo do corredor tectônico Transbrasiliano-Kandi com o artigo "The significance of the Transbrasiliano-Kandi tectonic corridor for the amalgamation of the West Gondwana". Devido a larga extensão do Orógeno, este capítulo foi desenvolvido em parceria com outros colaboradores e a contribuição do doutorando restringiu-se a correlação geológica do nordeste brasileiro e noroeste africano (item 9.4 do mesmo capítulo). Este capítulo foi publicado no periódico Brazilian Journal of Geology.

O capitulo 10 discute a existência de um proposto trato oceânico Cambriano (Oceano Clymene) na América do Sul com o artigo "Is there a Clymene Ocean in Central South America". Neste capítulo é debatido a provável não existência do Oceano Clymene em detrimento da presença do vasto Oceano Goiás-Farusiano e seu fechamento no período Ediacarano. Assim como no capítulo anterior, o mesmo foi elaborado por uma junção de colaboradores e a participação do doutorando restringiu-se ao que tange a história geológica da Faixa Araguaia, Província Borborema e as conexões de ambas entidades com a África (item 10.5.2). Este capítulo encontra-se publicado no periódico internacional American Journal of Science.

Por fim, o ultimo capítulo reúne de forma concisa todos os resultados e interpretações apresentados nos capítulos anteriores, constituindo assim, a conclusão da Tese e as avenidas futuras pelo qual a pesquisa científica deverá ser guiada a posteriori.

\subsection{Referencias}

Affaton, P., Rahaman, M.A., Trompette, R., Sougy, J., 1991. The Dahomeyide Orogen: Tectonothermal Evolution and Relationships with the Volta Basin. In: Dallmeyer, R.D., Lecorche, J.P. (Eds.), The West African Orogens and CircumAtlantic Correlatives. Springer-Verlag, Berlin, pp. 107-122.

Agbossoumondé Y., Menot R.P., Guillot S., 2001. Metamorphic evolution of Neo-proterozoic eclogites from south Togo (West Africa). Journal of African Earth Sciences 33, 227-244.

Almeida, F. F. M., Black, R., 1968. Geological comparison of northeastern South America and western Africa. Anais da Academia Brasileira de Ciencias 40, 317-319.

Almeida, F.F.M., Brito Neves, B.B. de, Fuck R.A., 1977. Províncias Estruturais Brasileiras. In: VIII Simpósio de Geologia do Nordeste - Actas. Campina Grande, SBG-NE, 363 - 391. 
Carlos E. Ganade de Araujo - Tese de Doutorado - Universidade de São Paulo

Capítulo 1 - Introdução

Almeida, F.F.M., Hasui, Y., Brito Neves, B.B. de, Fuck, R.A., 1981. Brazilian Structural Provinces: an introduction. Earth Sciences Reviews 17, 1-29.

Arthaud, M.H., Caby, R., Fuck, R.A., Dantas, E.L., Parente, C.V., 2008. Geology of the Northern Borborema Province, NE Brazil and its correlation with Nigeria, NW Africa. In: Pankhurst, R.J.; Trouw, R.A.J., Brito Neves, B.B., De Wit, M.J. (eds) West Gondwana: Pre-Cenozoic Correlations Across the Atlanti Region. Geological Society, London, special Publications, p. 294, 49-67.

Brito Neves, B.B., Cordani, U.G., 1981. Tectonic Evolution of South America during the Late Proterozoic. Precambrian Research 53, 23-40.

Brito Neves, B.B. de, Santos, E.J., Van Schumus, W., 2000. Tectonic history of the Borborema Province, NW Brazil. In: Cordani U.G., Milani E.J., Thomaz Filho A., Campos D. A. (eds) Tectonic Evolution of South America.

Brito Neves, B.B. de, Van Schmus, W.R., Fetter, A.H., 2001. Noroeste da África - Nordeste do Brasil (Província Borborema) Ensaio comparativo e problemas de correlação. In: Geologia USP Serie Cientifica 1, 59-78.

Caby, R., 1989. Precambrian terranes of Benin Nigeria and Northeast Brazil and Late Proterozoic SouthAtlanticfit. Geological Society of America Special Paper 230, 145-158.

Caby, R., 2003. Terrane assembly and geodynamic evolution of central-western Hoggar: a synthesis. Journal of African Earth Sciences 37, 133-159.

Castro, N.A., Ganade de Araujo, G.E., Basei, M.A.S., Osako, L.S., Nutman, A., Liu, D., 2012. Ordovician A-type granitoid magmatism on the Ceará Central Domain, Borborema Province, NE-Brazil. Journal of South American Earth Sciences 36, 18-31.

Cordani, U.G., D’Agrella-Filho, M.S., Brito-Neves, B.B., and Trindade, R.I.F., 2003, Tearing up Rodinia: The Neoproterozoic paleogeography of South American cratonic fragments. Terra Nova 15, 350-359.

De Wit, M.J., Stankiewicz, J., Reeves, C., 2008b. Restoring Pan-African-Brasiliano connections: more Gondwana control, less Trans-Atlantic corruption In: Pankhurst, R.J.; Trouw, R.A.J., Brito Neves, B.B., De Wit, M.J. (eds) West Gondwana: Pre-Cenozoic Correlations Across the Atlanti Region. Geological Society, London, special Publications, p. $294,1-8$.

De Wit, M.J., Brito Neves, B.B., Trouw, R.A.J., Pankhurst, R.J., 2008a. Pre-Cenozoic correlations across the South Atlantic region: "the ties that bind" In: Pankhurst, R. J.; Trouw, R. A. J., Brito Neves, B. B., De Wit, M. J. (eds) West Gondwana: Pre-Cenozoic Correlations Across the Atlanti Region. Geological Society, London, special Publications, p. 294, 1-8.

Ganade de Araújo, G.E.G, Santos, T.S. dos, 2008. Does the Neoproterozoic - Early Cambrian Transbrasiliano Lithospheric Shear System Delineates a Collisional Suture Trace in South America? In: $33^{\circ}$ International Geological Congress, Oslo, CD-ROM.

Jahn B., Caby R., Monié P., 2001. The oldest UHP eclogites of the World: age of UHP metamorphism, nature of protoliths and tectonic implications. Chemical Geology 178, 143-158.

Kennedy, W.Q., 1964. The structural differentiation of Africa in the Pan-African (= 500 millions years) tectonic episode. 8th Annu. Rep. Res. Inst. Geol. Leeds Univ., pp. 48-49.

Kröner, A., Cordani, U., 2003. African, southern Indian and South American cratons were not part of the Rodinia supercontinent: evidence from field relationships and geochronology. Tectonophysics 375, 325-332.

Pimentel M.M., Fuck R.A., Jost H., Ferreira-Filho C.F., Araújo S.M., 2000. The basement of the Brasília Fold Belt and the Goiás Magmatic Arc. In: Cordani U.G., Milani E.J., Thomaz Filho A., Campos D.A (eds.). Tectonic Evolution of South America: 31 st International Geological Congress, Rio de Janeiro, Brazil, p. 195-229.

Santos, T.J.S., Fetter, A.H., Nogueira Neto, J.A., 2008. Comparisons between the northwestern Borborema Province, NE Brazil, and the southwestern Pharusian Dahomey Belt, SW Central Africa). In: Pankhurst, R. J.; Trouw, R. A. J., 
Carlos E. Ganade de Araujo - Tese de Doutorado - Universidade de São Paulo Capítulo 1 - Introdução

Brito Neves, B. B., De Wit, M. J. (eds) West Gondwana: Pre-Cenozoic Correlations Across the Atlanti Region. Geological Society, London, special Publications, p. 294, 101-119.

Santos, T.J.S., Garcia, M.G.M., Amaral, W.S., Wernick, E., Dantas, E.L., Arthaud, M.H., Caby, R., Santosh, M., 2009. Relics of eclogite facies assemblages in the Ceará Central Domain, NW Borborema Province, NE Brazil: implications for the assembly of West Gondwana. Gondwana Research 15, 454-470.

Torquato, J.R., Cordani, U.C., 1981. Brazil-Africa geological links. Earth-Science Reviews 17, 155-176.

Trompette, R. 1994. Geology of Western Gondwana, Pan-African - Brasiliano aggregation of South America and Africa. A.A. Balkema, Rotterdam, Brookfield, 350p. 


\section{Zircão e sua versatilidade}

Como um proeminente geocronômetro, o zircão $\left(\mathrm{ZrSiO}_{4}\right)$, exerceu, exerce e provavelmente continuará exercendo um papel singular no entendimento da evolução crustal da Terra. O seu amplo uso na geocronologia, baseado no decaimento de urânio $(\mathrm{U})$ para chumbo $(\mathrm{Pb})$, vem difundido este mineral como um verdadeiro "guardião do tempo" (Harley \& Kelly, 2007). As modernas técnicas de análises sobre zircões, em conjunto com outra gama de minerais traços (e.g. monazita, badeleíta, titanita, rutilo) revelam idades de eventos de suma importância para a construção de modelos tectônicos sólidos, incluindo eventos de edificação de cadeias montanhosas, magmatismo, idades máximas de sedimentação, e indiretamente parâmetros temporais de construção e dispersão de grandes massas continentais ao longo do tempo (Rubato \& Hermann, 2007; Harley et al., 2007; Sherer et al., 2007).

A estrutura do zircão é relativamente aberta e suas vacâncias podem abrigar impurezas de interesse geoquímico da ordem de partes por milhão (ppm) (Harley \& Kelly, 2007; Hoskin \& Schaltegger, 2003). O zircão pode incorporar muitos elementos externos tais como, P, Sc, Nb, Hf, Ti, Y, U, Th, e Elementos Terras Raras (ETR) via processos de substituição iônica acoplada, principalmente controlada pelos raios iônicos dos cátions $\mathrm{Si}^{+4}$ e $\mathrm{Zr}^{+4}$ (Hoskin \& Schaltegger, 2003).

Além de seu versátil uso como um geocronômetro, recentes avanços nas técnicas de microanálise acabaram ampliando o espectro de problemas geológicos que podem ser abordados com o uso do zircão. Como uma fase que pode acomodar significativas concentrações de elementos traços (sensíveis a temperatura, pressão e processos da época de cristalização), o zircão pode fornecer informações importantes acerca dos processos que operaram na formação de um dado segmento da crosta (Hanchar \& van Westrenen, 2007, Harley et al., 2007). Composições isotópicas de oxigênio em zircão trazem informações sobre a relação entre processos de baixa e alta temperatura e auxiliam na investigação da fonte de fundidos magmáticos na crosta (Valley, 2003). A utilização do parâmetro Épsilon Hf obtido diretamente no domínio datado do zircão também é um forte traçador da evolução e fontes de magmas (Hawkesworth \& Kemp, 2006). Medidas dos conteúdos de U, Th e He no zircão podem ser utilizados para inferir temperaturas em que as rochas foram expostas a temperaturas próximas a da superfície atual, fornecendo importantes subsídios sobre a história de soerguimento e formação de relevo (Harley \& Kelly, 2007). Uma lista das principais características químicas do zircão e suas aplicações pode ser encontrada na tabela 2.1 .

\subsection{Geocronologia U-Th-Pb em zircão}

Três séries de decaimento radioativo são conhecidas para o sistema U-Th-Pb, que envolve os seguintes isótopos pais: ${ }^{238} \mathrm{U},{ }^{235} \mathrm{U}$ e ${ }^{232} \mathrm{Th}$ e seus respectivos isótopos radiogênicos filhos ${ }^{206} \mathrm{~Pb},{ }^{207} \mathrm{~Pb}$ e ${ }^{208} \mathrm{~Pb}(\mathrm{Faure} \&$ Mensing, 2005). Cada uma dessas séries envolve uma gama de passos intermediários que geram isótopos intermediários de vida curta. Pelo fato do ultimo estágio do decaimento nessas séries ser muito mais devagar do que os estágios intermediários, o processo de decaimento pode ser matematicamente descrito por uma simples equação, relacionado o número de isótopos pais que restam $\left(e . g{ }^{238} \mathrm{U}\right)$ e o número de final de isótopos radiogênicos filhos (e.g $\left.{ }^{207} \mathrm{~Pb}^{*}\right)$ com o tempo:

$$
206 \mathrm{~Pb} * / 238 \mathrm{U}=\mathrm{e}^{\lambda 238 \mathrm{t}}-\lambda
$$


Tabela 2.1 - Principais características químicas/isotópicas do zircão e suas aplicações, segundo Harley \& Kelly (2007).

\begin{tabular}{|c|c|c|c|}
\hline $\begin{array}{c}\text { Propriedade } \\
\text { física/química }\end{array}$ & Substituições & Principais aplicações & Comentários \\
\hline U e Th & $\left(\mathrm{U}^{+4}, \mathrm{Th}^{+4}\right)=\mathrm{Si}^{+4}$ & Geocronologia U-Pb & $\begin{array}{l}\text { O diagrama concórdia } \\
\text { pode ser usado na } \\
\text { contabilização de isótopos } \\
\text { de U e seu conteúdo de } \\
\mathrm{Pb} \text { radiogênico }\end{array}$ \\
\hline $\mathrm{He}$ & Decaimento de U e Th & $\begin{array}{l}\text { Determinação de taxas de } \\
\text { exumação e evolução do } \\
\text { relevo usando } \\
\text { termocronologia U-Th- } \\
\text { He }\end{array}$ & $\begin{array}{c}\text { A cronometria de baixa } \mathrm{T} \\
\text { e baseada na temperatura } \\
\text { de fechamento do zircão } \\
\text { para a perda de He }\end{array}$ \\
\hline $\mathrm{HfO}_{2}>3 \%$ eq. peso & $\mathrm{Hf}^{+4}=\mathrm{Si}^{4+}$ & $\begin{array}{l}\text { Informações sobre } \\
\text { residência crustal e } \\
\text { crescimento continental; } \\
\text { traçador de fontes } \\
\text { mantélicas e crustais }\end{array}$ & $\begin{array}{l}\text { O }{ }^{176} \mathrm{Lu} \text { decai para }{ }^{176} \mathrm{Hf} . \\
\text { A alta razão de } \\
{ }^{176} \mathrm{Hf} /{ }^{177} \mathrm{Hf} \text { mudou muito } \\
\text { pouco com o tempo e } \\
\text { pode ser usada para } \\
\text { inferir fontes a partir de } \\
\text { um modelo de referência } \\
\text { para Terra }\end{array}$ \\
\hline $\mathrm{Ti}>120 \mathrm{ppm}$ & $\mathrm{Ti}^{4+}=\mathrm{Si}^{4+}$ & Termocronologia & $\begin{array}{l}\text { Maximizada quando o } \\
\text { zircão esta em equilíbrio } \\
\text { com o rutilo. Pode } \\
\text { fornecer a T de } \\
\text { cristalização do zircão ou } \\
\text { a T de zircões } \\
\text { metamórficos em } \\
\text { equilíbrio com rutilo }\end{array}$ \\
\hline $\begin{array}{c}\mathrm{Y}>5000 \mathrm{ppm} \\
\text { ETR total }>2500 \mathrm{ppm}\end{array}$ & $\left(\mathrm{Y}^{3+}, \mathrm{ETR}^{3+}\right) \mathrm{P}^{5+}=\mathrm{Zr}^{4+} \mathrm{Si}^{4+}$ & $\begin{array}{c}\text { Reconstrução de historias } \\
\text { magmáticas; traçadores } \\
\text { de fontes magmáticas; } \\
\text { sintonia entre idades e } \\
\text { reações minerais }\end{array}$ & $\begin{array}{c}\text { Requer um grande } \\
\text { conhecimento do } \\
\text { coeficiente de partição } \\
\text { entre os elementos e o } \\
\text { zircão }\end{array}$ \\
\hline Isótopos de $\mathrm{O}$ & & $\begin{array}{c}\text { Traçador de contribuição } \\
\text { sedimentar e crosta na } \\
\text { fonte de magmas; } \\
\text { investigações sobre } \\
\text { reciclagem crustal }\end{array}$ & $\begin{array}{c}\mathrm{O} \text { fracionamento de }{ }^{18} \mathrm{O} \\
\text { para }{ }^{16} \mathrm{O} \text { ocorre em baixa } \\
\text { temperatura. Variações } \\
\text { de }{ }^{18} \mathrm{O} /{ }^{16} \mathrm{O} \text { são utilizadas } \\
\text { para discriminação de } \\
\text { fontes }\end{array}$ \\
\hline
\end{tabular}

onde, $e$ é uma função exponencial, $t$ é o tempo e $\lambda$ é a constante de decaimento específica para o esquema de decaimento (p.e. $\lambda^{238} \mathrm{U}=1,55125 \mathrm{e}^{-10} ;{ }^{206} \mathrm{~Pb} *$ refere-se ao ${ }^{206} \mathrm{~Pb}$ radiogênico formado a partir do ${ }^{238} \mathrm{U}$ ).

No exemplo a seguir, modificado de (Harley \& Kelly, 2007), considera-se uma fração de zircões formados durante a cristalização de um magma félsico. Por meio da incorporação de U e Th durante o crescimento magmático desses zircões, três diferentes "cronômetros" isotópicos são iniciados e cada um deles registrará a 
história isotópica (ou tempo decorrido) de acordo com sua própria taxa de decaimento (o decaimento do ${ }^{235} \mathrm{U}$ ocorre cerca de sete vezes mais rápido do que o ${ }^{238} \mathrm{U}$, enquanto o decaimento do ${ }^{232} \mathrm{Th}$ é muito lento).

Em princípio, podem-se obter idades a partir de qualquer um desses isótopos, medindo-se a razão isotópica apropriada e resolvendo a equação acima para o tempo $t$. Em um sistema ideal as três idades deveriam ser similares com valores concordantes, contudo em zircões reais não podemos assumir que U e Th estão igualmente "fechados" aos processos de recristalização posteriores, que perturbam o sistema isotópico. Igualmente é necessário corrigir o valor de chumbo presente antes de qualquer acúmulo de chumbo radiogênico.

A aplicação dessa sistemática na geocronologia considera os esquemas de decaimento do ${ }^{235} \mathrm{U}$ e ${ }^{238} \mathrm{U}$ em conjunto. Como a taxa moderna da razão ${ }^{235} \mathrm{U} /{ }^{238} \mathrm{U}$ é bem conhecida $(1 / 137,88)$, não se faz necessária a determinação das razões provenientes dos decaimentos do ${ }^{235} \mathrm{U}$ e ${ }^{238} \mathrm{U}$ separadamente. Desta forma, podem ser usadas mutuamente razões ${ }^{207} \mathrm{~Pb}^{*} / 235 \mathrm{U}$ e ${ }^{206} \mathrm{~Pb} * / 238 \mathrm{U}$ desde a formação do zircão investigado [p.e. $\left.{ }^{207} \mathrm{~Pb}^{*} / 235 \mathrm{U}=137,88\left({ }^{206} \mathrm{~Pb}^{*} / 238 \mathrm{U}\right)\right]$. Esta é a base do diagrama concórdia desenvolvida por Wheterill (1956). A curva esboçada no diagrama concórdia representa os resultados compatíveis e concordantes das razões ${ }^{207} \mathrm{~Pb}^{* / 235} \mathrm{U}$ e ${ }^{206} \mathrm{~Pb}^{*} / 238 \mathrm{U}$ desde a origem da Terra há 4,6 Ga até o presente.

A curva concórdia é o lugar geométrico onde mutuamente as razões ${ }^{207} \mathrm{~Pb} * / 235 \mathrm{U}$ e ${ }^{206} \mathrm{~Pb}^{*} / 238 \mathrm{U}$ são concordantes. No tempo zero, quando o zircão do exemplo é formado, não existe nenhum chumbo radiogênico $(\mathrm{Pb} *)$ nos zircões. Após 1,0 Ga essas razões terão valores 1,677 e 0,167 respectivamente (curva a na fig. 2.1). Pela mesma lógica se forem analisados zircões de uma rocha formada há 3,0 Ga esperaríamos que as razões ${ }^{207} \mathrm{~Pb}^{*} / 235 \mathrm{U}$ e ${ }^{206} \mathrm{~Pb}^{*} / 238 \mathrm{U}$ tivessem valores de 18,198 e 0,592 respectivamente (curva b na fig. 2.1). Essas são ditas idades concordantes, pois as duas razões $\mathrm{Pb} / \mathrm{U}$ medidas no zircão correspondem à mesma idade, portanto a posição deste ponto no diagrama concórdia é a medida direta da idade do zircão.

O diagrama também permite conclusões de análises que não caem diretamente sobre a curva concórdia. Para essas idades, em que as razões ${ }^{207} \mathrm{~Pb} * / 235 \mathrm{U}$ e ${ }^{206} \mathrm{~Pb} * / 238 \mathrm{U}$ não são concordantes é utilizado o termo idade discordante.

No exemplo da figura 2.2A as razões $\mathrm{Pb}$ */ $\mathrm{U}$ foram geradas pela superposição de um segundo evento geológico, três bilhões de anos depois da formação dos zircões anteriores. Este evento não só forma novos zircões, mas também perturba aqueles já formados, causando perda de chumbo radiogênico previamente acumulado desde o evento que originou estes zircões. A figura 2.2B ilustra o efeito no diagrama concórdia caso estes zircões sejam analisados um bilhão de anos depois deste segundo evento, digamos hoje.

No exemplo, todos os zircões terão acumulado chumbo radiogênico $\left(\mathrm{Pb}^{*}\right)$ durante este um bilhão de anos transcorridos, desde a ocorrência do segundo evento. Os zircões formados neste segundo evento apresentarão idades concordantes. Nos zircões mais antigos do que o segundo evento, o sistema terá sido "zerado" caso todo chumbo radiogênico acumulado tenha sido perdido durante o segundo evento, e logo estes zircões também forneceriam uma idade de 1,0 Ga. Alternativamente, e mais comumente, a perda de chumbo radiogênico é somente parcial ou confinado a subdomínios nestes zircões. 


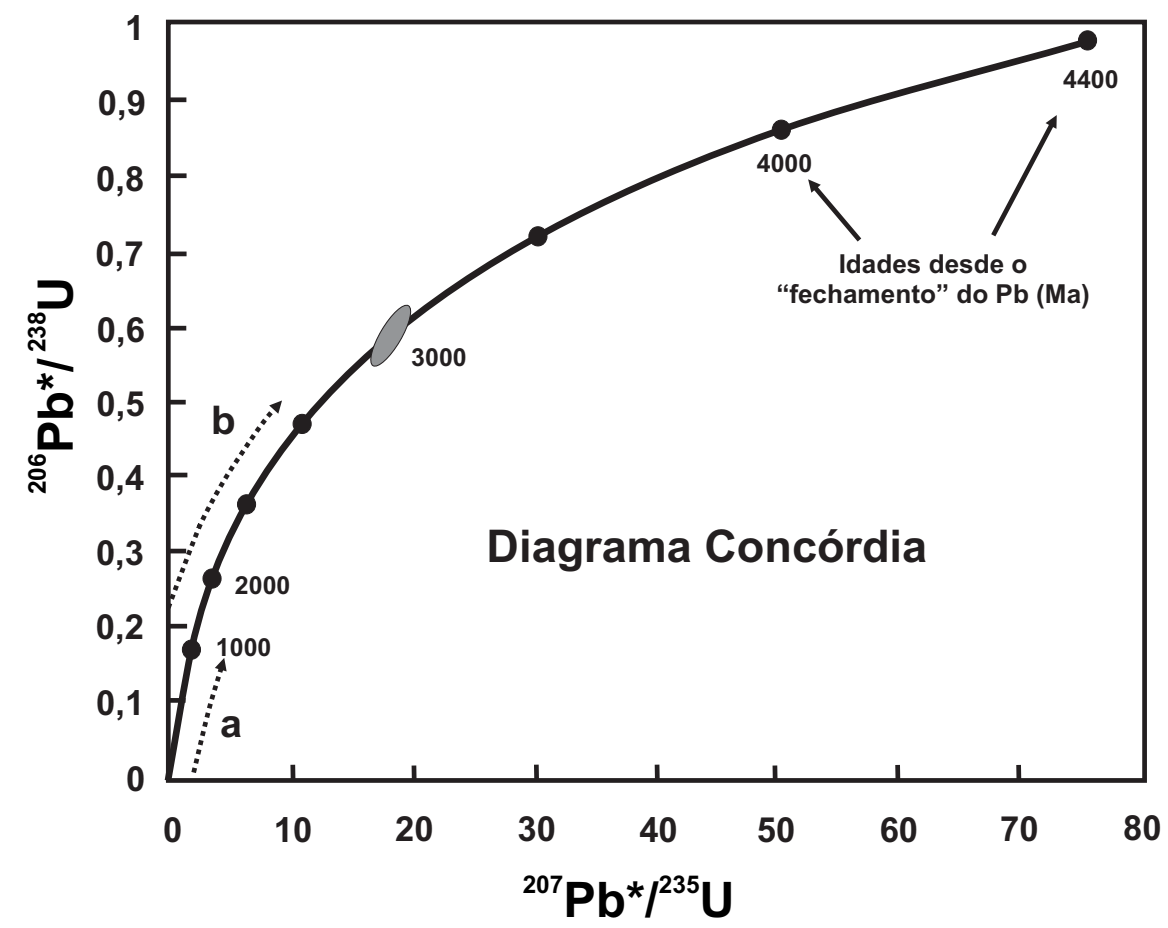

Figura 2.1 - A. Diagrama Concórdia de Wheterill (1956). Modificado de Harley \& Kelly (2007).

Neste caso, uma série de idades podem resultar em um alinhamento de dados, ao longo da curva discórdia, que intercepta a curva concórdia em dois pontos: um superior (mais antigo), que fornece à idade de formação dos zircões - 4,0 Ga - e um inferior que fornece uma idade de 1,0 Ga correspondente à idade do segundo evento (fig. 2.2B).
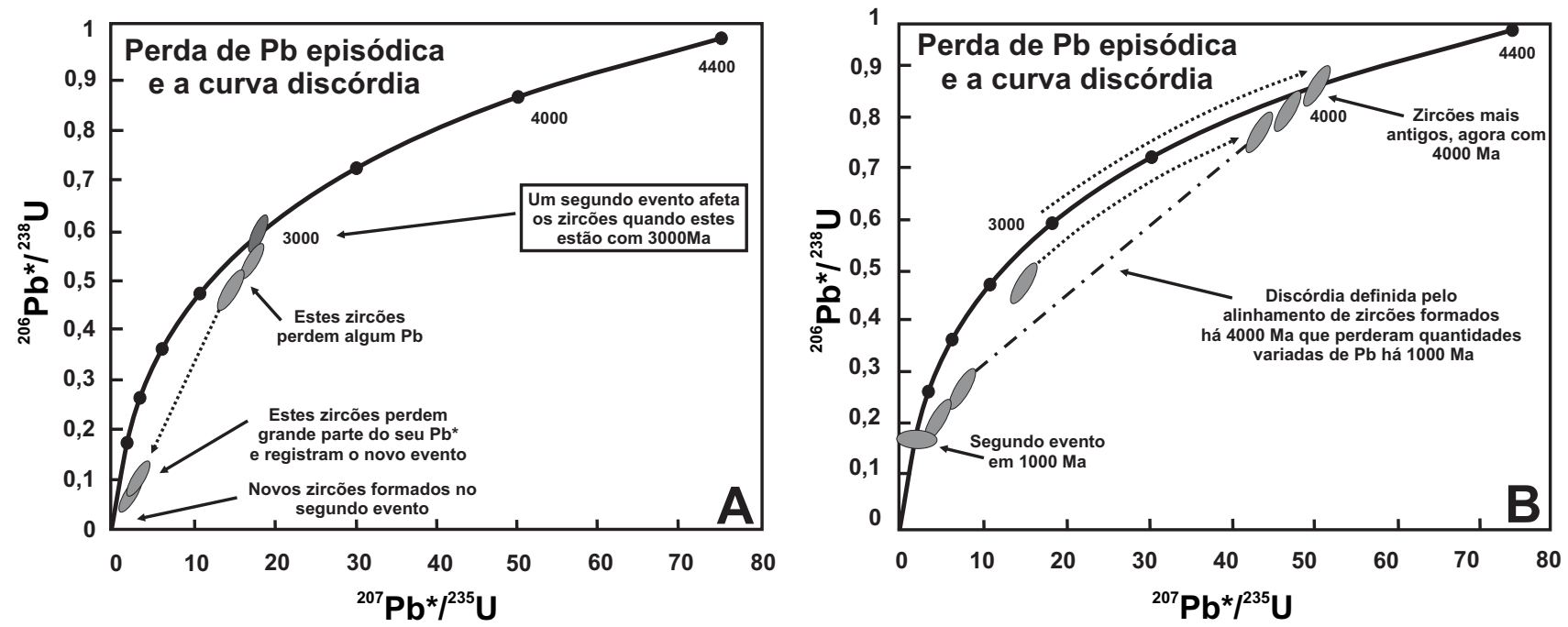

Figura 2.2 - A. e B. Diagrama Concórdia e a perda episódica de $\mathrm{Pb}$, neste caso devido ao efeito de um segundo evento que perturba o sistema isotópico há 1000 Ma gerando a curva discórdia - ver texto. Modificado de Harley \& Kelly (2007). 


\subsection{Imageamento de domínios complexos em zircões - catodoluminescência (CL)}

Durante as últimas duas décadas, o avanço das técnicas de imageamento elevou consideravelmente a observação das complexidades internas dos zircões. Similarmente, recentes avanços no desenvolvimento da espectrômetria de massa de íons secundários (secondary ion mass spectrometry - SIMS) e na espectrometria de massa de plasma por ablação a laser (laser-ablation inductevely coupled plasma mass espectrometry - LA-ICP-MS) tornaram possíveis à determinação de idades U-Pb in situ com elevada resolução espacial (spots com $\leq 20 \mu \mathrm{m}$ para técnicas SIMS). Interpretações concretas acerca dos eventos demarcados pelas idades obtidas por essas técnicas requer mais do que a simples utilização de geocronômetros U-Th-Pb, e novamente, modernas técnicas analíticas fornecem a solução. Determinações de elementos traços e terras raras (ETR) e isótopos de oxigênio, realizadas in situ em zircões, permite a ligação direta entre interpretações petrogenéticas e a idade do domínio analisado no zircão (Sherer et al., 2007). Adicionalmente, a utilização de isótopos de háfnio (Hf) em zircões datados por U-Pb revela quão grande foi à contribuição de crosta juvenil (e.g. diretamente derivada do manto) em relação à quantidade de crosta continental reciclada, fazendo do zircão uma "peça única" - sem a necessidade da análise de outros materiais (e.g. rocha total) no estabelecimento da evolução crustal de um dado segmento da crosta (Harrison, et al. 2005).

A observação de imagens pancromáticas de minerais traços alvos de determinações geocronológicas por catodoluminescência (CL), ou alternativamente por imagens obtidas com o auxílio do microscópio eletrônico de varredura (MEV), devem fazer parte da avaliação e interpretação dos resultados analíticos obtidos pelas técnicas SIMS e/ou LA-ICP-MS (Rubatto \& Gebauer, 1998; Hoskin, 2000; Silva, 2006). Este procedimento permite o reconhecimento de diferentes domínios com base no padrão textural apresentado pelo zircão, aumentando o controle na investigação geocronológica de diferentes domínios do zircão e consequentemente na interpretação dos dados.

As imagens de catodoluminescência registram com alta resolução a correlação quantitativa entre a intensidade da luminescência e o conteúdo de urânio do zircão (Rubatto \& Gebauer, 1998). Texturas magmáticas são caracterizadas por zoneamento oscilatório produzidas pela alternância de halos ricos em urânio (baixa luminescência) e halos pobres em urânio (alta luminescência). Zircões metamórficos são desprovidos de zoneamento oscilatório e são caracterizados por uma textura interna homogênea, levando à destruição da textura ígnea pretérita (Corfu et al., 2003) A tabela 2.2 de Silva (2006) sintetiza algumas características morfológicas do imageamento por CL e MEV (BSE - back scaterred electron) e suas respectivas interpretações.

A figura 2.3 ilustra como as técnicas de imageamento auxiliam na organização e controle dos domínios analisados assim como na interpretação, especialmente quando o mesmo cristal é analisado por mais de uma técnica na busca da integração de diferentes dados de um mesmo zircão ou ainda em um mesmo domínio do zircão. $\mathrm{O}$ reconhecimento de fases minerais inclusas no zircão pode indicar as condições P-T de cristalização deste mineral, desta forma permitindo a extração de idades relacionadas com determinadas condições em que o zircão foi formado. A figura 2.3 (abaixo) mostra zircões metamórficos submetidos a condições metamórficas eclogíticas, com inclusões de onfacita e coesita, em que a datação deste zircão fornecerá a idade do metamorfismo de alta pressão. 
Tabela 2.2 - Aspectos morfológicos do zircão e suas respectivas interpretações (modificado de Silva, 2006).

\begin{tabular}{|c|c|c|}
\hline Morfologia externa do cristal & $\begin{array}{c}\text { Idiomorfismo e recristalização } \\
\text { periférica }\end{array}$ & $\begin{array}{l}\text { Indica respectivamente preservação } \\
\text { das características ígneas ou } \\
\text { recristalização metamórfica }\end{array}$ \\
\hline \multirow{3}{*}{ Morfologia interna do cristal } & $\begin{array}{l}\text { Homogeneidade vs. distinção entre } \\
\text { núcleo e sobrecrescimentos(s) }\end{array}$ & $\begin{array}{l}\text { Indica evolução simples magmática } \\
\text { ou metamórfica }\end{array}$ \\
\hline & $\begin{array}{l}\text { Zoneamentos oscilatórios por setor } \\
\text { ou complexos }\end{array}$ & $\begin{array}{l}\text { Indica precipitação de fundidos } \\
\text { (melt-precipitaded) do domínio } \\
\text { (núcleo e/ou sobrecrescimento) }\end{array}$ \\
\hline & Obliteração de texturas magmáticas & $\begin{array}{c}\text { Alteração pós magmática, } \\
\text { metamorfismo ou metamitização }\end{array}$ \\
\hline \multirow{3}{*}{ Forma do núcleo } & Idiomórfico & $\begin{array}{c}\text { Ígneo (xenocristal) ou metamórfico } \\
\text { (xenocristal) }\end{array}$ \\
\hline & Arredondado & $\begin{array}{c}\text { Corrosão magmática, metamórfica } \\
\text { ou abrasão (detrítico) }\end{array}$ \\
\hline & Contorno Irregular & $\begin{array}{c}\text { Corrosão magmática e/ou } \\
\text { metamórfica }\end{array}$ \\
\hline \multirow{3}{*}{$\begin{array}{l}\text { Variações na intensidade de } \\
\text { luminescência }(\mathrm{CL}) \text { e (BSE) }\end{array}$} & $\begin{array}{l}\text { Tonalidades cinza-médio uniforme, } \\
\text { tanto em CL quanto em BSE }\end{array}$ & $\begin{array}{c}\text { Origem magmática, Conteúdos de U } \\
\text { e Th normais (magmáticos); razoes } \\
\text { Th/U magmática }(0.2-0.8)\end{array}$ \\
\hline & $\begin{array}{l}\text { Tonalidades cinza-claro e branco } \\
\text { (alta luminescência) }\end{array}$ & $\begin{array}{c}\text { Baixos conteúdos em } \mathrm{U}(\mathrm{e} \mathrm{Th}), \\
\text { baixas razoes } \mathrm{Th} / \mathrm{U}(>0.1) \text {, domínios } \\
\text { metamórficos de alto grau }\end{array}$ \\
\hline & $\begin{array}{l}\text { Tonalidades cinza-escuro e preto } \\
\text { (baixa luminescência) }\end{array}$ & $\begin{array}{l}\text { Alto conteúdo de U (>1000 ppm), } \\
\text { domínios magmáticos metamitizados }\end{array}$ \\
\hline
\end{tabular}

\subsection{Datação U-Th-Pb em zircões detríticos}

Datação U-Pb de zircões detríticos de rochas metassedimentares siliciclásticas é uma ferramenta poderosa para reconstrução geológica de terrenos polideformados e identificação de núcleos continentais antigos não mais preservados (Froude et al., 1983; Compston \& Pidgeon, 1986; Mueller et al., 1992, Condie et al. 2009). A técnica convencional de datação U-Pb por diluição isotópica TIMS (thermal ionization mass spectrometry) não é uma metodologia conveniente em estudos de proveniência de zircões detríticos, pelo fato de ser uma técnica não pontual (não in situ) e demorada para a aquisição de dados.

Portanto, para estudos de zircões detríticos, métodos como LA-ICP-MS e SHRIMP, são mais adequados, pois permitem a análise pontual (in situ) de grande número de zircões em um tempo relativamente curto (50 a 200 grãos em uma sessão de 24 horas). Em estudos de proveniência, a necessidade de datar grande quantidade de zircões é uma premissa estatística para que não se oculte as frações de grãos com menor abundância na amostra (e.g. Vermeesch, 2004; 2006). Segundo Vermeesch (2004), um numero ideal de 117 grãos são necessários para que nenhuma fração contendo no mínimo $5 \%$ da população total da amostra seja ocultada em um nível de confiança de 95 \%. 
Carlos E. Ganade de Araujo - Tese de Doutorado - Universidade de São Paulo Capítulo 2 - Zircão
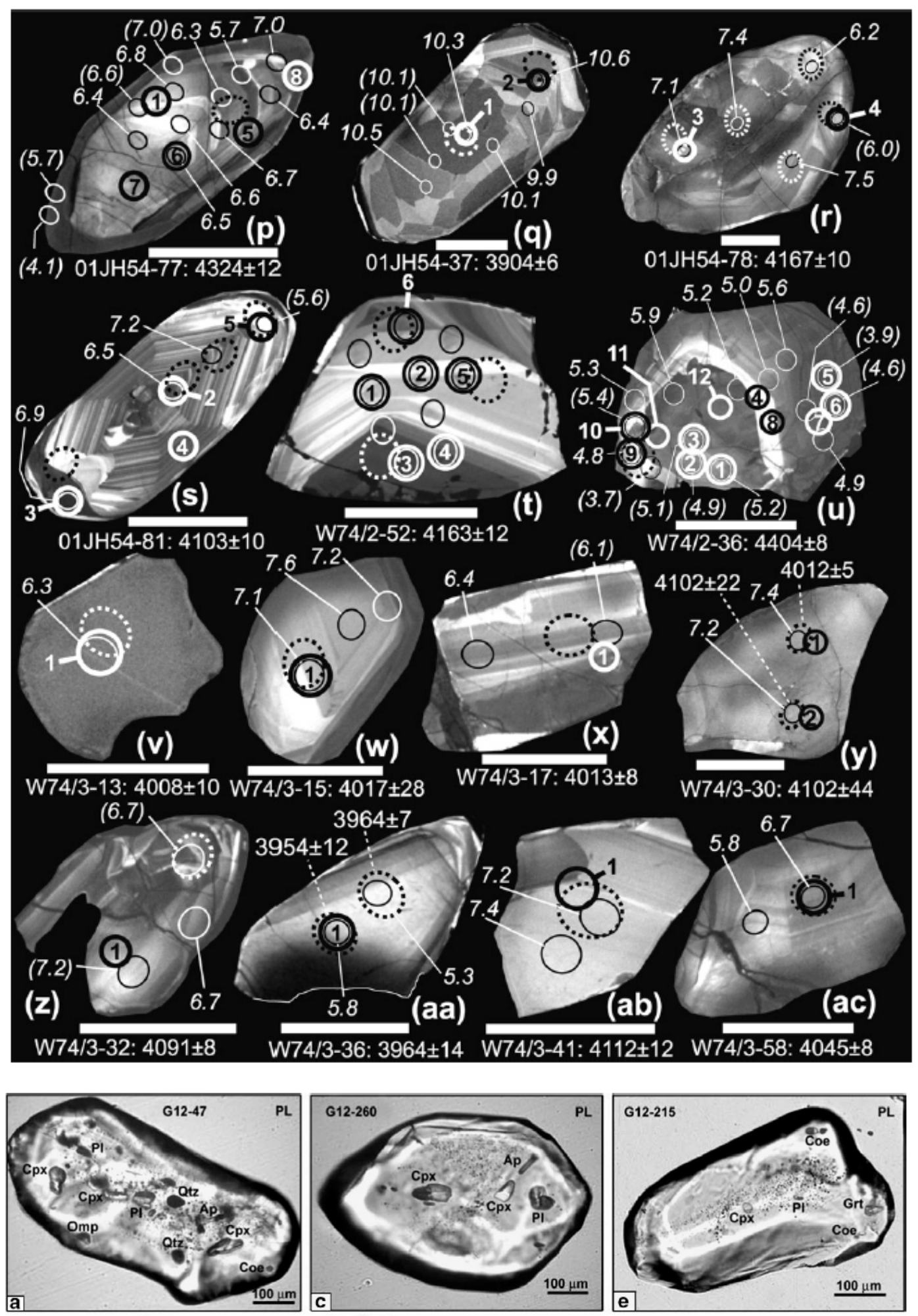

Figura 2.3 - Acima: imagens de catodoluminescência (CL) de zircões provenientes da localidade de Jack Hills, mostrando spots analisados para ETR, isótopos de oxigênio e geocronologia U-Th-Pb. (extraído de Cavosie et al., 2006). Abaixo: imagens de catodoluminescência (CL) em zircões submetidos a condições metamórficas eclogíticas de ultra-alta pressão, com inclusões de onfacita e coesita (extraído de Liu et al., 2008). 


\subsection{Determinação de isótopos de Hf em zircão}

Para elementos refratários, tais como Sm, Nd, Lu e Hf, assume-se que a composição destes na Terra é similar àquelas do reservatório uniforme condrítico (CHUR - chondritic uniform reservoir) definido por meteoritos indiferenciados (Faure \& Mensing, 2005). O comportamento do sistema Lu-Hf durante episódios de fusão parcial é similar ao do sistema $\mathrm{Sm}-\mathrm{Nd}$, em que o isótopo filho (Hf, Nd) é mais incompatível e, portanto, concentra-se em maior quantidade no fundido magmático do que o isótopo pai (Lu, Sm). Portanto, o sistema $\mathrm{Lu}-\mathrm{Hf}$ pode ser utilizado da maneira similar ao sistema Sm-Nd para monitorar o grau de heterogeneidade dos reservatórios silicáticos da Terra, no entanto com mais vantagens. As determinações in situ Lu-Hf (seguidas daquelas $\mathrm{U}-\mathrm{Pb}$ ) em zircão, além de fornecer informações isotópicas diretamente relacionada ao tempo de formação do domínio analisado no zircão, são aparentemente mais robustas do que aquelas analisadas em rocha total por Sm-Nd, fazendo deste método uma grande ferramenta na analise da evolução crustal de terrenos fortemente metamorfizados (Scherer et al., 2007).

A técnica por LA-MC-ICP-MS (multi colector) possibilita a determinação in situ da composição isotópica de Hf de diferentes zonas intercrescidas em um zircão (Thirlwall \& Walter, 1995).

A figura 2.4A ilustra como a composição isotópica de Hf no zircão se comporta na diferenciação da Terra tendo como exemplo um simples cenário, onde um fundido (melt) é extraído por fusão parcial do reservatório silicático total da Terra (Bulk Silicate Earth - BSE), deixando para trás um manto empobrecido devido a extração do material no ponto 1. Devido ao fato do elevado fracionamento de $\mathrm{Hf}$ em fundidos em relação ao $\mathrm{Lu}$, o fundido terá uma razão Lu/Hf mais baixa do que o reservatório silicático total da Terra (BSE), enquanto a razão Lu/Hf no manto empobrecido residual terá uma razão mais elevada. Por convenção, a composição isotópica de Hf é expressa em termos da divergência (em partes por $10^{4}$ ) em relação aos valores do reservatório condrítico uniforme (CHUR), em que cujos valores da razão ${ }^{176} \mathrm{Hf} /{ }^{177} \mathrm{Hf}$ são assumidos como o mesmo do reservatório silicático total da Terra (BSE). A notação usada para essas divergências, em algum segmento de tempo $t$, é tida como o parâmetro Épsilon $\mathrm{Hf}(t)$. Na figura 2.4B, onde $t$ é a idade de cristalização do zircão, o parâmetro Épsilon $\mathrm{Hf}(t)$ representa a composição isotópica inicial do zircão.

O uso de gráficos que utilizam o parâmetro Épsilon $\mathrm{Hf}(t)$ na ordenada versus a idade de cristalização na abscissa (fig. 2.4C) torna-se uma considerável ferramenta na geração de informação sobre a diferenciação da Terra primordial, assim como para um dado segmento da crosta onde pretende-se traçar fontes e processos petrogenéticos associados a evolução de séries magmáticas .

\subsection{Combinação dos métodos U-Pb e Lu-Hf em zircão detrítico}

O material proveniente da erosão da crosta continetal - sedimentos - fornece informações valiosas acerca dos processos de crescimento crustal (Scherer et al., 2007; Harrison, et al., 2005; Bodet \& Sharer, 2000), cujo registro já fora erodido. Estudos deste tipo são realizados com o auxilio do sistema Sm-Nd em rocha total, contudo problemas relacionados com a obtenção de idades mistas são muitas vezes interpretados sem o devido cuidado, levando a interpretações errôneas. Métodos como idades $\mathrm{K}-\mathrm{Ar}$ em micas detríticas e U-Pb são corriqueiramente empregados em estudos de fontes sedimentares. Porém o sistema K-Ar é facilmente desestabilizado durante o metamorfismo e espectros de idades $\mathrm{U}-\mathrm{Pb}$ em zircão frequentemente geram padrões similares em diferentes domínios crustais. 
Carlos E. Ganade de Araujo - Tese de Doutorado - Universidade de São Paulo Capítulo 2 - Zircão
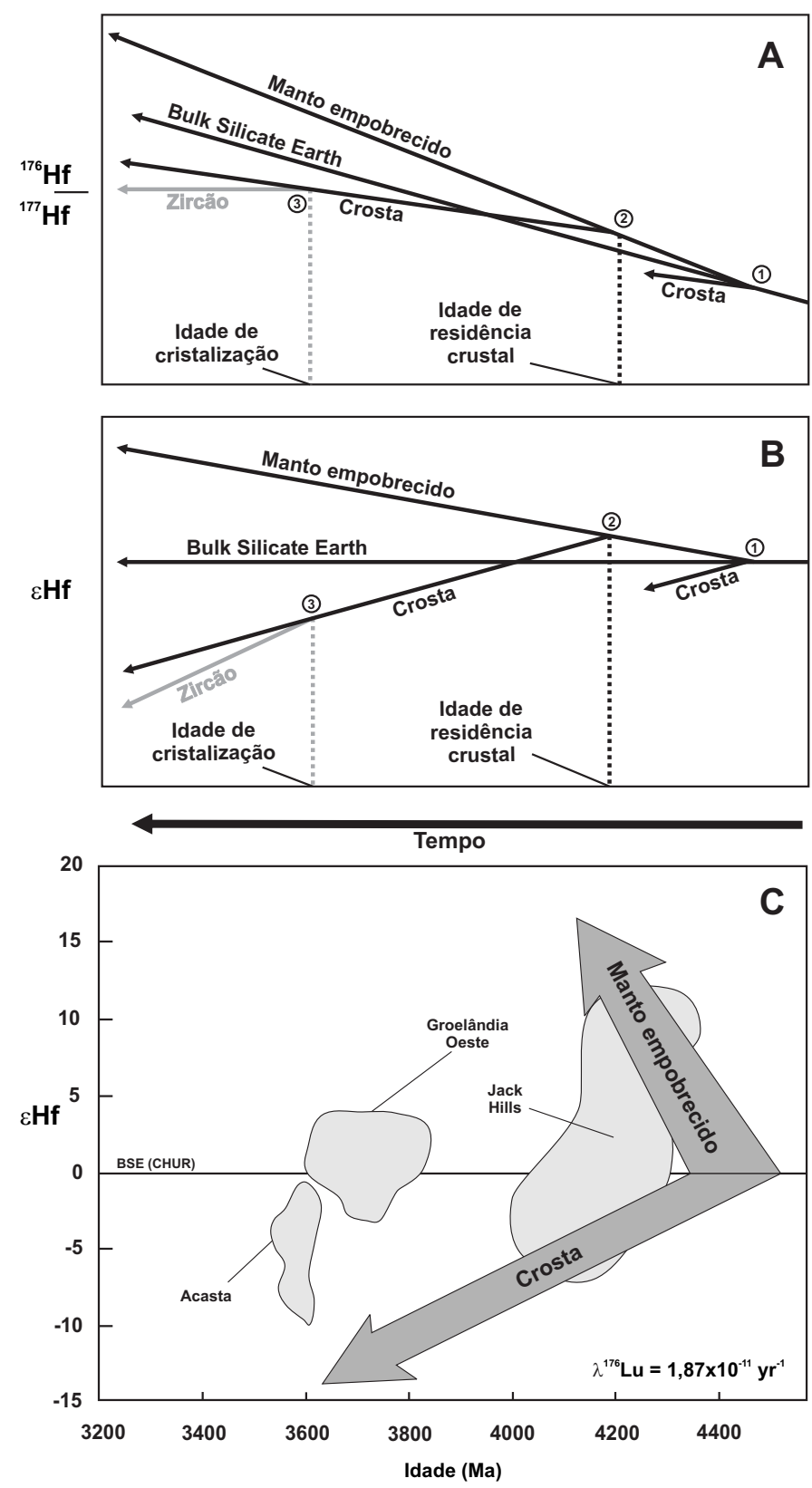

Figura 2.4 - A. Evolução hipotética da razão ${ }^{176} \mathrm{Hf} /{ }^{177} \mathrm{Hf}$ versus tempo para o (BSE) Bulk Silicate Earth, manto empobrecido (DM), para dois reservatórios crustais e para o zircão. B. Os mesmos reservatórios representados em termos do parâmetro Épsilon Hf versus tempo. A idade U-Pb no zircão data sua cristalização (3), a idade de Lu-Hf de residência crustal é uma estimativa do tempo decorrido da extração deste domínio crustal do manto empobrecido até a cristalização do zircão hospedado neste domínio. C. Trends evolutivos hipotéticos para o manto empobrecido (DM) e proto-crosta com valor da razão ${ }^{176} \mathrm{Lu} /{ }^{177} \mathrm{Hf}$ de 0,009 com parâmetro CHUR de Blichert-Toft and Albarede, 1997), (extraído e modificado de Scherer et al., 2007).

Nestes casos, estudos isotópicos combinados pelas técnicas U-Pb e Lu-Hf em zircões detríticos, permitem a distinção entre grãos que tem a mesma idade de cristalização, mas foram formados em domínios crustais com idades de extração mantélica distintas. Estes estudos podem ser realizados usando-se das idades de residência crustal determinadas em grãos individuais. Um valor assumido da razão ${ }^{176} \mathrm{Lu} /{ }^{177} \mathrm{Hf}$ para a crosta continental é usado para delinear a evolução da fonte crustal em tempos passados por meio da razão inicial ${ }^{176} \mathrm{Lu} /{ }^{177} \mathrm{Hf}$ 
no zircão (ponto 3 nas figs. 2.4A e B) até a interseção com a curva do manto empobrecido (ponto 2 nas figs. 2.4A e B). Novamente o uso de gráficos que utilizam o parâmetro Épsilon Hf na ordenada versus a idade de cristalização na abscissa (fig. 2.4C) fornece informações essenciais no estabelecimento de domínios crustais distintos em um dado segmento da crosta continental.

\subsection{Isótopos de Oxigênio em zircão}

A distinção entre granitóides que possuem assinaturas isotópicas evoluídas derivadas de uma fonte mista entre manto (juvenil) e reciclada (provenientes de rochas metassedimentares) de granitóides provenientes de uma rocha precursora mantélica que se colocou na base da crosta preteritamente é comprometida quando baseada somente em isótopos radiogênicos (e.g Lu-Hf) (Hawkesworth \& Kemp, 2006). Até que ponto idades modelo apontam para as verdadeiras idades de acresção crustal, ou se meramente representam a idade média de residência crustal é ainda um assunto para discussão (Arndt \& Goldstein, 1987). O problema é ainda mais grave para zircões detríticos ou herdados, pois dados de geoquímica isotópica de rocha total e observações de campo não são mais disponíveis.

Essa ambiguidade pode ser reduzida adicionando-se aos dados isótopicos radiogênicos os dados isótopos estáveis, cujo o fracionamento é independente do tempo. A razão ${ }^{16} \mathrm{O} /{ }^{18} \mathrm{O}$, expressa como $\delta^{18} \mathrm{O}$ relativo ao SMOW muda somente em processos superficiais de baixa temperatura e assim o $\delta^{18} \mathrm{O}$ de rochas derivadas do manto $(5.7 \pm 0.3 \%$ ) contrasta com aqueles de rochas que foram submetidas a um ciclo sedimentar ou alteração hidrotermal no assoalho oceânico, que tem valores de $\delta^{18} \mathrm{O}$ elevados (Hawkesworth \& Kemp, 2006). Esse processo é registrado nos zircões de granitóides com altos valores de $\delta^{18} \mathrm{O}$, fazendo dos isótopos de oxigênio um traçador para componentes de reciclagem crustal em granitos.

Estudos empíricos estabeleceram que a difusão de oxigênio no zircão e suficiente para manter o $\delta^{18} \mathrm{O}$ original do magma, mesmo durante o metamorfismo e fusão parcial (King et al., 1998; Peck et al., 2003). Os valores de $\delta^{18} \mathrm{O}$ podem ser medidos in situ no zircão com excelente precisão $(<0.5 \%)$ por sondas iônicas de grande raio com sistema multicoletor (e.g. SIMS) (Valley, 2003).

\subsection{Elementos traços e terras raras (ETR) em zircão}

Devido à configuração eletrônica similar entre os ETR muitos desses elementos obedecem ao mesmo comportamento geoquímico (Hollinson, 1993). Esses elementos possuem geralmente a mesma valência (e.g. $\left.3^{+}\right)$ e ocupam a mesma posição cristalográfica nos minerais que os hospedam. Contudo, o raio iônico destes elementos diminuem sistematicamente em função do seu número atômico desde o La $(0,116 \mathrm{~nm})$ até o Lu $(0,0977 \mathrm{~nm})$ - em coordenação 8 com oxigênio. É justamente esta diferença entre os raios iônicos, que governam as sutis diferenças no comportamento geoquímico destes elementos e que é amplamente explorada pela petrologia (Hanchar \& Westrenen, 2007). Por apresentarem raios iônios relativamente grandes, os ETR são considerados elementos incompatíveis, isto é, eles não substituem facilmente os cátions presentes nos principais minerais formadores de rocha e preferem residir no fundido coexistente. Em contraste, os ETR são geralmente compatíveis com relação aos minerais acessórios das rochas, que se formam nos estágios finais da cristalização do magma (Hanchar \& Westrenen, 2007; Wark \& Miller, 1993). Como resultado, tem-se estabelecido que o balanço dos ETR seja principalmente controlado pelos minerais acessórios ao invés dos minerais formadores de rocha (Wark \& Miller, 1993). Devido ao raio dos elementos terras raras leves (ETRL 
- La até $\mathrm{Gd}$ ) ser maior do que os elementos terras raras pesados (ETRP - Tb até Lu), os primeiros são relativamente mais incompatíveis em relação aos últimos.

No zircão os ETR (p.e. $\mathrm{ETR}^{3+}$ ) substituem o $\mathrm{Zr}^{4+}$ (de raio 0,084 $\eta \mathrm{m}$ ). Para compensar o desequilíbrio de cargas e assegurar a neutralidade do zircão, o elemento pentavalente $\mathrm{P}^{5+}$ é requisitado para a substituição do $\mathrm{Si}^{4+}$, na intitulada substituição da xenotima (e.g. $\left.\mathrm{Zr}^{4+}+\mathrm{Si}^{4+} \rightarrow \mathrm{ETR}^{3+}+\mathrm{P}^{5+}\right)($ Hanchar et al., 2001; Hoskin \& Schaltegger, 2003).

Tanto os zircões naturais quanto os sintéticos são enriquecidos em ETRP em relação aos ETRL, sendo esta uma premissa esperada uma vez que os ETRP têm raios iônicos similares ao $\mathrm{Zr}^{4+}$ (Hanchar \& Westrenen, 2007; Hanchar et al., 2001). Muitas pesquisas têm sido realizadas para quantificar os ETR em zircão e como estes elementos se relacionam com o fundido a partir de qual foram cristalizados. Para estes estudos, a relação da partição dos ETR entre mineral e fundido é utilizado o coeficiente de partição de Nernst $\left(\mathrm{D}_{\mathrm{i}}\right)$ definido por:

$$
\mathrm{D}_{\mathrm{i}} \text { Mineral/Fundido }=\mathrm{C}_{\mathrm{i}} \text { Mineral } / \mathrm{C}_{\mathrm{i}} \text { Fundido }
$$

Onde D é o coeficiente de partição para um elemento $i$ e GMineral e CFundido são as concentrações em porcentagem de peso do elemento $i$ respectivamente no mineral e no fundido (Beatie et al., 1993). Sabendo-se do coeficiente de partição dos ETR no zircão é possível calcular a composição do fundido a partir do qual o zircão foi cristalizado. Esta informação é importante em casos onde o contexto magmático em que o zircão cresceu foi completamente obliterado. Devido à alta resistência do zircão em relação aos principais minerais formadores de rocha, esses minerais acabam sendo a única testemunha de eventos magmáticos antigos. Essa informação geológica pode ser utilizada em estudos de proveniência de rochas metassedimentares combinados com isótopos traçadores de fontes e processos (e.g. Lu-Hf, O) e com a geocronologia U-Th-Pb (Sherer et al., 2007, Cavosie et al., 2008).

\subsection{Conexão entra a idade e padrões ETR em rochas de alto grau: proxies para $\mathrm{P}$ e $\mathrm{T}$}

Grande parte dos zircões metamórficos precipitam a partir de uma fase fluida ou fundida saturada em zircão, incorporando U em sua estrutura. O crescimento do zircão ocorre tanto por meio de dissolução sub-sólida quanto reprecipitação diretamente de um fundido ou fluido metamórfico (McCleland \& Lapen, 3013). O zircão metamórfico geralmente cresce em resposta ao metamorfismo progressivo ou retrógrado ao longo de trajetórias P-T que vão da facies afibolito a eclogito. Texturas de crescimento versus recristalização podem ser reconhecidos em imagens CL. Uma característica importante do zircão é a capacidade de preservar múltiplos domínios que registram eventos metamórficos ao longo da trajetória P-T-t, assim como a historia prémetamórfica do protólito (Rubatto and Hermann 2007).

Mudanças na composição dos elementos traços podem definir se o zircão cresceu sob alta pressão, independentemente de suas inclusões. Zircões da facies eclogito se formam na presença de granada, que preferencialmente sequestra elementos terras raras pesados (ETRP), e em conjunto com a ausência de plagioclásio conferem ao zircão uma assinatura de ETR característica: um padrão plano caracterizado pelo empobrecimento de ETRP e ausência de anomalia negativa de Eu. Essa assinatura distingue-se dos padrões característicos de zircões de protólito ígneo e das assinaturas de zircões precipitados a partir de fundidos formados na trajetória retrógada (Rubatto, 2002). A difusibilidade Ti em zircão funciona como um 
Carlos E. Ganade de Araujo - Tese de Doutorado - Universidade de São Paulo Capitulo 2 - Zircão

termômetro capaz de fornecer temperaturas associadas a formação do zircão (Tomkins et al., 2007). A variação de padrões ETR em conjunto com o conteúdo de Ti é ideal na definição de domínios dentro de zircões para amarração destes com as condições de P-T (e.g. Hermann et al., 2001; Mattinson et al., 2006).

\subsection{Referencias}

Arndt, N.T., Goldstein, S.L., 1987. Use and abuse of crust-formation ages. Geology 15, 893-895.

Beattie, P., Drake, M., Jones, J., Leeman, W., Longhi, J., McKay, G., Nielsen, R., Palme, H., Shaw, D., Takahashi, E., Watson, B., 1993. Terminology for trace-element partitioning. Geochimica et Cosmochimica Acta 57, 1605-1606

Bodet, F., Schärer, U., 2000. Evolution of the SE-Asian continent from U-Pb and Hf isotopes in single grains of zircon and baddeleyite from large rivers. Geochimica et Cosmochimica Acta 64, 2067-2091

Cavosie, A.J., Valley, J.W., Wilde S.A, E.I.M.F, 2006. Correlated microanalysis of zircon: Trace element, $\delta 18 O$, and U$\mathrm{Th}-\mathrm{Pb}$ isotopic constraints on the igneous origin of complex $>3900 \mathrm{Ma}$ detrital grains. Geochimica et Cosmochimica Acta 70, 5601-5616

Compston, W., Pidgeon, R.T., 1986. Jack Hills, evidence of more very old detrital zircon in Western Australia. Nature $321,766-769$

Condie, K.C., Belousova, E., Griffin, W.L., Sircombe K.N., 2009. Granitoid events in space and time: Constraints from igneous and detrital zircon age spectra. Gondwana Research 15, 228-242.

Corfu, F., Hanchar, J.M., Hoskin, P.W., Kinny, P., 2003. Atlas of zircon textures. Reviews in mineralogy and geochemistry 53, 469-500.

Faure, G., Mensing, T., 2005. Isotopes: Principles and applications. Ed. Jhon Willey and Sons, 605p

Froude, D.O., Ireland, T.R., Kinney, P.D., Williams, I.S., Compston, W., 1983. Ion microprobe identification of 4,1004,200 Myr-old terrestrial zircons. Nature 304, 616-618

Hanchar J.M, van Westrenen W., 2007. Rare earth element behavior in zircon-melt systems. Elements 3, 37-42

Hanchar J.M., Finch R.J., Hoskin P.W.O., Watson E.B., Cherniak D.J., Mariano A.N., 2001. Rare earth elements in synthetic zircon: Part 1. Synthesis, and rare earth element and phosphorus doping. American Mineralogist 86, 667-680

Harley, S.L, Kelly, N.M., Andreas Moller, 2007. Ziron Behaviour and the thermal histories of mountain chains. Elements 3, 25-30

Harley, S.L., Kelly, N.M., 2007. Zircon: tiny but timely. Elements 3, 13-18

Harrison, T.M., Blichert-Toft, J., Muller, W., Albarede, F., Holden, P.; Mojzsis, S.J., 2005. Heterogeneous Hadean hafnium: evidence for continental crust at 4.4 to $4.5 \mathrm{Ga}$. Science 310, 1947.1950.

Hawkesworth, G.J., Kemp, A. I. S., 2006. Using hafnium and oxygen isotopes in zircons to unravel the record of crustal evolution. Chemical Geology 226, 144-162.

Hermann, J., Rubatto, D., Korsakov, A., Shatsky, V.S., 2001. Multiple zircon growth during fast exhumation of diamondiferous, deeply subducted continental crust (Kokchetav Massif, Kazakhstan). Contributions to Mineralogy and Petrology 141, 66-82.

Hollinson, H.R. (1993) Using Geochemical Data: Evaluation, Presentation, Interpretation. Ed. Longman Geochemistry, 402p. 
Carlos E. Ganade de Araujo - Tese de Doutorado - Universidade de São Paulo Capítulo 2 - Zircão

Hoskin P.W.O., Schaltegger U., 2003. The composition of zircon and igneous and metamorphic petrogenesis. In: Hanchar J.M., Hoskin P.W.O. (eds) Zircon. Mineralogical Society of America Reviews in Mineralogy \& Geochemistry 53 , pp 27-62

Hoskin, P., 2000. Patterns of chaos: Fractal statistics and the oscillatory chemistry of zircon Geochimica et Cosmochimica Acta 64, 1905-1923.

King, E.W., Valley, J.W., Davis, D.W., Edwards, G.R., 1998. Oxygen isotope ratios of Archaean plutonic zircons from granite-greenstone belts of the Superior Province: indicator of magmatic source. Precambrian Research 92, 47-67.

Liu, F., Gerdes, A, Zeng L., Xue H., 2008. SHRIMP U-Pb dating, trace elements and the Lu-Hf isotope system of coesite-bearing zircon from amphibolite in the SW Sulu UHP terrane, eastern China. Geochimica et Cosmochimica Acta 72, 2973-3000.

Mattinson, G.G., Wooden, J.L., Liou, J.G., Bird, D.K., Wu, G.L., 2006. Age and duration of eclogite-facies metamorphism, North Qaidam HP/UHP terrane, Western China. American Journal of Science 306, 683-711.

McGlelland, W.C., Lapen, T.J. 2013. Linking time to the pressure-temperature path for ultrahigh-pressure rocks. Elements 9, 273-279.

Mueller, P.A., Wooden, J.L., Nutman, A.P., 1992. 3.96 Ga zircons from an Archean quartzite, Beartooth Mountains, Montana. Geology 20, 327-330.

Peck, W.H., Valley, J.W., Graham, C.M., 2003. Slow diffusion rates of O isotopes in igneous zircons from metamorphic rocks. American Mineralogist 88, 1003-1014.

Rubatto, D., 2002. Zircon trace element geochemistry: partitioning with garnet and the link between U-Pb ages and metamorphism. Chemical Geology 184, 123-138.

Rubatto D, Hermann, J., 2007 Zircon behaviour in deeply subducted rocks. Elements 3, 3135

Rubatto, D., Gebauer, D., 1998. Use of cathodoluminescence for U-PB zircon dating by ion microprobe: some examples from theWestern Alps. In: Pagel, M., Barbin, V., Blanc, P., Ohnenstetter, D. (Eds.), Cathodoluminescence in Geosciences. Springer-Verlag, Berlin, pp.

Scherer, E.E., Whitehouse, M.J., Münker, C., 2007. Zircon as a monitor of crustal growth. Elements 3, 19-24

Silva, L.C., 2006. Geocronologia aplicada ao mapeamento regional, com ênfase na técnica U-Pb SHRIMP e ilustrada com estudos de casos brasileiros, SGB-CPRM, 2006, 132 p. (Publicações Especiais do Serviço Geológico do Brasil; 1)

Thirlwall M.F., Walder A.J., 1995. In situ hafnium isotope ratio analysis of zircon by inductively coupled plasma multiple collector mass spectrometry. Chemical Geology 122: 241-247

Tomkins, H.S, Powell, R., Ellis, D.J., 2007. The pressure dependence of the zirconium-in-rutile thermometer. J Metamorph Geol 25, 703-713.

Valley, J.W., 2003. Oxygen isotopes in zircon. In: Hanchar, J.M., Hoskin, P.W.O (eds.) Zircon. Mineralogical Society of America Reviews in Mineralogy and Geochemistry, 53, pp 343-385.

Vermeesch, P., 2006. Comment on Detrital zircon as tracers of sedimentary provenance: limit condition to statistics and numerical simulation. Chemical Geology 226, p. 73

Vermeesch, P., 2004. How many grains are needed for a provenance study? Earth and Planetary Science Letters 224, $441-451$

Wark D.A., Miller C.F., 1993. Accessory mineral behavior during differentiation of a granite suite: monazite, xenotime and zircon in the Sweetwater Wash pluton, southeastern California, U.S.A. Chemical Geology 110, 49-67

Wetherill G.W., 1956. Discordant uranium-lead ages, I. Transactions of the American Geophysical Union 37: $320-326$ 


\section{Contexto Geológico}

\subsection{Orógeno Gondwana Oeste}

Como explicitado no capítulo introdutório, sugeriu-se aqui chamar de Orógeno Gondwana Oeste todos as áreas orogenéticas Pan-africanas/Brasilianas alinhadas ao longo do Lineamento Transbrasiliano-Kandi. Este orógeno foi resultante do consumo e fechamento do Oceano Goiás-Farusiano (Caby, 2003; Kroner and Cordani, 2003), que culminou na colisão continental envolvendo os crátons Amazônico/Oeste África, São Francisco-Congo e o metacráton Saara.

O Orógeno registra em toda sua extensão um longo período de convergência (> que 400 m.y) com o desenvolvimento de diversos arcos intraoceânicos e continentais que são hoje observados dentro da zona colisional fóssil profundamente erodida (Pimentel and Fuck, 1992; Caby, 2003; Berger et al., 2011; Ganade de Araujo et al., 2012). As principais assembleias petrotectônicas entre as regiões cratônicas envolvidas na colisão são representadas por margens passivas, arcos juvenis, arcos continentais tardios e sequencias sin-orogênicas. Os detritos da erosão das montanhas resultantes da colisão no orógeno estão hoje documentadas em bacias molássicas e do tipo foreland, e o final da atividade orogenética é datado em ca. 540-500 Ma com base nos granitoides pós-colisionais dispostos ao longo do orógeno (Affaton et al., 2000; Caby, 2003; Pimentel et al., 2011; Ganade de Araujo et al., 2012).

Neste capítulo serão apresentados as características geológicas de um setor importante do Orógeno Gondwana Oeste, particularmente no Domínio Ceara Central da Província Borborema, onde se concentraram as investigações desta pesquisa.

\subsection{A Província Borborema}

A província Borborema Setentrional (fig. 3.1) situa-se a norte do Lineamento Patos e é subdividida por Delgado et al. (2003) entre os domínios Médio Coreaú, Ceará Central e Rio Grande do Norte. Alguns autores dividem o Domínio Rio Grande do Norte entre os Domínios Jaguaribeano, Rio Piranhas e Caldas Brandão (ver fig. 3.1). Abaixo serão descritos em maior detalhe o Domínios Ceará Central e Médio Coreaú, que abrangem a área física desta pesquisa.

\subsubsection{Domínio Médio Coreaú}

Este domínio (DMC) é marcado por um intenso sistema de zonas de cisalhamento SW-NE desenvolvidas em regime compressivo-transpressivo relacionados ao sistema cisalhante Transbrasiliano (Lineamento Transbrasiliano) que separa este do domínio do Ceará Central, a sudoeste. Em termos tectono-estratigráficos DMC compreende o Complexo Granja além da faixa de supracrustais Martinópole-Ubajara tidas com seqüências vulcanossedimentares e metassedimentares marginais ao cráton São Luiz-Oeste Africano.

O Complexo Granja é apresentado como "embasamento" da faixa supracrustal Martinópole-Ubajara e compreende gnaisses para- e ortoderivados, em parte migmatíticos, de fácies anfibolito a granulito, além de ortognaisses de afinidade TTG. 
Carlos E. Ganade de Araujo - Tese de Doutorado - Universidade de São Paulo Capítulo 3 - Contexto Geológico
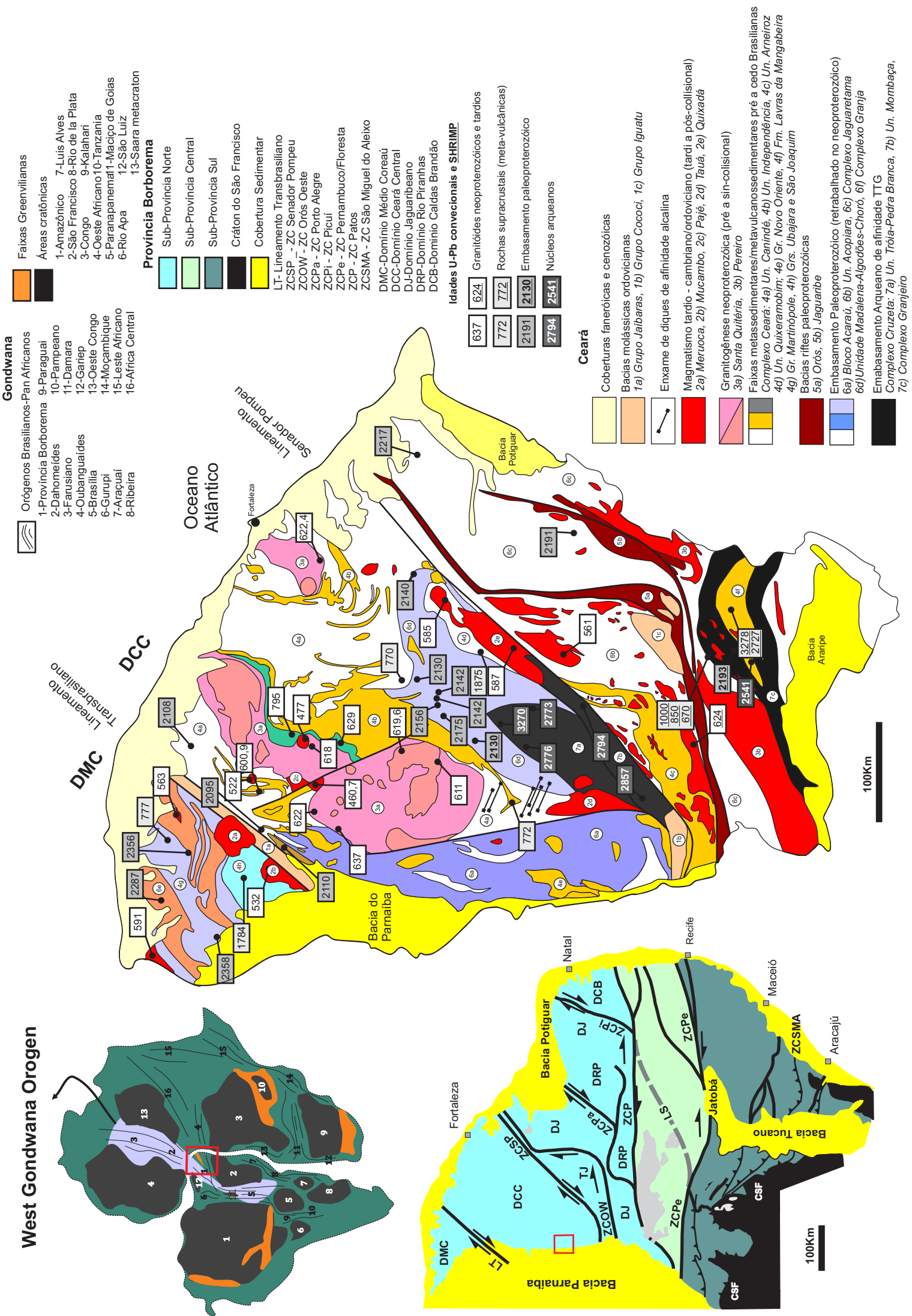

Figura 3.1 - Contexto geológico da área de estudo (a partir de De Wit et al., 2008, Cavalcante, 1999; Delgado et al., 2003; Cavalcante et al., 2003), compilação geocronológica baseada em Osako et al. (2008). 
Fetter et al. (1997) reportam idades U-Pb em kondalitos de ca. 2,28 Ga. Santos et al. (2008) sugere uma crosta juvenil gerada em ambiente de arco entre 2,3-2,5 Ga, com posterior retrabalhamento crustal no Paleoproterozóico e Neoproterozóico. Idades Ar-Ar e U-Pb em titanita vinculadas ao evento termotectônico do Neoproterozóico estão distribuídas entre 0,575 e 0,554 Ga (Caby et al., 1995).

A faixa supracrustal Martinópole-Ubajara engloba seqüências de margem passiva, com deposição entre 0,775 e 0,808 Ga e metamorfismo estimado com base em idade U-Pb em titanita em ca. 0.650 Ga (Fetter, 1999). O grupo Martinópole abrange as Formações: 1) Goiabera composta de xistos aluminosos, quartzitos ferríferos e subordindamente paragnaisses; 2) São Joaquim, compostas de quartzitos, metacalcários e metavulcânicas intercaladas; 3) Covão e Santa Terezinha que comprende um conjunto carbonato-psamítico-pelítico de baixo grau metamórfico, com evidencias de glaciação (?). A posição estratigráfica interna deste contexto ainda não está perfeitamente estabelecida e, portanto, não deve ser tomada como o verdadeiro empilhamento estratigráfico. Fetter et al., 1997 estabeleceram uma idade neoproterozóica de deposição entre 0,775-0,810 $\mathrm{Ga}$, com base em determinações U-Pb em derrames ácidos intercalados nesta seqüência. O grupo Ubajara correspondente à unidade superior, de ambiente fluvio-marinho, contendo rochas metassedimentares clastopelíticas da Formação Trapiá e Caiçaras, com importante contribuição carbonática pertencentes à Formação Frecherinha, a qual se sobrepõe uma recorrência clastopelítica da Formação Coreaú.

\subsubsection{O Domínio Ceará Central}

O presente conhecimento permite a divisão deste domínio (figs. 3.1) entre três unidades cronológicas distintas, sendo estas: (1) Associações/núcleos arquenos e embasamento paleoproterozóico e; (2) Supracrustais de idade proterozóica indefinida a neoproterozóicas; e (3) Complexos granito-migmatíticos de idade neoproterozóica, bem como uma série de corpos granitóides pós-colisionias a anorogênicos de idade predominantemente cambriana para o primeiro grupo e ordoviciana para o ultimo.

\subsubsection{Registro arqueano e associações do embasamento paleoproterozóico}

A divisão litoestratigráfica entre o registro arqueano e as associações paleoproterozóicas ainda esbarra em certo desentendimento, principlamente pela falta de estudos geocronológicos e isotópicos.

As primeiras denominações para os terrenos arqueanos e das associações paleoproterozóicas deste segmento do Domínio Ceará Central foram designadas por Brito Neves (1975) para o Maciço Tróia-Tauá dividido pela zona de cisalhamento Sabonete-Inharé entre os Blocos Mombaça (gnaisses granulíticos do tipo TTG) a sudeste, e Tróia-Pedra Branca (associação do tipo granito greenstone belt) a noroeste.

Oliveira e Cavalcante (1993) inserem essas rochas dentro do Complexo Cruzeta (unidades 7a e 7b na legenda da figura 3.1), e dividem o mesmo em quatro unidades: 1) Tróia: seqüência metaplutonovulcanossedimentar; 2) Pedra Branca: ortognaisses cinzentos TTG; 3) Mombaça: gnaisses diversos e migmatitos com lentes de metacalcários, anfibolitos, rochas cálcio-silicáticas e metaultrabásicas; 4) Cedro: metaleucogranitóides tabulares encaixados segundo a superfície tectono-metamórfica regional.

Delgado et al. (2003) referem-se ao Bloco Tróia-Pedra Branca para as rochas deste contexto, e inserem-nas como parte integrante do Complexo Cruzeta, que é dividido entre as unidades Tróia, Pedra Branca, Mombaça e Algodões, incluindo a Suíte Cedro e Madalena. 
A unidade Tróia compreende uma associação do tipo greenstone belt, composta por metabasaltos, metagabros, metadacitos, metariolitos intercalados com quartzito, grafita xistos, metacalcários, metachert e formações ferríferas bandadas. Sheets intrusivos nesta unidade compostos de ortognaisses de composição tonalíticagranodiorítica e leucogranítica da Suíte Cedro forneceram uma idade U-Pb de 2,77 Ga e idades modelo $\mathrm{T}_{\mathrm{DM}}$ entre 2,92 e 3,04 (Fetter, 1999).

A unidade Pedra Branca que ocorre em associação próxima com a unidade Tróia é composta de ortognaisses de afinidade TTG, com idade U-Pb entre 2,77 e 2,85 (Fetter, 1999). Entretanto, Silva et al. (2002) demonstraram a ocorrência de um evento do Mesoarqueno por meio de analise SHRIMP, em zircões de gnaisses tonalíticos situados a SW de Boa Viagem. A análise revelou um núcleo mais antigo datado de 3,27 Ga e uma borda sobrecrescida datada de 2,08 Ga. Ainda, retrabalhamentos do neoproterozóico $(\sim 0,57 \mathrm{Ga})$ foram registrados por Monié et al. (1997) e Fetter (1999) respectivamente, pelos métodos Ar-Ar e U-Pb em monazita.

A unidade Mombaça é formada por ortognaisses diversos, migmatitos e rochas paraderivadas em alto grau metamórfico e distingui-se da unidade Pedra Branca por envolver um maior grau de retrabalhamento (Delgado et al., 2003).

A unidade Algodões (unidade 6d na legenda da figura 3.1) é composta por uma associação de rochas metassedimentares, metabásicas, e ortognaisses tonalíticos a granodioríticos, de idade U-Pb entre 2,13 e 2,33 Ga e idades modelo $\mathrm{T}_{\mathrm{DM}}$ entre 2,24 e 2,44 (Martins, 2000). Estas rochas ocorrem emoldurando o Complexo Cruzeta em seu limite noroeste e oeste (Arthaud, 2007).

A Suíte Madalena (Castro, 2004) é uma associação de quartzo-diorito e diques microdioríticos que cortam o Complexo Cruzeta. Essas rochas mostram fraca deformação e não são migmatizadas. Idades U-Pb em zircão variam em torno de 2,15 e 2,2 Ga (Castro, 2004) para as rochas deste contexto.

Dentro do âmbito do Paleoproterozóico ocorrem ainda no Domínio Ceará Central uma série de associações gnáissicas migmatíticas, carentes de mapeamento geológico e de estudos geocronológicos, designadas como embasamento das supracrustais neoproterozóicas. Estas associações compreendem ortognaisses de composição tonalítica a granodiorítica, geralmente metamorfizados em fácies anfibolito de alta temperatura com condições variáveis de migmatização e rara contraparte sedimentar (Cavalcante et al., 2003). Idades U$\mathrm{Pb}$ para essa associação caem entre 2,11 e 2,19 Ga com idades modelo $\mathrm{T}_{\mathrm{DM}}$ entre 2,42 e 2,48 Ga (Hackspacher et al., 1990; Fetter, 1999; Castro, 2004).

\subsubsection{Supracrustais de idade proterozóica (neoproterozóica?)}

As seqüências supracrustais proterozóicas são representadas pelas rochas metassedimentares do Complexo Ceará (unidades 4a, b, c e d na legenda da figura 1C), o qual abriga as unidades Canindé, Independência, Quixeramobim e Arneiroz (Cavalcante et al., 2003). Essas seqüências ocorrem nas adjacências do Complexo granito-migmatítico Tamboril Santa Quitéria, e apresentam paragênese de moderada a alta temperatura, característica do fácies anfibolito alto a granulito, localmente com relictos de paragênese eclogítica, combinado com um conspícuo bandamento tectônico de baixo ângulo. No Bloco ou Sub Dominío Acaraú (unidade 6a na legenda da figura 3.1) as rochas supracrustais do Grupo Novo Oriente (unidade 4e na legenda da figura 3.1) representam um segmento de uma margem passiva [com idade máxima de 1,36 Ga, 
(Ferreira et al., 2008)] com provável evolução para condições oceânicas francas que foi subsequentemente acrecionada durante a colisão neoproterozóica (Ganade de Araújo et al., 2010a).

De um modo geral, a associação sedimentar original do Complexo Ceará abarca largos tratos psamíticos, psamo-pelíticos e pelíticos, associados ou não a sedimentação química. Ocorrências de anfibolitos representam provavelmente o magmatismo básico sin-sedimentar associado à deposição destes sedimentos (Castro, 2004, Arthaud, 2007). Recentemente, alguns estudos termobarométricos realizados sobre esses anfibolitos granatíferos indicaram registros de condições eclogíticas (Castro, 2004; Garcia, 2006, Santos et al., 2009). Sob uma óptica preliminar, o posicionamento geográfico dessas rochas de alta pressão ocorre emoldurando o Complexo Tamboril Santa Quitéria.

Em termos estruturais, essas seqüências foram fortemente afetadas pelo evento tectono-termal associado à colisão Brasiliana-Pan Africana, que materializou nestas rochas um bandamento tectônico de baixo ângulo, que levaram Caby e Arthaud (1986) a interpretarem a presença de extensas nappes neoproterozóicas com vergência geral para sul, na região a leste do Complexo Tamboril Santa Quitéria. Na região oeste deste complexo, nas proximidades de Sobral, o bandamento tectônico de baixo ângulo evolui e é posteriormente truncado por um sistema de zonas de cisalhamentos transcorrentes dextrais integrante do sistema cisalhante Transbrasiliano, evidenciando uma mudança no regime tectônico, provavelmente associado ao escape lateral nos estágios finais da colisão continental (Ganade de Araújo \& Santos, 2007, Gunha, 2007).

Os primeiros marcos geocronológicos acerca da idade da deposição dos detritos que compõem o Complexo Ceará foram obtidos por Fetter (1999), que obteve uma idade U-Pb de 0,77 Ga derivada de ortognaisses interpretados como derrames ácidos sin-sedimentares, encontrado próximo à localidade de Independência. Castro (2004) reporta uma idade U-Pb semelhante de $c a$. 0,70 Ga para rochas similares na região de Itataia. Recentemente, estudos pioneiros de proveniência realizados por Arthaud (2007) na região de Itatira, assinalaram três populações de zircões detríticos distintas com aglomerados de idades em torno de $0,8 \mathrm{Ga}$ (quatro zircões); 1,0 a 1,2 Ga e diversos zircões em torno de 1,85 Ga. O mesmo autor interpreta as idades em zircões detríticos em torno de $0,8 \mathrm{Ga}$, em conjunto com uma idade $\mathrm{U}-\mathrm{Pb}$ de $0,749 \mathrm{Ga}$ obtida em granada anfibolitos, interpretados como magmas básicos sin-sedimentares, como sendo a idade da deposição do Complexo Ceará, dada em um ambiente extensional sobre um embasamento arqueano/paleoproterozóico. Entretanto, o comportamento dos isótopos de Nd (Castro, 2004; Arthaud, 2007) indica que a maior parte da sedimentação foi oriunda da erosão das litologias paleoproterozóicas e provavelmente com subordinada contribuição arqueana. A falta de idades entre 2,0-2,2 Ga e 2,7-2,8 Ga no espectro de zircões detríticos no estudo de Arthaud (2007), característico do embasamento adjacente, aponta que é necessário entender o Complexo Ceará em termos de diversos ciclos deposicionais (e.g. sobreposição de bacias) associados respectivamente com o ambiente tectônico vigente para um dado segmento do espaço-tempo (e.g. bacias mais antigas paleo a mesoproterozóicas [?] vs. bacias brasilianas marginais possivelmente associadas a ambiente de arco). Amaral et al. (2008) reportam uma idade U-Pb/Lu-Hf de ca. 1,56 Ga, interpretada como a idade de cristalização de granada anfibolitos inseridos nas rochas metassedimentares do complexo, contudo a validade deste dado na demarcação de um evento termo-tectônico amplo desta idade ainda carece de melhor sustentação. Ainda, a estruturação proposta por Arthaud e Caby (1986), pode justapor por meio de um sistema de nappes em uma tectônica thick-skinned, onde o embasamento é afetado, conjuntos de rochas metassedimentares mais antigas (e.g. meso-paleoproterozóicos) com mais novas (e.g. brasilianas), separadas por zonas de cisalhamento de baixo ângulo, cartograficamente indistinguíveis entre si devido à forte impressão termo-tectônica da colisão Brasiliana-Pan Africana. Neste sentido, visando o melhor esclarecimento deste contexto estudos isotópicos aplicados à cartografia geológica devem ser realizados com mais freqüência. 


\subsubsection{0 Complexo granito-migmatítico neoproterozóico Tamboril Santa-Quitéria}

O Complexo Tamboril Santa Quitéria (Cavalcante et al., 2003) está alinhado segundo a direção NE-SW, cobrindo uma área de $40.000 \mathrm{~km}^{2}$ e representa significante parte dos complexos granitóides do Domínio Ceará Central. Este complexo consiste de um conjunto litológico que abrange gnaisses metatexíticos e diatexíticos, no sentido de Sawyer (2008) que variam de composição diorítica a granítica. Esparsos corpos de granitóides porfiríticos a equigranulares, mostrando claras relações intrusivas sobre os metatexitos e diatexitos e composição predominantemente granodiorítica a granítica, atestam que diversos pulsos magmáticos foram envolvidos no desenvolvimento deste complexo.

Fetter et al. (2003), vem interpretando o complexo como uma bem desenvolvida suíte magmática originada em ambiente de arco continental, com sucessivos episódios magmáticos, ativos durante o neoproterozóico.

Datações U-Pb realizadas por Fetter (1999) geraram idades entre 0,637 e 0,623 Ga para os granitóides deformados do Complexo Tamboril-Santa Quitéria, e ainda idades modelo $\left(T_{\mathrm{DM}}\right.$ ) variando entre 0,86 a 1,92 $\mathrm{Ga}$, com Épsilon Nd (600 Ma) variando entre -20 a +4 , sugerindo uma fonte mista para a origem dos granitóides. Castro (2004) obteve idades U-Pb similares para estas rochas, variando entre 0,620 a 0,611 Ma. Brito Neves et al. (2003) reportam uma idade de 0,660 Ma para um granitóide inserido neste complexo. Uma idade de 0,795 Ga (Epsilon Nd (800 Ma) $=+4,4)$, foi obtida pelo método Pb-Pb em zircão de ortognaisse tonalítico a granodiorítico da borda leste do Complexo Tamboril-Santa Quitéria, atestando para a contribuição de material juvenil em torno de 0,8 Ga (Ganade de Araujo et al., 2010b).

A descoberta de retroeclogitos por Castro (2004) levou a uma interpretação divergente da discutida por Fetter (2003), em relação à posição da zona de subducção que teria dado origem ao Complexo Tamboril Santa Quitéria. Com base no posicionamento geográfico desses retroeclogitos (a oeste do complexo), Castro (2004), sugere um sentido noroeste para o fechamento oceânico, já Fetter (2003), baseado na posição atual do Batólito e por anomalias gravimétricas positivas (Lesquer et al., 1984) propõem um sentido sudeste para o processo de subducção. Novos dados termobarométricos de Santos et al. (2009), em rochas eclogíticas a oeste do Complexo Tamboril Santa Quitéria reforçam a teoria de uma subducção para leste-sudeste. O panorama atual mostra que estas rochas de alta pressão ocorrem ao redor do Complexo Tamboril Santa Quitéria, sugerindo que o processo colisional pode ter envolvido zonas de alta pressão em ambos os lados do Complexo Tamboril-Santa Quitéria em uma espécie de extrusão tectônica vertical, similares a estruturas de flores positivas. Alternativamente, modelos envolvendo duas ou mais subducções próximas também podem ser empregados a exemplo do modelo proposto por Caby (2003) na evolução neoproterozóica do escudo Hoggar no centro africano. Este mesmo autor (com. pess.) acredita que o Complexo Tamboril Santa Quitéria (independentemente de sua natureza) trata-se de uma unidade alóctone, e, portanto, qualquer esforço atribuído à construção crustal desta região com base nos elementos associados ao arco magmático de Santa Quitéria (e.g. subducção a leste ou oeste da presente posição arco, bacias marginais de forearc, foredeep e/ ou back arc, prismas acrecionários) deve-se levar em consideração a aloctonia do mesmo.

\subsubsection{Granitogenese pós-colisional}

Adicionalmente, deve ser ressaltado a granitogênese de idade próxima, mas, no entanto, mais jovem que as porções integrantes do Complexo Tamboril Santa Quitéria. O primeiro deles representado pelas suíte Quixadá-Quixeramobim, com idades U-Pb de 0,585 Ga (Almeida, 1999), e granitóide Chaval (no Domínio 
Médio Coreaú) com idade U-Pb em monazita de 0,591 Ga (Fetter, 1999). O segundo, e mais jovem episódio, é representado por uma série de corpos, no qual se destacam os corpos Mucambo, Meruoca, Barriga, Pagé, Serrote São Paulo e Complexo Anelar Quintas com idades U-Pb variando entre 0,530 a 0,480 Ga (Castro, 2004, Fetter, 1999). A inter-relação do ponto de vista tectônico entre esses episódios magmáticos ainda foi pouco explorada (e.g. Ganade de Araujo, 2008, 2011) carecendo ainda de mais dados geocronológicos e do emprego de técnicas traçadoras de fontes e processos, possibilitando uma melhor analise dos processos tectônicos relacionados à geração destes magmas e bem como a historia pós-colisional da cadeia.

\subsubsection{Calhas tardi-brasilianas e o início da sedimentação da Bacia do Parnaíba}

Após a colisão neoproterozóica um sistema extensional instalado preferencialmente sobre as zonas de cisalhamento tardias do escape colisional (Sistema Transbrasiliano), representados pelos riftes Jaíbaras, Jaguapari, Cococi, São Julião e Raimundo Nonato sugere um período de colapso orogenético. Este episódio foi acompanhado de magmatismo, já mencionado acima, que compreende corpos intrusivos com idades variando entre 0,53 a 0,48 Ga, assim como vulcanismo representado pelo enxame de diques Coreaú e pela Suíte de sills e diques Parapuí. Subseqüentemente a este estágio mecânico, inicia-se a fase termal de subsidência, em que se inicia a sedimentação da bacia intracratônica do Parnaíba (Oliveira \& Mohriak, 2003).

O preenchimento dessas calhas extensionais inicia-se com depósitos caracterizados por rápidas variações na espessura e mudança de fácies, associados a espessos pacotes conglomeráticos e conformidades locais e inconformidades de variada extensão (Abreu et al., 1993 Oliveira \& Mohriak, 2003). A calha de Jaíbaras apresenta a melhor exposição desta sedimentação e é organizada estratigraficamente da base para o topo nas Formações Massapê, Pacujá e Aprasível.

A Formação Massapé é caracterizada por conglomerados polimíticos clasto-suportados e arenitos de granulação grossa associados à debris flowes e mudflowes depositados em leques aluviais, localmente restritos a limites de falhas (Oliveira \& Mohriak, 2003). A Formacao Pacujá representa a parte distal da Formação Massapé (Gorayeb et al., 1988) e consiste em arenitos, siltitos e folhelhos. A seqüência superior consiste de conglomerados polimíticos que difere daqueles basais por apresentarem fragmentos clásticos de rochas vulcânica e intrusivas (Oliveira \& Mohriak, 2003). A atividade magmática crono-correlata ao preenchimento sedimentar desta bacia esta representada por quatro eventos. O enxame de diques Coreaú é caracterizado por diques de direção ENE-WNW de composição riolítica-dacítica de textura porfirítica. Os Plutons Mucambo e Meruoca respectivamente com idades de 0,532 Ga (U-Pb) e 0,507 Ga (Rb-Sr) (Fetter, 1999; Sial \& Long, 1981) exibem contatos intrusivos e causam auréolas de contato sobre o conteúdo sedimentar da calha Jaíbaras. A suíte Parapuí com idade mínima ordoviciana é composta de andesitos, riolitos, syenitos, basaltos andesíticos e vulcanoclásticas que localmente podem chegar a 350 m de espessura (Oliveira \& Mohriak, 2003).

A fase de subsidência termal na Bacia do Parnaíba inicia-se no Siluriano com a deposição das seqüências basais do Grupo Serra Grande, provavelmente a partir de detritos oriundos do desmonte da cadeia neoproterozóia. Este grupo engloba as Formações Ipu, Tianguá e Jaicós onde Góes e Feijó (1994) interpretam que esses pacotes foram depositados em ambientes fluvio-glacial e glacial, passando a transicional marinho e retornando as condições continentais. A área de ocorrência do pacote sedimentar do Grupo Serra Grande delimita a bacia em seus flancos nordeste, leste e sudeste. Apresenta uma notável quebra no relevo regional com característica morfológica de cuestas. As maiores espessuras estão situadas a nordeste, particularmente sobre o sistema de zonas de cisalhamento Transbrasiliana, com adelgaçamento em direção a sul e sudeste (Santos \& Carvalho, 2004). 
Carlos E. Ganade de Araujo - Tese de Doutorado - Universidade de São Paulo Capítulo 3 - Contexto Geológico

A geocronologia dessas bacias é baseada essencialmente em determinações Rb-Sr em rochas vulcânicas, portanto, ainda não se encontra bem definida. Parente et al. (2004) sugere um intervalo entre 0,56-0,53 Ga para a deposição da seqüência inferior e 0,53-0,44 Ga para a seqüência superior.

\subsection{Referencias}

Abreu, F.A.M, Hasui, Y., Gorayeb, P.S.S., 1993. Grabéns eopaleozóicos do oeste cearense: considerações sobre as seqüências lito-estratigraficas. In: XXXVII Congresso Brasileiro de Geologia, São Paulo, 1, p.300-301

Almeida, A.R., Ulbrich, H.H.G.J., McReath, I., 1999. O Batólito Quixadá Petrologia e Geoquímica, Revista de Geologia 12, 29-52.

Amaral, W.S., Santos T.J.S, Matteini, M., Dantas, E.L., 2008. U-Pb e Lu-Hf por LA-ICPMS em zircão de rochas metabásicas Mesoproterozóicas da região de Forquilha (CE), NW da Província Borborema. In: $44^{\circ}$ Congresso Brasileiro de Geologia, Guritiba, Anais

Arthaud, M.H., 2007. Evolução Neoproterozóica do Grupo Ceará (Domínio Ceará Central, NE Brasil): da sedimentação à colisão continental brasiliana. Inst. de Geociências, Universidade de Brasília, Brasília, Tese de Doutoramento, 170.

Berger, J., Caby, R., Liégeois, J.P., Mercier, J-C C., Demaiffe, D., 2011. Deep inside a Neoproterozoic intra-oceanic arc: growth, differentiation and exhumation of the Amalaoulaou Complex (Gourma, Mali). Contributions to Mineralogy and Petrology 162, 773-796.

Brito Neves, B.B. de., 1975. Regionalização geotectônica do Précambriano nordestino. Inst. Geociências, Universidade de São Paulo, São Paulo, Tese de Doutoramento, 198 p.

Caby, R., 2003. Terrane assembly and geodynamic evolution of central-western Hog- gar: a synthesis. Journal of African Earth Sciences 37, 133-159.

Caby, R., Arthaud, M.H., 1986. Major Precambrian nappes of the Brazilian belt, Ceará, northeast Brazil. Geology, $14: 871-874$

Caby, R., Arthaud, M.H., Archanjo, G.J., 1995. Lithostratigraphy and petrostructural characterization of supracrustal units in the Brasiliano Belt of Northeast Brazil: geodynamic implications. Journal of South American Earth Sciences 8, 235-246.

Castro, N.A., 2004. Evolução Geológica Proterozóica da região entre Madalena e Taperuaba, Domínio Tectônico Geará Central (Província Borborema). Instituto de Geociências. Universidade de São Paulo - Tese de Doutoramento, 221 p.

Cavalcante, J.C., 1999. Limites e evolução do Sistema Jaguaribeano, Província Borborema, Nordeste do Brasil. Dissertação de mestrado, Universidade Federal do Rio Grande do Norte, Natal 183p.

Cavalcante, J.C., Vasconcelos, A.M., Medeiros, M.F., Paiva, I.P., Gomes, F.E.M., Cavalcante, S.N., Cavalcante, J.E., Melo, A.C.R., Duarte Neto, V.C., Bevenides, H.C., 2003. Mapa Geológico do Estado do Ceará - Escala 1:500.000. Fortaleza, Ministério de Minas e Energia/Companhia de Pesquisa de Recursos Minerais.

Cunha, F.S.S da, 2007. Condicionamento Estrutural das zonas de Cisalhamento da Regiao de Forquilha, Domínio Ceará Central: Uma Abordagem Integrada de Sensoriamento Remoto e Geologia Estrutural, Tese de Doutoramento, Universidade Federal do Rio Grande do Norte, Natal. 190p.

Ganade de Araújo G.E.G., Pineo, T.R.G., Caby, R., Costa, F.G, Cavalcante, J.C., Vasconcelos, A.M., Rodrigues, J.B., 2010a. Provenance of the Novo Oriente Group, southwestern Ceará Central Domain, Borborema Province (NE-Brazil): A dismembered segment of a magma-poor passive margin or a restricted rift-related basin? Gondwana Research.

Ganade de Araújo, G.E.G, 2008a. Are orogenic (subduction-related) and anorogenic (intraplate-like) magmatism all part of the same episode? Some insights from Ceará State, NE Brazil. In: 44 Congresso Brasileiro de Geologia, Curitiba, Anais 
Carlos E. Ganade de Araujo - Tese de Doutorado - Universidade de São Paulo Capítulo 3 - Contexto Geológico

Ganade de Araújo, C.E.G, Santos, T.S. dos, 2008b. Does the Neoproterozoic - Early Cambrian Transbrasiliano Lithospheric Shear System Delineates a Collisional Suture Trace in South America? In: $33^{\circ}$ International Geological Congress, Oslo, GD-ROM.

Ganade de Araujo, G.E.G, Santos, T.S., 2007. Transition from Compressive to Transpressive Tectonics at the Northwestern Limito of the Santa Quitéria Magmatic Arc, Region of Forquilha, Ceará, NE Brazil. Simpósio Nacional de Estudos Tectonicos, Natal, Anais, p.231.

Ganade de Araujo, G.E.G., Costa, F.G., Palheta, E.S.M., Cavalcante, J.C., Vasconcelos, A.M., Moura, G.A.V., 2010b. ${ }^{207} \mathrm{~Pb} /{ }^{206} \mathrm{~Pb}$ zircon ages of pre- and syn collisional granitoids from the Tamboril-Santa Quiteria granitic-migmatitic Complex, Ceará Central Domain, Borborema Province (NE-Brazil): Geodynamic implications. In: VII South American Symposium on Isotope Geology, Brasília, 2010.

Ganade de Araujo, C.E., Cordani, U.G., Basei, M.A.S., Castro, N.A., Sato, K., Sproesser, W.M., 2012.U-Pb detrital zircon provenance of metasedimentary rocks from the Ceará Central and Médio Coreaú domains, Borborema Province, NE-Brazil: Tectonic implications for a long-lived Neoproterozoic active continental margin. Precambrian Research 206207, 36-51.

Ganade de Araujo, G.E.G., 2011. A synthesis of the Neoproterozoic to Ordovician granitoid record from Ceará Central Domain, Borborema Province, NE-Brazil: precollision, collision and mountain belt collapse to a sedimentary basin development. In: 7th Hutton Symposium on Granites and Related Rocks, 2011, Avila, Spain

De Wit, M.J., Brito Neves, B.B., Trouw, R.A.J., Pankhurst, R.J., 2008a. Pre-Cenozoic correlations across the South Atlantic region: "the ties that bind" In: Pankhurst, R. J.; Trouw, R. A. J., Brito Neves, B. B., De Wit, M. J. (eds) West Gondwana: Pre-Cenozoic Correlations Across the Atlantic Region. Geological Society, London, special Publications, p. 294, 1-8.

Delgado, I. de M. et.al., 2003. Geotectônica do Escudo Atlântico. In: Bizzi, L.A., Schobbenhaus, G.; Vidotti, R.M., Gonçalves J.H. (eds). Geologia, Tectonica e Recursos Minerais do Brasil. Ministério de Minas e Energias. Serviço Geológico do Brasil - CPRM.

Ferreira, I.G., 2008. Aspectos geológicos, estruturais e geocronológicos da Seqüência Metavulcano-Sedimentar de Novo Oriente-GE. Dissertação de Mestrado, Universidade Federal do Ceará, 103p.

Fetter, A.H., 1999. U/Pb and $\mathrm{Sm} / \mathrm{Nd}$ geochronological constraints on the crustal framework and geologic history of Ceará State, NW Borborema Province, NE Brazil: implications for the assembly of Gondwana. Ph.D. Thesis, Departament of Geology, Kansas University, Lawrence, KS - USA, 164p.

Fetter, A.H., Van Schmus, W.R., Santos, T.J.S. dos; Arthaud, M., Nogueira Neto, J.A. 1997. Geocronologia e estruturação do estado do Ceará: NW da Província Borborema, NE Brasil. In: SBG/Núcleo Nordeste, Simpósio de Geologia do Nordeste, 17, Fortaleza, Boletim n ${ }^{\circ}$ 15,32-33.

Garcia, M.G.M., Arthaud, M.H., Santos T.J.S., Nogueira Neto, J.A., 2006. Retroeclogitos nas nappes brasilianas do Domínio Ceará Central, Província Borborema: dados texturais e termobarométricos preliminares. $43^{\circ}$ Congresso Brasileiro de Geologia. Anais. p.23

Góes, A.M.O., Feijó, F.J., 1994. Bacia do Parnaíba. Boletim de Geociências da Petrobrás 8, 57-67.

Gorayeb, P.S.S., Abreu, F.A.M., Correa, J.A.M, Moura, G.A.V., 1998. Relações estratigráficas entre o Granito Meruoca e a sequencia Ubajara-Jaibaras. In: XXXV Congresso Brasileiro de Geologia, Belém, 6, p.2678-2688

Hackspacher, P.G.; Van Schmus, W.R.; Dantas, E.L., 1990. Um embasamento Transamazônico na Província Borborema. Congresso Brasileiro de Geologia, 36, Natal - Anais, v.6, p.683-2696.

Kröner, A., Cordani, U., 2003. African, southern Indian and South American cratons were not part of the Rodinia supercontinent: evidence from field relationships and geochronology. Tectonophysics 375, 325-352.

Lesquer, A., Beltrao, J.F., De Abreu, F.A.M., 1984. Proterozoic links between northeastern Brazil and West Africa: a plate tectonic model based on gravity data. Tectonophysics 110, 9-26.

Martins, G., 2000. Litogeoquímica e controles geocronológicos da Suíte Metamórfica Algodões - Choró. Tese de Mestrado, Instituto de Geociências - Universidade Estadual de Campinas. 218p. 
Carlos E. Ganade de Araujo - Tese de Doutorado - Universidade de São Paulo

Capítulo 3 - Contexto Geológico

Monié, P., Caby, R., Arthaud, M.H., 1997. The Neoproterozoic Brasiliano orogeny in northeast Brazil: 40Ar/39Ar and petrostructural data from Ceará. Precambrian Research 81, 241-264.

Oliveira J.F, Gavalcante, J.C., 1993. Programa Levantamentos Geológicos Básicos do Brasil; Mombaça, Folha SB.24-VD-V, Estado do Ceará, Escala 1:100.000, Texto Explicativo. Brasília DNPM/CPRM, 195p.

Oliveira, D.C. Mohriak, W.U., 2003. Jaibaras trough: an important element in the early tectonic evolution of the Parnaíba interior sag basin, Northern Brazil. Marine and Petroleum Geology 20, 351-383.

Osako, L.S., Castro, N.A., Basei, M.A.S., 2008. Isotopic Database of the Ceará State: Initial Analysis in a Geographic Information System. In: VI South American Symposium on Isotope Geology, San Carlos de Bariloche, p. 1-4.

Parente, G.V., Silva Filho, W.F., Almeida A.R., 2004. Bacias do Estágio da Transicão do Domínio Setentrional da Província Borborema. In: Mantesso-Neto, V., Bartorelli, A., Carneiro, C. D. R., Brito Neves, B. B. (Ed.). Geologia do Continente Sul-Americano: Evolução da obra de Fernando Flávio Marques de Almeida. Editora Beca, São Paulo, 525536.

Pimentel, M.M., Fuck, R.A., 1992. Neoproterozoic accretion in Central Brazil. Geology 20, 375-379.

Pimentel M.M., Rodrigues J.B., DellaGiustina M.E.S., Junges S.L., Matteini M., 2011. The tectonic evolution of the Brasilia Belt, central Brazil, based on SHRIMP and LA-ICPMS U-Pb sedimentar provenance data. Journal of South American Earth Sciences 31, 345-357.

Santos, M.E.C.M, Carvalho, M.S.S., 2004. Paleontologia das Bacias do Parnaíba, Grajaú e São Luiz, Programa Levantamentos Geológicos Básicos, Serviço Geológico do Brasil, 211 p.

Santos, T. J. S. ; Fetter, A. H. ; Nogueira Neto, J. A. (2008). Comparisons between the northwestern Borborema Province, NE Brazil, and the southwestern Pharusian Dahomey Belt, SW Central Africa). In: Pankhurst, R. J.; Trouw, R. A. J., Brito Neves, B. B., De Wit, M. J. (eds) West Gondwana: Pre-Cenozoic Correlations Across the Atlanti Region. Geological Society, London, special Publications, p. 294, 101-119.

Santos, T.S., Garcia, M.G.M., Amaral, W.S., Wernick, E., Dantas, E.L., Arthaud, M.H., Caby, R.; Santosh, M., 2009. Relics of eclogite facies assemblages in the Ceara Central Domain, NW Borborema Province, NE Brazil: implications for the assembly of West Gondwana. Gondwana Research, 2009.

Sawyer, E.W., 2008. Atlas of migmatites. The Canadian Mineralogist. In: Special Publication, vol. 9. NRG Research Press, Ottawa, Ontario, p. 371.

Sial, A.N., Figueiredo, M.C.H., Long, L.E., 1981. Rare-earth element geochemistry of the Meruoca and Mucambo Plutons, Geará, Northeast Brazil. Chemical Geology 31, 271-283.

Silva, L.C, Armstrong, R., Pimentel, M.M., Scandolara, J., Ramgrab, J., Wildner, W., Angelim, L.A.A., Vasconcelos, A.M., Rizzoto, G., Quadros, M.L.E.S., Sander, A., Rosa, A.L.Z., 2002. Reavaliação da evolução geológica em terrenos Pré-Cambrianos brasileiros com base em novos dados U-Pb SHRIMP, parte 3. Províncias Borborema Mantiqueira Meridional e Rio Negro Jurena. Revista Brasileira de Geociências. 
Carlos E. Ganade de Araujo - Tese de Doutorado - Universidade de São Paulo Capítulo 4 - Procedimentos Analíticos

\section{Procedimentos Analíticos}

\subsection{Geoquímica}

Os dados concernentes a geoquímica de rocha apresentados aqui foram obtidos independentemente pelo Laboratório SGS-GEOSOL de acordo com o pacote de análises pleiteado pelo Serviço Geológico da Brasil para aquisição de dados geoquímicos no âmbito dos mapeamentos geológicos do território nacional.

Os elementos maiores foram determinados por meio da técnica ICP-AES utilizando o espectrômetro da marca Varian Vista Pro. Os elementos traços e terras raras foram determinados pela técnica ICP-MS utilizando o espectrômetro de massa da marca Perkin-Elmer Sciex ELAN 6000. Análises de padrões de rochas do USGS (BCR-2, BHVO-1 and AGV-1) indicam precisão e acurácia da ordem de 1\% para os elementos maiores e de 5\% para os elementos traços e terras raras. Os resultados foram tratados com a utilização do programa GCDkit (Janousek et al., 2006) e Petrograph v.beta (Petrelli et al., 2005). Valores de normalização para o manto primitivo de condrito foram retirados de McDonough and Sun (1995) e Sun and McDonough (1989), respectivamente.

\subsection{Geocronologia U-Th-Pb em zircão}

Nesta Tese foram utilizados duas técnicas distintas para a datação in situ pelo método U-Th-Pb em zircão. Para a datação de zircões detríticos optou-se pela técnica LA-ICP-MS (laser ablation-inductevely coupled plasma mass spectrometer) enquanto que para os zircões ígneos optou-se pela técnica SHRIMP (sensitive high resolution ion microprobe). O equipamento utilizado para a datação dos zircões detríticos por LA-ICP-MS foi o Finnigan Neptune acoplado em um laser $\operatorname{ArF}$ excimer $(\lambda=193 \eta \mathrm{m})$, instalado no IGc/USP. Em relação aos zircões ígneos foram utilizados os equipamentos da Australian Scientific Instruments (ASI) SHRIMP IIe, instalado no IGc/USP e SHRIMP II, instalado na Research School of Earth Sciences (RSES) da Australian National University (ANU) em Camberra, Austrália. A separação dos zircões investigados seguiram os padrões do laboratório de separação mineral do Centro de Pesquisas Geocronológicas do IGc/USP de acordo com Loios et al. (2009).

\subsubsection{Imageamento dos zircões por Catodoluminescência (CL)}

Para revelar a textura interna dos cristais de zircão analisados foi utilizados o microscópio eletrônico de varredura Quanta 250 FEG equipado com um espectroscópio de catodoluminescência Mono CL3+ da marca Centaurus, instalado no IGc/USP. Na RSES foi utilizado o microscópio eletrônico de varredura JEOL-6610A acoplado com um sistema de catodoluminescência Robinson. As condições operantes foram 15 $\mathrm{kV}, 70 \mu \mathrm{A}$ and a $20 \mathrm{~mm}$ para a distancia focal.

\subsubsection{0 método U-Th-Pb por SHRIMP}

Embora os avanços na determinação geocronológica usando separação química e dissolução isotópica (TIMS) tenham trazido excelente progresso, o uso de técnicas pontuais (in situ) para análise de minerais mostrando cristais complexos (e.g. aqueles contendo sobrecrescimento metamórfico e/ou zonas xenomórficas) tornou-se necessário para melhor extração e interpretação dos dados. No final da década de 70 , foi desenvolvido na Austrália, um espectrômetro de massa de alta resolução de íons secundários (secondary ion mass spectometer SIMS). Este instrumento conhecido como SHRIMP (sensitive high resolution ion microprobe) foi utilizado para a determinação de domínios de idade em cristais complexos, já que pequenas porções deste cristal podem ser 
analisadas pontualmente. A primeira publicação de idades SHRIMP foi em 1982 (Compson et al.,1982) e somente um ano depois o mesmo instrumento foi usado para a determinação do primeiro mineral terrestre com mais de 4,0 Ga (Froude et al., 1983).

Determinações in situ de U-Th-Pb por microssondas de alta resolução são obtidas em superfícies polidas, usualmente com metade da espessura original do cristal, por meio do bombardeamento de um feixe primário de ânions $\mathrm{O}_{2}$ (Williams, 1998 e referencias citadas neste trabalho). Este bombardeamento de íons (sputtering) produzidos pela descarga do oxigênio dentro de um catodo de níquel libera uma fração pequena do zircão gerando uma ampla variedade de íons secundários. Os íons secundários são então duplamente focados, primeiramente por meio de um analisador eletrostático que os filtram segundo seus valores de energia cinética, então esses íons são focados novamente para um setor magnético, que descrimina estes íons com base em suas respectivas massas (Williams, 1998). O setor magnético é similar aquele utilizado nos espectrômetros de ionização termal. Porem, como exibem um raio maior é capaz de operar em uma resolução de massa maior, permitindo a discriminação de isótopos de urânio e chumbo de íons e complexos moleculares de massas similares produzidos na incidência de $\mathrm{O}_{2}$ no zircão $\left(\right.$ e.g. ${ }^{96} \mathrm{Zr},{ }^{94} \mathrm{Zr},{ }^{16} \mathrm{O}$ versus ${ }^{206} \mathrm{~Pb}$ em análises em zircão) (Patchett \& Samson, 2005).

Além da análise do zircão e outros minerais traços, determinações pontuais de elementos terras raras e outros elementos-traços proporcionam uma extrema versatilidade da metodologia SHRIMP. Entretanto, é a alta resolução espacial em escala $\mu \mathrm{m}$, possibilitando a seleção de domínios homogêneos em cristais de zircão com estrutura interna complexa, aliadas à rapidez analítica que fornecem à sistemática SHRIMP sua mais importante vantagem comparativa (Silva, 2006). A figura 4.1 ilustra o tamanho das cavidades geradas pelas técnicas SHRIMP e LA-ICP-MS.

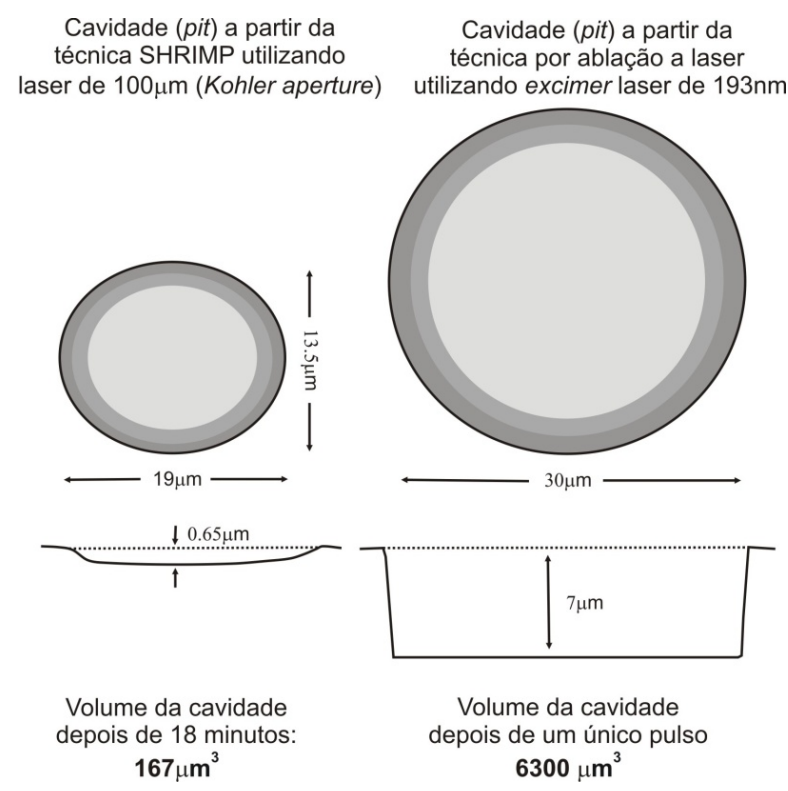

Figura 4.1 - Ilustração comparativa entre as cavidades geradas pelas técnicas SHRIMP e LA-ICP-MS (modificado de Patchett \& Samson, 2005). 
Os detalhes acerca da instrumentação e da técnica SHRIMP podem ser encontrados em Williams (1998). Os dados apresentados aqui foram coletados em blocos de cinco scans sobre todas as massas de interesse, com o padrão TEMORA (Black et al., 2003) intercalado a cada quatro análises. Para zircões com baixo conteúdo de $\mathrm{U}$, os mesmos procedimentos foram adotados, contudo o numero de scans utilizado foi de seis, e o tempo de analise em cada canal foi aumentado na busca de uma maior sensibilidade. Todas as análises foram corrigidas para o ${ }^{204} \mathrm{~Pb}$ com base nas razões ${ }^{207} \mathrm{~Pb} /{ }^{206} \mathrm{~Pb}$ medidas de acordo com Williams (1998) e baseado na composição do ${ }^{204} \mathrm{~Pb}$ de Stacey and Kramers (1975). Tratamento dos dados e cálculo das idades forma realizados utilizando-se os programas Squid and Isoplot/Ex (Ludwig, 2003).

\subsection{3. $O$ método U-Th-Pb por LA-ICP-MS}

No começo dos anos 80 foram desenvolvidos espectrômetros de massa quadripolos, utilizando plasma de argônio como fonte de ionização (inductevely coupled plasma mass spectrometres - ICP-MS). Embora estes instrumentos tenham sido desenvolvidos para a determinação de elementos traços, muitos estudos utilizaramnos para a obtenção de idades U-Pb. Idades ${ }^{206} \mathrm{~Pb}^{*} /{ }^{238} \mathrm{U},{ }^{207} \mathrm{~Pb} * / 235 \mathrm{U}$ e ${ }^{208} \mathrm{~Pb} * / 232 \mathrm{Th}$ podem ser determinadas, assim como idades ${ }^{207} \mathrm{~Pb} /{ }^{206} \mathrm{~Pb}$, utilizando-se de técnicas de ablação a laser (laser ablation - LA-ICP-MS). O apelo óbvio do uso de datações U-Th-Pb pela técnica LA-ICP-MS é a eliminação de procedimentos de separação U-Th-Pb, a não utilização de processos de dissolução ultra-limpos (necessários na técnica TIMS thermal ionization mass espectrometer), a velocidade das análises (menor que 3 minutos por análise) e a possibilidade de análises pontuais in situ. Neste sentido esta técnica compartilha diversas similaridades com a técnica de determinação por microssonda iônica U-Th-Pb (SHRIMP). A principal diferença é que o volume do pit escavado pelo laser é muito maior do que aquele escavado pela técnica de microssonda iônica, e por isso a técnica de ablação por laser pode ser considerada uma técnica destrutiva (Patchett \& Samson, 2005) - ver figura 4.1.

As primeiras tentativas para diretamente datar zircões utilizando as técnicas de LA-ICP-MS envolveram o uso de lasers de Nd-YAG para a ablação de zircões, operando com comprimentos de onda de 1064 ๆm (Fryer et al. 1993). Devido à variação significativa das razões $\mathrm{U} / \mathrm{Pb}$ esses primeiros estudos por ablação a laser concentraram-se na determinação de idades ${ }^{207} \mathrm{~Pb} /{ }^{206} \mathrm{~Pb}$, que geravam precisão em torno de 0,5 a $6 \%$. No entanto, o fracionamento elementar diminui com a diminuição do comprimento de onda do laser e então pela quadruplicação de lasers de Nd-YAG (266 ๆm), ou utilizando lasers à base de gás operando na faixa UV (tais como lasers de Ar-F que produzem lasers com comprimento de onda de 193ฤm), idades $\mathrm{U} / \mathrm{Pb}$ com maior fidedignidade podem ser obtidas e comparadas com aquelas que utilizam lasers com maiores comprimentos de onda (Patchett \& Samson, 2005). Para contrabalancear os efeitos do fracionamento devido à indução do laser, foram analisados padrões conhecidos sob as mesmas condições de calibração e aplicados fatores de correção para os zircões desconhecidos (Patchett \& Samson, 2005). A precisão de idades ${ }^{206} \mathrm{~Pb} /{ }^{238} \mathrm{U}$ utilizando padrões externos conhecidos em lasers com capacidade quadruplicada é parcialmente dependente da disponibilidade da concentração suficiente de urânio e chumbo, no entanto valores corriqueiramente típicos apresentam concentrações da ordem de vários \%. O fracionamento elementar produzido pela ablação é ainda significante e de qualquer modo correções devem ser aplicadas para a obtenção de idades precisas, as razões $\mathrm{Pb} / \mathrm{U}$ medidas são menores que as razões reais e o efeito e variável de acordo com o tempo de ablação (Patchett \& Samson, 2005).

Nos anos 90 espectrômetros de massa com setores magnéticos e uma gama de coletores Faraday foram acoplados na fonte de plasma. Esses instrumentos multi-coletores (LA-MC-ICP-MS) produzem os mesmos picos planos produzidos pela técnica TIMS e, portanto, são capazes de realizar medidas de razões isotópicas 
com maior precisão do que utilizando quadripolos. Existe um considerável interesse na utilização destes novos equipamentos na datação de cristais de zircão e monazita seguindo os mesmos moldes originalmente desenvolvidos para os instrumentos quadripolos.

Os dados U-Pb em zircões detríticos apresentados nesta Tese foram obtidos por meio do espectrômetro da marca Finnigan Neptune acoplado em um laser $\operatorname{ArF}$ excimer $(\lambda=193 \eta \mathrm{m})$ da marca Photon, instalado no IGc/USP. Os mounts contendo os zircões foram limpos em solução $\mathrm{HNO}_{3}(3 \%)$ e depois com água ultralimpa. A ablação foi realizada a uma frequência de $6 \mathrm{~Hz}$ e intensidade de $6 \mathrm{~mJ}$ gerando uma cavidade $(s p o t)$ de 29 $\mu \mathrm{m}$ no zircão investigado. O material foi carreado pelos gases $\mathrm{Ar}(0.7 \mathrm{l} / \mathrm{min})$ e $\mathrm{He}(0.6 \mathrm{l} / \mathrm{min}) \mathrm{em}$ análises de 60 ciclos de 1 segundo. Os zircões investigados foram intercalados com o padrão GJ-1, seguindo a sequencia: 2 brancos, 3 padrões, 13 zircões, 2 brancos e 2 padrões. O dado bruto foi reduzido e corrigido para o chumbo comum presente $\left({ }^{204} \mathrm{~Pb}\right)$, interferências de fundo (background) e qualquer possível viés instrumental utilizando-se uma planilha excel desenvolvida pelo CPGeo/USP. As idades foram calculadas por meio do programa Isoplot 3.0 (Ludwig, 2003).

\subsection{Isótopos de $\mathrm{Sr}-\mathrm{Nd}$}

As composições isotópicas Sr-Nd em rocha total foram determinadas pela técnica TIMS (thermal ionization mass espectrometer) por meio do espectrômetro VG354 equipado um mono detector Faraday no IGc/USP. As amostras foram digeridas em ácido e os elementos de interesse foram separados em colunas iônicas seguindo os procedimentos descritos em Sato et al. (1995). As razões ${ }^{87} \mathrm{Rb} /{ }^{86} \mathrm{Sr}$ and ${ }^{147} \mathrm{Sm} /{ }^{144} \mathrm{Nd}$ foram calculadas a partir de análises por Fluorescência de raios-X (Rb e Sr) e ICP-MS (Sm e Nd) realizadas paralelamente.

\subsection{Isótopos de Hf em zircão (LA-MC-ICP-MS)}

As análises Lu-Hf em zircão também realizadas no espectrômetro Finnigan Neptune acoplado em um laser $\operatorname{ArF}$ excimer $(\lambda=193 \eta \mathrm{m}$ ) Photon, instalado no IGc/USP. O diâmetro da cavidade (spot) foi de $39 \mathrm{~mm}$ com tempo de ablação de 60 segundos a uma frequência de $7 \mathrm{~Hz}$ com o material carreado pelo gás $\mathrm{He}(0.61 / \mathrm{min})$ (Sato et al., 2009). As razões ${ }^{176} \mathrm{Hf} /{ }^{177} \mathrm{Hf}$ foram normalizadas para ${ }^{179} \mathrm{Hf} /{ }^{177} \mathrm{Hf}=0.7325$. Os isótopos ${ }^{172} \mathrm{Yb}$, ${ }^{173} \mathrm{Yb},{ }^{175} \mathrm{Lu},{ }^{177} \mathrm{Hf},{ }^{178} \mathrm{Hf},{ }^{179} \mathrm{Hf},{ }^{180} \mathrm{Hf}$, e ${ }^{176}(\mathrm{Hf}+\mathrm{Yb}+\mathrm{Lu})$ foram simultaneamente medidos. A razão ${ }^{176} \mathrm{Lu} /{ }^{175} \mathrm{Lu}$ de 0.02669 foi usada para o cálculo da razão ${ }^{176} \mathrm{Lu} /{ }^{177} \mathrm{Hf}$. Para a correção do viés de massa nas razões isotópicas Lu-Hf foram empregadas variações obtidas a partir padrão GJ-1 (Sato et al., 2009). A constante de decaimento utilizada para o ${ }^{176} \mathrm{Lu}$ de $1.867 \times 10^{-11}$ (Söderlund et al., 2004) e os valores do condrito para as razões ${ }^{176} \mathrm{Hf} /{ }^{177} \mathrm{Hf}=0.282772 \mathrm{e}{ }^{176} \mathrm{Lu} /{ }^{177} \mathrm{Hf}=0.0332$ (Blichert-Toft and Albarede, 1997) foram adotados para o cálculo dos valores de $\varepsilon$ Hf. As idades modelo em duplo estágio foram calculadas usando a razão inicial ${ }^{176} \mathrm{Hf} /{ }^{177} \mathrm{Hf}$ do zircão e a razão ${ }^{176} \mathrm{Lu} /{ }^{177} \mathrm{Hf}=0.022$ para a crosta continental inferior (Griffin et al., 2004).

\subsection{Isótopos de 0 em zircão (SHRIMP)}

As composições isotópicas de Oxigênio foram obtidas em seções analíticas posteriores utilizando o SHRIMPII equipado com uma fonte de Gs na Research School of Earth Science (RSES) da Australian National University (ANU). Detalhes da metodologia estão descritas em Ickert et al. (2008). O padrão utilizado foi o TEMORA 2 $\left(\delta^{18} \mathrm{O}=8.2 \%\right.$; Black et al., 2004) analisado em conjunto com o padrão FC-1. Os valores isotópicos das análises do FG-1 no SHRIMP-II, normalizados pelo TEMORA 2 forneceram um valor médio de $\delta^{18} \mathrm{O}$ de 5.5 $\pm 0.3 \%$ 


\subsection{Química mineral}

\subsubsection{Zircão e rutilo (LA-ICP-MS)}

Elementos traços e terras raras em zircão e rutilo foram analisados por LA-ICP-MS (laser-ablation inductively coupled plasma mass spectrometry) na Research School of Earth Sciences da Australian National University (ANU). As análises foram realizadas no espectrômetro quadrupolo Agilent 7500s conectado a uma célula de ablação 'HelEx' (Eggins et al., 1998) desenvolvida para receber um feixe de $\operatorname{ArF}$ Excimer laser (193 $\eta \mathrm{m}$ ) pulsado a 5 $\mathrm{Hz}$ com energia de saída de $100 \mathrm{~mJ}$. O instrumento foi calibrado para máxima sensitividade e mínima produção de espécies moleculares mantendo a razão $\mathrm{ThO}^{+} / \mathrm{Th}^{+} \mathrm{em}<0.5 \%$. O laser foi operado de forma a gerar uma cavidade de $48 \mu \mathrm{m}$. O tempo de analise total foi de $60 \mathrm{~s}$, sendo os primeiros $25 \mathrm{~s}$ representantes do background antes da ablação. Vidros sintéticos (NIST 612 para o zircão e NIST 610 para o rutilo) foram utilizados para calibração externa e valores de referencia foram retirados de Pearce et al. (1997). Padrões internos foram $\mathrm{SiO}_{2}\left(32.45\right.$ peso eq. \%) para o zircão de $\mathrm{TiO}_{2}$ (98 peso eq. \%) para o rutilo. O vidro natural BCR-2G foi utilizado como um padrão secundário para monitorar acurácia das análises. $\mathrm{O}$ tratamento dos dados foi realizado no programa Iolite (Paton et al., 2011). Valores para a normalização do condrito foram de Sun and McDonough (1989).

\subsubsection{Outros silicatos (ME)}

As análises de química mineral para elementos maiores foram realizadas em seções delgadas polidas utilizando uma microssonda eletrônica CAMEGA SX100 na Research School of Earth Sciences da Australian National University (ANU), operando no modo de comprimento de ondas dispersivo. A voltagem e corrente do feixe foram de 15 $\mathrm{kV}$ e 20 ๆA com um feixe focado de $1 \mu \mathrm{m}$ para piroxênio e granada and $5 \mu \mathrm{m}$ para micas. O tempo de contagem por elemento foram de 20 s para $\mathrm{Na}, \mathrm{Mg}, \mathrm{Si}, \mathrm{Al}, \mathrm{K}$, Ca e Fe e 60 s para $\mathrm{Ti}$, Cr e $\mathrm{Mn}$. K e Na foram sempre analisados primeiramente na rotina analítica. Varias análises em cada fase mineral foram realizadas para obter composições representativas de pares de núcleo e borda também foram investigadas para acessar padrões de zoneamento. Minerais sintéticos e naturais foram utilizados como padrões e que todos foram determinados na camada Ka de emissão de pico. Outros minerais do acervo foram utilizados como padrões secundários.

\subsection{Referencias}

Black, L.P., Kamo, S.L., Allen, G.M., Aleinikoff, J.N., Davis, D.W., Korsch, R.J., Foudoulis, C., 2003.

TEMORA 1: a new zircon standard for Phanerozoic U-Pb geochronology. Chemical Geology 200, 155-170.

Black, L.P., Kamo, S.L., Allen, G.M., Davis, D.W., Aleinikoff, J.N., Valley, J.W., Mundil, R., Campbell, I.H., Korsch, R.J., Williams, I.S., Foudoulis, C., 2004. Improved Pb-206/U- 218 microprobe geochronology by the monitoring of a trace-element-related matrix effect; SHRIMP, ID-TIMS, ELA-ICP-MS and oxygen isotope documentation for a series of zircon standards. Chemical Geology 205, 115-140.

Blichert-Toft J., Albarede F., 1997. The Lu-Hf isotope geochemistry of chondrites and the evolution of themantle-crust system. Earth and Planetary Sciences Letters 148, 243-258.

Compston, W., Pidgeon, R.T., (1986). Jack Hills, evidence of more very old detrital zircon in Western Australia. Nature 321, 766-769. 
Eggins, S.M., Rudnick, R.L., McDonough, W.F., 1998. The composition of peridotites and their minerals: A laser ablation ICP-MS study. Earth Planetary Science Letters 154, 53-71.

Froude, D.O., Ireland, T.R., Kinney, P.D., Williams, I.S., Compston, W., (1983). Ion microprobe identification of 4,100-4,200 Myr-old terrestrial zircons. Nature 304, 616-618.

Fryer. B.J., Jackson, S.E. e Longerich, H.P. (1993) The application of laser ablation microprobe-inductevely coupled plasma-mass spectrometry (LAM-ICP-MS) to in situ (U)-Pb geochronology. Chemical Geology, 109, $1-8$.

Griffin W.L., Belousova E.A., Shee S.R., Pearson N.J., O'Reilly S.Y. 2004. Archean crustal evolution in the northern Yilgarn Craton: U-Pb and Hf isotope evidence from detrital zircons. Precambrian Research 131, 231 282.

Ickert, R. B., Hiess, J., Williams, I. S., Holden, P., Ireland, T. R., Lanc, P., et al., 2008. Determining high precision, in situ, oxygen isotope ratios with a SHRIMP II: Analyses of MPI-DING silicate-glass reference materials and zircon from contrasting granites. Chemical Geology 257, 114-128.

Janousek, V. Farrow, G.M., Erban, V., 2006. Interpretation of whole-rock geochemical data in igneous geochemistry: introducing Geochemical Data Toolkit (GCDkit). Journal of Petrology 47, 1255-1259.

Ludwig, K.R., 2001. Squid 1.02 - A User’s Manual. Berkeley Geochronology Center. Special Publication No 2.

Ludwig, K.R., 2003. Isoplot 3.00 - A Geochronological Toolkit for Microsoft Excel. Berkeley Geochronology Center. Special Publication No 4.

McDonough, W.F., Sun, S.S., 1995. The composition of the earth. Chemical Geology 120, 223-254.

Patchett, P.J.; Samson, S.D., 2005. Ages and Growth of the Continental Crust from Radiogenic Isotopes pp. 321-348. In: The Crust ( ed. R.L. Rudnick) Vol.3, Treatise on Geochemistry (eds. H.D. Holland; K.K. Turekian), Elsevier - Pergamon, Oxford.

Paton, C., Hellstrom, J., Paul, B., Woodhead, J., Hergt, J. 2011. Iolite: Freeware for the visualisation and processing of mass spectrometric data. Journal of Analytical Atomic Spectrometry 26, 2508-2518.

Pearce, N.J.G. et al., 1997. A compilation of new and published major and trace element data for NIST SRM 610 and NIST SRM 612 glass reference materials. Geostandard News 21, 115-144.

Petrelli, M., Poli, G., Perugini, D., Peccerillo, A., 2005. Petrograph: a New Software to Visualize, Model, and Present Geochemical Data in Igneous Petrology, Geochem. Geophys. Geosyst., Vol. 6, Q07011, DOI 10.1029/2005GC000932, 26 July 2005

Sato K., Siga Jr. O., Silva J.A., McReath I., Liu D., Iizuka T., Rino S., Hirata T., Sproesser W.M., Basei M.A.S. 2009. In Situ Isotopic Analyses of $\mathrm{U}$ and $\mathrm{Pb}$ in Zircon by Remotely Operated SHRIMP II, and Hf by LA-ICP-MS: an Example of Dating and Genetic Evolution of Zircon by 176Hf/177Hf from the Ita Quarry in the Atuba Complex, SE Brazil. Geologia USP, Série Cientifica São Paulo 9, 61-69.

Sato, K.; Tassinari, G. C. G.; Kawashita, K.; Petronilho, L., 1995. O método geocronológico Sm-Nd no IG/USP e suas aplicações. Anais da Academia Brasileira de Ciências 67, 315-336.

Silva, L. C. (2006) Geocronologia aplicada ao mapeamento regional, com ênfase na técnica U-Pb SHRIMP e ilustrada com estudos de casos brasileiros, SGB-GPRM, 2006, 132 p. (Publicações Especiais do Serviço Geológico do Brasil; 1) 
Söderlund U., Patchett J.P., Vervoort J.D., Isachsen C.E. 2004. The 176Lu decay constant determined by Lu$\mathrm{Hf}$ and U-Pb isotope systematics of Precambrian mafic intrusions. Earth and Planetary Science Letters 219, 311 324.

Stacey, J.S., Kramer, J.D., 1975. Approximation of terrestrial lead isotope by a two-stage model. Earth and Planetary Science Letters 26, 207-212.

Sun, S.S., McDonough, W.F., 1989. Chemical and isotopic systematics of oceanic basalts: implication for mantle composition and processes. In: Saunders, A.D., Norry, M.J. (Eds.), Magmatism in Ocean Basins. Geological Society, London, Special Publications, vol. 42, pp. 313-345.

Williams, I.S., 1998. In: McKibben, M.A., Shanks, W.C., Ridley, W.I. (Eds.), U-Th-Pb geochromology by ion microprobe, applications of microanalytical techniques to understanding mineralizing processes. Reviews in Economic Geology 7, pp. 1-35. 


\title{
5. U-Pb detrital zircon provenance of metasedimentary rocks from the Ceará Central and Médio Coreaú Domains, Borborema Province, NE-Brazil: Tectonic implications for a long-lived Neoproterozoic active continental margin
}

\author{
Garlos E. Ganade de Araujo ${ }^{(1)(2)^{*}}$; Umberto G. Cordani ${ }^{(1)}$; Miguel A. S. Basei(1); Neivaldo A. Castro ${ }^{(3)}$, Kei $^{\text {i }}$ \\ Sato $^{(1)}$, Walter M. Sproesser(1)
}

\author{
(1)Centro de Pesquisas Geocronológicas - CPGeo/IGc-USP, São Paulo-SP, Brazil \\ (2)Geological Survey of Brazil - CPRM, Fortaleza-CE, Brazil \\ (3)Universidade Federal do Ceará - UFG, Fortaleza-GE, Brazil
}

\begin{abstract}
$\mathrm{U}-\mathrm{Pb}$ geochronological analyses have been acquired on detrital zircon grains collected from 14 samples in the Ceará Central (CCD) and Médio Coreaú (MCD) tectonic domains, separated by the Transbrasiliano-Kandi Lineament (TKL) on the Borborema Province. To the West of this lineament, the basement of the MCD has a tectonic affinity with the West African and São Luis Cratons, where Paleoproterozoic rocks predominate. Within this area, three samples of the São Joaquim quartzite yielded Paleoproterozic and Archean ages only, with the youngest ${ }^{206} \mathrm{~Pb} /{ }^{207} \mathrm{~Pb}$ ages at $c a$. $1750 \mathrm{Ma}$. However, the Goiabeira Formation schist, in the same domain, yielded younger ${ }^{207} \mathrm{~Pb} / 235 \mathrm{U}$ ages around $720 \mathrm{Ma}$, with predominance of zircons within the 750-1100 Ma interval. To the East of the TKL, the Borborema Province correlates well with the Transaharan Belt of West Africa, where the Paleoproterozoic-Archean basement was affected by a strong tectonic imprint of the Neoproterozoic Brasiliano-Pan African orogeny. Three samples from the region between the TKL and the Tamboril-Santa Quitéria granitic-migmatitic Complex (TSQgmC) yielded younger ${ }^{207} \mathrm{~Pb} /{ }^{235} \mathrm{U}$ concordant ages (ca. 660-700 Ma), which are 20-60 Ma younger than those of the Goiabeira Formation. Further east within the GCD, eastern of the TSQgmC, six samples yielded two distinct detrital patterns, with some samples showing younger concordant ages ( $c a .900$ and $750 \mathrm{Ma}$ ), while others demonstrate a strong Paleoproterozoic source component with zircons older than $c a .1500 \mathrm{Ma}$. Finally, one sample of the post-collisional extensional Jaíbaras Trough, within the main axis of the TKL, yielded a maximum deposition age of $c a$. 540 Ma, with a strong source component ranging from 540 to $640 \mathrm{Ma}$, derived mainly from the TSQgmC. Evidence of a large ocean basin prior to $800 \mathrm{Ma}$, along the vicinity of the TKL, is well established in Central Brazil and West Africa. We believe that the strong source component at around 800-700 Ma, and possibly also the older ones at $c a .1000 \mathrm{Ma}$, were shed from magmatic arc systems developed at the margins of the ancient continent which makes up the basement of the Borborema Province. Abrupt cessation of the detrital zircons input at $c a$. $650 \mathrm{Ma}$, suggests a change in the tectonic regime at this time, marking the onset of collisional tectonics and main metamorphism in the province. This fact is supported by the ages spanning the 640-590 Ma interval found in the metamorphic domains of the studied zircons which are partially synchronous with the development of the main tectonic and magmatic stages of the TSQgmC.
\end{abstract}

Key words: Borborema Province, Provenance, Detrital Zircon

\subsection{Introduction}

Detrital zircon age analysis has proven to be a strong tool to unravel tectonic histories and paleogeographical reconstructions of high grade Precambrian terranes, with numerous published studies in the last 20 years. Interpretation of detrital zircon signatures rely on the comparison of the acquired detrital age spectra with the age of surrounding exposed rocks (Condie et al., 2009), however preservation bias of the source rocks must be considered (Hawkesworth et al., 2009). Regardless of interpretation problems, the technique not only provides a useful method in establishing maximum age limits for sedimentary systems, but also valuable information on 
whether a particular sedimentary basin evolved in an active or a passive margin setting or yet within an intracontinental environment (Cawood and Nemchin, 2001; DeGraaff-Surpless et al., 2002; Chew et al., 2008; Sun et al., 2009, de Araujo et al., 2010).

The Central Ceará and Médio Coreaú domains of the Borborema Province are located in a pivotal position to understand West Gondwana reconstruction (De Wit et al., 2008). The provenance of the supracrustal rocks of these domains, and their role in the context of the Brasiliano - Pan-African orogenesis is crucial to restore paleogeography of part of Gondwanaland and pre-drift correlations between South America and West Africa.

In this contribution we provide LA-MC-ICP-MS U-Pb detrital zircon geochronology of fourteen samples from metasedimentary rocks of the Ceará Central and Médio Coreaú domains. The main goals of this paper are: 1) compare the provenance of the Médio Coreaú and Ceará Central domains to test the hypothesis of the Transbrasiliano-Kandi Lineament as a major terrane boundary; 2) obtain further information on depositional ages of the different metasedimentary units; 3) provide information about the source areas from which the sediments have been shed and finally; 4) establish paleogeographic reconstructions by comparing ages of the detrital zircons with the ages of the surrounding possible sources, including stable cratonic areas (during the Neoproterozoic orogenesis) and crust-forming events (exposed or not) associated with the formation of the West Gondwana.

\subsection{Geological setting}

The Ceará Central and Médio Coreaú domains are crustal entities of the northern portion of the Borborema Province (Almeida et al., 1981) which lies in the northeastern portion of the South America Platform (fig. 5.1). This province is characterized by magmatic, tectonic, and thermal phenomena spanning from the Archean to the Cambrian-Ordovician period. Final arrangement was accomplished mainly through the Neoproterozoic Brasiliano/Pan-African orogenesis caused by the convergence of major "cratonic" blocks such as the Amazonian-São Luiz-West Africa and the São Francisco-Congo, including the participation of minor blocks during the assembly (ca. 900-530 Ma) of West Gondwana (Brito Neves and Cordani, 1991; Brito Neves et al. 2000; Arthaud et al., 2008).

The northern Borborema Province is limited in the south by the E-W dextral Patos Shear Zone and it is subdivided into four distinct geological domains separated by large NE-SW to ENE-WSW shear zones (Arthaud et al., 2008), including the Ceará Central and Médio Coreaú domains. These domains are separated by the Transbrasiliano Lineament, a major NE-SW trending shear system, which extends into the African territory by the name of Kandi Lineament.

\subsubsection{The Médio Coreaú Domain (MCD)}

Regional geological framework of the Médio Coreaú Domain was described in detail by Santos et al. (2008a) and Santos et al. (2009b). This domain is primarily composed of: 1) Early Paleoproterozoic gray orthogneiss and migmatite basement from the Granja Complex; 2) Late Paleoproterozoic (?) volcano-sedimentary Saquinho Unit; 3) Neoproterozoic Martinópole and Ubajara Groups and 4) Post-collisional Chaval and 
Carlos E. Ganade de Araujo - Tese de Doutorado - Universidade de São Paulo Capítulo 5 - U-Pb zircon provenance

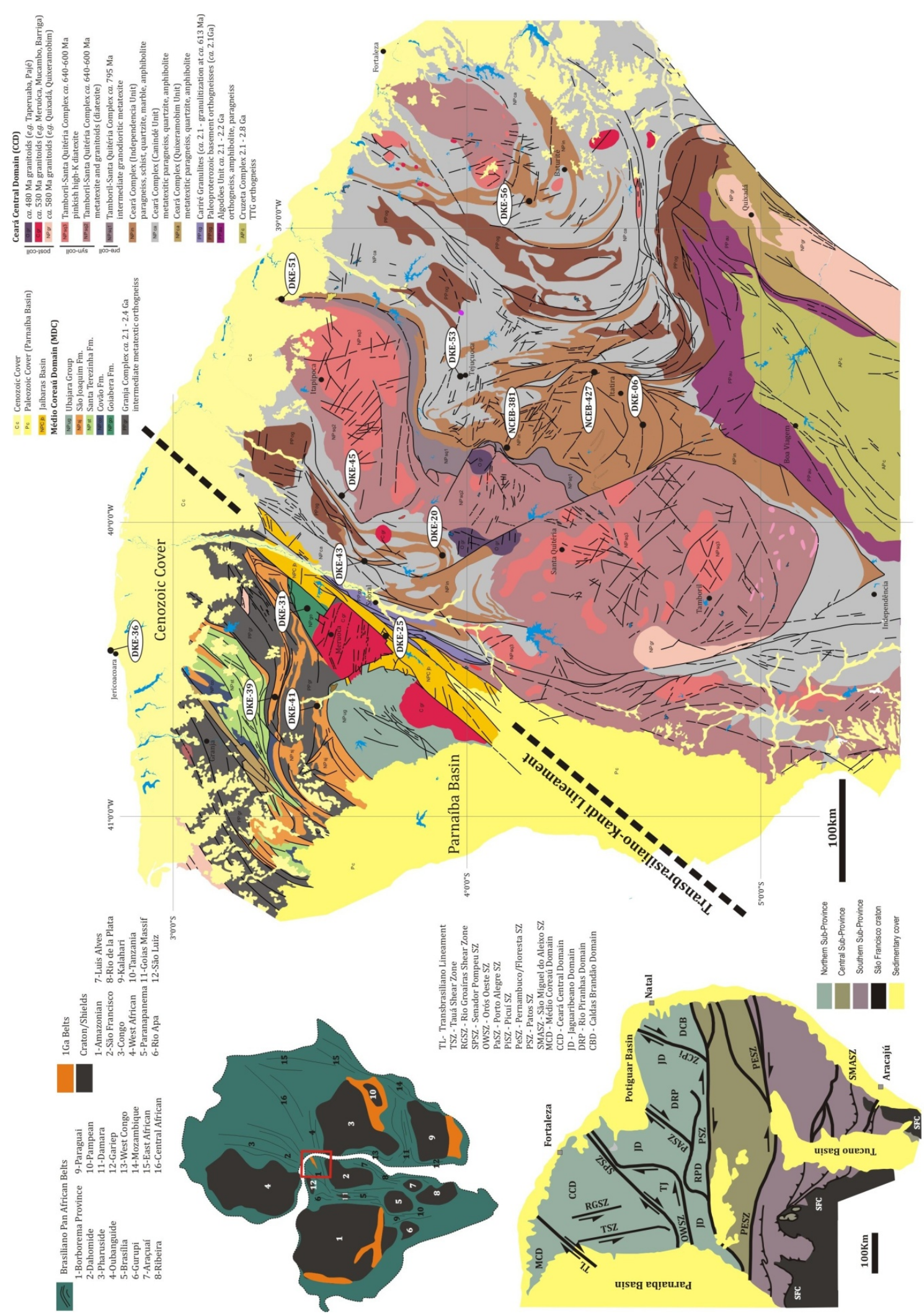

Figure 5.1 - Geological setting of the Ceará Central and Médio Coreaú domains and sample site location (modified from Cavalcante et al., 2003, de Araujo et al., 2010a and De Wit et al., 2008). 
Tucunduba (ca. $590 \mathrm{Ma}$ ), Meruoca and Mucambo Granitoids (ca. $530 \mathrm{Ma})$ (fig. 5.1).

The Granja Complex is composed of juvenile 2.35-2.27 Ga metatexitic orthogneisses of tonalitic to granodioritic composition and high grade rocks such as kinzigite, charnockite and enderbite (Nogueira Neto et al., 1989; Gaudette et al., 1993; Monié et al., 1997; Fetter, 1999; Santos et al., 2008a). Although Siderian ages (ca. $2.3 \mathrm{Ga}$ ) are recorded in the rocks of Granja Complex, $\mathrm{Pb}-\mathrm{Pb}$ evaporation Rhyacian ages at $2088 \pm 24$ and U-Pb ID-TIMS at 2176 $\pm 21 \mathrm{Ma}$ are also reported (Gaudette et al., 1998). The Martinópole Group is divided into four formations represented from bottom to top by the Goiabeira, São Joaquim, Covão and Santa Terezinha formations (Santos et al., 2008a). The Goiabeira Formation is in tectonic contact with the Granja Complex (Santos et al., 2008b) and it is composed of metapelites, schists and paragneisses (Cavalcante, et al., 2003, Santos et al., 2008a). São Joaquim Formation comprises several quartzite layers with variable mineralogical compositions including kyanite, sillimanite and muscovite. The Covão and Santa Terezinha formations are composed of schists and metadiamictites and metapelites, metacarbonates, with intercalations of metagreywacke, metarhythmites, quartzite and felsic metavolcanic rocks (Santos et al., 2008a). The Ubajara Group is interpreted as a proximal platformal sequence (Santos et al., 2008a) composed of three distinct formations. The Caiçaras Formation is constituted of low-grade fine-grained siliciclastic rocks and the TrapiáFrecheirinha of metasandstone and metacarbonate while the Coreaú Formation comprises metasandstone and metagreywacke. Fetter et al. (2003) suggest a Neoproterozoic age of deposition at ca. $777 \mathrm{Ma}$ for the Martinópole Group, based on ID-TIMS U-Pb determinations in zircons from felsic metavolcanic rocks found within São Joaquim and Santa Terezinha Formations. Four granitoid plutons can be recognized in the MDG.

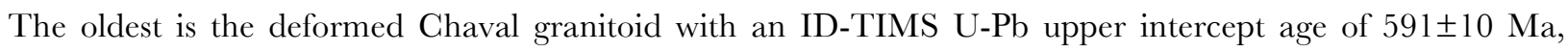
followed by the deformed Tucundumba granitoid which yielded an ID-TIMS U-Pb upper intercept age of $563 \pm 17 \mathrm{Ma}$ (Santos et al., 2008a; Fetter, 1999). The non-deformed Meruoca and Mucambo plutons are younger and comprise alkali to peralkalic granites (Sial et al., 1981). The Mucambo pluton yielded an IDTIMS U-Pb upper intercept age at 532 \pm 7 Ma (Santos et al., 2008a; Fetter, 1999), while the Meruoca pluton

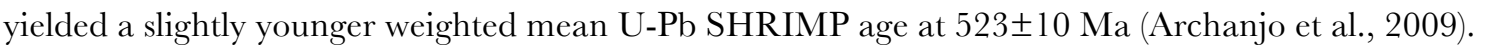

\subsubsection{The Ceará Central Domain (CCD)}

This domain is composed of (1) Archean remnants of tonalite-trondhjemite-granodiorite (TTG) units of the Cruzeta Complex; (2) juvenile Paleoproterozoic (2.1-2.2 Ga) and high-grade felsic to intermediate orthogneisses and migmatites, including their associated supracrustal rocks of the Algodões Unit (Fetter et al., 2000; Martins et al., 2009); (3) high-grade Early Proterozoic to Neoproterozoic supracrustal rocks partially represented by the units of the Ceará Complex (e.g. Arthaud, 2007; Arthaud et al., 2008) and the Novo Oriente Group (Ganade de Araujo et al., 2010a); (4) granitoids and migmatites of the Tamboril-Santa Quitéria Complex (Fetter et al., 2003; Arthaud et al., 2008); and (5) widespread Neoproterozoic to Ordovician post-collisional to anorogenic granitoids (Fetter, 1999; Castro et al., 2012). The first two associations acted as the basement for the so-called Brasiliano-Pan- African Neoproterozoic orogenesis (fig. 5.1).

This basement, particularly the Cruzeta Complex, records an intricate geological history, from the Archean to the Paleoproterozoic period. The Archean remnants (2.85-2.64 Ga). The Ceará Complex is composed of metapelites, metasemipelites and metagreywacke normally showing a prominent schistosity to gneissic fabric;

regionally and locally migmatized. Quartzites, marble, calc-silicate rocks and amphibolites also form large 
tracts within this complex (Cavalcante et al., 2003; Caby and Arthaud, 1986; Arthaud et al., 2008). Taking into account the degree of partial melting, Cavalcante et al. (2003) divided part of the Ceará Complex into the Independência and Canindé units. The supracrustals rocks preserved from extensive migmatization were grouped in the former, while those that exhibit severe conditions of melting were included in the latter. The age of the Ceará Complex is still a matter of debate. Some authors consider the time of deposition at around $770 \mathrm{Ma}$ (Fetter et al., 2003; Castro, 2004; Arthaud, 2007) based on U-Pb ID-TIMS geochronological data from sheets of granitic gneisses that have been interpreted as alkaline syn-sedimentary rhyolite flows and/or sills. Based on SHRIMP U-Pb detrital zircon studies, Arthaud (2007) argued that the continental fragmentation and passive margin development was around 750 Ma. However, considering that the Early Paleoproterozoic-Archean crust is ubiquitously found as the basement of younger supracrustal rocks in CCD; the lack of older detrital zircons than $1.8 \mathrm{Ga}$ is inconsistent with proposed intracontinental rift setting.

The Neoproterozoic Tamboril-Santa Quitéria granitic-migmatitic Complex (TSQgmC) is a wedge-shaped composite anatetic/igneous association, characterized by a number of magmatic pulses where large volumes of magma intruded in the form of veins, layers, sheets and plutons (Cavalcante et al., 2003; Fetter et al., 2003; Arthaud et al., 2008). The plutonic rocks display syn- to late-magmatic deformation that was in part coeval with the injection of younger and less deformed magma (Arthaud et al., 2008). In general they range from mafic diorite to granite, with predominance of monzogranitic/granitic compositional members (Ganade de Araujo et al., 2012). This plutonic association intruded the supracrustal rocks of Ceará Complex, which are preserved as large resisters, pendants and enclaves of calc-silicate rocks, amphibolites and quartzite, probably derived from infertile portions unable to melt. The granitoids related to the development of this complex range from 650 to $610 \mathrm{Ma}$ (Fetter et al., 2003; Castro, 2004; Santos et al., 2007, de Araujo et al., 2012). However, provenance studies on the adjacent supracrustal rocks (Arthaud, 2007), coupled with a $\mathrm{Pb}-\mathrm{Pb}$ evaporation zircon age at $795 \mathrm{Ma}$ on granodioritic gneisses from the eastern border of the complex (Ganade de Araujo et al., 2010b) suggest that its development could have started as early as $800 \mathrm{Ma}$. The Nd isotopic signatures are consistent with variable mixtures between juvenile Neoproterozoic magmas and the surrounding Paleoproterozoic gneisses, indicating that the complex neither represents a juvenile arc nor a suite of crustal melts (Fetter et al., 2003). The tectonic setting of the Tamboril-Santa Quitéria Complex has been interpreted as a Neoproterozoic Andean-type magmatic arc (Fetter et al., 2003), however recent discussions propose a collisional Himalayan setting with an early Andean arc component reworked during the collisional event (Ganade de Araujo et al., 2010b; Costa et al., 2010; de Araujo, 2011; de Araujo et al., 2012).

Magmatic pulses related to the emplacement of granitoids at ca. 580, 530 and 480 are representative of postcollisional manifestations in the Geará Central Domain (Ganade de Araujo, 2011). The final ca. 480 Ma Atype pulse is marked by small semi-circular stocks which are in some extent temporally close to the deposition of the first strata of the Phanerozoic Parnaíba Basin, developed in the west portion of the collisional Neoproterozoic mountain chain (Castro et al., 2012; Ganade de Araujo, 2011).

\subsubsection{The Jaíbaras Trough}

The Late Neoproterozoic to Early Paleozoic Jaíbaras basin is inserted along the main axis of the Transbrasiliano-Kandi Lineament. It consists of a basal fault-scarp-related paraconglomerates package 
(Massapê Formation) followed laterally and vertically by fluvial-lacustrine sandstones (Pacujá Formation) interbedded with reddish shales (Oliveira and Mohriak, 2003). The upper Aprazível Formation consists of polymitic conglomerates, and differs from the underlying Massapê Formation by the presence of clasts of plutonic/volcanic rocks from the Meruoca-Mucambo plutons and Parapuí Suite (Oliveira and Mohriak, 2003). The axis of the Jaíbaras Trough is aligned with the main depocenter of the Parnaíba Basin further northwest and it constitutes its precursory stage that was slightly inverted before the initial deposition of the large intracratonic basin.

\subsection{Sampling and analytical procedures}

\subsubsection{Sampling strategy}

Taking the Transbrasiliano-Kandi Lineament (TKL) and the Tamboril-Santa Quitéria Complex as regional markers, our sampling approach intended to answer two fundamental questions. The first one is whether the Transbrasiliano-Kandi Lineament demarks a terrane boundary, if so, do the MCD and CGD have distinct provenance signatures or do the detrital ages overlap favoring a correlated development of both domains? The second question is: are there basins related to the Neoproterozoic Tamboril-Santa Quitéria Complex within the adjacent supracrustal rocks in CCD? Bearing these questions in mind, we have collected four samples in the MCD, to the west of the Transbrasiliano-Kandi Lineament, including three quartzites from the São Joaquim Formation (DKE-36, DKE-39, DKE-41) and one schist from the Goiabeira Formation (DKE-30) both from the Martinópole Group. One reddish sandstone of the Pacujá Formation (DKE-25) from the Jaíbaras Trough, inserted in the main axis of the lineament. Three samples in the zone between the lineament and the Tamboril-Santa Quitéria Complex including two metatexitic paragneiss (DKE-43 and DKE-45) and one quartzite rhythmically interleaved with metapelitic layers (DKE-19). Six samples to east of the TamborilSanta Quitéria Complex which include five quartzites (DKE-51, DKE-06, DKE-56, NCEB-427 and NGEB351) and one metatexitic paragneiss (DKE-53).

\subsubsection{Sample preparation}

Zircons were separated from the crushed rocks $(3-5 \mathrm{~kg})$ using conventional and heavy liquid and magnetic techniques (jaw crusher, disk grinder, Wilfley table, Frantz isodynamic magnetic separator and density separation using bromoform and methylene iodite). To avoid bias introduced during handpicking, no visual morphological or color differentiation was made. Around 250-300 zircons from each sample were mounted in epoxy resin, polished to half of mean grain thickness for further imaging with transmitted light and 43athodeluminescence to unravel its internal complexities. Dodson et al. (1988) states that 59 grains must be analyzed to achieve $95 \%$ confidence of finding every population that exists at the $5 \%$ level in a given sample, however Vermeesh (2004) taking into account different levels of probability based upon number potential sources areas states that 117 grains should be dated. For each sample about 50 to 80 zircons were dated comprising a total of $836 \mathrm{U}-\mathrm{Pb}$ age measurements.

\subsubsection{CL imaging and $\mathrm{U}-\mathrm{Pb}$ geochronology}


Cathodo-luminescence (CL) images of zircons were obtained using a Quanta 250 FEG electron microscope equipped with Mono CL3+ cathodoluminescence spectroscope (Centaurus) at the Geochronological Research Center in São Paulo University, Brazil. After that, U-Pb analyses by LA-MC-ICP-MS were carried out using the Finnigan Neptune coupled to an excimer $\operatorname{ArF}$ laser $(\lambda=193$ pm) ablation system also at the Geochronology Research Center of the São Paulo University. The mounts containing zircons were cleaned in a $\mathrm{HNO}_{3}$ solution $(3 \%)$ and in ultraclean water bath. The ablation was done with spot size of $29 \mu \mathrm{m}$, at a frequency of 6 $\mathrm{Hz}$ and an intensity of $6 \mathrm{~mJ}$. The ablated material was carried by $\operatorname{Ar}(\sim 0.7 \mathrm{~L} / \mathrm{min})$ and $\mathrm{He}(\sim 0.6 \mathrm{~L} / \mathrm{min})$ in analyses of 60 cycles of 1s. Unknowns were bracketed by measurements of the international standard GJ-1, following the sequence 2 blanks, 3 standards, 13 unknowns, 2 blanks, and 2 standards. Raw data were reduced using a home-made spreadsheet and corrections were done for background, instrumental mass bias drift and common $\mathrm{Pb}$. The ages were calculated using ISOPLOT 3.0 (Ludwig, 2003).

\subsection{Results}

\subsubsection{CL images}

Selected CL images of dated zircons are given in figure 5.2. Zircons display a wide range of morphology and internal textures with predominance of concentric oscillatory zoning, a typical feature of primary magmatic crystals (Corfu et al., 2003). In the majority of samples zircons show rounded grain morphology, suggesting that they have experienced a long distance of transportation. Zircons extracted from sample DKE-25 of the Jaíbaras Trough are euhedral indicating a near-source region. Xenocrystic cores with magmatic overgrowths are also present in some examples (cf. DKE-30-2.1 and 11.1). Homogeneous strong dark crystals in CL (trace element-rich zircons - $c f$. DKE-06-35.1) and bright (trace element-poor zircons - $c f$. DKE-53-29.1) are abundant; however their dark colors in CL images can be suspected of metamictization. Complex zoned zircons and fractured zircons, with domains smaller than the beam diameter were avoided since the results would reflect mixed isotopic patterns. Secondary sub-solidus modifications caused by subsequent thermal events are easily recognizable in some samples. They constitute overgrowths around the rounded pre-existing detrital cores, characterized by low and bright luminescence rims. These overgrowths are predominantly homogeneous and regular concentric around the cores ( $c f$. DKE-45-22.1 and 8.1), but concentrated sometimes at the crystal terminations ( $f$. DKE-43-42.1 and DKE-53-11.1).

\subsubsection{U-Pb ages of detrital zircons}

We performed 836 analyzes on detrital zircons and some metamorphic overgrowths. Among them 647 yielded reliable ages with less than $5 \%$ discordance $\left({ }^{206} \mathrm{~Pb} /{ }^{238} \mathrm{U}\right.$ to $\left.{ }^{207} \mathrm{~Pb} /{ }^{235} \mathrm{U}\right)$ and $10 \%$ discordance $\left({ }^{206} \mathrm{~Pb} /{ }^{238} \mathrm{U}\right.$ to $\left.{ }^{207} \mathrm{~Pb} /{ }^{206} \mathrm{~Pb}\right)$. Ages are reported in terms of the ${ }^{207} \mathrm{~Pb} /{ }^{206} \mathrm{~Pb}$ ratios for grains older than $1.4 \mathrm{Ga}$, with correlated discordance of ${ }^{206} \mathrm{~Pb} /{ }^{238} \mathrm{U}$ to ${ }^{207} \mathrm{~Pb} / 206 \mathrm{~Pb}$, or the ${ }^{206} \mathrm{~Pb} /{ }^{238} \mathrm{U}$ ratios for zircons younger than 1.4 $\mathrm{Ga}$, with correlated discordance of ${ }^{206} \mathrm{~Pb} / 238 \mathrm{U}$ to ${ }^{207} \mathrm{~Pb} / 235 \mathrm{U}$. Sample descriptions and results (tables 2 to 15) are available in the appendix I and supplementary data.

\subsubsection{Region to the west of the Transbrasiliano-Kandi Lineament - Médio Coreaú Domain}


Samples DKE-36, DKE 39 and DKE-41 (São Foaquim Quartzite - Martinópole Group). A total of 180 zircons from three samples of São Joaquim Quartzite were analyzed, and among them, 129 yielded reliable Paleoproterozoic and Archean U-Pb ages. The dominant population consists of ages ranging from $2300 \mathrm{Ma}$ to $2050 \mathrm{Ma}(59 \%$ of total) and from $2500 \mathrm{Ma}$ to $2300 \mathrm{Ma}(20 \%$ of total) with the youngest concordant ${ }^{207} \mathrm{~Pb} /{ }^{206} \mathrm{~Pb}$ age at $1745 \pm 16 \mathrm{Ma}$ (sample DKE-41) (fig. 5.3A, B and C).

Sample DKE-30 (Goiabeira Schist-Martinópole Group). The youngest ${ }^{206} \mathrm{~Pb} /{ }^{238} \mathrm{U}$ age at $705 \pm 07$ (98\% concordant) and the youngest population at $c a .720$ Ma provides the maximum age of deposition for the Goiabeira schist. Main age clusters are at 705-754 Ma (15\% of total), 768-883 Ma (45\%) and 930-1139 Ma (16\%). A minor population is represented by five Paleoproterozoic grains that spread between 1817 and $2465 \mathrm{Ma}$ and four Archean grains which the oldest concordant ${ }^{207} \mathrm{~Pb} / 206 \mathrm{~Pb}$ zircon yielded an age of $2766 \pm 13 \mathrm{Ma}$ (fig. 5.3D).

\subsubsection{Region between the Transbrasiliano-Kandi Lineament and the Tamboril-Santa Quitéria Complex - Ceará Central Domain}

Sample DKE-25 (Reddish Pacujá sandstone - Faibaras Trough). The youngest zircon found in the Pacujá sandstone within the Jaíbaras Trough yielded an age of $530 \pm 08 \mathrm{Ma}(98 \%$ concordant) with the youngest population at ca. $550 \mathrm{Ma}$. The Neoproterozoic zircons can be divided into two groups ranging from $550 \mathrm{Ma}$ to $598 \mathrm{Ma}$ ( $42 \%$ of total) and from 600 to $630(20 \%$ of total). Paleoproterozoic zircons were also identified in this sample ranging from $2110 \mathrm{Ma}$ to $2193 \mathrm{Ma}$ (fig. 5.3E).

Samples DKE-43 and DKE-45 (metatexitic paragneisses - Canindé Unit of Ceara Complex). The youngest zircon of this sample yielded a ${ }^{206} \mathrm{~Pb} /{ }^{238} \mathrm{U}$ age of $648 \pm 15 \mathrm{Ma}$ (sample DKE-43) with the young population established at $c a$. $660 \mathrm{Ma}$. A young low-U homogeneous zircon (\#44.1/sample DKE-43) presented a ${ }^{206} \mathrm{~Pb} /{ }^{238} \mathrm{U}$ age of $632 \pm 20$ Ma which is similar to the ages obtained in the metamorphic overgrowths in other zircons from this study, and was therefore interpreted as a metamorphic zircon. Similarly, for the sample DKE-45 the youngest ${ }^{206} \mathrm{~Pb} /{ }^{238} \mathrm{U}$ age is at $692 \pm 09 \mathrm{Ma}$, with the youngest population clustering around $705 \mathrm{Ma}$. Two important Neoproterozoic populations were verified in these samples ranging from $c a .700$ to $780 \mathrm{Ma}(24 \%$ of total) and from $c a .810$ to $920 \mathrm{Ma}(40 \%$ of total), respectively (fig. 5.3F and 5.3G).

Sample DKE-19 (muscovite-sillimanite quartzite - Independência Unit of Ceará Complex). Zircons were extracted from a quartzitic layer of a rhythmically sequence which the youngest one yielded a ${ }^{206} \mathrm{~Pb} / 238 \mathrm{U}$ age at $903 \pm 13 \mathrm{Ma}$, with the youngest population clustering around $940 \mathrm{Ma}$. The Neoproterozoic zircons (10\% of total) spread from 903 to $973 \mathrm{Ma}$. Mesoproterozoic grains (22\% of total) form a second group comprising the 1027-1196 Ma time interval. Paleoproterozoic zircons (27\% of total) are arranged in two peaks roughly at 1850 and 2000 Ma. Three Archean zircons were dated and the oldest one yielded a concordant ${ }^{207} \mathrm{~Pb} / 206 \mathrm{~Pb}$ age at $2919 \pm 12$ 
Carlos E. Ganade de Araujo - Tese de Doutorado - Universidade de São Paulo Capítulo 5 - U-Pb zircon provenance

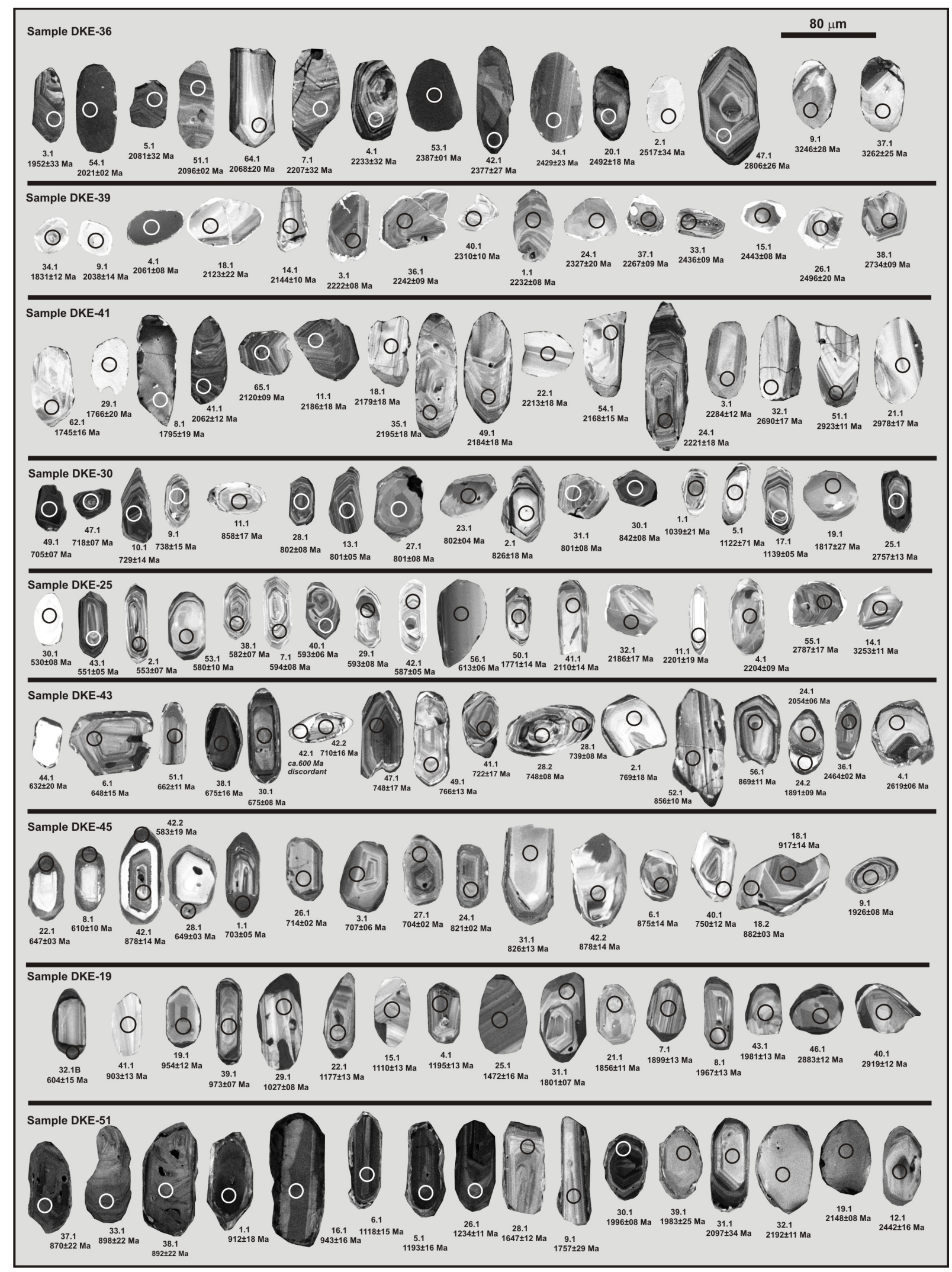

Figure 5.2 - Selected CL images and spot placement from the analyzed zircons. 


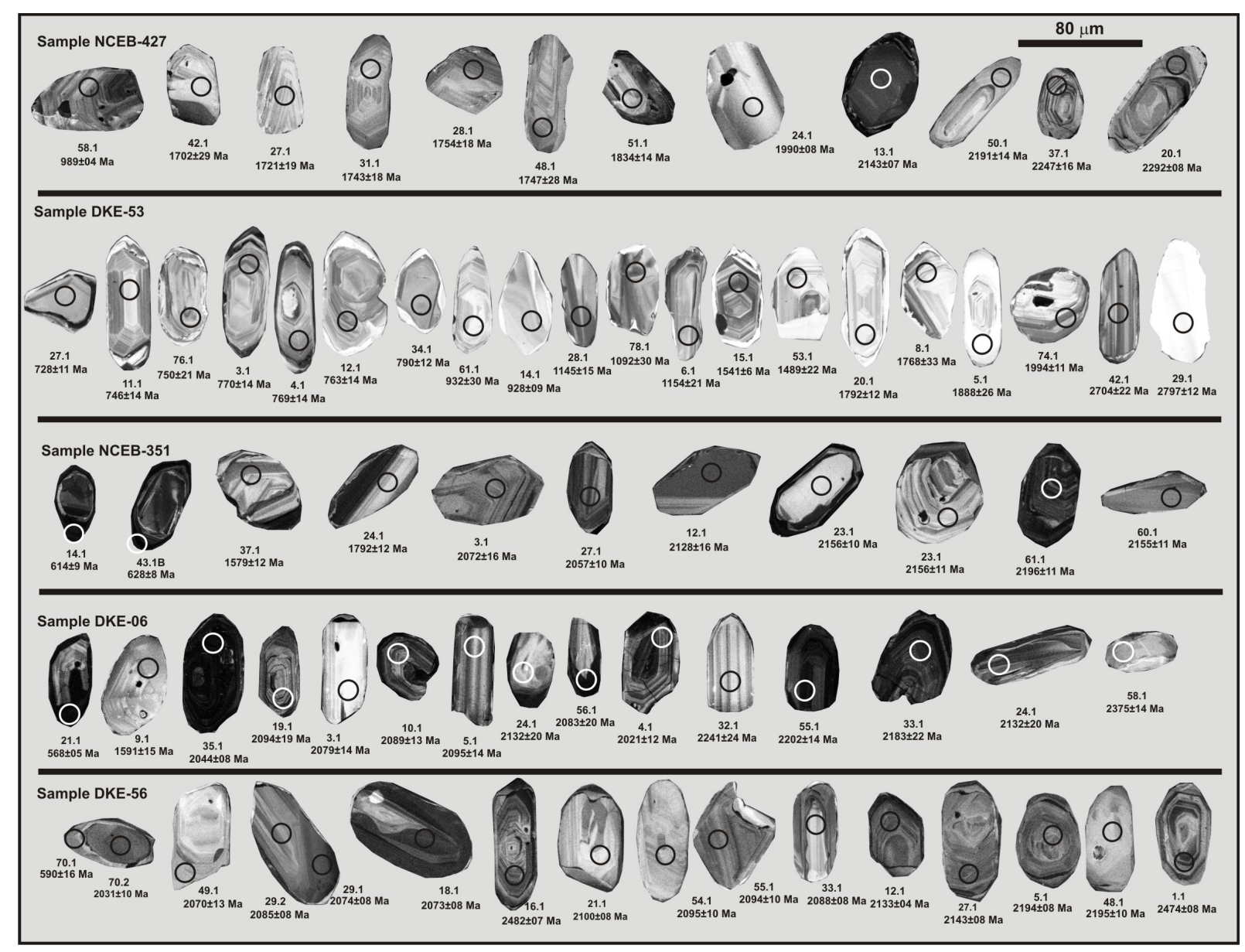

Figure 5.2 - (continued)

Ma. Some metamorphic overgrowths were analyzed, however only one (\#32.1) yielded a reliable concordant ${ }^{206} \mathrm{~Pb} /{ }^{238} \mathrm{U}$ age at $604 \pm 05 \mathrm{Ma}(\mathbf{f i g}$. 5.3H $)$.

\subsubsection{Region to the east of the Tamboril-Santa Quitéria Complex - Ceará Central Domain}

Sample DKE-51 (muscovite-bearing quartzite - Independência Unit of Ceará Complex). Youngest ${ }^{206} \mathrm{~Pb} / 238 \mathrm{U}$ age at $870 \pm 22 \mathrm{Ma}$ and the youngest population at $c a$. $900 \mathrm{Ma}$ constrain the maximum deposition age for this sample. Two younger groups can be observed; one with Neoproterozoic grains ranging from 870 to $967 \mathrm{Ma}$ (20\% of total) and a second Late Mesoproterozoic group ranging from 1014 to $1197 \mathrm{Ma}(17 \%$ of total). Few Mesoproterozoic ages around $1250 \mathrm{Ma}$ and $1650 \mathrm{Ma}$ were also detected. Paleoproterozoic zircons are abundant, comprising 41\% of the total grains, with peaks roughly around 1773, 1969, 2076, 2133 and 2444 Ma (fig. 5.3I).

Sample NCEB-427 (quartzite - Independência Unit of Ceará Complex). From the zircons analyzed in this sample only two yielded reliable ${ }^{206} \mathrm{~Pb} /{ }^{238} \mathrm{U}$ Neoproterozoic ages with the youngest constraining the maximum age of deposition at $963 \pm 09$ Ma. Mesoproterozoic ages comprise $23 \%$ of the total ages and peak mainly at 1066 , 1117 and 1324 Ma. Paleoproterozoic zircons dominate this sample constituting $67 \%$ of the total zircons, with peaks at 1660, 1833, 2019 and 2122 Ma. (fig. 5.3J). 
Sample DKE-53 (metatexitic paragneisses - Canindé Unit of Ceará Complex). The youngest analyzed zircon yielded a ${ }^{206} \mathrm{~Pb} / 238 \mathrm{U}$ age at $728 \pm 11 \mathrm{Ma}$ with the youngest population clustering at $c a .750 \mathrm{Ma}$. Of the total dated zircons, $28 \%$ show Neoproterozoic ages and can be divided into two distinct populations ranging from 728 to $790 \mathrm{Ma}$ and from 860 from $983 \mathrm{Ma}$. Late Mesoproterozoic zircons are also abundant, spanning from 1012 to 1193 Ma. Mesoproterozoic source component at ca. 1250, 1320 and 1550 Ma were also detected. Paleoproterozoic zircons are also rather abundant, comprising $25 \%$ of the dated zircons with main peaks at $c a$. 1780 and $1887 \mathrm{Ma}$ with some grains around 2020 and 2200 Ma. Three Archean zircons were analyzed and the oldest one yielded a concordant ${ }^{207} \mathrm{~Pb} / 206 \mathrm{~Pb}$ age at $3039 \pm 21 \mathrm{Ma}$ (fig. 5.3K).

Sample NCEB-351 (quartzite - Independencia Unit of Ceará Complex). Zircons from this sample spread mainly from the Paleoproterozoic to the Archean. One Mesoproterozoic zircon with a ${ }^{207} \mathrm{~Pb} /{ }^{206} \mathrm{~Pb}$ age at $1579 \pm 12(102 \%$ concordant) constrains the maximum age of deposition. Of the dated zircons, $70 \%$ are Paleoproterozoic ranging from 2040 to $2196 \mathrm{Ma}$. Six Archean zircons (20\% of total) ranging from 2658 to $2852 \mathrm{Ma}$ were also dated, with the oldest yielding a concordant ${ }^{207} \mathrm{~Pb} /{ }^{206} \mathrm{~Pb}$ age at $3134 \pm 09 \mathrm{Ma}$ (fig. 5.3L). Dated metamorphic overgrowths are mainly represented by homogeneous very high- $\mathrm{U}$ rims around the detrital cores, however some can be texturally zoned resembling primarily magmatic growth zoned zircons. The ${ }^{206} \mathrm{~Pb} / 238 \mathrm{U}$ ages of these metamorphic domains demonstrate a widespread variation ranging from 645 to $540 \mathrm{Ma}$.

Sample DKE-06 (feldspathic quartzite - Independência Unit of Ceará Complex). With the exception of the youngest zircon which yielded a Mesoproterozoic ${ }^{207} \mathrm{~Pb} / 206 \mathrm{~Pb}$ age at $1579 \pm 12(93 \%$ concordant), all zircons from this sample have Paleoproterozoic ages. The main population, comprising 55\% of the zircons, spread from 2101 to $2190 \mathrm{Ma}$. The oldest dated zircon yielded a concordant ${ }^{207} \mathrm{~Pb} /{ }^{206} \mathrm{~Pb}$ age at $2439 \pm 22 \mathrm{Ma}$. Three metamorphic overgrowths yielded reasonable ${ }^{206} \mathrm{~Pb} /{ }^{238} \mathrm{U}$ concordant ages at 578,575 and $540 \mathrm{Ma}$ (fig. $5.3 \mathrm{M})$.

Sample DKE-56 (feldspathic quartzite - Independência Unit of Ceará Complex). The youngest zircon yielded a ${ }^{207} \mathrm{~Pb} / 206 \mathrm{~Pb}$ age at $2031 \pm 10 \mathrm{Ma}$. With the exception of a $2591 \pm 91 \mathrm{Ma}$ Archean zircon, all the zircons of this sample yielded Paleoproterozoic ages. Two distinct Paleoproterozic populations can be identified at 2050$2130 \mathrm{Ma}$ and 2160-2210 Ma time intervals (fig. 5.3N).

\subsection{Discussion}

\subsubsection{Metamorphism}

Several metamorphic domains were dated in the studied zircons. They are represented mainly by high- and low-U overgrowths around the detrital cores detected in the CL images. The ages of these overgrowths are in agreement with $\mathrm{U}-\mathrm{Pb}$ zircon and monazite metamorphic ages previously reported (640 to $580 \mathrm{Ma}-$ e.g. Fetter, 1999; Castro, 2004; Arthaud, 2007; Amaral et al., 2010). Three distinct groups of metamorphic ${ }^{206} \mathrm{~Pb} /{ }^{238} \mathrm{U}$ ages are recorded in the selected overgrowths (fig. 5.30). The older group comprises the interval of ca. 650$630 \mathrm{Ma}$, and it is possible associated with the ages of the eclogitic metamorphism dated by Amaral et al. (2010) in the zone between the Transbrasiliano-Kandi Lineament and the Tamboril-Santa Quitéria Complex. The 
second and well defined group ranges from ca. 610 to $590 \mathrm{Ma}$ and is correlated with the widespread regional thermal event that affected the Borborema Province, including part of the migmatization and granitoid emplacement (e.g. Fetter, 1999; Arthaud 2007; Castro, 2004; Neves et al., 2009). The younger group clusters around $540 \mathrm{Ma}$ and is arguably related with the emplacement of post-collisional plutons at 540-520 Ma, or even with isotopic disturbance due to late fluid infiltration. If it proves to be regionally reproducible in the $\mathrm{CCD}$, the metamorphic ages clustering at around $647 \mathrm{Ma}$ in the older group defines the minimum age of deposition of the studied samples in this particular domain.

\subsubsection{Detrital zircon provenance patterns}

The visual comparison of the dated samples in the probability density distribution $(\mathbf{f i g}$. 5.4A $)$ and cumulative density distribution (fig. 5.4B) diagrams allowed the differentiation of four groups with specific provenance patterns. To assess the heterogeneity of the age distributions we also applied the Kolmogorov-Smirnov (K-S) two-sample test (Berry et al., 2001) (table 1 in the supplementary data). This test is a means to mathematically compare two detrital zircon distributions and determine if there is a statistically significant difference between the two distributions (Gehrels et al., 2000). The method is independent of any assumptions about the probability distribution of a sample and allows comparison of both age values (peak locations) and distributions (peak shapes) using the (P) parameter (DeGraff-Surpless et al., 2003). The higher the $\mathrm{P}$ value, the more likely it is that the two age distributions were drawn from the same population. To be $95 \%$ confident that two populations are not statistically different the P value must exceed 0.05 (DeGraff-Surpless et al., 2003).

Group I

This group is represented by samples that contain dominantly Paleoproterozoic and Archean zircons. The three samples from the São Joaquim Formation in the MCD (DKE-36, DKE-39 and DKE-41) share the same pattern defined by a Statherian youngest population (excepted by sample DKE-36) with a main Rhyacian source component combined with the presence of old Archean grains $(>3.0 \mathrm{Ga})$. The $P$ values for this group range from 0.221 to 0.944 (table 1), indicating significant similarities in the detrital zircon distribution throughout the São Joaquim Formation.

An associated subgroup in the CCD can be defined by the samples NCEB-351, DKE-06 and DKE-56, with $P$ values ranging from 0.363 to 0.414 (table 1). These samples have few youngest zircons, but no clustering populations, at the Mesoproterozoic era. The main provenance is defined by Rhyacian zircons with a subordinate Siderian component. With the exception of sample NCEB-351, this subgroup is characterized by the lack of Archean zircons. The $\mathrm{P}$ values of the sample NCEB-351 varies from 0.038 to 0.126 when compared with samples from the São Joaquim Formation, indicating some similarities in the detrital zircon distribution, but not necessarily sharing the same source areas.

Group II

This group is represented by a set of samples located both in the eastern (DKE-19) and western (DKE-51, DKE-53 and NCEB-427) sides of the Tamboril-Santa Quitéria Complex in CCD. It is characterized by a 
heterogeneous distribution including Archean to Neoproterozic zircons. $P$ values for samples DKE-53, DKE51 and DKE-19 range from 0.457 to 0.070 suggesting similar detrital zircon distribution, especially for samples DKE-19 and DKE-51 that were sampled on the opposite borders of the complex. Sample NCEB427 has similar detrital zircon distribution of sample DKE-51 ( $P$ value of 0.120$)$, however it shows low $P$ values $(>0.05)$ when compared to the other samples of the group. Except for sample DKE-53, the other ones show the youngest clustering of zircons at the Early Neoproterozoic (Tonian) at ca. 900-960 Ma. Some zircons from the Late Mesoproterozoic (Stenian 1000-1200 Ma) are also common, but Ectasian (1200-1400 Ma) zircons are subordinate. There are few zircons at ca. $1500 \mathrm{Ma}$, abundant Statherian (1600-1800 Ma) and extremely abundant Rhyacian (2050-2300 Ma) zircons combined with subordinate occurrence of Siderian (2300-2500 Ma) zircons. Few Archean zircons are present, but they are rarely older than $2800 \mathrm{Ma}$, unlike the Archean zircons from Group I that presented older ages. The sample DKE-53 has the same described pattern, however with younger Neoproterozoic zircons around $730 \mathrm{Ma}$.

\section{Group III}

This group includes the samples DKE-43, DKE-45, DKE-30 which is characterized by the abundance of Cryogenian (660-850 Ma) zircons. The youngest population is around $650 \mathrm{Ma}$ for the sample DKE-43 and ca. $700 \mathrm{Ma}$ for the samples DKE-45 and DKE-30. Zircons within the interval of 1000-1300 are rare, with the exception of the sample DKE-30 that contains some Stenian zircons. Although less evident, this group also contain some Paleoproterozoic and few Archean zircons suggesting a rather small contribution of older crystalline rocks. The $P$ value for samples DKE-43 and DKE-45 is 0.122 , indicating a good statistical fit for these samples from the Canindé Unit of Ceará Complex.

Group IV

This group was defined solely by the sample DKE-25. It is characterized by a distinctive presence of Ediacaran (542-630 Ma) zircons with the youngest population at $c a .550 \mathrm{Ma}$. An important feature of this group is the lack of any Neoproterozoic grain older than 630 Ma. Some Rhyacian grains are present along with a scarce Archean component.

\subsection{Potential source areas}

Attributing source areas to detrital zircon provenance patterns is not always a straightforward task and can sometimes be highly speculative.

The record of Archean crust is restricted to certain sites inside the Borborema Province. They can be found in the basement of the Ceará Central (e.g. Fetter, 1999) and Rio Grande do Norte (e.g. Dantas et al., 2004) domains, and also in the Sergipano Belt (e.g. Oliveira et al., 2010). The surrounding cratonic areas represented by the São Francisco and Amazonian-West African cratons also contain numerous Archean inliers and blocks (Teixeira et al., 1989; Tassinari and Macambira, 1999; Barbosa and Sabaté, 2004). Paleoproterozic crust is extensive found in all domains of the Borborema Province. However, at the present 
Carlos E. Ganade de Araujo - Tese de Doutorado - Universidade de São Paulo Capítulo 5 - U-Pb zircon provenance
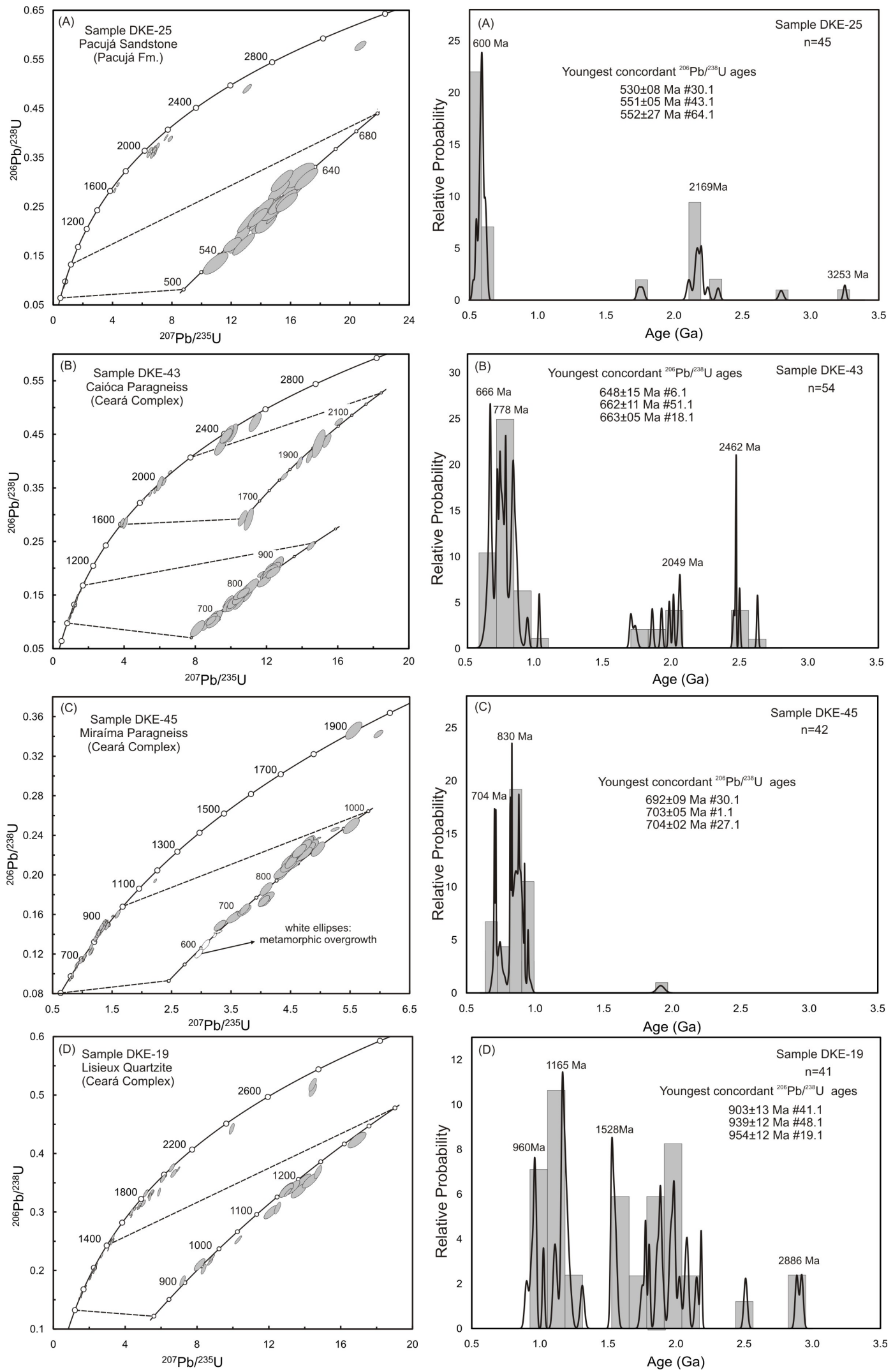

Figure 5.3 - Concordia (right) and relative age probability (left) diagrams for selected zircons analyzed in this study. 
Carlos E. Ganade de Araujo - Tese de Doutorado - Universidade de São Paulo Capítulo 5 - U-Pb zircon provenance
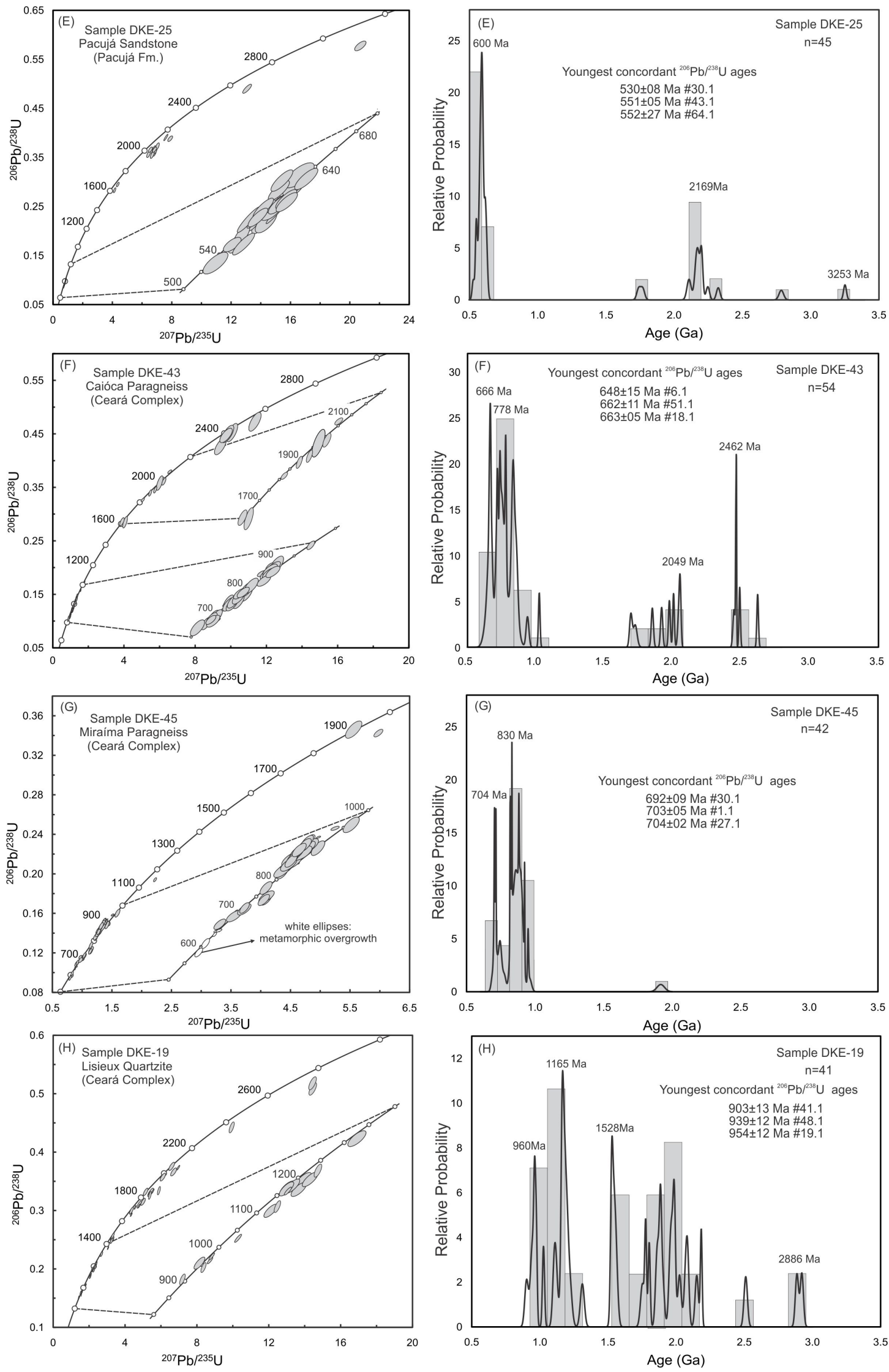

Figure 5.3 - (continued) 
Carlos E. Ganade de Araujo - Tese de Doutorado - Universidade de São Paulo Capítulo 5 - U-Pb zircon provenance
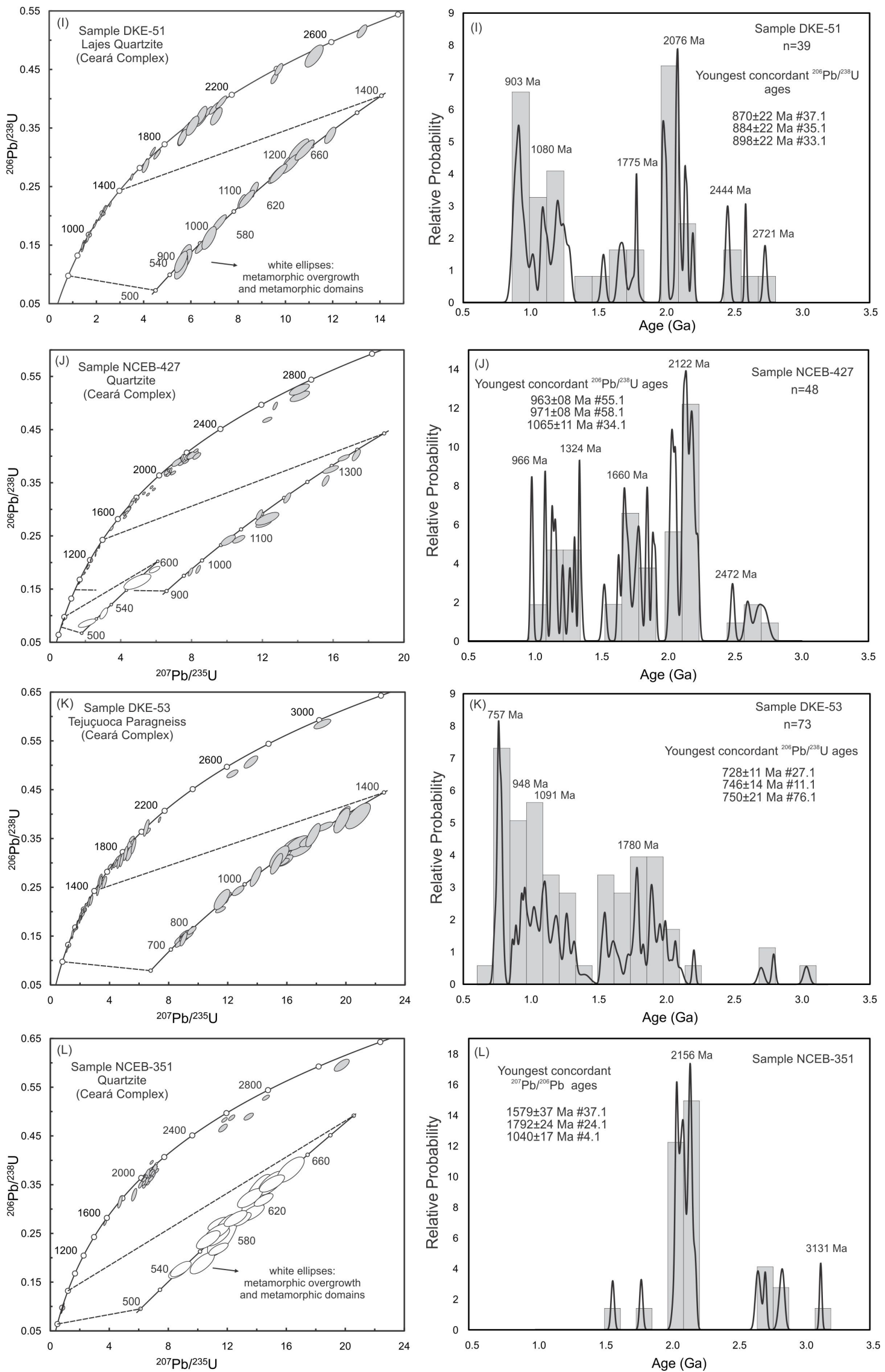

Figure 5.3 - (continued) 
Carlos E. Ganade de Araujo - Tese de Doutorado - Universidade de São Paulo Capítulo 5 - U-Pb zircon provenance
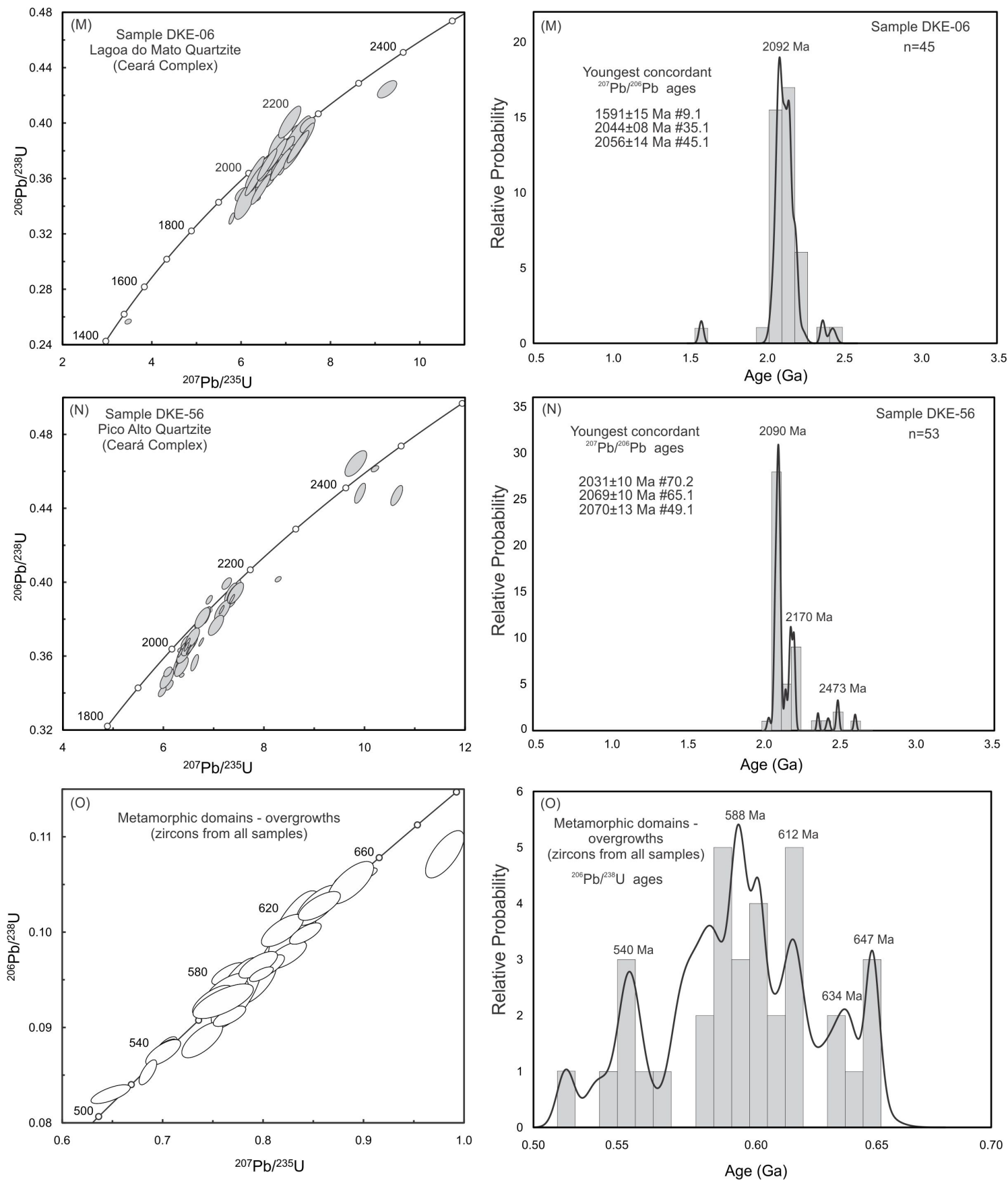

Figure 5.3 - (continued)

level of knowledge, Siderian crust is abundantly found in the basement of MCD (Santos et al., 2008b) with minor expositions in the GCD (Castro, unpublished). This Siderian event was recognized in the SE portion of the Amazon craton (Vasquez et al., 2008) and also in the West African craton (Lemoine et al., 2006) suggesting that these rocks could form a coherent trend, where great part of it is now hidden by the Paleozoic cover of the Parnaíba Basin. The major crust-forming event in the Borborema Province and within the surrounded cratonic blocks took place during the Rhyacian period in the so called Transamazonian orogenesis (Amazon craton) and Eburnian orogenesis (West African craton). 
The samples from group I contain basically Paleoproterozoic and Archean zircons. The quartzites of São Joaquim Formation are dominantly composed of Rhyacian zircons, but due to the widespread area of occurrence of the Rhyacian crust it is impossible to ascribe any particular source region. On the other hand, the same samples demonstrate a combined Siderian source component that can be derived directly from the basement of the Martinópole Group, particularly of the Granja Complex in the MCD or from further west in the SE Amazonian (to the west of the Araguaia Belt) and West African cratons. This interpretation can also explain the occurrence of Archean zircons $(>3.0 \mathrm{Ga}$ ) that can be shed from the West African craton, largely from the Archean rocks of Liberia, Sierra Leone and Guinea (e.g. Thiéblemont et al., 2001; Thiéblemont et al., 2004) and central regions of Amazon Craton, particularly from the Carajás-Imataca Block (Tassinari et al., 2000). With the exception of the Late Paleoproterozoic (Statherian) zircons, which could be also shed from the Amazon Craton, the São Joaquim quartzite has similar provenance to those of the Novo Oriente Group (Ganade de Araujo et al., 2010). This group is interpreted as a segment of a passive margin, possibly floored by oceanic crust in its distal portion that flanked the eastern part of the Amazonian-West African craton (present day position); in our opinion this interpretation can be extended for the São Joaquim quartzites in the MCD. Samples NCEB-351, DKE-06 and DKE-56 are also composed of Rhyacian zircons, but with a less evident or even lacking of the Siderian and Archean component, suggesting they do not share the same source area to those of the São Joaquim Formation. The more immature characteristics of these samples, evidenced by their high feldspar content, imply in a proximal source area possibly associated with small depocenters within the Paleoproterozoic-Archean basement of the Borborema Province. Few Late Paleoproterozoic (Statherian) zircons could also been shed from the Orós belt (Sá et al., 2002). The source for the ca. $1.5 \mathrm{Ga}$ zircons is still obscure, but Amaral et al. (2010) reported similar ages for mafic rocks within the basement of the CGD.

The Archean and Paleoproterozoic ages found in the samples that contain Neoproterozoic zircons, especially those from group II, can be derived from the former continent (a possible detached portion of the adjacent cratonic areas - possibly the São Francisco-Congo craton), represented today by the reworked basement of Borborema Province. A provenance from the main cratonic areas is not discarded as well, especially from the São Francisco-Congo craton, but in this case the Sergipano Belt would constitute a significant barrier or drainage divide. The source of the Mesoproterozoic zircons at ca. 1100-1400 Ma in the metasedimentary rocks from the Central Borborema Province is uncertain as there are no obvious local sources for these zircons. Neves et al. (2009) argued for a provenance derived from the Amazon craton for the 1100-1400 Ma zircons, however, the Araguaia Belt or basin, which was inverted only at the end of Neoproterozoic (Moura et al. 2008), would constitute an important obstacle for the zircons from further west and northwest of Amazonian craton, particularly from the Sunsás Province (1.45 to $1.1 \mathrm{Ga}$ ) (Santos et al., 2008).

Zircons within the 920-1000 Ma interval are possibly derived from the crystalline rocks related to Cariris Velhos event in the Central portion of the Borborema Province (e.g. Santos et al., 2010). The Cryogenian zircons in the interval of 660-850 Ma are widespread in some samples, especially in those from the group III. Related magmatism to this time interval is still unusual in the Borborema Province (Ganade de Araujo et al., 2010; Neves et al., 2011), however it has a strong component in the detrital zircons from this study and from others in the Borborema Province (e.g. Van Schmus et al., 2003, 2011; Neves et al., 2009). Some authors 
Carlos E. Ganade de Araujo - Tese de Doutorado - Universidade de São Paulo Capítulo 5 - U-Pb zircon provenance

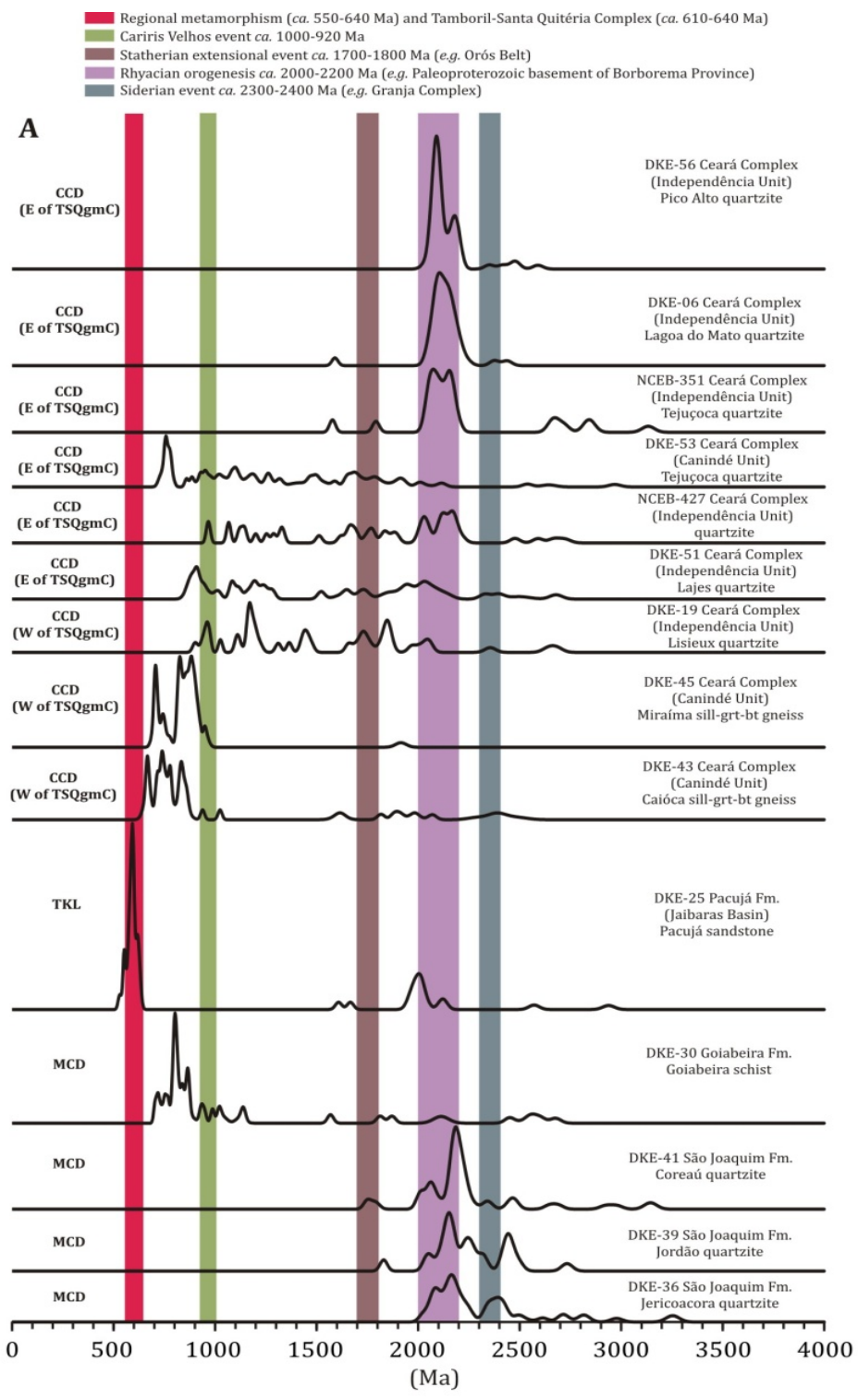

B

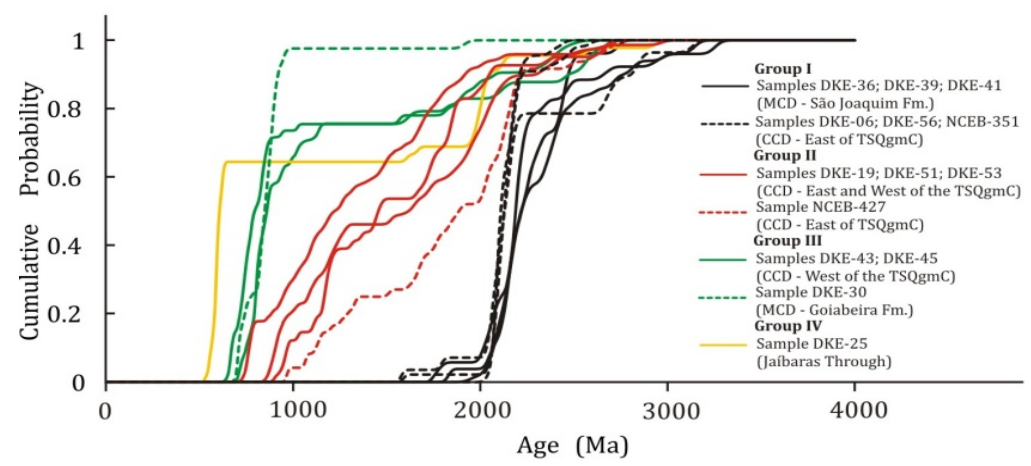

Figure 5.4 - A. Relative age probability diagram comparing ages of detrital zircon grains from samples of the Médio Coreaú and Ceará Central Domains. B. Cumulative age density distribution diagram comparing ages of detrital zircon grains from samples of the Médio Coreaú (MCD) and Ceará Central Domains (CCD). TSQgmC - Tamboril-Santa Quitéria granitic-migmatitic Complex. 
proposed an extensional period for this interval. However, the quasi-continuous spectrum of ages ranging from ca. 900 to ca. $700 \mathrm{Ma}$ are not suggestive of such event, since extensional events are more restricted to a certain duration [e.g. ca. 30 m.y. for the Red Sea Rift (Hofmann et al., 1995; Kazmim and Byakov, 2000), ca. 30 m.y. for the Main Ethiopian Rift (Corti et al., 2009)]. In addition, magmatic pulses related to extensional settings are short-lived and less fertile in zircons when compared to those of a convergent magmatic arc setting. The lack of immature terrigenous siliciclastic rocks, or evidence to abrupt facies variations in the lithological record of the CCD also do not fit with the proposed extensional setting. Instead, when recognized, the rocks display a rhythmic intercalation of metagreywacke, metapelites and metapsmites coherent with turbititic deposits associated or not with marbles. Recently, Ganade de Araujo et al. (2010b) presented a Pb$\mathrm{Pb}$ evaporation age of $c a .795 \mathrm{Ma}$ for a metatexitic granodiorite-tonalite in the western portion of the Tamboril-Santa Quitéria Complex and based on preliminary geochemical and Nd isotopic data interpreted this manifestation as pre-collisional subduction-related magmatism in the CCD. The presence of abundant grains in the 900-700 Ma interval reinforces the interpretation of long-lived active continental margin, or subduction systems, since the beginning of the Neoproterozoic time.

The Ediacaran zircons within interval of 630-600 Ma found in the sample from the Jaíbaras Trough are clearly derived from the 640-600 Ma Tamboril Santa Quitéria granitic-migmatitic Complex (Fetter et al., 2003; de Araujo et al., 2012), and also from the post-collisional granitoids ranging from ca. 580 to $540 \mathrm{Ma}$ (Fetter, 1999).

\subsubsection{Tectonic implications: A long-lived continental margin?}

Evidences from West Transaharan orogen in Africa (Caby et al., 1989; Caby, 2003; Berger et al., 2011) and Central Brazil (Pimentel and Fuck, 1992, Pimentel et al., 2000; Laux et al., 2005) demonstrated that part of the Neoproterozoic growth of western Gondwana occurred firstly during the Late Tonian and Cryogenian, through the development of intraoceanic arcs suggesting the presence of a large ocean separating the São Francisco and Amazonian/West African cratons. These accretionary settings subsequently became collisional orogens that reworked the previous continent (basement) during the Late Cryogenian to Early Ediacaran at ca. 650-620 Ma (Liégois et al., 1987, Piuzana, et al., 2003; DellaGiustina et al., 2009; de Araujo et al., 2012). The Borborema Province, specially its crustal domains located in the vicinities of the Transbrasiliano-Kandi shear system, represents the link between the Central Brazil and West Sahara orogens. In this scenario, does the region represented by Borborema Province narrowed into a small ocean or does it remained opened configuring a vast oceanic domain connecting the Goias (in Central Brazil) and Pharusian (in West Africa) oceans?

Two contrasting views regarding the tectonic reconstruction of the Borborema Province are currently in vogue. In one hand, following the assertion of Van Schmus et al. (2008), some believe that Mesoproterozoic to Early Neoproterozoic break-up of a Paleoproterozoic supercontinent created a large region between Congo/São Francisco and Amazonian/West African cratons, consisting of extensional basins floored by Paleoproterozoic-Archean crust, local basins approaching small oceans, and a larger ocean along the main axis of the Transbrasiliano-Kandi shear system. On the other hand, other authors believe in an essentially intracontinetal development, where an autochthonous setting is implied (Neves, 2003; Neves et al. 2009). 
In fact, the timing of continental break-up, passive margin development, seafloor spreading, subduction and continental collision related to development of West Gondwana in the Borborema Province is still debatable. The $c a$. 1000-920 Ma Cariris Velho event in the Central Sub-Province (Zona Transversal - see Van Schmus et al., 2011) is regarded as orogenic (Santos et al., 2010); however the lack of any metamorphism of this age has led some authors to interpret this event as an intracontinental extension (e.g. Neves, 2003). In the Geará Central and Médio Coreaú domains, some authors favour break-up and rift development at around $770 \mathrm{Ma}$ (Fetter et al., 2003; Castro, 2004; Arthaud, 2007), as proposed by Oliveira and Tarney (1990) for the Canindé Rift within the Sergipano Belt, further southwest.

In the Borborema Province, arc building period is conventionally constrained at $c a$. 640-610 Ma (Fetter et al., 2003; Van Schmus et al., 2011) with initial collisional tectonics at ca. 610-590 Ma. Such a short time for arc construction (ca. 30 m.y.) is not consistent with a consumption of a large oceanic setting, hosting intraoceanic arcs as evidenced in Central Brazil and in the West Transaharan orogen in Africa. The abundance of detrital zircons younger than the Cariris Velhos event, but older than the main phase of metamorphism and deformation (ca. $650 \mathrm{Ma}$ ) indicate that this time interval was also an import period of crustal growth in the Borborema Province as noted in the Central Brazil and Northwestern Africa. Although still poorly characterized, a Pb-Pb zircon evaporation age of $c a .795 \mathrm{Ma}$ (Ganade de Araujo et al., 2010) in CCD and U$\mathrm{Pb}$ ages at $c a .870$ and $851 \mathrm{Ma}$ (Neves et al., 2011) in the Central Borborema Province attest for the regional expression of granitoids within this time interval. In our opinion, this period is defined by the pre-collisional arc related systems compatible with a long lived continental margin setting that were overprinted by the collisional tectonics at $c a$. 640-610 Ma (fig. 5.5). The sudden cessation of detrital zircons at $c a$. $650 \mathrm{Ma}$ indicates an abrupt change in the tectonic regime arguably caused by the onset of collisional tectonics and inversion of the basins that were fed by arc-related detritus. The absence of Neoproterozoic zircons older than ca. $650 \mathrm{Ma}$ in the Jaíbaras Trough, inserted within the Transbrasiliano-Kandi Shear System, indicate that great part of the provenance was derived from the collisional front associated with the late extensional phases of the orogeny.

The similar provenance of the Goiabeira Formation to the west to the Transbrasiliano-Kandi Lineament to those of the supracrustal rocks to the east of the same lineament indicates that it does not mark the suture itself as previously thought by some authors (e.g. Ganade de Araujo and Santos, 2008). This Lineament represents a structure developed during the collisional event, analogous to the Anatolian Fault System in Turkey, or to the shear zones developed due to the Cenozoic India-Eurasia collisional escape tectonics. In this way, the final arrangement of the segmented crustal blocks in the Borborema Province is assigned by the development strike-slip shear zones of the Transbrasiliano Shear System, which is linked with the ultimate stages of the escape collisional processes, combined with a northeastward extrusion that reflects the final configuration of the province. 
Carlos E. Ganade de Araujo - Tese de Doutorado - Universidade de São Paulo Capítulo 5 - U-Pb zircon provenance

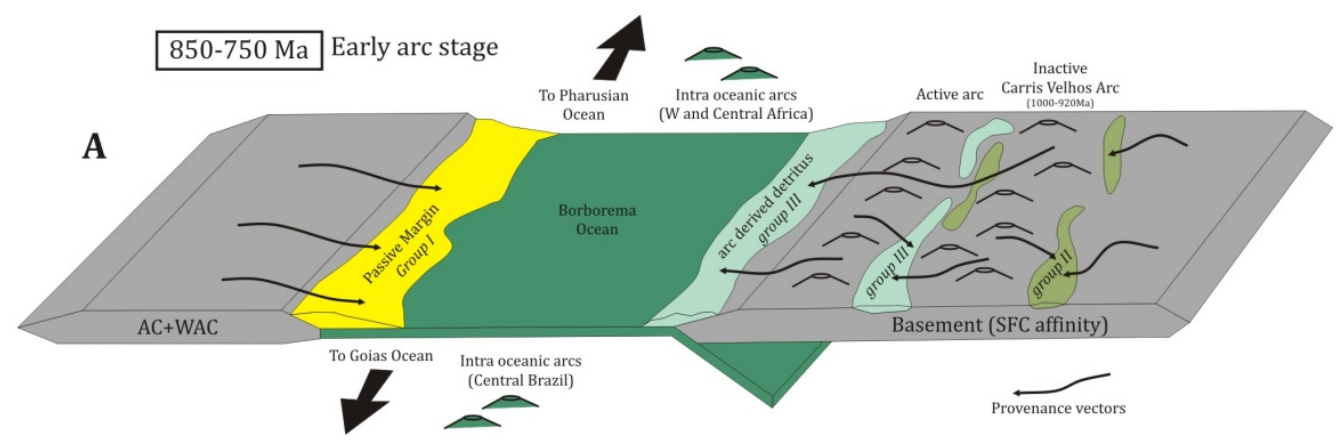

750-650 Ma Late arc stage
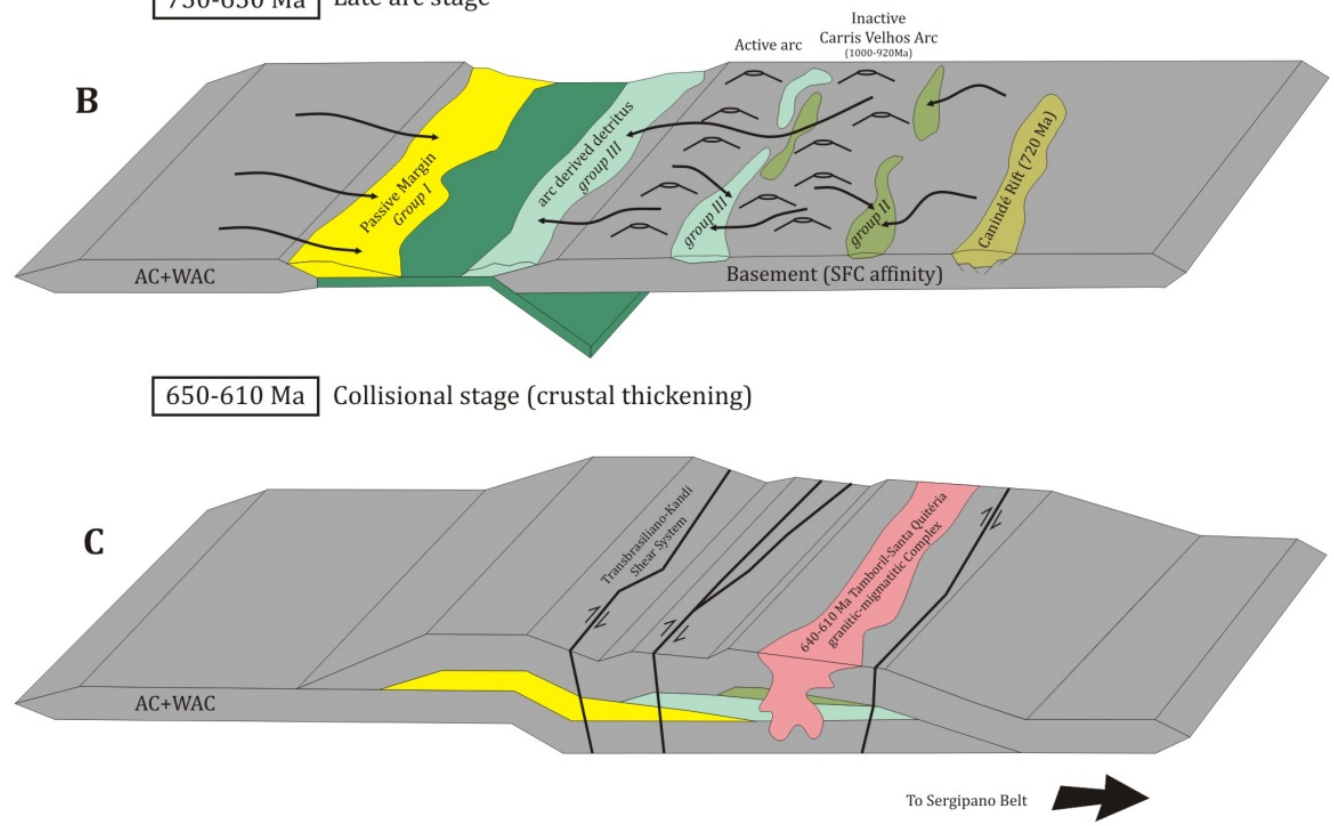

610-500 Ma Post-collisional stage (extension and collapse)

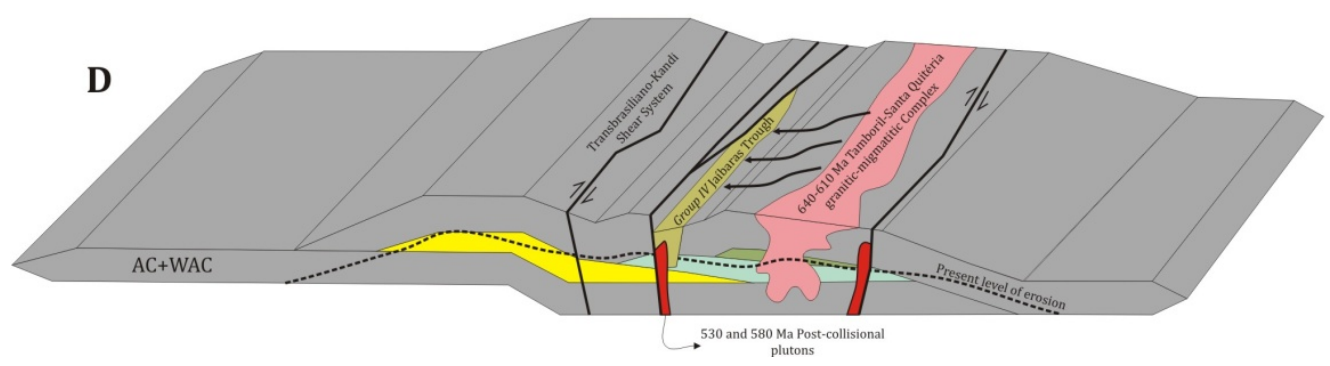

Figure 5.5 - Tectonic model for the Neoproterozoic to Cambrian evolution in the Ceará Central and Médio Coreaú Domains of the Borborema Province. A. Wide oceanic setting in an early arc stage with inactive precursors arcs (Cariris Velhos) and intraoceanic arcs in Central Brazil and Africa. B. Narrowing of the oceanic domain and development of some extensional settings inboard of the eastern (present day position) plate. G. Continental collision and development of the Tamboril-Santa Quitéria granitic-migmatitic Complex and strike-slip shear zones of the Transbraliliano-Kandi Shear System. D. Late orogenic stage related with the development of extensional setting (Jaíbaras Trough) arguably associated with the collapse of the orogen. ACAmazonian Craton, WAC- West African Craton, SFC-São Francisco Craton.

\subsection{Conclusions}


Carlos E. Ganade de Araujo - Tese de Doutorado - Universidade de São Paulo

Capítulo 5 - U-Pb zircon provenance

Large scale provenance of the metasedimentary rocks from the Ceará Central and Médio Coreaú domains of Borborema Province has been assessed using U-Pb zircon geochronological studies by LA-MC-ICP-MS. Although reconnaissance in nature, several first-order conclusions can be addressed from our study such as:

i) The rocks from the São Joaquim Formation in the MCD have a particular provenance signature that differs from the supracrustals rocks of the CCD. The detrital zircons from the São Joaquim quartzites were presumably shed from a continental region dominated by Paleoproterozoic and Archean crystaline rocks containing subordinate 1.7-1.8 Ga rocks. The zircon ages are in agreement with a provenance derived from the West African craton and Paleoproterozoic Granja Complex in a passive margin setting. Rocks to the west of the Araguaia belt in the Amazon craton could also have shed detritus to this passive margin system.

ii) The Goiabeira Formation has similar patterns to the supracrutal rocks of CCD suggesting that the Transbrasiliano-Kandi Lineament does not represent a suture or a terrane boundary, but a large collisionrelated shear zone.

iii) Samples from the Ceará Complex in the CCD demonstrate a heterogeneous provenance pattern characterized by deposits exclusively composed by Paleoproterozic-Archean detritus, probably representative of small basins floored by sialic crust within the orogenic realm, and arc-related deposits with strong Cryogenian source component. In ancient active-margin settings, the sedimentary record contained within forearc strata can provide a more complete history of arc magmatism than the present exposure of the arc itself (DeGraaff-Surpless et al., 2002). Geological relationships along the prolongation of the TransbrasilianoKandi Lineament in Africa and Central Brazil, combined with the detrital zircon data presented herein, suggest that the Neoproterozoic paleogeography of this sector of the Gondwana is consistent with a long-lived active margin.

iv) Zircons with ages in the range of the Tamboril-Santa Quitéria Complex are only found in the molassic basins, represented here by the Jaíbaras Trough, thus indicating that the supracrustals from the MCD e GCD are not related with the development of this complex as previously thought (e.g. Fetter et al., 2003).

v) Metamorphic overgrowths around the detrital zircon cores indicate a pluri-metamorphic evolution with distinct modes at $c a$. 640,610,580 and $540 \mathrm{Ma}$. The ages of metamorphic overgrowths partially overlap the main phases of the Tamboril-Santa Quitéria granitic-migmatitic Complex (ca. 640-610 Ma), indicating that this complex developed during the climax of the Neoproterozoic collisional orogenesis in Borborema Province.

\section{Acknowledgments}

We thank the staff of the Geochronology Research Centre (CPGeo), in special Vasco Loios for his skilled support to the first author during sample preparation. We are grateful to the FAPESP support through the grants 05/58688-1. The first author also thanks Dunito for stimulation and companion while he was writing this manuscript. Gonzalo Blanco and an anonymous reviewer are gratefully thanked by the suggestions given on the early version of the manuscript. 
Carlos E. Ganade de Araujo - Tese de Doutorado - Universidade de São Paulo

Capítulo 5 - U-Pb zircon provenance

\subsection{References}

Almeida, F.F.M., Hasui, Y., Brito Neves, B.B., Fuck, R.A., 1981. Brazilian structural provinces: an introduction. Earth Sciences Reviews 17, 1-29.

Amaral, W.S., Santos, T.J.S., Wernick, E., Matteini, M., Dantas, E. L., Moreto, C.P.N., 2010. U-Pb, Lu-Hf and Sm-Nd geochronology of rocks from the Forquilha Eclogite Zone, Ceará Central Domain, Borborema Province, NE-Brazil. In: VII-SSAGI South American Symposium on Isotope Geology, 2010, Brasília.

Archanjo, C.J., Launeau, P., Hollanda, M.H.B.M., Macedo, J.W.P., Liu, D., 2009. Scattering of magnetic fabrics in the Cambrian alkaline granite of Meruoca (Ceará State, northeastern Brazil). International Journal of Earth Sciences 98, 1793-1807.

Arthaud, M.H., 2007. Evolução Neoproterozóica do Grupo Geará (Domínio Ceará Central, NE Brasil): da sedimentação à colisão continental brasiliana. PhD Thesis, Universidade de Brasília, Brasília, 170p.

Arthaud, M.H., Caby, R., Fuck, R.A., Dantas, E.L., Parente, G.V., 2008. Geology of the Northern Borborema Province, NE Brazil and its correlation with Nigeria, NW Africa. In: Pankhurst, R.J., Trouw, R.A.J., Brito Neves, B.B., De Wit, M.J. (Eds.), West Gondwana: Pre-Cenozoic Correlations Across the Atlanti Region: Geological Society of London Special Publications, vol. 294, pp. 49-67.

Barbosa, J.S.F, Sabaté, P., 2004. Archean and Paleoproterozoic crust of the São Francisco Craton, Bahia, Brazil: geodynamic features. Precambrian Research, 133, 1-27.

Berger, J., Caby, R., Liégois, J.P., Mercier, J.C., Demaiffe, D., 2011. Deep inside a neoproterozoic intra-oceanic arc: growth, differentiation and exhumation of the Amalaoulaou complex (Gourma, Mali). Contributions to Mineral Petrol. DOI 10.1007/s00410-011-0624-5

Berry, R.F., Jenner, G.A., Meffre, S., and Tubrett, M.N., 2001, A North American provenance for Neoproterozoic to Cambrian sandstones in Tasmania?: Earth and Planetary Science Letters, v. 192, p. 207-222.

Brito Neves, B.B. de., Cordani, U.G., 1991. Tectonic evolution of South America during the Late Proterozoic. In: Stern, R.J., Van Schmus, W.R. (Eds.), Crustal Evolution in the Late Proterozoic: Precambrian Research 53, $23-40$.

Brito Neves, B.B. de., Santos, E.J., Van Schmus, W.R., 2000. Tectonic history of the Borborema Province, NW Brazil. In: Cordani, U.G., Milani, E.J., Thomaz Filho, A., Campos, D.A. (Eds.), Tectonic Evolution of South America - Rio de Janeiro, 151-182.

Caby, R., 1989. Precambrian terranes of Benin Nigeria and Northeast Brazil and Late Proterozoic SouthAtlanticfit. Geological Society ofAmerica Special Paper 230,145-158.

Caby, R., 2003. Terrane assembly and geodynamic evolution of central-western Hoggar: a synthesis. Journal of African Earth Sciences 37, 133-159. 
Carlos E. Ganade de Araujo - Tese de Doutorado - Universidade de São Paulo

Capítulo 5 - U-Pb zircon provenance

Castro, N. A., 2004. Evolução Geológica Proterozóica da região entre Madalena e Taperuaba, Domínio Tectônico Ceará Central (Província Borborema). PhD Thesis, Universidade de São Paulo, 322p.

Castro, N.A., Ganade de Araujo, G.E., Basei, M.A.S., Osako, L.S., Nutman, A., Liu, D., 2012. Ordovician A-type granitoid magmatism on the Ceará Central Domain, Borborema Province, NE-Brazil. Journal of South American Earth Sciences, 36, 18-31.

Cavalcante, J. C., Vasconcelos, A. M., Medeiros, M. F., Paiva, I. P., Gomes, F. E. M., Cavalcante, S. N., Cavalcante, J. E., Melo, A. G. R., Duarte Neto, V. G., Bevenides, H. G., 2003. Mapa Geológico do Estado do Ceará - Escala 1:500.000. Fortaleza, CPRM-SGB Serviço Geológico do Brasil.

Cawood, P.A., Nemchin, A.A., 2001. Paleogeographic development of the Laurentian margin: constraints from U-Pb dating of detrital zircons in the Newfoundland Appalachians. Geological Society of America Bulletin 113, 1234-1246.

Chew, D.M., Magna, T., Kirkland, C.L., Mišković, A., Cardona A., Spikings, R., Schaltegger, U., 2008. Detrital zircon fingerprint of the Proto-Andes: Evidence for a Neoproterozoic active margin? Precambrian Research 167, $186-200$.

Corfu, F., Hanchar, J.M., Hoskin, P.W.O., Kinny, P., 2003. Atlas of zircon textures. In: Hanchar, J.M., Hoskin, P.W.O. (eds) Zircon. Mineralogical Society of America Reviews in Mineralogy \& Geochemistry 53, 469-495.

Condie, K.C., Belousova, E., Griffin, W.L., Sircombe, K.N., 2009. Granitoid events in space and time: Constraints from igneous and detrital zircon age spectra. Gondwana Research 15, 228-242.

Costa, F.G., de Araujo, G.E.G., Vasconcelos, A.M., Palheta, E.S.M., Justo, A.P., 2010. O Complexo Tamboril-Santa Quitéria: Evidências de Slab Breakoff durante colisão continental neoproterozóica, Norte da Província Borborema. In: $45^{\circ}$ Congresso Brasileiro de Geologia, Belém-PA., 2010. 45 Congresso Brasileiro de Geologia, Belém-PA.

Corti, G., 2009. Continental rift evolution: From rift initiation to incipient break-up in the Main Ethiopian Rift, East Africa Earth-Science Reviews, 96, 1-53

Dantas, E.L., Van Schmus, W.R., Hackspacher, P.C., Fetter, A., Brito Neves, B.B., Cordani, U.G., Nutman, A.P., Williams, I.S., 2004. The 3.4-3.5 Ga Sao José do Campestre massif, NE Brazil: remnants of the oldest crust in South America. Precambrian Research 130, 113-137.

de Araújo C.E.G., Pineo, T.R.G., Cavalcante, J.C., Caby, R., Costa, F.G., Vasconcelos, A.M., Rodrigues, J.B., $2010 a$. Provenance of the Novo Oriente Group, southwestern Ceará Central Domain, Borborema Province (NE-Brazil): A dismembered segment of a magma-poor passive margin or a restricted rift-related basin? Gondwana Research 18, 497513.

de Araujo C.E.G., Costa, F.G., Palheta, E.S.M., Cavalcante, J.G., Vasconcelos, A.M., Moura, C.A.V., $2010 b$. ${ }^{207} \mathrm{~Pb} /{ }^{206} \mathrm{~Pb}$ zircon ages of pre- and syn collisional granitoids from the Tamboril-Santa Quitéria granitic-migmatitic Complex, Geará Central Domain, Borborema Province (NE-Brazil): Geodynamic implications. In: VII South American Symposium on Isotope Geology, Brasília, 2010.

de Araújo, C.E.G., 2011. A synthesis of the Neoproterozoic to Ordovician granitoid record from Ceará Central Domain, Borborema Province, NE-Brazil: pre-collision, collision and mountain belt collapse to a sedimentary basin development. 
Carlos E. Ganade de Araujo - Tese de Doutorado - Universidade de São Paulo Capítulo 5 - U-Pb zircon provenance

In: 7th Hutton Symposium on Granites and Related Rocks, 2011 , Avila, Spain. 7th Hutton Symposium on Granites and Related Rocks, 2011.

de Araujo, C.E.G., Costa, F.G., Pinéo, T.R.G., Cavalcante, J.G., Moura, G.A.V., 2112. Geochemistry and $207 \mathrm{~Pb} / 206 \mathrm{~Pb}$ zircon ages of granitoids from the southern portionof the Tamboril-Santa Quitéria granitic-migmatitic complex, Ceará Central Domain, Borborema Province (NE Brazil). Journal of South American Earth Sciences, 33, 21 33.

De Wit, M.J., Brito Neves, B.B., Trouw, R.A.J., Pankhurst, R.J., 2008. Pre-Cenozoic correlations across the South Atlantic region: "the ties that bind". In: Pankhurst, R.J., Trouw, R.A.J., Brito Neves, B.B., De Wit, M.J. (Eds.), West Gondwana: Pre-Cenozoic Correlations Across the Atlanti Region: Geological Society, London, Special Publications, vol. 294, pp. 1-8.

DeGraaff-Surpless, K., Graham, S.A., Wooden, J.L., McWilliams, M.O., 2002. Detrital zircon provenance analysis of the Great Valley Group, California: evolution of an arc forearc system. Geological Society of America Bulletin 114, $1564-1580$.

DeGraaff-Surpless, K., Mahoney, J. B., Wooden, J.L., McWilliams M.O., 2003. Lithofacies control in detrital zircon provenance studies: Insights from the Cretaceous Methow basin, southern Canadian Cordillera. GSA Bulletin 115, 8, 899-915.

DellaGiustina, M.E.S., Oliveira, G.G., Pimentel, M., Buhn, B., 2009. Neoproterozoic magmatism and high-grade metamorphism in the Goiás Massif: new LA-MCICMPS U-Pb and Sm-Nd data and implications for collisional history of the Brasília Belt. Precambrian Research 172, 67-79.

Dodson, M.H., Compston, W., Williams, I.S., and Wilson, J.F., 1988, A search for ancient detrital zircons in Zimbabwean sediments: Geological Society (London) Journal, 145, 977-983.

Fetter, A.H., 1999. U/Pb and $\mathrm{Sm} / \mathrm{Nd}$ geochronological constraints on the crustal framework and geologic history of Ceará State, NW Borborema Province, NE Brazil: implications for the assembly of Gondwana. PhD Thesis, Kansas University.

Fetter, A.H., Santos, T.J.S., Van Schumus, W.R., Hackspacher, P.C., Brito Neves, B.B., Arthaud, M.H., Nogueira Neto, J.A., Wernick, E., 2003. Evidence for Neoproterozoic continental arc magmatism in the Santa Quitéria Batholith of Geará State, NW Borborema Province, NE Brazil: implications for the assembly of west Gondwana. Gondwana Research 6, 265-273.

Fetter, A.H., Van Schmus, W.R., Santos, T.J.S., Arthaud, M.H., Nogueira Neto, J.A., 2000. U-Pb and Sm-Nd geochronological constraints on the crustal evolution and basement architecture of Ceará State, NWBorborema Province, NE Brazil: implications for the existence of the Paleoproterozoic supercontinent "Atlantica". Revista Brasileira de Geociências 30, 102-106.

Gaudette, H.E., Abreu, F. de A.M. de, Lafon, J.M., Gorayeb, P.S. de S., 1993. Evolução transamazônica do cinturão de cisalhamento noroeste do Ceará: novas evidências geocronológicas. Anais do Simpósio de Geologia do Nordeste 13, 317-319. 
Carlos E. Ganade de Araujo - Tese de Doutorado - Universidade de São Paulo

Capítulo 5 - U-Pb zircon provenance

Gaudette, H.E., Lafon, J.M., Macambira, M.J.B., Moura, G.A.V., Scheller, T., 1998. Comparison of single filament Pb evaporation/ionization zircon ages with conventional $\mathrm{U}-\mathrm{Pb}$ results: examples from Precambrian of Brazil. Journal of South American Earth Sciences 11, 351363.

Gehrels, G.E., Dickinson, W.R., Riley, B.C.D., Finney, S.C., Smith, M.T., 2000. Detrital zircon geochronology of the Roberts Mountains allochthon, Nevada: Geological Society of America Special Papers, 347, 19-42.

Hawkesworth, C.J., Cawood, P.A., Kemp, A.I.S., Storey, C.D., Dhuime, B., 2009. A matter of preservation. Science 323, 49-50.

Hofmann, G., Feraud, G., Pik, R., Coulon, C., Yirgu, G., Ayalew, D., Deniel, G. and Courtillot, V. 1995. 40Ar/39Ar dating of Ethiopian traps (abstract). Terra Abstracts 7,159.

Kazmin, V.G., Byakov. A.F., 2000. Magmatism and crustal accretion in continental rifts Original Research Article. Journal of African Earth Sciences, 30, 555-568.

Laux, J.H., Pimentel, M.M., Dantas, E.L., Armstrong, R., Junges, S.L., 2005. Two Neoproterozoic crustal accretion events in the Brasília Belt, central Brazil. Journal of South American Earth Sciences, 18, 183-198.

Lemoine, S., Tempier, P., Bassot, J.P., Caen-Vachette, M., Vialette, Y., Touré, S., Wenmenga, U., 2006. The Burkinian orogenic cycle, precursor of the Eburnian orogeny in West Africa. Geological Journal 25, 171-188.

Liegois, J.P., Bertrand, J.M. and Black, R. (1987) The subduction and collision-related batholith of the Adrar des Iforas (Mali); geochemical trends in space and time: a review. In: Kinnaird,J. and Bowden, F. (Eds.), Afri. Geol. Rev. Wiley, New Yorkp. 187-277.

Ludwig, K.R., 2003. Isoplot 3.00 - A Geochronological Toolkit for Microsoft Excel. Berkeley Geochronology Center, Special Publication No 4.

Martins, G., Oliveira, E.P., Lafon, J.M., 2009. The Algodões amphibolite-tonalite gneiss sequence, Borborema Province, NE Brazil: geochemical and geochronological evidence for Palaeoproterozoic accretion of oceanic plateau/back-arc basalts and adakitic plutons. Gondwana Research 15, 71-85.

Monié, P., Caby, R., Arthaud, M.H., 1997. The Neoproterozoic Brasiliano Orogeny in Northeast Brazil: 40Ar/39Ar and petrostructural data from Ceará. Precambrian Research 81, 241-264.

Moura, G.A.V., Pinheiro, B.L.S, Nogueira, A.C.R., Gorayeb, P.S.S., Galarza, M.A., 2008. Sedimentary provenance and palaeoenvironment of the Baixo Araguaia Supergroup: constraints on the palaeogeographical evolution of the Araguaia Belt and assembly of West Gondwana. Geological Society, London, Special Publications 294, 173-188.

Neves, S.P., 2003. Proterozoic history of the Borborema Province (NE Brazil): correlations with neighboring cratons and Pan-African belts, and implications for the evolution of western Gondwana. Tectonics 22, 1031.

Neves, S.P., Bruguier, O., Mariano G., da Silva, J.M.R., 2011. O magmatismo pós-cariris velhos, pré-brasiliano na porção oriental da província borborema: implicações tectônicas. XIII Simpósio Nacional de Estudos Tectonicos, Campinas-SP, CD-ROM. 
Carlos E. Ganade de Araujo - Tese de Doutorado - Universidade de São Paulo

Capítulo 5 - U-Pb zircon provenance

Neves, S.P., Bruguier, O., Silva, J.M.R., Delphine Bosch, D., Alcantara, V.C., Cristiane Marques Lima, C.M., 2009. The age distributions of detrital zircons inmetasedimentary sequences in eastern Borborema Province (NE Brazil): evidence for intracontinental sedimentation and orogenesis? Precambrian Research 175, 187-205.

Nogueira Neto, J.A., Marques Jr., F., Néri, T.F.O., Pedreira, L.H.S.T., 1989. Contribuição à geologia do município de Chaval (CE). Atas do XIII Simpósio de Geologia do NE. Fortaleza, SBG, 11, 27-28.

Oliveira, D.G., Mohriak, W.U., 2003. Jaibaras trough: an important element in the early tectonic evolution of the Parnaı'ba interior sag basin, Northern Brazil). Marine and petroleum geology 20, 351-383.

Oliveira, E.P., Tarney, J., 1990. Petrogenesis of the Canindé de São Francisco Complex: a major late Proterozoic gabbroic body in the Sergipe Fold Belt, northeastern Brazil. Journal of South American Earth Sciences, 3, 125-140.

Oliveira, E.P., Windley, B.F.,Araújo, M.N.C., 2010. The Neoproterozoic Sergipano orogenic belt, NE Brazil: a complete plate tectonic cycle in western Gondwana. Precambrian Research 181, 64-84.

Pimentel, M.M., Fuck, R.A., 1992. Neoproterozoic accretion in Central Brazil. Geology, 20, 375-379.

Pimentel, M.M., Fuck,R.A, Jost, H., Ferreira Filho, C.F, Araujo, S., 2000. The basement of the Brasília Fold Belt and the Goiás Magmatic Arc. In: Cordani, U.G., Milani, E.J., Thomaz Filho, A., Campos, D.A. (Eds.), Tectonic Evolution of South America - Rio de Janeiro, 151-182.

Piuzana, D., Pimentel, M.M., Fuck, R.A., Armstrong, R.A., 2003. SHRIMP U-Pb and Sm-Nd data for the Araxá Group and associated magmatic rocks: constraints for the age of sedimentation and geodynamic context of the southern Brasília Belt, central Brazil. Precambrian Research 125, 139e160.

Sá, J.M., Bertrand, J.M., Leterrier, J., Macedo, M.H.F., 2002. Geochemistry and geochronology of pre-Brasiliano rocks from the Transversal Zone, Borborema Province, Northeast Brazil. Journal of South American Earth Sciences 14, 851866.

Santos, E.J., Van Schmus, W.R., Kozuch, M., Brito Neves, B.B., 2010. The Cariris Velhos tectonic event in northeast Brazil. Journal of SouthAmericanEarthSciences 29, 61-76.

Santos, T.J.S., Dantas, E.L., Fuck, R.A. ; Rosa, F.F. da ; de Araujo, C.E.G, Amaral, W.S., 2007. The geology and U-Pb and Sm-Nd geochronology from the northern portion of the Santa Quitéria batholith, NE Brazil. In: Simpósio Nacional de estudos Tectônicos, 2007, Natal - RN. Anais, 142-144.

Santos, T.J.S., Fetter, A.H., Hackspacher, P.C., Schmus, W.R.V., Nogueira Neto, J.A., 2008a. Neoproterozoic tectonic and magmatic episodes in the NW sector of the Borborema Province, NE Brazil, during assembly of western Gondwana. Journal of South American Earth Sciences 25, 271-284.

Santos, T.J.S., Fetter, A.H., Nogueira Neto, J.A., 2008b. Comparisons between the northwestern Borborema Province, NE Brazil, and the southwestern Pharusian Dahomey Belt, SW Central Africa. In: Pankhurst, R.., Trouw, R.A.J., Brito Neves, B.B., De Wit, M.J. (Eds.), West Gondwana: Pre-Cenozoic Correlations Across the Atlantic Region: Geological Society, London, Special Publications 294, 101-119.

Santos, T.J.S., Fetter, A.H., Schmus, W.R.V., Hackspacher, P.G., 2009b . Evidence for 2.35 to 2.30 ga juvenile crustal growth in the northwest Borborema Province, NE Brazil. Geological Society Special publication 323, $271-281$. 
Carlos E. Ganade de Araujo - Tese de Doutorado - Universidade de São Paulo

Capítulo 5 - U-Pb zircon provenance

Santos, J.O.S., Rizzotto, G.J, Potter, P.E., McNaughton, N.J., Matos, R.S., Hartmann, L.A., Chemale Jr., F., Quadros, M.E.S., 2008. Age and autochthonous evolution of the Sunsás Orogen in West Amazon Craton based on mapping and U-Pb geochronology. Precambrian Research, 165, 120-152.

Sial, A.N., Figueiredo, M.C.H., Long, L.E., 1981. Rare-earth element geochemistry of the Meruoca and Mucambo Plutons, Ceará, Northeast Brazil. Chemical Geolog y, 31, 271-283.

Sun, W.H., Zhoua, M.F., Yanb, D.P., Li, J.W., Mad, Y.M., 2008. Provenance and tectonic setting of the Neoproterozoic Yanbian Group, western Yangtze Block (SW China). Precambrian Research 167, 213-236.

Tassinari, G. C. G. ; Macambira, M., 1999. Geochronologiacal Provinces of the Amazonian Craton. Episodes, 22, 174182.

Teixeira, W., Tassinari, C., Cordani, U., Kawashita, K., 1989. A review of the geochronology of the Amazonian Craton: Tectonic implications. Precambrian Research, 42, 213-227.and U-Pb geochronology. Journal of South American Earth Sciences 31, 227-252.

Thiéblemont, D., Delor, C., Cocherie, A., Lafon, J.M, Goujou, J.G., Baldé, A., Bah, M., Sané, H., Fanning, M., 2001. A 3.5 Ga granite- gneiss basement in Guinea: further evidence for early archean accretion within the West African Craton. Precambrian Research, 108, 179-194.

Thiéblemont, D., Goujou J.C., Egal, E., Cocherie, A., Delor, C., Lafon, J.M, Fanning, M., 2004. Archean evolution of the Leo Rise and its Eburnean reworking, Journal of African Earth Sciences 39, 97-104.

Van Schmus, W.R., Oliveira, E.P., Da Silva Filho, A., Toteu, S.F., Penaye, J., Guimarães, I.P., 2008. Proterozoic links between the Borborema Province, NE Brazil, and the Central African Fold Belt. Geological Society, London, Special Publications 294, 69-99.

Van Schmus, W.R., Brito Neves, B.B., Williams, I.S., Hackspacher, P., Fetter, A.H., Dantas, E.L., Babinski, M., 2003. The Seridó Group of NE Brazil, a late Neoproterozoic pre- to syn-collisional basin in West Gondwana: insights from SHRIMP U-Pb detrital zircon ages and Sm-Nd crustal residence (TDM) ages. Precambrian Research 127, $287-327$.

Van Schmus, W.R., Kozuch, M., de Brito Neves, B.B., 2011. Precambrian history of the Zona Transversal of the Borborema Province, NE Brazil: Insights from $\mathrm{Sm}-\mathrm{Nd}$ and $\mathrm{U}-\mathrm{Pb}$ geochronology. Journal of South American Earth Sciences 31, 227-252.

Vasquez, M.L., Macambira, M.J.B., Armstrong, R.A., 2008. Zircon geochronology of granitoids from the western Bacajá Domain, southeastern Amazonian craton, Brazil: Neoarchean to Orosirian evolution. Precambrian Research 161, 279302.

Vermeesch, P., 2004. How many grains are needed for a provenance study? Earth and Planetary Science Letters, 224, 441-451. 
Carlos E. Ganade de Araujo - Tese de Doutorado - Universidade de São Paulo

Capítulo 5 - U-Pb zircon provenance

\section{APPENDIX 1 - Sample description and location information}

\section{Sample DKE-36 (UTM 331598, 9690964)}

This sample from the São Joaquim Formation was collected in the well-known exposition of the São Joaquim quartzite at the Jericoacora beach called Pedra Furada. It consists of a metasiliciclastic sequence of metapsmites with well-preserved regular parallel primary bedding associated with some ferruginous quartzite layers. The sample is a rather pure foliated quartzite composed by quartz $(97 \%)$ and muscovite $(3 \%)$ and displays a penetrative lattice preferred orientation of the quartz accompanied by the orientation of the muscovite flakes.

\section{Sample DKE-39 (UTM 314069, 9627149)}

This sample from the São Joaquim Formation is a muscovite-bearing quartzite collected near de locality of Jordão along the main road. Petrographically it shows a strong dynamic recrystalization of the quartz grains and well developed lattice preferred orientation that defines a penetrative foliation.

\section{Sample DKE-41 (UTM 314228, 9610804)}

This sample from the São Joaquim Formation is a strongly folded muscovite- bearing quartzite collected near the locality of Coreaú along the main road. The sample is composed by quartz (89\%), muscovite $(8 \%)$ and opaque minerals $(2 \%)$. It displays a penetrative lattice preferred orientation of the quartz grains, accompanied by the orientation of the muscovite flakes.

Sample DKE-30 (UTM 345334, 9616391)

This sample from the Goiabeira Formation is a grayish schist collected along the main road close to the locality of Massapê. It is composed chiefly by quartz (55\%), feldspar $(20 \%)$ with plagioclase predominating over K-feldspar, muscovite $(15 \%)$ and biotite $(5 \%)$ and traces of chlorite. The quartz grains are elongated and dynamically recrystalized defining a well-developed lattice preferred orientation and the schistosity is defined by the platy minerals.

\section{Sample DKE-25 (UTM 345334, 9616391)}

This sample is a coarse grained reddish brown feldspathic sandstone of the Aprazível Formation from the Jaíbaras Trough. It demonstrates small cross bedding and ripple marks that are seen on bedding surfaces of fine-grained layers.

\section{Sample DKE-43 (UTM 366196, 9595516)}

This sample from the Canindé Unit of the Ceará Complex was collected close to the locality of Caióca and consists in a strongly deformed sillimanite-garnet-biotite metatexitic paragneiss. The leucossomes were avoided during sample preparation; however some very small patches of neossomes were difficult to separate.

Sample DKE-45 (UTM 391833, 9605570)

This sample from the Canindé Unit of the Ceará Complex is also a deformed sillimanite-garnet-biotite metatexitic paragneiss collected at the margin of the Miraíma River close to the homonymous locality.

Sample DKE-19 (UTM 369488, 9566121) 
This sample from the Independência Unit of the Ceará Complex was collected in a road cut close to the locality of Lisieux. It consists in a sequence of interleaved metapelites with kyanite and metapsamites characterized by muscovite-bearing quartzites with silimanite. Zircons were extracted from the quartzitic layer.

Sample DKE-51 (UTM 464240, 9627273)

Zircons from this sample were extracted from a muscovite-bearing quartzite from the Independência Unit of the Ceará Complex along the eastern border of the Tamboril-Santa Quitéria Complex close of the locality of Lajes.

Sample NCEB-427 (435811, 9513362)

This sample is a muscovite-bearing quartzite from the Independência Unit of the Ceará Complex collected close do the region of Taperuaba town.

Sample DKE-53 (UTM 435809, 9560168)

This sample from the Canindé Unit was collected near the locality of Tejuçuoca and consists in a strongly foliated sillimanite-garnet-biotite metatexitic paragneiss.

Sample NCEB-351(UTM 410488, 9547439)

This sample is a muscovite-bearing quartzite from the Independência Unit of the Ceará Complex collected close do the region of Taperuaba town.

Sample DKE-06 (UTM 417895, 9491153)

This sample from the Independência Unit of the Ceará Complex was collected close to the locality of Lagoa do Mato and comprises a strongly folded arcosean quartzite with subordinate fribrolite and garnet.

Sample DKE-56 (UTM 502851, 9534867)

This sample from the Independência Unit of the Ceará Complex is a feldspathic-quartzite collected in the Pico Alto locality at the highest elevation of the study area. 
Carlos E. Ganade de Araujo - Tese de Doutorado - Universidade de São Paulo

Capítulo 6 - Tracing Neoproterozoic subduction in NE-Brazil

\title{
6. Tracing Neoproterozoic subduction in the Borborema Province (NE- Brazil): clues from $\mathrm{U}-\mathrm{Pb}$ geochronology and $\mathrm{Sr}-\mathrm{Nd}-\mathrm{Hf}-\mathrm{O}$ isotopes on granitoids and migmatites
}

\author{
Carlos E. Ganade de Araujo ${ }^{(1)(2)^{*}}$; Umberto G. Cordani(2); Roberto Weinberg(3); Miguel A. S. Basei(2); \\ Richard Armstrong(4), Kei Sato(2) \\ (1)Serviço Geológico do Brasil - SGB/CPRM, Fortaleza-CE, Brazil \\ (2)Centro de Pesquisas Geocronológicas, Universidade de São Paulo - CPGeo/IGc-USP, São Paulo-SP, Brazil \\ (3)Monash University, Melbourne, Australia \\ (4)Australian National University, Canberra, Australia
}

\begin{abstract}
The Ceará Central Domain of the Borborema Province is a key tectonic domain within the $5000 \mathrm{~km}-\mathrm{long}$ West Gondwana Orogen, which extends from Algeria in Africa to Central Brazil. Igneous rocks of the Tamboril-Santa Quitéria Complex, investigated in this study, record a long-lived history of convergent magmatism and crustal anatexis. SHRIMP U-Pb dating and $\mathrm{Hf}-\mathrm{O}$ isotope analyses of zircons from granitoids and migmatites, coupled with whole-rock Sr-Nd isotopes were used to constrain the evolution of this longlived continental margin. Magmatism can be divided into three main periods: i) an early period comprising essentially juvenile arc magmatism at ca. 880-800 Ma and continuing to $650 \mathrm{Ma}$ as evidenced indirectly by detrital zircons from syn-orogenic deposits, ii) a more mature arc period at ca. 660-630 Ma characterized by hybrid mantle-crustal magmatic rocks, and iii) crustal anatexis at 625-618 Ma continuing until ca. $600 \mathrm{Ma}$. Detrital zircons with mantle values of $\delta \mathrm{O}^{18}(<5.7 \%$ ) in the range of 950 to $650 \mathrm{Ma}$ retrieved from fore-arc deposits indicate that juvenile input persisted throughout whole evolution of the convergent magmatism. Juvenile and mature arc igneous rocks underwent anatexis that gave rise to extensive areas of diatexites within the complex. Anatexis overlap in time with the ages of (ultra)-high pressure (U)HP eclogitic metamorphism dated at 625-615 Ma. In accordance with other continental collision zones, age of UHP/HP metamorphism are interpreted to mark the timing of continental collision and therefore indicate that the anatexis of arc rocks took place during continental subduction in a continent-continent collisional setting. Extensive migmatization continued until ca. $600 \mathrm{Ma}$ and are in part synchronous to the exhumation of the rocks to shallower crustal levels. Thus, the 350 m.y. of magmatic activity in the Ceará Central Domain records the evolution of the West Gondwana margin of the Borborema Province from a juvenile arc setting through a mature arc and continental collision at around 625-600 Ma.
\end{abstract}

\subsection{Introduction}

Subduction zones are sites of intensive magmatism and are currently creating $>20 \%$ of the terrestrial magmatic products (Tatsumi and Eggins, 1995). In these sites, complex compositional variations in the generated magmas arise from interaction between fluids released from the subducting oceanic lithosphere and the overlying mantle wedge, intrinsic heterogeneities from the mantle and magma fractionation (Tatsumi and Kogiso, 2003). Assimilation of crustal material, particularly in Andean-type settings, adds an important component and further variations to the magmas generated in subduction zones (Hildreth and Moorbath, 1988; McMillan et al. 1989).

Subduction of oceanic lithosphere and generation of arcs inevitably precede Himalayan-type collisional orogens. However, in old collisional, deeply eroded terranes, earlier stages of arc magmatism are relatively poorly preserved and have commonly been obliterated by pervasive collisional tectonics. In some extreme cases, earlier arcs can even be subducted along continuous or renewed subduction zones and not be preserved 
(Yamamoto et al., 2009). Determining at what stage in the tectonic history of a subduction system a magmatic arc begins to evolve from a juvenile state, dominated by mafic-intermediate magmatism, towards a mature state dominated by felsic granitoid plutonism is critical to understand evolution of arcs and the stages preceding continental collision (Treloar et al., 1996). One important fact to consider is whether these earlier arcs are punctual in time, disconnected from the more mature stage, or are continuously linked to continental arc subduction that precede terminal collision. For example, the Kohistan and Ladakh arcs of northern Pakistan and northwest India represent a Cretaceous early intra-oceanic arc formed during the northward subduction of the Neotethys oceanic lithosphere beneath the Karakoram (e.g. Bard, 1983; Burg et al., 1998; Weinberg and Dunlap, 2000; Schaltegger et al., 2002). This arc was subsequently sutured to the Karakoram Terrane (southern margin of Asia) between $102 \mathrm{Ma}$ and 85-75 Ma (Petterson, 2010). The incorporated arc then became the Andean-type margin (mature stage) of Eurasia until collision with India at around $50 \mathrm{Ma}$ (Hodges, 2000). Another example is the Mesozoic Sierra Nevada batholith in California, one of the best studied sites for convergent magmatism, where subduction of the Farallon plate beneath North America during the Triassic to early Cretaceous was characterized by early fringing island arcs just off the Paleozoic continental margin. With continued subduction, a mature stage continental arc was developed and a progressively more compressional environment developed as the age of subducting slab continued to young (Busby, 2004; Lee et al., 2007). In this mature arc stage, O-Sr isotopic relations and the variation of ${ }^{147} \mathrm{Sm} /{ }^{144} \mathrm{Nd}$ with $\varepsilon_{\mathrm{Nd}}$ suggests that assimilation of crustal rocks by magmas rising from the mantle and undergoing fractional crystallization could have been the major process responsible for the mixing of crustaland mantle-derived components (DePaolo, 1981).
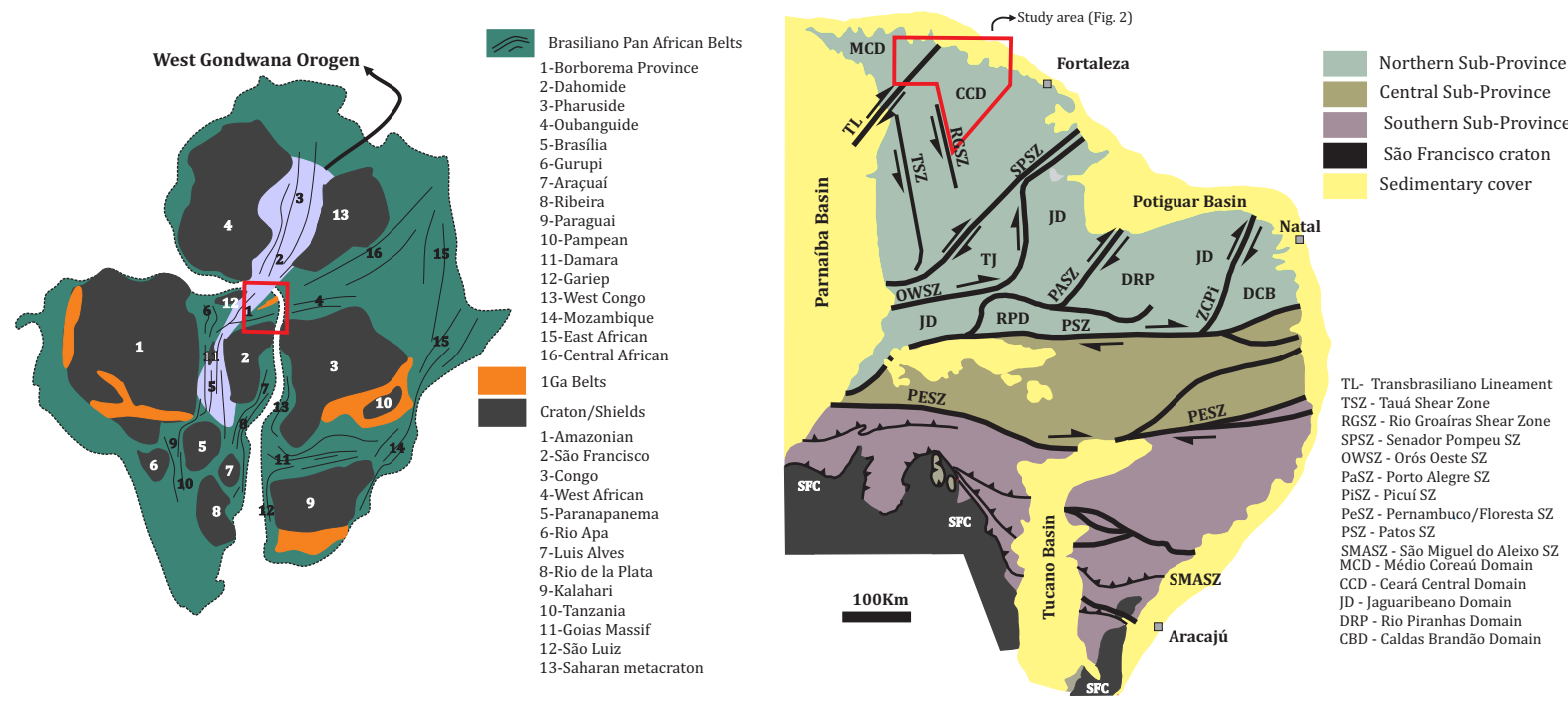

Figure 6.1 - Main cratonic blocks and mobile belts of the West Gondwana (modified from De Wit et al., 2008) and the Borborema Province and its main sub-divisions.

In ancient orogenic systems where great part of the petrological history has been obliterated by deformation and/or erosion, zircon can serve as an exceptional crustal growth monitor (Scherer et al., 2007). Coupling of radiogenic and stable isotopes allow measurements of time-stamped of hafnium and oxygen isotopes that can uniquely reveal whether zircon crystallized from a mantle-derived source (juvenile) during crustal generation, 
Carlos E. Ganade de Araujo - Tese de Doutorado - Universidade de São Paulo

Capítulo 6 - Tracing Neoproterozoic subduction in NE-Brazil

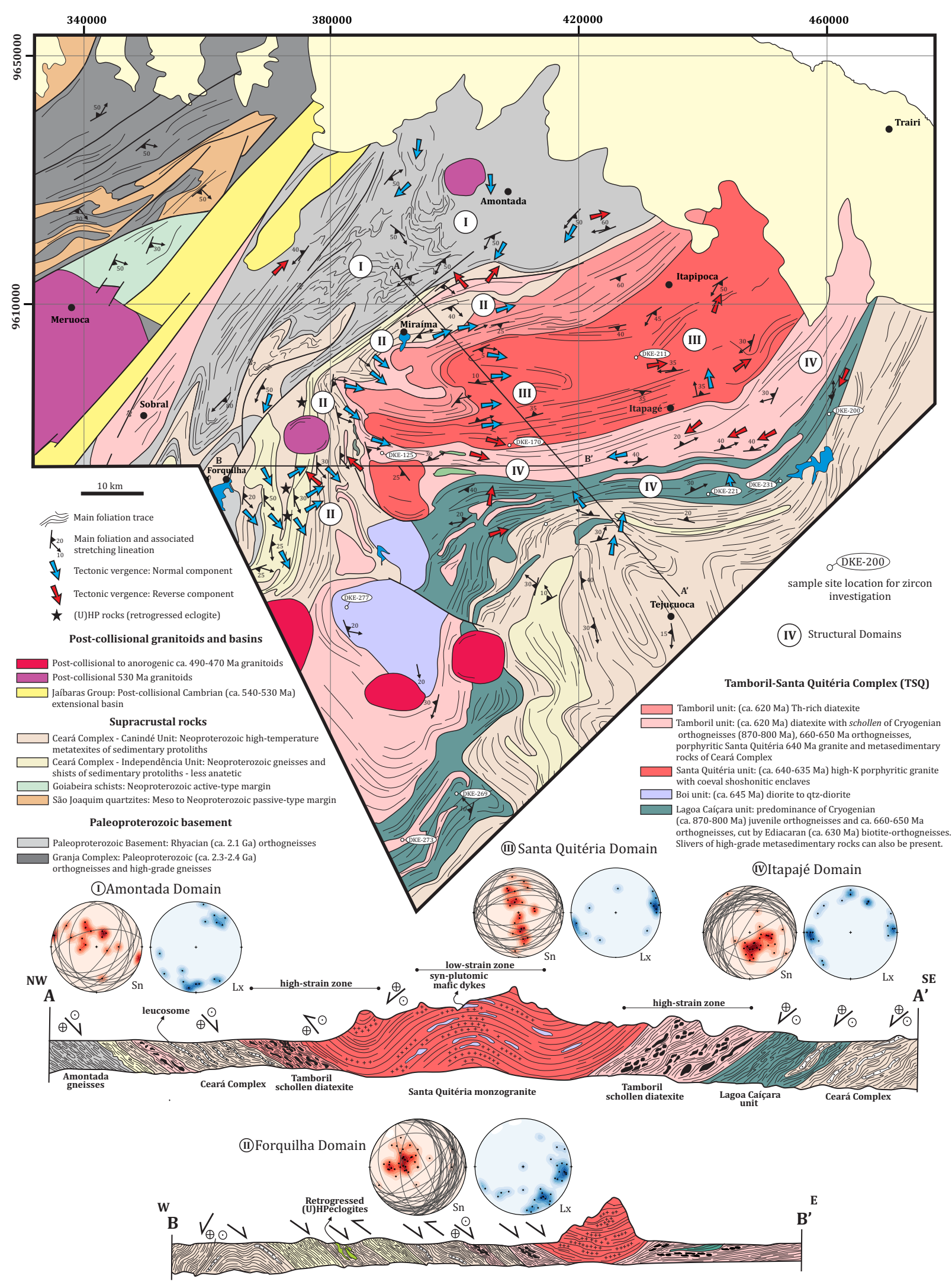

Figure 6.2 - Geological map and structure of the northern portion of the Tamboril-Santa Quitéria Complex and its neighbouring units. 
Carlos E. Ganade de Araujo - Tese de Doutorado - Universidade de São Paulo Capítulo 6 - Tracing Neoproterozoic subduction in NE-Brazil

or from magma derived by reworking of pre-existing igneous or sedimentary rocks (Hawkesworth and Kemp, 2006; Scherer et al., 2007).

In this sense, the Lu-Hf system is analogous to the Sm-Nd, and Hf-Nd isotopes form coherent arrays for most mantle-derived rocks (Vervoort et al., 1999). A larger drawback with relying on Hf isotopes from zircons alone to infer episodes of crustal growth concerns the possibility that the zircons crystallized from magmas with mixed source rocks that separated from the mantle at different times (Hawkesworth and Kemp, 2006). The use of oxygen isotopes greatly reduces this ambiguity, because its fractionation is time-independent. The ${ }^{18} \mathrm{O} /{ }^{16} \mathrm{O}$ ratio, expressed as $\delta^{18} \mathrm{O}$ relative to $\mathrm{SMOW}$, is only changed by low temperature and surficial processes, and so the $\delta \mathrm{d}^{18} \mathrm{O}$ of mantle-derived magmas $(5.7 \pm 0.3 \%$ ) contrasts with those from rocks that have experienced a sedimentary cycle or hydrothermal alteration on the sea-floor, which have elevated $\mathrm{d}^{18} \mathrm{O}$ (Hawkesworth and Kemp, 2006). This is reflected in the high $\delta^{18} \mathrm{O}$ of crystallizing zircons and is a fingerprint for a recycled component in granite genesis (Hawkesworth and Kemp, 2006; Hoefs, 2009). Likewise, the NdSr isotopes retrieved from whole-rock analysis also provide a way to make such distinction (DePaolo, 1981; Jacobsen, 1988; DePaolo et al., 1991) and are useful to monitor and evaluate isotopic differences between data acquired from minerals (e.g. zircon) and rocks from the same representative sample.

The Ceará Central Domain of the Northern Borborema Province, NE-Brazil, was part of a long-lived active continental margin of the West Gondwana Orogen that consumed the Goiás-Pharusian Ocean during the Early Neoproterozoic until final collision at Ediacaran times (Fetter et al., 2003; Arthaud et al., 2008; Ganade de Araujo et al., 2012a; Cordani et al., 2013ab; Ganade de Araujo et al., in press). The deep level of exposition, with extensive outcrops of migmatites and exhumed eclogites (Santos et al., 2009), requires the use of isotopic geology to disentangle the evolution of this complex, multi-domain orogenic system. Although timing for arc-building (Andean-type margin) in the Ceará Central Domain is usually attributed to the 650620 Ma time interval (Fetter et al., 2003; Van Schmus et al., 2008), geochronological evidence from detrital zircons in arc-related basins of the Ceará Complex suggest that arc magmatism could have started as early as 900-800 Ma (Ganade de Araujo et al., 2012a). In addition, several occurrences of Early Neoproterozoic juvenile arc assemblages are described along the length of the orogen in Africa and Central Brazil (e.g. Pimentel and Fuck, 1992; Berger et al., 2011). In some cases, these earlier juvenile arcs subsequently evolved into more mature arc stage preceding final collision that eventually reworked these arcs and precursor basement (continents) during the Late Neoproterozoic period (Liegeois et al., 1987; Caby, 2003; Pimentel et al., 2000).

In this study, we focus in the plutonic rocks of the Tamboril-Santa Quitéria Complex in the Ceará Central Domain, that record a long-lived magmatic system attributed to the subduction of the Goiás-Pharusian Ocean during the Neoproterozoic. Here, we combine U-Pb dating and Hf-O isotope composition of zircons, in addition to whole-rock Sr-Nd isotope compositions from granitoids and migmatite protoliths to unravel the tectonic evolution of this complex and sources (crust vs. mantle) of subduction-related magmas from the Early Neoproterozoic to final collision in the Ediacaran period. 
Carlos E. Ganade de Araujo - Tese de Doutorado - Universidade de São Paulo

Capítulo 6 - Tracing Neoproterozoic subduction in NE-Brazil

Table 6.1 - Localization and units of the investigated samples from the Tamboril-Santa Quitéria Complex.

\begin{tabular}{llll}
\hline Sample & Lithology & Investigated lithology & Unit \\
\hline DKE-221 & net veined structured granodioritic metatexite & granodioritic paleosome & Lagoa Caíçara \\
DKE-200A & mafic tonalitic metatexite & tonalitic paleosome & Lagoa Caíçara \\
DKE-269 & gray biotite orthogneisses injected by felsic veins & orthogneiss & Lagoa Caíçara \\
DKE-231 & gray biotite orthogneisses injected by felsic veins & orthogneiss & Lagoa Caíçara \\
DKE-277 & quartz diorite injected by felsic veins & quartz-diorite & Boi \\
DKE-211 & porphyritic biotiite monzogranite & monzogranite & Santa Quitéria \\
DKE-170 & granodioritic metatexite with diatexitic portions & granodioritic schollen & Tamboril/Santa Quitéria \\
DKE-125A & tonalitic metatexite intruded by felsic granite & tonalitic paleossome & Tamboril \\
DKE-125B & tonalitic metatexite intruded by felsic granite & felsic granite & Tamboril \\
DKE-273A & biotite diatexite with granodioritic schollen & granodioritic schollen & Tamboril \\
DKE-273B & biotite diatexite with granodioritic schollen & diatexite & Tamboril
\end{tabular}

\subsection{Geological setting: the Ceará Central Domain}

Excluding the extensional Mesozoic event that separated South America from Africa, the Borborema Province in northeast Brazil is characterized by magmatic, tectonic, and thermal events spanning the Archean to the Cambrian-Ordovician (Brito Neves et al., 2000). The major cratonic blocks involved in the tectonic events that built the Province include (fig. 6.1): 1) the Amazonian-São Luiz-West Africa Craton, including the Parnaíba Block; 2) the São Francisco-Congo Craton, and 3) the Paleoproterozoic-Archean collage forming the basement of the Borborema Province (Brito Neves and Cordani, 1991, Brito Neves et al., 2000; Arthaud et al., 2008; Klein et al., 2008; Ganade de Araujo et al., in press). Its final tectonic arrangement was a result of two Neoproterozoic continental collisions: the first and older along the Ceará Central Domain at ca. 620-615 Ma, as part of the West Gondwana Orogen, followed by the collision at ca. 590-570 Ma of the consolidated Borborema Province against the São Francisco Craton along the Sergipano Orogen in the south (Oliveira et al., 2010; Ganade de Araujo et al., in press).

The Neoproterozoic evolution of West Gondwana Orogen in the Ceará Central Domain results from the development of a convergent margin, related to the consumption of the Goiás-Pharusian Ocean (Cordani et al., 2013a), until the collision between the Parnaíba block (hidden beneath the Phanerozoic Parnaíba basin) and the Paleoproterozoic/Archean basement that extends further east into the Northern Borborema Province (Rio Grande do Norte Domain) (Ganade de Araujo et al., in press).

The Ceará Central domain is composed of several litho-tectonic assemblages that includes: (1) Archean (ca. 2.8-2.7 Ga) remnants of TTG of the Cruzeta Complex; (2) vast tracts of juvenile Paleoproterozoic (ca. 2.2-2.0 Ga) high-grade amphibolites and felsic to intermediate orthogneisses and migmatites (Fetter et al., 2000; Martins et al., 2009); (3) high-grade Neoproterozoic supracrustal rocks represented essentially by the units of Ceará Complex (e.g. Arthaud et al., 2008; Arthaud, 2007, Ganade de Araujo et al., 2012a); (4) large volumes of Neoproterozoic granitoids represented by the Tamboril-Santa Quitéria granitic-migmatitic Complex (Fetter et al., 2003; Arthaud et al., 2008); and (5) widespread Neoproterozoic to Cambrian post-collisional and Ordovician anorogenic granitoids (Castro et al., 2012). The first two associations are considered as the basement for the Neoproterozoic orogeny. 
Carlos E. Ganade de Araujo - Tese de Doutorado - Universidade de São Paulo

Capítulo 6 - Tracing Neoproterozoic subduction in NE-Brazil

This basement, particularly the Cruzeta Complex, records an intricate geological history, from the Archean to the Paleoproterozoic period. The Archean remnants (2.85-2.64 Ga) are represented by gray gneisses of TTG affinity, locally migmatized and tectonically interleaved with the Paleoproterozoic gneisses (Fetter, 1999). Throughout the Ceará Central Domain there are several small Paleoproterozoic basement inliers preserved within the Neoproterozoic tectonic framework. These rocks are mainly polycyclic intermediate orthogneisses, migmatized not only during the Paleoproterozoic (ca. 2.0 Ga) but also in Late Neoproterozoic collision, with protolith crystallization ages clustering at ca. 2.13-2.15 Ga (Fetter et al., 2000; Castro, 2004).

The Ceará Complex is composed of metamorphosed pelites, semipelites and greywacke, normally showing a prominent schistosity or gneissosity, and are regionally or locally migmatized. Quartzites, marbles, calc-silicate rocks and amphibolites also form large tracts within this complex (Cavalcante et al., 2003; Caby and Arthaud, 1986; Arthaud et al., 2008; Ganade de Araujo et al. 2012a). Taking into account the degree of partial melting, Cavalcante et al. (2003) divided part of the Ceará Complex into the Independência and Canindé units. The supracrustal rocks with only minor migmatization were grouped in the former, while those that exhibit significant melting were included in the latter. Locally in the Ceará Complex, felsic sheets and amphibolites interleaved with metasedimentary rocks are interpreted as former volcanic or sub-volcanic rocks and were dated at ca. 800-750 Ma (Fetter, 1999, Castro, 2004, Arthaud, 2007). U-Pb zircon provenance studies from the Ceará Complex demonstrate a heterogeneous provenance pattern characterized by deposits exclusively composed by Paleoproterozic-Archean detritus, probably representative of small basins floored by sialic crust within the Neoproterozoic orogenic realm, and orogenic arc-related deposits with strong early to middle Neoproterozoic (900-650 Ma) source component (Arthaud, 2007; Ganade de Araujo et al., 2012a).

In the Ceará Complex, retrogressed eclogites have been described to the east and west of the Tamboril-Santa Quitéria Complex. In the east, in the region of Forquilha, retrogressed eclogites occurs interleaved with highgrade migmatitic metasedimentary rocks (Santos et al., 2009) and protolith crystallization was dated at ca. 1.5 Ga (Amaral et al., 2010). These rocks preserve relics of eclogite facies metamorphism (1.7 GPa, Santos et al., 2009), which may have reached ultra-high pressure (UHP) conditions (Santos et al., 2013) at ca. 615 Ma (Ganade de Araujo, submitted). To the west, in the region of Itataia retrogressed eclogites were also described by Castro (2004), however peak pressure conditions (1.4 GPa, Castro, 2004) are lower than those estimated for the Forquilha region.

\subsubsection{The Tamboril-Santa Quitéria Complex}

The Neoproterozoic Tamboril-Santa Quitéria Complex (fig. 6.2) is a wedge-shaped composite anatectic/igneous association surrounded by metasedimentary rocks of the Ceará Complex. It is characterized by a number of magmatic pulses where large volumes of magma intruded in the form of dykes, sills, sheets and plutons (Cavalcante et al., 2003; Fetter et al., 2003; Arthaud et al., 2008).

The plutonic rocks display syn- to late-magmatic deformation that was in part coeval with the injection of younger and less deformed magma (Arthaud et al., 2008). In general they range from diorite to granite, with predominance of monzogranitic/granitic rocks (Ganade de Araujo et al., 2012b) of the Santa Quitéria unit in its central part. 
Previous age determinations indicate that granitoids of this complex range from 640 to $610 \mathrm{Ma}$ (Fetter et al., 2003; Castro, 2004; Santos et al., 2007; Ganade de Araujo et al., 2012b, Costa et al., 2013). For this time interval, $\mathrm{Nd}$ isotopic signatures are consistent with variable mixtures between juvenile Neoproterozoic magmas and older basement, indicating that the granitoids hybrids (Fetter et al., 2003). The tectonic setting of this complex has been interpreted as a Neoproterozoic Andean-type magmatic arc (Fetter et al., 2003), however recent works have proposed an evolution from an arc at ca. 850 to $640 \mathrm{Ma}$ into a collisional Himalayan setting (Ganade de Araujo et al., 2012c, Costa et al., 2013).

In accordance with the nomenclature used by the Geological Survey of Brazil and also those proposed by Castro (2004), in the present study the complex is divided into four different units named Lagoa Caíçara, Boi, Santa Quitéria and Tamboril units. Although majorly composed by distinctive and older rocks, we opted to include the Lagoa Caíçara unit in the complex as it corresponds to the earlier evolution of the long-lived continental active margin proposed here. Investigated samples from these units and their main features are listed in Table 6.1.

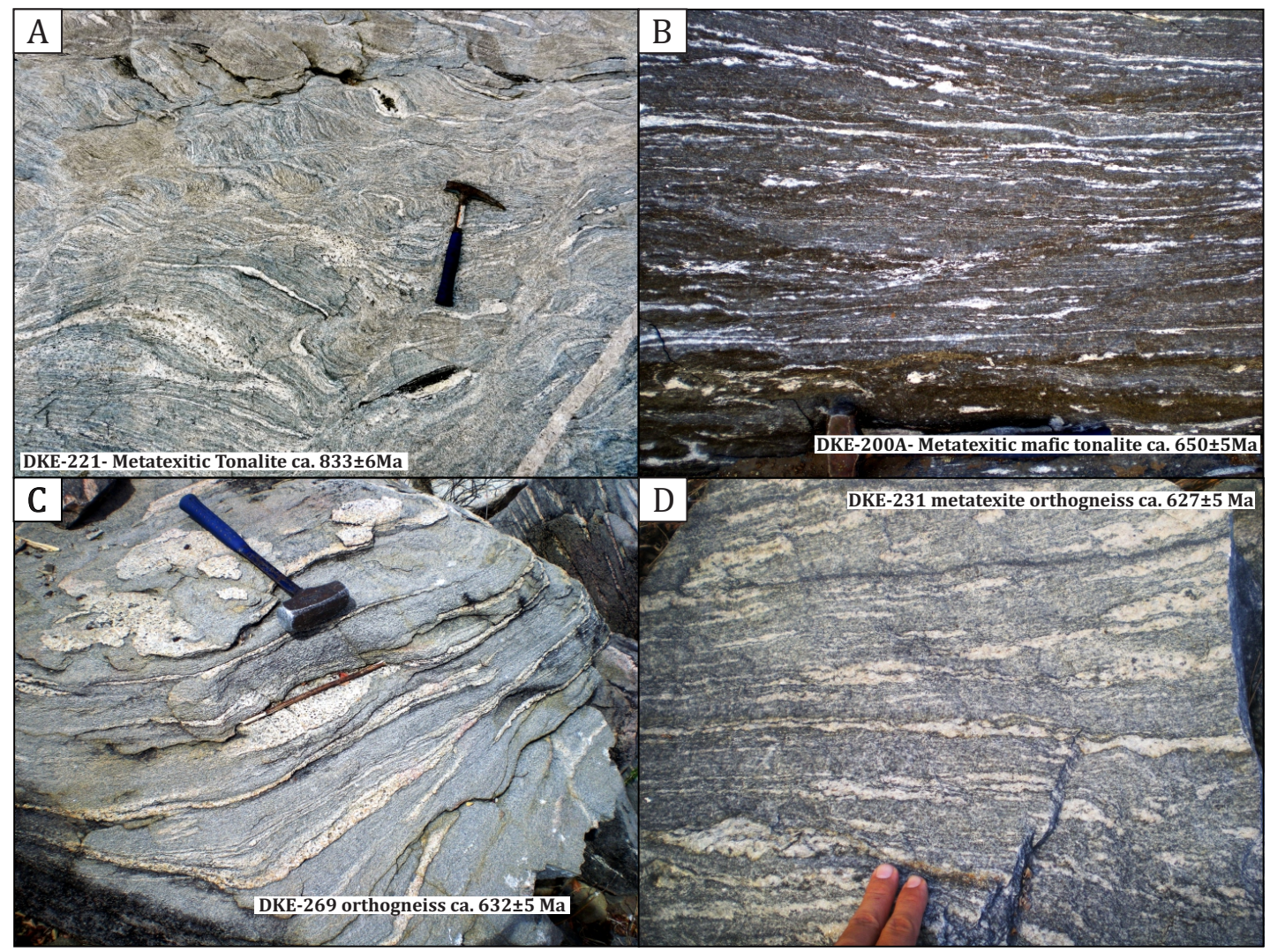

Figure 6.3 - Field aspects of the studied rocks from the Lagoa Caíçara unit. A. Stromatic metatexite after a $833 \pm 6$ Ma tonalitic protolith (sample DKE-221) with hornblende-bearing leucosomes, interpreted to result from water-fluxed melting. B. Stromatic metatexite after a $650 \pm 5$ Ma mafic tonalite (sample DKE-200A). C. $632 \pm 5$ Ma biotite gneiss with injected leucocratic veins parallel to the gneissic foliation (sample DKE-269). D. Metatexite after a $627 \pm 5$ biotite orthogneiss (sample DKE-231). 
Carlos E. Ganade de Araujo - Tese de Doutorado - Universidade de São Paulo

Capítulo 6 - Tracing Neoproterozoic subduction in NE-Brazil

\subsubsection{Lagoa Caíçara unit}

This unit comprises a heterogeneous meta-igneous association composed predominantly of stromatic metatexites of granodioritc to tonalitic protoliths (fig. 6.3). They are in contact with granitic diatexites of the Tamboril unit and the sedimentary-derived metatexites of the Ceará Complex to the east and south. These meta-igneous rocks are also commonly found preserved as blocks, known as schollen or rafts, within the diatexites of the Tamboril unit. Also in the Lagoa Caíçara unit, sheets of biotite-orthogneisses (c.f. samples DKE-269 and DKE-231) (fig. 6.3C and D) with moderate to small volume of leucosomes cut the more complex deformed migmatitic granodiorite-tonalite. Remnants of sedimentary-derived metatexites, of the Ceará Complex are also present within this unit.

Distinction between the different orthogneisses of Lagoa Caíçara unit is difficult in the field. It seems that this unit comprises multiple intrusions of granitoid rocks. Deformation adds complications and it is challenging in many outcrops to ascribe unambiguously a sample to the broader lithological group. For example, we expect that many late dykes of the Tamboril-Santa Quitéria magmatic event intruded the Lagoa Caíçara unit, and similarly, we have recognized schollen and xenolithic blocks of the Lagoa Caíçara unit in the diatexites of the Tamboril Unit. This distinction although obvious in some places, is less evident when the blocks are of a similar nature to the host magmatic rock. In the present study, geochronological and isotopic data permitted the distinction of three different granitoids protoliths in the Lagoa Caíçara unit: i) ca. 880-830 Ma juvenile tonalitic/granodioritic metatexites with high volume of leucosomes, ii) ca. $650 \mathrm{Ma}$ mafic tonalitic metatexites, and iii) ca. 630 Ma crust-derived orthogneisses with low volume of leucosome.

The regional foliation in this unit is simple and has low to moderate dips $(<40$ degrees $)$ to northwest and north-northwest (Itapajé structural domain in figure 6.2). Along the contact with the diatexites of the Tamboril unit, the stretching lineation has a low rake indicating a strong strike-slip component. They generally plunge gently to ENE and a number of shear sense indicators such as $\mathrm{S} / \mathrm{G}$ structures suggest a dextral strike-slip movement with a dominant small reverse component. Further south, in the contact of the Lagoa Caiçára unit and the Ceará Complex, the lineation changes to dominantly down-dip, plunging northward and shear sense indicators within the foliations demonstrate a change to top-to north-northeast defining normal movement.

The older (830 Ma and $650 \mathrm{Ma}$ ) tonalitic to granodioritic protolith of the metatexites contains biotite (10$20 \%$ ) and hornblende (5-25\%) as the main ferro-magnesian phases. The schollen of this unit found in the Tamboril diatexites have low contents or lack hornblende and are predominantly composed of biotite, plagioclase, K-feldspar and quartz. The neosome of the tonalitic migmatites is composed majorly of plagioclase, quartz and hornblende with no anhydrous peritectic phases, suggesting that melting was due to influx of water rather than hydrate breakdown reactions (Weinberg and Hasalova, submitted). The younger orthogneisses (ca. $630 \mathrm{Ma}$ ) have biotite as the main mafic phase accompanied or not of minor muscovite with K-feldspar invariably more abundant than plagioclase. 
Carlos E. Ganade de Araujo - Tese de Doutorado - Universidade de São Paulo

Capítulo 6 - Tracing Neoproterozoic subduction in NE-Brazil

\subsubsection{Boi Unit}

The Boi unit differs from the Lagoa Caíçara unit by the presence of more homogenous mafic rocks of predominant quartz-diorite to tonalitic/granodioritic composition $(\mathbf{f i g} . \mathbf{6 . 5 A})$. They are easily recognizable and mapable in the satellite and gama-ray image due to characteristic low total counts. In the field these rocks may be strongly foliated to rather isotropic. Migmatitic sectors may occur, however the intrusion of felsic melts may generate pseudo-migmatitic patterns. Rocks from this unit are comprised of plagioclase (45-35\%), hornblende (10-25\%), biotite (15-25\%), quartz (15-5\%) and K-feldspar (8-3\%). They are in part intruded by the Santa Quitéria and Tamboril units. Further south of the study area a U-Pb ID-TIMS zircon age of $637 \pm 6.5 \mathrm{Ma}$ was obtained for a juvenile $(\varepsilon \mathrm{Nd}(600 \mathrm{Ma})=+3.4)$ dioritic migmatitic gneiss (Fetter et al., 2003), possibly associated with the Boi unit.

\subsubsection{Santa Quitéria Unit}

The Santa Quitéria unit forms a large batholith in the central portion of the complex. It is by far the most voluminous magmatic component of the complex and comprises mainly porphyritic K-feldspar monzogranites (fig. 6.4B). Composition and strain intensity vary, however toward its central portion, low strain and larger phenocrysts dominate (fig. 6.2). The contact of the Santa Quitéria monzogranites with the diatexites of the Tamboril unit is well defined in the satellite and geophysical gamma-ray images (available at the Geological Survey of Brazil), but can be gradual in some places. Locally, close to the town of Iraúçuba, disrupted rafts of the monzogranite can be found within the diatexite indicating that crustal anatexis occurred after the intrusion of this batholith.

One especial feature of this unit is the existence of local disrupted coeval mafic syn-plutonic dikes (fig. 6.4D). Geochemical data of these mafic dikes indicate an enriched shoshonitic component derived from mantle sources (Costa et al., 2013; Zincone, 2011). Less common xenoliths of gray orthogneisses, probably derived from the Lagoa Caíçara unit, can also be present within the Santa Quitéria monzogranite. Biotite (20-10\%) and hornblende (10-1\%) are the main ferro-magnesian mafic phases of Santa Quitéria monzogranites along with plagioclase (40-15\%), K-feldspar (35-10\%) and quartz (25-15\%). Accessories include zircon, titanite, apatite, epidote and opaques. In general, the mafic syn-plutonic dikes are constituted of plagioclase (35-30\%), biotite (25-20\%), hornblende (20-15\%), K-feldspar (15-10\%) and quartz (5-2\%).

Structurally this unit has a wedge-shaped geometry with foliations in both the NE-SW and E-W trending flanks dipping inwards towards the complex (fig. 6.2). In general the regional foliation dips at moderate angles $\left(35-50^{\circ}\right)$ to south-southeast in the northern portion of the domain and to north-northwest in its southern portion (Santa Quitéria structural domain in fig. 6.2). The stretching lineation within this domain has low angles and plunges predominantly northeast. Shear sense indicators in the monzogranite indicate topto-east or northeast sense defining a dominantly strike slip motion with both normal and reverse components, broadly the same movement direction as defined in the Itapagé domain. This pattern defines the wedgeshaped geometry that some authors attributed as a product of the necking-down of the Tamboril-Santa Quitéria Complex responsible for its extrusion under a transpressive regime in sort of a positive-flower 
Carlos E. Ganade de Araujo - Tese de Doutorado - Universidade de São Paulo

Capítulo 6 - Tracing Neoproterozoic subduction in NE-Brazil

structure (Castro, 2004). However, satellite and geophysical image analysis suggest that this geometry could be due to the presence of ENE-WSW late large-scale open upright folds (fig. 6.2).

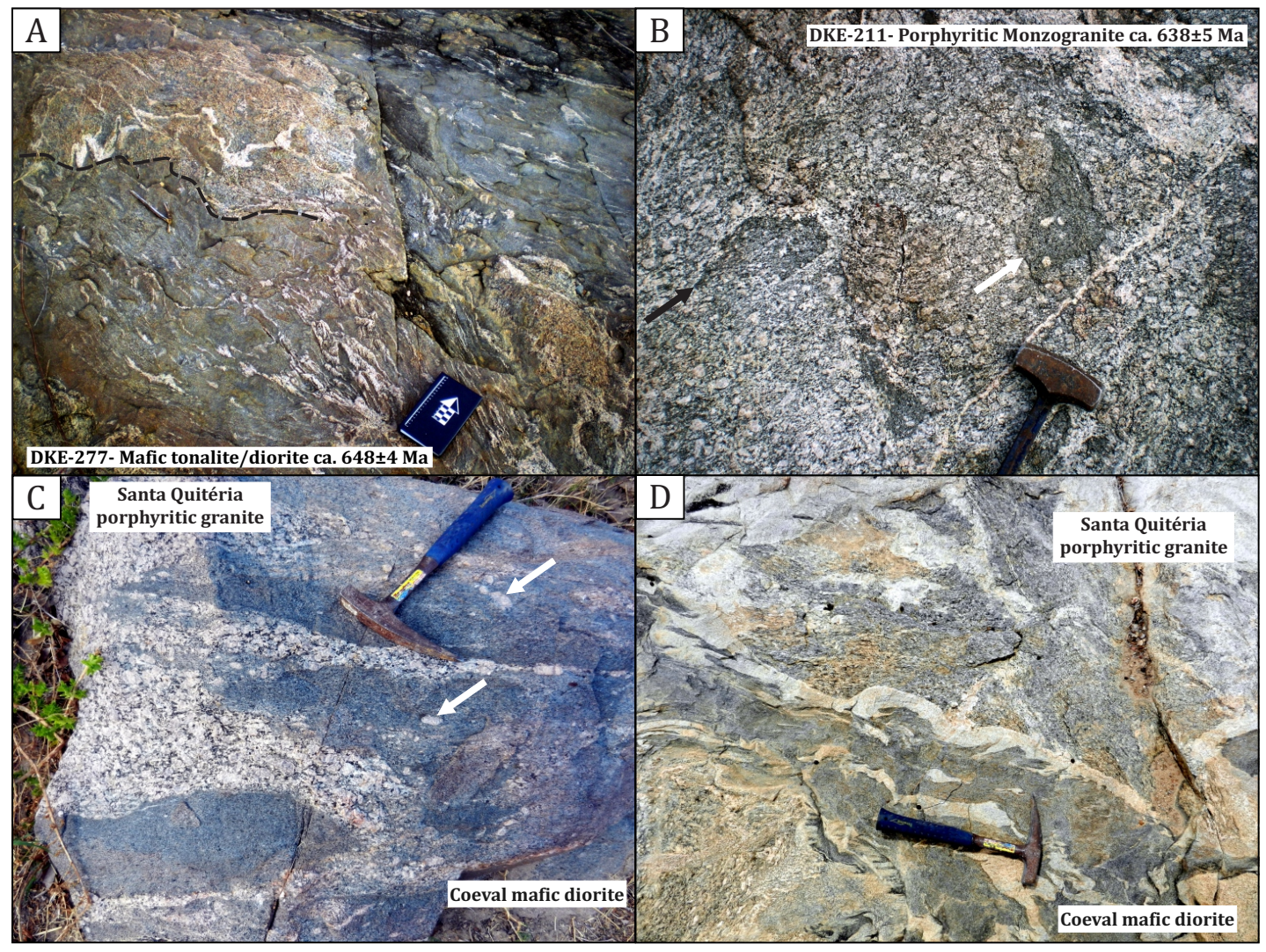

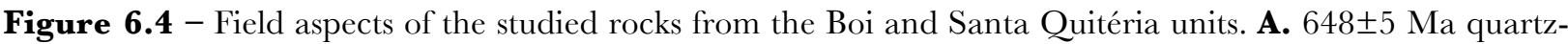
diorite of the Boi Unit injected by felsic quartz-feldspathic melt (Sample DKE-277). B. $638 \pm 5$ porphyritic monzogranites of the Santa Quitéria unit with mafic enclaves exhibiting crystal-transfer structures (white arrow) (Sample DKE-211). C. Coeval Santa Quitéria monzogranite with mafic dioritic enclaves showing evidence for transfer of crystals from the granite to the diorite (arrows). D. Syn-plutonic dikes of diorites cutting through the Santa Quitéria porphyritic monzogranite.

\subsubsection{Tamboril Unit}

The Tamboril unit represents a gradational unit at the contact between the monzogranite of the Santa Quitéria unit and the gneisses of the Lagoa Caíçara unit, but generally this unit encircles the Santa Quitéria unit. It is dominated by diatexites containing blocks (rafts or schollen) of both Santa Quitéria porphyritic monzogranite and Lagoa Caíçara orthogneisses. Rafts of Santa Quitéria monzogranites dominate close to the contact with the Santa Quitéria unit whereas high-grade metasedimentary and orthogneisses rafts are found close to the contact of the Lagoa Caíçara unit in the vicinity of Itapajé town.

In general the foliation in these diatexites are defined by a well-developed syn-magmatic flow banding usually defined by biotite schlieren (fig. 6.5D). Isotropic domains can be found locally. In the south, along the contact with the Lagoa Caíçara unit, foliation in diatexite dips at moderate angles to NNW with an associated 
Carlos E. Ganade de Araujo - Tese de Doutorado - Universidade de São Paulo

Capítulo 6 - Tracing Neoproterozoic subduction in NE-Brazil

stretching lineation characterized by a strong strike-slip component and shear sense indicators, such as $\mathrm{S} / \mathrm{C}$ pairs, suggesting a right-lateral movement (top-to-NW). In the north, foliation in the diatexites dips to SSE and E, with a stretching lineation plunging predominantly to SE. Kinematic indicators indicate a top-to-southeast normal displacement, however movement in the opposite direction could also be observed (fig. 6.2).

In general, these diatexites lack residual anhydrous peritectic phases, with the exception of rare garnet clusters. Biotite (20-5\%) is the main ferro-magnesian phase, but hornblende is present in some samples. In general the rocks tend to have greater concentrations of K-feldspar (45-15\%) than plagioclase (25-10\%), but in some cases this latter phase can dominate. Previous U-Pb ID-TIMS geochronological data yielded zircon ages for the diatexites of the Tamboril unit at the 620-610 Ma interval (Castro, 2004).

\subsection{Analytical Procedures}

In order to better understand the temporal evolution and the source of different magmas we carried out in situ $\mathrm{U}-\mathrm{Pb}$ zircon geochronology coupled with $\mathrm{Hf}$ and $\mathrm{O}$ isotopes on the same dated zircon domains. Zircon isotopic data were complemented by whole-rock $\mathrm{Nd}$ and $\mathrm{Sr}$ isotopes to better constrain granite sources for the same representative samples used for zircon investigation.

Zircons were separated from the fresh crushed rocks $(3-5 \mathrm{~kg})$ using conventional and heavy liquid and magnetic techniques (jaw crusher, disk grinder, Wilfley table, Frantz isodynamic magnetic separator and density separation using bromoform and methylene iodite). Around 50-80 zircons from each sample were mounted in epoxy resin, polished to half of mean grain thickness for further imaging with transmitted light and cathodo-luminescence to unravel its internal complexities. Cathodo-luminescence (CL) images of zircons were obtained using a Quanta 250 FEG electron microscope equipped with Mono CL3+ cathodoluminescence spectroscope (Centaurus) at the Geochronological Research Center in São Paulo University, Brazil.

U-Pb analyses were done using SHRIMP IIe at the Geochronological Research Centre (CPGeo) at the São Paulo University. The data have been reduced in a manner similar to that described by (Williams 1998, and references therein), using the SQUID Excel Macro of Ludwig (2001). Uncertainties given for individual U-Pb analyses (ratios and ages) are at the $1 \sigma$ level, however uncertainties in the calculated weighted mean ages are reported as 95\% confidence limits and include the uncertainties in the standard calibrations where appropriate. For the age calculations, corrections for common $\mathrm{Pb}$ were made using the measured ${ }^{204} \mathrm{~Pb}$ and the relevant common $\mathrm{Pb}$ compositions from the Stacey and Kramers (1975) model. Concordia plots, regressions and any weighted mean age calculations were carried out using Isoplot/Ex 3.0 (Ludwig, 2003) and where relevant include the error in the standard calibration. U-Pb geochronological results are presented in Table $\mathrm{S} 1$ of supplementary data.

Lu-Hf analyses were also carried out at the Geochronological Research Centre (CPGeo) at the São Paulo University on a Neptune laser-ablation multi-collector inductively coupled plasma mass spectrometer equipped with a Photon laser system. The laser spot used was $39 \mu \mathrm{m}$ in diameter with an ablation time of 60 seconds, repetition rate of $7 \mathrm{~Hz}$, and $\mathrm{He}$ used as the carrier gas (Sato et al., 2009). ${ }^{176} \mathrm{Hf} /{ }^{177} \mathrm{Hf}$ ratios wer 
Carlos E. Ganade de Araujo - Tese de Doutorado - Universidade de São Paulo

Capítulo 6 - Tracing Neoproterozoic subduction in NE-Brazil

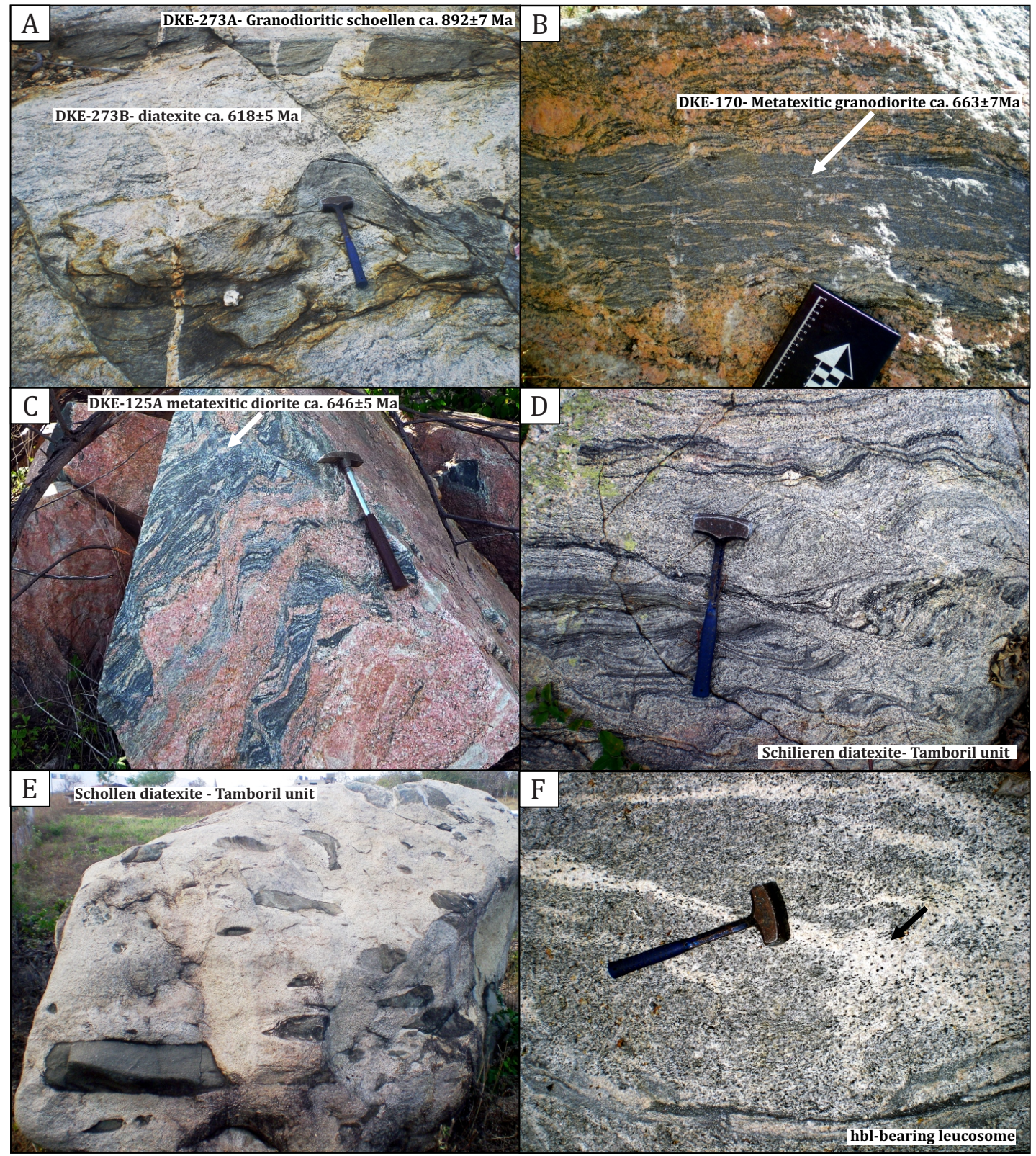

Figure 6.5 - Field aspects of the studied rocks from Tamboril unit. A. Composite outcrop of patchy metatexite after a $882 \pm 7 \mathrm{Ma}$ granodioritic orthogneiss (schollen) embedded in a $618 \pm 5$ granitic diatexite of Tamboril unit within Lagoa Caíçara unit (Sample DKE-273A and B). B. Raft of a $663 \pm 7$ Ma granodioritic orthogneiss embedded in a granitic host close to the contact between Santa Quitéria and Tamboril units (Sample DKE-170). C. Folded stromatic metatexite tonalite to diorite (Boi unit) injected by crustal granitic veins of Tamboril unit (Sample DKE-125). D. Characteristic flow banding defined by schlieren diatexite of the Tamboril unit. E. Characteristic schollen diatexite of the Tamboril unit. F. Hornblende-bearing leucosomes in diatexite of Tamboril unit.

normalized to ${ }^{179} \mathrm{Hf} /{ }^{177} \mathrm{Hf}=0.7325$. Zircon $\mathrm{Hf}$ isotopic data are presented in table 3. The isotopes ${ }^{172} \mathrm{Yb}$, ${ }^{173} \mathrm{Yb},{ }^{175} \mathrm{Lu},{ }^{177} \mathrm{Hf},{ }^{178} \mathrm{Hf}$, ${ }^{179} \mathrm{Hf},{ }^{180} \mathrm{Hf}$, and ${ }^{176}(\mathrm{Hf}+\mathrm{Yb}+\mathrm{Lu})$ were simultaneously collected. ${ }^{176} \mathrm{Lu} /{ }^{175} \mathrm{Lu}$ ratio of 0.02669 was used to calculate ${ }^{176} \mathrm{Lu} /{ }^{177} \mathrm{Hf}$. Mass bias corrections of $\mathrm{Lu}-\mathrm{Hf}$ isotopic ratios were done applying 
Carlos E. Ganade de Araujo - Tese de Doutorado - Universidade de São Paulo

Capítulo 6 - Tracing Neoproterozoic subduction in NE-Brazil

the variations of GJ1 standard. A decay constant for ${ }^{176} \mathrm{Lu}$ of 1.867 x 10-11 (Söderlund et al., 2004), the presentday chondritic ratios of ${ }^{176} \mathrm{Hf} /{ }^{177} \mathrm{Hf}=0.282772$ and ${ }^{176} \mathrm{Lu} /{ }^{177} \mathrm{Hf}=0.0332$ (Blichert-Toft and Albarede, 1997) were adopted to calculate $\varepsilon \mathrm{Hf}$ values. A two-stage continental model $\left(\mathrm{T}_{\mathrm{DM}}\right)$ was calculated using the initial ${ }^{176} \mathrm{Hf} /{ }^{177} \mathrm{Hf}$ of zircon and the ${ }^{176} \mathrm{Lu} /{ }^{177} \mathrm{Hf}=0.022$ ratio for the lower continental crust (Griffin et al., 2004). Zircon Lu-Hf isotopic results are presented in Table $\mathbf{S 2}$ of supplementary data.

Oxygen isotopic compositions were obtained in three separate analytical sessions using the SHRIMP-II equipped with a Cs-gun at the Research School of Earth Science (RSES) in The Australian National University as described by Ickert et al. (2008). TEMORA 2 zircon ( $\mathrm{d}^{18} \mathrm{O}=8.2 \%$; Black et al., 2004) was analyzed along with FC1 zircon. The results are presented in Table S3 of supplementary data and plotted on figure 6.10A. No corrections for IMF/gain drift or EISIE were necessary. Oxygen isotope analyses of FG1 on SHRIMP II, normalized to TEMORA 2, yield a mean $\mathrm{d}^{18} \mathrm{O}$ value of $5.5 \pm 0.3 \%$

$\mathrm{Nd}-\mathrm{Sr}$ isotopic compositions were determined thermal ionization mass spectrometry (TIMS) in a VG354 spectrometer equipped with a single Faraday detector at the Geochronological Research Centre (CPGeo) at the São Paulo University. The same powders used for whole-rock elemental analyses were taken into solution by acid digestion, and the elements of interest were separated in ion-exchange columns following the procedures described in Sato et al. (1995). No spikes were added; ${ }^{87} \mathrm{Rb} /{ }^{86} \mathrm{Sr}$ and ${ }^{147} \mathrm{Sm} /{ }^{144} \mathrm{Nd}$ ratios were calculated from whole-rock analyses obtained by XRF ( $\mathrm{Rb}$ and $\mathrm{Sr}$ ) and ICP-MS (Sm and Nd). Nd-Sr isotopic results are presented in Table $\mathbf{S 4}$ of supplementary data.

Major and trace elements, were analyzed at the SGS GEOSOL laboratories according to the package used by the Geological Survey of Brazil. Major element oxides were determined using a Varian Vista Pro ICP-AES. Trace elements were determined using a Perkin-Elmer Sciex ELAN 6000 ICP-MS. Analyses of USGS rock standards (BCR-2, BHVO-1 and AGV-1) indicate precision and accuracy better than 1\% for major elements and $5 \%$ for trace elements and REE. Whole rock geochemical results are presented in Table S5 of supplementary data.

\subsection{Results}

Isotopic results for the granitoids and migmatites of the Tamboril-Santa Quitéria Complex are available in the supplementary data related to this article. Zircon $\mathrm{U}-\mathrm{Pb}$, Lu-Hf and oxygen isotopic measurements were all carried out on the same textural domain in each zircon, which permitted us to link age and isotopic parameters directly. A summary of the isotopic data acquired herein is provided in table 6.2.

\subsubsection{Zircon SHRIMP U-Pb ages, zircon $\mathrm{Hf}-\mathrm{O}$ and whole-rock $\mathrm{Nd}-\mathrm{Sr}$ isotopes}

\subsubsection{Lagoa Caíçara unit}

As described earlier, it is difficult to distinguish the igneous rocks of this unit based solely on their field characteristics. The isotopic results summarized in table 6.2 define three groups of igneous rocks based on the age of the protoliths and their sources, which revealed how subduction-related magmas developed through time. 


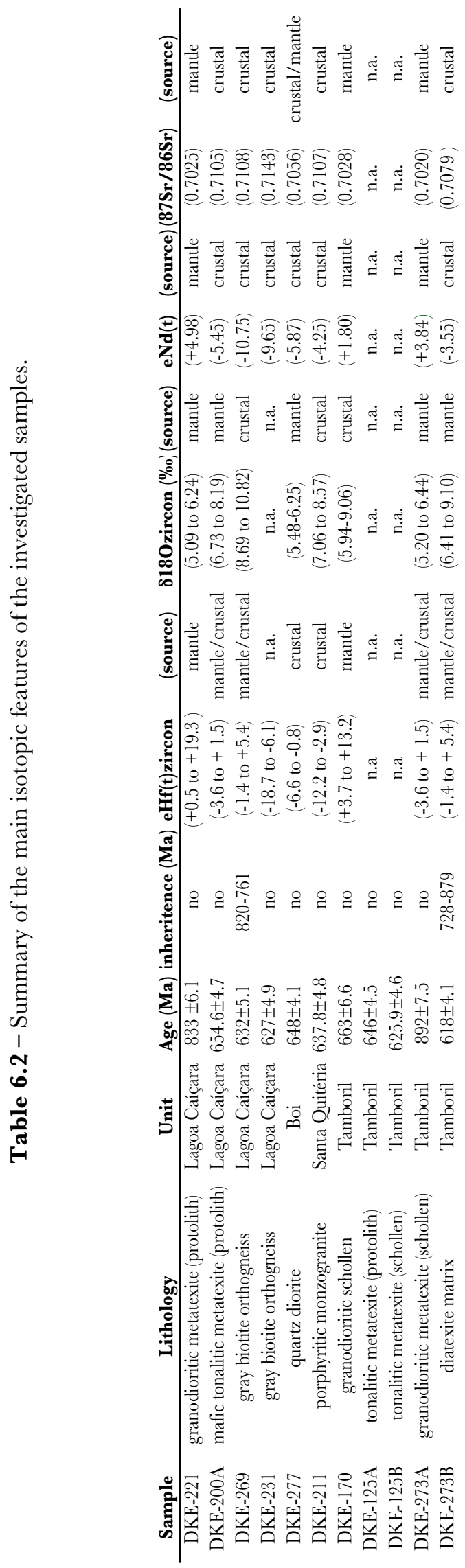




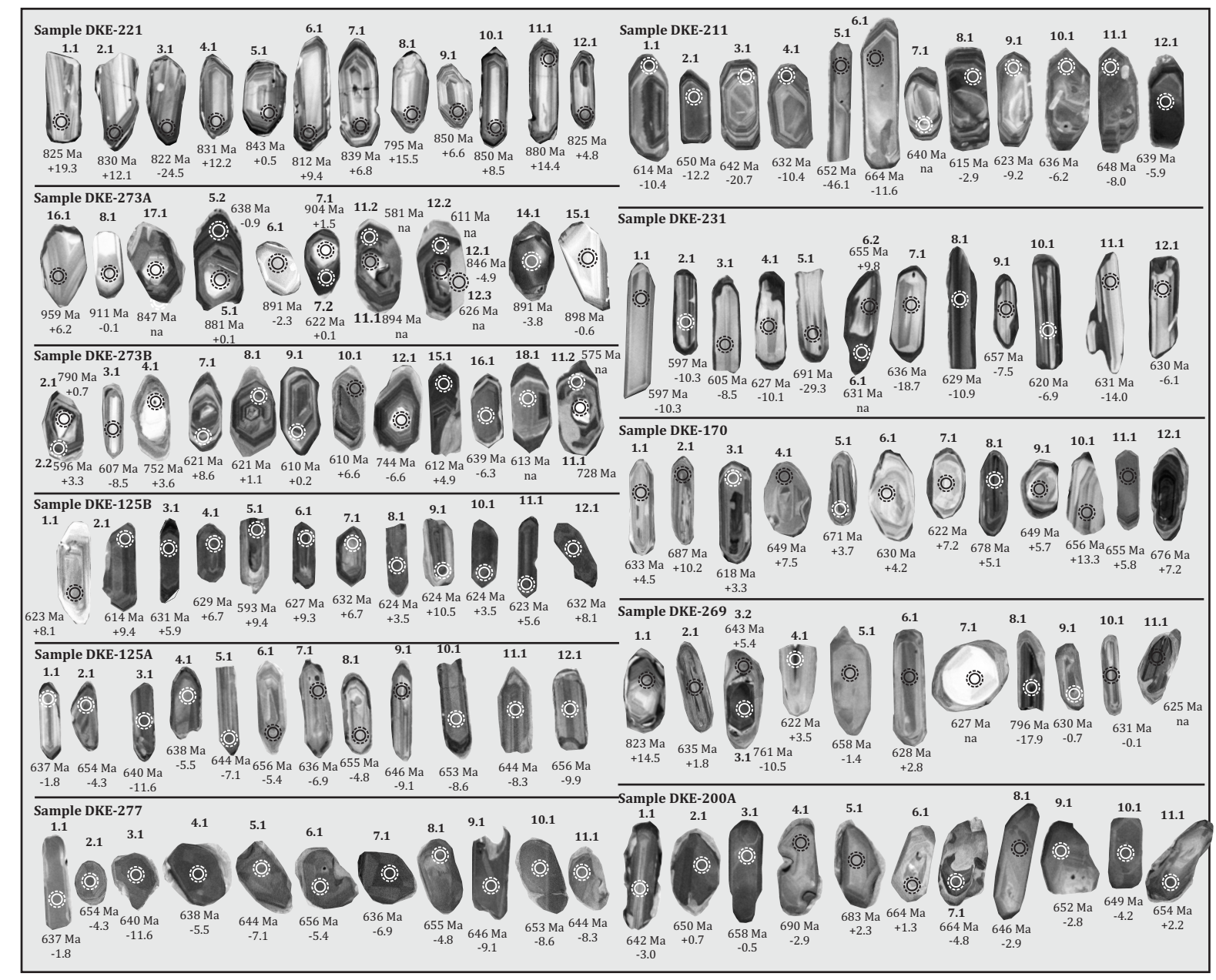

Figure 6.6 - Cathodoluminescence images from zircons selected for U-Pb geochronology and Hf-O isotopic investigation.

\section{Sample DKE-221}

This sample is a hornblende-biotite stromatic metatexite of tonalitic composition (fig. 6.3A). Zircons were extracted from the paleosome (or the protolith), avoiding contamination with the neosome, and are euhedral, translucent and colorless. In general they range in size from 80 to $200 \mu \mathrm{m}$ and have a length to width ratios ranging from 2:1 to 4:1. Cathodoluminesce images reveal a well-developed oscillatory zoning typical of magmatic zircons $(\mathbf{f i g}$. 6.6). Some zircons have low-U, thin metamorphic rims, too small for SHRIMP analysis. Analyzed zircons have $\mathrm{U}$ contents between $52-256 \mathrm{ppm}$ and $\mathrm{Th} / \mathrm{U}$ ratios ranging from 0.50 to 0.78 . Fourteen analyses were done in the zircons and a calculated Concordia age using all analyzed zircons yielded an age of $833 \pm 6.1 \mathrm{Ma}(1 \sigma)$ (table 2), interpreted as the crystallization age of the tonalitic protolith (fig. 6.7).

Zircons have a significant variation of ${ }^{176} \mathrm{Hf} /{ }^{177} \mathrm{Hf}$ as a function of ${ }^{206} \mathrm{~Pb} / 238 \mathrm{U}$ ages with values ranging from 0.282261 to 0.282800 for ages between 880 and 795 Ma. Despite such variation all analyzed zircons yielded consistently positive $\varepsilon \mathrm{Hf}_{(t)}$ varying from +0.5 to +19.3 indicating that the tonalitic protolith was derived from mantle or juvenile sources at $c a .830 \mathrm{Ma}(\mathbf{f i g}$. 6.10A). Oxygen isotopes further support the mantle origin 
indicated by the $\mathrm{Hf}$ isotopes in the zircons. The $\delta^{18} \mathrm{O}$ values of 5.09 to $6.24 \%$ are in agreement with values of mantle zircon $(5.7 \pm 0.3 \%$, Hawkesworth and Kemp, 2006) (fig. 6.10B). Whole rock Sr-Nd isotopes also support a juvenile origin for the tonalitic protolith, with low initial ${ }^{87} \mathrm{Sr} / 86 \mathrm{Sr}$ of 0.7025 and positive $\varepsilon \mathrm{Nd}_{(t)}$ value of +4.98 at the time of crystallization at $833 \mathrm{Ma}(\mathbf{f i g} . \mathbf{6 . 1 1})$.

\section{Sample DKE-200A}

This mafic tonalitic metatexite was collected in quarry close to the Itapajé town and differs from the previous sample, not only in terms of age and source, but also by higher content of hornblende (fig. 6.3B). Zircons were extracted from the paleosome, avoiding contamination with the neosome. In general they are subhedral to euhedral, translucent and colorless, with dimensions ranging from 60 to $150 \mu \mathrm{m}$. They have complex zoned patterns (c.f. zircon \#7.1 - fig. 6.6) to well-developed oscillatory zoning. Most of the grains have a pronounced metamorphic overgrowth possibly due to anatexis of the protolith, not dated in this study. Th/U ratios of the dated zircon spots range from 0.55 to 0.85 . A Concordia age defined by nine concordant zircons yielded an age of 650.6 $\pm 5.1 \mathrm{Ma}(1 \sigma)$ (table 6.2), much younger than the previous sample and interpreted as the crystallization age of the igneous protolith $(\mathbf{f i g} \cdot 6.7) .{ }^{176} \mathrm{Hf} /{ }^{177} \mathrm{Hf}$ ratios from the analysed zircons vary from 0.282226 to 0.282428 with $\varepsilon \mathrm{Hf}_{(t)}$ varying from -3.6 to +1.5 . The $\delta^{18} \mathrm{O}$ values for the same zircons in the same CL zones range from 6.73 to $8.19 \%$ and combined with whole-rock initial ${ }^{87} \mathrm{Sr} /{ }^{86} \mathrm{Sr}$ ratio of 0.7105 and negative $\varepsilon \mathrm{Nd}_{(t)}$ value of -5.45 suggest that this grantoid was predominantly sourced from crustal material, in contrast to the previous sample.

\section{Sample DKE-231}

This orthogneiss differs from the surrounding migmatitic gneiss found in the same unit by the incipient anatexis (e.g. small leucosome volume) and by the absence of hornblende and a more granitic composition (s.l.) than previous samples (fig. 6.3C).

Investigated zircons are colourless and mostly euhedral ranging in size from 80 to $200 \mu \mathrm{m}$. They have prominent high-U rim related to late thermal events (c.f. zircon \#6.1 - fig. 6.6). Analysed magmatic zircons have $\mathrm{Th} / \mathrm{U}$ ratios varying from 0.27 to 0.60 and define a twelve-point concordia age of $627 \pm 4.9 \mathrm{Ma}(1 \sigma)$ that reflects crystallization of the protolith to the orthogneiss (fig. 6.7). One zircon with a ${ }^{206} \mathrm{~Pb} / 238 \mathrm{U}$ age of $691 \pm 18 \mathrm{Ma}$ represents an outlier and is likely inherited. No oxygen analysis was carried out for this sample. ${ }^{176} \mathrm{Hf} /{ }^{177} \mathrm{Hf}$ ratios for the analyzed zircons in spots along the same CL zone range from 0.281848 to 0.282207 with correspondent $\varepsilon \mathrm{Hf}_{(t)}$ varying from -18.7 to -6.1 , and together with a high initial whole rock ${ }^{87} \mathrm{Sr} /{ }^{86} \mathrm{Sr}$ ratio of 0.7143 and negative $\varepsilon \mathrm{Nd}_{(t)}$ value of -9.65 , suggests this magma was essentially sourced from older crustal rocks.

\section{Sample DKE-269}

This migmatitic orthogneiss is compositionally similar to the previous one and was found in the same geological context. Zircons from the protolith are euhedral to subhedral with sizes ranging from 50 to 150 
Carlos E. Ganade de Araujo - Tese de Doutorado - Universidade de São Paulo

Capítulo 6 - Tracing Neoproterozoic subduction in NE-Brazil

$\mu \mathrm{m}$. Most zircons have a well-developed rim surrounding inherited cores (c.f. zircons \#3.1 and \#8.1 - fig. 6.7). In general $\mathrm{U} / \mathrm{Th}$ ratios vary from 0.17 to 1.52 (0.17-0.58 for inherited cores). A concordia age of $632 \pm 5.1 \mathrm{Ma}(1 \sigma)$ was defined by eleven concordant points and reflects the age of crystallization of the protoliths. Three inherited zircons with ${ }^{206} \mathrm{~Pb} /{ }^{238} \mathrm{U}$ ages of $823 \pm 23,796 \pm 19$ and $761 \pm 19$ Ma suggest that Early Neoproterozoic protoliths, such as the $800 \mathrm{Ma}$, juvenile tonalite of sample DKE-221, were involved in the genesis of the protolith. ${ }^{176} \mathrm{Hf} /{ }^{177} \mathrm{Hf}$ ratios from zircons with ${ }^{206} \mathrm{~Pb} /{ }^{238} \mathrm{U}$ ages in the range of 600 to $658 \mathrm{Ma}$ vary from 0.282323 to 0.282523 with $\varepsilon \mathrm{Hf}_{(\mathrm{t})}$ of -1.4 to +5.4 , pointing to a juvenile component in the genesis of the precursor magmas. One inherited core yielded a highly radiogenic ${ }^{176} \mathrm{Hf} /{ }^{177} \mathrm{Hf}$ ratio of 0.282685 with correspondent $\varepsilon \mathrm{Hf}_{(t)}$ of +14.5 , further supporting the suggestion that juvenile sources were involved in the genesis of the protolith of this orthogneiss. However, $\delta^{18} \mathrm{O}$ values range from 8.69 to $10.82 \%$. This contrasts with expectations from magmas generated by juvenile sources and suggests either crustal material contributed to the formation of the precursor magmas or external, isotopically evolved water was present during melting of the source (see discussion in section 6.5.1.3). High initial ${ }^{87} \mathrm{Sr} /{ }^{86} \mathrm{Sr}$ ratio of 0.7108 and strong negative $\varepsilon \mathrm{Nd}_{(t)}$ value of -10.75 also support the participation of older crustal material in the genesis of the magma.

\subsubsection{Boi Unit}

\section{Sample DKE-277}

Zircons from this mafic tonalite are subhedral with ovoid shapes ranging in size from 40 to $100 \mu \mathrm{m}$. In general, they have a well-developed igneous oscillatory zoning surrounded by a thin metamorphic overgrowth not accessible by the SHRIMP analyses (c.f. zircons 6.1 and 4.1 - fig. 6.6). The dated igneous zircons have $\mathrm{U} / \mathrm{Th}$ ratios of (0.56-0.97) and yielded a twelve-point concordia age of $648 \pm 4.1 \mathrm{Ma}(1 \sigma)$ that reflects the age of crystallization of tonalite (fig. 6.7). ${ }^{176} \mathrm{Hf} /{ }^{177} \mathrm{Hf}$ ratios from these zircons have a narrow variation between 0.282201 and 0.282348 which corresponds to $\varepsilon \mathrm{Hf}_{(t)}$ values between -6.6 to -0.8 . Initial ${ }^{87} \mathrm{Sr} /{ }^{86} \mathrm{Sr}$ ratio of 0.7056 and negative $\varepsilon \mathrm{Nd}_{(t)}$ value of -5.87 indicate that both mantle and older crust were involved in the magma genesis, however $\delta^{18} \mathrm{O}$ values for the dated zircons range from 5.48-6.25\%, which fall within the proposed range for mantle zircons $(5.7 \pm 0.3 \%$, according Hawkesworth and Kemp, 2006).

\subsubsection{Santa Quitéria unit}

\section{Sample DKE-211}

This sample of porphyritic mozogranite from the core of the batholith is representative of the most voluminous igneous unit found within the complex. Zircons from this sample $(\mathbf{f i g}$. 6.4B) are euhedral (80-200 $\mu \mathrm{m})$ and display nicely developed oscillatory zoning (fig. 6.6) with $\mathrm{U} / \mathrm{Th}$ ratios ranging from 0.45 to 1.06 . Eleven spot analyses yielded a concordia age of $637.8 \pm 4.8 \mathrm{Ma}$ (fig. 6.7), which reflects the age of the crystallization of the monzogranite. This age is slightly younger than the mafic sample DKE-277 from the Boi unit. ${ }^{176} \mathrm{Hf} /{ }^{177} \mathrm{Hf}$ ratios from the analyzed zircons range from 0.282028 to 0.282314 corresponding to a $\varepsilon \mathrm{Hf}_{(t)}$ between -12.2 to -2.9 , indicating participation of crustal material in the genesis of the monzogranitic magma, as also suggested by the high $\delta^{18} \mathrm{O}$ values of 7.06 to 8.57 . Despite of evident interaction with mafic magmas of 
Carlos E. Ganade de Araujo - Tese de Doutorado - Universidade de São Paulo

Capítulo 6 - Tracing Neoproterozoic subduction in NE-Brazil

the Boi unit, high initial ${ }^{87} \mathrm{Sr} /{ }^{86} \mathrm{Sr}$ ratio of 0.7107 and negative $\varepsilon \mathrm{Nd}_{(t)}$ value of -4.25 also point to involvement of crustal sources in the genesis of this monzogranite.
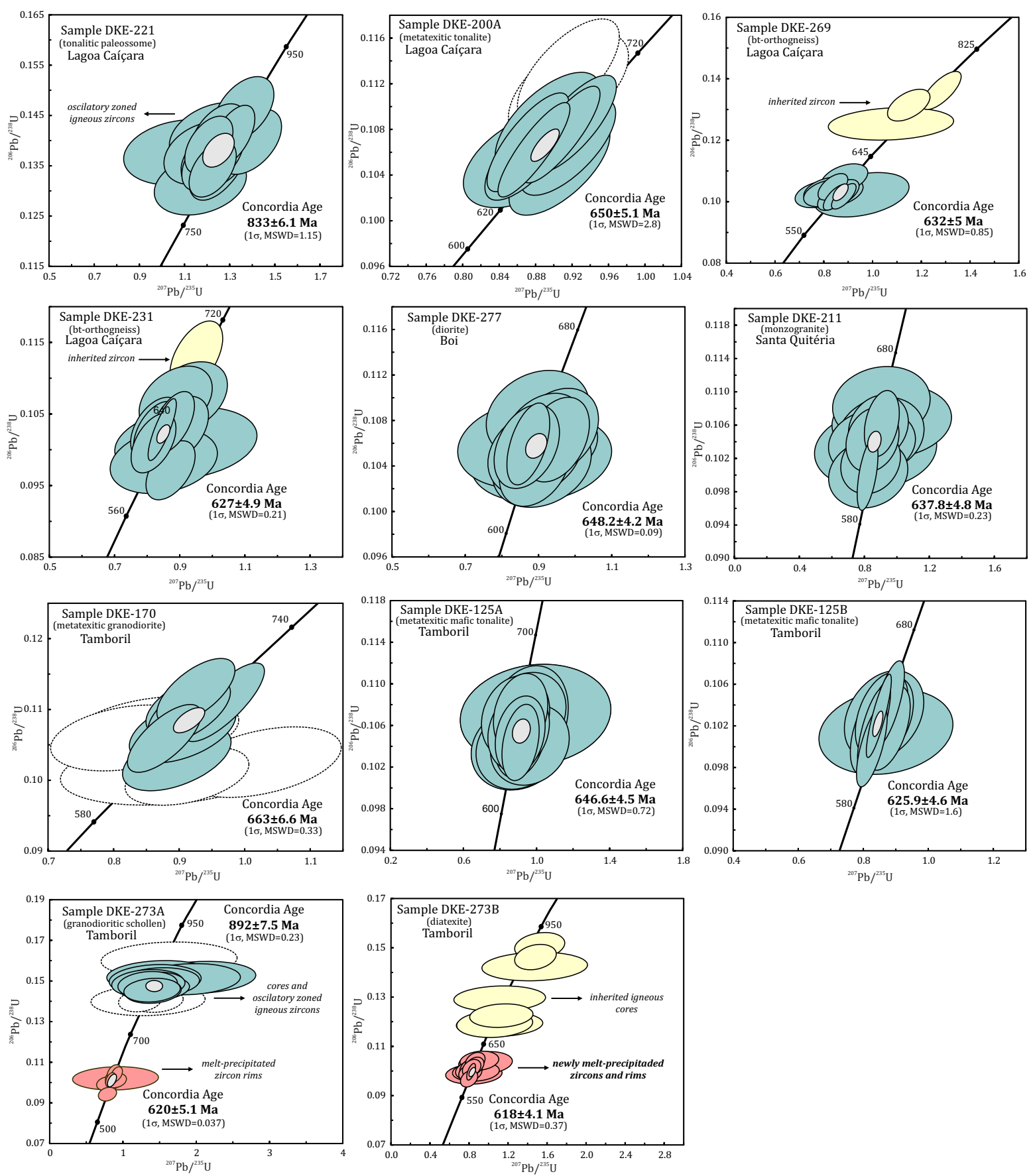

Figure 6.7 - U-Pb Whetheril Concordia diagrams for the investigated samples. Green elipses indicate protolith crystallization; yellow ellipses indicate inheritance; pink ellipses indicate melt precipitated zircons; white ellipses were excluded from the dataset. 
Carlos E. Ganade de Araujo - Tese de Doutorado - Universidade de São Paulo

Capítulo 6 - Tracing Neoproterozoic subduction in NE-Brazil

\subsubsection{Tamboril Unit}

This unit is dominated by granitic diatexites that often contain rafts (schollen) from older igneous rocks of the complex. It represents a gradational unit at the contact between the monzogranite of the Santa Quitéria unit and the gneisses of the Lagoa Caíçara unit and Ceará Complex in the north. The isotopic results does confirm field observations with samples with characteristics similar to those of the Santa Quitéria (DKE-170, DKE125A) and samples of older juvenile material similar to the Lagoa Caíçara (DKE-273A).

Sample DKE-170

Zircons from this metatexitic granodiorite raft (fig. 6.5B) extracted from the contact between the Santa Quitéria unit with the diatexites of the Tamboril unit are mostly euhedral $(80-150 \mu \mathrm{m})$ and characterized by a prominent oscillatory zoning surrounded by a thin high-U metamorphic overgrowth (c.f. zircons 7.1 and 9.1 -

fig. 6.6). Th/U ratios for the dated zircons vary significantly from 0.11 to 1 . Seven concordant analyses fall in a group yielding a concordia age of $663 \pm 6.6 \mathrm{Ma}(1 \sigma)(\mathbf{f i g} \cdot \mathbf{6 . 7}) .{ }^{176} \mathrm{Hf} /{ }^{177} \mathrm{Hf}$ ratios from the analyzed zircons are slightly radiogenic with values ranging from 0.282471 and 0.282741 , with correspondent $\varepsilon \mathrm{Hf}_{(\mathrm{t})}$ of +3.7 to +13.2 , indicating involvement of juvenile sources in the genesis of the magmas. Low initial ${ }^{87} \mathrm{Sr} /{ }^{86} \mathrm{Sr}$ ratio of 0.7028 and positive $\varepsilon \mathrm{Nd}_{(\mathrm{t})}$ value of +1.80 also lend support to partial melting of depleted mantle sources. However, the $\delta^{18} \mathrm{O}$ values (5.94-9.06\% ) for the dated igneous zircons fall outside the field of mantle zircons and suggest that crustal contaminants or isotopically evolved water interaction during crystallization could contribute to the observed higher $\delta^{18} \mathrm{O}$ values.

Sample DKE-125

We collected two samples in this outcrop. Sample DKE-125A is a mafic stromatic metatexitic diorite raft embedded in the granitic diatexite of the Tamboril unit. Sample DKE-125B represents the host granite diatexite (fig. 6.5G). Field evidence does not support derivation of the diatexite from the partial melting of the diorite because the leucosomes in the diorite have different composition of the host diatexite evidenced by abundant plagioclase. Zircons from the metatexitic diorite are euhedral to subhedral (60-200 $\mu \mathrm{m})$ and have well-defined igneous oscillatory zoning with $\mathrm{Th} / \mathrm{U}$ ratios ranging from 0.50 to 0.80 . Twelve zircons form a group in the concordia line yielding a mean age of $646 \pm 4.5 \mathrm{Ma}(1 \sigma)$ for the dioritic protolith crystallization (fig. 6.7). Zircons from the host granitic diatexite are also euhedral to subhedral and have well-defined igneous oscillatory zoning with $\mathrm{Th} / \mathrm{U}$ ratios from 0.13 to 0.84 . A concordia age of $625.9 \pm 4.6 \mathrm{Ma}(1 \sigma)$ defined by eleven concordant analyses reflects the age of the crystallization of this diatexite (fig. 6.7). No zircon Hf-O isotopes or whole-rock Sr-Nd analyses were performed for either of these samples. These results suggest that mafic intrusive rocks of an age similar to that of the Boi unit were involved in an anatectic event that occurred only 20 m.y. after their crystallization. 
Carlos E. Ganade de Araujo - Tese de Doutorado - Universidade de São Paulo Capítulo 6 - Tracing Neoproterozoic subduction in NE-Brazil

Sample DKE-273

The composite sample DKE-273 is divided into a schollen of granodioritic composition (sample DKE-273A) and the host diatexite of the Tamboril unit (sample DKE-273B) (fig. 6.5A). Different from sample DKE125, field evidence such as continuity between the host diatexite and leucosomes in the schollen, as well as textural similarity supports partial melting of the granodioritic schollen as one of the sources of the diatexite. Zircons from the granodioritic schollen are euhedral, transparent, colorless to light yellow. Most of them are equant to short prismatic. Crystals range in length from 80 to $200 \mu \mathrm{m}$. Most zircons are oscillatory zoned and interpreted as the result of magmatic growth (c.f. zircons 16.1 and 15.1 - fig. 6.6), but newly developed rims around magmatic cores also with a characteristic oscillatory zoning are interpreted as melt-precipitated zircons from the partial melting event (c.f. zircons 5.2 and 7.1 - fig. 6.6). A third type of zircon is characterized by homogenous domains that crosscut the two types described above (c.f. zircon 12.2 - Fig. 6.6). Two clusters of crystallization ages were obtained from zircons in the schollen. The older, with a calculated Concordia age of $892 \pm 7.5 \mathrm{Ma}$ is considered to be the protolith age, and was obtained from both old cores (c.f. zircons 5.2 and 7.1 - fig. 6.6) and from zircons with prominent oscillatory zoning but lacking overgrowths (c.f. zircons 16.1 and 15.1 - fig. 6.6). The younger cluster with a calculated concordia age of $620 \pm 5.1 \mathrm{Ma}$ (fig. 6.7) is interpreted as the age of anatexis and was obtained from magmatic overgrowths (melt-precipitated) around older cores (c.f. zircons 5.2 and 7.1 - fig. 6.7). We note that this age is similar within error to the age of the anatectic matrix of the previous sample DKE125B. Th/U ratios in this sample vary systematically with younger zircons showing lower ratios (0.07-0.22) while the older zircons demonstrate higher values (0.22-0.67).

The analyzed zircons for sample DKE-273A zircons have initial ${ }^{176} \mathrm{Hf} /{ }^{177} \mathrm{Hf}$ ratio with values ranging from 0.282104 to 0.282249 for ages between 904 to $846 \mathrm{Ma}$ and correspondent $\mathrm{eHf}_{(t)}$ varying from -3.6 to +1.5 . The highest $\left({ }^{176} \mathrm{Hf} /{ }^{177} \mathrm{Hf}\right)_{i}$ ratio of 0.282348 occurs in an inherited zircon with a ${ }^{206} \mathrm{~Pb} / 238 \mathrm{U}$ age of $959 \mathrm{Ma}$, corresponding to the maximum $\varepsilon \mathrm{Hf}_{(t)}$ value of +6.2 . Two grains with well-defined younger melt-precipitated rims were analyzed with ${ }^{206} \mathrm{~Pb} / 238 \mathrm{U}$ ages of 638 and $622 \mathrm{Ma}$ and correspondent $\varepsilon \mathrm{Hf}_{(t)}$ of -0.9 and +0.1 , respectively. Although the $\varepsilon \mathrm{Hf}_{(t)}$ for the zircons of the granodioritic protolith yielded mostly neutral values hampering the possibility of evaluation between the distinction of juvenile vs. crustal material, time-resolved oxygen isotopes on the same zircons were more conclusive. The $\delta^{18} \mathrm{O}$ values for the older zircons (830-959 $\mathrm{Ma}$ ) of 5.20 to $6.44 \%$ fall mostly within the range of mantle zircon $(5.7 \pm 0.3 \%$ ), indicating addition of juvenile mantle-derived material in the referred time. Conversely, $\delta^{18} \mathrm{O}$ values of 7.69 to $8.17 \%$ for the meltprecipitated rims (643-581 Ma) are significantly higher than the mantle zircon, indicating involvement with crustal material or addition of water during the melting event. The granodioritic schollen also have also low initial ${ }^{87} \mathrm{Sr} /{ }^{86} \mathrm{Sr}$ of 0.7020 and positive $\varepsilon \mathrm{Nd}_{(\mathrm{t})}$ of +3.84 at $(t=892 \mathrm{Ma})$, pointing to derivation of juvenile mantlederived sources.

Sample DKE-273B, representative of the diatexite matrix yielded younger ages and several inherited zircons from the melted protolith. Zircons from this sample are also euhedral, transparent, colorless, with crystals ranging in length from 80 to $200 \mu \mathrm{m}$ (fig. 6.6). The calculated Concordia age at $618 \pm 4.1 \mathrm{Ma}$ (fig. 6.7) was acquired from newly formed zircons from the melt (c.f. zircons 3.1 and 9.1 - fig. 6.6) or from meltprecipitated overgrowths around older magmatic cores (c.f. zircons 2.2 and 7.1 - fig. 6.6). This age is 
equivalent to that obtained from the melt-precipitated overgrowths found in the zircons from the schollen in the sample DKE-273A and also from the diatexite sample DKE125B, and represents more precisely the time of the anatexis. Ages from older cores (c.f. zircons 2.1 and 4.1 - fig. 6.6) scatter between 728 and $879 \mathrm{Ma}$ and do not define a precise age in the concordia diagram, suggesting an inherited nature from the precursor source material prior the melting event. In general, variations between the initial ${ }^{176} \mathrm{Hf} /{ }^{177} \mathrm{Hf}$ ratio and the ${ }^{206} \mathrm{~Pb} /{ }^{238} \mathrm{U}$ ages for the melt-precipitated zircons in diatexite of the sample 273B are significantly higher than the zircons extracted from the schollen, with values ranging from 0.282152 to 0.282687 for ages between 637 to $607 \mathrm{Ma}$ and correspondent $\varepsilon \mathrm{Hf}_{(t)}$ varying from -1.4 to $+5.4(\mathbf{f i g} . \mathbf{6 . 1 0 A})$. Two older cores, inherited from the schollen were also analyzed and yielded $\varepsilon \mathrm{Hf}_{(t)}$ of -0.5 and +14.5 , suggesting some incorporation of juvenile material from the schollen protolith, as expected from field observations. The $\delta^{18} \mathrm{O}$ values for the melt-precipitated rims and newly formed zircons of 6.41 to $9.10 \%$ are also higher than the mantle zircon, indicating addition of water during the melting event and or contamination with crustal material (fig. 6.10B). As also expected, the older cores inherited from the schollen have mantle signatures with zircons values ranging from 4.64 to $5.53 \%$ (fig. 6.10B). This diatexite have initial ${ }^{87} \mathrm{Sr} /{ }^{86} \mathrm{Sr}$ ratio of 0.7079 and negative $\varepsilon \mathrm{Nd}_{(t)}$ of -3.55 at $t=618 \mathrm{Ma}$, suggesting that crustal material was also involved in the genesis of the diatexites (fig. 6.11).

\subsubsection{Zircon SHRIMP $O$ isotopes in detrital zircons}

Forty-one analyses of Neoproterozoic zircons (939-648 Ma) extracted from two samples of metatexitic paragneisses (samples DKE-43 and 45) of the Ceará Complex (close to Miraíma town) were also performed to evaluate the changes in mantle and crustal involvement with time. ${ }^{206} \mathrm{~Pb} / 238 \mathrm{U}$ ages of the same analyzed zircons were previously acquired by Ganade de Araujo et al. (2012a) and the ages of the paragneisses are younger than $650 \mathrm{Ma}$ and their anatexis was estimated to be at 640-600 Ma.

According to these authors zircons were shed from a long-lived arc system (the Tamboril-Santa Quitéria Complex) and deposited in a forearc basin. In general both samples have a significant variation between low and high $\mathrm{d}^{18} \mathrm{O}$ values, however, lower mantle-like values $\left(\delta^{18} \mathrm{O}<6.0 \%\right.$ ) are consistently more abundant in the sample DKE-43. The $\delta^{18} \mathrm{O}$ values for this sample range from 3.64 to $8.11 \%$ with $78 \%$ of the total analyzed zircons $(n=22)$ exhibiting values of $\delta^{18} \mathrm{O}<6.0 \%$ throughout the range of 949 to $648 \mathrm{Ma}(\mathbf{f i g} . \mathbf{6 . 1 0 B})$. For the sample DKE-45 $\delta^{18} \mathrm{O}$ values varies from 5.09 to $7.73 \%$ with $36 \%$ of the analyzed zircons $(\mathrm{n}=19)$ showing

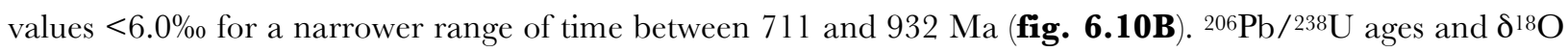
values indicates that mantle derived sources persisted throughout time since the beginning of the Neoproterozoic arc magmatism, however the presence of zircons with high $\mathrm{d}^{18} \mathrm{O}$ values $(>6.0 \%$ ) from 869 to $662 \mathrm{Ma}$ also suggests that the sources (magmas) of these zircons also have interacted with crustal materials. 
Carlos E. Ganade de Araujo - Tese de Doutorado - Universidade de São Paulo

Capítulo 6 - Tracing Neoproterozoic subduction in NE-Brazil
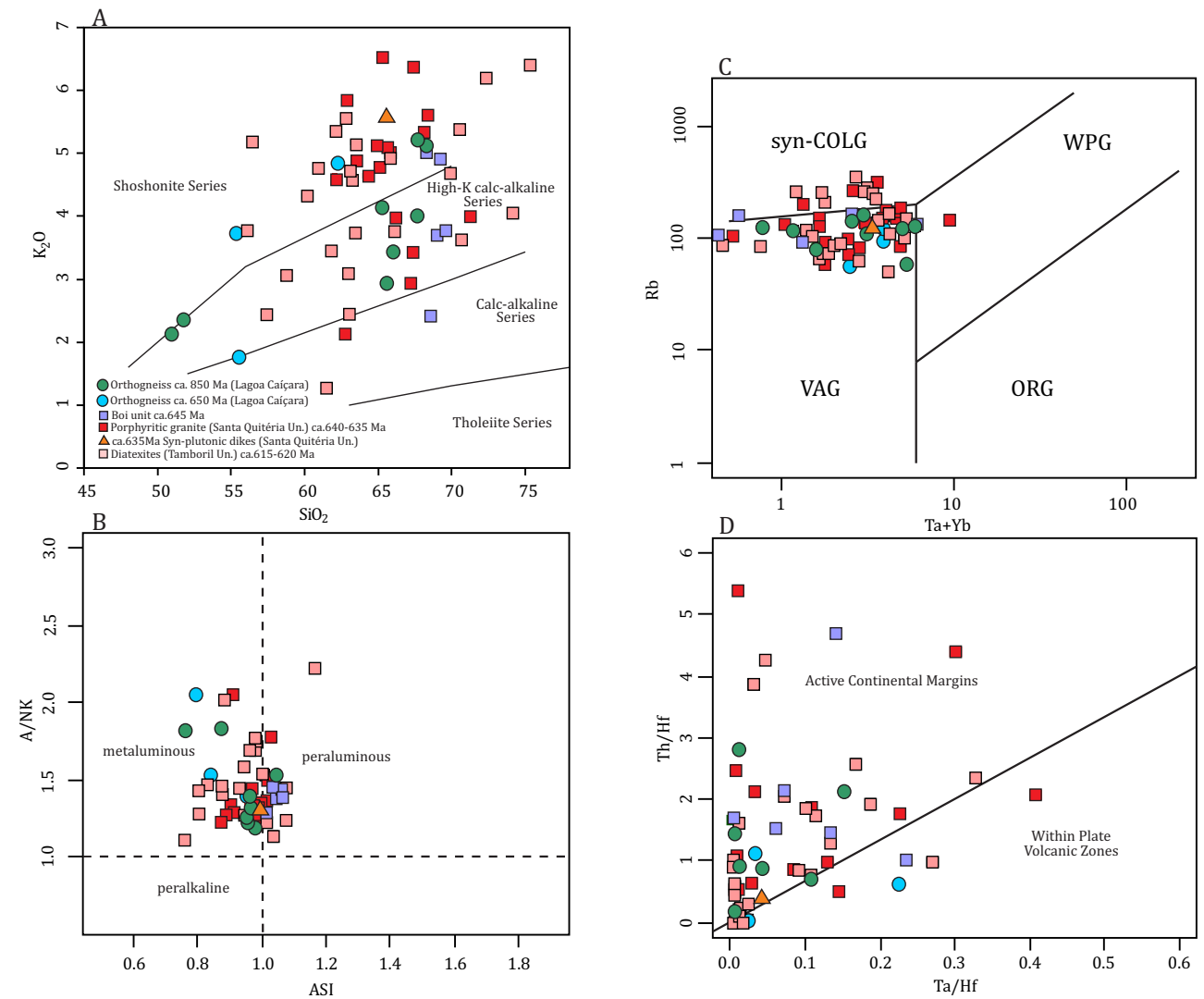

Figure 6.8 - $\mathbf{A} \cdot \mathrm{K}_{2} \mathrm{O}$ versus $\mathrm{SiO}_{2}$ diagram of Peccerillo and Taylor (1976), showing that granitoids are high-K calc-alkaline to shoshonitic in nature. B. A/NK vs. ASI diagram modified from Shand (1947). C. Rb versus $\mathrm{Ta}+\mathrm{Yb}$ tectonic discrimination diagram of Pearce et al. (1984). D. Th/Hf versus Ta/Hf discrimination diagram between continental active margins and within plate volcanic zones of Shandl and Gorton (2002).

\subsubsection{Major and trace elements}

Geochemical results does not allow any particular discrimination among the major units of the TamborilSanta Quitéria Complex, instead, granitoids show similar trace and REE patterns mostly characteristic of convergent plate margins.

\subsubsection{Lagoa Caíçara unit}

Geochemically, the non-melted portions of from the older group of gneisses and migmatites (ca. $830 \mathrm{Ma}$ ) have $\mathrm{SiO}_{2}$ ranging from 65.3 to 68.2 wt. $\%$. The $\mathrm{K}_{2} \mathrm{O}$ contents range between 2.1 and $5.9 \mathrm{wt} . \%$ with an average of 3.9 wt. $\%$ with the samples plotting mostly in the high-K calc-alkaline field in the $\mathrm{K}_{2} \mathrm{O}$ versus $\mathrm{SiO}_{2}$ classification diagram of Peccerillo and Taylor (1976) (fig. 6.8A). Their $\mathrm{Al}_{2} \mathrm{O}_{3}$ contents ranges from 13.8 to $19.6 \mathrm{wt} \%$ yielding a metaluminous to subordinately weak peraluminous signatures (ASI $=0.73-1.08)$ (fig. 6.8B). The geochronological data presented herein identified not only Early Neoproterozoic migmatitic orthogneisses, but also orthogneisses, which protoliths have crystalized at ca. $650 \mathrm{Ma}$. These ca. $650 \mathrm{Ma}$ orthogneisses have $\mathrm{SiO}_{2}$ ranging from 55.5 to 62.2 wt. $\%$ with an average of 57.7 wt. $\%$ and similar $\mathrm{K}_{2} \mathrm{O}(1.77-$ 4.86 wt. $\%$ ) contents of the older gneisses. 
Carlos E. Ganade de Araujo - Tese de Doutorado - Universidade de São Paulo

Capítulo 6 - Tracing Neoproterozoic subduction in NE-Brazil

In the primitive mantle-normalized spidergram (fig. 6.9), the samples from the both groups (ca. 800 and ca. $650 \mathrm{Ma}$ ) show characteristic negative anomalies of $\mathrm{Th}, \mathrm{Nb}, \mathrm{La}, \mathrm{P}$ and $\mathrm{Ti}$. In the case of $\mathrm{P}$ and $\mathrm{Ti}$ this is attributed to a residue of apatite and ilmenite in the parental magma. These rocks have similar REE contents when compared with typical I-type granites. All samples of the older group (ca. $800 \mathrm{Ma}$ ) exhibit high REE contents, relatively enrichment of LREE ((La/Yb)N ratios of 4.3 to 44.5 with an average of 10.2), flat HREE patterns ((Tb/Yb)N ratios of 1.0 to 2.4) and strong to weakly negative Eu anomalies (Eu/Eu* ratios of 0.56 to 0.99) (fig. 6.9). Samples from both groups plot within the VAG field in the tectonic discriminant diagram of Pearce et al. (1982) and in the active-margin granites of Shandl and Gorton (2002) (figs. 6.8C and D).

\subsubsection{Boi unit}

In general, samples from this unit have $\mathrm{SiO}_{2}$ ranging from 67.0 to $69.1 \mathrm{wt} . \%$ with an average of $67.8 \mathrm{wt} . \%$. They have rather high $\mathrm{K}_{2} \mathrm{O}$ (2.4-7.4 wt.\%) and low $\mathrm{MgO}$ (0.63-1.0 wt.\%) contents with samples plotting mostly in the high- $\mathrm{K}$ calc-alkaline field in the $\mathrm{K}_{2} \mathrm{O}$ versus $\mathrm{SiO}_{2}$ diagram (fig. 6.8A). Their $\mathrm{Al}_{2} \mathrm{O}_{3}$ contents are between 14.9 and $15.7 \mathrm{wt} \%$ giving the rock a weak peraluminous signature (ASI=0.99-1.06) (fig. 6.8B). They have low $\mathrm{Ba}$ (479-868 ppm) and $\mathrm{Sr}(152-329 \mathrm{ppm})$ contents, and characteristic negative anomalies of $\mathrm{Nb}$ and $\mathrm{Ti}$ and positive anomalies of $\mathrm{U}, \mathrm{K}$ and $\mathrm{Ce}$ in the primitive mantle-normalized spidergram (fig. 6.9). Normally, the samples show a relatively enrichment of light rare earth elements (LREEs)((La/Yb $)_{\mathrm{N}}$ ratios of 8.2 to 91.5 with an average of 11.8$)$ ), and a predominant strong negative Eu anomalies (Eu/Eu* ratios $\approx 0.63$ ).

\subsubsection{Santa Quitéria unit}

Geochemically, the samples of Santa Quitéria unit have $\mathrm{SiO}_{2}$ contents in between 58.7 and 75.4 wt.\%, with an average of 61.1 wt. $\%$. $\mathrm{K}_{2} \mathrm{O}$ contents range between 1.8 and 7.4 wt. $\%$ with an average of 3.1 wt. $\%$ with the samples plotting mostly in the high-K calc-alkaline and shoshonitic fields in the $\mathrm{K}_{2} \mathrm{O}$ versus $\mathrm{SiO}_{2}$ classification diagram of Peccerillo and Taylor (1976) (fig. 6.8A). The samples demonstrate overall patterns of decreasing $\mathrm{Mg}, \mathrm{Fe}, \mathrm{Ca}, \mathrm{Ti}, \mathrm{Al}$ and $\mathrm{P}$ with increasing $\mathrm{SiO}_{2}$. Their $\mathrm{Al}_{2} \mathrm{O}_{3}$ contents are in between 13.3 and 17.4 wt.\% indicating a metaluminous to weak peraluminous character $(\mathrm{ASI}=0.73-1.07)$ (fig. 6.8B). The samples display an enriched LILE pattern, defining a downward sloping profile in the primordial mantle normalized spidergram, combined with positive anomalies of $\mathrm{K}, \mathrm{Pb}$ and $\mathrm{Nd}$ and negative $\mathrm{Nb}, \mathrm{Th}, \mathrm{P}$ and $\mathrm{Ti}$ anomalies (fig. 6.9). In spite of the significant variance of $\mathrm{Ba}$ and $\mathrm{Sr}$, the former appears especially abundant, with average values of 727 and $223 \mathrm{ppm}$, respectively. Generally the analysed samples exhibit high REE contents, relatively enrichment of light rare earth elements (LREEs) $(\mathrm{La} / \mathrm{Yb})_{\mathrm{N}}$ ratios of 3.3 to 67.8 with an average of 14.9), flat HREE patterns $\left((\mathrm{Tb} / \mathrm{Yb})_{\mathrm{N}}\right.$ ratios of 0.7 to 3.1$)$ and predominant negative Eu anomalies $\left(\mathrm{Eu} / \mathrm{Eu}^{*}\right.$ ratios $\approx 0.83$ ).

\subsubsection{Tamboril unit}

In general terms, samples of the Tamboril diatexite are geochemically similar to that of the Santa Quiteria unit. They have $\mathrm{SiO}_{2}$ ranging from 62.4 to $68.3 \mathrm{wt} . \%$ with an average of $64.3 \mathrm{wt} . \%$. $\mathrm{K}_{2} \mathrm{O}$ contents range 
Carlos E. Ganade de Araujo - Tese de Doutorado - Universidade de São Paulo

Capítulo 6 - Tracing Neoproterozoic subduction in NE-Brazil
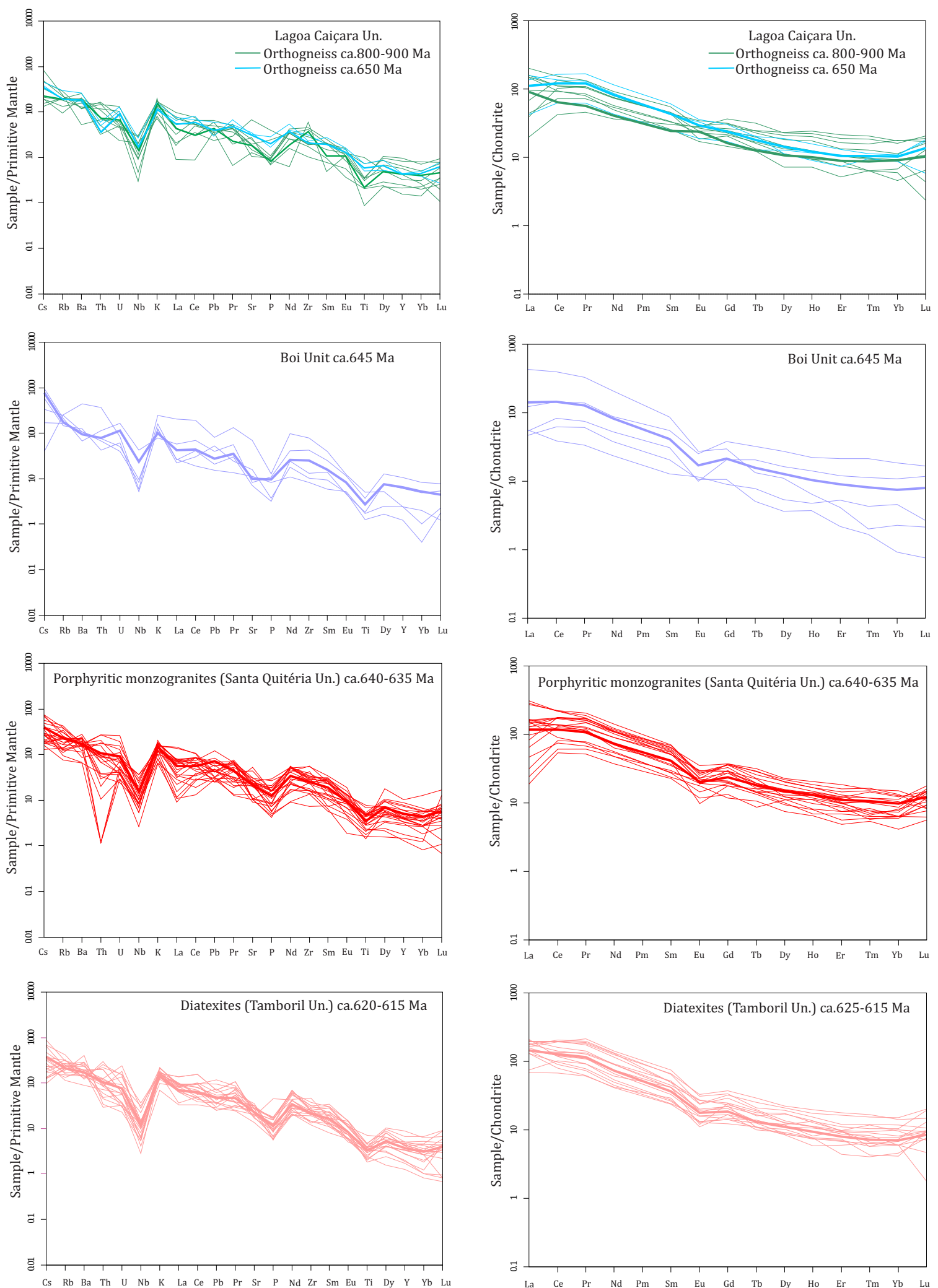

Figure 6.9 - REE and spider diagrams for granitoid rocks of the protolith of granitoids and migmatites from Tamboril-Santa Quitéria Complex. Primitive mantle and Chondrite normalized values from McDonough and Sun (1995) and Sun and McDonough (1989), respectively. 
Carlos E. Ganade de Araujo - Tese de Doutorado - Universidade de São Paulo

Capítulo 6 - Tracing Neoproterozoic subduction in NE-Brazil

between 1.6 and 6.5 wt. $\%$ with an average of 3.9 wt. $\%$ with the samples plotting mostly in the high-K calcalckaline and shoshonitic fields in the $\mathrm{K}_{2} \mathrm{O}$ versus $\mathrm{SiO}_{2}$ diagram (fig. 6.8A). Their $\mathrm{Al}_{2} \mathrm{O}_{3}$ contents are in between 13.6 and 16.9 wt.\% that gives a metaluminous to subordinately weak peraluminous characteristic (ASI=0.84-1.04) (fig. 6.8B). In the primitive mantle-normalized spidergram samples show characteristic negative anomalies of $\mathrm{Nb}, \mathrm{P}$ and $\mathrm{Ti}$ that should be attributed in part to the residue of apatite and ilmenite in the parental magma. The samples exhibit high REE contents, relatively enrichment of light rare earth elements (LREEs) $\left((\mathrm{La} / \mathrm{Yb})_{\mathrm{N}}\right.$ ratios of 2.9 to 85.1 with an average of 20.4)), flat HREE patterns $\left((\mathrm{Tb} / \mathrm{Yb})_{\mathrm{N}}\right.$ ratios of 0.7 to 4.7$)$ and predominant negative $\mathrm{Eu}$ anomalies $\left(\mathrm{Eu} / \mathrm{Eu}^{*}\right.$ ratios $\left.\approx 0.63\right)(\mathbf{f i g} .6 .9)$.

\subsection{Discussion}

\subsubsection{Magmatic Evolution}

Geochemistry, $\mathrm{U}-\mathrm{Pb}$ zircon ages, time-resolved zircon $\mathrm{Hf}-\mathrm{O}$ isotopic determinations and whole-rock Sr-Nd isotopes of the Tamboril-Santa Quitéria Complex obtained in this study provide important constraints on the magmatic and tectonic evolution of the Ceará Central Domain. Trace element concentrations of the investigated samples display a typical spectrum of arc-related igneous rocks, the so-called "arc-signature", characterized by the enrichment of highly mobile large ion lithophile elements (LILE) relative to high field strength elements (HFSE) (McMillan et al., 1989). However, it is the isotopic composition that characterizes better the source of the investigated granitoids. Essentially, magmatism can be divided into three main periods with their particular characteristics: i) an early period comprising essentially juvenile arc magmatism at ca. 880-800 Ma, ii) a more mature arc period at ca. 660-630 Ma characterized by hybrid mantle-crustal components, and iii) crustal anatexis at 625-618 Ma continuing until ca. $600 \mathrm{Ma}$. In the following discussion we will avoid the unit nomenclature based on mapping, and divide the investigated samples according to their age and isotopic signatures.

\subsubsection{Early $880-800$ Ma juvenile arc-related magmatism}

Samples 273A and DKE-221 of granodioritic/tonalitic, yielded the oldest zircon crystallization ages at $892 \pm 7.5$ and $833 \pm 6.1 \mathrm{Ma}$, respectively. These samples have predominantly positive $\varepsilon \mathrm{Hf}_{(t)}(-3.6$ to +19.3$)$ and positive $\varepsilon \mathrm{Nd}_{(t)}(+4.98$ to +3.84$)$ combined with low initial ${ }^{87} \mathrm{Sr} /{ }^{86} \mathrm{Sr}(<0.7025)$, suggesting derivation from a depleted mantle (juvenile) source. Nonetheless, detrital zircons from forearc deposits of the Ceará Complex suggests that magmatism was continuously active from at least ca. 900 to ca. $650 \mathrm{Ma}$ (Ganade de Araujo, 2012a) (fig. 6.12). The $d^{18} \mathrm{O}$ values retrieved from the same detrital zircons previously dated by these authors (samples DKE-43 and DKE-45 of the Ceará Complex), indicate that the juvenile input persisted throughout great part of the convergent magmatism ascribed to the consumption of the Goiás-Pharusian Ocean (fig. 6.10B).

Geochemistry of these 880-800 Ma tonalitic to granodioritic rocks suggests that this juvenile signature was acquired in a arc-related setting rather than during rifting. In the Ceará Central Domain, some authors favour break-up and rift development at around 770-750 Ma (Fetter et al., 2003; Castro, 2004; Arthaud, 2007; Brito Neves et al. 2013), however the lack of characteristic features of rift settings such as concomitant immature 
terrigenous sedimentation, abrupt tectonically-controlled facies variations and abundant bimodal volcanism, does not support this idea.
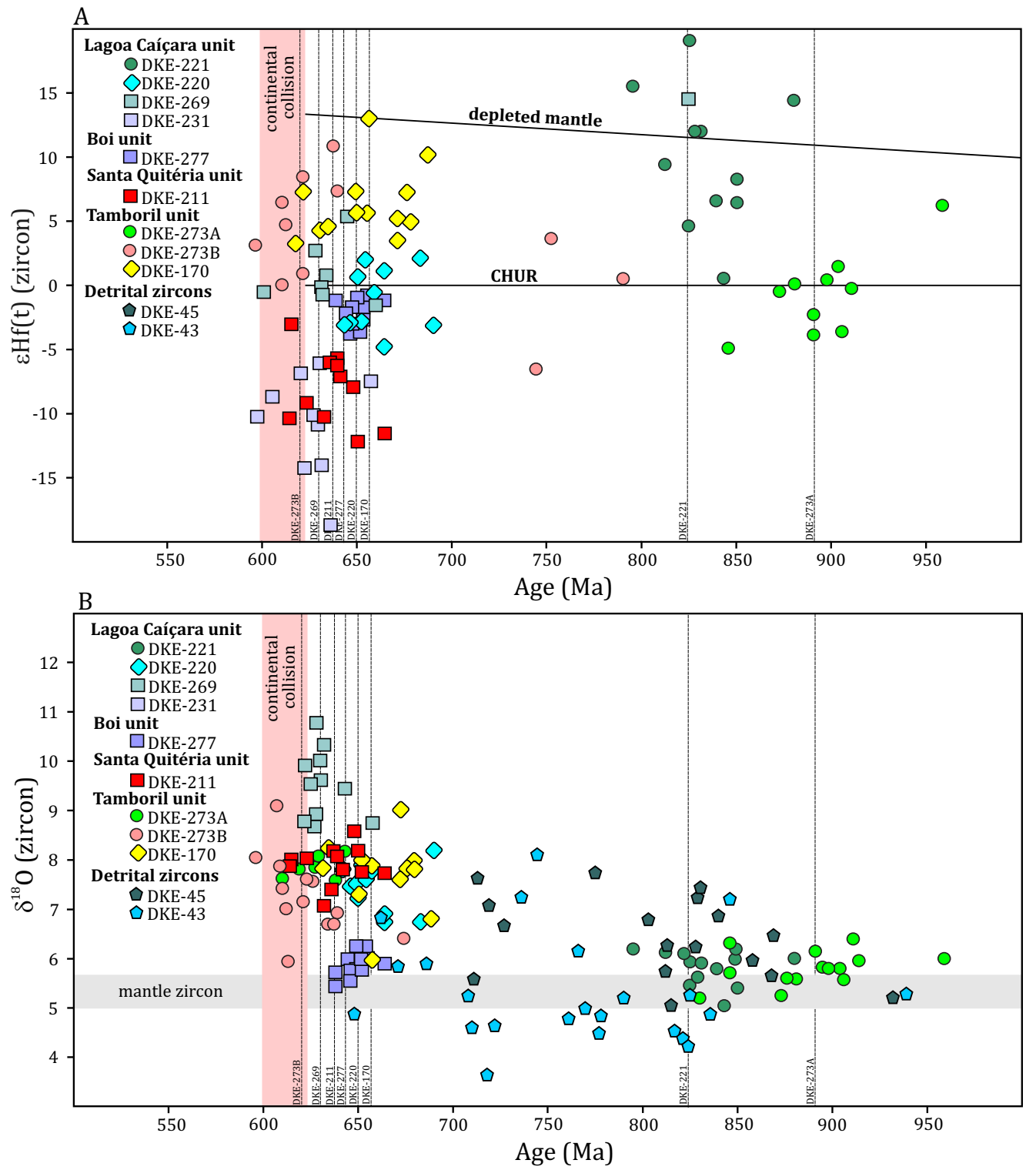

Figure 6.10 - A. Variations of $\delta^{18} \mathrm{O}$ values with age for zircons from protolith of granitoids and migmatites from Tamboril-Santa Quitéria Complex. B. Schematic diagram for Lu-Hf isotopic evolution vs. U-Pb age for zircons from protolith of of granitoids and migmatites from Tamboril-Santa Quitéria Complex.

Instead, such extensional event may be related to an extensional subduction setting and development of diachronous back-arc basins to the east of the Lagoa Caíçara unit. On the other hand, a U-Pb ID-TIMS age of ca. 770 (Fetter et al. 2003) retrieved from volcanic rocks found associated with passive margin deposits of the Martinópole Group in the Médio Coreaú Domain (west of the Transbrasiliano Lineament in fig. 6.2) suggest that extension and passive margin development was concurrent with subduction and arc development in the Ceará Central Domain. 

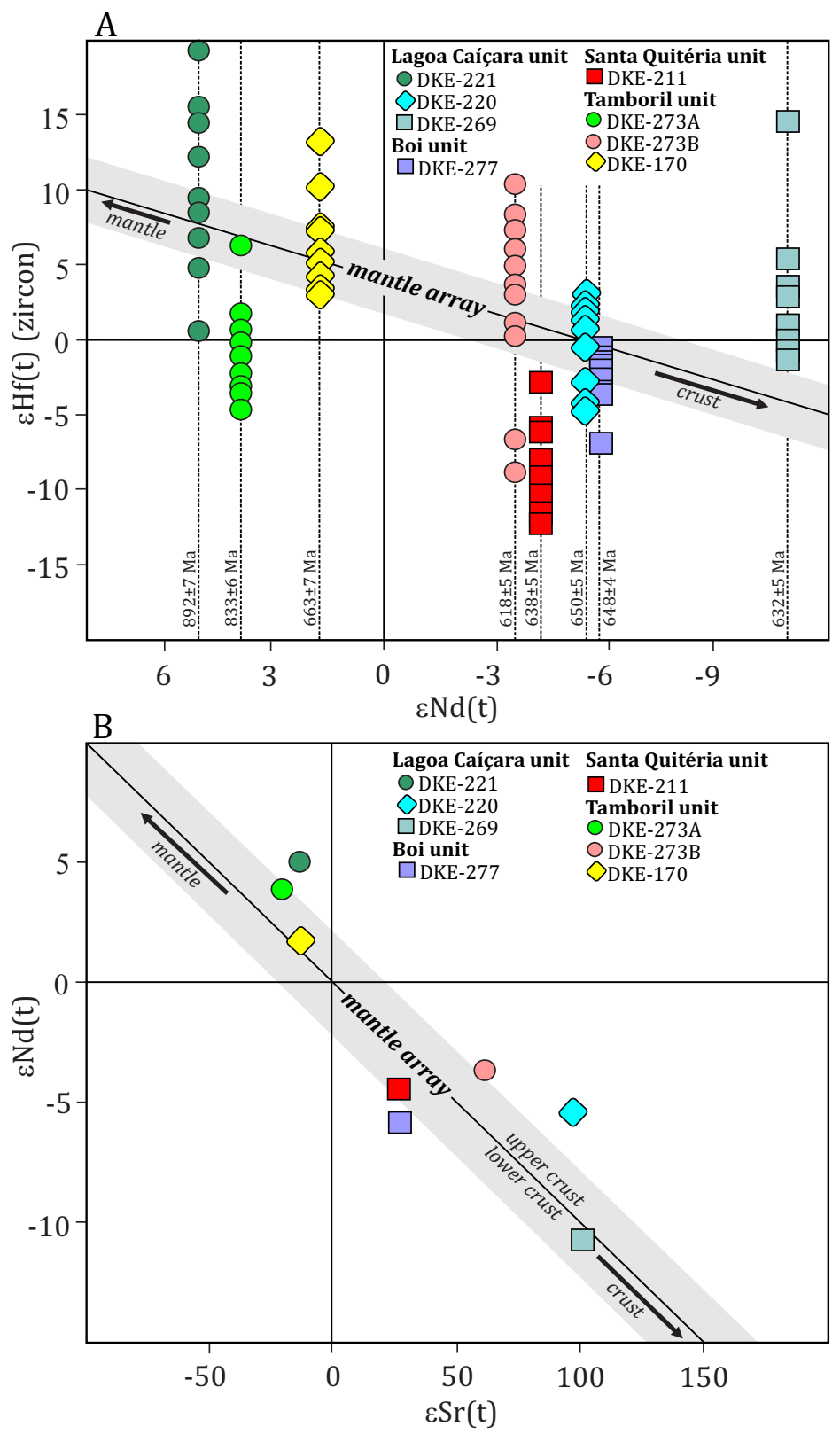

Figure 6.11 - A. Relationship between zircon $\varepsilon \mathrm{Hf}(t)$ and whole-rock $\varepsilon \mathrm{Nd}(t)$ for protolith of granitoids and migmatites from Tamboril-Santa Quitéria Complex. Mantle and crust arrays are from to Vervoort et al. (1999). B. $\varepsilon N d(t)$ vs. $\varepsilon \operatorname{Sr}(\mathrm{t})$ diagram protolith of granitoids and migmatites from Tamboril-Santa Quitéria Complex. The line separating materials derived from upper (high positive $\varepsilon \mathrm{Sr}$ ) to lower crust (low positive $\varepsilon \mathrm{Sr}$ ) have been proposed by DePaolo and Wasserburg (1979).

Evidence from the West Gondwana Orogen in Africa (Caby, 1989, 2003; Berger et al., 2011; Dostal et al. 1994) and Central Brazil (Pimentel and Fuck, 1992; Pimentel et al., 2000; Laux et al., 2005) demonstrates that part of the Neoproterozoic growth of western Gondwana occurred firstly during the Late Tonian and Cryogenian (950-750 Ma), through the development of intraoceanic juvenile arcs, suggesting the presence of a large ocean separating the São Francisco and Amazonian/West African and Saharan cratons. In Hoggar, within the Silet region (Algeria), diorite-tonalite and monzogranite plutons from the Iskel magmatic arc yielded U-Pb zircon ages at ca. 868 and $839 \mathrm{Ma}$ (Caby et al., 1982). Occurrence of slices of pre-Pan-African 
Carlos E. Ganade de Araujo - Tese de Doutorado - Universidade de São Paulo

Capítulo 6 - Tracing Neoproterozoic subduction in NE-Brazil

basement directly overlain by shelf sediments and capped by arc volcanic rocks in several localities suggests that the Iskel magmatic arc was built on attenuated continental crust adjacent to possible slices of oceanic lithosphere (Lapierre et al., 1986; Caby, 2003). Further south, in the Gourma region (Mali) the TilemsiAmalaoulaou intraoceanic arc assemblages (Dostal et al., 1994) were dated within the 790-710 Ma time interval (Caby et al., 1989; Berger et al., 2011). The Tilemsi arc is considered the upper crust supra-structure equivalent of the Amalaoulaou complex (Berger et al., 2011). Although precise geochronological data is lacking for the Kabyé massif in the Dahomeyan belt (Togo), geochemical and field characteristics suggest that this massif could in fact represent the roots of a continental arc (Duclaux et al., 2006).

In Africa the active continental margin (Andean-type) are located east of the oceanic terranes (Caby, 2003; Berger et al., 2011). This stage of ocean-continent subduction was dated at $696 \pm 5 \mathrm{Ma}$ within the Kindal Terrane and at $716 \pm 6 \mathrm{Ma}$ in the Idras des Iforas region in Mali (Caby and Andréopoulos-Renaud, 1987; Bruguier et al., 2008), indicating that it was partially coeval with the ocean-ocean subduction stage active further west. In Central Brazil, the Neoproterozoic Goiás magmatic arc in the Brasilia Belt is composed of juvenile orthogneisses ranging from ca. 920 to $780 \mathrm{Ma}$ (Pimentel and Fuck, 1992; Laux et al., 2005; Matteini et al., 2010). Younger ages at ca. 670-630 Ma were also reported (Laux et al., 2005) and may represent a second stage of the pre-collisional magmatism in Central Brazil, also with hybrid mantle-crustal isotopic signatures.

In other words, the juvenile nature of these rocks in the $\mathrm{GCD}$ and geological relationships along the orogen in Africa and Central Brazil suggests that the large Goiás-Pharusian Ocean were connected and did not narrow into a small ocean in the Borborema Province as suggested by some authors (Castaing et al. 1994; Neves et al., 2003; Brito Neves et al., 2013).

\subsubsection{Mature Andean-type arc magmatism: ca. $660-630 \mathrm{Ma}$}

The granitoids of the younger magmatism marked by the Santa Quitéria and Boi units (samples DKE-211 and DKE-277) together with the gneissic granitoids found in the Lagoa Caíçara unit (samples DKE-269 and DKE-231) and granitoid schollen (samples DKE-170 and DKE-125A) found within the diatexites of the Tamboril unit range in age between 663 and $627 \mathrm{Ma}$. These rocks have negative to positive $\operatorname{eHf}_{(t)}(-18.7$ to $+13.2)$ and $\varepsilon \operatorname{Nd}_{(t)}(-10.75$ to +1.80$)$ combined with moderate to high initial ${ }^{87} \mathrm{Sr} /{ }^{86} \mathrm{Sr}(0.7056-0.7143)$. Isotopic results for the granitoids within this $30 \mathrm{~m}$.y. span of magmatism indicate sources ranging from mantle to continental (table 6.2), which characterizes a mature arc stage.

After the juvenile granitoids of the 890-800 Ma arc, the oldest granitoid (663 $\pm 6.6 \mathrm{Ma}$, sample DKE-170) within the Tamboril-Santa Quitéria Complex occurs as a raft inserted in the Tamburil unit close to the contact with the Santa Quitéria unit. The $\varepsilon \mathrm{Hf}_{(t)}, \varepsilon \mathrm{Nd}_{(t)}$ and initial initial ${ }^{87} \mathrm{Sr} /{ }^{86} \mathrm{Sr}$ indicate that this granitoid was derived from the partial melting of depleted mantle sources (figs. 6.10 and 6.11). However, high zircon $\delta^{18} \mathrm{O}$ values (5.94-9.06\%) suggests that these juvenile magmas would have also interacted with (meta)sedimentary rocks that contributed to increased $\delta^{18} \mathrm{O}$ values. Sample DKE-170 contrasts with sample DKE-200A, the next oldest rock in this group, however. Sample DKE-200A is a mafic tonalite dated at 650.6 \pm 5.1 Ma. Its isotopic composition indicates that old continental rocks were its main source (initial 
Carlos E. Ganade de Araujo - Tese de Doutorado - Universidade de São Paulo

Capítulo 6 - Tracing Neoproterozoic subduction in NE-Brazil

${ }^{87} \mathrm{Sr} /{ }^{86} \mathrm{Sr}=0.7105 ; \varepsilon \mathrm{Hf}_{(t)}=-5.45$ and $\delta^{18} \mathrm{O} 6.73-8.19$, table 6.2). The difference between the two samples is taken to indicate that contrasting sources (crust and mantle) were mobilized in this period. This is in fact confirmed by consideration of the remaining samples in this group.

The high-K to shoshonitic mafic dioritic and tonalitic rocks of the Boi Unit are the oldest (648土4.1 Ma, sample DKE-277) coherent and mappable magmatic rocks identified within the complex. Whilst $\varepsilon \mathrm{Hf}_{(t)}$ for sample DKE-277 is negative (-6.6 to -0.8) and suggestive of crust participation, juvenile $\varepsilon \mathrm{Nd}_{(t)}$ signatures (Fetter et al., 2003), attest for mixing between rocks with mantle and crustal signatures. Mantle involvement is further supported by the zircon $\delta^{18} \mathrm{O}$ values (5.48-6.25\%o). The diorite gneiss of sample DKE-125A although lacking isotopic data, has a similar zircon U-Pb age of $646 \pm 4.5 \mathrm{Ma}$ and is correlated with the Boi unit magmatism.

The youngest magmatic intrusive pulses in the Tamboril-Santa Quitéria Complex are represented by the $632 \pm 5.1$ and $627 \pm 4.9 \mathrm{Ma}$ biotite granitic magmatism found in the Lagoa Caíçara unit. Nd-Sr isotopic data for these rocks are coherent with a crustal origin as also suggested by high zircon $\delta^{18} \mathrm{O}$ values $(6.73-10.82 \%$ ). Inherited zircons with ages at $823 \pm 23,796 \pm 19$ and $761 \pm 19 \mathrm{Ma}$ indicate that Early Neoproterozoic juvenile protoliths from the Lagoa Caíçara unit were also important sources for this granitic magmatism, and may contributed for the partially positive $\varepsilon \mathrm{Hf}_{(\mathrm{t})}$ in the sample DKE-269.

As discussed above, one of the main features of the Santa Quitéria monzogranitic magmatism is the close association with syn-plutonic mafic dikes of enriched mantle affinity, likely connected with the Boi unit magmatism. This mantle input is geochemically enriched and predominantly shoshonitic in nature (Costa et al., 2013; Zincone, 2011). Available geochronological data for the high-K to shoshonitic porphyritic granites of the Santa Quitéria unit allow us to bracket its formation to within the 640-635 Ma time interval (Fetter et al. 2003 and our data). Negative $\varepsilon \mathrm{Hf}_{(t)}(-12.2$ to -2.9$)$ and $\varepsilon \mathrm{Nd}_{(t)}(-4.25)$ values together high initial ${ }^{87} \mathrm{Sr} /{ }^{86} \mathrm{Sr}$ $(0.7107)$ and high zircon $\delta^{18} \mathrm{O}$ values $(7.06-8.57 \%)$ indicate that crustal also were involved in the formation of the Santa Quitéria monzogranites. The Boi and Santa Quitéria units are part of the same magmatic system and illustrate well the interaction of crust-mantle sources commonly described in mature arcs (DePaolo, 1981).

The enriched signatures observed in the Santa Quitéria-type granitoids could be explained by partial melting of a modified metassomatic mantle combined with significant crustal contamination, rather than an asthenosphere input. In many arcs described worldwide magmas have enriched geochemical features, which are consistent with a derivation from mantle sources modified by metasomatic fluids. These fluids can be derived from subducted incompatible element-rich sediments (Tatsumi et al., 1986), or from slab melts (Martin et al., 2005). The relative roles of crustal contamination and mantle source enrichment (e.g. through the contribution of subducted terrigenous sediments or slab fluids) are often debated in arc petrogenesis (e.g. Fourcade et al., 1994), but difficult to quantify. The expected modifications in the underlying mantle would arise from the long-lasting interaction of subduction derived melts since the ca. $850 \mathrm{Ma}$, initiated by the Lagoa Caíçara juvenile magmatism.

Along the West Gondwana Orogen, other late Andean-type arcs have also been identified in the time bracket between 650 and $600 \mathrm{Ma}$. As mentioned above, in Hoggar (Mali) such arc magmatism is related with the 
Carlos E. Ganade de Araujo - Tese de Doutorado - Universidade de São Paulo

Capítulo 6 - Tracing Neoproterozoic subduction in NE-Brazil

consumption of the Goiás-Pharusian Ocean by east-southeast directed subduction (Caby et al., 1981) and the formation of the large Adrar des Iforas continental arc batholith at around $630 \mathrm{Ma}$ (Liegois et al., 1987). In the Dahomey section of the orogen in Togo and Benin, arc-type Neoproterozoic granitoid rocks dated at ca. 650-630 Ma (Kalsbeek et al., 2012) are also related with an east-dipping subduction zone evolved during consumption of the Goiás-Pharusian Ocean. Finally, in the central Brazil branch of the orogen, final magmatic pulses of the Goiás magmatic arc at ca. $630 \mathrm{Ma}$ (Pimentel et al., 1999; Laux et al., 2005) could be correlated with this mature arc setting that predates final collision in the West Gondwana Orogen.

\subsubsection{Reworking of arc rocks: the $620-610$ Ma crustal anatexis event}

Samples of neosomes resulting from crustal anatexis define the youngest group of rocks within the complex at 625-610 Ma, generally grouped in the Tamboril unit. In the field the Tamboril magmatism results from the remelting of the surrounding protoliths (fig. 6.5), mainly orthogneisses of intermediate compositions of the Lagoa Caíçara and Santa Quitéria units and minor metasedimentary rocks of the Ceará Complex.

The resulting magmatism in the Tamboril unit dated here at 625-618 Ma (Samples DKE-273 and DKE-125) consists of neosomes and their isotopic composition reflects the variations of their source from juvenile to hybrids with some crustal input.

The schollen diatexite of sample DKE-273 suggests that it was derived from the partial melting of the juvenile rocks of the Lagoa Caíçara unit, which is found as rafts within the diatexites. Intermediate granitoids, such as those of the Lagoa Caíçara unit have no muscovite and small amounts of biotite or hornblende (10-25 \%), precluding generation of large melt fractions by dehydration melting (Sawyer, 2008). The large melt fraction and the lack of residual anhydrous phases in these migmatites, such as garnet, sillimanite, orthopyroxene or cordierite, suggest melting by influx of water close to the solidus temperature promoting water-saturated melting of quartz+plagioclase-K-feldspar (Kenah and Hollister, 1983; Sawyer 1998; Sawyer, 2008). In support of this interpretation is the existence of peritectic hornblende in leucosomes in some sections of the Lagoa Gaíçara unit (see sample DKE-221). Gardien et al. (2000) have demonstrated that the stability of residual hornblende formed from biotite breakdown requires addition of external water.

Close investigation of our analyses of diatexitic granite and schollen of samples DKE-273A and 273B suggest however that other sources were also involved in the generation of melts surrounding the schollen. Although melting of the tonalitic/granodioritic paleosome and generation of the diatexite melt is evident in the field, zircon $\operatorname{eHf}_{(t)}$ values diverge from the whole-rock $\mathrm{eNd}_{(t)}$, suggesting $\mathrm{Hf}-\mathrm{Nd}$ isotope decoupling in the diatexites (fig. 6.11A). The behavior of the Lu-Hf system during melting is analogous to that of the Sm-Nd system, with the daughter element $\mathrm{Hf}$ and $\mathrm{Nd}$ fractionating into the melt to a higher degree than the parent element $\mathrm{Lu}$ and Sm (Scherer et al., 2007). Because Hf and Nd fractionate more strongly into melts than Lu and Sm, the melt will have lower $\mathrm{Lu} / \mathrm{Hf}$ and $\mathrm{Sm} / \mathrm{Nd}$ values than the protolith and over time the isotopic compositions of the melt and protolith will diverge into lower and higher ${ }^{176} \mathrm{Hf} /{ }^{177} \mathrm{Hf}$ and ${ }^{143} \mathrm{Nd} /{ }^{144} \mathrm{Nd}$ values, respectively. The $\left({ }^{176} \mathrm{Hf} /{ }^{177} \mathrm{Hf}\right)_{i}$ values for the zircons of the diatexite of the Lagoa Caíçara unit are higher or equal to the $\left({ }^{176} \mathrm{Hf} /{ }^{177} \mathrm{Hf}\right)_{i}$ of the source juvenile material (schollen), indicating that radiogenic ${ }^{176} \mathrm{Hf}$ remained constant or slightly increased during the melting event. We interpret this feature as a direct consequence of the isotopic 
Carlos E. Ganade de Araujo - Tese de Doutorado - Universidade de São Paulo

Capítulo 6 - Tracing Neoproterozoic subduction in NE-Brazil

inheritance of the juvenile source zircons to the melt-precipitated zircons. We believe that the $\mathrm{Hf}$ budget in the melt is being controlled mainly by the zircons with high $\left({ }^{176} \mathrm{Hf} /{ }^{177} \mathrm{Hf}\right)_{i}$ derived from the juvenile protoliths and that rapid melting by addition of water would preclude radiogenic ${ }^{176} \mathrm{Hf}$ to homogenize with other possible sources and thus reflect the direct isotopic composition of the protolith (fig. 6.12). The decoupling of zircon $\mathrm{Hf}$ versus whole-rock $\mathrm{Nd}$ isotopes in the Lagoa Caíçara diatexites is due to the retention of radiogenic Hf during partial melting of juvenile arc-derived zircons, similarly suggested Wu et al. (2006) for the reworking of juvenile crust in South China. Since the bulk ${ }^{143} \mathrm{Nd}$ is available from a variety of minerals and sources, rather than zircon which is the main container of $\mathrm{Hf}$ in crustal rocks (Hoskin and Schaltegger, 2003) we believe that during partial melting the whole-rock Sm-Nd system was readily equilibrated with the new melt, and reflects the addition of other external, old continental sources that contributed to the lower and less radiogenic $\varepsilon \mathrm{Nd}_{(t)}$ value. Hf provided by zircons from the external contaminants were minor compared with the Hf provided by the juvenile protolith, and this may reflect: i) low zircon fertility of the crustal contaminants; ii) low magmatic resorbing of these zircons in the melt; or iii) a bias introduced by our low resolution sampling. This external sources are also observed in the field as preserved schollen of metasedimentary rocks, granites and older Paleoproterozoic $(2.1 \mathrm{Ga})$ orthogneisses from the basement.

The rapid addition of water during melting could explain the conservation of the protolith $\mathrm{Hf}$ isotopic signature of the melt-precipitated zircons as well as their high $\delta^{18} \mathrm{O}$ values (fig. 6.12). The origins of the fluids in geological processes are always intriguing and difficult to address. The time of diatexite formation is in agreement with the time of continental collision in Ceará Central Domain (see discussion below) and thus fluids associated with subducted material and underlying metasomatized mantle wedge are not possible sources. Instead, fluids released by prograde collisional metamorphic dehydration-type reactions of the adjacent rocks are suitable candidates, as proposed White et al. (2005) at a smaller scale by for the diatexites of Broken Hill, Australia.

\subsubsection{Bracketing collision time}

The fundamental question that arises when addressing temporal relationship of magmatic lineages of a given orogenic system, using the prefixes pre-, syn- and post-collisional is: when did the collisional stage start? Initial collision, starting at the first contact of the continental blocks, evolves into crustal thickening (due to plate overriding) followed much later by thinning due to gravitational adjustments in response to delamination of crustal root (Leech et al., 2001). Each of these tectonic stages can be fingerprinted by a related tectono-thermal and magmatic manifestation preserved within the final orogenic record.

Retrogressed eclogitic rocks found between the western border of the Santa Quitéria Complex and the Transbrasiliano Lineament (Santos et al. 2009) are an essential piece of the collisional story of de orogen. Santos et al. (2013) reported the find of coesite inclusions within garnet, suggesting UHP ( $>2.7 \mathrm{GPa})$ metamorphic conditions at depths major than $90 \mathrm{~km}$. It is well known from recent collisional orogens, as well as in some fossil collisional zones, that eclogite facies metamorphism, including UHP rocks, is one the best markers of the onset of the collisional process (e.g. Liou et al. 2004; Liu et al., 2008; de Sigoyer et al., 2000; Leech et al., 2005, Gilotti, 2013). Petrochronology for the (U)HP metamorphism in the Forquilha eclogitic zone in CCD and along the West Gondwana Orogen in Togo and Mali indicate that the timing of continental 
collision was nearly synchronous for at least $2500 \mathrm{~km}$ along the orogen around 615-610 Ma (Ganade de Araujo et al., submitted).

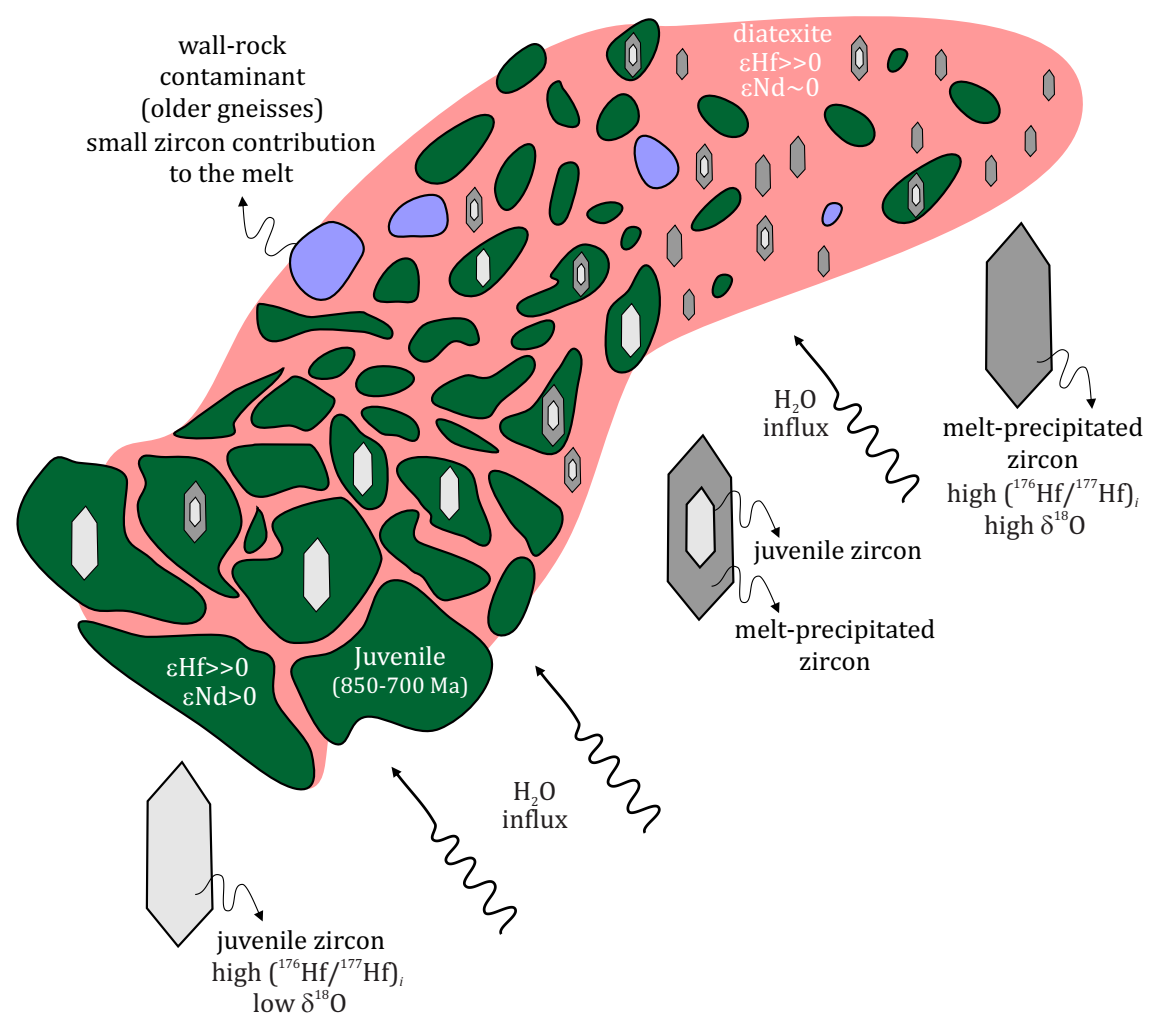

Figure 6.12 - Schematic illustration of the water-fluxed melting of the juvenile protoliths. Hf budget in the melt is mainly controlled by high initial $\left({ }^{176} \mathrm{Hf} /{ }^{177} \mathrm{Hf}\right)$ of the juvenile arc-related protoliths, thus yielding a melt with high initial $\left({ }^{176} \mathrm{Hf} /{ }^{177} \mathrm{Hf}\right)$. Nd budget is controlled by the mixing of juvenile protoliths and crustal contaminants yielding neutral $\varepsilon N d$ signatures in the melt. Water-fluxed melting of the juvenile protoliths are indicated by the lack of anhydrous peritetic phases in the melt, as well as by high $\delta^{18} \mathrm{O}$ signatures.

Given the marked change in the nature of magmatism, from primary arc magma intrusion down to $625 \mathrm{Ma}$, to secondary magmatic rocks derived from the remelting of these primary magmatic rocks, at around 620-615 $\mathrm{Ma}$, we postulate that this marks a change from early magmatism related to plate convergence associated to the consumption of the Goiás-Pharusian Ocean along the West Gondwana Orogen to crustal recycling due to collision.

The India-Asia collision is our type locality for large-scale continental collision. There collision started ca. 55 Ma (Klootwijk et al., 1992), ultimately creating the Himalaya and Tibet. The most obvious metamorphism occurred during partial melting ca. $20 \mathrm{Ma}$, but rare relict metamorphic minerals, textures, and isotope ages as old as 35-55 Ma attest to earlier Himalayan metamorphism (e.g., see Hodges, 2000; de Sigoyer et al., 2000). In the Himalayas ages for the coesite-bearing UHP eclogites are 45-55 Ma (de Sigoyer et al., 2000; Kaneko et al., 2003; Donaldson et al., 2013) while geochronology on the partially melted rocks indicates that melting was 
Carlos E. Ganade de Araujo - Tese de Doutorado - Universidade de São Paulo

Capítulo 6 - Tracing Neoproterozoic subduction in NE-Brazil

almost simultaneous at 18-22 Ma (Harrison et al., 1998), constraining a gap between 37-23 m.y. since the beginning of the collision and the main period of melting. Thus, widespread melting of mid-crustal levels is thought to have started at around $30 \mathrm{Ma}$, with more voluminous magmatism at around $20 \mathrm{Ma}$, and with melt present today $\sim 15 \mathrm{~km}$ below the surface underneath the Tibetan Plateau (Harrison et al., 2006). Thermal modeling of crustal thickening suggests that the concomitant thickening of the layer enriched in heat producing elements leads to crustal heating generating crustal anatexis some tens of millions of years after crustal thickening in accordance to observations (England et al. 1998). This seems not to be the case in the Ceará Central Domain.

If our interpretation is correct, the swap from arc magmatism to crustal anatexis occurred concurrently with collision suggesting one of several possibilities: a) the CGD is a deeper section of the collisional belt than the one presently exposed in the Himalayas, b) the thermal evolution of the exposed section of the GCD was different from that of the Himalayan front upon collision, with the CCD remaining hotter, c) influx of water related to the arrival of continental sediments into the subduction zone bringing water to the arc. It should be stated that although melting was synchronous to the onset of collision in CCD, younger leucosomes containing anhydrous peritetic garnet and sillimanite derived from the partial melting of the metasedimentary rocks of the Ceará Complex were dated at 610-600 Ma (Castro, 2004; Arthaud, 2007) and possibly younger at $580 \mathrm{Ma}$ (Fetter, 1999).

\subsection{From a juvenile to mature arc setting and terminal collision.}

Our new data indicate that subduction initiation of the Goiás-Pharusian Ocean may have been active as early as $890 \mathrm{Ma}$ in the Ceará Central Domain and, as suggested by detrital zircon studies from supracrustal rocks (Ganade de Araujo et al., 2012a), may have been continuous until terminal collision at ca. 620-615 Ma. However, the continuity of detrital zircon spectra contrasts with the apparent long pause between ca. $800 \mathrm{Ma}$ and 660 Ma recorded by the magmatic rocks of the GCD alone. This apparent gap could be due to erosion of the earlier arc granitoids or by insufficient geochronological data (fig. 6.13).

In any case, the igneous samples investigated here record two main arc-building stages. The first, early to middle Neoproterozoic stage I, comprising mainly juvenile tonalites and granodiorites from the Lagoa Caíçara unit, followed by a second stage (stage II) that comprises abundant diorites, tonalites and mainly high-K monzogranites with mixed mantle-crustal signatures from the Santa Quitéria and Boi units and younger orthogneisses found in the Lagoa Caíçara unit.

The juvenile nature of the stage I arc granitoids suggest an initial emplacement outboard of the leading edge of the continental margin of the Paleoproterozoic-Archean basement of the Borborema Province to the east, at ca. $890 \mathrm{Ma}$ possibly in an oceanic environment. This scenario is similar to that described in the earlier stages of Mesozoic convergent margin of Baja California, Mexico (Busby, 2004). In this area, the subducting Farallon plate at that time was old and cold at the trench and therefore the subduction zone was in retreat and the arc was thus emplaced in an extensional setting, generating intra-arc to backarc basins. 


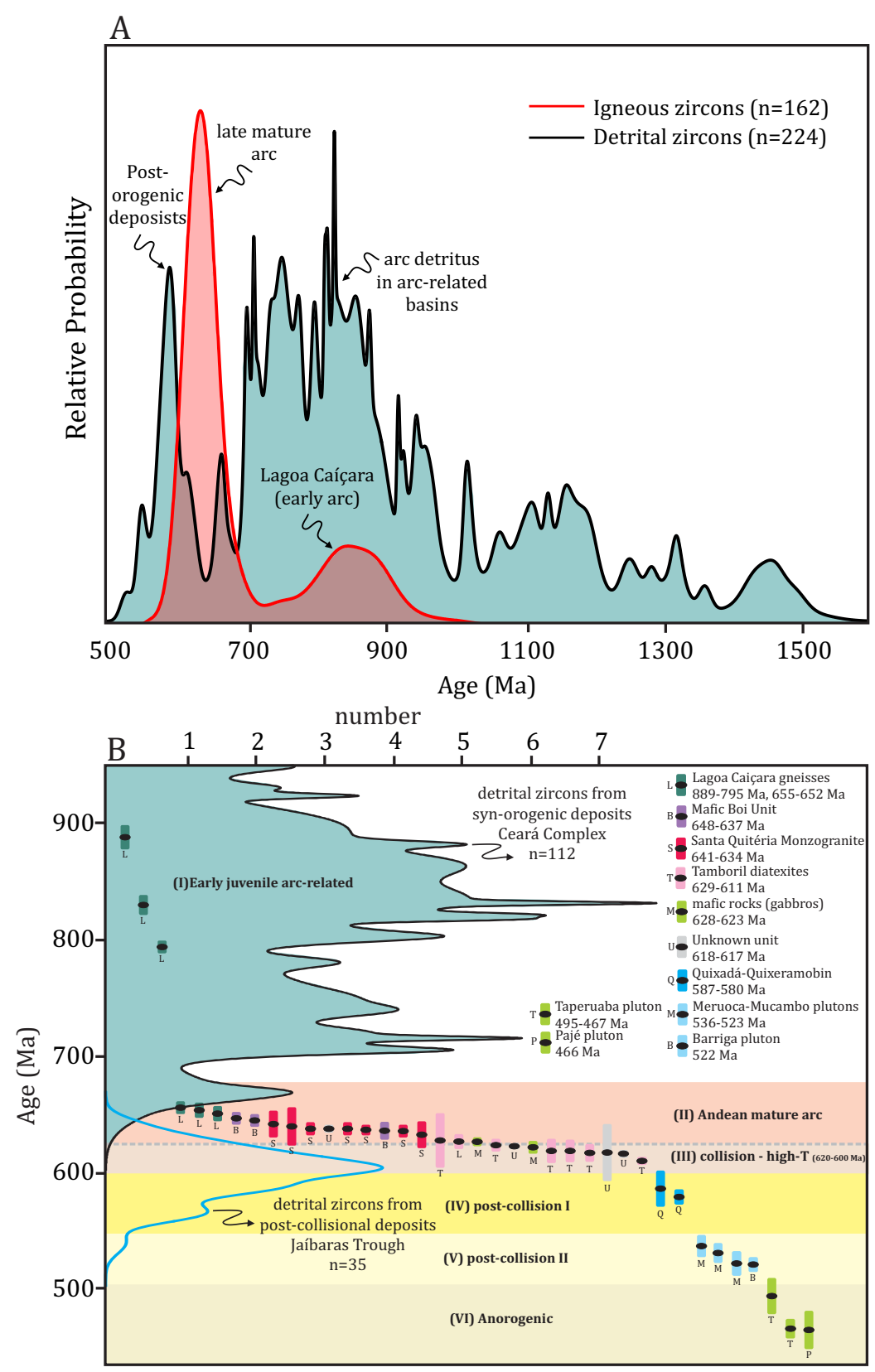

Figure 6.13 - A. Comparison between zircon ages acquired from the granitoids of the Tamboril-Santa Quitéria in this study versus detrital zircons from the back arc and fore arc basins from Ceará Complex (data from the detrital zircons from Ganade de Araujo, 2012a). B. Summary of magmatic ages of the granitiod rocks of the Tamboril-Santa Quitéria Complex.

Similarly, if the oceanic plate of the Pharusian-Goiás Ocean was old and cold at the time of subduction in the Ceará Central Domain an extensional setting would have developed between stage I arc and the former continental margin explaining for example the sediments deposited in the rear area of the arc in a possible back-arc setting between the juvenile Lagoa Caíçara unit and the Paleoproterozic/Archean basement to east. However, provenance studies through detrital zircon investigation in these marine sediments of the Ceará Complex have both arc and continental signatures (Ganade de Araujo et al., 2012a) suggesting that stage I arc magmatism was not far off the continental margin (fig. 6.14A and B). Furthermore, some authors have proposed that the bimodal alkaline (high-Nb) and mafic magmatism associated with these sediments between 
Carlos E. Ganade de Araujo - Tese de Doutorado - Universidade de São Paulo

Capítulo 6 - Tracing Neoproterozoic subduction in NE-Brazil

840-750 Ma is related to extension (Castro, 2004; Arthaud, 2007; Arthaud et al. 2008). Imprecise upper intercept ID-TIMS U-Pb zircon ages at ca. $840 \mathrm{Ma}$ from alkaline rhyolites with high-Nb content close to Itataia town (Castro, 2004) and ID-TIMS U-Pb zircon ages of $772 \mathrm{Ma}$ from felsic gneissic sheets found further south close to Independência town may constrain the period of extension.

Development of a back-arc basin during stage I arc magmatism and extension of the continental crust to the east of the Lagoa Caíçara unit, yielding space that was filled with progradational back-arc deposits that record arc growth above sea level to the west (fig. 6.14B). No clear evidence is available to say if the back-arc basin developed into an incipient oceanic crust, however the mafic rocks close to Pentecoste town could be candidates and should be studied in detail.

The mature arc stage II magmatism is comprised of several pulses of granitoids and overprints magmatism related to stage I arc at ca. 660-630 Ma (Fetter et al., 2003; Castro, 2004; Ganade de Araujo et al., 2012b)

(fig. 6.14C). These magmatic rocks are geochemically enriched when compared with the intermediate granitoids of stage I arc (fig. 6.8A). Likewise, contrasting to the stage I arc granitoids, isotopic signatures of stage II rocks show variable mixtures between juvenile and crustal material.

We postulate that after the last pulse of arc magmatism at ca. $627 \mathrm{Ma}$ (sample DKE231), initial continentcontinent collision in Ceará Central Domain is marked by the first contact between the stretched passive margin of Paleoproterozoic-Archean basement to the east (the Northern Borborema basement) and the Paleproterozoic basement to the west (the Parnaíba + Granja Complex). Continental subduction is evidenced by the (U)HP eclogitic metamorphism in the Forquilha HP domain, which may have initiated as early as ca. $624 \mathrm{Ma}$ reaching peak P conditions at ca. $615 \mathrm{Ma}$ (Ganade de Araujo, submitted) (fig. 6.14D). At this stage remelting of the arc assemblages took place in the Tamboril-Santa Quitéria Complex.

The period following continental subduction at ca. $615 \mathrm{Ma}$ is related to exhumation of the (U)HP eclogites, especially those found at the Forquilha (U)HP domain. The emplacement of the (U)HP rocks into shallower crustal levels was probably facilitated by extensional tectonics and buoyancy-aided exhumation (fig. 6.14E).

\subsection{Conclusions}

The Geará Central Domain of the Borborema Province is a Neoproterozoic orogenic area (Brito Neves et al. 2000), part of the $5000 \mathrm{~km}$-long West Gondwana Orogen (Ganade de Araujo, in press), which extends from Algeria in Africa to Central Brazil. Our results allowed determination of three stages of magmatism reflecting three distinct tectonic environments: i) an early period of essentially juvenile arc magmatism at ca. 880-800 Ma, ii) a second, mature arc period between 660-630 Ma, characterized by hybrid mantle-crustal components, and iii) remelting of the arc-related igneous rocks during continental collision, evidenced by abundant extensive migmatization dated to between 625 and 600 Ma. These ages overlap with those of $(\mathrm{U}) \mathrm{HP}$ eclogitic metamorphism at 624-615 Ma suggesting that migmatization occurred during continental subduction in a continent-continent collisional setting. 
Carlos E. Ganade de Araujo - Tese de Doutorado - Universidade de São Paulo

Capítulo 6 - Tracing Neoproterozoic subduction in NE-Brazil

A. ca.880 Ma

Goiás-Pharusian Ocean early extensional arc setting

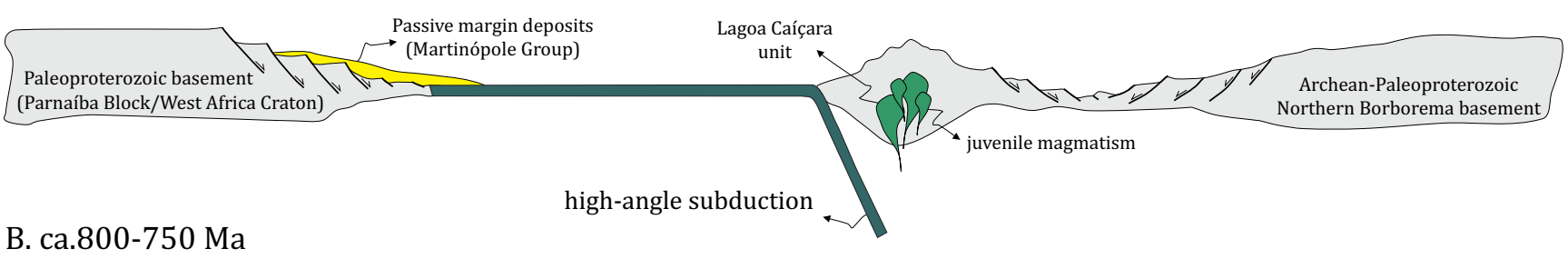

passive margin volcanism

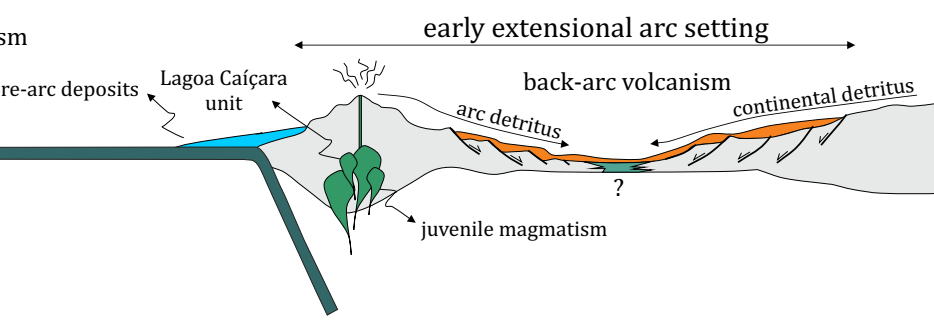

C. ca.660-630 Ma

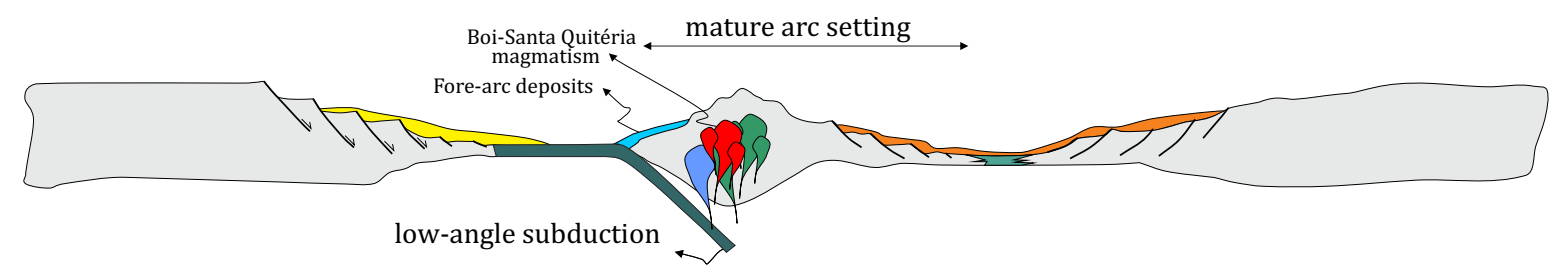

D. ca.620-615 Ma
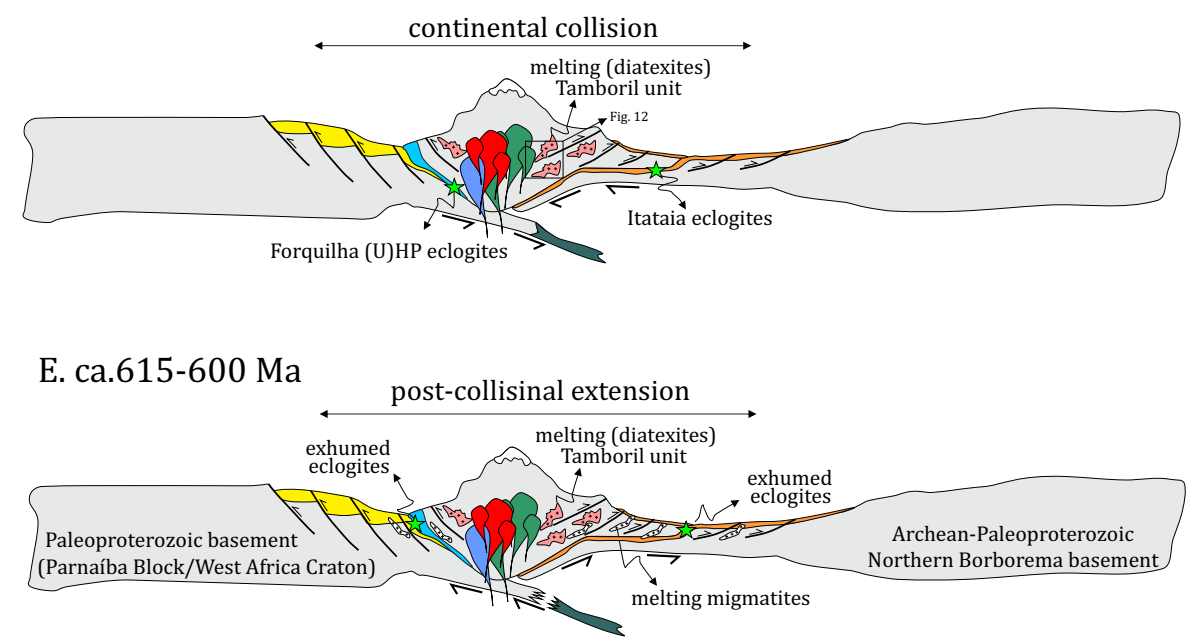

Figure 6.14 - Sketch tectonic model for Neoproterozoic tectonic evolution for the continental convergent margin of Ceará Central Domain. A. Early subduction stage in an extensional setting, due to old oceanic lithosphere subduction and juvenile magmatism accretion on a stretched continental margin. B. Continuous subduction with development of extensinal back-arc basins with associated magmatism and both arc- and continental-derived detritus. C. Compressive arc-setting and development of the Santa Quitéria arc. D. Terminal collision with subduction of stretched continental crust to the west of the Santa Quiteria arc and subduction of the stretched continental crust (e.g. back-arc basin) to the east of the Santa Quitéria arc. Collisional metamorphism on both sides of the arc are evidenced by (U)HP-eclogite rocks of Forquilha (Santos et al., 2009; Santos et al., 2013; Ganade de Araujo, submitted) and Itataia HP eclogites (Castro, 2004). E. Post-collision extension and exhumation of the $(\mathrm{U}) \mathrm{HP}$ and HP rocks. 
Carlos E. Ganade de Araujo - Tese de Doutorado - Universidade de São Paulo

Capítulo 6 - Tracing Neoproterozoic subduction in NE-Brazil

The apparent gap between the two periods of arc magmatism could be explained by incomplete exposure and erosion. Evidence for continuous magmatism comes from abundant detrital zircons in the fore- and back-arc basins with ages in the range of 900 to $650 \mathrm{Ma}$. Oxygen isotopes from detrital zircons in the fore-arc indicate that juvenile input persisted throughout the entire evolution of convergent magmatism. Igneous rocks of the Tamboril-Santa Quitéria Complex record a long-lived history of convergent magmatism lasting up to 350 m.y.

\section{Acknowledgments}

Carlos E. Ganade de Araujo acknowledges the Geological Survey of Brazil for continuous support throughout the time. Carlos E. Ganade de Araujo, Umberto G. Cordani and Miguel A. S. Basei are also grateful to FAPESP by the support through the grant 2012/00071-2. Iaponira Paiva and João Naleto are thanked by petrographic and field support, respectively. This is a contribution to the IGCP-628, Gondwana Map Project.

\subsection{References}

Amaral, W.S., 2010. Análise geoquímica, geocronológica e geotermobarométrica das rochas de alto grau metamórfico adjacentes ao arco magmático de Santa Quitéria, NW da Província Borborema. PhD thesis, Universidade Estadual de Campinas, Campinas, 210 pp.

Arthaud, M.H., 2007. Evolucão Neoproterozóica do Grupo Ceará (Domínio Ceará Central, NE Brasil): da sedimentacão à colisão continental brasiliana. PhD thesis, Universidade de Brasília, Brasília, 170 pp.

Arthaud, M.H., Caby, R., Fuck, R.A., Dantas, E.L., Parente, G.V., 2008. Geology of the Northern Borborema Province, NE Brazil and its correlation with Nigeria, NW Africa. In: Pankhurst, R.J., Trouw, R.A.J., Brito Neves, B.B., De Wit, M.J. (Eds.), West Gondwana: Pre Cenozoic Correlations Across the Atlanti Region. Geological Society, London, Special Publications 294, 49-67.

Bard, J.P., 1983. Metamorphism of an obducted island arc: example of the Kohistan sequence (Pakistan) in the Himalayan collided range. Earth and Planetary Science Letters 65, 133-144.

Berger, J., Caby, R., Liégeois, J.P., Mercier, J.C.C., Demaiffe, D., 2011. Deep inside a Neoproterozoic intra-oceanic arc: growth, differentiation and exhumation of the Amalaoulaou complex (Gourma, Mali). Contributions to Mineralogy and Petrology 162, 773-796.

Black, L.P., Kamo, S.L., Allen, G.M., Davis, D.W., Aleinikoff, J.N., Valley, J.W., Mundil, R., Campbell, I.H., Korsch, R.J., Williams, I.S., Foudoulis, C., 2004. Improved Pb-206/U- 218 microprobe geochronology by the monitoring of a trace-element-related matrix effect; SHRIMP, ID-TIMS, ELA-ICP-MS and oxygen isotope documentation for a series of zircon standards. Chemical Geology 205, 115-140.

Blichert-Toft J., Albarede F., 1997. The Lu-Hf isotope geochemistry of chondrites and the evolution of themantle-crust system. Earth and Planetary Sciences Letters 148, 243-258.

Brito Neves, B.B., Cordani, U.G., 1991. Tectonic evolution of South America during the Late Proterozoic. In: Stern, R.J., Van Schmus, W.R. (Eds.), Crustal Evolution in the Late Proterozoic. Precambrian Research 53, 23-40.

Brito Neves, B.B., Fuck, R., 2013. Neoproterozoic evolution of the basement of the South-American platform, Journal of South American Earth Sciences 47, 72-89.

Brito Neves, B.B.de., Santos, E.J., Van Schmus, W.R., 2000. Tectonic history of the Borborema Province, NW Brazil. In: Cordani, U.G., Milani, E.J., Thomaz Filho, A., Campos, D.A. (Eds.), Tectonic Evolution of South America. Rio de Janeiro, pp. 151-182. 
Carlos E. Ganade de Araujo - Tese de Doutorado - Universidade de São Paulo

Capítulo 6 - Tracing Neoproterozoic subduction in NE-Brazil

Bruguier, O., Bosch, D., Gaby R., Galland, B., Hammor, D., 2008. Sampling an active continental paleomargin: a LAICP-MS U-Pb zircon study from the Adrar des Iforas (Mali). Geochimica et Cosmochimica Acta 72, A1 18.

Burg, J.P., Bodinier, J.L., Chaudhry, S., Hussain, S., Dawood, H., 1998. Infra-arc mantle-crust transition and intra-arc mantle diapirs in the Kohistan Complex (Pakistani Himalaya): petro-structural evidence. Terra Nova 10, 74-80.

Busby, C., 2004. Continental growth at convergent margins facing large ocean basins: a case study from Mesozoic convergent-margin basins of Baja California, Mexico. Tectonophysics 392, 241-277.

Caby, R., 1989. Precambrian terranes of Benin Nigeria and Northeast Brazil and Late Proterozoic South Atlantic fit. Geological Society of America Special Paper 230, 145-158.

Caby, R., 2003. Terrane assembly and geodynamic evolution of central-western Hoggar: a synthesis. Journal of African Earth Sciences 37, 133-159.

Caby, R., Andreopoulos-Renaud, U., 1987. Le Hoggar oriental, bloc cratonisé à 730 Ma dans la chaîne pan-africaine du nord du continent africain. Precambrian Research 36, 335-344.

Caby, R., Andreopoulos-Renaud, U., Gravelle, M., 1982. Cadre geologique et geochronologie U/Pb sur zircon des batholites precoces dans le segment pan-africain du Hoggar central (Algerie). Bulletin de la Societe Geologique de France 24, 677-684.

Caby, R., Arthaud, M.H., 1986. Major Precambrian nappes of the Brazilian belt, Ceará, northeast Brazil. Geology 14, $871-874$.

Caby, R., Betrand, J.M.L, Black, R., 1981. Oceanic closure and continental collision in the Hoggar-Iforas-Pan-African segment. In: Kroner A., (Ed.), Precambrian Plate Tectonics, Elsevier, Amsterdam, pp. 407-434.

Castaing, C., Feybesse, J. A., Thiéblemont, D., Triboulet, C., Chevremont, P., 1994. Palaeogeographical reconstructions of the Pan-African/Brasiliano orogen: closure of an oceanic domain or intracontinental convergence between major blocks?. Precambrian Research 69, 327-344.

Castro, N.A., 2004. Evolucão Geológica Proterozóica da região entre Madalena e Taperuaba, Domínio Tectônico Ceará Central (Província Borborema). PhD thesis, Universidade de São Paulo, 322 pp.

Castro, N.A., Ganade de Araujo, C.E., Basei, M.A.S., Osako, L.S., Nutman, A., Liu, D., 2012. Ordovician A-type granitoid magmatism on the Ceará Central Domain, Borborema Province, NE-Brazil. Journal of South American Earth Sciences 36, 18-31.

Cavalcante, J.C., Vasconcelos, A.M., Medeiros, M.F., Paiva, I.P., Gomes, F.E.M., Cavalcante, S.N., Cavalcante, J.E., Melo, A.C.R., Duarte Neto, V.G., Bevenides, H.C., 2003. Mapa Geológico do Estado do Geará - Escala 1:500.000. CPRM-SGB Servico Geológico do Brasil, Fortaleza.

Cordani, U.G., Pimentel, M.M., Ganade de Araújo, C.E.G., Basei, M.A.S., Fuck, R.A., Girardi, V.A.V., 2013a. Was there an Ediacaran Clymene Ocean in central South America?. American Journal of Science 313, 517-539.

Cordani, U.G., Pimentel, M.M., Ganade de Araújo, G.E.G., Fuck, R.A., 2013b. The significance of the TransbrasilianoKandi tectonic corridor for the amalgamation of West Gondwana. Brazilian Journal of Geology 43, 583-597.

Costa, F.G., Ganade de Araújo, C.E., Amaral, W.D.S., Vasconcelos, A.M., Rodrigues, J.B., 2013. Idade U-Pb (LAICPMS) em zircão e isótopos de Nd para granitoides do Complexo Tamboril-Santa Quitéria, Domínio Ceará Central: implicações para magmatismo neoproterozoico sin-colisional no domínio norte da Província Borborema. Geologia USP Série Científica 13, 159-174.

de Sigoyer, J., Chavagnac, V., Blichert-Toft, J., Villa, I.M., Luais, B., Guillot, S., Mascle, G., 2000. Dating the Indian continental subduction and collisional thickening in the northwest Himalaya: Multichronology of the Tso Morari eclogites. Geology 28, 487-490.

De Wit, M.J., Brito Neves, B.B., Trouw, R.A.J., Pankhurst, R.J., 2008. Pre-Cenozoic cor- relations across the South Atlantic region: the ties that bind. In: Pankhurst, R.J., Trouw, R.A.J., Brito Neves, B.B., De Wit, M.J. (Eds.), West 
Carlos E. Ganade de Araujo - Tese de Doutorado - Universidade de São Paulo

Capítulo 6 - Tracing Neoproterozoic subduction in NE-Brazil

Gondwana: Pre-Cenozoic Correlations Across the Atlanti Region. Geological Society, London, Special Publications 294, $1-8$.

DePaolo, D.J., 1981. A neodymium and strontium isotopic study of the Mesozoic calc-alkaline granitic batholiths of the Sierra Nevada and Peninsular Ranges, California. Journal of Geophysical Research: Solid Earth 86, 10470-10488.

DePaolo, D.J., Linn, A.M., Schubert, G., 1991. The continental crustal age distribution: Method of determing mantle separation ages from Sm-Nd isotopic data and application to the southwerstern United States. Journal of Geophysical Research 96, 2071-2088.

DePaolo, D.J., Wasserburg, G.J., 1979. Sm-Nd age of the Stillwater Complex and the mantle evolution curve for neodymium. Geochimica et Cosmochimica Acta 43, 999-1008.

Donaldson, D.G., Webb, A.A.G., Menold, C. A., Kylander-Clark, A.R., Hacker, B.R. 2013. Petrochronology of Himalayan ultrahigh-pressure eclogite. Geology 41, 835-838.

Dostal, J., Dupuy, C., Caby, R., 1994. Geochemistry of the Neoproterozoic Tilemsi belt of Iforas (Mali, Sahara): a crustal section of an oceanic island arc. Precambrian Research 65, 55-69.

Duclaux, G., Ménot, R.P., Guillot, S., Agbossoumondé, Y., Hilairet, N., 2006. The mafic layered complex of the Kabye massif (north Togo and north Benin): Evidence of a Pan-African granulitic continental arc root. Precambrian Research 151, 101-118.

England, P.C., Houseman, G.A., Osmaston, M.F., Ghosh, S., 1988. The Mechanics of the Tibetan Plateau [and Discussion]. Philosophical Transactions of the Royal Society of London, Mathematical and Physical Sciences 326, 301320.

Fetter, A.H., 1999. U/Pb and Sm/Nd geochronological constraints on the crustal framework and geologic history of Ceará State, NW Borborema Province, NE Brazil: implications for the assembly of Gondwana. PhD thesis, Kansas University.

Fetter, A.H., Santos, T.J.S., Van Schumus, W.R., Hackspacher, P.C., Brito Neves, B.B., Arthaud, M.H., Nogueira Neto, J.A., Wernick, E., 2003. Evidence for Neoproterozoic continental arc magmatism in the Santa Quitéria Batholith of Ceará State, NW Borborema Province, NE Brazil: implications for the assembly of west Gondwana. Gondwana Research 6, 265-273.

Fetter, A.H., Van Schmus, W.R., Santos, T.J.S., Arthaud, M.H., Nogueira Neto, J.A., 2000. U-Pb and Sm-Nd geochronological constraints on the crustal evolution and basement architecture of Ceará State, NW Borborema Province, NE Brazil: implications for the existence of the Paleoproterozoic supercontinent Atlantica. Revista Brasileira de Geociências 30, 102-106.

Fourcade, S., Maury, R., Defant, M. J., McDermott, F., 1994. Mantle metasomatic enrichment versus arc crust contamination in the Philippines: Oxygen isotope study of Batan ultramafic nodules and northern Luzon arc lavas. Chemical Geology 114, 199-215.

Ganade de Araujo, C.E., Cordani, U.G., Basei, M.A.S. and Sato, K., 2012c. Arc reworking during collision: combined $\mathrm{Lu}-\mathrm{Hf}$ LA-ICP-MS and U-Pb SHRIMP results from the Tamboril- Santa Quit_eria Complex, NE Brazil. In: 6th International SHRIMP Workshop - Program and Abstracts. Record 2012/52 (N. Kositcin and S. Bodorkos, eds), Geoscience Australia, Canberra.

Ganade de Araujo, C.E., Costa, F.G., Palheta, E.S.M., Cavalcante, J.C., Vasconcelos, A.M., Moura, C.A.V., 2010b. $207 \mathrm{~Pb} / 206 \mathrm{~Pb}$ zircon ages of pre- and syn collisional granitoids from the Tamboril-Santa Quitéria granitic-migmatitic Complex, Ceará Central Domain, Borborema Province (NE-Brazil): Geodynamic implications. In: VII South American Symposium on Isotope Geology, Brasília.

Ganade de Araujo, C.E., Weinberg, R.F., Cordani, U.G., in press. Extruding the Borborema Province (NE-Brazil): a two-stage Neoproterozoic collision process, Terra Nova xx, xx-xx.

Ganade de Araujo, G.E.G., Cordani, U.G., Basei, M.A., Castro, N.A., Sato, K., Sproesser, W.M., 2012a. U-Pb detrital zircon provenance of metasedimentary rocks from the Ceará Central and Médio Coreaú Domains, Borborema Province, 
Carlos E. Ganade de Araujo - Tese de Doutorado - Universidade de São Paulo

Capítulo 6 - Tracing Neoproterozoic subduction in NE-Brazil

NE-Brazil: Tectonic implications for a long-lived Neoproterozoic active continental margin. Precambrian Research 206, 36-51.

Gardien, V., Thompson, A.B., Ulmer, P., 2000. Melting of biotite+ plagioclase+ quartz gneisses: the role of $\mathrm{H}_{2} \mathrm{O}$ in the stability of amphibole. Journal of Petrology 41, 651-666.

Gilotti, J.A., 2013. The Realm of Ultrahigh-Pressure Metamorphism. Elements 9, 255-260.

Griffin W.L., Belousova E.A., Shee S.R., Pearson N.J., O'Reilly S.Y. 2004. Archean crustal evolution in the northern Yilgarn Craton: U-Pb and $\mathrm{Hf}$ isotope evidence from detrital zircons. Precambrian Research 131, 231-282.

Harrison, T.M., 2006. Did the Himalayan Crystallines extrude partially molten from beneath the Tibetan Plateau?. Geological Society, London, Special Publications 268, 237-254.

Harrison, T.M., Grove, M., Lovera, O.M., Catlos, E.J., 1998. A model for the origin of Himalayan anatexis and inverted metamorphism. Journal of Geophysical Research: Solid Earth 103, 27017-27032.

Hawkesworth, G.J., Kemp, A. I. S., 2006. Using hafnium and oxygen isotopes in zircons to unravel the record of crustal evolution. Chemical Geology 226, 144-162.

Hildreth, W., Moorbath, S., 1988. Crustal contributions to arc magmatism in the Andes of central Chile. Contributions to Mineralogy and Petrology 98, 455-489.

Hodges, K.V., 2000. Tectonics of the Himalaya and southern Tibet from two perspectives. Geological Society of America Bulletin 112, 324-350.

Hoefs, J., 2004. Stable Isotope Geochemistry, 5th ed. Springer-Verlag, Berlin, Heidelberg, p. 244.

Hoskin, P.W., Schaltegger, U., 2003. The composition of zircon and igneous and metamorphic petrogenesis. Reviews in mineralogy and geochemistry 53, 27-62.

Ickert, R. B., Hiess, J., Williams, I. S., Holden, P., Ireland, T. R., Lanc, P., et al., 2008. Determining high precision, in situ, oxygen isotope ratios with a SHRIMP II: Analyses of MPI-DING silicate-glass reference materials and zircon from contrasting granites. Chemical Geology 257, 114-128.

Jacobsen, S.B., Pimentel-Klose, M.R., 1988. Nd isotopic variations in Precambrian banded iron formations. Geophysical Research Letters 15, 393-396.

Kalsbeek, F., Affaton, P., Ekwueme, B., Freid, R., Thranea, K., 2012. Geochronology of granitoid and metasedimentary rocks from Togo and Benin, West Africa: Comparisons with NE Brazil. Precambrian Research 196-197, 218-233.

Kaneko, Y., Katayama, I., Yamamoto, H., Misawa, K., Ishikawa, M., Rehman, H. U., Shiraishi, K. 2003. Timing of Himalayan ultrahigh-pressure metamorphism: Sinking rate and subduction angle of the Indian continental crust beneath Asia. Journal of Metamorphic Geology 21, 589-599.

Kenah, G., Hollister, L.S., 1983. Anatexis in the central gneiss complex, British Columbia. In: Migmatites, melting and metamorphism, (M.P. Atherton and C.D. Grimbbe, eds.) Shiva, Nantwich, U.K., 142-162.

Klein, E.L., Moura, G.A.V., 2008. São Luís craton and Gurupi Belt (Brazil): possible links with the West African craton and surrounding Pan-African belts. In: Pankhurst, R.J., Trouw, R.A.J., Brito Neves, B.B., De Wit, M.J. (Eds.), West Gondwana: Pre-Cenozoic Correlations Across the Atlantic Region. Geological Society, London, Special Publications 294, 137-151.

Klootwijk, G.T., Gee, J.S., Peirce, J.W., Smith, G.M., McFadden, P.L., 1992. An early India-Asia contact: paleomagnetic constraints from Ninetyeast Ridge, ODP leg 121. Geology 20, 395-398.

Lapierre, H., Bendali, M., Dupont, P.L., Gravelle, M., 1986. Nouvelles donnees stratigraphiques et structurales sur le rameau oriental de la chaine pharusienne, region de Silet (Hoggar, Algerie). Comptes Rendus de l'Academie des Sciences Paris 303, 1731- 1736 . 
Carlos E. Ganade de Araujo - Tese de Doutorado - Universidade de São Paulo

Capítulo 6 - Tracing Neoproterozoic subduction in NE-Brazil

Laux, J.H., Pimentel, M.M., Dantas, E.L., Armstrong, R., Junges, S.L., 2005. Two Neo- proterozoic crustal accretion events in the Brasília Belt, central Brazil. Journal of South American Earth Sciences 18, 183-198.

Lee, G.T.A., Morton, D.M., Kistler, R.W., Baird, A.K., 2007. Petrology and tectonics of Phanerozoic continent formation: from island arcs to accretion and continental arc magmatism. Earth and Planetary Science Letters 263, 370387.

Leech, L. L., 2001. Arrested orogenic development: eclogitization, delamination, and tectonic collapse. Earth and Planetary Science Letters 185, 149-159.

Leech, M.L., Singh, S., Jain, A.K., Klemperer, S.L., Manickavasagam, R.M., 2005. The onset of India-Asia continental collision: early, steep subduction required by the timing of UHP metamorphism in the western Himalaya. Earth and Planetary Science Letters 234, 83-97.

Liegois, J.P., Bertrand, J.M., Black, R., 1987. The subduction- and collision-related batholith of the Adrar des Iforas (Mali); geochemical trends in space and time: a review. In: Kinnaird, J. and Bowden, F? (Eds.), Afri. Geol. Rev. Wiley, New York, pp. 187-277.

Liou, J.G., Tsujimori, T., Zhang, R.Y., Katayama,I., Maruyama, S., 2004. Global UHP metamorphism and continental subduction/collision: The Himalayan model. International Geology Review 46, 1-27.

Liu, Y., Zong, K., Kelemen, P. B., Gao, S., 2008. Geochemistry and magmatic history of eclogites and ultramafic rocks from the Chinese continental scientific drill hole: Subduction and ultrahigh-pressure metamorphism of lower crustal cumulates. Chemical Geology 247, 133-153.

Ludwig, K.R., 2001. Squid 1.02 - A User's Manual. Berkeley Geochronology Center. Special Publication No 2.

Ludwig, K.R., 2003. Isoplot 3.00 - A Geochronological Toolkit for Microsoft Excel. Berkeley Geochronology Center. Special Publication No 4.

Martin, H., Smithies, R.H., Rapp, R., Moyen, J.F., Champion, D., 2005. An overview of adakite, tonalite--trondhjemitegranodiorite (TTG), and sanukitoid: relationships and some implications for crustal evolution. Lithos 79, 1-24.

Martins, G., Oliveira, E.P., Lafon, J.M., 2009. The Algodões amphiboliteetonalite gneiss sequence, Borborema Province, NE Brazil: geochemical and geochrono- logical evidence for Palaeoproterozoic accretion of oceanic plateau/back-arc basalts and adakitic plutons. Gondwana Research 15, 71-85.

Matteini, M., Junges, S.L., Dantas, E.L., Pimentel, M.M., Bühn, B., 2010. In situ zircon U-Pb and Lu-Hf isotope systematic on magmatic rocks: Insights on the crustal evolution of the Neoproterozoic Goiás Magmatic Arc, Brasília belt, Central Brazil. Gondwana Research 17, 1-12.

McDonough, W.F., Sun, S.S., 1995. The composition of the earth. Chemical Geology 120, 223-254.

McMillan, N.J., Harmon, R.S., Moorbath, S., Lopez-Escobar, L., Strong, D.F., 1989. Crustal sources involved in continental arc magmatism: A case study of volcan Mocho-Choshuenco, southern Chile. Geology 17, 1152-1156.

Neves, S.P., 2003. Proterozoic history of the Borborema Province (NE Brazil): correlations with neighboring cratons and Pan-African belts, and implications for the evolution of western Gondwana. Tectonics 22, 1031.

Oliveira, E.P., Windley, B.F., Araujo, M.N.C., 2010. The Neoproterozoic Sergipano orogenic belt, NE Brazil: a complete plate tectonic cycle in western Gondwana. Precambrian Research 181, 64-84.

Padilha, A.L., Vitorello, Í., Pádua, M.B., Bologna, M.S., 2014. Electromagnetic constraints for subduction zones beneath the northwest Borborema province: Evidence for Neoproterozoic island arc-continent collision in northeast Brazil. Geology 42, 91-94.

Pearce, J.A., Harris, N.B.W., Tindle, A.W., 1984. Trace element discrimination diagrams for the tectonic interpretation of granitic rocks. Journal of Petrology 25, 956-983. 
Carlos E. Ganade de Araujo - Tese de Doutorado - Universidade de São Paulo

Capítulo 6 - Tracing Neoproterozoic subduction in NE-Brazil

Peccerillo, A., Taylor, S.R., 1976. Geochemistry of Eoceno calc-alkaline volcanic rocks from the Kastamonu area, northern Turkey. Contributions to Mineralogy and Petrology 58, 63-81.

Petterson, M.G., 2010. A review of the geology and tectonics of the Kohistan island arc, north Pakistan. Geological Society, London, Special Publications 338, 287-327.

Pimentel, M.M., Fuck, R.A, Jost, H., Ferreira Filho, C.F, Araujo, S., 2000. The basement of the Brasília Fold Belt and the Goiás Magmatic Arc. In: Cordani, U.G., Milani, E.J., Thomaz Filho, A., Campos, D.A. (Eds.), Tectonic Evolution of South America. Rio de Janeiro, pp. 151-182.

Pimentel, M.M., Fuck, R.A., 1992. Neoproterozoic crustal accretion in central Brazil. Geology 20, 375-379.

Pimentel, M.M., Fuck, R.A., Botelho, N.F., 1999. Granites and the geodynamic history of the Neoproterozoic Brasılia belt, central Brazil: a review. Lithos 46, 463-483.

Santos, T.J.S., Amaral, W.S., Ancelmi, M.F., Dantas, E.L., Fuck, R.A., Pitarello, M.Z., 2013. A faixa eclogítica de Forquilha e sua importância no contexto tectônico da Província Borborema. In: 25 $5^{\text {th }}$ Simpósio de Geologia do Nordeste, Recife, Brazil, pp. 525.

Santos, T.J.S., Dantas, E.L., Fuck, R.A., Rosa, F.F.da, Ganade de Araujo, G.E., Amaral, W.S., 2007. The geology and $\mathrm{U}-\mathrm{Pb}$ and $\mathrm{Sm}-\mathrm{Nd}$ geochronology from the northern portion of the Santa Quitéria batholith, NE Brazil. In: Simpósio Nacional de estudos Tectônicos, 2007. <>?Miut45 3Natal-RN, Anais, pp. 142-144.

Santos, T.J.S., Garcia, M.G.M., Amaral, W.S., Wernick, E., Dantas, E.L., Arthaud, M.H., Caby, R., Santosh, M., 2009. Relics of eclogite facies assemblages in the Ceará Central Domain, NW Borborema Province, NE Brazil: implications for the assembly of West Gondwana. Gondwana Research 15, 454-470.

Sato K., Siga Jr. O., Silva J.A., McReath I., Liu D., Iizuka T., Rino S., Hirata T., Sproesser W.M., Basei M.A.S. 2009. In Situ Isotopic Analyses of $\mathrm{U}$ and $\mathrm{Pb}$ in Zircon by Remotely Operated SHRIMP II, and Hf by LA-ICP-MS: an Example of Dating and Genetic Evolution of Zircon by 176Hf/177Hf from the Ita Quarry in the Atuba Complex, SE Brazil. Geologia USP, Série Cientifica São Paulo 9, 61-69.

Sato, K.; Tassinari, G. G. G.; Kawashita, K.; Petronilho, L., 1995. O método geocronológico Sm-Nd no IG/USP e suas aplicações. Anais da Academia Brasileira de Ciências 67, 315-336.

Sawyer, E.W., 1998. Formation and evolution of granite magmas during crustal reworking: the significance of diatexites. Journal of Petrology 39, 1147-1167.

Sawyer, E.W., 2008. Atlas of migmatites. The Canadian Mineralogist. In: Special Publication, vol. 9. NRC Research Press, Ottawa, Ontario, p. 371.

Schaltegger, U., Zeilinger, G., Frank, M., Burg, J.P., 2002. Multiple mantle sources during island arc magmatism: U-Pb and Hf isotopic evidence from the Kohistan arc complex, Pakistan. Terra Nova 14, 461-468.

Schandl, E.S., Gorton, M.P., 2002. Application of high field strength elements to discriminate tectonic settings in VMS environments. Economic Geology 97, 629-642.

Scherer, E.E., Whitehouse, M.J., \& Münker, C., 2007. Zircon as a monitor of crustal growth. Elements 3, 19-24.

Söderlund U., Patchett J.P., Vervoort J.D., Isachsen C.E. 2004. The 176Lu decay constant determined by Lu-Hf and U$\mathrm{Pb}$ isotope systematics of Precambrian mafic intrusions. Earth and Planetary Science Letters 219, 31 1-324.

Stacey, J.S., Kramer, J.D., 1975. Approximation of terrestrial lead isotope by a two-stage model. Earth and Planetary Science Letters 26, 207-212.

Sun, S.S., McDonough, W.F., 1989. Chemical and isotopic systematics of oceanic basalts: implication for mantle composition and processes. In: Saunders, A.D., Norry, M.J. (Eds.), Magmatism in Ocean Basins. Geological Society, London, Special Publications, vol. 42, pp. 313-345.

Tatsumi, Y., 1986. Formation of the volcanic front in subduction zones. Geophysical Research Letters 13, 717-720.

Tatsumi, Y., 2005. The subduction factory: How it operates in the evolving Earth. GSA today, 15, 4. 
Carlos E. Ganade de Araujo - Tese de Doutorado - Universidade de São Paulo

Capítulo 6 - Tracing Neoproterozoic subduction in NE-Brazil

Tatsumi, Y., Eggins, S., 1995. Subduction zone magmatism. Oxford: Blackwell Science.

Tatsumi, Y., Kogiso, T., 2003. The subduction factory: its role in the evolution of the Earth's crust and mantle. Geological Society, London, Special Publications 219, 55-80.

Treloar, P.J., Petterson, M.G., Jan, M.Q., Sullivan, M.A., 1996. A re-evaluation of the stratigraphy and evolution of the Kohistan arc sequence, Pakistan Himalaya: implications for magmatic and tectonic arc-building processes. Journal of the Geological Society 153, 681-693.

Van Schmus, W.R., Oliveira, E.P., Da Silva Filho, A., Toteu, S.F., Penaye, J., Guimarães, I.P., 2008. Proterozoic links between the Borborema Province, NE Brazil, and the Central African Fold Belt. In: Pankhurst, R.J., Trouw, R.A.J., Brito Neves, B.B., De Wit, M.J. (Eds.), West Gondwana: Pre-Cenozoic Correlations Across the Atlanti Region. Geological Society, London, Special Publications 294, 69-99.

Vervoort, J.D., Patchett, P.J., Blichert-Toft, J., Albarede, F., 1999. Relationship between Lu-Hf and Sm-Nd isotopic systems in the global sedimentary system. Earth and Planetary Science Letters 168, 79-99.

Weinberg, R.F., Dunlap, W.J., 2000. Growth and deformation of the Ladakh Batholith, northwest Himalayas: implications for timing of continental collision and origin of calc-alkaline batholiths. The Journal of Geology 108, 303320

White, R.W., Pomroy, N.E., Powell, R., 2005. An in situ metatexite-diatexite transition in upper amphibolite facies rocks from Broken Hill, Australia. Journal of Metamorphic Geology 23, 579-602.

Williams, I.S., 1998. In: McKibben, M.A., Shanks, W.G., Ridley, W.I. (Eds.), U-Th-Pb geochromology by ion microprobe, applications of microanalytical techniques to understanding mineralizing processes. Reviews in Economic Geology 7, pp. 1-35.

Wu, R.X., Zheng, Y.F., Wu, Y.B., Zhao, Z.F., Zhang, S.B., Liu, X., Wu, F.Y., 2006. Reworking of juvenile crust: element and isotope evidence from Neoproterozoic granodiorite in South China. Precambrian Research 146, $179-212$.

Yamamoto, S., Senshu, H., Rino, S., Omori, S., Maruyama, S., 2009. Granite subduction: arc subduction, tectonic erosion and sediment subduction. Gondwana Research 15, 443-453.

Zincone, S.A., 2011. Petrogênese do Batólito Santa Quitéria: implicações ao magmatismo brasiliano na porção norte da Província Borborema, NE Brasil. Master dissertation, Universidade Estadual de Campinas, 160pp. 


\title{
7. Extruding the Borborema Province (NE-Brazil): a two-stage Neoproterozoic collision process
}

Garlos E. Ganade de Araujo(1),(3), Roberto F. Weinberg(2), Umberto G. Cordani(3)

${ }^{1}$ Geological Survey of Brazil - SGB/CPRM, Fortaleza-CE, Brazil

${ }^{2}$ Monash University, Clayton-VIC, Australia

${ }^{3}$ Universidade de São Paulo, São Paulo-SP, Brazil

\begin{abstract}
We propose that Borborema Province development from 620 to 570 Ma resulted from two discrete collisional events. Collision I, along the West Gondwana Orogen on the west side of the Province, took place at ca. 620$610 \mathrm{Ma}$ as the result of collision between the Parnaíba Block, as the forefront of the much larger AmazonianWest Africa Craton, and the old basement of the Borborema Province. The suture zone related to this collision was reactivated by a dextral transform zone (the Transbrasiliano Lineament), allowing the Borborema Province to approach and collide against the São Francisco Craton in the south at ca. 590-580 Ma marking collision II along the Sergipano Orogen. The combined stresses related to eastward push from collision I and northward push from the cratonic indentation onto a thickened lithosphere gave rise to an extensive network of strike-slip shear zones across the Province forcing its northeastward extrusion.
\end{abstract}

\subsection{Introduction}

Lateral escape of continental blocks occurs in many active collisional areas (e.g., Sengör et al., 1985; Tapponier et al., 1982). Extrusion tectonics has been suggested for the Borborema Province, in northeast Brazil (e.g., Brito Neves et al., 2000; Alkmim et al., 2001; Bueno et al., 2009), but the relation to its large-scale tectonic evolution remains unclear. Here we present the hypothesis that the evolution of the Province during the Neoproterozoic (620-570 Ma) results from interference between two collisions.

The Province is bound to the west by the Parnaíba Block, which is inferred from geophysics and considered here as the forefront of the much larger Amazonian-West African Craton (fig. 7.1). This boundary is adjacent to a set of dextral high-T shear zones collectively known as the Transbrasiliano Lineament (equivalent to the Kandi Lineament in Africa). To the south the Province is bound by the São Francisco Craton.

It is composed of large areas of Archean/Paleoproterozoic gneissic/migmatitic rocks, as well as restricted Mesoproterozoic/Early Neoproterozoic rocks of the Cariris Velhos Belt, which make up the basement of metamorphosed supracrustal rocks, Neoproterozoic to Cambrian intrusions, and its well-known network of transcurrent shear zones (Caby, 1989; Vauchez et al., 1995; Brito Neves et al., 2000; Weinberg et al., 2004; Neves et al., 2012; Archanjo et al., 2013). In our view, by the end of the Neoproterozoic, the Province constituted a coherent block of stable continental crust of pre-Neoproterozoic age, with small intracontinental basins in its central portion (Neves, 2003), which was highly remobilized during and after the following collisional events described here.

In the Province, a number of crustal-scale shear zones branch out of the major Transbrasiliano shear system (fig. 7.2). Continuity between high-strain zones, similar P-T conditions of deformation and kinematic coherence suggest that this network represents a single system (Vauchez et al., 1995). 


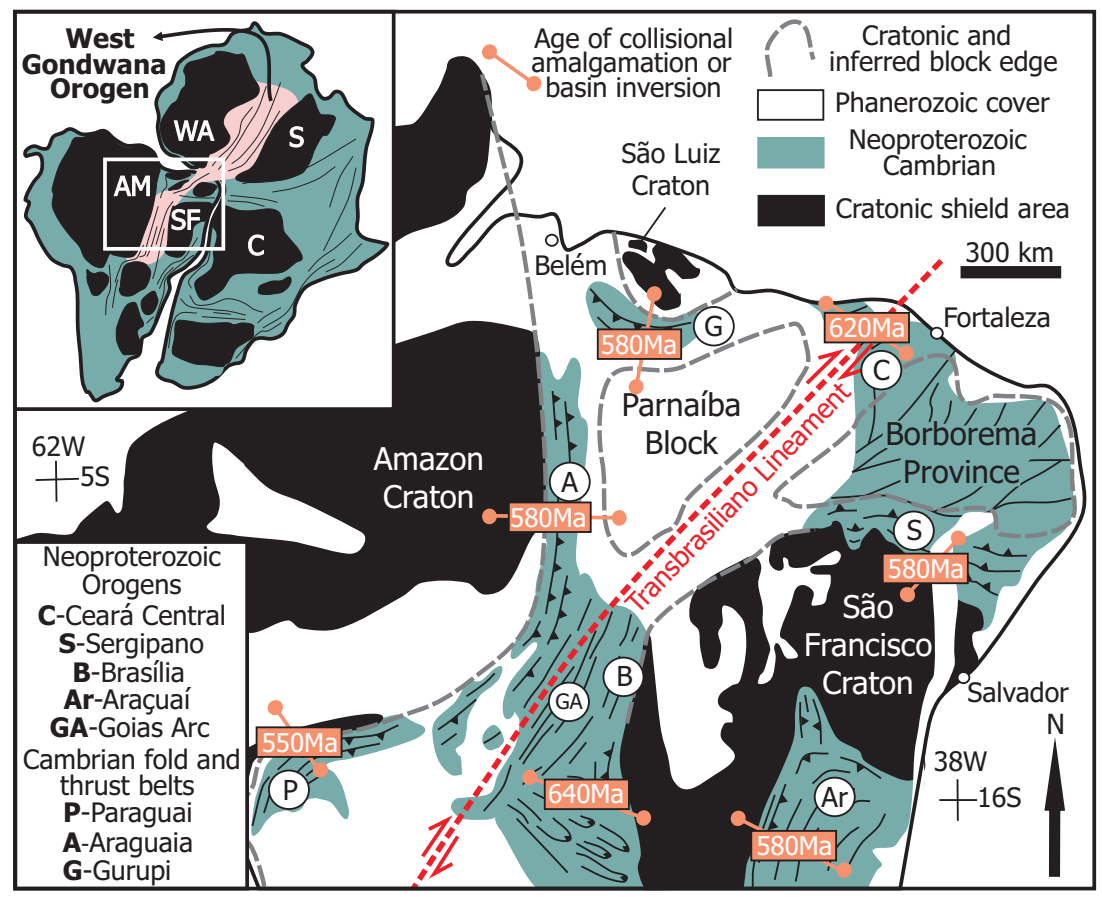

Figure 7.1 - Position of cratons, blocks, Brasiliano Neoproterozoic orogens and Neoproterozoic to Cambrian fold and thrust belts in Brazil (modified from Alkmim et al., 2001). Cratons in the inset: AM: Amazonian, WA: West Africa, SF: São Francisco, C: Congo, S: Saharan "metacraton".

The E-W trending Patos and Pernambuco dextral shear zones divide the province into Northern, Central and Southern sub-provinces (Brito Neves et al., 2000; Neves, 2003). Dextral strike-slip shear zones trending NESW characterize the Northern sub-province. The Central sub-province is characterized by a network of conjugate shear zones, comprising a set of E-W trending dextral shear zones and a sinistral set trending NESW (Neves et al., 2012). The Southern sub-province is limited by the São Francisco Craton in the south and is characterized by south-verging thrusting with a small dextral component (Oliveira et al., 2010). Geochronological $(\mathrm{U}-\mathrm{Pb})$ and thermochronological (Ar-Ar) data (table 7.1 and figure 7.2) indicate that deformation along these shear zones peaked with associated magmatism from 590 to 560 Ma and extended into lower T conditions from 550 to $500 \mathrm{Ma}$ in the Central sub-province (e.g., Monié et al., 1997; Corsini et al., 1998; Guimarães et al., 2004; Neves et al., 2008; Hollanda et al., 2010; Neves et al., 2012; Archanjo et al., 2013).

Regional deformation and metamorphism were synchronous throughout the Northern and Central subprovinces, starting before ca. $630 \mathrm{Ma}$, but are younger in the Southern sub-province, starting at ca. 610-570 Ma (Arthaud et al., 2008; Oliveira et al., 2010; Amaral et al., 2010; Neves et al., 2012). High-P/high-T regional metamorphism prevails in the northern part, where eclogites have been found between the Transbrasiliano Lineament and the Santa Quitéria continental arc (Santos et al., 2009).

Low-P/high-T metamorphism characterizes the central part, dominated by migmatites and gneisses (Neves et al., 2012), and lower P/T conditions (amphibolite to greenschist facies) are dominant in the Southern subprovince (Oliveira et al., 2010). 
Carlos E. Ganade de Araujo - Tese de Doutorado - Universidade de São Paulo

Capítulo 7 - Extruding the Borborema Province

Table 7.1 - Summary of the main U-Pb zircon and Ar-Ar ages of the Borborema Province.

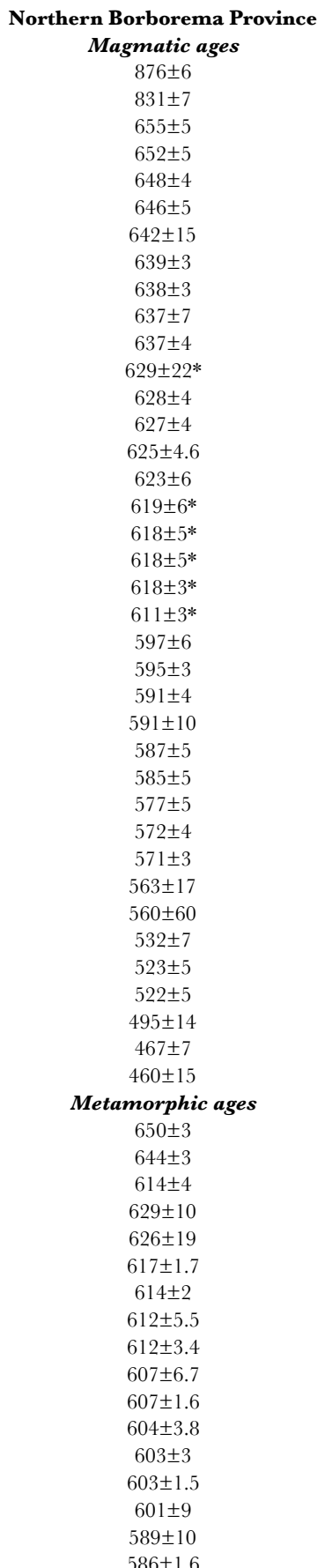

$$
\begin{gathered}
\text { Lagoa Caíçara Complex granodiorite } \\
\text { Lagoa Caíçara Complex tonalite } \\
\text { Tamboril Santa Quitéria Complex granodiorite } \\
\text { Tamboril Santa Quitéria Complex granodiorite } \\
\text { Tamboril Santa Quitéria Complex diorite } \\
\text { Tamboril Santa Quitéria Complex diorite } \\
\text { Novo Oriente granites } \\
\text { Novo Oriente granites } \\
\text { Novo Oriente granites }
\end{gathered}
$$

Tamboril-Santa Quitéria Complex diorite

Tamboril Santa Quitéria Complex monzogranite Lagoa Caíçara Complex diatexite

Lagoa Caíçara Complex two-mica orthogneiss

Lagoa Caíçara Complex two-mica orthogneiss

Tamboril Santa Quitéria Complex diatexite gnaissic granodiorite

Tamboril Santa Quitéria Complex diatexite

Tamboril Santa Quitéria Complex diatexite

Tamboril Santa Quitéria Complex diatexite

Tamboril Santa Quitéria Complex diatexite

Tamboril Santa Quitéria Complex diatexite Tororó diorite

Tororó gabbro norite

Tororó granite

Chaval granite

Quixeramobim monzonite

Quixeramobim monzonite

Acarí porphiritic granite

Acarí leucogranite

Pereiro granite

Tucunduba monzonite

Padre cosme granite

Mucambo syenite

Meruoca monzosyenite

Barriga granite

Taperuaba granite

Taperuaba granite

Pajé granite

Calc-silicate rock

Aluminous paragneiss

Mafic retro-eclogite

Aluminous paragneiss

Aluminous paragneiss

Aluminous paragneiss

Aluminous paragneiss

Aluminous paragneiss

Mafic granulite

Leucossome

Leucossome

Aluminous paragneiss Diatexite

Aluminous paragneiss

Aluminous paragneiss

Mafic granulite

Aluminous granitoid

Central Borborema Province

Magmatic ages

$618 \pm 5$

\begin{tabular}{|c|c|c|}
\hline Mineral & Technique & Reference \\
\hline zircon & SHRIMP & Ganade de Araujo et al. (2012a) \\
\hline zircon & SHRIMP & Ganade de Araujo et al. (2012a) \\
\hline zircon & SHRIMP & Ganade de Araujo et al. (unpublished) \\
\hline zircon & SHRIMP & Ganade de Araujo et al. (unpublished) \\
\hline zircon & SHRIMP & Ganade de Araujo et al. (unpublished) \\
\hline zircon & SHRIMP & Ganade de Araujo et al. (unpublished) \\
\hline zircon & $\mathrm{Pb}$ evaporation & Ganade de Araujo et al. (2012c) \\
\hline zircon & $\mathrm{Pb}$ evaporation & Ganade de Araujo et al. (2012c) \\
\hline zircon & LA-ICP-MS & Ganade de Araujo et al. (2010) \\
\hline zircon & ID-TIMS & Fetter (1999) \\
\hline zircon & SHRIMP & Ganade de Araujo et al. (unpublished) \\
\hline zircon & ID-TIMS & Castro (2004) \\
\hline zircon & SHRIMP & Ganade de Araujo et al. (unpublished) \\
\hline zircon & SHRIMP & Ganade de Araujo et al. (unpublished) \\
\hline zircon & SHRIMP & Ganade de Araujo et al. (unpublished) \\
\hline zircon & ID-TIMS & Castro (2004) \\
\hline zircon & ID-TIMS & Castro (2004) \\
\hline zircon & SHRIMP & Ganade de Araujo et al. (2012a) \\
\hline zircon & SHRIMP & Ganade de Araujo et al. (2012a) \\
\hline zircon & ID-TIMS & Castro (2004) \\
\hline zircon & ID-TIMS & Castro (2004) \\
\hline zircon & SHRIMP & Archanjo et al. (2013) \\
\hline zircon & SHRIMP & Archanjo et al. (2013) \\
\hline zircon & SHRIMP & Archanjo et al. (2013) \\
\hline zircon & ID-TIMS & Fetter (1999) \\
\hline zircon & ID-TIMS & Nogueira (2004) \\
\hline zircon & ID-TIMS & Nogueira (2004) \\
\hline zircon & SHRIMP & Archanjo et al. (2013) \\
\hline zircon & SHRIMP & Archanjo et al. (2013) \\
\hline zircon & ID-TIMS & Magini (2001) \\
\hline zircon & ID-TIMS & Fetter (1999) \\
\hline zircon & ID-TIMS & Magini (2001) \\
\hline zircon & ID-TIMS & Fetter (1999) \\
\hline zircon & U-Pb SHRIMP & Archanjo et al. (2009) \\
\hline titanite & ID-TIMS & Fetter (1999) \\
\hline zircon & U-Pb SHRIMP & Castro et al. (2012) \\
\hline zircon & ID-TIMS & Castro et al. (2012) \\
\hline zircon & ID-TIMS & Teixeira (2005) \\
\hline zircon & LA-ICP-MS & Amaral et al. (2010) \\
\hline Monazite & U-Pb EPMA & Castro (2004) \\
\hline zircon & LA-ICP-MS & Amaral (2010) \\
\hline Monazite & U-Pb EPMA & Castro (2004) \\
\hline Monazite & U-Pb EPMA & Castro (2004) \\
\hline zircon & ID-TIMS & Castro (2004) \\
\hline zircon & ID-TIMS & Castro (2004) \\
\hline zircon & SHRIMP & Arthaud (2007) \\
\hline zircon & LA-ICP-MS & Amaral et al. (2012) \\
\hline zircon & ID-TIMS & Arthaud (2007) \\
\hline zircon & ID-TIMS & Arthaud (2007) \\
\hline zircon & ID-TIMS & Castro (2004) \\
\hline zircon & ID-TIMS & Castro (2004) \\
\hline zircon & ID-TIMS & Castro (2004) \\
\hline Monazite & U-Pb EPMA & Castro (2004) \\
\hline zircon & LA-ICP-MS & Amaral et al. (2012) \\
\hline zircon & ID-TIMS & Fetter (1999) \\
\hline Mineral & Technique & Reference \\
\hline zircon & SHRIMP & Ferreira et al. (2011) \\
\hline zircon & SHRIMP & Guimarães et al. (2011) \\
\hline zircon & LA-ICP-MS & Neves et al. (2012) \\
\hline zircon & LA-ICP-MS & Neves et al. (2008) \\
\hline zircon & ID-TIMS & Guimarães et al. (2004) \\
\hline zircon & ID-TIMS & Archanjo and Fetter (2004) \\
\hline zircon & $\mathrm{Pb}$ evaporation & Neves et al. (2004) \\
\hline zircon & SHRIMP & Archanjo et al. (2008) \\
\hline zircon & ID-TIMS & Guimarães et al. (2004) \\
\hline
\end{tabular}

$616 \pm 5$

$616 \pm 4$

$606 \pm 8$

$592 \pm 7$

$592+5$

$591 \pm 5$

$591 \pm 5$

$588 \pm 12$ 
Carlos E. Ganade de Araujo - Tese de Doutorado - Universidade de São Paulo

Capítulo 7 - Extruding the Borborema Province

Table $7.1-($ continued $)$

$587 \pm 8$
$587 \pm 5$
$586 \pm 21$
$586 \pm 2$
$581 \pm 3$
$581 \pm 2$
$577 \pm 4$
$576 \pm 3$
$575 \pm 14$
$573 \pm 4$
$570 \pm 24$
$564 \pm 5$
$548 \pm 4$
$543 \pm 7$
$542 \pm 5$
$538 \pm 23$
$537 \pm 6$
$534 \pm 4$
$533 \pm 4$
Metamorphic ages
$626 \pm 15$
$625 \pm 24$
$632 \pm 17$
$623 \pm 6$
$612 \pm 54$
$600 \pm 22$

Southern Borborema Province

Magmatic ages

$628 \pm 12$

$625 \pm 2$

$584 \pm 10 *$

$571+9 *$

Metamorphic ages

$573 \pm 1$

*magmatic and metamorphic ages (melting ages

$\begin{array}{lc}\text { zircon } & \text { LA-ICP-MS } \\ \text { zircon } & \text { Pb evaporation } \\ \text { zircon } & \text { ID-TIMS } \\ \text { zircon } & \text { LA-ICP-MS } \\ \text { zircon } & \text { ID-TIMS } \\ \text { zircon } & \text { ID-TIMS } \\ \text { zircon } & \text { SHRIMP } \\ \text { zircon } & \text { SHRIMP } \\ \text { zircon } & \text { ID-TIMS } \\ \text { zircon } & \text { LA-ICP-MS } \\ \text { zircon } & \text { ID-TIMS } \\ \text { zircon } & \text { LA-ICP-MS } \\ \text { zircon } & \text { SHRIMP } \\ \text { zircon } & \text { LA-ICP-MS } \\ \text { zircon } & \text { SHRIMP } \\ \text { zircon } & \text { LA-ICP-MS } \\ \text { zircon } & \text { SHRIMP } \\ \text { zircon } & \text { SHRIMP } \\ \text { zircon } & \text { SHRIMP }\end{array}$

leucossome of migmatitic paragneiss zircons from banded orthogneiss Alcantil orthogneiss

zircon overgrowth in a paragneiss metamorphic zircons in orthogneiss metamorphic zircons in orthogneiss

Pre-collision Camará tonalite Coronel Sá pre-collisoinal granodiorite Angico syn-collisinal granite

Pedra Furada syn-collisional granite

Macururé garnet-mica schist zircon

zircon

zircon

zircon

zircon

zircon
LA-ICP-MS

LA-ICP-MS

LA-ICP-MS

LA-ICP-MS

LA-ICP-MS

LA-ICP-MS

$\begin{array}{ccc}\text { zircon } & \text { SHRIMP } & \text { Bueno et al. (2009) } \\ \text { zircon } & \text { ID-TIMS } & \text { Long et al. (2005) } \\ \text { titanite } & \text { ID-TIMS } & \text { Bueno et al. (2009) } \\ \text { titanite } & \text { ID-TIMS } & \text { Bueno et al. (2009) } \\ & & \\ \text { WR-garnet } & \text { Sm-Nd isochron } & \text { Oliveira et al. (2010) }\end{array}$

Northern Borborema Province

Colling ages

$641 \pm 2$

$611 \pm 3$

$601 \pm 4$

$601 \pm 2$

$599 \pm 8$

$599 \pm 2$

$598 \pm 2$

$597 \pm 1$

$595 \pm 2$

$595 \pm 1$

$594 \pm 2$

$594 \pm 2$

$592 \pm 1$

$588 \pm 1$

$584 \pm 1$

$583 \pm 1$

$582 \pm 1$

$582 \pm 1$

$578 \pm 1$

$576 \pm 1$

$574 \pm 6$

$573 \pm 1$

$573 \pm 1$

$572 \pm 6$

$568 \pm 5$

$563 \pm 5$

$562 \pm 1$

$561 \pm 3$

$557 \pm 1$

$556 \pm 1$

$555 \pm 5$

$\begin{array}{cc}\text { biotite } & \mathrm{Ar}-\mathrm{Ar} \\ \text { amphibole } & \mathrm{Ar}-\mathrm{Ar} \\ \text { biotite } & \mathrm{Ar}-\mathrm{Ar} \\ \text { amphibole } & \mathrm{Ar}-\mathrm{Ar} \\ \text { biotite } & \mathrm{Ar}-\mathrm{Ar} \\ \text { amphibole } & \mathrm{Ar}-\mathrm{Ar} \\ \text { amphibole } & \mathrm{Ar}-\mathrm{Ar} \\ \text { biotite } & \mathrm{Ar}-\mathrm{Ar} \\ \text { amphibole } & \mathrm{Ar}-\mathrm{Ar} \\ \text { biotite } & \mathrm{Ar}-\mathrm{Ar} \\ \text { amphibole } & \mathrm{Ar}-\mathrm{Ar} \\ \text { biotite } & \mathrm{Ar}-\mathrm{Ar} \\ \text { biotite } & \mathrm{Ar}-\mathrm{Ar} \\ \text { biotite } & \mathrm{Ar}-\mathrm{Ar} \\ \text { biotite } & \mathrm{Ar}-\mathrm{Ar} \\ \text { biotite } & \mathrm{Ar}-\mathrm{Ar} \\ \text { biotite } & \mathrm{Ar}-\mathrm{Ar} \\ \text { muscovite } & \mathrm{Ar}-\mathrm{Ar} \\ \text { muscovite } & \mathrm{Ar}-\mathrm{Ar} \\ \text { biotite } & \mathrm{Ar}-\mathrm{Ar} \\ \text { amphibole } & \mathrm{Ar}-\mathrm{Ar} \\ \text { muscovite } & \mathrm{Ar}-\mathrm{Ar} \\ \text { muscovite } & \mathrm{Ar}-\mathrm{Ar} \\ \text { amphibole } & \mathrm{Ar}-\mathrm{Ar} \\ \text { biotite } & \mathrm{Ar}-\mathrm{Ar} \\ \text { biotite } & \mathrm{Ar}-\mathrm{Ar} \\ \text { muscovite } & \mathrm{Ar}-\mathrm{Ar} \\ \text { biotite } & \mathrm{Ar}-\mathrm{Ar} \\ \text { muscovite } & \mathrm{Ar}-\mathrm{Ar} \\ \text { biotite } & \mathrm{Ar}-\mathrm{Ar} \\ \text { amphibole } & \mathrm{Ar}-\mathrm{Ar} \\ & \\ & \end{array}$

Neves et al. (2008)

Neves et al. (2004)

Van Schumus et al. (1995)

Neves et al. (2012)

Mariano et al. (2009)

Guimarães et al. (2004)

Ferreira et al. (2011)

Archanjo et al. (2008)

Guimarães et al. (2004)

Neves et al. (2008)

Guimarães et al. (2004)

Ferreira et al. (2011)

Hollanda et al. (2010)

Guimarães et al. (2004)

Hollanda et al. (2010)

Guimarães et al. (2004

Hollanda et al. (2010)

Hollanda et al. (2010)

Hollanda et al. (2010)

Neves et al. (2006)

Neves et al. (2006)

Neves et al. (2012)

Neves et al. (2009)

Neves et al. (2006)

Neves et al. (2006)
Castro (2004)

Castro (2004)

Monie et al. (1997)

Castro (2004)

Castro (2004)

Castro (2004)

Castro (2004)

Castro (2004)

Castro (2004)

Castro (2004)

Castro (2004)

Castro (2004)

Castro (2004)

Castro (2004)

Castro (2004)

Castro (2004)

Castro (2004)

Castro (2004)

Castro (2004)

Castro (2004)

Monie et al. (1997)

Castro (2004)

Castro (2004)

Monie et al. (1997)

Monie et al. (1997)

Monie et al. (1997)

Castro (2004)

Corsini et al. (1998)

Castro (2004)

Castro (2004)

Monie et al. (1997) 
Carlos E. Ganade de Araujo - Tese de Doutorado - Universidade de São Paulo

Capítulo 7 - Extruding the Borborema Province

Table 7.1 - (continued)

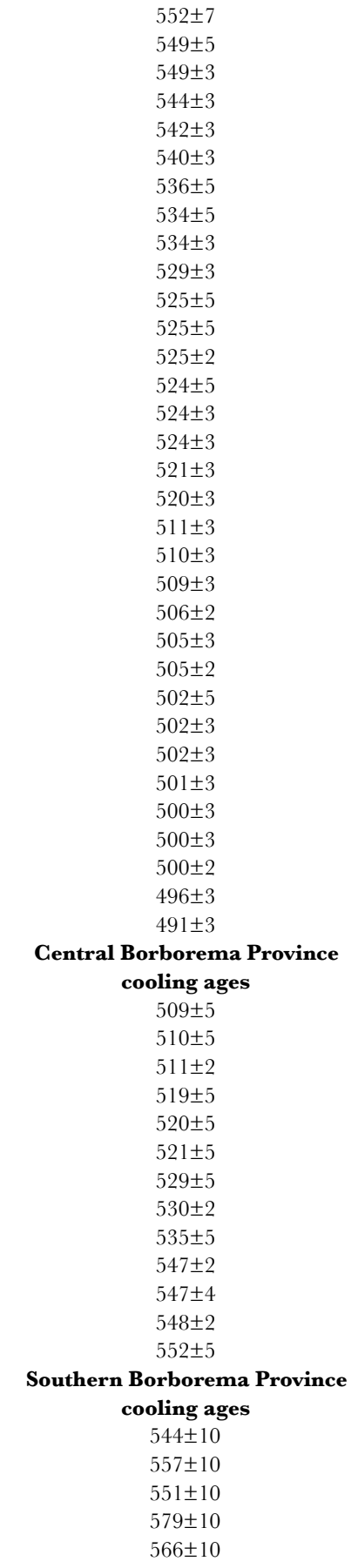

\begin{tabular}{|c|c|c|}
\hline Chaval granite & muscovite & Ar-Ar \\
\hline Archean basement & amphibole & Ar-Ar \\
\hline Mylonitic tonalite & biotite & Ar-Ar \\
\hline Mafic layer & amphibole & Ar-Ar \\
\hline Biotite-rich dyke & amphibole & Ar-Ar \\
\hline Mylonitic granite & amphibole & Ar-Ar \\
\hline Oros schist & phlogopite & $\mathrm{Ar}-\mathrm{Ar}$ \\
\hline Paragneiss (Ceara Central) & muscovite & Ar-Ar \\
\hline Mafic boudin & amphibole & Ar-Ar \\
\hline Mafic boudin & biotite & Ar-Ar \\
\hline Paragneiss (Ceara Central) & biotite & Ar-Ar \\
\hline Archean basement & muscovite & Ar-Ar \\
\hline Pegmatite & biotite & Ar-Ar \\
\hline Proterozoic cover & muscovite & Ar-Ar \\
\hline Metapelite & biotite & Ar-Ar \\
\hline Biotite-rich dyke & biotite & Ar-Ar \\
\hline Mafic layer & biotite & Ar-Ar \\
\hline Muscovite-quartz mylonite & muscovite & Ar-Ar \\
\hline Metapelite & biotite & Ar-Ar \\
\hline Mylonitic granite & biotite & Ar-Ar \\
\hline Quartzite & muscovite & Ar-Ar \\
\hline Hydrothermal muscovite & muscovite & Ar-Ar \\
\hline Mylonitic orthogneiss & muscovite & Ar-Ar \\
\hline Mylonitic schist & muscovite & Ar-Ar \\
\hline Aluminous granitoid & biotite & Ar-Ar \\
\hline Granite vein & muscovite & Ar-Ar \\
\hline Mylonitic orthogneiss & biotite & Ar-Ar \\
\hline Serido metapelite & biotite & Ar-Ar \\
\hline Equador schist & biotite & Ar-Ar \\
\hline Sheared granite & muscovite & Ar-Ar \\
\hline Mylonitic schist & biotite & Ar-Ar \\
\hline Equador schist & biotite & Ar-Ar \\
\hline Sheared granite & biotite & Ar-Ar \\
\hline anta Cruz do Capibaribe pluton & biotite & Ar-Ar \\
\hline Coxixola mylonites & muscovite & Ar-Ar \\
\hline Coxixola mylonites & muscovite & Ar-Ar \\
\hline Alcantil orthogneiss & biotite & Ar-Ar \\
\hline Coxixola mylonites & muscovite & Ar-Ar \\
\hline Jupi orthogneiss & biotite & Ar-Ar \\
\hline Alcantil orthogneiss & amphibole & Ar-Ar \\
\hline Prata mafic stock & biotite & Ar-Ar \\
\hline Metagranodiorite & biotite & Ar-Ar \\
\hline Prata mafic stock & amphibole & Ar-Ar \\
\hline Coxixola mylonites & muscovite & Ar-Ar \\
\hline Coxixola mylonites & muscovite & Ar-Ar \\
\hline Cachoeirinha pluton & biotite & Ar-Ar \\
\hline Leucogranite Major Isidoro & biotite & Ar-Ar \\
\hline Leucossome Major Isidoro & muscovite & Ar-Ar \\
\hline Kinzigitic gneiss Rio Couripe & biotite & Ar-Ar \\
\hline Biotite gneiss Rio Couripe & biotite & Ar-Ar \\
\hline Leucossome Rio Couripe & biotite & Ar-Ar \\
\hline
\end{tabular}

Monie et al. (1997)

Monie et al. (1997)

Corsini et al. (1998)

Corsini et al. (1998)

Corsini et al. (1998)

Corsini et al. (1998)

Monie et al. (1997)

Monie et al. (1997)

Corsini et al. (1998)

Corsini et al. (1998)

Monie et al. (1997)

Monie et al. (1997)

Araujo et al. (2005)

Monie et al. (1997)

Corsini et al. (1998)

Corsini et al. (1998

Corsini et al. (1998)

Araujo et al. (2005)

Corsini et al. (1998)

Corsini et al. (1998)

Corsini et al. (1998)

Araujo et al. (2005)

Corsini et al. (1998)

Araujo et al. (2005)

Corsini et al. (1998)

Corsini et al. (1998)

Corsini et al. (1998)

Corsini et al. (1998)

Corsini et al. (1998)

Corsini et al. (1998)

Araujo et al. (2005)

Corsini et al. (1998)

Corsini et al. (1998)

Hollanda et al. (2010)

Hollanda et al. (2010)

Hollanda et al. (2010)

Hollanda et al. (2010)

Hollanda et al. (2010)

Hollanda et al. (2010)

Hollanda et al. (2010)

Neves et al. (2012)

Neves et al. (2012)

Neves et al. (2012)

Neves et al. (2012)

Neves et al. (2012)

Neves et al. (2012)

Brito et al. (2008)

Brito et al. (2008)

Brito et al. (2008)

Brito et al. (2008)

Brito et al. (2008)

In this work, we use existing data on the temporal and spatial tectonothermal and magmatic evolution of the Province to propose a new integrated tectonic model for its evolution between 620 and 550 Ma resulting from two collisional events. 
Carlos E. Ganade de Araujo - Tese de Doutorado - Universidade de São Paulo

Capítulo 7 - Extruding the Borborema Province

\subsection{The West Gondwana Orogen: the 620-600 Ma Collision I}

The Geará Central Domain of the Northern sub-province is part of a large collisional belt (denominated here as the West Gondwana Orogen) that extends from Hoggar in Africa to Central Brazil (e.g., Caby, 1989, Trompette, 1994, Cordani et al., 2013a). Due to continued post-collisional convergence and escape, this collisional belt was subsequently reactivated by dextral shear zones (Caby, 1989, Castaing et al., 1994). In the Ceará Central Domain, relics of retrogressed eclogitic rocks $\left(800^{\circ} \mathrm{C} ; 17 \mathrm{kbar}\right)$ have been dated at ca. $615 \mathrm{Ma}$ (Amaral, 2010), although older ages at $c a .650 \mathrm{Ma}$ from related calc-silicate rocks have also been putatively attributed to high-P conditions. These rocks are roughly aligned with other HP and UHP rocks in Africa also dated at ca. 620-610 Ma (Bernard Griffiths et al., 1991; Affaton et al., 2000; Jahn et al., 2001) defining a large Himalayan-scale collisional orogen.

Along this orogen, and pre-dating collision, there are older, 950-630 Ma magmatic and sedimentary assemblages, interpreted as remnants of intraoceanic or continental arcs (e.g., Pimentel and Fuck, 1992; Caby, 2003; Duclaux et al., 2006; Berger et al., 2011; Ganade de Araujo et al., 2012a,b), related to the PharusianGoias Ocean, consumed before collision (Kröner and Cordani, 2003; Cordani et al., 2013b). This view of the large Pharusian-Goias Ocean challenges the previous proposed Cambrian Clymene Ocean, where a younger suture is inferred along the Paraguay-Araguaia fold and thrusts-belts (Trindade et al., 2006; Thover et al., 2012; Cordani et al. 2013b).

The Tamboril-Santa Quitéria Complex in the Ceará Central Domain is a large igneous unit representing arc granitoids (Fetter et al., 2003) emplaced slightly before high-P metamorphism at ca. 650-630 Ma. These arc rocks, together with supracrustal rocks, were reworked and partially melted soon after the inferred collision at ca. 620-600 Ma (Arthaud, 2007; Ganade de Araujo et al., 2012a).

Throughout the Northern and Central sub-provinces a gently-dipping foliation associated with thrusting developed at the time of collision I (e.g. Caby and Arthaud, 1986; Neves et al., 2012). In the Central subprovince, where detailed studies have been carried out, this foliation is associated with peak metamorphic conditions of $640-750^{\circ} \mathrm{C}$ and 6-8 kbar, at ca. $620 \mathrm{Ma}$ (Neves et al., 2012).

We argue that collision of the Borborema Province against the Parnaíba block, representing part of the Amazonian-West-African Craton, is marked in Ceará Central Domain by the end of arc-related magmatism at ca. $630 \mathrm{Ma}$ and high-P metamorphism at ca. 620-615 Ma, and was followed by thickening of the crust with the development of the thrust-related foliation (Caby and Arthaud, 1986), and heating, reaching peak thermal conditions and widespread anatexis at ca. 620-600 Ma.

\subsection{The Sergipano Orogen: the 590-570 Ma collision II}

The Sergipano Orogen in the Southern sub-province is composed of supracrustal rocks related to the development of the Sergipano Basin that may have initiated before $900 \mathrm{Ma}$ (Brito Neves et al., 2000; Oliveira et al., 2010). Rifting at ca. $700 \mathrm{Ma}$ is well-documented in one of its domains (the Canindé Domain) and could have lasted until ca. $640 \mathrm{Ma}$ (Oliveira et al., 2010). Like in the Ceará Central Domain, early convergent magmatism has arc-related signatures dated at ca. 630-625 Ma (Long et al., 2005; Bueno et al., 2009), generated during consumption of a restricted Sergipano Ocean between the São Francisco Craton and the Pernambuco-Alagoas Massif (PEAL) (Oliveira et al., 2010). 
Carlos E. Ganade de Araujo - Tese de Doutorado - Universidade de São Paulo Capítulo 7 - Extruding the Borborema Province

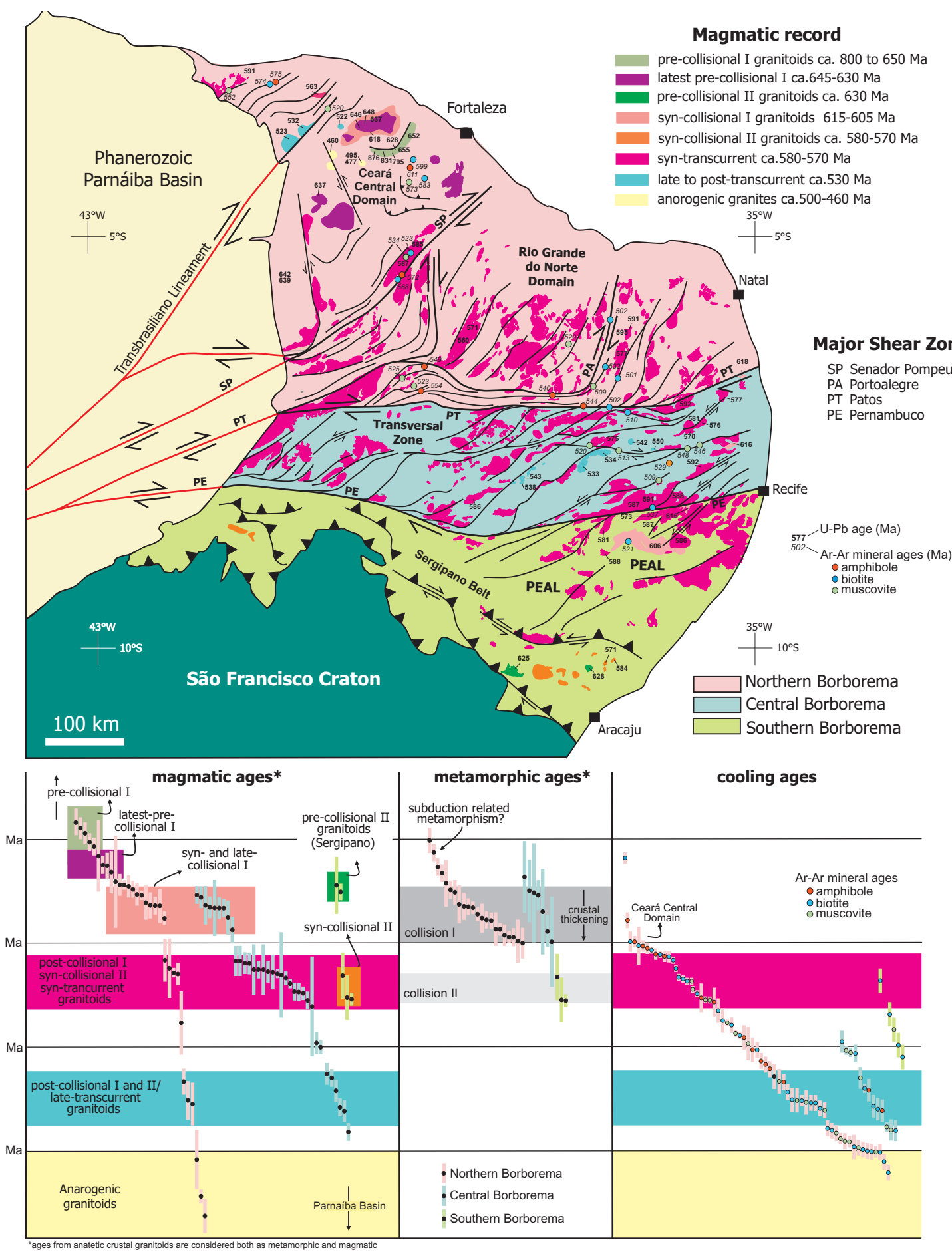

Figure 7.2 - Temporal and spatial distribution of granitoid rocks in the Borborema Province. The figure depicts a systematic younging of arc-related pre-collisional magmatism from north to south across the Province, as well as in the timing of metamorphism. Arc magmatism ends at ca. $630 \mathrm{Ma}$ in the NW-section of the province but starts at ca. $630 \mathrm{Ma}$ in the south (Fetter et al., 2003; Oliveira et al., 2010). Whilst the most voluminous magmatism is centred around $580 \mathrm{Ma}$ across the entire Province, the timing of collisional magmatism in each region varies: $620 \mathrm{Ma}$ in the NW section of the Province, along the trend of the Transbrasiliano Lineament and 590-570 Ma in the south, along the Sergipano Orogen, contemporaneous with peak magmatism in the Province. Ar-Ar cooling ages also show the same systematic decreasing age pattern from the site of collision I in the Ceará Central Domain to the site of collision II in the Sergipano Belt, 
but suggest final cooling was established only at $c a .500 \mathrm{Ma}$, which is interpreted to indicate the end of collisional deformation. Voluminous magmatism during development of the shear zones at ca. 590-560 Ma has dominant lithospheric mantle affinities (Neves et al., 2000; Guimarães et al., 2004) possibly related to delamination of the orogenic crustal root after thickening promoted by collision I (Ganade de Araujo, 2011). Ar-Ar ages also indicate slow colling rate with continuous heat supply until the Cambrian (Monié et al., 1997; Corsini et al., 1998; Hollanda et al., 2010). References for ages are listed in table 1.

Three deformation events were recognized in the Sergipano Orogen (Bueno et al., 2009; Oliveira et al., 2010): south-verging $\mathrm{D}_{1}$ nappes and thrusts zones, which thrusted the supracrustal rocks over the São Francisco Craton; reactivation of $\mathrm{D}_{1}$ structures during $\mathrm{D}_{2}$ transpression associated with significant vertical movements and emplacement of most granitoids; and brittle to ductile-brittle $\mathrm{D}_{3}$ structures associated with exhumation in response to continued compression. Peak amphibolite facies metamorphism occurred during $\mathrm{D}_{2}$ at ca. $570 \mathrm{Ma}$ (garnet/whole-rock $\mathrm{Sm}-\mathrm{Nd}$ isochron, Oliveira et al., 2010) similar to the $\mathrm{U}-\mathrm{Pb}$ titanite ages of syn- $\mathrm{D}_{2}$ leucogranites, such as the $584 \pm 10 \mathrm{Ma}$ Angico and the $571 \pm 9$ Ma Pedra Furada leucogranites (Bueno et al., 2009).

Combining the nature of deformation and timing of leucogranites, Bueno et al. (2009) interpreted that peak metamorphism resulted from collision between the São Francisco Craton and the Pernambuco-Alagoas Massif (PEAL), thrusting the supracrustal rocks onto the craton during $\mathrm{D}_{2}$. The climax of this collision and associated granitic magma production can be reasonably bracketed to between 590-570 Ma (Bueno et al., 2009; Oliveira et al., 2010), some time after peak temperatures in collision I.

\subsection{Extrusion Tectonics (ca. $590-570 \mathrm{Ma}$ )}

Figure 7.3 summarises the evolution of the two orogenies starting with collision I closing the Goiás-Pharusian Ocean, marking the beginning of the West Gondwana Orogen, followed by closure of the Sergipano Ocean and collision of the São Francisco Craton with the Borborema Province, producing collision II at ca. 590 Ma, marking the beginning of the Sergipano Orogen. Interaction between the two collisions, led to the extrusion of the Province between 590 and $560 \mathrm{Ma}$ along the network of strike slip shear zones accompanied by intrusion of syn-kinematic granitoids. The ca. 30 m.y. time gap between collision I and II (ca. 620 and 590 Ma, respectively) is also reflected in the time gap between peak temperatures (620-600 Ma and 590-570 Ma, respectively).

Structures developed during the interaction of the two orogenies change systematically from the SE to NW across the Province (fig. 7.4). In the Southern sub-province, south-verging thrusting of the Sergipano Belt with a small dextral component indicates dominant N-S shortening and crustal thickening (Bueno et al. 2009; Oliveira et al., 2010).

In contrast, the Central sub-province has an older (ca. $620 \mathrm{Ma}$ ) penetrative foliation, possibly related to farreaching stresses from collision I, overprinted by the conjugate sets of E-W dextral and NE-SW sinistral, subvertical, mylonitic belts that characterize its main deformation phase (Neves et al., 2012). Here, the 600$590 \mathrm{Ma}$ time interval corresponds to transition from the contractional event to transcurrent regime, which reached slightly lower P-T conditions at $690-730{ }^{\circ} \mathrm{C}$ and 4-6 kbar (Neves et al., 2012) between 590 to $570 \mathrm{Ma}$, as constrained by ages of syn-transcurrent granitoids (e.g., Guimarães et al., 2004; Neves et al., 2008; Neves et al., 2012). This late deformational event defines a pure shear deformation with maximum shortening oriented 
NW-SE and strain taken up by the conjugate pair of transcurrent shear zones with first-order dextral E-W shear zones associated to second order sinistral NE-SW shear zones (fig. 7.4).

The Northern sub-province also has its early low-angle contractional foliation overprinted by regional NE-SW trending dextral shear zones. Movement in these shear zones, dated by different methods bracket movement to between 590 and $570 \mathrm{Ma}$ (Fetter, 1999; Archanjo et al., 2013; Souza et al., 2006), extending into low-T conditions until the Cambrian period (530-500 Ma) (Corsini et al., 1998; Araújo et al., 2005; Hollanda et al., 2010). Unlike the Central sub-province, the lack of well-developed sinistral conjugate sets of shear zones in the Northern sub-province suggests a dominant simple shear transcurrent movement at 590-570 Ma, dominated by a NNE-directed block extrusion, and characterized by an inferred maximum shortening strain axis trending approximately $\mathrm{E}-\mathrm{W}$ (fig. 7.4).

Accordingly, coeval ca. 590-570 Ma regional structures indicate a large scale anticlockwise rotation of the maximum shortening axis from N-S in the southeast to E-W in the northwest of the Province. This is accompanied by a change from thrusting with a small dextral component in the south and southeast, to pure shear expressed by a conjugate set of transcurrent shear zones in the centre, to dextral transcurrent movement and NNE block extrusion in the northwest (fig. 7.4). It is important to notice that deformation was not simple rigid block rotation along faults, but consisted also of internal ductile block deformation through widespread deformation. Regional-scale rotation of strain axes is interpreted to be a result of superposition between a continued eastward push of the conjoined Parnaíba Block and the Amazonian-West African Craton, and the stresses generated by the northward push of the São Francisco Craton in the south. In this case, axes rotation reflects the relative impact of each collision: collision I dominating deformation in the northwest imposing NNE to NE escape, and collision II dominating in the southeast, causing south-verging thrusting. Deformation in the inter-collisional Central sub-province reflects interaction between the two collisions leading to its conjugate transcurrent system.

Whilst our focus has been restricted to South America, the conclusions can be expanded to Africa. The São Francisco Craton was part of the much wider São Francisco-Congo Craton, and collision II with the Borborema Province was a result of the closure of the Sergipano-Oubanguides Ocean (e.g. Van Schmus et al., 2008).

Likewise, collision I was part of a broader collisional belt, the West Gondwana Orogen, including the Dahomey and Hoggar in Africa, where magmatism, eclogitization, thrusting and later dextral reactivation follow the same overall timing as in the Ceará Central Domain (Caby, 1989; Bernard Griffiths et al., 1991; Caby, 2003). Moreover, the large scale shear zone system that resulted from the interaction between the two collisions can be correlated to large lineaments in the Benino-Nigerian Province and the E-W trending shear zones of Cameroon (Caby, 1989; Trompette, 1994; Van Schmus et al. 2008).

\subsection{Transbrasiliano-Kandi Strike-Slip Belt (TKSSB): A Neoproterozoic Transform Plate Boundary?}

The dextral TKSSB formed as a result of relative movement obliquity during the West Gondwana Orogen, collision I (fig. 7.3). 
A ca. $800-650 \mathrm{Ma}$ (pre-collision I)

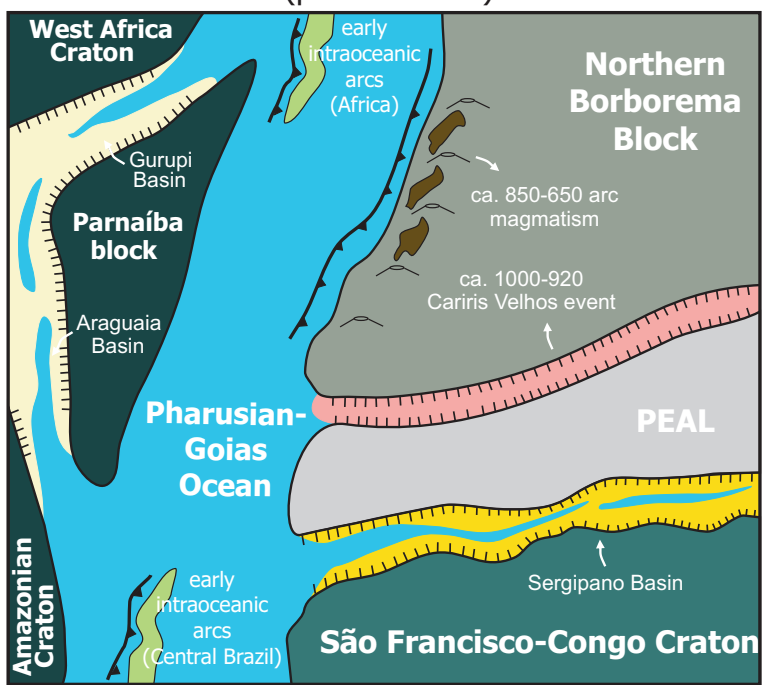

C ca. 590-570 Ma (collision II)

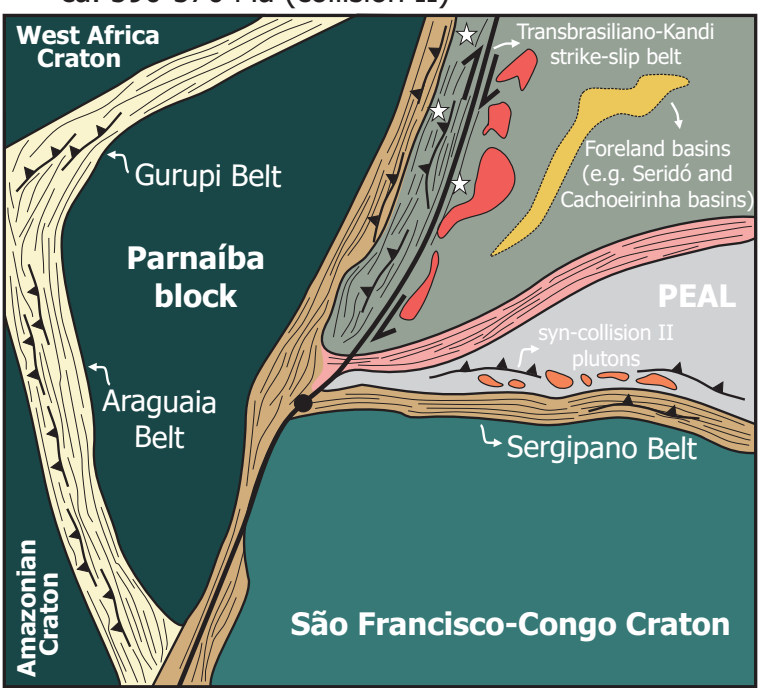

B ca. $620-600 \mathrm{Ma}$ (collision I)

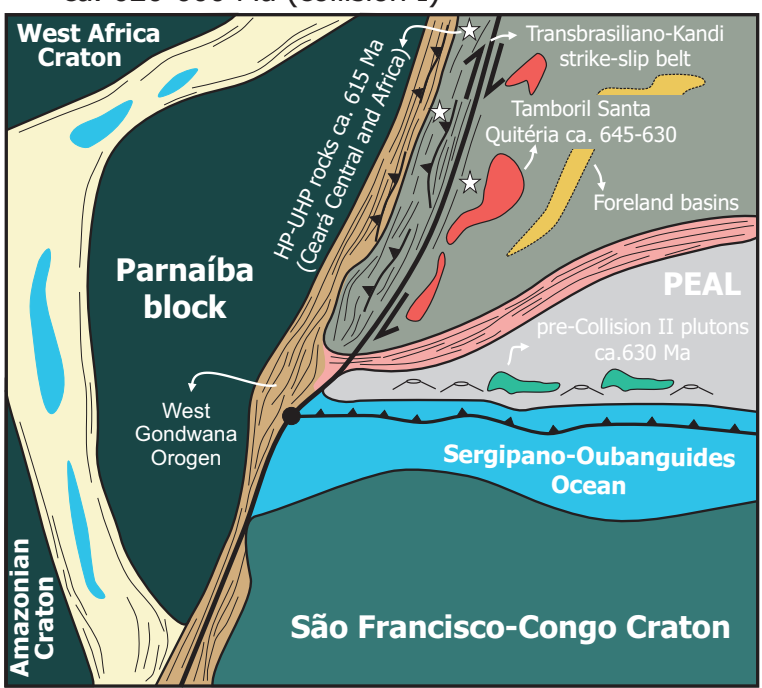

D ca. 580-550 Ma (extrusion)

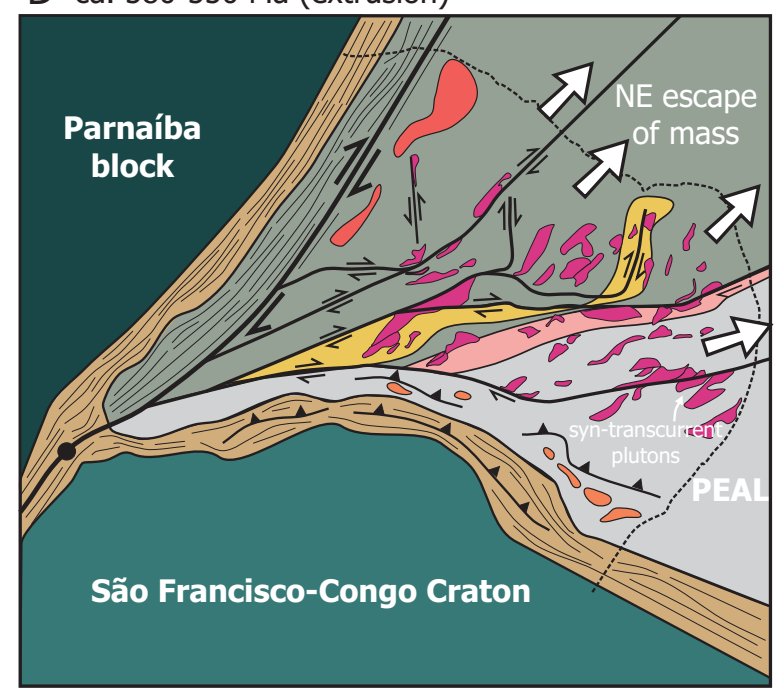

Figure 7.3 - Simplified Neoproterozoic tectonic evolution of the Borborema Province and adjoining regions. A. Position of main tectonic components of the region in the pre-collision I stage (ca. 800-650 Ma), based on Caby (1989), Pimentel and Fuck (1992), Brito Neves et al. (2000), Berger et al. (2011), Ganade de Araujo et al. (2012a,b), including the Cariris Velhos extensional event (Neves, 2003). The Parnaíba Block is inferred from geophysical evidence (de Castro et al., 2003) and is separated from the Amazonian-West-African Craton by the Gurupi and Araguaia volcano-sedimentary belts (Klein et al., 2005; Moura et al., 2008). Opening of the Sergipano Basin (>800 Ma) and continued rifting (ca. 700-640 Ma) separating the PEAL from the rest of the São Francisco-Congo Graton (Oliveira et al., 2010). B. Collision I (ca. 620-610 Ma) in the west, leading to the West Gondwana Orogen marked by HP and UHP metamorphism and anatexis of continental crust (BernardGriffiths et al., 1991; Agbossoumonde et al., 2001; Jahn et al., 2008; Fetter et al., 2003; Santos et al., 2009) and arc magmatism at the Sergipano Orogen due to initiation of subduction (Oliveira et al., 2010). C. Collision II (ca. 590-570 Ma) resulting from the closure of the Sergipano-Oubanguides Ocean and leading to thrusting of sedimentary rocks onto the craton, and development of inboard orogenic basins in the Borborema Province (e.g., Van Schmus et al., 2003), and syn-collisional magmatism (Bueno et al., 2009; Oliveira et al., 2010). Inversion of the Gurupi and Araguaia basins (Klein et al., 2005; Moura et al., 2008). D. Final craton indentation and northeastward extrusion stage (ca. 580-550 Ma) with development of major shear zones (Neves et al., 2012, Archanjo et al., 2013) emanating from the main Transbrasiliano-Kandi Strike-Slip Belt. White arrows: direction of mass escape. Dashed line: shore line. 


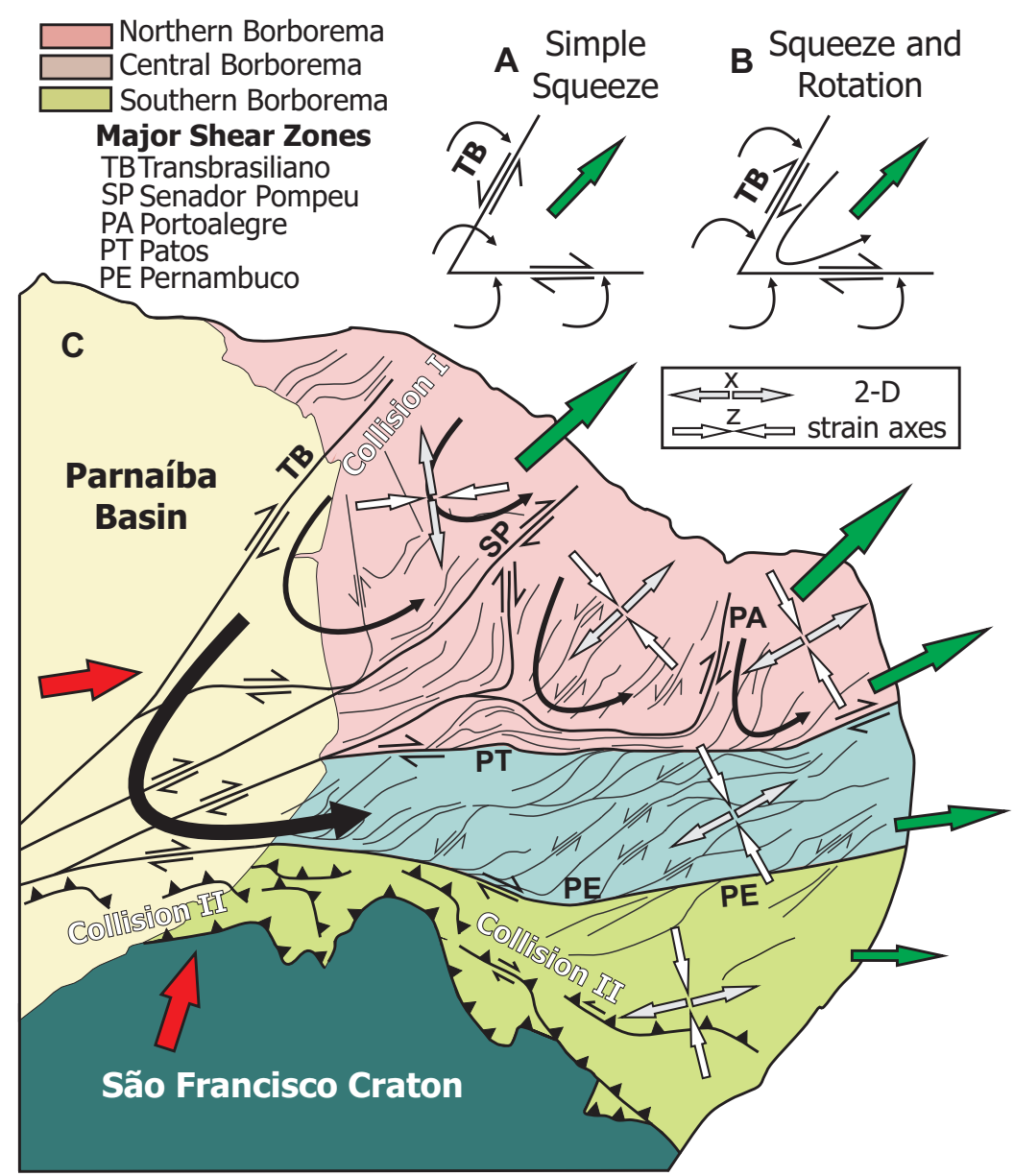

Figure 7.4 - Extrusion of Borborema Province. A. Simple squeezing model that requires sinistral movement of the Transbrasiliano shear zone after collision II. B. Squeezing and anticlockwise internal block rotation due to ductile deformation of the Borborema Province allowing northeast escape and dextral movement on the Transbrasiliano shear zone. C. Estimated orientations of 2-D strain axes for the different domains illustrating their counter-clockwise rotation from southeast to northwest. Borborema Province scale block rotation (black thick arrow) and domain-scale rotations (solid black arrows) illustrating east and northeast mass escape. Straight red gray arrows: relative movement direction at ca. 590-570 Ma. Straight green arrows: mass escape direction at ca. 590-570 Ma.

This strike-slip belt reactivated the previous sutures (e.g. Caby, 1989; Castaing et al., 1994), and the onset of dextral movement along it started possibly as early as 615 Ma soon after collision I. In our view, it may have functioned as a transform plate boundary allowing approximation of the Borborema Province to the São Francisco Craton, and leading to closure of the Sergipano Ocean and collision II (fig. 7.3).

Extrusion of the Borborema Province via a simple squeezing model after indentation of the São Francisco Craton requires a change from dextral to sinistral shear movement in the TKSSB (fig. 7.4A). This movement switch at ca. 590-580 Ma has not been documented, and therefore we suggest instead an anticlockwise block rotation of the Borborema Province in relation to the São Francisco Craton, associated with internal ductile deformation of its tectonic domains so as to maintain dextral shear sense along the TKSSB (fig. 7.4B). It is 
this rotation resulting from collision interference and cratonic indentation that triggered the inferred northeastward extrusion of Borborema Province.

\subsection{Conclusion}

We present the first attempt to integrate the tectonothermal and magmatic history of the Borborema Province within the 650-550 Ma timespan. Granitoid and migmatite ages indicate that its Neoproterozoic evolution started with an early collision associated with the closure of the large Goiás-Pharusian Ocean at 620-600 Ma and generalized crustal thickening, marked by the development of eclogites and high- $\mathrm{T}$ thrusting foliation defining the West Gondwana Orogen. The site of this collision was subsequently reactivated by a set of dextral shear zones, forming the Transbrasiliano-Kandi Strike Slip Belt, which acted as a transform plate boundary, allowing the closure of the restricted Sergipano Ocean and collision against São Francisco Craton at ca. 590 Ma. Interaction between the two collisions between 590 and $570 \mathrm{Ma}$ and continuous cratonic indentation led to the province-wide switch to transcurrent deformation and block escape generally to the NE, associated with province-wide magmatism and regional rotation of the maximum shortening axis.

\section{Acknowledgments}

Carlos E. Ganade de Araujo is indebted to Ticiano S. Santos who introduced him to the splendid geology of the BP in 2005 and to the Geological Survey of Brazil for continuous support throughout the time. Carlos E. Ganade de Araujo and Umberto G. Cordani are also grateful to FAPESP by the support through the grants 2005/58688-1 and 2012/00071-2. Eric Thover and two anonymous reviewers are thanked for their comments that helped to improve the manuscript. This is a contribution to the IGCP-628, Gondwana Map Project.

\subsection{References}

Alkmim, F.F., Marshak, S., Fonseca, M.A., 2001. Assembling West Gondwana in the Neoproterozoic: Clues from the São Francisco craton region, Brazil. Geology 29, 319-322.

Amaral, W.S., 2010. Análise geoquímica, geocronológica e geotermobarométrica das rochas de alto grau metamórfico adjacentes ao arco magmático de Santa Quitéria, NW da Província Borborema. PhD thesis, Universidade Estadual de Campinas, Campinas, 210 p.

Amaral, W.S., Santos, T.J.S., Wernick, E., Matteini, M., Dantas, E.L., Moreto, C.P.N., 2010. U-Pb, Lu-Hf and Sm-Nd geochronology of rocks from the Forquilha Eclogite Zone, Geará Central Domain, Borborema Province, NE-Brazil. In: VIISSAGI South American Symposium on Isotope Geology, 2010, Brasília.

Amaral, W.S. Santos, T.J.S, Wernick, E., Nogueira Neto, J.A., Dantas, E.L., Matteini, M., 2012. High-pressure granulites from Cariré, Borborema Province, NE Brazil: Tectonic setting, metamorphic conditions and $\mathrm{U}-\mathrm{Pb}, \mathrm{Lu}-\mathrm{Hf}$ and $\mathrm{Sm}-\mathrm{Nd}$ geochronology. Gondwana Research 22, 892-909.

Affaton, P., Kröner, A., Seddoh, K.F., 2000. Pan-African granulite formation in the Kabye Massif of northern Togo (West Africa): $\mathrm{Pb}-\mathrm{Pb}$ zircon ages. International Journal of Earth Sciences 88, 778-790.

Agbossoumonde', Y., Menot, R.P., and Guillot, S., 2001, Metamorphic evolution of Neo-proterozoic eclogites from south Togo (West Africa): Journal of African Earth Sciences 33, 227-244.

Araújo, M.N.C., Vasconcelos, P.M., Alves da Silva, F.C., Jardim de Sá, E.F., Sá, J.M., 2005. ${ }^{40}$ Ar $/{ }^{39}$ Ar geochronology of gold mineralization in Brasiliano strike-slip shear zones in the Borborema province, NE Brazil, Journal of South American Earth Sciences 19, 445-460. 
Carlos E. Ganade de Araujo - Tese de Doutorado - Universidade de São Paulo

Capítulo 7 - Extruding the Borborema Province

Archanjo, C.J., Fetter, A.H., 2004. Emplacement setting of the granite sheeted pluton of Esperança (Brasiliano orogen, northeastern Brazil). Precambrian Research 133, 193-215.

Archanjo, C.J., Launeau, P., Hollanda, M.H.B.M., Macedo, J.W.P., Liu, D., 2009. Scattering of magnetic fabrics in the Cambrian alkaline granite of Meruoca (Ceará state, northeastern Brazil). International Journal of Earth Sciences 98, 1793-1807.

Archanjo, C.J., Hollanda, M.H.B.M., Rodrigues, S.W.O., Brito Neves, B.B., Armstrong, R., 2008. Fabrics of pre- and syntectonic granite plutons and chronology of shear zones in the Eastern Borborema Province, NE Brazil. Journal of Structural Geology 30, 310-326.

Archanjo, G.J, Viegas, L.G.F, Hollanda, M.H.B.M., Souza, L.C., Liu, D., 2013. Timing of the HT/LP transpression in the Neoproterozoic Seridó Belt (Borborema Province, Brazil): Constraints from U $\mathrm{Pb}$ (SHRIMP) geochronology and implications for the connections between NE Brazil and West Africa. Gondwana Research 23, 701-714.

Arthaud, M.H., 2007. Evolução Neoproterozóica do Grupo Ceará (Domínio Ceará Central, NE Brasil): da sedimentação à colisão continental brasiliana. PhD thesis, Universidade de Brasília, Brasília, 170 pp.

Arthaud, M.H., Caby, R., Fuck, R.A., Dantas, E.L., Parente, G.V., 2008. Geology of the Northern Borborema Province, NE Brazil and its correlation with Nigeria, NW Africa. In: Pankhurst, R.J., Trouw, R.A.J., Brito Neves, B.B., De Wit, M.J. (Eds.), West Gondwana: Pre-Cenozoic Correlations Across the Atlantic Region. Geological Society, London, Special Publications 294, 49-67.

Bernard-Griffiths, J., Peucat, J.-J., Menot, R.-P., 1991. Isotopic Rb-Sr, U-Pb and Sm-Nd and trace element geochemistry of eclogites from the Pan-African belt: a case study of REE fractionation during high-grade metamorphism. Lithos 27, 43-57.

Brito Neves, B.B., Santos, E.J., Van Schmus, W.R., 2000. Tectonic history of the Borborema Province, NW Brazil. In: Cordani, U.G., Milani, E.J., Thomaz Filho, A., Campos, D.A. (Eds.), Tectonic Evolution of South America. Rio de Janeiro, pp. 151-182.

Brito, R.S.C., Vasconcelos, P.M., Dantas, E.D., Pimentel, M.M., Macambira, M.J.B., 2008. Ar-Ar Dating for the Braziliano Orogeny in the Soutern Alagoas Zone-Sergipano Belt. In: VI South American Symposium on Isotope Geology, 2008, San Carlos de Bariloche.

Berger, J., Caby, R., Liégeois, J.P., Mercier, J-C C., Demaiffe, D., 2011. Deep inside a Neoproterozoic intra-oceanic arc: growth, differentiation and exhumation of the Amalaoulaou Complex (Gourma, Mali). Contributions to Mineralogy and Petrology 162, 773-796.

Bueno, J.F., Oliveira, E.P., McNaughton, N., Laux, J.H., 2009. U-Pb dating of granites in the Neoproterozoic Sergipano Belt, NE-Brazil: implications for the timing and duration of continental collision and extrusion tectonics in the Borborema Province. Gondwana Research 15, 86-97.

Caby, R., 1989. Precambrian terranes of Benin Nigeria and Northeast Brazil and Late Proterozoic South Atlantic fit. Geological Society of America Special Paper 230, 145-158.

Caby, R., 2003. Terrane assembly and geodynamic evolution of central-western Hoggar: a synthesis. Journal of African Earth Sciences 37, 133-159.

Caby, R., Arthaud, M.H., 1986. Major Precambrian nappes of the Brazilian belt, Ceará, northeast Brazil. Geology 14, 871-874.

Castaign, C., Feybesse, J.L., Thiéblemont, D., Triboulet, C., Chèvremont, P., 1994. Palaeogeographical reconstructions of the Pan-African/Brasiliano orogen: closure of an oceanic domain or intracontinental convergence between major blocks? Precambrian Research 69, 327-344.

Castro, N.A., 2004. Evolução Geológica Proterozóica da região entre Madalena e Taperuaba, Domínio Tectônico Ceará Central (Província Borborema). PhD Thesis, Instituto de Geociências, Universidade de São Paulo, p.221.

Castro, N.A., Ganade de Araujo, C.E., Basei, M.A.S., Osako, L.S., Nutman, A., Liu, D., 2012. Ordovician A-type granitoid magmatism on the Ceará Central Domain, Borborema Province, NE-Brazil. Journal of South American Earth Sciences 36, 18-31. 
Carlos E. Ganade de Araujo - Tese de Doutorado - Universidade de São Paulo

Capítulo 7 - Extruding the Borborema Province

Cordani, U.G., Pimentel, M.M., Ganade de Araujo, G.E., Basei, M.A.S., Fuck, R.A., Girardi, V.A.V., 2013b. Was there an Ediacaran Clymene Ocean in central South America? American Journal of Sciences 313, 517-539.

Cordani, U.G., Pimentel, M.M., Ganade de Araujo, G.E.G., Fuck, R.A., 2013a. The significance of the TransbrasilianoKandi tectonic corridor for the amalgamation of West Gondwana. Brazilian Journal of Geology 43, 583-597.

Corsini, M., Figueiredo, L.L., Caby, R., Féraud, G., Ruffet, G., Vauchez, A., 1998. Thermal history of the PanAfrican/Brasiliano Borborema Province of northeast Brazil deduced from ${ }^{40} \mathrm{Ar} /{ }^{39} \mathrm{Ar}$ analysis. Tectonophysics 285, 103117.

de Castro, D.L.; Phillips, J.D., Fuck, A.R., Vidotti, R.M., Bezerra, F.H.R., 2013, Using airbourne gravity and magnetic data to recognize crustal domains concealed underneath the Parnaíba basin. In: 13 th International Congress of Brazilian Geophysical Society, 2013, Rio de Janeiro, Brazil.

Duclaux, G., Ménot, R.P., Guillot, S., Agbossoumondé, Y., Hilairet, N., 2006. The mafic layered complex of the Kabyé massif (north Togo and north Benin): Evidence of a Pan-African granulitic continental arc root, Precambrian Research 151, 101-118.

Ferreira, V.P., Sial, A.N., Pimentel, M.M., Armstrong, R., Spicuzza, M.J., Guimarães, I.P., Silva Filho, A.F., 2011. Contrasting sources and $\mathrm{P} / \mathrm{T}$ crystallization conditions of epidote-bearing granitic rocks, northeastern Brazil: $\mathrm{O}, \mathrm{Sr}$, and Nd isotopes. Lithos 121, 189-201.

Fetter, A.H., 1999. U/Pb and Sm/Nd geochronological constraints on the crustal framework and geologic history of Ceará State, NW Borborema province, NE Brazil: implications for the assembly of Gondwana. PhD Thesis, Department of Geology, Kansas University, Lawrence, KS - USA, p. 164

Fetter, A.H., Santos, T.J.S., Van Schmus, W.R., Hackspacher, P.G., Brito Neves, B.B., Arthaud, M.H., Nogueira Neto, J.A., Wernick, E., 2003. Evidence for Neoproterozoic continental arc magmatism in the Santa Quitéria Batholith of Ceará State, NW Borborema Province, NE Brazil: implications for the assembly of west Gondwana. Gondwana Research 6, 265-273.

Ganade de Araujo, G.E.G., 2011. A synthesis of the Neoproterozoic to Ordovician granitoid record from Ceará Central Domain, Borborema Province, NE-Brazil: precollision, collision and mountain belt collapse to a sedimentary basin development. In: 7th Hutton Symposium on Granites and Related Rocks, 2011, Avila, Spain

Ganade de Araujo, C.E., Cordani, U.G., Basei, M.A.S., Castro, N.A., Sato, K., Sproesser, W.M., 2012b.U-Pb detrital zircon provenance of metasedimentary rocks from the Ceará Central and Médio Coreaú domains, Borborema Province, NE-Brazil: Tectonic implications for a long-lived Neoproterozoic active continental margin. Precambrian Research 206207, 36-51.

Ganade de Araujo, G.E., Cordani, U.G., Basei, M.A.S., Sato, K., 2012a. Arc reworking during collision: combined LuHf LA-ICP-MS and U-Pb SHRIMP results from the Tamboril-Santa Quitéria Complex, NE Brazil In: Kositcin, N. and Bodorkos, S. (editors). 6th International SHRIMP Workshop - Program and Abstracts. Record 2012/52. Geoscience Australia, Canberra.

Ganade de Araujo, G.E.G., Pinéo, T.R.G., Gavalcante, J.G., Gosta, F.G., Moura, G.A.V., 2012c. Geochemistry and ${ }^{207} \mathrm{~Pb} /{ }^{206} \mathrm{~Pb}$ zircon ages of granitoids from the southern portion of the Tamboril-Santa Quitéria granitic-migmatitic complex, Geará central domain, Borborema province (NE Brazil). Journal of South American Earth Sciences 33, 21-33.

Ganade de Araujo, G.E.G., Pineo, T.R.G., Cavalcante, J.G., Caby, R., Costa, F.G., Vasconcelos, A.M., Rodrigues, J.B., 2010. Provenance of the Novo Oriente Group, southwestern Ceará Central Domain, Borborema Province (NE-Brazil): a dismembered segment of a magma-poor passive margin or a restricted rift related basin? Gondwana Research 18, 497513.

Guimarães, I.P., Da Silva Filho, A.F., Almeida, G.N., Macambira, M.J.B., Armstrong, R., 2011. U-Pb SHRIMP data constraints on calc-alkaline granitoids with 1.3-1.6 Ga Nd TDM model ages from the central domain of the Borborema province, NE Brazil. Journal of South American Earth Sciences 31, 383-396.

Guimarães, I.P., Da Silva Filho, A.F., Almeida, G.N., Van Schmus, W.R., Araújo, J.M.M., Melo, S.G., Melo, E.B., 2004. Brasiliano (Pan-African) granite magmatism in the Pajeú-Paraíba belt, Northeast Brazil: an isotopic and geochronological approach. Precambrian Research 135, 23-53. 
Hollanda, M.H.B.M., Archanjo, C.J., Souza, L.G., Armstrong, R., Vasconcelos, P.M., 2010. Cambrian mafic to felsic magmatism and its connections with transcurrent shear zones of the Borborema Province (NE Brazil): Implications for the late assembly of the West Gondwana. Precambrian Research 178, 1-14.

Jahn, B., Caby, R., Monie, P., 2008. The oldest UHP eclogites of the World: age of UHP metamorphism, nature of protoliths and tectonic implications. Chemical Geology 178, 143-158.

Klein, E.L., Moura, G.A.V., Krymsky, R.S., Griffin, W.L., 2005. The Gurupi Belt, northern Brazil: Lithostratigraphy, geochronology, and geodynamic evolution, Precambrian Research 141, 83-105.

Kröner, A., Cordani, U., 2003. African, southern Indian and South American cratons were not part of the Rodinia supercontinent: evidence from field relationships and geochronology. Tectonophysics 375, 325-352.

Long, L.E., Castellana, C.H., Sial, A.N., 2005. Age, origin and cooling history of the Coronel João Sá Pluton, Bahia, Brazil. Journal of Petrology 46, 255-273.

Magini, C. 2001. Evolução Pré-Cambriana da Província Borborema: O Extremo Oeste Potiguar. PhD Thesis, Universidade Estadual Paulista, 218p.

Mariano, G., Correia, P.B., Neves, S.P., Da Silva Filho, A.F., 2009. The high-K calcalkaline Alagoinhas pluton: anisotropy of magnetic susceptibility, geochemistry, emplacement setting and implications for the evolution of Borborema province, Northeast Brazil. International Geology Review 51, 502-519.

Monié, P., Caby, R., Arthaud, M.H., 1997. The neoproterozoic Brasiliano orogeny in northeast Brazil: ${ }^{40} \mathrm{Ar}{ }^{39} \mathrm{Ar}$ and petrostructural data from Ceará. Precambrian Research 81, 241-264.

Moura, G. A. V., Pinheiro, B. L. G., Nogueira, A. C. R., Gorayeb, P. S. S., and Galarza, M. A., 2008, Sedimentary provenance and paleoenvironment of the Baixo Araguaia Supergroup: constraints on the paleogeographical evolution of the Araguaia Belt and Assembly of West Gondwana, in: Pankhurst, R. J., Trouw, R. A. J., Brito Neves, B. B., and De Wit, M., editors, West Gondwana: Pre-Cenozoic Correlations Across the South Atlantic region: Geological Society, London, Special Publications, 294, 173-196.

Neves, S.P., 2003. Proterozoic history of the Borborema Province (NE Brazil): correlations with neighboring cratons and Pan-African belts, and implications for the evolution of western Gondwana. Tectonics 22, 1031.

Neves, S.P., Bruguier, O., Bosch, D., Silva, J.M.R., Mariano, G., 2008. U-Pb ages of plutonic and metaplutonic rocks in southern Borborema Province (NE Brazil): timing of Brasiliano deformation and magmatism. Journal of South American Earth Sciences 25, 285-297.

Neves, S.P., Bruguier, O., Silva, J.M.R., Delphine Bosch, D., Alcantara, V.C., Cristiane Marques Lima, C.M., 2009. The age distributions of detrital zircons in metased- imentary sequences in eastern Borborema Province (NE Brazil): evidence for intracontinental sedimentation and orogenesis? Precambrian Research 175, 187-205.

Neves, S.P., Bruguier, O., Vauchez, A., Bosch, D., Silva, J.M.R., Mariano, G., 2006.

Timing of crust formation, deposition of supracrustal sequences, and Transamazonian and Brasiliano metamorphism in the East Pernambuco belt (Borborema Province, NE Brazil): implications for western Gondwana assembly. Precambrian Research 149, 197-216.

Neves, S.P., Mariano, G., Guimarães, I.P., Silva Filho, A.F., Melo, S.C., 2000. Intralithospheric differentiation and crustal growth: Evidence from the Borborema Province, northeastern Brazil. Geology, 28, 519-522.

Neves, S.P., Melo, S.C., Moura, G.A.V., Mariano, G., Silva, J.M.R., 2004. Zircon Pb-Pb geochronology of the Caruaru area, northeastern Brazil: temporal constraints on the Proterozoic evolution of Borborema Province. International Geology Review 46, 52-63.

Neves, S.P., Monié, P., Bruguier, O., da Silva, J.M.R., 2012. Geochronological, thermochronological and thermobarometric constraints on deformation, magmatism and thermal regimes in eastern Borborema Province (NE Brazil). Journal of South American Earth Sciences 38, 129-146. 
Carlos E. Ganade de Araujo - Tese de Doutorado - Universidade de São Paulo

Capítulo 7 - Extruding the Borborema Province

Nogueira, J.F., 2004. Estrutura, geocronologia e alojamento dos batólitos Quixadá, Quixeramobim e Senador Pompeu Ceará Central. PhD Thesis, Universidade Estadual Paulista, 123p.

Oliveira, E.P., Windley, B.F., Araújo, M.N.G., 2010. The Neoproterozoic Sergipano orogenic belt, NE Brazil: a complete plate tectonic cycle in western Gondwana. Precambrian Research 181, 64-84.

Pimentel, M.M., Fuck, R.A., 1992. Neoproterozoic accretion in Central Brazil. Geology 20, 375-379.

Santos, T.J.S., Garcia, M.G.M., Amaral, W.S., Wernick, E., Dantas, E.L., Arthaud, M.H., Caby, R., Santosh, M., 2009. Relics of eclogite facies assemblages in the Ceará Central Domain, NW Borborema Province, NE Brazil: implications for the assembly of West Gondwana. Gondwana Research 15, 454-470.

Sengör, A.M.C., Görür, N., Aroglu, F., 1985. Strike-slip faulting and related basin formation in zones of tectonic escape: Turkey as a case study. In: Biddle, K.T., Christie-Blick, N. (Editors), Strike-Slip Faulting and Basin Formation: Society of Economic Paleontologists and Mineralogists, Special Publications 37, 227-267.

Souza, Z.S., Montel, J.M., Gioia, S.M.L.C., Hollanda, M.H.B.M., Nascimento, M.A.L., Jardim de Sá, E.F., Amaro, V.E., Pimentel, M., Lardeaux, J.M., Veschambre, M., 2006. Eletron micropobe dating of monazite from high-T shear zones in the São José de Campreste Massif, NE Brazil. Gondwana Research 9, 441-455.

Tapponier, P., Peltzer, G., Le Dain, A.Y., Armijo, R., Cobbold P., 1982. Propagating extrusion tectonics in Asia: new insights from simple experiments with plasticine. Geology 10, 611-616.

Teixeira, M.L.A., 2005 Integração de dados aerogeofísicos, geológicos e isotópicos do limite norte do Complexo Tamboril Santa Quitéria- CE (Província Borborema). Msc. Dissertation, Universidade de Brasília, Brasilia-DF, p. 91.

Tohver E., Cawood P.A., Rossello E.A., Jourdan F., 2012. Closure of the Clymene Ocean and formation of West Gondwana in the Cambrian: Evidence from the Sierras Australes of the southernmost Rio de la Plata craton, Argentina. Gondwana Research 21, 193-222.

Trindade, R.I., D'Agrella-Filho, M.S., Epof,I., Brito Neves, B.B., 2006. Paleomagnetism of Early Cambrian Itabaiana mafic dikes (NE Brazil) and the final assembly of Gondwana. Earth and Planetary Science Letters 244, 361-377.

Trompette, R., 1994, Geology of Western Gondwana, Pan-African (2000-500 Ma)-Pan-African Brasiliano Aggregation of South America and Africa: Rotterdam, A. A. Balkema, 350 p.

Van Schmus, W.R., Brito Neves, B.B., Hackspacher, P., Babinski, M., 1995. U/Pb and Sm/Nd geochronologic studies of the eastern Borborema Province, northeastern Brazil: initial conclusions. Journal of South America Earth Sciences 8, 267-288.

Van Schmus, W.R., Brito Neves, B.B., Williams, I.S., Hackspacher, P., Fetter, A.H.,Dantas, E.L., Babinski, M., 2003. The Seridó Group of NE Brazil, a late Neoproterozoic pre- to syn-collisional basin in West Gondwana: insights from SHRIMP U-Pb detrital zircon ages and Sm-Nd crustal residence (TDM) ages. Precambrian Research 127, $287-327$.

Van Schmus, W.R., Oliveira, E.P., Silva Filho, A.F., Toteu, F., Penaye, J., Guimarães, I.P.,2008. Proterozoic links between the Borborema Province, NE Brazil, and the Central African Fold Belt. Geological Society, London, Special Publications 294, 69-99.

Vauchez, A., S. P. Neves, R. Caby, M. Corsini, M. Egydio-Silva, M. H. Arthaud, and V. Amaro, 1995. The Borborema shear zone system, NE Brazil. Journal of South American Earth Sciences 8, 247-266.

Weinberg, R.F., Sial, A.N., Mariano, G., 2004. Close spatial relationship between plutons and shear zones. Geology 32, $377-380$ 
Carlos E. Ganade de Araujo - Tese de Doutorado - Universidade de São Paulo Capítulo 8 - Ediacaran megamoutains

\title{
8. Ediacaran megamountains: evidence for $>2500-\mathrm{km}$-long deep continental subduction in the West Gondwana Orogen
}

\author{
Garlos E. Ganade de Araujo*1,2, Daniela Rubatto ${ }^{3}$, Joerg Hermann³, Umberto G. Cordani², Renaud
}

Caby $^{4}$, Miguel A.S. Basei ${ }^{2}$

\author{
${ }^{1}$ Geological Survey of Brazil, Fortaleza-CE, Brazil \\ ${ }^{2}$ Universidade de São Paulo, Sao Paulo-SP, Brazil \\ ${ }^{3}$ Research School of Earth Sciences, Australian National University, 0200 Canberra, Australia \\ ${ }^{4}$ Universite de Montpellier II, Montpellier, France
}

\begin{abstract}
The 5000-km-long, deeply eroded West Gondwana Orogen (WGO) is a major continental collision zone that exposes numerous occurrences of deeply subducted rocks (i.e. eclogites) along its strike. The position of these eclogites marks the suture zone between colliding cratons and the age of metamorphism constrains the transition from subduction-dominated tectonics to continental collision and mountain building. Here we investigate the metamorphic conditions and age of ultrahigh-pressure (UHP) eclogites from three key localities within the WGO in Mali, Togo and NE-Brazil by coupled U-Th-Pb and rare earth element zircon analyses. Protracted tectonic evolution in the WGO and synchronicity of UHP metamorphism indicate that continental subduction occurred simultaneously over at least $2500 \mathrm{~km}$ during the Ediacaran period (620-610 Ma). We consider this to be the first record of modern, Himalayan-scale deep-continental subduction and the consequent appearance of megamountains in the geological record. The formation of these megamountains $\mathrm{c}$. 40 m.y. before the explosion of Life in the Late Ediacaran is perfectly timed to deliver by erosion the sediments (nutrients) that have been deemed necessary for Life evolution.
\end{abstract}

\subsection{Introduction}

In rare cases, the buoyant continental crust is subducted to ultrahigh-pressure (UHP) conditions (i.e. depth > $90 \mathrm{~km}$ ) and exhumed back to the surface. It is has been recently recognised that exhumed UHP rocks derive from subducted continental margins, where the cold and dense slab of oceanic crust pulls the attached continental crust to mantle pressures (Beltrando et al., 2010, Hacker et al., 2013, Gilotti, 2013). These UHP rocks are exhumed during the collision that immediately follows subduction of the margin - within 2-30 m.y. at rates of $\mathrm{cm}$ to mm/year (e.g. Rubatto and Hermann 2001, Kylander Clarke et al., 2012). Deep subduction of felsic continental crust leads to collisional zones with deep roots that consist of material with a density lower than mantle rocks (Austrheim, 1991, Gilotti, 2013). This density contrast produces an isostatic rebound that gives rise to significant topographic relief (Fischer, 2002; Burov and Toussaint, 2007). Indeed, most UHP rocks are exposed within large mountains belts like the present Alps and the Himalayas or the now-eroded Paleozoic orogenies (Gilotti, 2013). Therefore, the finding of rocks that underwent relatively low temperatures and HP to UHP conditions is a tracer not only for paleo subduction zones (sutures), but also for large mountain edifices.

UHP crustal rocks appear relatively late in the Earth's history. The oldest coesite-bearing eclogite is c. $620 \mathrm{Ma}$ old and is found in Mali (Caby, 1994; Jahn et al., 2001), which is part of the West Gondwana Orogen. It has been argued that the first appearance of such low-temperature - high-pressure rocks during the Neoproterozoic marks the onset of modern plate tectonics dominated by the subduction of very cold slabs 
(Stern, 2005; Brown, 2008). During the Neoproterozoic Era and particularly the Ediacaran Period (635-542 $\mathrm{Ma}$ ), Earth and Life underwent significant changes with the rise of the metazoans (Waggoner, 2003) and increase in atmospheric $p \mathrm{O}_{2}$ to the presently known levels (Canfield et al., 2007). It has been argued that major rises in athospheric $p \mathrm{O}_{2}$ throughout the Earth history (the largest in absolute amount of oxygen added occurred at c. 600-570 Ma) are linked to massive supply of sediments from mountain belts that were produced during the amalgamation of supercontinents (Campell and Allen, 2008). The existence of such mountain belts in the Ediacarian period was postulated on the chronology of sediments and rare metamorphic rocks (Squire et al., 2008, Campbell and Squire 2010). However, key factors for the model such as the exact timing and spatial distribution of the change from subduction- to collision-dominated tectonics, and the size of the mountain belt have not been constrained.

In this article, we investigate the timing and metamorphic conditions of UHP rocks from three key localities distributed along the West Gondwana Orogen and compile the magmatic and sedimentary record of this vast collision zone. We argue that the simultaneous age of subduction of the continental margin marks the onset for the formation of the first large mountain chain (megamountains) similar in size to the Himalayas and we discuss potential consequences for the evolution of Life on Earth.

\subsection{The West Gondwana Orogen (WGO)}

The Neoproterozoic West Gondwana Orogen (WGO) (fig. 8.1) is a linear belt that extended for more than $5000 \mathrm{~km}$ from nowadays northeast Africa to Central Brazil (Caby, 1989, Cordani et al., 2013). Modern views suggest that this orogen resulted from the consumption and closure of the Goiás-Pharusian Ocean (Caby, 2003; Cordani et al., 2013) that culminated in a continent-continent collision involving mainly the conjoined Amazon and West African cratons against the São Francisco-Congo and Saharan cratons (fig. 8.1A). The rocks involved in this orogen record long-lived, accretionary convergent tectonics since the Early Neoproterozoic with development of several intra-oceanic and continental arcs that are now preserved within a deeply eroded, fossil collisional zone (Pimentel and Fuck, 1992; Caby, 2003; Berger et al., 2011; Ganade de Araujo et al. 2012). The orogen has a protracted tectonic history (up to 400 m.y., fig. 8.1) from the inception of oceanic arc-related juvenile magmatism at ca. $850 \mathrm{Ma}$ to terminal continental collision at c. 615-610 Ma, to Molasse deposition and post-collisional granites at 550-500 Ma. The orogen can be subdivided into four different sectors (fig. 8.1C) that all have key features that are observed in modern collision zones such as the Alps and the Himalayas. Ophiolites represent remnants of oceanic crust that once separated the continental blocks and they can be found as elongated units within the suture zone, as exemplified by the Bou Azzer ophiolite in Morocco (El Hadi et al., 2010). The dominant rock types between the cratonic blocks are passive margin deposits, early (juvenile) and late arc-related rock assemblages and syn-orogenic supracrustal sequences. The erosion of mountains that resulted from the collision is documented in molasses and foreland sedimentary deposits and the termination of orogenic activity is dated by the age of post-collisional granitoids at ca. $540 \mathrm{Ma}$ (Caby, 2003; Ganade de Araujo et al., 2012). 
Carlos E. Ganade de Araujo - Tese de Doutorado - Universidade de São Paulo Capítulo 8 - Ediacaran megamoutains

\subsection{Deep subduction in the West Gondwana Orogen}

One main characteristic of the WGO is the existence of several mafic-ultramafic massifs containing relics of UHP/HP metamorphism [fig. 8.1, Agbossoumondé et al., 2001; Jahn et al., 2001; Santos et al., 2009).
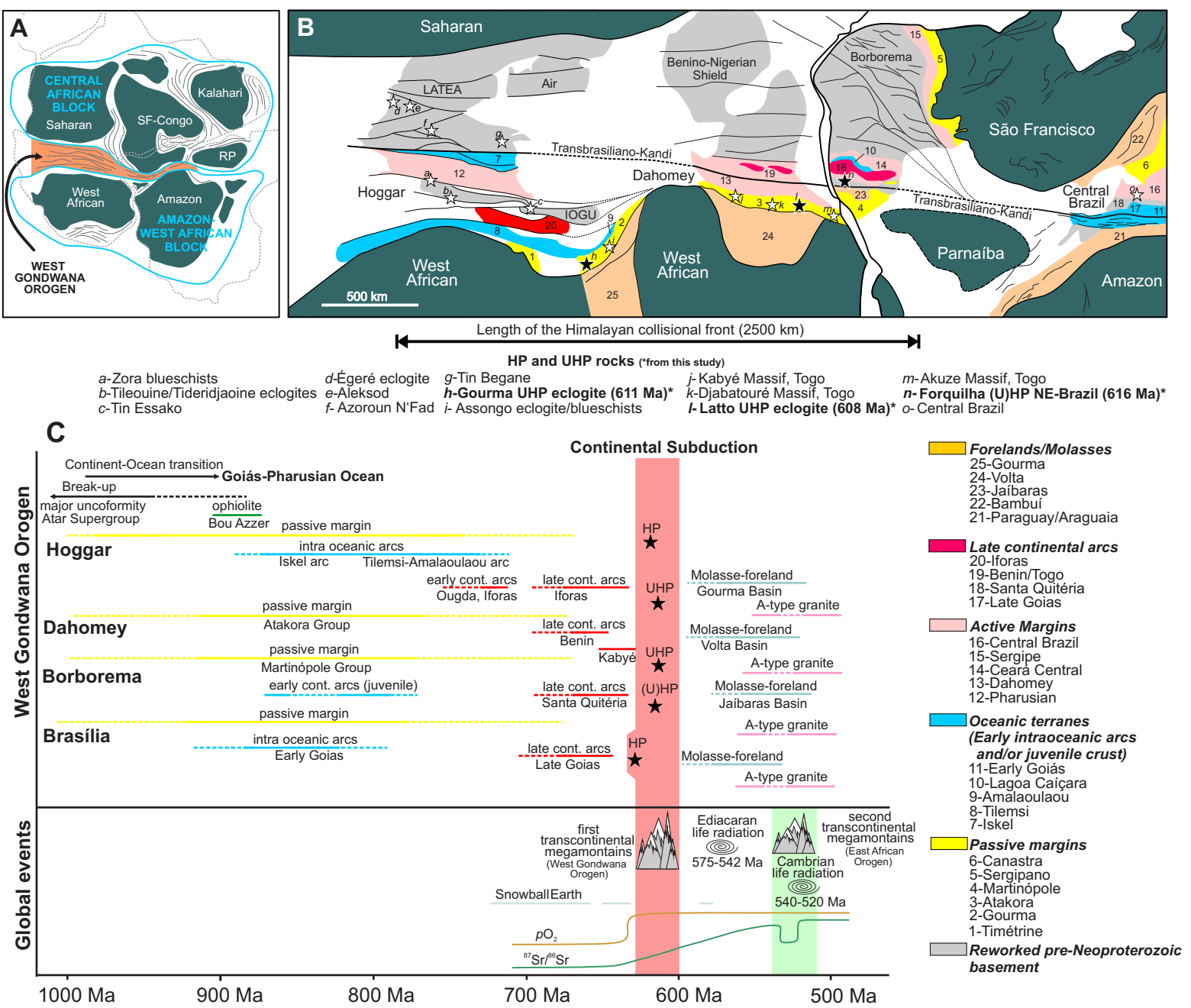

Figure 8.1 - A. Main cratons and tectonic blocks involved in the formation of the collisional West Gondwana Orogen. B. Spatial distribution of HP and UHP rocks and main lithotectonic assemblages in the 5000-km-long collisional orogen. C. Temporal distribution of the main lithotectonic units along each sector of the orogen together with main global events. Sr-isotope values for sea water after Veizer (1989) and $\mathrm{pO}_{2}$ after Canfield et al. (2007). Timing of pre-collision geological events are mostly based on Pimentel (1992), Caby (1989), Caby (2003), Ganade de Araujo et al. (2012).

In order to constrain the geochronological and petrological record of HP and UHP rocks across the WGO we investigated eclogitic samples from Mali (S-506), Togo (DKE-350) and NE-Brazil (DKE-107) using a coherent approach. Eclogites from Mali and Togo are interlayered with UHP/HP quartzites from passive margin deposits (Jahn et al., 2001; Agboussomondé et al., 2001). They preserve a fresh peak paragenesis of garnet, omphacite, phengite, coesite/quartz and accessory rutile (Fig. 2). Thermobarometric calculations for the peak eclogitic conditions were performed using a set of pressure sensitive net-transfer equilibria coupled with $\mathrm{Fe}-\mathrm{Mg}$ exchange thermometry for the assemblage omphacite-garnet-phengite (Ravna and Terry, 2004) combined 
with Zr-in-rutile (Tomkins et al., 2007) and Ti-in-zircon (Watson et al., 2006) thermometers (see details in Supplementary Figure 8.1 and Tables S1 and S2).

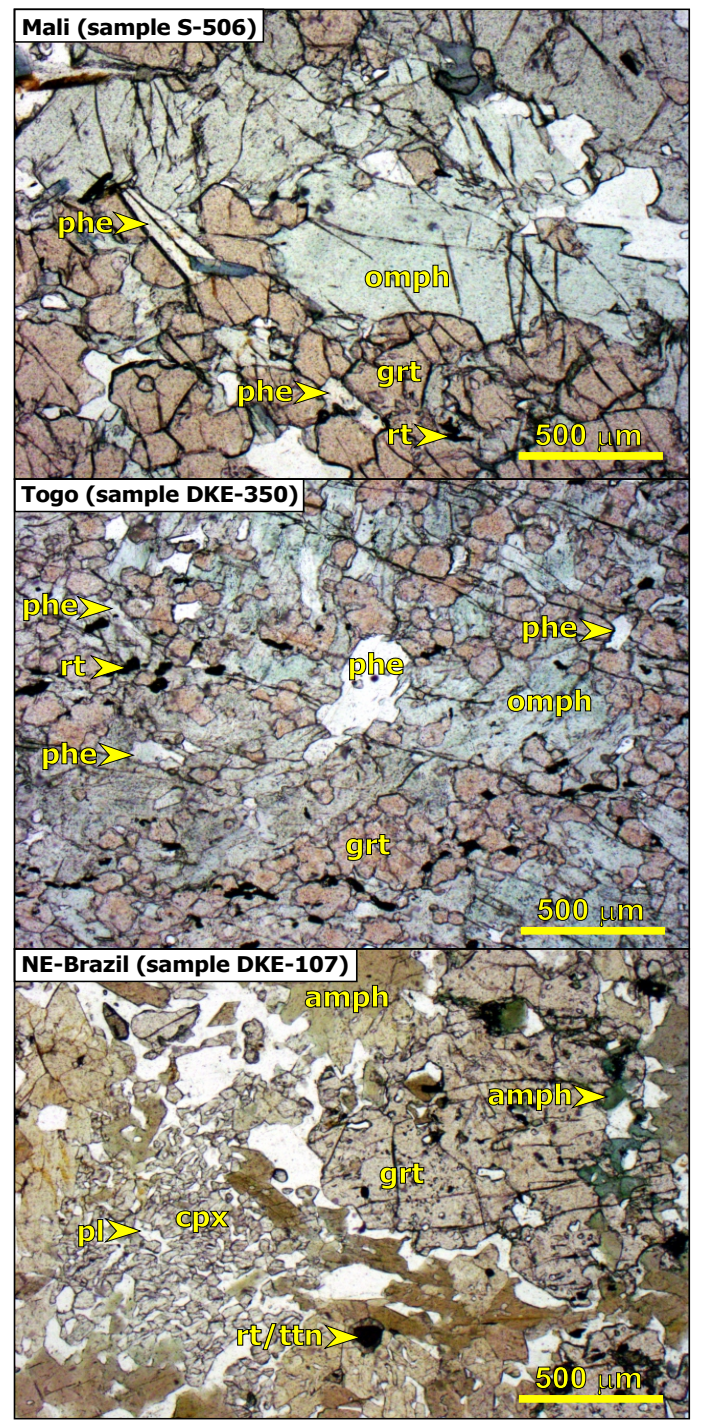

Figure 8.2 - Photomicrographs (polarized light) of the investigated samples. Eclogites from Mali and Togo exhibit phase equilibria among garnet (grt), omphacite (omph), phengite (phe) and rutile (rt). Retrogressed eclogites from NE-Brazil have abundant amphibole (amph), garnet and simplectic clinopyroxene (cpx) - plagioclase (pl) resulting from the breakdown of former omphacite. In this sample rutile is often rimed by titanite (ttn).

To calculate the peak-pressure condition we selected phases with petrographic evidence of equilibrium among omphacite with the highest jadeite content, garnet with highest grossular and pyrope contents, and phengite with the highest Si content, as proposed by Ravna and Terry (2004). Uncertainties are presented as stated by the authors.

Peak P-T condition in the Gourma region (Mali) was retrieved from an omphacite-garnet-phengite quartzite (sample S-514), which occurs in contact with the eclogites. Thermobarometric calculations using omphacitegarnet-phengite yielded a P-T range of $3.0-3.3 \mathrm{GPa}( \pm 0.3 \mathrm{GPa})$ and $690-705^{\circ} \mathrm{C}\left( \pm 65^{\circ} \mathrm{C}\right)$ (fig. 8.3). Metamorphic zircons in the UHP Mali eclogite have 6-26 ppm Ti, corresponding to Ti-in-zircon temperatures of $700-830^{\circ} \mathrm{C}$ with a mean temperature of $720 \pm 20^{\circ} \mathrm{C}$ in concordance with a mean $\mathrm{Zr}$-in-rutile temperature of $740 \pm 35^{\circ} \mathrm{C}$. These metamorphic conditions are consistent with the rare occurrence of coesitebearing eclogites and testify UHP conditions for this area, indicating subduction of the Gourma passive margin to depths of $>100 \mathrm{~km}$ (Caby, 1994). 
Further south, in the Dahomey segment (Togo), UHP and HP eclogitic and granulitic rocks are exposed in the Latto region (Agbossoumondé et al., 2001). For the Togo eclogite, calculations indicate a P-T condition in the range of $2.8-3.0 \mathrm{GPa}( \pm 0.3 \mathrm{GPa})$ and $620-700^{\circ}\left( \pm 65^{\circ} \mathrm{C}\right)$ (fig. 8.3). Ti-in-zircon temperatures range from 640 to $760^{\circ} \mathrm{C}$ with a mean temperature of $680 \pm 20^{\circ} \mathrm{C}$, which is in agreement with the mean temperature of $\mathrm{Zr}$-inrutile of $720 \pm 30^{\circ} \mathrm{C}$. Although no coesite relics have been found so far in Togo, calculated P-T conditions are well within the coesite stability field, suggesting UHP metamorphism.

Eclogites from NE-Brazil are found as boudins within high-T partially melted metasedimentary rocks (Santos et al., 2009). As a consequence, they are intensely retrogressed and composed of garnet, Ca-rich pyroxene, hornblende and symplectite of Na-augite and plagioclase. From the composition of relic phases, a minimum P-T conditions for the decompression stage of $1.7 \mathrm{GPa}$ and $770^{\circ} \mathrm{C}$ have been established (Santos et al., 2009), however recent finds of coesite inclusion in garnet from the same area examined here suggests UHP metamorphism (Santos et al. 2013). In the investigated sample DKE 107, zircon displays striking similarities in age and composition to the zircon retrieved from the UHP rocks. Ti-in-zircon temperatures yield a mean temperature of $700 \pm 15{ }^{\circ} \mathrm{C}$ for type- 1 and $690 \pm 15{ }^{\circ} \mathrm{C}$ for type-2 zircons (see below). The mean Zr-in-rutile temperature of $790 \pm 35{ }^{\circ} \mathrm{C}$ are slightly higher than those recorded by Ti-in-zircon, potentially recording increasing temperature during decompression form the eclogite to the granulitic stage.

In Hoggar, the ca. $620 \mathrm{Ma}$ Tideridjaouime-Tileouine HP metamorphic belt $\left(550-600^{\circ} \mathrm{C}, 1.4-1.8 \mathrm{GPa}\right)$ represents a slab of subducted continental material exposed along the edge of the IOGU terrane, which has been interpreted as a microcontinent (Caby and Monie, 2003). In the southern LATEA terrane, the Tin Begane eclogite $\left(790^{\circ} \mathrm{C}, 1.5 \mathrm{GPa}\right)$ is preserved as boudins within the thrust zone of an allochthonous supracrustal sequence (Boughrara, 1999). The Azroun N'Fad eclogite represents the deepest unit within LATEA terrane owing to the highest pyrope content of relict garnet (up to $44 \%$ ), with a decompression path from 1.5 to 1.1 GPa between 800 and $700^{\circ} \mathrm{C}$ (Zetounou et al., 2004).

\subsection{Timing of deep continental subduction}

The UHP samples investigated contain zircons that were imaged by cathodoluminescence to show internal zoning, dated by the U-Pb method with a Sensitive High Resolution Ion Microprobe (SHRIMP) and characterised for their trace element composition by Laser Ablation Inductively Coupled Plasma Mass Spectrometer (LA-ICP-MS) (analytical methods in Appendix).

The zircon crystals from the Mali and Togo eclogite are composed of relict cores and metamorphic rims and minor rounded homogeneous zircons. The cores show regular zoning (fig. 8.4) and high $\mathrm{Th} / \mathrm{U}(0.5-0.4)$ and rare earth element (REE) contents. The zircon REE pattern is enriched in heavy-REE and shows a marked negative Eu-anomaly (fig. 8.4). All these features indicate a magmatic origin (Rubatto, 2002). The zircon cores from the Mali eclogite are severely discordant and yield spurious individual ages (Supplementary table S3), which suggest partial resetting of the U-Pb system. An upper discordia intercept points to a protolith age of $>1.0 \mathrm{Ga}$. For the Togo eclogite the zircon cores yield a protolith age of 703.2 $\pm 8.1 \mathrm{Ma}$. 
The zircon rims in the Mali and Togo eclogite show a distinct internal texture, chemistry and age. They have weak or no zoning, low REE contents with flat HREE in the Mali sample and steep to flat HREE in the Togo

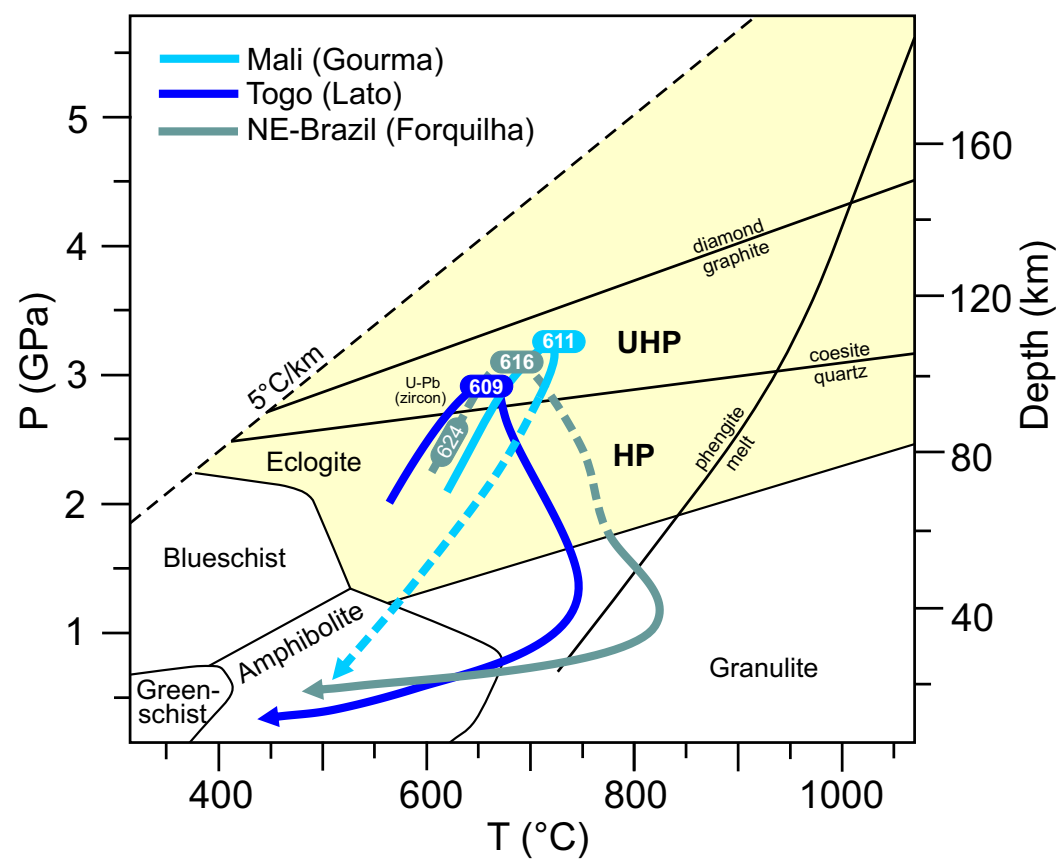

Figure 8.3 - Pressure-temperature diagram comparing P-T paths (dashed curves are inferred) for the HPUHP terranes from Mali, Togo and NE-Brazil. Peak metamorphic conditions are discussed in the text and data are available in the electronic appendix. No geothermobarometric information is available for the retrograde P-T path in Mali, but petrographic (Caby, 1994) and geochronological (Jahn et al., 2001) evidence suggests rapid exhumation without passing through the granulite field. Geothermobarometric data from Lato terrane (Agbossoumondé et al., 2001) indicate a retrograde path through granulite facies (1.0-0.8 GPa and $\left.700-750^{\circ} \mathrm{C}\right)$ and later amphibolite facies $\left(0.6-0.4 \mathrm{GPa}\right.$ and $\left.500-600^{\circ} \mathrm{G}\right)$. Minimum calculated P-T condition from NE-Brazil for the retrogression $\left(1.7 \mathrm{GPa}\right.$ and $\left.770^{\circ} \mathrm{C}\right)$ was followed by a granulitic stage $(1.4 \mathrm{GPa}$ and $\left.870^{\circ} \mathrm{C}\right)$ and then an amphibolitic stage at $\left(0.5-0.75 \mathrm{GPa}\right.$ and $\left.530-700^{\circ} \mathrm{C}\right)$ (Santos et al., 2009).

sample. In contrast to the cores, the zircon rims commonly have lower Th/ $\mathrm{U}$ (mostly 0.01-0.09) and no significant Eu-anomaly. Depletion of HREE together with the lack of negative Eu-anomaly indicates that these zircons have grown in the presence of garnet and in the absence of plagioclase (Rubatto, 2002). This mineral assemblage is diagnostic of eclogite-facies conditions. For the Togo zircons, the decreasing HREE+Y content and increasing $\mathrm{Eu} / \mathrm{Eu}^{*}$ (fig. 8.3 inset) is consistent with zircon rim growth over increasing garnet modal abundance, as expected during prograde metamorphism. For the Mali samples 15 analyses yield a

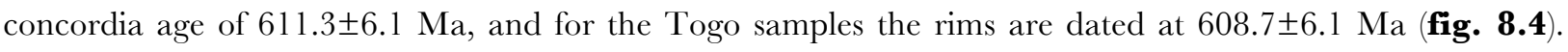
Since individual zircon domains that grew during prograde to peak metamorphism in the Togo sample show no age difference within the analytical resolution (c. $12 \mathrm{Ma}$ ) a rapid tectonic burial rate can be inferred for the Togo eclogite.

Zircons from the NE-Brazil eclogite have rare magmatic cores and two distinct metamorphic domains. The texturally older metamorphic domain is U-poor, is commonly rounded and displays no internal structure (type 1 in fig. 8.2). The texturally younger, U-richer domain shows weak or no zoning (type 2). Type-1 zircon is HREE enriched and middle-REE depleted when compared with the type-2 zircon, which has a flat HREE pattern with no negative Eu-anomaly, similar to the eclogite-facies zircon rims from Togo and Mali. The 
Carlos E. Ganade de Araujo - Tese de Doutorado - Universidade de São Paulo Capítulo 8 - Ediacaran megamoutains
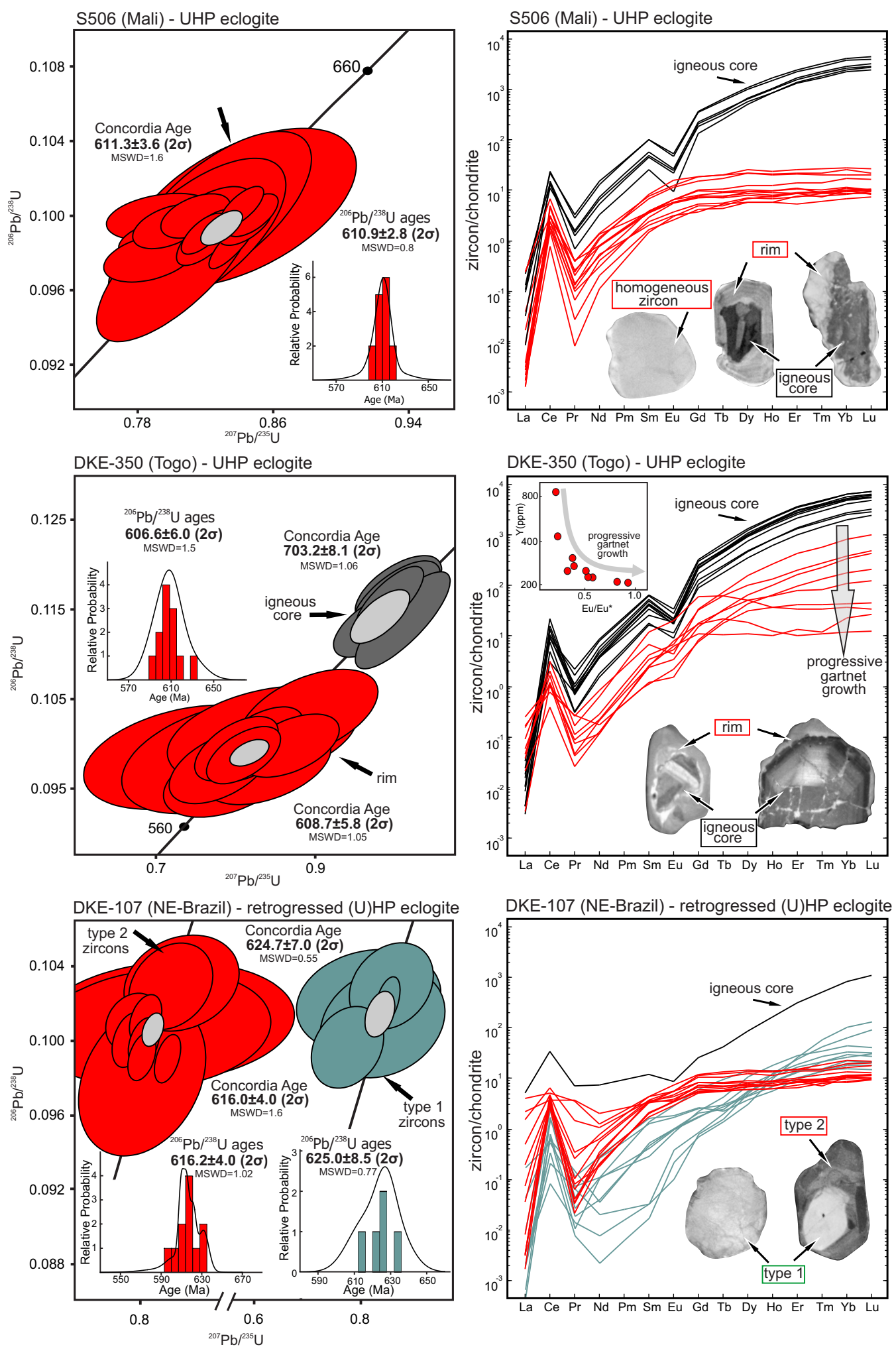

Figure 8.4 - Left: Wetherill Concordia plots of the U-Pb zircon data. Ellipse colours reflect zircon growth domains as defined by zoning and REE composition. Grey ellipse represents the Concordia age. Right: Internal structure of the zircons revealed by cathodoluminescence and rare earth element (REE) composition (chondrite-normalised patterns) for each zircon type. 
significant change in REE pattern is attributed to MREE-rich titanite breaking down to rutile and increasing garnet growth during burial to (U)HP conditions. The two chemically different zircon domains yield ages that are within error, but support their textural relationships: the inner, U-poor rims is $624.7 \pm 7.0$ Ma old ( $\mathrm{n}=5$, 2sigma) while the outer rim is dated at $616.0 \pm 6.1 \mathrm{Ma}$.

\subsection{The West Gondwana megamountains and implications for the Ediacaran Earth}

The P-T determinations for the Mali and the Togo sample provide evidence for subduction of a continental margin to UHP conditions. The metamorphic zircon domains in the HP/UHP rocks from Mali, Togo and NE-Brazil have a trace element composition indicating growth at high-pressure conditions (flat HREE pattern and no negative Eu-anonaly). In the Togo and NE-Brazil samples, zircon growth also occurred during prograde metamorphism and burial. The geochronological data (forced to $1 \%$ to account for external errors) from the Mali (611 $\pm 6 \mathrm{Ma})$, Togo $(609 \pm 6 \mathrm{Ma})$ and NE-Brazil (616 $\pm 6 \mathrm{Ma})$ eclogites indicates contemporaneous subduction in these localities of the WGO. Although precise geochronological control is missing in the eclogites of Hoggar, the protracted geological evolution of this sector (fig. 8.1) is similar to that of other sectors where timing for eclogite metamorphism is better constrained. Overall this record indicates that subduction, and the continental collision that followed, occurred simultaneously along at least $2500-\mathrm{km}$ of the WGO (fig. 8.1).

This is a unique scenario in the Ediacaran Earth comparable in size to the modern Himalayan continental collision. While small UHP units can initially be exhumed by tectonic forces, continental collision that follows UHP subduction of continental margins give rise to significant relief (Fischer, 2002; Burov and Toussaint, 2007). Relief is the primarily regulator of erosion rate. This dynamic is best documented in present mountain belts. In the Alps, the raise of the mountains is related to the continental collision, immediately following the subduction of the European continental margin at c. 35 Ma (Rubatto and Hermann, 2001; Beltrando et al. 2010). In the Himalayas, UHP metamorphism is dated at c. 50 Ma (Leech et al. 2005) providing evidence that a high relief can be sustained for at least $50 \mathrm{~m}$.y. postdating subduction of the continental margin.

The high mountain relief produced as a result of the Himalayan-scale continental subduction and collision along the WGO in the Late Ediacaran (615-610 Ma) has the appropriate time to shed sediments vital to the rise of the metazoans at ca. 600-575 Ma. We propose that a high-altitude mountain range existed in the WGO in the period 610-560 Ma and was, therefore, most susceptible to surface erosion. In the Himalayan collisional orogen, 4-5 km thick deltaic sediments extending over $3000 \mathrm{~km}$ into the Indian Ocean were deposited over the last 7 m.y., in the late-stage exhumation of the orogen (Yin, 2006). The sink for the detritus related to the dissection of the WGO collisional chain is preserved within basins that records the transition from a rifted passive margin to fully developed foreland basins (fig. 8.1), usually to the west of the orogen. The best examples are the Gourma and Taoudeni basins (Bertrand-Sarfati et al., 1995) in Algeria and Mali, the upper portion of the Volta Basin (Carney et al., 2010) in Togo and Ghana and the Paraguay Basin in Central Brazil where Ediacaran biota have been described (Warren et al., 2012). The Ediacaran sedimentary rocks in South America are also masked by younger sedimentary cover, however evidence from the Parecis basin in the 
southwestern portion of the Amazon craton suggest that the extent of the Ediacaran forelands can be larger than previously though (Vasconcelos et al., in press).

Based on the oldest known UHP rocks in Mali (Jahn et. al., 2001), it has been proposed that this time marks the onset of modern plate tectonics (Stern, 2005; Brown, 2008). Here we show that deep and cold subduction of continental crust occurred simultaneously over a distance of at least $2500 \mathrm{~km}$ and thus is a key characteristic of the West Gondwana Orogen. The appearance of this first megamountains in the geological record at ca. $610 \mathrm{Ma}$ is followed by remarkable biological, climatic and geochemical turnovers, including the radiation of life in the Late Ediacaran to Early Cambrian periods (ca. 600-575 to $510 \mathrm{Ma}$ ).

A number of authors have recognized that nutrients such as $\mathrm{P}, \mathrm{Ca}, \mathrm{K}, \mathrm{Fe}, \mathrm{Mg}, \mathrm{Zn}$ and Mo from continental sediments are essential to sustain complex life forms (Brasier, 1990). Ediacaran and Cambrian life radiation was also aided by increased oxygen in the atmosphere and oceans (Canfield et al., 2007). Environmental conditions suitable for life radiation was strongly influenced by high and rapidly increasing rates of sediment accumulation and subsidence associated with amalgamation of the Gondwana supercontinent (Brasier and Lindsay, 2001). The systematic increase of ${ }^{87} \mathrm{Sr} /{ }^{86} \mathrm{Sr}$ ratios in the seawater during Ediacaran period reflects the addition of soluble Sr derived from erosion of old continents into oceans (Veizer, 1989). Erosion of mountains that were produced during the amalgamation of supercontinents has been linked to steep rises in atmospheric $\mathrm{O}_{2}$ (Campbell and Allen, 2008) as it provided nutrients for algae and cyanobacteria responsible for photosynthetic production of $\mathrm{O}_{2}$. Increased sedimentation and burial of organic carbon and pyrite (Campbell and Squire et al. 2010) prevents their reaction with oxygen in the environment, leading to further increases in atmospheric oxygen.

Previous geochronology of zircons from sediments has suggested that the erosion of the Transgondwana supermountains that formed at the collision of East and West Gondwana (Squire et al. 2006) is responsible for the supply of nutrients necessary for life radiation. However, the timing is problematic as this poly-phased orogen was completely assembled only at ca. 520-500 Ma (Collins and Pisarevsky, 2005), and therefore postdates the Ediacaran life radiation. These Ediacaran organisms first appeared in interglacial and post-glacial environments in deep water between 600 and 560 million years ago and latter colonized environments around the world in a variety of facies, in both shallow and deep water showing little geographic endemism (Waggoner, 2003). Our rationale is also consistent with the view that the ancestries of the Cambrian explosion extend some 50-70 million years before its expression in the fossil record (Meert and Lieberman, 2008), thus placing the West Gondwana Orogen as one of the potential environmental triggers for Life sustainability. We report the precise timing and significant extent of the oldest known UHP rocks in geological history, which makes the West Gondwana Orogen one of the events that could have changed the way evolution proceeded on Earth.

\subsection{Appendix: Analytical methods}

Mineral chemistry. Chemical analyses of major elements in minerals (Supplementary Table S1) were performed on polished thin sections with a CAMECA SX100 electron microprobe of RSES, ANU, operating in the wavelength-dispersive mode. Acceleration voltage and beam current were $15 \mathrm{kV}$ and $20 \mathrm{nA}$ with a 
focused beam diameter of $1 \mu \mathrm{m}$ for pyroxene and garnet and $5 \mu \mathrm{m}$ for micas. Counting times per element were $20 \mathrm{~s}$ for $\mathrm{Na}, \mathrm{Mg}, \mathrm{Si}, \mathrm{Al}, \mathrm{K}, \mathrm{Ca}$ and $\mathrm{Fe}$ and $60 \mathrm{~s}$ for $\mathrm{Ti}, \mathrm{Cr}$ and $\mathrm{Mn} . \mathrm{K}$ and $\mathrm{Na}$ were always analysed first in the routine. Several analyses on each phase were performed to obtain representative compositions and core-rim analyses were done to assess zoning patterns. Standards were natural and synthetic minerals, which were all determined on the Ka emission peak. In-house mineral standards were used as secondary standards.
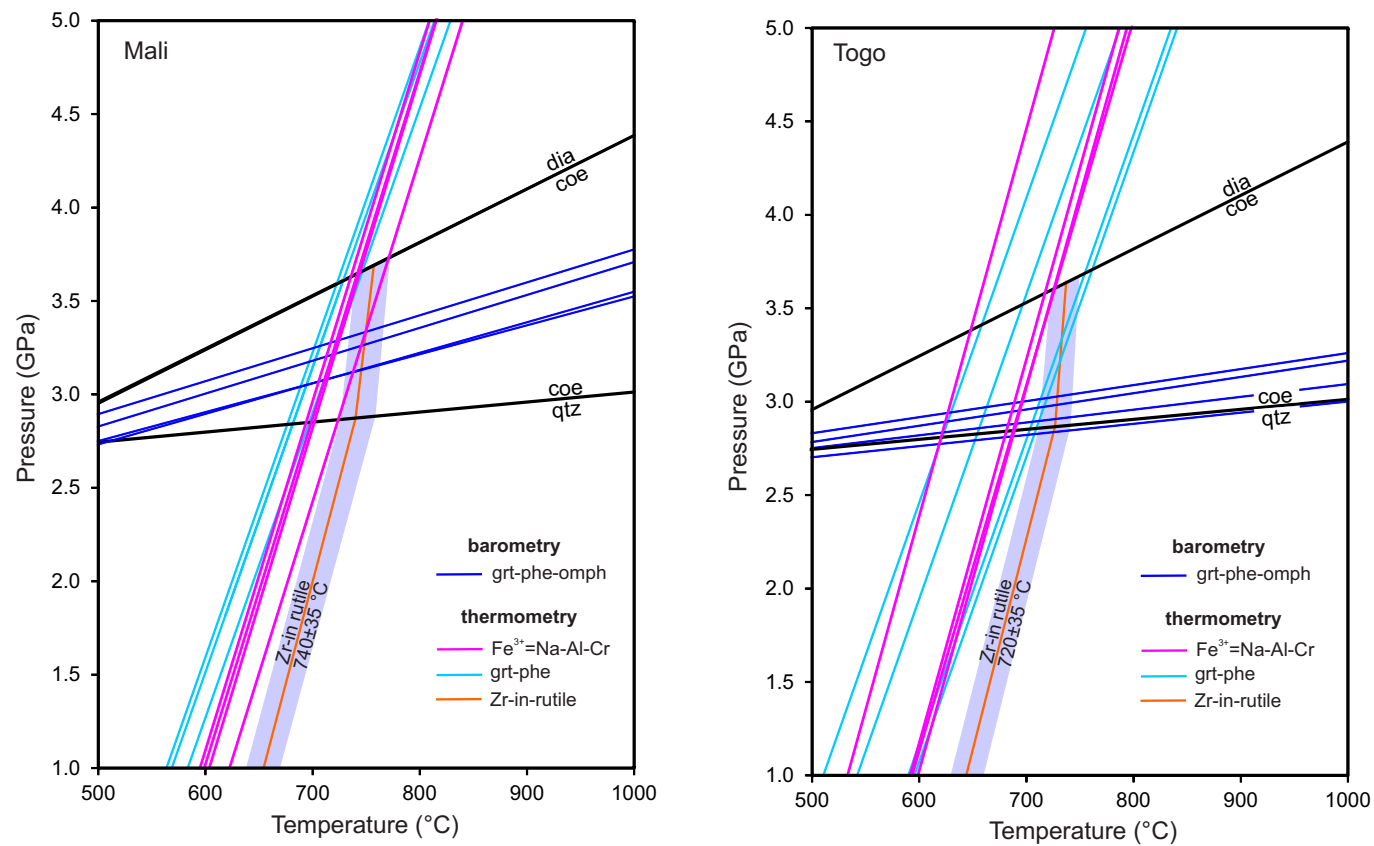

Supplementary Figure 1 - Calculated P-T conditions for the Mali (left: sample S-514) and Togo (right: sample DKE-350) using the geothermobarometry of Ravna and Terry (2004). Temperatures of garnetphengite exchange reaction of and Zr-in-rutile accordingly Green and Hellman (1982) and Tomkins et al. (2007), respectively.

Imaging of internal zoning. Zircons were separated from the crushed rocks using conventional heavy liquid and magnetic techniques. Grains were mounted in epoxy resin and polished down to expose the near-equatorial section. Imaging of grain sections was carried out at the RSES in Canberra and in the Geochronological Research Centre (CPGeo) at the University of São Paulo (USP). Cathodoluminescence (CL) investigation at RSES employed a JEOL-6610A scanning electron microscope (SEM) supplied with a Robinson detector for cathodoluminescence. Operating conditions for the SEM were $15 \mathrm{kV}, 70 \mu \mathrm{A}$ and a $20 \mathrm{~mm}$ working distance. In Sao Paulo CL images were acquired using a Quanta 250 FEG SEM equipped with a Centaurus Mono CL3+ detector for cathodoluminescence.

Trace elements. Trace elements of zircon and rutile (Supplementary Tables S2 and S3) were analysed by laser-ablation inductively coupled plasma mass spectrometry (LA-ICP-MS) at the Research School of Earth Sciences (ANU). The instrument includes an ANU 'HelEx' laser ablation cell built to receive a pulsed $193 \mathrm{~nm}$ wavelength ArF Excimer laser with $100 \mathrm{~mJ}$ output energy at a repetition rate of $5 \mathrm{~Hz}$ and coupled to an Agilent 7500s quadrupole ICPMS. The instrument was tuned for maximum sensitivity and minimum production of molecular species, maintaining $\mathrm{ThO}^{+} / \mathrm{Th}^{+}$at $<0.5 \%$. The laser was operated in drilling mode 
with spot sizes of $47 \mu \mathrm{m}$ for rutile and $28 \mu \mathrm{m}$ for zircon. Total analysis time was $\sim 60 \mathrm{~s}$, the first $\sim 25 \mathrm{~s}$ of which was background acquisition prior to ablation. Synthetic glasses (NIST 612 for zircon and NIST 610 for rutile) were used for external calibration. Internal standards were $\mathrm{SiO}_{2}$ of 32.45 weight $\%$ for zircon and $\mathrm{TiO}_{2}$ of 98 weight $\%$ for rutile. The BCR-2G natural glass was used as a secondary standard to monitor accuracy. Data evaluation was done wit the software package Iolite v.2.5. Chondrite values for normalization are from Sun and McDonough (1989).

SHRIMP. Zircon was analysed for $\mathrm{U}$, Th and $\mathrm{Pb}$ in the epoxy mount using the SHRIMP-II at the ANU in Canberra and the SHRIMP-IIe at USP in São Paulo. For zircon, instrumental conditions and data acquisition were generally as described previously (Williams, 1998). The data were collected in sets of six scans throughout the masses and a reference zircon (TEMORA 2) was analysed each fourth analysis. The analyses (Supplementary Table S4) were corrected for common $\mathrm{Pb}$ on the basis of the measured ${ }^{207} \mathrm{~Pb} /{ }^{206} \mathrm{~Pb}$ ratios as described previously (Williams, 1998). The common $\mathrm{Pb}$ composition was assumed to be that predicted by the model in (Stacey and Kramer, 1975). U-Pb data were collected over five analytical sessions using the same standard, with the different sessions having calibration errors between $1.23 \%$ and $2.16 \%$ (2 sigma), which was propagated to single analyses. Data evaluation and age calculation were done using the software Squid and Isoplot/Ex (Ludwig, 2003), respectively. Average ${ }^{206} \mathrm{~Pb} / 238 \mathrm{U}$ ages are quoted at the 2-sigma confidence level and forced to at least $1 \%$ to account for external errors.

\section{Acknowledgments}

CEGA is grateful to Y. Agbossoumondé for field guidance in Togo and to J. Peucat and P.R. Menot for providing extra zircons for sample DKE-350. R. Weinberg and I. Campbell are thanked for careful reading of the manuscript. CEGA, UGG and MASB are thankful to financial support of São Paulo Research Foundation (FAPESP) 2012/00071-2 and to the Brazilian National Research Council (CNPq) for the grant 246206/2012-8 to CEGA. DR acknowledges the financial support of the Australian Research Council DP110101599. This is a contribution to the IGCP-628, Gondwana Map Project.

\subsection{References}

Agbossoumondé Y., Menot R.P., Guillot S., 2001. Metamorphic evolution of Neo-proterozoic eclogites from south Togo (West Africa). Journal of African Earth Sciences 33, 227-244

Austrheim, H., 1991. Eclogite formation and dynamics of crustal roots under continental collision zones. Terra Nova 3, 492-499.

Beltrando, M., Rubatto, D., and Manatschal, G., 2010, From passive margins to orogens: the link between oceancontinent transition zones and (ultra-)high pressure metamorphism. Geology 38, 559-562.

Berger J., Caby R., Liégois J.P., Mercier J.C., Demaiffe D., 2011. Deep inside a Neoproterozoic intra-oceanic arc: growth, differentiation and exhumation of the Amalaoulaou complex (Gourma, Mali). Contributions to Mineralogy and Petrology 162, 773-796.

Bertrand-Sarfati, J., Moussine-Pouchkine, A., Amard, B., Ahmed, A.A.K., 1995. First Ediacaran fauna found in western Africa and evidence for an Early Cambrian glaciation. Geology 23, 133-136. 
Carlos E. Ganade de Araujo - Tese de Doutorado - Universidade de São Paulo

Capítulo 8 - Ediacaran megamoutains

Boughrara, M., 1999. Analyse pétrologique et géochronologique de la région de Tin Begane (Hoggar, Algérie): un exemple de la datation d'une série métamorphique en contexte polycyclique. Thesis Muséum d'Histoire Naturelle Paris $361 \mathrm{p}$ (unpublished).

Brasier, M.D., 1990. Nutrients in the early Cambrian. Nature 347, 521-522.

Brasier, M.D., Lindsay, J.F., 2001. Did supercontinental amalgamation trigger the "Cambrian explosion”? In: Zhuralev, A.Y., Riding, R. (Eds.), The Ecology of the Cambrian Radiation. Columbia University Press, New York, pp. 69-89.

Brown, M., 2008. Characteristic thermal regimes of plate tectonics and their metamorphic imprint throughout Earth history: When did Earth first adopt a plate tectonics mode of behavior? When Did Plate Tectonics Begin on Planet Earth? 440, 97.

Burov, E., Toussaint, G., 2007. Surface processes and tectonics: forcing of continental subduction and deep processes. Global and Planetary Change 58, 141-164.

Caby R., 1989. Precambrian terranes of Benin, Nigeria and Northeast Brazil and the late Proterozoic South Atlantic fit. Geological Society of America Special Paper 230, 145-158.

Caby R., 2003. Terrane assembly and geodynamic evolution of central-western Hoggar: a synthesis. Journal of African Earth Sciences 37, 133-159.

Caby, R., 1994. Precambrian coesite from northern Mali: first record and implications for plate tectonics in the TransSaharan segment of the Pan-African belt. Eur. J. Mineral. 6, 235-244.

Caby, R., Monié, P., 2003. Neoproterozoic subductions and differential exhumation of western Hoggar (southwest Algeria): new structural, petrological and geochronological evidence. Journal of African Earth Sciences 37, $269-293$.

Campbell, I. H., Squire, R. J., 2010. The mountains that triggered the Late Neoproterozoic increase in oxygen: the Second Great Oxidation Event. Geochimica et Cosmochimica Acta 74, 4187-4206.

Campbell, I.H., Allen, G.M., 2008. Formation of supercontinents linked to increases in atmospheric oxygen. Nature Geoscience 1, 554-558.

Canfield, D.E., Poulton, S.W., Narbonne, G.M., 2007. Late-Neoproterozoic deep-ocean oxygenation and the rise of animal life. Science 315, 92-94.

Carney, J.N., Jordan, C.J., Thomas, C.W., Condon, D.J., Kemp, S.J., Duodo, J.A., 2010. Lithostratigraphy, sedimentation and evolution of the Volta Basin in Ghana. Precambrian Research 183, 701-724.

Collins, A.S., Pisarevsky, S.A., 2005. Amalgamating eastern Gondwana: the evolution of the Circum-Indian Orogens. Earth Science Reviews 71, 229-270.

Cordani U.G., Pimentel M.M., Ganade de Araújo G.E., Basei M.A.S., Fuck R.A., Girardi V.A.V., 2013. Was there an Ediacaran Glymene Ocean in central South America? American Journal of Science 313, 517-539.

El Hadi, H., Simancas, J.F., Martínez-Poyatos, D., Azor, A., Tahiri, A., Montero, P., Fanning, C.M., Bea, F., GonzálesLodeiro, F., 2010. Structural and geological constraints on the evolution of the Bou Azzer Neoproterozoic ophiolite (Anti-Atlas, Morocco). Precambrian Research 182, 1-14.

Fischer, K.M., 2002. Waning buoyancy in the crustal roots of old mountains. Nature 417, 933-936.

Ganade de Araújo C.E., Cordani U.G., Basei M.A.S., Castro N.A., Sato K., Sproesser W. 2012. U-Pb detrital zircon provenance of metasedimentary rocks from the Ceará Central and Médio Coreaú Domains, Borborema Province, NEBrazil: Tectonic implications for a long-lived Neoproterozoic active continental margin. Precambrian Research 206-207, 36-51.

Gilotti, J.A., 2013. The realm of ultrahigh-pressure metamorphism: Elements 9, 255-260. 
Carlos E. Ganade de Araujo - Tese de Doutorado - Universidade de São Paulo

Capítulo 8 - Ediacaran megamoutains

Green, T.H., Hellman, P.L., 1982. Fe-Mg partitioning between coexisting garnet and phengite at high pressure, and comments on a garnet-phengite geothermometer. Lithos 15, 253-266.

Hacker, B.R., Gerya, T.V., and Gilotti, J.A., 2013. Formation and exhumation of ultrahigh-pressure terranes. Elements 9, 289-293.

Jahn B., Caby R., Monié P., 2001. The oldest UHP eclogites of the World: age of UHP metamorphism, nature of protoliths and tectonic implications. Chemical Geology 178, 143-158.

Kylander-Clark, A.R.C., Hacker, B.R., Mattinson, G.G., 2012. Size and exhumation rate of ultrahigh-pressure terranes linked to orogenic stage: Earth and Planetary Science Letters 321-322, 115-120.

Leech, M.L., Singh, S., Jain, A.K., Klemperer, S.L., Manickavasagam, R.M., 2005. The onset of India-Asia continental collision: early, steep subduction required by the timing of UHP metamorphism in the western Himalaya. Earth and Planetary Science Letters 234, 83-97.

Ludwig, K.R., 2003. Isoplot 3.00 - A Geochronological Toolkit for Microsoft Excel. Berkeley Geochronology Center. Special Publication No 4.

Meert, J.G., Lieberman, B.S., 2008. The Neoproterozoic assembly of Gondwana and its relationship to the EdiacaranCambrian radiation. Gondwana Research 14, 5-21.

Pimentel M.M., Fuck R.A. 1992. Neoproterozoic crustal accretion in central Brazil. Geology 20, 375-379.

Ravna, E.J.K., Terry, M.P., 2004. Geothermobarometry of UHP and HP eclogites and schists-an evaluation of equilibria among garnet-clinopyroxene-kyanite-phengite-coesite/quartz. Journal of metamorphic Geology 22 579-592.

Rubatto, D., 2002. Zircon trace element geochemistry: partitioning with garnet and the link between U-Pb ages and metamorphism. Chemical Geology 184, 123-138.

Rubatto, D., Hermann, J., 2001. Exhumation as fast as subduction? Geology 29, 3-6.

Santos, T.J.S., Amaral, W.S., Ancelmi, M.F., Dantas, E.L., Fuck, R.A., Pitarello, M.Z., 2013. A faixa eclogítica de Forquilha e sua importância no contexto tectônico da Província Borborema. In: 25 $5^{\text {th }}$ Simpósio de Geologia do Nordeste, Recife, Brazil, pp. 525.

Santos, T.J.S., Garcia, M.D.G.M., Amaral, W.S., Caby, R., Wernick, E., Arthaud, M.H., Santosh, M., 2009. Relics of eclogite facies assemblages in the Ceará Central Domain, NW Borborema Province, NE Brazil: Implications for the assembly of West Gondwana. Gondwana Research 15, 454-470.

Squire, R.J., Campbell, I.H., Allen, G.M., Wilson, G.J.L., 2006. Did the Transgondwanan Supermountain trigger the explosive radiation of animals on Earth? Earth and Planetary Science Letters 250, 116-133.

Stacey, J.S., Kramer, J.D., 1975. Approximation of terrestrial lead isotope by a two-stage model. Earth and Planetary Science Letters 26, 207-212.

Stern, R., 2005. Evidence from ophiolites, bluescgists, and ultrahigh-pressure metamorphic terranes that the modern episode of subduction began in Neoproterozoic time. Geology 33, 557-560.

Sun, S.S., McDonough, W.F., 1989. Chemical and isotopic systematics of oceanic basalts: implication for mantle composition and processes. In: Saunders, A.D., Norry, M.J. (Eds.), Magmatism in Ocean Basins. Geological Society, London, Special Publications, vol. 42, pp. 313-345.

Tomkins, H.S, Powell, R., Ellis, D.J., 2007. The pressure dependence of the zirconium-in-rutile thermometer. J Metamorph Geol 25, 703-713.

Vasconcelos, C.S., Morales, I.V.F., TrosdtorfJunior, I., Santos, S.F., Figueiredo, M.F. Revisão da estratigrafia na seção perfurada pelo poço 2-SM-1-MT (Salto Magessi), Bacia dos Parecis-Alto Xingu, MT. Boletim de Geociências da Petrobras, in press. 
Carlos E. Ganade de Araujo - Tese de Doutorado - Universidade de São Paulo

Capítulo 8 - Ediacaran megamoutains

Veizer, J., 1989. Strontium isotopes in seawater through time. Annual Review of Earth and Planetary Sciences 17, 141167.

Waggoner, B., 2003. The Ediacaran biotas in space in time. Integrative and Comparative Biology 43, $104-113$.

Warren, L.V., Pacheco, M.L.A.F., Fairchild, T.R., Simões, M.G., Riccomini, G., Boggiani, P.G., Cáceres, A.A., 2012. The dawn of animal skeletogenesis: Ultrastructural analysis of the Ediacaran metazoan Corumbella werneri. Geology 40, 691-694.

Watson, E.B., Wark, D.A, Thomas. J.B., 2006. Crystallization thermom- eters for zircon and rutile. Contrib Mineral Petrol 151, 413-433.

Williams, I.S., 1998. In: McKibben, M.A., Shanks, W.C., Ridley, W.I. (Eds.), U-Th-Pb geochromology by ion microprobe, applications of microanalytical techniques to understanding mineralizing processes. Reviews in Economic Geology 7, pp. 1-35.

Yin, A., 2006. Cenozoic tectonic evolution of the Himalayan orogeny as constrained by along-strike variation of structural geometry, exhumation history and foreland sedimentation. Earth Science Reviews 76, 1-131.

Zetounou S., Ouzegane K. Boubazine, S., Kienast JR., 2004. Azroun N'Fad (Central Hoggar, Algeria), one of the deepest terranes of LATEA: arguments based on P-T evolution in eclogite. Journal of African Earth Sciences 39, 193200. 


\title{
9. The significance of the Transbrasiliano- Kandi tectonic corridor for the amalgamation of West Gondwana
}

\author{
Umberto Giuseppe Cordani*(1), Marcio Martins Pimentel(2), Carlos Eduardo Ganade de Araujo (3)(1), \\ Reinhardt Adolfo Fuck(2) \\ (1) Instituto de Geociências da Universidade de São Paulo, São Paulo, SP, Brasil \\ (2) Instituto de Geociências da Universidade de Brasília, Brasília, DF, Brasil \\ (3) CPRM/SGB Serviço Geológico do Brasil, Fortaleza, CE, Brasil
}

\begin{abstract}
The assembly of West Gondwana was completed by the end of the Precambrian, when the Amazonian, West African, São Francisco-Congo, Kalahari and Rio de la Plata cratons, as well as the Saharan metacraton and the Parnaíba, Paranapanema and Luiz Alves cratonic fragments were united by means of the Brasiliano-Pan African orogeny, a geotectonic process that was active from the late Neoproterozoic to the early Paleozoic, related to the closure of a large oceanic domain, the Goiás- Pharusian Ocean. Several accretionary complexes and possible microcontinents were trapped within the Brasiliano-Pan African mobile belts, and they have been accommodated within a few hundred kilometers of the Transbrasiliano-Kandi tectonic corridor. The supercontinent was already formed at about $600 \mathrm{Ma}$, as indicated by the existence of a very large Ediacaran epicontinental sea covering large areas of west-central Brazil and southern Uruguay along the margins of the Amazonian and Rio de la Plata cratons, demonstrating the connection of both cratonic units at that time and making the idea of a collisional suture closing a supposed Clymene Ocean unsustainable. In the Cambrian, a major plate reorganization occurred, being responsible for the initiation of subduction of the oceanic lithosphere along an open and unconfined Pacific Ocean. The resulting Pampean Orogeny correlates nicely in time with the Saldania, Ross, and Tasmanian belts along the southern Gondwana margin. Simultaneously, extensional-type post-tectonic episodes occurred repeatedly along the Transbrasiliano-Kandi tectonic corridor.
\end{abstract}

\subsection{Introduction}

Almost all studies on the formation of Gondwana suggest that the supercontinent was formed by the amalgamation of a few building blocks of different sizes, in a series of continental collisions. Most of these blocks originated from the breakup of Rodinia, covering the entire timeframe of the Neoproterozoic (Li et al., 2008).

Several large-scale models were put forward for the assembly of Gondwana. The simplest one describes the final amalgamation of two large continental masses, West Gondwana (made of South America and Africa) and East Gondwana (made of Antarctica, Australia, India and Madagascar), forming the Mozambique belt (Kröner, 1980; McWilliams, 1981; Shackleton, 1996). With the progress of geological knowledge in recent years, especially in the fields of paleomagnetism and geochronology, the mechanisms of Gondwana assembly are now more precisely constrained, especially concerning the timing of the successive collisions between continental building blocks. Different models for the assembly of Gondwana were suggested, such as those by Meert (2003), Cordani et al. (2003), Yoshida et al. (2003), Collins and Pisarevski (2005), Trindade et al. (2006), among others. 
The schematic map of figure 9.1 shows the nomenclature used in this article for supracontinental building blocks: (1) the Amazon-West African block is formed by the Amazonian and West African cratons, as well as the small São Luis craton and a possible microcontinent covered by the Phanerozoic Parnaíba basin; (2) the Central African block includes Congo-São Francisco, Rio de la Plata and Kalahari cratons, plus the Paranapanema block concealed beneath the Paraná basin and most of northern Africa, named the Saharan metacraton; (3) the Indo- Arabian block includes the Indian shield, Madagascar, Sri Lanka, and the eastern basement of the Arabian-Nubian shield; and (4) the Australian-Antarctic block includes East Antarctica and Australia, excluding the Tasman orogen. Sizes and relative positions are only indicative, and figure 9.1 should not be considered as a palinspastic reconstruction.

The main objective of this paper was to review the process of amalgamation of West Gondwana due to the convergence of the Amazon-West African and the Central African blocks, related to the closure of a large oceanic domain, the Goiás-Pharusian Ocean. From our point of view, this was responsible for the BrasilianoPan African orogeny, a geotectonic process that was active in the late Neoproterozoic. We will also review the alternative scenario proposed by Trindade et al. (2006), as well as Tohver et al. (2012), arguing that the final assembly of Gondwana would have occurred in the Cambrian, as a result of the closure of a different ocean, called Clymene. This topic, which is relevant to the age of amalgamation of West Gondwana, will be briefly discussed in the appropriate chapter.

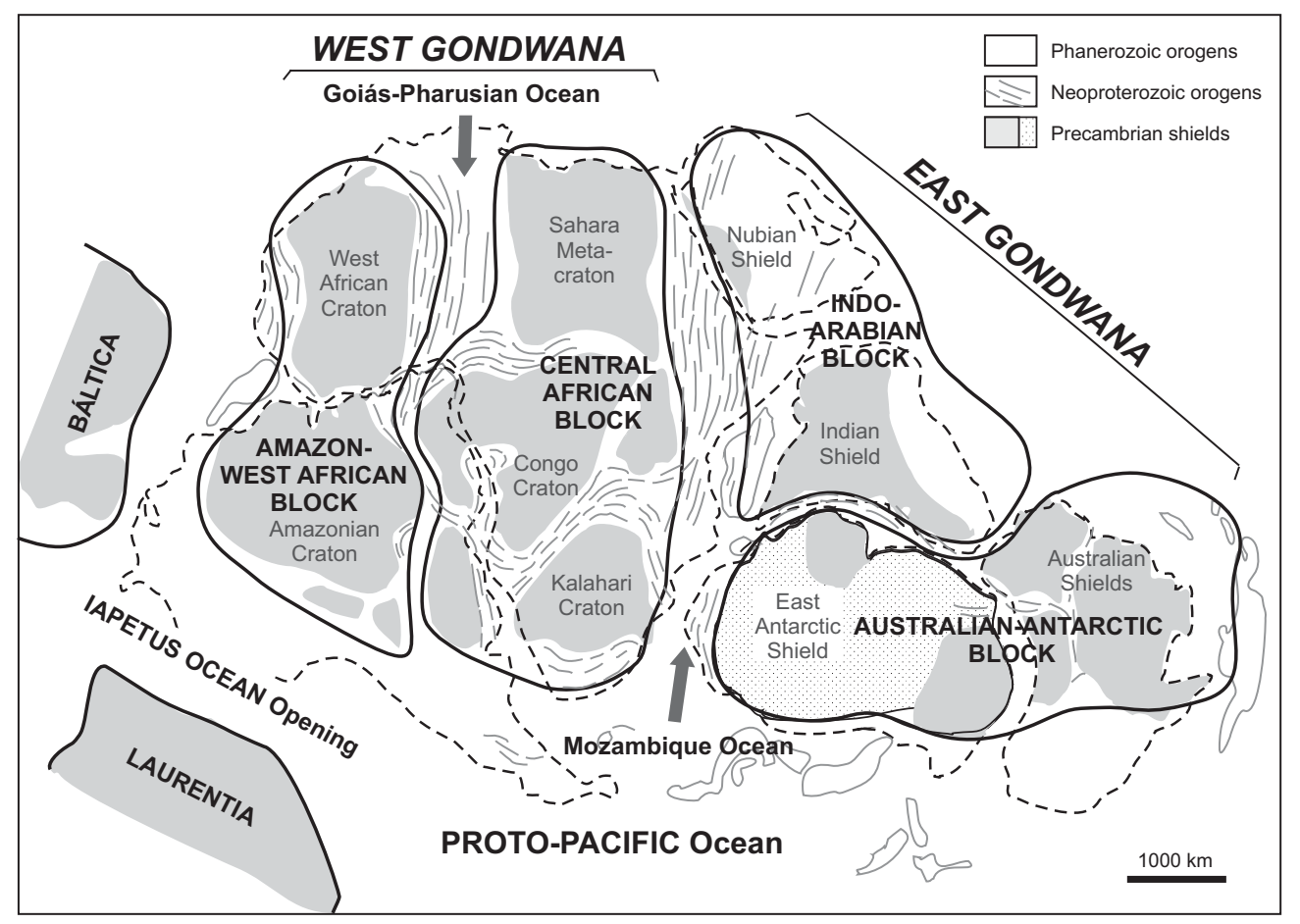

Figure 9.1 - Crustal building blocks for the amalgamation of Gondwana, after the closing of the GoiásPharusian and Mozambique oceans. Location of the Iapetus Ocean between SW Gondwana, Laurentia and Baltica, and location of the Proto-Pacific Ocean before the onset of the subduction of the Pacific Plate. 
Carlos E. Ganade de Araujo - Tese de Doutorado - Universidade de São Paulo Capítulo 9 - Transbrasiliano-Kandi tectonic corridor

\subsection{Geotectonic Setting of West Gondwana}

The Amazon-West African block and the Central African block (fig. 9.1) are formed by several juxtaposed continental nuclei, which are residual fragments from the disruption of Rodinia, in a process that started around $900 \mathrm{Ma}$, and finished only at ca. $570 \mathrm{Ma}$, when Laurentia was finally separated from the AmazonWest African block, with the formation of the Iapetus Ocean (Meert 2003, Li et al., 2008, among others). However, the disruption of Rodinia is not free of controversy. For example, based on a great deal of geochronological and tectonic evidence, Cordani et al. (2003) and Kroener \& Cordani (2003) suggested that the Central African block may have never been part of Rodinia. Tohver et al. (2006) reached a similar conclusion based on their review regarding the available paleomagnetic data from Africa and South America. The position of the Goiás-Pharusian Ocean (Kröner \& Cordani 2003), where intraoceanic island arcs were formed at about $850-900 \mathrm{Ma}$, is indicated in figure 9.2, adapted from Cordani et al. (2013). In many paleomagnetic reconstructions, such as those by Meert (2003) or Cordani et al. (2003), this ocean was named "Brasiliano", or sometimes "Adamastor". A more restricted Adamastor Ocean (Hartnady et al., 1985), located along the western- southwestern boundary of the Central African block, is illustrated in figure 9.2. Its formation and disappearance are related to initial rifting, followed by dispersion, and later the reassembly of two important cratonic nuclei, Kalahari and Rio de la Plata, and some smaller cratonic fragments, such as Paranapanema and Luís Alves, against the larger Congo-São Francisco craton. Although data from the early arc assemblages in the Adamastor Ocean yielded juvenile signatures for ca. 800 Ma granitoids (Tupinambá et al., 2012), its extension seems to be much more restricted than the ones of Goias-Pharusian Ocean due to the confined nature of the Araçuaí Orogen. As a consequence of the subduction of oceanic lithosphere related to the closure of the Goiás-Pharusian Ocean, several accretionary complexes and possible microcontinents were trapped within mobile belts formed during the Neoproterozoic collisional events. The tectonic process was extremely complex, leading to the formation of several sutures. The mobile belts were the result of the Brasiliano-Pan African orogeny, and are now exposed in very large areas of West Africa and South America. They may be classified into two types of orogenic units, showing different ages, tectonic environments and evolution:

1. An older component (dated at $950-650 \mathrm{Ma}$ ) made of magmatic and sedimentary assemblages, many of which have mantle-derived intraoceanic features, constituting accretionary-type orogenic belts. They essentially comprise plutonic-volcanic magmatic associations, which are exposed at upper-middle crustal levels, such as the Iskel, Tilemsi, Amalaoulaou, Kabyé and Goiás magmatic arcs, trapped between the Amazon- West African and the Central African blocks (Dostal et al., 1994, Caby 2003, Laux et al., 2005, among others). The tectonic evolution is coeval with that of the Arabian-Nubian Shield, whose intraoceanic magmatic arcs are exposed between the Central African and Indo-Arabian blocks;

2. A younger component (dated at ca. $700-520 \mathrm{Ma}$ ) formed by the collage of orogenic belts located along the cratonic margins, comprising reworked basement plus collisional fold-and-thrust and metamorphic belts. They consist of metasedimentary and metavolcanic rocks, which were intruded by large amounts of granitoid rocks, exposed at deep to shallow crustal level, and were tectonically affected by a protracted Brasiliano- Pan African orogeny. These tectonic units may include oceanic assemblages, such as ophiolites, accretionary prisms and 
island-arc magmatic suites, and in some places HP, UHP and UHT metamorphic assemblages. Examples are the Trans-Saharan, Dahomeyan, Brasília and Paraguay belts (fig. 9.3).

In addition, the Gondwana Supercontinent was subjected to widespread Ediacaran-Cambrian tectonothermal reactivation in almost all regions that were previously affected by the Neoproterozoic accretionary, collisional or intracontinental orogenies, be it within the mobile belts of that age or at the marginal parts of cratonic areas. This tectono- thermal overprint is also detected over very large areas, such as the Saharan metacraton in Africa and its counterpart in South America, within the Borborema Province.

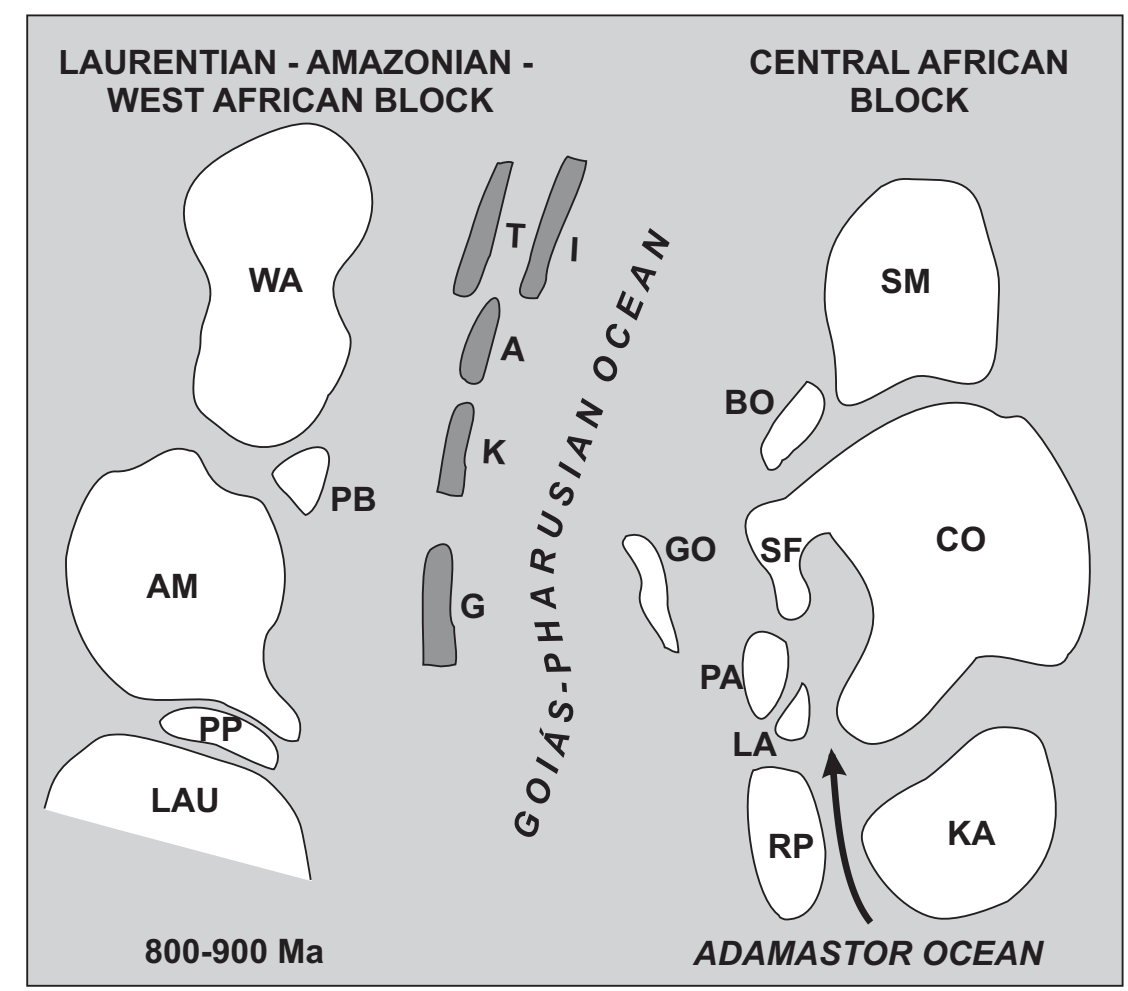

Figure 9.2 - Major tectonic elements related to West Gondwana at about 800 - $900 \mathrm{Ma}$ ago, prior to the final amalgamation. Cratons: $\mathrm{AM}=$ Amazonian; $\mathrm{CO}=$ Congo; $\mathrm{KA}=$ Kalahari; $\mathrm{LAU}-$ Laurentia; $\mathrm{RP}=\mathrm{Rio}$ de La Plata; SF = São Francisco; SM = Sahara metacraton; WA = West African. Smaller cratonic fragments: $\mathrm{BO}=$ Borborema; $\mathrm{GO}=$ Goiás Central Massif; LA = Luiz Alves; $\mathrm{PA}=$ Paranapanema; $\mathrm{PB}=$ Parnaiba; $\mathrm{PP}=$ Pampia. Intra-oceanic magmatic arcs: $\mathrm{A}=$ Amalaoulaou; $\mathrm{G}=$ Goiás; $\mathrm{I}=\mathrm{Iskel} ; \mathrm{K}=$ Kabyé; $\mathrm{T}=$ Tilemsi. Adapted from Cordani et al. (2013).

\subsection{Closure of the Goiás-Pharusian Ocean}

The Goiás-Pharusian Ocean occupies a very large area and includes many intraoceanic magmatic arcs, whose tectonic evolution started as early as $c a .900$ Ma. Approximately $300 \mathrm{Ma}$ later, this ocean closed due to successive continental collisions, which sutured the West African Craton against the Saharan metacraton (Abdelsalam et al., 2002) in the north, and the Amazonian against the São Francisco Craton in the south.

The several Brasiliano-Pan African orogenic belts, which were created in this process, are aligned along a very long corridor in South America and Africa that is domi- nated by a megashear zone, which is one of the major 
tectonic elements in the world. Schobbenhaus (1975) coined the name "Transbrasiliano lineament" in his compilation of the tectonic map of Brazil, showing that this structure crosses a large part of the continent, from northeast Brazil down to Paraguay and Argentina. Caby (1989), Trompette (1994), Fairhead and Maus (2003), Santos et al. (2008), among many others, have shown that it extends to Africa, where it crosses the western part of the continent, from Togo to Algeria, along the Hoggar 4o50'-Kandi shear system (fig. 9.3). The megashear is formed by a series of ductile shear zones, which occur in very large areas. It probably reaches the bottom of the lithosphere, and the shear zone motion must have started shortly after the closure of the Goiás-Pharusian Ocean, taking advantage of the several weak lithospheric zones formed during continental collisions. All collisional sutures related to the Brasiliano-Pan African belts are accommodated within a few hundred kilometers of the lineament, in a region that will be referred to as the TransbrasilianoKandi tectonic corridor.

The coherence of the lineament is clearly marked by the strong linear magnetic anomalies obtained from the CHAMP satellite survey and reported by Fairhead \& Maus (2003). Within the Trans-Saharan and Dahomey belts of West Africa, a string of positive gravimetric anomalies, locally associated with linear magnetic anomalies, is observed near the margin of the West African craton, associated with a series of mafic and ultramafic massifs. Their tectonic significance may be attributed to the rise of mantle diapirs, which indicate the position of Neoproterozoic suture zones (Trompette 1994). In South America, the lineament is clearly visible in the aeromagnetic mosaic of central and northeast Brazil, forming a series of low amplitude magnetic anomalies, which can be traced across the country from NE to SW. Elongated gravimetric and aeromagnetic anomalies along the main trend of the lineament have also been observed in Brazil, such as a strong anomaly observed within the Parnaíba basin, associated with the main depocenter of the Paleozoic sed- imentary sequences (Nunes 1993).

\subsection{The Borborema Province and the Trans-Saharan belt}

The Saharan metacraton, named by Abdelsalam et al. (2002), is not well defined. It is characterized as a large por- tion of cratonized continental crust of the pre-Neoproterozoic age dominated by medium to high-grade gneissic and migmatitic terrains, which were highly remobilized during the Pan- African orogeny. These authors interpreted the evolution of this tectonic unit as an initially coherent cratonic mass that was subjected to a widespread extensional tectonic regime, which caused, possibly during the early Neoproterozoic, pervasive rifting and the formation of narrow oceanic basins. These basins closed during the late Neoproterozoic, forming a collage of continental blocks. The aforementioned tectonic evolution seems to be similar to the one described for the basement of the central part of the Borborema Province of Brazil, where the Archean to Paleoproterozoic sialic basement (Brito Neves et al., 2000, Van Schmus et al., 2008, among others) underwent widespread Neoproterozoic rejuvenation and pervasive granite magmatism.

In figure 9.4, the dividing line between the Trans- Saharan belt and the Saharan metacraton established by Abdelsalam et al. (2002) is the Raghane shear zone, located in the eastern part of the Tuareg Shield (Liégeois et al., 1994; 2000), where the Barghot and Aouzegueur terraneshave been thrust from west to east across a rigid cratonic block. 


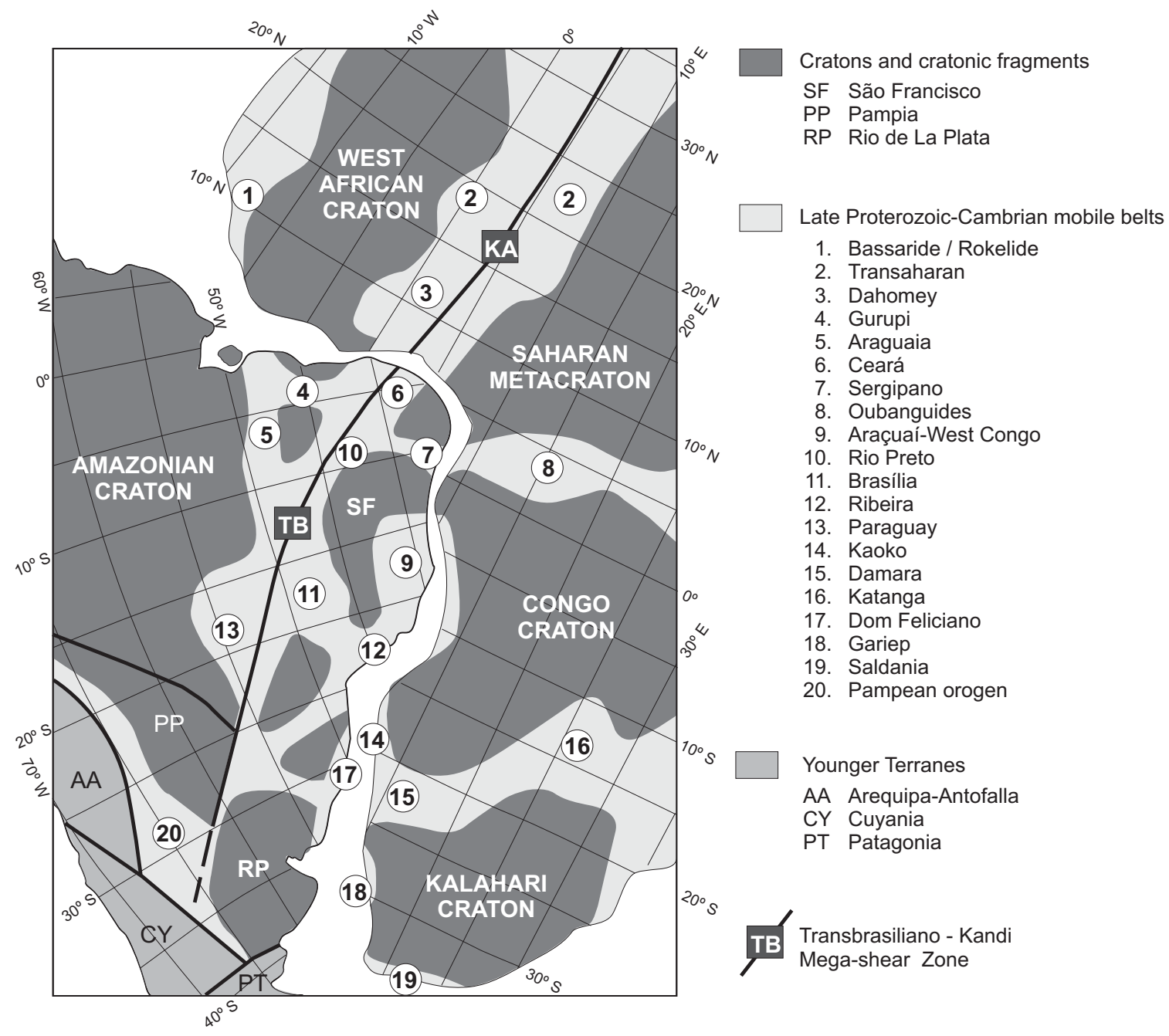

Figure 9.3 - Outline of the Transbrasiliano-Kandi mega-shear zone in a late Paleozoic pre-drift reconstruction of South America and Africa, with the relative position of cratons, cratonic fragments and lateProterozoic- Cambrian mobile belts. Adapted from Cordani et al. (2013).

The Raghane shear zone extends to the south, cutting through the Air Massif and disappearing beneath undeformed Phanerozoic rocks. Although we acknowledge the need for better control an additional evidence, we propose that the dividing line between the Dahomeyan belt and the Saharan metacraton, as a continuation of the Raghane shear zone, could be represented by the important lineament at the eastern limit of the "Nigerian schist belt", which marks the boundary between the western and eastern Nigeria terranes, as depicted by Arthaud et al. (2008). Also in figure 9.4, along the eastern side of the West African craton, there are two typical marginal sequences deposited at the boundary of the cratonic region and facing an eastern ocean. These are the Gourma and Volta basins, in which there are several kilometres thick sedimentary sequences accumulated. The deposits are mainly flyschoid material made up of siltstones, shales and greywackes, with some intercalation of carbonatic rocks with stromatolites, which indicate the late Neoproterozoic age (Trompette 1994).

Early Neoproterozoic (ca. $870-700 \mathrm{Ma}$ ) oceanic terranes have been identified in many parts of the TransSaharan belt (fig. 9.4), from the Hoggar to the Dahomeyan segments (Caby 1989, 2003; Berger et al., 2011). 
In Hoggar, in the Silet region (Algeria), diorite-to- nalite and monzogranite plutons from the Iskel island arc yielded U-Pb zircon ages of $c a .868$ and $839 \mathrm{Ma}$. The occurrence of slices of pre Pan-African basement directly overlain by shelf sediments and capped by volcanic arc rocks in several localities suggests that the Iskel magmatic arc was built on attenuated continental crust, adjacent to possible slices of oceanic lithosphere (Lapierre et al., 1986, Caby 2003). Further to the south, in the Gourma region (Mali), the TilemsiAmalaoulaou intraoceanic arc assemblages (Dostal et al. 1994) were dated at $c a .790-710 \mathrm{Ma}$, and the Tilemsi arc is considered as the upper crust superstructure, equivalent to the Amalaoulaou com- plex (Berger et al. 2011). Although there are not enough precise geochronological data for the Kabyé massif in the Dahomeyan belt (Togo), geochemical and field characteristics suggest that this massif may be the continuation of the Iskel-Tilemsi-Amalaoulaou intraoceanic arc system (Duclaux et al., 2006). The late Neoproterozoic Andean- type active continental margin, which produced extensive arc plutonism, is located east of the oceanic terranes. This stage of ocean-continent subduction was dated at $696 \pm 5 \mathrm{Ma}$ in the Kindal terrane and $716 \pm 6 \mathrm{Ma}$ in the Adrar des Iforas region, in Mali (Bruguier et al., 2008), indicating that it was partially coeval with the ocean-ocean subduction active further west.

To the south, the Dahomey belt is characterized by a com- plex thrust stack and suture, representing the convergence and subsequent collision between the Benino-Nigerian province, part of the Saharan metacraton, and the West-African craton. This belt comprises a series of metasiliciclastic rocks (quartzites and schists) from the Atakora and Kante units, but it also contains high-grade metamorphic rocks (up to eclogite facies) with mafic and ultramafic protoliths (Agbossoumondé et al., 2001). In Benin, possible arc-type granitoids related to the consumption of the Pharusian Ocean were dated at ca. 660 - 650 Ma (Kalsbeek et al., 2013).

The subsequent closure of the Pharusian oceanic domain, by means of a continent-continent collision (Himalayan- type orogen), is constrained by the presence of UHP and HP rocks in the Trans-Saharan orogenic belt (fig. 9.4). In the Gourma region, coesite-bearing eclogites (up to $25 \mathrm{kbar}$ ) and blueschists have been identified (Caby 1994, Jahn et al., 2001). Geochronological studies on these rocks indicated the age of eclogitization at $c a .620 \mathrm{Ma}$. Eclogites (ca. $19 \mathrm{kbar}$ ) and HP granulites have also been described in Togo (Attoh 1998, Agbossoumoundé et al. 2001). Geochronological ages of these rocks are scarce. However, a single $\mathrm{Pb}-\mathrm{Pb}$ zircon age of $612 \pm 1 \mathrm{Ma}$ obtained from a HP granulite (Affaton et al. 2000) suggests that collision was already going on at that time in this sector of the Trans-Saharan orogenic belt.

As shown in figure 9.3, the central part of the Borborema tectonic province in Brazil is very probably the counterpart of the Saharan metacraton of northern Africa. The north- western part of this province has been correlated with the Trans-Saharan domains of West Africa for many years (Torquato \& Cordani 1981, among many others). In particular, the region close to the Transbrasiliano lineament in northeast Brazil, represented by the Médio Coreaú and Ceará Central domains (figs. 9.4 and 9.5), is considered to be the counterpart of the Dahomeyan rocks in Togo and Benin along the area of the Kandi lineament (Caby 1989, Arthaud et al., 2008). In that region, evidence of pre-collisional magmatic assemblages (intraoceanic and Andean- type settings) is still scarce. However, an important period of crustal growth at 900-700 Ma can be inferred from the record of detrital zircon grains from the regional supracrustal rocks (Ganade de Araújo et al., 2012); the presence of abundant grains spanning the entire interval of about $200 \mathrm{Ma}$ al- lows us to infer the presence of a 
long-lived active continental margin, where subduction-related magmatism had been ongoing since the beginning of the Neoproterozoic.

In the Ceará Central domain, east of the Transbrasiliano lineament (TB, from now on), the Tamboril-Santa Quitéria Complex, a large area formed by different types of 640 - 610 Ma old granitoid rocks and migmatites, was described as a continental magmatic arc by Fetter et al. (2003). Van Schmus et al. (2011) indicate the age of col- lision at $c a .610-590$ Ma. However, Amaral et al. (2010) reported ages of $c a .650-630 \mathrm{Ma}$ for some high-pressure metamorphic rocks also located east of the lineament, in the Forquilha Eclogite Zone (fig. 9.5). These ages have been interpreted as being related to the eclogite formation, and suggest that the continental collision may have taken place earlier. More recently, however, Amaral et al. (2012) reported ages between $c a$. 613 and $590 \mathrm{Ma}$ for the metamorphism of granulite facies in mafic granulites of the nearby Cariré area, and therefore the precise age of continental collision remains controversial. After isostatic uplift, cooling, and denudation, the mobility and tectonic activity along the megashear continued for a long time.

Considering the continuity of major faults, the similarity of regional lithostratigraphic trends and the westward polarity of structural features, the correlation between the Trans-Saharan belt and the northwestern part of the Borborema Province is highly probable. However, as pointed out by Santos et al. (2008), the eclogites and related rocks of the Hoggar, as well as the HP metamafic rocks of the Dahomeyides, were located west of the Kandi-Hoggar 4o50' lineament, but UHP or HP metamorphic rocks were not identified in the Médio Coreaú domain. On the other hand, the known high-grade metamorphic rocks occurring in the Ceará Central domain are located to the east of TB.

\subsection{The Brasília Belt, the Goiás Magmatic Arc and the Paraguay Belt}

The Brasilia Belt, in central Brazil, presents unequiv- ocal evidence indicating the closure of the long-lived (900-630 Ma) Goiás Ocean at ca. $630 \mathrm{Ma}$. The belt is one of the largest and better preserved Neoproterozoic orogenic belts in Brazil (Pimentel et al., 2000), comprising: (i) a thick Neoproterozoic metasedimentary pile, including the Paranoá, Canastra, Araxá, Ibiá, Vazante, and Bambuí groups, mostly overlying Paleoproterozoic and oc- casionally Archean basement at the western margin of the São Francisco Craton; (ii) the Goiás Massif, a microcontinent (or allochthonous sialic terrain) composed of the Archean Crixás-Goiás granite-greenstones and associated Proterozoic formations; and (iii) the large juvenile Neoproterozoic Goiás Magmatic Arc in the west (fig. 9.5).

The several low to medium-grade supracrustal rock units of the Neoproterozoic metasedimentary pile show tectonic vergence to the east, towards the cratonic area (Dardenne, 2000) and metamorphic grade increases west- ward. Recent zircon provenance data suggest that some of these units (e.g., the Ibiá, Araxá and part of the Serra da Mesa groups) were deposited and deformed within a short interval between ca. 650 and $630 \mathrm{Ma}$ (Pimentel et al., 2011). Moreover, a Neoproterozoic ophiolitic mélange has been identified in the Araxá Group as a representative of the oceanic crust (Strieder and Nilson 1992). 


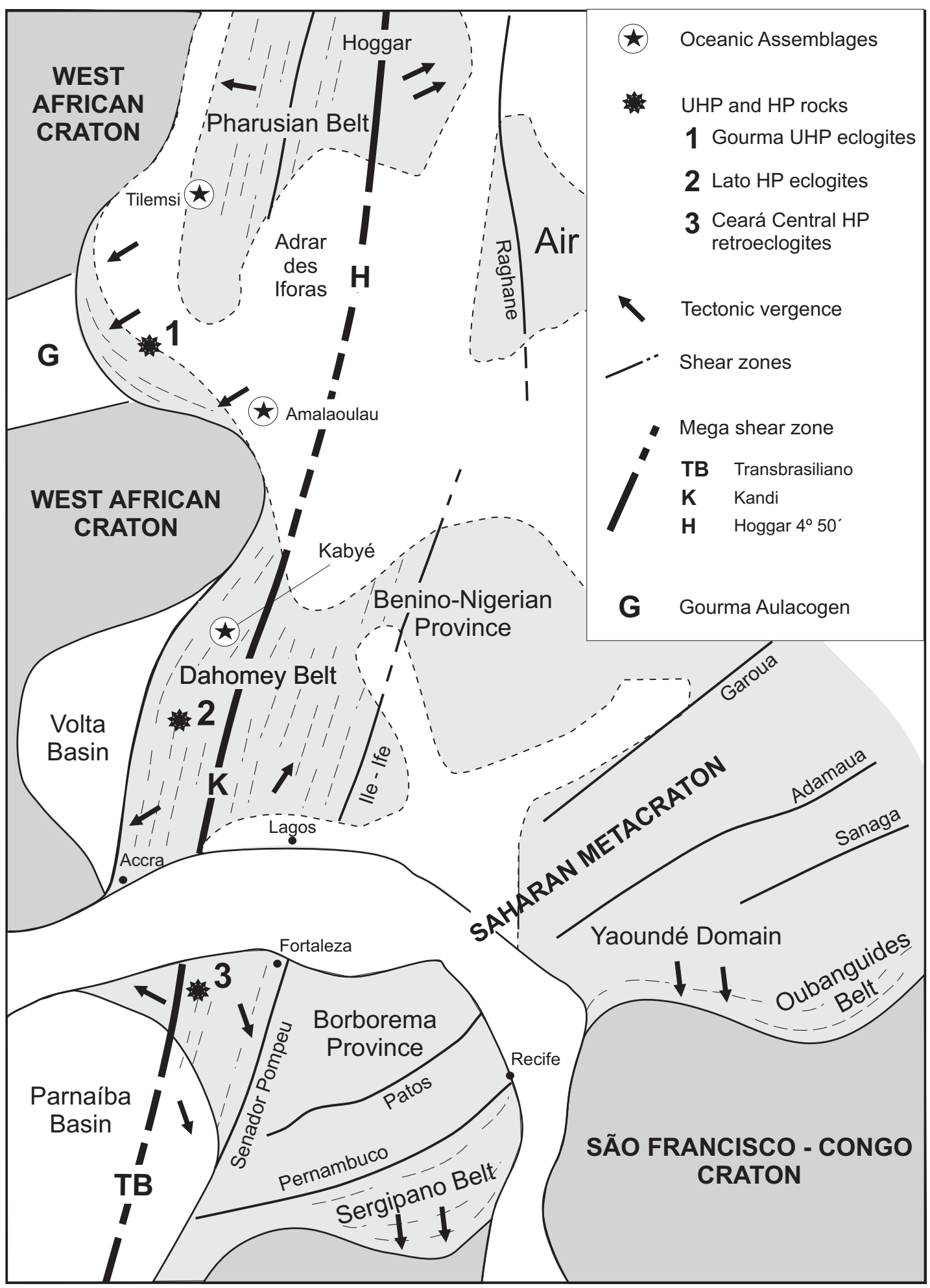

Figure 9.4 - Geological correlations between northeastern South America and north-western Africa, in a late Paleozoic pre-drift reconstruction. 
In the western part of the Brasília belt, a large area formed of Neoproterozoic juvenile crust records the closure of a large oceanic domain between the Amazonian and São Francisco paleocontinents from at least $c a$. 900 to $600 \mathrm{Ma}$ (Pimentel \& Fuck 1992). This is known as the Goiás Magmatic Arc, which represents one of the most important tectonic components of the Brasília Belt (fig. 9.5). It is divided into the Arenópolis arc to the south, and the Mara Rosa arc to the north, comprising: (i) juvenile island-arc (ca. 900-800 Ma; e.g., Mara Rosa and Arenópolis sequences), volcanic-sedimentary sequences associated with mantle-derived tonalitegranodiorite-granite orthogneisses; and (ii) younger (ca. 650-630 Ma) continental arc-type volcano-sedimentary sequences intruded by a series of tonalite-granodiorite plutonic complexes (Junges et al., 2002, and references therein). The juvenile signature of the older metavolcanic and metaplutonic rocks with tholeiitic to calcalkaline signature is demon- strated by their low initial ${ }^{87} \mathrm{Sr} /{ }^{86} \mathrm{Sr}$ isotopic ratios, positive $\varepsilon N d$ values and $\mathrm{Sm}$ Nd TDM model ages mostly between 0.8 and 1.1 Ga (Laux et al., 2005, and references therein). Tonalite and granodiorite of the younger arc association have older Nd TDM model ages and slightly negative $\varepsilon \mathrm{Nd}$ values, suggesting a continental arc setting for this magmatic event. For the amalgamation of Gondwana, the intraoceanic magmatic arcs were fused together by a series of soft collisions, and granitoid magmatism persisted during the tectono-magmatic episodes of the Brasiliano orogeny (Pimentel et al., 2000). The predominant calc-alkaline composition of these magmatic rocks indicates the action of continued subductionrelated active margin processes.

It is not an easy task to identify the main sutures related to the closure of the Goiás Ocean, and the available geophysical evidence is just starting to reveal some important discontinuities. Deep crustal and lithospheric studies using seismic tomography (Assumpção et al., 2004, Feng et al., 2007), as well as deep seismic refraction and teleseismic receiver function investigations (Soares et al., 2006, Ventura et al., 2011) were conducted over the surface outcrops of the Goiás Magmatic Arc, where a large positive Bouguer anomaly occurs along the TB. The hot and dense litho- spheric mantle underlying the magmatic arc, where the crust is only $36-38 \mathrm{~km}$ thick, compensates this Bouguer anomaly. To the east, crustal thickness increases to up to $43 \mathrm{~km}$ below the marginal Brasília belt and the western part of the São Francisco craton. Westwards, seismological data show an abrupt $16 \mathrm{~km}$ step in the Moho discontinuity in the passage from the Goiás arc to the Araguaia belt and the Amazonian craton. Such structure is considered as the result of the duplication of the lower mafic crust of the Amazonian paleoplate during late Neoproterozoic subduc- tion below the Goiás magmatic arc (Ventura et al., 2011). In this context, the Serra Azul Archean metamorphic rocks are interpreted as an obducted sliver of the Amazonian craton basement (Soares and Fuck 2011). The geochrono- logical evidence that is available so far indicates that the main subduction event ended at $c a$. 630-600 Ma, and that the main regional metamorphic peak occurred at ca. 650-630 Ma, as recorded by the granulites of the Anápolis-Itauçu Complex indicated in figure 9.5 (Della Giustina et al., 2009), as well as by several other rock units of the Brasília Belt (Baldwin and Brown 2008, and references therein). In this granulite complex, UHT sapphirine-bearing rocks yielded U-Pb metamorphic ages of $c a .650 \mathrm{Ma}$, which are roughly coeval with the emplacement of maficultramafic complexes, thus representing the met- amorphic core of the Brasília orogen (Piuzana et al., 2003).

The Paraguay Belt (location in figure 9.3) is a typical fold-and-thrust belt located along the southeastern mar- gin of the Amazonian Craton (Alvarenga et al., 2000, Campanha et al., 2011). It is affected by tectonic deformation, which is almost imperceptible at the border of the craton, but increases up to tight isoclinal folds towards its inner areas. It comprises the older Cuiabá Group, including glacial sediments of the Puga 
Formation, and the younger Corumbá Group, comprising carbonates and pelites with Ediacaran-age fossils (Boggiani et al., 2010). The Cuiabá Group was affected by low-grade metamorphism, up to the biotite zone of the greenschist facies. Within the Cuiabá Group, some "cap carbonates" of the Araras Group, directly overlying diamictites of the Puga Formation, were dated at $c a$. $630 \mathrm{Ma}$ (Babinski et al., 2006). In addition, in Planalto da Serra, Mato Grosso, DeMin et al. (2013) reported ${ }^{40} \mathrm{Ar} /{ }^{39} \mathrm{Ar}$ dating on phlogopite, as well as additional $\mathrm{Rb}-\mathrm{Sr}$ and $\mathrm{Sm}-\mathrm{Nd}$ ages, for high-K ultramafic rocks, plugs and dykes affecting an area about $30 \mathrm{~km}$ long, intrusive into the low-grade metasedimentary rocks of the Cuiabá Group. Their ages, close to 600 Ma, represent the minimum age for the deposition and deformation of this unit. Later, during Cambrian, the Cuiabá Group was thrust over the Corumbá Group in a thin skin deformation, basically westerly directed. Moreover, rocks of the upper part of the Corumbá Group, located farther to the west, were virtually undeformed and unconformably deposited on the sialic basement of the Amazonian Craton. A final regional deformational phase of very low intensity, exten- sional in character and related to a few intrusions of granite bodies, took place during the Cambrian, or even later.

The sedimentary environment of the Corumbá Group is generally attributed to a restricted marine shelf within an epicontinental sea overlying the southeastern margin of the Amazonian Craton, and the resulting deposits correlate with the sedimentary filling of the nearby Tucavaca aulacogen, in Bolivia. Some other sedimentary sequences that are similar in age and tectonic setting to the Corumbá Group have been recently attributed to the Ediacaran and seem to represent very extensive marine transgressions, in a general context of epicontinental seas. For example, recent geochronological data by Pimentel et al. (2011) for the Bambuí Group in the western part of the São Francisco Craton suggest Ediacaran (ca. 600 Ma or younger) depositional ages for this foreland sequence. Moreover, Gaucher et al. (2003, 2008, 2009) and Poiré and Gaucher (2010) demonstrated the existence of a very important close correlation of the Corumbá Group with the Arroyo del Soldado Group, in Uruguay, which practically have the same stratigraphy and the same fossiliferous content of the Ediacaran age. They would therefore belong to the same continental shelf, along the margins of the Amazonian and Rio de la Plata cratons, and this reasoning is a powerful paleogeographic indicator for a connection of these two cra- tonic units in the Ediacaran.

The Amazonian-Rio de la Plata link in the Ediacaran is the main argument to deny the existence of oceanic lithosphere in central South America, as proposed by Trindade et al. (2006) and Tohver et al. (2012). In the latter, the suture resulting from the collision between the

Amazonian and São Francisco-Congo cratons and the closure of a supposed Clymene Ocean is crossing the entire South American continent. These authors reviewed the tectonic history of the Pampean, Paraguay, and Araguaia belts along the margins of the Amazonian and Rio de la Plata cratons, and tried to demonstrate that these belts were tectonically active from the late Ediacaran to the late Cambrian, as the final stages of Gondwana formation.

In addition to the already mentioned close correlation between the Corumbá and the Arroyo del Soldado groups, located along the same Ediacaran continental shelf, which precludes the existence of a wide ocean, a few other arguments against the idea of a Clymene Ocean in central South America were presented and discussed with the pertinent details in Cordani et al. (2013). Some of them are briefly summarized here: 
1. The most important evidence for the hypothesis of the Cambrian Clymene Ocean, the Puga paleopole, is located at low latitude, not far from the present pole, and therefore could be related to a younger remagnetization.

2. The assembly of West Gondwana was completed by $c a .600 \mathrm{Ma}$, After this, there is no geological evidence of an oceanic lithosphere (e.g., ophiolites, magmatic arcs etc.) in central South America.

3. The tentative correlation between the Pampean and Paraguay belts cannot be accepted, because their tectonic significance is totally different. There is no similarity in lithology, metamorphism, or structural trends.

4. The Araguaia Belt started as a Neoproterozoic in- traplate aulacogenic-type basin, formed over an ancient sialic basement, which may have extended into a premature oceanic stage with limited width, with the possibility of once having been connected to the main Goiás-Pharusian Ocean.

\subsection{Ediacaran/Cambrian Tectonic Evolution in Southern West Gondwana}

The Goiás-Pharusian Ocean closed at the end of the Neoproterozoic, and from then on, West Gondwana became a single continental mass (Cordani et al., 2013). After the probable uplift following the Brasiliano-Pan African orogeny, orogenic collapse and extension took place not only within the Transbrasiliano tectonic corridor, but also in adjacent areas. Simultaneously, a major spread- ing center was developing between West Gondwana and Laurentia, which led to plate reorganization, responsible for the initiation of convergence along the Pacific margin of Gondwana.

Cawood (2005) suggested that the subduction of the Pacific oceanic lithosphere occurred at the Gondwana margin at ca. $570 \mathrm{Ma}$. The name "Terra Australis Orogen" was proposed for a very large tectonic province located along the southern margin of Gondwana, forming an open and unconfined Pacific Ocean and comprising sev- eral accretionary orogens. The Pampean orogeny (Ramos 1988, Rapela et al., 1998) is the South American representative in Terra Australis. According to Ramos (1988), the Eastern Pampean ranges, in which high-grade metamorphic rocks are recognized, were formed as a result of normal subduction of oceanic lithosphere, followed by continent-continent collision between the Rio de la Plata Craton and the Pampia microcontinent. Geochronological data indicate a Cambrian age for the entire tectonic devel- opment of the Pampean orogen, which correlates in time with the Saldania, Ross, and Tasmanian companion belts of Terra Australis (Cawood 2005, Schwartz et al., 2008).

Escayola et al., (2011), dealing with the study of the Pampean orogen, summarized the available lithological, stratigraphic, and structural knowledge of the Puncoviscana formation in northern Argentina and presented conclusive evidence for its syntectonic character as an accretionary complex. They showed that the orogenic process had already started in the Ediacaran, around $560 \mathrm{Ma}$, being tectonically active during most of the Cambrian, until at least 520 Ma. 
Carlos E. Ganade de Araujo - Tese de Doutorado - Universidade de São Paulo Capítulo 9 - Transbrasiliano-Kandi tectonic corridor

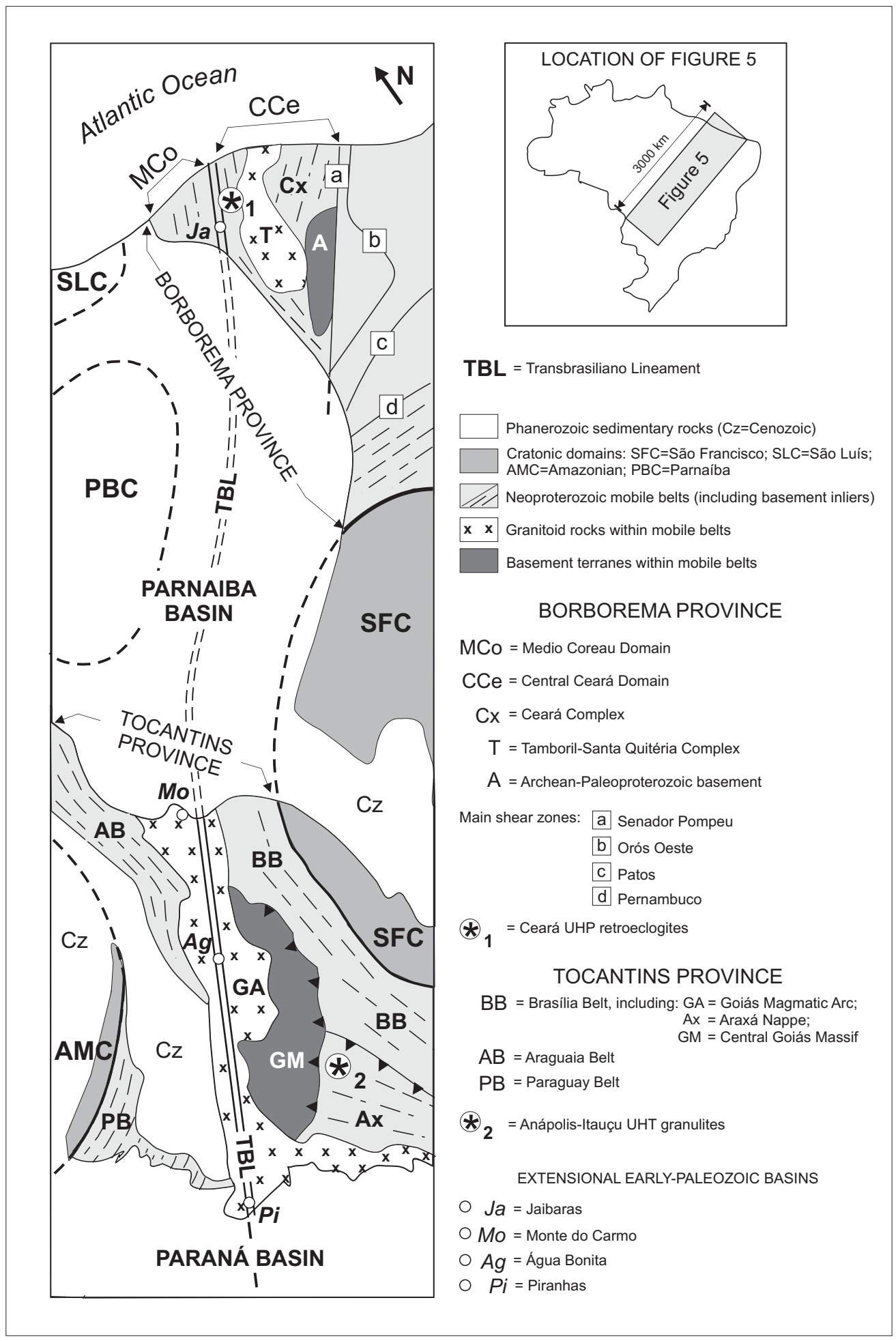

Figure 9.5 - Main tectonic elements within the Borborema and Tocantins provinces and the Parnaíba Basin, in South America, in the vicinity of the Transbrasiliano Lineament. 
As already mentioned, this period was marked by the subduction of the Pacific oceanic lithosphere, which produced tectonic compression and regional metamorphism, associated with voluminous granite magmatism of orogenic and subduction-related na- ture (Ramos 1988, Rapela et al., 1998). Given the time involved, 560$520 \mathrm{Ma}$, the Pampean orogenic system is much younger than the Neoproterozoic collisional belts responsible for closing the Goiás-Pharusian Ocean.

While subduction was going on at the southern part of Gondwana, extensional post-tectonic episodes occurred along the Transbrasiliano-Kandi megashear, and the overall extensional tectonic scenario in central Brazil clearly contrasts with that of the coeval compressional scenario of the Pampean orogen, in Argentina. Extensional tectonic reactivation occurred repeatedly at specific intervals along the me- gashear. The KandiHoggar 4050 lineament in Africa cuts through the region of the Pan-African Trans-Saharan orogen and is covered, in some parts, by relatively young and shal- low cratonic covers (fig. 9.4). In South America, TB crosses the entire Borborema and Tocantins tectonic provinces, and it also cuts through the basement of three large and relatively thick cratonic basins, the Parnaíba, to the north, and the Paraná and Chaco-Paraná, to the south (fig. 9.5). As indicated by Cordani et al. (2013), when TB leaves the Parnaíba Basin, immediately to the southwest of it, the linear structures of the megashear truncate the north-south structural trends of the Araguaia Belt of the Neoproterozoic age.

A series of small extensional cratonic sedimentary basins were formed along the TB in graben troughs, such as the Jaibaras, Monte do Carmo, Água Bonita, and Piranhas basins (Brito Neves et al., 1984). They are early Paleozoic, formed by brittle reactivation processes that affected old- er shear zones of the lineament. The Jaibaras rift is located at the northwestern corner of the Borborema Province (Oliveira and Mohriak 2003, Aguiar et al., 2011), and is described as an extensional structure forming a graben, which continues to the southwest, beneath the sedimen- tary rocks of the Parnaiba basin. Brito Neves et al. (1984) showed that it represents a precursor intracratonic rift for the thermal subsidence that started in the Silurian with the deposition of the Serra Grande formation. The main depocenters for this formation and for the younger sedimentary sequences, which continue into the Carboniferous, are located along the TB. Further south, within the Tocantins Province in central Brazil, TB maintains a northeast-south-west trend and affects parts of the Goiás Magmatic Arc. The Monte do Carmo rift, with a similar tectonic evolution to the Jaibaras rift, as well as the Água Bonita and Piranhas grabens, filled with Paleozoic sediments, are also located along the same structural trend.

Towards the southwest, TB disappears beneath the Paraná Basin. From geophysical evidence produced by Mantovani and Brito Neves (2005), and as previously suggested by Cordani et al. (1984), the megashear separates the supracrustal rocks of the Paraguay Belt to the west from the Paranapanema cratonic fragment to the east. Finally, continuing into Paraguay and Argentina, the TB is present within the basement of the Chaco-Paraná basin, where it has affected the tectonic evolution of sedimentary systems, as shown by the prominent depocenters of the Pilar and Las Breñas basins, where a total thickness of several kilometers is found (Wiens 1985).

Concomitantly to extensional tectonics along the Transbrasiliano tectonic corridor, mafic magma underplating and anatexis of the continental crust may have been responsible for the onset of postorogenic 
bimodal magmatism, active from the Ediacaran to the Ordovician (580-450 Ma), accompanied by the intrusion of practically undeformed K-rich, A-type granite bodies. The related rifting of the lithosphere may well have been produced by transtensional stresses, as a distant reflection of the more or less coeval compression produced at the southern border of Gondwana, during the subduction of the Pacific lithosphere.

A few examples of the Ediacaran to Cambro-Ordovician magmatism along the TB are given, as follows:

- In the state of Ceará, the emplacement of the Mucambo (530 Ma) and Meruoca (523 Ma) granitesintrusive into the sedimentary rocks of the Jaibaras rift (Archanjo et al., 2009), as well as the Quintas Ring Complex (495 Ma), located to the east of the TB (Castro et al., 2012).

- In the region of the Goiás Magmatic Arc and vicinities, the emplacement of a number of intrusive complexes com- prising small gabbro-diorite bodies associated with large K-rich granite plutons and A-type granitic intrusions, such as the Serra Negra (508 Ma), Iporá (490 Ma), and Serra do Impertinente (485 Ma) (Pimentel et al., 1996).

- Within the area of the Paraguay belt in Mato Grosso do Sul, in the vicinity of the TB megashear, the emplacement of the São Vicente (521 Ma), Coxim (542 Ma), Rio Negro (549 Ma), Sonora (549 Ma) and Taboco (546 Ma), intruding deformed metasedimentary rocks of the Cuiabá Group (Ferreira et al., 2008, McGee et al., 2012).

\subsection{Conclusion}

In conclusion, the collage of West Gondwana was largely completed by the end of the Precambrian, when the Amazonian, West African, São Francisco-Congo, Kalahari and Rio de la Plata cratons, the Saharan metacraton and the Parnaíba, Paranapanema and Luiz Alves cratonic fragments were united and tectonically stabilized. The geological evidence available so far indicates that the Neoproterozoic Goiás-Pharusian Ocean was already closed at about $600 \mathrm{Ma}$, and the resulting sutures are located within or close to the Transbrasiliano-Kandi tectonic corridor.

Later, in the Ediacaran and continuing at least during early Paleozoic, following the final stages of the Brasiliano orogeny, extension was predominant over West Gondwana and this structural regime may have been a result of two main factors: (1) the orogenic collapse of the folded belts produced by the Brasiliano orogeny; and (2) a distant tectonic reflection of the compressional Pampean orogeny, which was in action at the south-western margin of Gondwana. As a corollary, we argue that the idea of a collisional suture in central South America, closing a supposed Cambrian Clymene Ocean in the Cambrian, is not sustainable.

\section{Acknowledgements}

The authors would like to thank the associate editor Robert Pankhurst, as well referees Cesar Casquet and Eric Tohver, for their helpful comments and suggestions, which improved an earlier version of this paper. UGC and CEGA wish to acknowl- edge FAPESP (Foundation Agency for Research Support of the State of São Paulo) for its support through grant 12/0071- 1, and RAF also wishes to acknowledge the help received 
Carlos E. Ganade de Araujo - Tese de Doutorado - Universidade de São Paulo

Capítulo 9 - Transbrasiliano-Kandi tectonic corridor

from $\mathrm{CNPq}$ (Brazilian Council for Scientific and Technological Development) by means of grant 573713/2008-1.

\subsection{References}

Abdelsalam M.G., Liégeois J.P., Stern R.J., 2002. The Saharan metacraton. Journal of African Earth Sciences 34, 119136.

Affaton P., Kröner A., Seddoh K.F, 2000. Pan-African granulite formation in the Kabye Massif of northern Togo (West Africa): $\mathrm{Pb}-\mathrm{Pb}$ zircon ages. International Journal of Earth Sciences 88, 778-790.

Agbossoumondé Y., Menot R.P., Guillot S.. 2001. Metamorphic evolution of Neo-proterozoic eclogites from south Togo (West Africa). Journal of African Earth Sciences 33, 227-244.

Aguiar M.P, Chamani M.A.C., Riccomini C., 2011. O "Graben” de Água Bonita, TO-GO e seu significado tectônico. Anais do 13o Simpósio Nacional de Estudos Tectônicos e do VII International Symposium on Tectonics. Campinas, Sociedade Brasileira de Geologia, Núcleo São Paulo, p. 443-446.

Amaral W.S., Santos T.J.S., Wernick E., Matteini M., Dantas E.L., Moreto C.P.N., 2010. U-Pb, Lu-Hf and Sm-Nd geochronology of rocks from the Forquilha Eclogite Zone, Geará Central Domain, Borborema Province, NE-Brazil. In: VII SSAGI South American Symposium on Isotope Geology, Brasília.

Amaral W.S., Santos T.J.S., Wernick E., Neto J.A.N., Dantas E.L., Matteini M., 2012. High-pressure granulites from Cariré, Borborema Province, NE Brazil: Tectonic setting, metamorphic conditions and $\mathrm{U}-\mathrm{Pb}, \mathrm{Lu}-\mathrm{Hf}$ and $\mathrm{Sm}-\mathrm{Nd}$ geochronology. Gondwana Research 22, 892-909

Archanjo C.J, Launeau P., Hollanda M.H.B.M., Macedo J.W.P., Liu D, 2009. Scattering of magnetic fabrics in the Cambrian alkaline granite of Meruoca (Ceará State, Northeastern Brazil). International Journal of Earth Sciences 98, 1793-1807.

Arthaud M.H., Caby R., Fuck R.A., Dantas E.L., Parente G.V., 2008. Geology of the Northern Borborema Province, NE Brazil and its correlation with Nigeria, NW Africa. In: R.J. Pankhurst R.J., Trouw R.A.J., Brito Neves B.B., Wit M.J. (eds.). West Gondwana: Pre-Genozoic Correlations Across the Atlantic Region: Geological Society of London Special Publications 294, p. 49-67.

Assumpção M., An M., Bianchi M., Franca G.S.L., Rocha M., Barbosa J.R., Berrocal J., 2004. Seismic studies of the Brasilia fold belt at the western border of the São Francisco Craton, central Brazil, using receiver function, surface-wave dispersion and teleseismic tomography. Tectonophysics 388, 173-185

Attoh K. 1998. High-pressure granulite facies metamorphism in the Pan-African Dahomeyide orogen, West Africa. Journal of Geology, 106, 236-246.

Babinski M., Trindade R.I., Alvarenga C.J.S, Boggiani P.C., Liu D., Santos R.V., Brito Neves B.B. 2006. Chronology of Neoproterozoic ice ages in central Brazil. In: SSAGI, VI South American Symposium on Isotope Geology, Abstracts, Mar del Plata, CD-ROM.

Baldwin J.A., Brown M, 2008. Age and duration of ultrahigh- temperature metamorphism in the Anápolis-Itauçu Complex, Southern Brasília Belt, central Brazil - constraints from U-Pb geochronology, mineral rare earth element chemistry and traceelement thermometry. Journal of Metamorphic Geology 26, 213-233.

Berger J., Caby R., Liégois J.P., Mercier J.C., Demaiffe D., 2011. Deep inside a neoproterozoic intra-oceanic arc: growth, differentiation and exhumation of the Amalaoulaou complex (Gourma, Mali). Contributions to Mineralogy and Petrology 162, 773-796.

Boggiani P.C., Gaucher C., Sial A.N., Babinski M., Simona C., Riccomini C., Ferreira V.P., Fairchild T.R., 2010. Chemostratigraphy of the Tamengo Formation (Corumba Group, Brazil): A contribution to the calibration of the Ediacaran carbon-isotope curve. Precambrian Research 182, 382-401. 
Carlos E. Ganade de Araujo - Tese de Doutorado - Universidade de São Paulo

Capítulo 9 - Transbrasiliano-Kandi tectonic corridor

Brito Neves B.B., Fuck R.A., Cordani U.G., Thomaz-Filho A., 1984. Influence of basement structures on the evolution of the major sedimentary basins of Brazil: A case of tectonic heritage. Journal of Geodynamics 1, 495-510.

Brito Neves B.B., Santos E., Van Schmus W.R., 2000. Tectonic history of the Borborema Province, NW Brazil. In: Cordani U.G., Milani E.J., Thomaz Filho A., Campos D.A. (eds.). Tectonic Evolution of South America: Rio de Janeiro, p. 151-182.

Bruguier O., Bosch D., Caby R., Galland B., Hammor D., 2008. Sampling an active continental paleo-margin: a LAICP-MS U-Pb zircon study from the Adrar des Iforas (Mali). Geochimica et Cosmochimica Acta 72, A118.

Caby R., 1989. Precambrian terranes of Benin, Nigeria and Northeast Brazil and the late Proterozoic South Atlantic fit. Geological Society of America Special Paper 230, 145-158.

Caby R., 1994. Precambrian coesite from northern Mali: first record and implications for plate tectonics in the TransSaharan segment of the Pan-African belt. European Journal of Mineralogy 6, 235-244.

Caby R., 2003. Terrane assembly and geodynamic evolution of central-western Hoggar: a synthesis. Journal of African Earth Sciences 37, 133-159.

Castro N.A., Ganade de Araújo C.E., Basei M.A.S., Osako L.S., Nutman A., Liu D, 2012. Ordovician A-type granitoid magmatism on the Ceará Central Domain, Borborema Province, NE-Brazil. Journal of South American Earth Sciences $36,18-31$.

Cawood P.A. 2005. Terra Australis orogen: Rodinia breakup and development of the Pacific and Iapetus margins of Gondwana during the Neoproterozoic and Paleozoic. Earth-Science Reviews 69, 249-279.

Collins A.S., Pisarevsky S.A. 2005. Amalgamating eastern Gondwana: The evolution of the Circum-Indian Orogens. Earth- Science Reviews 71, 229-270.

Cordani U.G., Brito Neves B.B., Fuck R.A., Porto R., Thomaz-Filho A., Cunha F.M.B., 1984. Estudo preliminar de integração do Pré-Cambriano com os eventos tectônicos das bacias sedimentares brasileiras. Ciência Técnica Petróleo, Seção Exploração Petróleo 15, 1-70.

Cordani U.G., D’Agrella-Filho M.S., Brito Neves B.B., Trindade R.I.F. 2003. Tearing up Rodinia: the Neoproterozoic palaeogeography of South American cratonic fragments. Terra Nova 15, 350-359.

Cordani U.G., Pimentel M.M., Ganade de Araújo G.E., Basei M.A.S., Fuck R.A., Girardi V.A.V., 2013. Was there an Ediacaran Clymene Ocean in central South America? American Journal of Science 313, 517-539.

Dardenne M.A., 2000. The Brasilia Fold belt. In: Cordani U.G., Milani E.J., Thomaz Filho A., Campos D.A. (eds.). Tectonic Evolution of South America: Rio de Janeiro, CPRM, p. 231-263.

De Min A., Hendriks B., Slejko F., Comin-Chiaramonti P., Girardi V.A.V., Ruberti E., Gomes G., Neder R.D., Pinho F.C., 2013. Age of ultramafic-K rocks from Planalto da Serra, Mato Grosso, Brazil. Journal of South American Earth Science 41, 57-64.

Della Giustina M.E.S., Oliveira C.G., Pimentel M., Buhn B., 2009. Neoproterozoic magmatism and high-grade metamorphism in the Goiás Massif: new LA-MC-ICMPS U-Pb and Sm-Nd data and implications for collisional history of the Brasília Belt. Precambrian Research 172, 67-79.

Dostal J., Dupuy C., Caby R. 1994. Geochemistry of the neoproterozoic Tilemsi belt of Iforas (Mali, Sahara) - a crustal section of an oceanic island-arc. Precambrian Research 65, 55-69.

Duclaux G., Ménot R.P., Guillot S., Agbossoumondé Y., Hilairet N. 2006. The mafic layered complex of the Kabyé massif (north Togo and north Benin): Evidence of a Pan-African granulitic continental arc root. Precambrian Research 151, 101-118.

Escayola M.P., Van Staal C.R., Davis W.J, 2011. The age and tectonic setting of the Puncoviscana Formation in northwestern Argentina: An accretionary complex related to Early Cambrian closure of the Puncoviscana Ocean and accretion of the Arequipa-Antofalla block. Journal of South American Earth Sciences 32, 438-459. 
Carlos E. Ganade de Araujo - Tese de Doutorado - Universidade de São Paulo

Capítulo 9 - Transbrasiliano-Kandi tectonic corridor

Fairhead J.D., Maus S., 2003. CHAMP satellite and terrestrial magnetic data help define the tectonic model for South America and resolve the lingering problem of the pre-break-up fit of the South Atlantic Ocean. The Leading Edge 22, 779-783.

Feng M., Van der Lee S., Assumpção M., 2007. Upper mantle structure of South America from joint inversion of waveforms and fundamental mode group velocities of Rayleigh waves. Journal of Geophysical Research 112, B4.

Ferreira C., Dantas E., Pimentel M., Buhn B., Ruiz A.S., 2008. Nd isotopic signature and U-Pb LA-ICPMS ages of Cambrian intrusive granites in the boundaries between Brasília Belt and Paraguay Belt. In: South American Symposium on Isotope Geology, 6, Bariloche, Abstracts, CD-ROM.

Fetter A.H., Santos T.J.S., Van Schmus W.R., Hackspacher, P.C., Brito Neves B.B., Arthaud M.H., Nogueira Neto J.A., Wernick E., 2003. Evidence for Neoproterozoic continental arc magmatism in the Santa Quiteria Batholith of Ceará State, NW Borborema Province, NE Brazil: implications for the assembly of west Gondwana. Gondwana Research 6, 265-273.

Ganade de Araújo G.E., Cordani U.G., Basei M.A.S., Castro N.A., Sato K., Sproesser W. 2012. U-Pb detrital zircon provenance of metasedimentary rocks from the Ceará Central and Médio Coreaú Domains, Borborema Province, NEBrazil: Tectonic implications for a long-lived Neoproterozoic active continental margin. Precambrian Research 206-207, $36-51$.

Gaucher C., Boggiani P.C., Sprechmann P., Sial A.N., Fairchild T.R. 2003. Integrated correlation of the Vendian to Cambrian Arroyo del Soldado and Corumbá Groups (Uruguay and Brazil): palaeogeographic, palaeoclimatic and palaeobiologic implications. Precambrian Research 120, 241-278.

Gaucher G., Finney S.C., Poiré D.G., Valencia V.A., Grove M., Blanco G., Pamoukaghlián K., Gómez Peral L., 2008. Detrital zircon ages of Neoproterozoic sedimentary successions in Uruguay and Argentina: insights into the geological evolution of the Río de la Plata Craton. Precambrian Research 167, 150-170.

Gaucher C., Frimmel H.E., Germs G.J.B., 2009. Tectonic events and palaeogeographic evolution of Southwestern Gondwana in the Neoproterozoic and Cambrian. In: Gaucher C., Stal A.N., Halverson G.P., Frimmel H.E. (eds.). Neoproterozoic-Cambrian tectonics, global change and evolution: a focus on southwestern Gondwana: Developments in Precambrian Geology 16, 295-316.

Hartnady C., Joubert P., Stowe C., 1985. Proterozoic crustal evolution in Southwestern Africa. Episodes 8, $236-244$.

Jahn B., Caby R., Monié P. ,2001. The oldest UHP eclogites of the World: age of UHP metamorphism, nature of protoliths and tectonic implications. Chemical Geology, 178(1-4):143-158.

Junges S.L., Pimentel M.M., Moraes R., 2002. Nd Isotopic study of the Neoproterozoic Mara Rosa Arc, central Brazil: implications for the evolution of the Brasilia Belt. Precambrian Research 117, 101-118.

Kalsbeek F., Affaton P., Ekwueme B., Freid R., Thranea K, 2012. Geochronology of granitoid and metasedimentary rocks from Togo and Benin, West Africa: Comparisons with NE Brazil. Precambrian Research 196-197, $218-233$.

Kröner A., 1980. Pan African Crustal Evolution. Episodes 2, 3-8.

Kröner A, Cordani U.G., 2003. African, southern Indian and South American cratons were not part of the Rodinia supercontinent: evidence from field relationships and geochronology. Tectonophysics 375, 325-352.

Lapierre H., Bendali M., Dupont P.L., Gravelle M. 1986. Nouvelles données stratigraphiques et structurales sur le rameau oriental de la chane pharusienne, region de Silet (Hoggar, Algerie): Comptes Rendus de l'Academie des Sciences Paris 303, 1731-1736.

Laux J.H., Pimentel M.M., Dantas E.L., Armstrong R.A., Junges S.L., 2005. Two Neoproterozoic crustal accretion events in the Brasília belt, central Brazil. Journal of South American Earth Sciences 18, 183-198.

Li Z.X., Bogdanova S.V., Collins A.S., Davidson A., De Waele B., Ernst R.E., Fitzsimons I.G.W., Fuck R.A., Gladkochub D.P., Jacobs J., Karlstrom K.E., Lu S., Natapov L.M., Pease V., Pisarevsky S.A., Thrane K., Vernikovsky V. 2008. Assembly, configuration, and break-up history of Rodinia: a synthesis. Precambrian Research 67, 179-210. 
Carlos E. Ganade de Araujo - Tese de Doutorado - Universidade de São Paulo Capítulo 9 - Transbrasiliano-Kandi tectonic corridor

Liégeois J.P., Black R., Navez J., Latouche L, 1994. Early and late Pan- African orogenies in the Aïr assembly of terranes (Tuareg shield, Niger). Precambrian Research 67, 59-88.

Liégeois J.P., Latouche L., Navez J., Black R. 2000. Pan African collision, collapse ans escape tectonicsin the Tuareg Shield:relations with the East Sharan Ghost craton and the West African craton. In: 18th Colloquium of African Geology, Graz, Austria. Journal of African Earth Science 30, 53-54.

Mantovani M.S.M., Brito Neves B.B., 2005. The Paranapanema Lithospheric Block: Its importance for Proterozoic (Rodinia, Gondwana) supercontinent theories. Gondwana Research 8, 303-315.

McGee B. \& Collins A., Trindade R.I., 2012. G'Day Gondwana the final accretion of a supercontinent: U-Pb ages from the post-orogenic São Vicente Granite, northern Paraguay Belt, Brazil. Gondwana Research 21, 316-322.

McWilliams M.O., 1981. Paleomagnetism and Precambrian Tectonic Evolution of Gondwana. In: Kröner A. (ed.). Precambrian Plate Tectonics, Developments in Precambrian Geology 4, Elsevier, p. 649-687.

Meert J.G., 2003. A synopsis of events related to the assembly of eastern Gondwana. Tectonophysics 362, 1-40.

Nunes K.C., 1993. Interpretação integrada da Bacia do Parnaiba com ênfase nos dados aeromagnéticos. In: Congresso Internacional da Sociedade Brasileira de Geofisica, 2: Resumos expandidos, 1:152-157.

Oliveira D.C., Mohriak W.U., 2003. Jaibaras trough: an important element in the early tectonic evolution of the Parnaíba interior sag basin, Northern Brazil. Marine and Petroleum Geology 20, 351-383.

Pimentel M.M., Fuck R.A., 1992. Neoproterozoic crustal accretion in central Brazil. Geology 20, 375-379.

Pimentel M.M., Fuck R.A., Alvarenga C.J.S., 1996. Post-Brasiliano (Pan African) high-K granitic magmatism in central Brazil: late Precambrian/early Paleozoic extension. Precambrian Research 80, 217-238.

Pimentel M.M., Fuck R.A., Jost H., Ferreira-Filho C.F., Araújo S.M., 2000. The basement of the Brasília Fold Belt and the Goiás Magmatic Arc. In: Cordani U.G., Milani E.J., Thomaz Filho A., Campos D.A (eds.). Tectonic Evolution of South America: 31st International Geological Congress, Rio de Janeiro, Brazil, p. 195-229.

Pimentel M.M., Rodrigues J.B., DellaGiustina M.E.S., Junges S.L., Matteini M., 2011. The tectonic evolution of the Brasilia Belt, central Brazil, based on SHRIMP and LA-ICPMS U-Pb sedimentar provenance data. Journal of South American Earth Sciences 31, 345-357.

Piuzana D., Pimentel M.M., Fuck R.A., Armstrong R.A., 2003. SHRIMP U-Pb and Sm-Nd data for the Araxá Group and associated magmatic rocks: constraints for the age of sedimentation and geodynamic context of the southern Brasília Belt, central Brazil. Precambrian Research 125, 139-160.

Poiré D., Gaucher C., 2010. Lithostratigraphy. In: C. GGaucher C., Stal A.N., Halverson G.P., Frimmel H.E. (eds.). Neoproterozoic- Cambrian tectonics, global change and evolution: Developments in Precambrian Geology, 16. Elsevier, p. $87-101$

Ramos V.A., 1988. Late Proterozoic - Early Proterozoic of South America - A collisional history. Episodes, 11:168-174.

Rapela C.W., Pankhurst R.J., Casquet C., Baldo E., Saavedra J., Galindo C., Fanning C.M., 1998. The Pampean Orogeny of the southern proto- Andes: evidence for Cambrian continental collision in the Sierras de Córdoba. In: Pankhurst R.J. \& Rapela C.W. The Proto-Andean Margin of Gondwana: Geological Society Special Publication, 142:181-217.

Santos T.J.S., Fetter A.H., Nogueira Neto J.A., 2008. Comparisons between the northwestern Borborema Province, NE Brazil, and the southwestern Pharusian Dahomey Belt, SW Central Africa). In: R.J. Pankhurst, R.A.J. Trouw, B.B. Brito Neves, M.J. De Wit (eds.). West Gondwana: Pre-Cenozoic Correlations Across the Atlantic Region: Geological Society of London Special Publications, 294:49-67.

Schobbenhaus C. (coord.)., 1975. Carta Geológica do Brasil ao Milionésimo - Folha Goiás (SD 22) (texto explicativo). DNPM, Brasília 114 p. 
Carlos E. Ganade de Araujo - Tese de Doutorado - Universidade de São Paulo

Capítulo 9 - Transbrasiliano-Kandi tectonic corridor

Schwartz J.J., Gromet L.P., Miró R., 2008. Timing and duration of the calc-alkaline arc of the Pampean Orogeny: Implications for the Late- Neoproterozoic to Cambrian evolution of Western Gondwana. The Journal of Geology 116 , $39-61$.

Shackleton R.M., 1996. The final collision zone between East and West Gondwana: where is it? Journal of African Earth Sciences 23, 271-287.

Soares J.E.P., Berrocal J.A., Fuck R.A., Mooney W.D., Ventura D.B.R. 2006. Seismic characteristics of central Brazil crust and upper mantle: a deep seismic refraction study. Journal of Geophysical Research 111, (B12).

Soares J.E.P., Fuck R.A., 2011. Neoproterozoic suture in central Brazil: Geophysical characteristics of West Gondwana collage. In: Schmitt R.S., Trouw R., Carvalho I.S., Collins A., Gondwana 14, Abstracts: Rio de Janeiro, UFRJ, p. 107.

Strieder A.J., Nilson A.A., 1992. Mélange ofiolítica nos metassedimentos do Grupo Araxá de Abadiânia (GO) e implicações tectônicas regionais. Revista Brasileira de Geociências 22, 204-215.

Tohver E., D’Agrella-Filho M.S., Trindade R.I.F., 2006. Paleomagnetic record of Africa and South America for the 1200-500 Ma interval, and evaluation of Rodinia and Gondwana assemblies. Precambrian Research 147, 193-222.

Tohver E., Cawood P.A., Rossello E.A., Jourdan F., 2012. Closure of the Clymene Ocean and formation of West Gondwana in the Cambrian: Evidence from the Sierras Australes of the southernmost Rio de la Plata craton, Argentina. Gondwana Research 21, 193-222.

Torquato J.R. Cordani U.G., 1981. Brazil-Africa geological links. Earth-Science Reviews, 17:155-176.

Trompette R. 1994. Geology of Western Gondwana, Pan-African - Brasiliano aggregation of South America and Africa: A. A. Balkema, Rotterdam, Brookfield, 350 p.

Tupinambá M., Heilbron M., Valeriano C., Porto Júnior R., de Dios F.B., Machado N., Silva L.G.E., Almeida J.C.H., 2012. Juvenile contribution of the Neoproterozoic Rio Negro Magmatic Arc (Ribeira Belt, Brazil): Implications for Western Gondwana amalgamation. Gondwana Research 21, 422-438.

Ventura D.B.R., Soares J.E.P., Fuck R.A., Caridade L.C., 2011. Caracterização sísmica e gravimétrica da litosfera sob a linha de refração sísmica profunda de Porangatu, Província Tocantins, Brasil central. Revista Brasileira de Geociências 41, 130-140.

Van Schmus W.R., Oliveira E.P., Silva-Filho A.F., Toteu S.F., Penaye J., Guimarães I.P. 2008. Proterozoic links between the Borborema Province, NE Brazil, and the Central African Fold Belt. In: Pankhurst R.J., Trouw R.A.J., Brito Neves B.B., Wit M.J. West Gondwana: Pre-Cenozoic Correlations Across the South Atlantic Region, Geological Society of London, Special Publications 294, 69-99.

Van Schmus W.R., Kozuch M., Brito Neves B.B. 2011. Precambrian history of the Zona Transversal of the Borborema Province, NE Brazil: Insights from Sm-Nd and U-Pb geochronology. Journal of South American Earth Sciences 31, $227-$ 252.

Wiens F., 1985. Phanerozoic Tectonics and Sedimentation in the Chaco Basin of Paraguay, with Comments on Hydrocarbon Potential. In: Tankard A.J., Suarez Soruco R., Welsink H.J. (eds.). Petroleum basins in South America: AAPG Memoir 62, p. 185-205.

Yoshida M., Jacobs J., Santosh M., Rajesh H.M., 2003. Role of pan African events in the Circum-East Antarctic Orogen of East Gondwana: a critical overview. In: M. Yoshida, B.F. Windley, S. Dasgupta (eds.). Proterozoic East Gondwana: Supercontinent Assembly and Breakup, Geological Society of London, Special Publications 206, 57-75. 


\title{
10. Was there an Ediacaran Clymene Ocean in Central South America?
}

\author{
Umberto Giuseppe Cordani $^{(1)}$, Marcio Martins Pimentel(2), Carlos Eduardo Ganade de Araujo (3)(1),

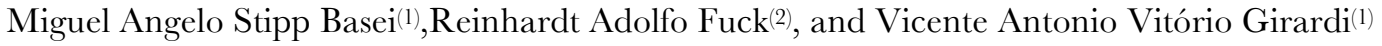 \\ (1) Instituto de Geociências da Universidade de São Paulo, São Paulo, SP, Brasil \\ (2) Instituto de Geociências da Universidade de Brasília, Brasília, DF, Brasil \\ (3) CPRM/SGB Serviço Geológico do Brasil, Fortaleza, CE, Brasil
}

\section{Abstract}

Previous studies have proposed that a major suture resulted from the collision between the Amazonian and São Francisco-Congo cratons during the Cambrian, following the closure of a supposed Clymene Ocean. The proposal tentatively located this ocean along the Araguaia and Paraguay belts at the eastern margin of the Amazonian Craton, and its southern extension reached the Pampean belt in Argentina. In the present study we will argue that the existence of Ediacaran-Cambrian oceanic lithosphere in central South America is highly unlikely. West Gondwana was assembled during the convergence between the Amazonian, West African, São Francisco-Congo and Rio de La Plata cratons as well as the Saharan Metacraton, leading to the closure of the Goiás-Pharusian Ocean during the Neoproterozoic. Final closure and continental collision resulted in the development of the Transbrasiliano-Kandi mega-shear zone that cuts through several mobile belts, but leaves the cratonic areas totally untouched. Consistent results of radiometric dating along the Transbrasiliano (TB) mega-shear in South America and of metamorphic rocks of the Brasília Belt have indicated that the Neoproterozoic collision finished at ca. $620 \mathrm{Ma}$. After isostatic uplift, cooling, and denudation, between 590 and $500 \mathrm{Ma}$, emplacement of undeformed K-rich postorogenic granites represented the main tectonic event. At this time or afterwards, a series of small extensional sedimentary basins formed in graben troughs, most of which are within the TB tectonic corridor. They all were of extensional character, contrasting clearly with the convergent tectonics occurring within the coeval Pampean Orogen in Argentina. The main arguments showing that an Ediacaran to Cambrian oceanic closure in central Brazil is untenable include: (i) the assembly of West Gondwana was completed by ca. $600 \mathrm{Ma}$, when the convergence between the Amazonian, São Francisco and Rio de La Plata cratons had already ended. After this, there is no geological evidence of an oceanic lithosphere (for example, ophiolites, magmatic arcs, et cetera), ruling out the possible existence of an Ediacaran or Cambrian Clymene Ocean in Central Brazil; (ii) the Gurupi and Araguaia belts in Brazil, as well as the Bassaride and Rokelide belts in West Africa, are regarded as aulacogenic-type systems formed within an intraplate tectonic setting. Their tectonic history precedes the collision between the Amazonian and São Francisco-Congo cratons, as demonstrated by the linear structures of the Transbrasiliano megashear which truncate the N-S structural trends of the Araguaia Belt; (iii) there is a close correlation between the Corumbá Group of the Paraguay Belt in Brazil and the Arroyo del Soldado Group in Uruguay. These sedimentary sequences belonged to the same Ediacaran continental shelf and this is a powerful indicator for an Ediacaran connection between the Amazonian and Rio de La Plata cratons, which precludes the existence of a wide ocean (for example, the Clymene) between them. On the other hand, the tentative correlation between the Sierras de Cordoba and the Paraguay Belt cannot be accepted, because these are far apart and there is no similarity in lithology, metamorphism, or structural trends; (iv) the Puga paleopole is the most important evidence for the hypothesis of the Cambrian Clymene Ocean, however the age of about 600 Ma for this paleopole, taken on the basis of $\mathrm{Sr}$ and $\mathrm{G}$ isotopes, is loosely constrained. In addition this is located at low latitude, not far from the present pole, and therefore could be related to a younger remagnetization; (v) the Pampean Orogen is made up of medium- to high-grade metamorphic rocks constrained between $560 \mathrm{Ma}$ and $520 \mathrm{Ma}$ and therefore was tectonically active during most of the Cambrian. However, at this time, an oceanic lithosphere is not evident in the vicinity of the Paraguay belt, and in central Brazil extensional rather than convergent tectonic processes have been observed. 
Carlos E. Ganade de Araujo - Tese de Doutorado - Universidade de São Paulo

Capítulo 10 - Was there a Clymene Ocean?

\subsection{Introduction}

Almost all publications regarding the formation of Gondwana stress that it was formed by the amalgamation of several building blocks of different sizes, most of them originating from the breakup of Rodinia. They assembled through a series of continental collisions that covered the entire Neoproterozoic (see, for example, Li et al., (2008) and references therein). West Gondwana, the largest building block of the supercontinent, included the Amazonian and West African cratons, the Congo-São Francisco, Rio de La Plata, and Kalahari cratons, as well as a few smaller continental fragments, such as the Paranapanema, the Goiás Massif, and the Luiz Alves (see figure 10.1). It also included a large region of northern Africa, named the Saharan Metacraton.

West Gondwana was assembled during the convergence between the Saharan Metacraton and the Amazonian, West African, and Congo-São Francisco cratons. This event led to the closure of the GoiásPharusian Ocean and to the development of several orogens during the Neoproterozoic Era. In central Brazil the Brasilia Belt occurs along the western margin of the São Francisco Craton. Further to the west, along the eastern/southeastern margins of the Amazonian Craton, they are known as the Paraguay and Araguaia belts. According to most existing tectonic, stratigraphic, and geochronological evidences, West Gondwana was already assembled by ca. $650 \mathrm{Ma}$ to $600 \mathrm{Ma}$.

As an alternative scenario, Trindade et al. (2006) postulated that the final assembly of Gondwana occurred in the Cambrian, after the closure of a large oceanic basin, named the Clymene Ocean. This event was a result of the convergence and collision between the Amazonian and Congo-São Francisco continents. Their rationale for this model was based on paleomagnetic data for sedimentary rocks of the Araras Formation, which were obtained by Trindade et al. (2003) from the Paraguay Belt of Central Brazil. These rocks were believed to have been deposited at ca. $600 \mathrm{Ma}$. However, its paleopole plotted quite far from the other Gondwana poles for that time. This observation was understood to imply that the Amazonian Craton and the rest of Gondwana were far apart during Ediacaran to Cambrian times. Although the Clymene Ocean was not properly described in their work, the concept was readily accepted by esearchers working in southern South America, such as Li et al. (2008), Pisarevski et al. (2008), Cordani et al. (2009), Tohver et al. (2010), and Ramos et al. (2010).

The hypothesis of a Cambrian ocean seems appealing in terms of its elegance and simplicity, and has been seriously considered. For instance, Cordani et al. (2009) indicated two alternative timeframes for the assembly of West Gondwana. In the first timeframe, the Amazonian and West African cratons joined the São Francisco-Congo Craton before the Ediacaran. In the second timeframe, the model put forward by Trindade et al. (2006) was followed, and the assembly of West Gondwana was completed only after the Ediacaran.

Supporting the idea of the Cambrian Clymene Ocean and looking for a suitable location for the suture resulting from its closure, Tohver et al. (2012) proposed that the suture zone crossed the entire South American continent (as shown in figure 10.2). They presented new geochronological data indicating Ediacaran to Cambrian magmatism at the Sierras de la 


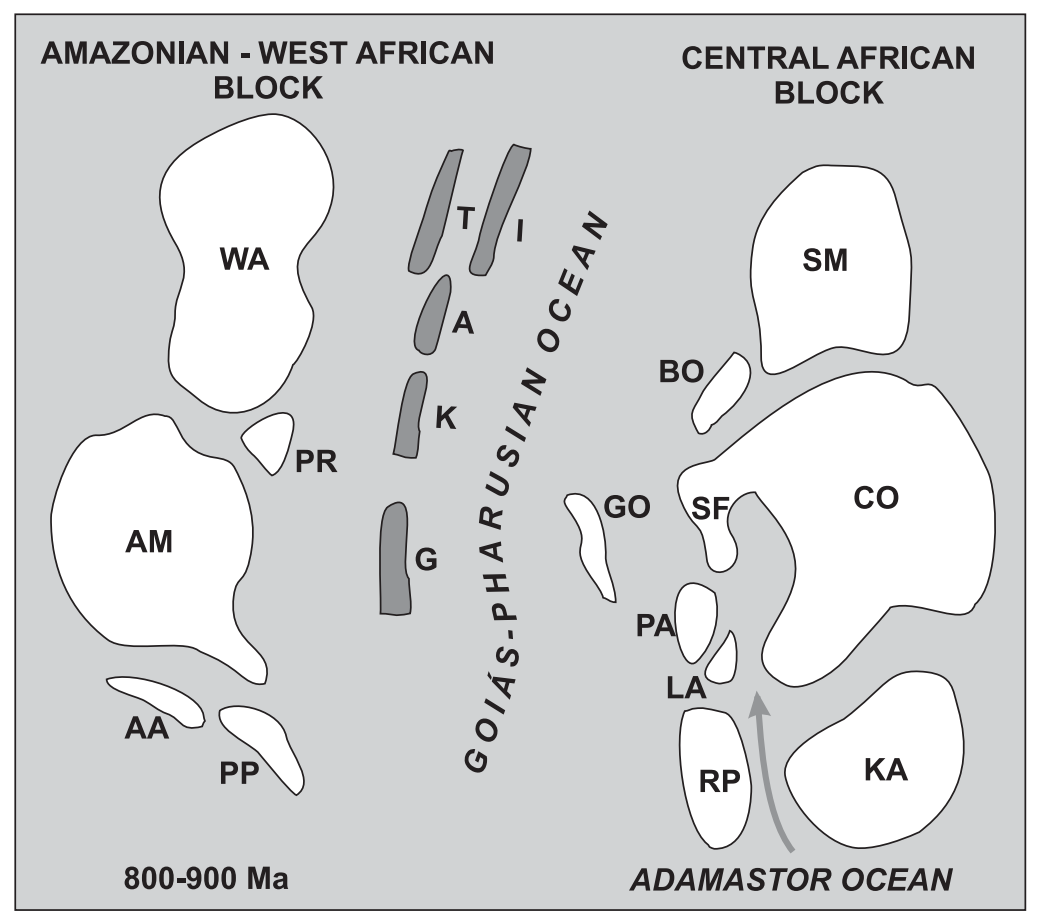

Figure 10.1- Major tectonic elements related to West Gondwana, prior to the final amalgamation. Major cratons: $\mathrm{AM}=$ Amazonian; $\mathrm{CO}=$ Congo KA $=$ Kalahari; $\mathrm{RP}=$ Rio de La Plata; $\mathrm{SF}=$ São Francisco; $\mathrm{SM}=$ Sahara Metacraton; WA $=$ West African. Smaller cratonic fragments: $\mathrm{AA}=$ Arequipa-Antofalla; $\mathrm{BO}=$ Borborema; $\mathrm{GO}=$ Goiás Central Massif; LA = Luiz Alves; $\mathrm{PA}=$ Paranapanema; $\mathrm{PB}=$ Parnaiba; $\mathrm{PP}=$ Pampia. Intra-oceanic magmatic arcs: A = Amalaoulaou; $\mathrm{G}=$ Goiás; $\mathrm{I}=\mathrm{Iskel} ; \mathrm{K}=$ Kabyé; $\mathrm{T}=$ Tilemsi.

Ventana of Argentina. They also suggested a correlation with the Pampean belt, although the shallow level of magma emplacement in the Sierra de la Ventana contrasted with the deeply exhumed high-grade rocks of the Pampean Orogen. Moreover, they reviewed the tectonic history of the Pampean, Paraguay, and Araguaia belts along the margins of the Amazonian and Rio de La Plata cratons. They tried to demonstrate that these three belts were tectonically active from the late Ediacaran to the late Cambrian times along the Clymene suture zone, marking the closure of the ocean and the final stages of formation of Gondwana.

In this paper, we will present the available evidence indicating that the South American Platform was already in place in the Neoproterozoic. We will argue that the existence of an area with an oceanic lithosphere in its central region during the period from Ediacaran to early Cambrian is highly unlikely. As a corollary, we will suggest that the Clymene Ocean and its Cambrian closure, as put forward by Trindade et al. (2006) and Tohver et al. (2012), are untenable on the grounds of the available evidence.

\subsection{Closure of the Goiás-Pharusian Ocean}

Figure 10.1 presents a likely model for the relative positions of the main cratonic elements around $750 \mathrm{Ma}$ to $700 \mathrm{Ma}$, prior to closure of the Goiás-Pharusian Ocean and the final collisions that led to West Gondwana. This figure shows the approximate location of the oceanic realms, where the intraoceanic island arcs were 
Carlos E. Ganade de Araujo - Tese de Doutorado - Universidade de São Paulo

Capítulo 10 - Was there a Clymene Ocean?

already in place; outlines of the cratonic masses and fragments, together their marginal basins that would become Neoproterozoic mobile belts; some of the accretionary units within the intervening oceans; smaller microcontinents (e.g., Arequipa-Antofalla and Pampia); and smaller ancient blocks located in the Borborema and Tocantins Provinces. Figure 10.1 also illustrates the position of the confined Adamastor Ocean, located in Gentral Gondwana, whose tectonic history ended only in the Cambrian.

The name "Goiás-Pharusian Ocean" was suggested by Kröner and Cordani (2003), although many paleomagnetic reconstructions, such as those by Meert (2003) and Cordani et al. (2003), have named this ocean "Brasiliano" or "Adamastor". This ocean occupied a very large area and included intraoceanic magmatic arcs, whose tectonic evolution started as early as ca. $900 \mathrm{Ma}$ and covered the entire Neoproterozoic. As mentioned above, this ocean closed ca. $650 \mathrm{Ma}$ to $600 \mathrm{Ma}$, after a series of successive continental collisions that gave rise to the many mobile belts of the Brasiliano-Pan African orogenic cycle. In most recent paleomagnetic reconstructions, such as these by Rapalini (2006) or Tohver et al. (2010), all workers agree on a consolidated West Gondwana by Middle Cambrian.

The closure of the Pharusian Ocean, in consequence of the convergence between the West African Craton and the Saharan Metacraton, was characterized by Himalayan-type continental collisions, with the development of UHP and HP rock associations in the Trans-Saharan orogenic belt (see figure 10.3). Blueschists and eclogites have been identified in the Gourma region and in Togo, and geochronological studies have estimated the age of metamorphism at ca. 620 Ma (Caby, 1994; Trompette, 1994; Jahn et al., 2008; Attoh, 1998; Agbossoumoundé et al., 2001; Affaton et al., 2000). Oceanic terranes, relicts of the Pharusian Ocean, have been identified in many regions, from the Hoggar to the Dahomeyan segments (Caby, 1989, 2003; Berger et al., 2011; Dostal et al., 1994; Duclaux et al., 2006). These terranes, which have been dated within the $900 \mathrm{Ma}$ to $700 \mathrm{Ma}$ timeframe, correspond to the Iskel island arc in the Hoggar, the TilemsiAmalaoulaou intraoceanic arc assemblages in the Gourma region, and the Kabyé massif in the Dahomeyan Belt of Togo.

Abdelsalam et al. (2002) set the boundary between the Trans-Saharan Belt and the Saharan Metacraton along the eastern margin of the Tuareg Shield (Liégois et al., 2000). However, their Saharan Metacraton was not well-defined. It was characterized as a large portion of pre-Neoproterozoic cratonized continental crust dominated by medium- to high-grade gneissic and migmatitic terrains, which were highly remobilized during the Neoproterozoic. The NE portion of the Borborema Province of Brazil-where large areas with Paleoproterozoic or older crust have been found, may correlate with the Saharan Metacraton. Moreover, a correlation between the northwest part of the Borborema Province and the Trans-Saharan belt is highly likely, given the similarity of the regional lithostratigraphic trends (Caby, 1989; Arthaud et al., 2008), the continuity of the major faults, and the correlation between the granitoid rocks of Dassa and Savá in Benin (Cordani and others, 1993) with rocks of the Tamboril-Santa Quitéria Complex in the Ceará State of Brazil, a large area formed by different types of granitic rocks and migmatites (Fetter et al., 2003). Ceará HP retroeclogites that are located close to the eastern side of this complex (see fig. 10.5), dated at ca. $650 \mathrm{Ma}$ by Amaral et al. (2010), are considered to be representative of the Neoproterozoic suture.

Similar to the Pharusian Ocean, the Goiás Ocean was consumed as a consequence of the convergence between the Amazonian and São Francisco Cratons. As one of the largest, most complete, and most preserved 
Neoproterozoic orogenic belts in Brazil (Pimentel and others, 2000), the Brasília Belt presents compelling evidence for closure of the Goiás Ocean at ca. $650 \mathrm{Ma}$ to $630 \mathrm{Ma}$, as recorded by granulitic rocks of the Anápolis-Itauçu Complex (A in fig. 10.3) and several other rock units (Baldwin and Brown, 2008). This belt comprises a thick Meso-Neoproterozoic sedimentary pile in the east, a microcontinent composed of Archean rock units and associated Paleoproterozoic formations (the Goiás Massif), and a large magmatic arc in the west, the so-called Goiás Magmatic Arc (GMA in figure 10.3). Due to its tectonic significance and areal magnitude, the GMA represents the most important tectonic element of the Brasilia Belt, and is formed by Neoproterozoic juvenile crust that records the closure of the Goiás Ocean from ca. 900 Ma to $600 \mathrm{Ma}$ (Pimentel and Fuck 1992).

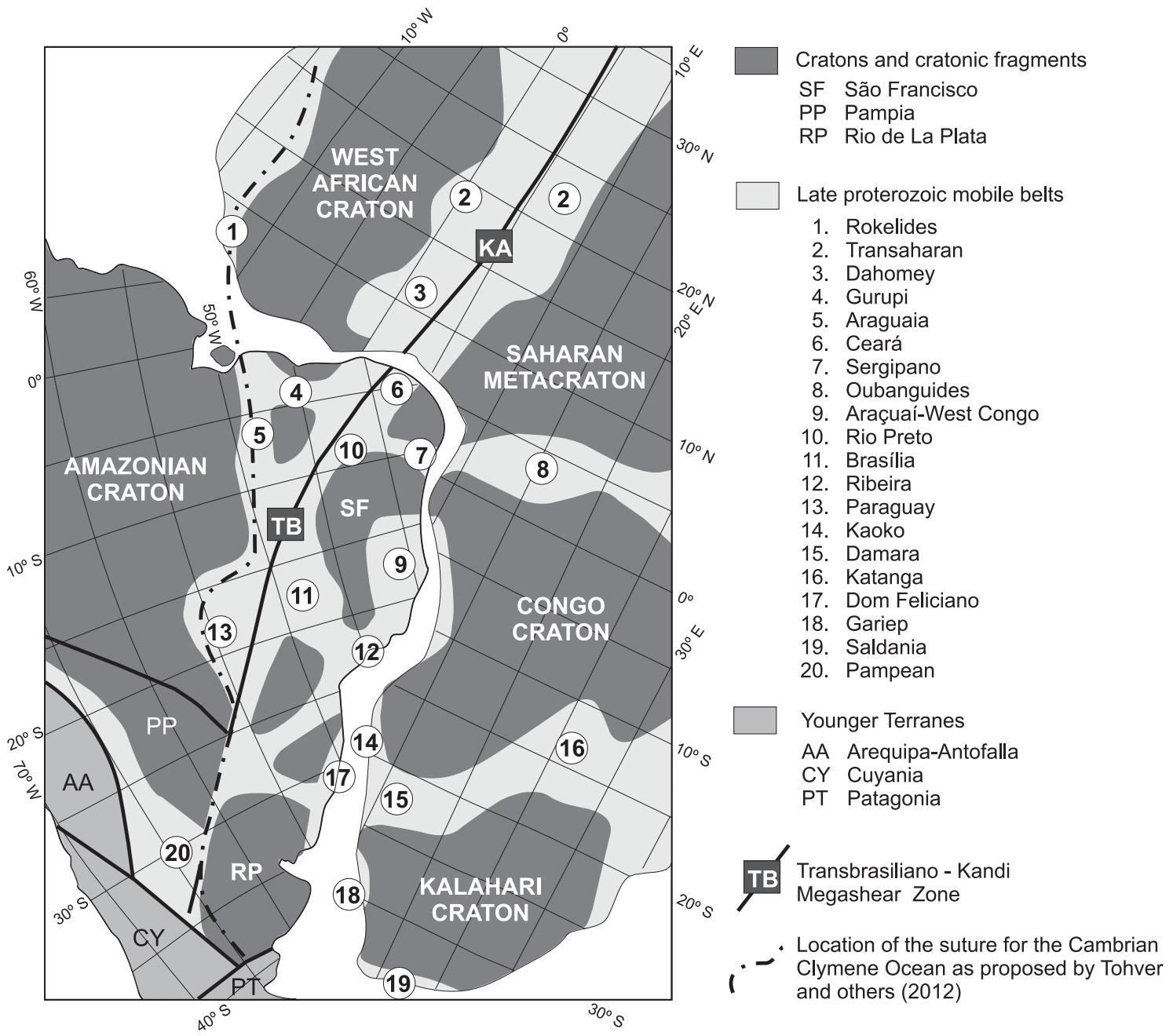

Figure 10.2 - Outline of the Transbrasiliano-Kandi mega-shear zone in a pre-drift reconstruction of South America and Africa. The suggested position of the Cambrian suture proposed by Tohver et al. (2012) is indicated. Phanerozoic covers are omitted.

The GMA is divided into the Arenópolis arc to the south and the Mara Rosa arc to the north, which are separated from each other by the Goiás Massif. The arc includes: (i) juvenile island arcs (ca. 900-800 Ma) with volcanic-sedimentary sequences that are spatially associated with tonalitic-granodioritic-granitic orthogneisses with a mantle signature; (ii) younger (ca. 650-630 Ma), island arc-type volcano-sedimentary sequences and 
associated tonalite-granodiorite plutonic complexes; and (iii) late- to post-orogenic ( $<600 \mathrm{Ma})$ granites that are associated with gabbro-diorite bodies (Junges et al., 2002, and references therein).

The Brasiliano-Pan-African belts with Neoproterozoic sutures are aligned along a very long area $(>6000 \mathrm{Km})$ of South America and Africa that is dominated by one of the most important tectonic elements of the world. This megashear zone is called the Trans-Brasiliano lineament in Brazil, continues as the Kandi-Hoggar 450' lineament into Africa (Caby, 1989), and will be referred to in this work as the "Transbrasiliano-Kandi". As shown in figures 10.2 to 10.5, the megashear zone cuts through many of the Brasiliano-Pan African belts, but leaves the cratonic areas untouched. It may be the largest coherent shear zone on Earth (Attoh and Brown, 2008). Its coherence has been well-characterized by the very long linear magnetic anomalies obtained from the CHAMP satellite survey and reported by Fairhead and Maus (2003). This lineament probably reaches the bottom of the lithosphere and is formed of a series of ductile shear zones, comprised of many parallel sets of faults, which may cover very broad areas. The shear zone motion must have started shortly after the closure of the Goiás-Pharusian Ocean. Tectonic reactivations have repeatedly occurred along the shear zone, where low-intensity seismic activity continues through the present day.

The $650 \mathrm{Ma}$ to $600 \mathrm{Ma}$ timeframe for the orogenic tectono-magmatic episodes in northwest Africa and central South America indicate that the convergence of the continental blocks leading to the closing of the Goiás-Pharusian Ocean was finished at that time along the corridor of the Transbrasiliano-Kandi megashear.

\subsection{Ediacaran and Cambrian subduction of the oceanic lithosphere in southern South America}

In the previous chapter, we showed that the Goiás-Pharusian Ocean closed at the end of the Neoproterozoic, at which time West Gondwana was in place as a single continental mass. At about the same time, the Mozambique Ocean was also closing, with termination of the convergence between West Gondwana and the different components of East Gondwana. A major center was developing and spreading between West Gondwana and Laurentia, which led to a need for major plate reorganization. This reorganization was associated with the initiation of convergence along the Pacific margin of Gondwana.

Cawood (2005) suggested that the subduction of the Pacific oceanic lithosphere occurred at the Gondwana margin at ca. $570 \mathrm{Ma}$, more or less simultaneously with the separation of Laurentia and the opening of the Iapetus Ocean. The name "Terra Australis Orogen" was proposed for a very large tectonic province that was located at the southern Gondwana margin, along an open and unconfined Pacific Ocean and comprising a collection of accretionary orogens. These orogens were formed by the stacking of magmatic arc complexes, which were formed in successive subduction zones by the tectonic processes of "soft collision" and accretion, accompanied by the extensive production of felsic volcanic and granitoid magmas. Knowledge about such major tectonic processes is necessary for understanding the tectonic development of southern South America within the $600 \mathrm{Ma}$ to $500 \mathrm{Ma}$ timeframe and for assessing the possible presence of the suggested Clymene Ocean. The initiation of the Pacific subduction and the development of the Pampean Orogen are the key elements needed to analyze the plate reorganization that occurred just after the amalgamation of Gondwana. 
Figure 10.4 shows a schematic tectonic outline for the southwestern part of South America. Describing the general tectonic setting of the Sierras Pampeanas from a mobilistic perspective, Ramos (1988) pointed to differences between the Puncoviscana Formation in the north and the Eastern Pampean ranges, including the Sierra Norte and the Sierra de Cordoba, in the southeast. Covering a very large region of northern Argentina and southern Bolivia, the Puncoviscana Formation consisted of turbidites, which have been interpreted as a deep-water "flysch-type" sequence and as part of a passive margin, whose basin was linked to a stable craton to the east but was probably open to the west to a proto-Pacific Ocean. The Eastern Pampean ranges, in which high-grade metamorphic rocks have been found, were thought to be formed as the result of normal subduction of oceanic lithosphere, followed by a continent-continent collision between the same Pampean terrane (Pampia in figure 4) and the Rio de La Plata Craton.

Rapela et al. (1998), working on the polymetamorphic basement of the Sierras de Cordoba, presented a comprehensive report on what they called the "Pampean Orogeny," in which the low-grade meta-sedimentary rocks of the Puncoviscana Formation and the medium- to high-grade metamorphic rocks of the Sierras Pampeanas were attributed to the same tectonic episode. Their geochronological data indicated a clear Cambrian age for the entire tectonic development. Detrital zircons from the low-grade sediments established a maximum age of deposition at $560 \mathrm{Ma}$ to $550 \mathrm{Ma}$. An age of $530 \mathrm{Ma}$ was obtained for the emplacement of the calc-alkaline granites, as a result of northeast-directed subduction. These authors followed the same interpretation offered by Ramos (1988) and proposed that the high-grade metamorphism characteristic of the Pampean Orogeny, dated shortly after emplacement of the granites at ca. $525 \mathrm{Ma}$, was produced by a continental collision of the western side of Gondwana (the Rio de La Plata Craton in figure 10.4) with an exotic terrane, retaining for it the name of "Pampean Terrane".

Schwartz et al. (2008), studying the Sierra Norte, performed an additional geochronological program and extended the time interval for the calc-alkaline magmatism from $555 \mathrm{Ma}$ to $525 \mathrm{Ma}$. These authors discussed the implications of the tectono-magmatic evolution of the Pampean Orogen, correlating it with the Saldania, Ross, and Tasmanian companion belts of the Terra Australis. In particular, they noted that the plutonism in all of them was roughly coeval from Ediacaran to early Paleozoic and included very similar calc-alkaline and strongly peraluminous suites.

Escayola et al. (2011), dealing mainly with the Puncoviscana Formation in the northern part of Argentina, proposed a new tectonic interpretation. They summarized the available lithological, stratigraphic, and structural knowledge on that formation and presented conclusive evidence for the syntectonic character of it as an accretionary complex. They also highlighted the almost north-south strike of the belt along the protoAndean active margin of West Gondwana, where they located an oceanic opening called the "Puncoviscana tract" (see figure 10.4). This opening is in approximately the same position as that of the oceanic basins envisioned by Ramos (1988) and Rapela et al. (1998).

Recalling that Escayola et al. (2007) had identified ophiolite remnants within the high-grade metamorphics of the Sierra de Cordoba, and considering the presence of some Early Cambrian felsic and mafic arc volcanic rocks in the older parts of the Puncoviscana Formation, as well as the arc-like composition of the associated turbidites, Escayola et al. (2011) inferred that sedimentation occurred adjacent to an approximately coeval arc 
terrane. In their model, this process occurred in a basin that formed on the accretionary wedge, associated with a west-facing Pampean arc built upon the proto-Andean margin of West Gondwana. They proposed that their Puncoviscana tract was closed by a collision between Gondwana and the exotic Arequipa-Antofalla microcontinent. They indicated that this tectonic episode could be related to the separation of Laurentia and the spreading of the Iapetus Ocean.

The above discussion demonstrates the controversy surrounding the issue of the tectonic significance of the Pampean Orogeny. Regardless of whether the Puncoviscana Formation represents an active or passive margin, whether the tectonic process is collisional or non-collisional, or whether the Puncoviscan Ocean is open or restricted, the timing of the orogenic processes is clearly well-constrained between $560 \mathrm{Ma}$ and 520 Ma. Therefore, the Pampean orogenic system is much younger than the Neoproterozoic belts responsible for closing the Goiás-Pharusian Ocean. The Pampean system had already started in the Ediacaran and was tectonically active during most of the Cambrian. Given that the Amazonian, São Francisco-Congo, and Rio de La Plata Cratons were already together after the Brasiliano Orogeny, it can be concluded that instead of representing the final amalgamation of Gondwana, the Pampean Orogeny marks the oldest evidence of subduction of the Pacific oceanic plate under the southwestern margin of Gondwana.

\subsection{Extensional-type post-tectonic episodes along the Transbrasiliano Lineament in South America}

The Kandi-Hoggar 4 ${ }^{\circ} 50^{\prime}$ lineament in Africa cuts through the mobile belts of the Trans-Saharan orogen and is covered, in some parts, by relatively young and shallow cratonic covers. Its South American counterpart, the Transbrasiliano lineament (hereafter, TB), cuts through parts of the Borborema Province and Tocantins tectonic provinces, as well as the basement of three large and relatively thick cratonic basins, the Parnaiba basin (figure 10.3) and the Paraná and Chaco-Paraná basins to the south. The TB is clearly visible in the aeromagnetic mosaic of the central and eastern parts of the Brazilian territory, crossing the country from northeast to southwest. Comprised of a series of low-amplitude magnetic anomalies, it starts at the northwestern tip of the Borborema Province, continues through the eastern part of the Parnaíba Basin to the central part of Goiás, travels to the northern part of the Paraná basin, and goes to the southwest, to Paraguay and Argentina, where it seems to end near the city of Cordoba.

Consistent results of radiometric dating along the TB have indicated that the Neoproterozoic collisional tectono-magmatic events finished at ca. $620 \mathrm{Ma}$. However, after isostatic uplift, cooling, and denudation, the mobility and tectonic activity along the megashear continued for a long time. Within the period between 590 and $500 \mathrm{Ma}$, emplacement of virtually undeformed K-rich postorogenic granites represented the main geological/tectonic event, which was sometimes associated with gabbros and diorites. This fact can be verified all along the TB. At the north, in Ceará State, a few granitic plutons emplaced at 530 Ma to 500 Ma have been identified that are representative of late to postcollisional processes in the Ceará Central Domain (Fetter et al., 2003; Castro et al., 2012). In Mato Grosso do Sul State, several undeformed granitic plutons with ages between $550 \mathrm{Ma}$ and $520 \mathrm{Ma}$ (Ferreira et al., 2008, and references therein) have been encountered along the $\mathrm{TB}$, which cut through the supracrustal rocks of the Paraguay Belt, as will be described later. 

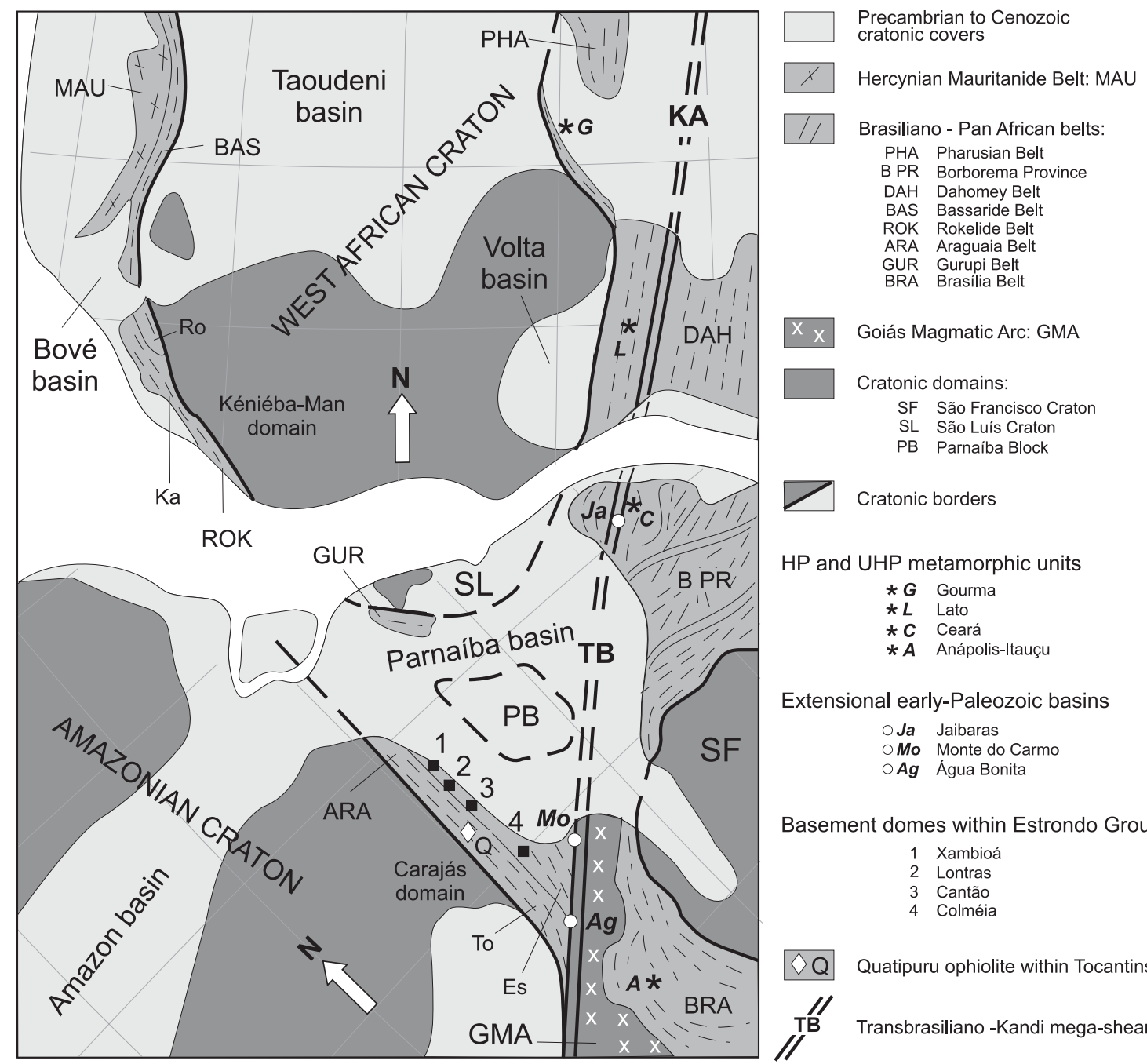

Goiás Magmatic Arc: GMA

Cratonic domains:

SF São Francisco Craton
SL São Luís Craton

SL São Luís Craton
PB Parnaíba Block

Cratonic borders

HP and UHP metamorphic units

$$
\begin{array}{ll}
* G & \text { Gourma } \\
* L & \text { Lato } \\
* C & \text { Ceará } \\
* A & \text { Anápolis-Itauçu }
\end{array}
$$

Extensional early-Paleozoic basins

$$
\begin{array}{ll}
\circ \text { Ja } & \text { Jaibaras } \\
\circ \text { Mo } & \text { Monte do Carmo } \\
\hline \boldsymbol{A g} & \text { Água Bonita }
\end{array}
$$

Basement domes within Estrondo Group

$$
\begin{array}{ll}
1 & \text { Xambioá } \\
2 & \text { Lontras } \\
3 & \text { Cantão } \\
4 & \text { Colméia }
\end{array}
$$

$\triangleright \mathrm{Q}$ Quatipuru ophiolite within Tocantins Group

TI $^{\text {TB Transbrasiliano -Kandi mega-shear }}$

Figure 10.3 - Geological correlations between north-eastern South America and north-western Africa, in a pre-drift reconstruction. The location of specific tectonic features mentioned in the text are indicated: HP and UHP metamorphic units of Neoproterozoic age; extensional early Paleozoic basins; and basement mantled domes within the Araguaia Belt.

In Goiás State, deep crustal and lithospheric seismic tomography (Assumpção et al., 2004; Feng et al., 2007) and deep seismic refraction and teleseismic receiver function investigations (Soares et al., 2006; Ventura et al., 2011) have been conducted at the location of a large positive Bouguer anomaly, corresponding to the surface exposure of the GMA. In this region, using group-velocity tomography and lithospheric s-velocity studies, Feng et al., (2007) demonstrated that there was a region of thinner lithosphere along the shear system. This finding may suggest a process of delamination of the crustal root of the collisional orogen, which gave way to an asthenospheric uplift, with the heating and formation of posttectonic high-K and A-type granitic intrusions. Especially within the area of the Goiás Magmatic Arc, these granitic plutons, whose radiometric ages were between $560 \mathrm{Ma}$ and $520 \mathrm{Ma}$, were virtually undeformed, indicating that they were related to extensional-type tectonics along the megashear (Pimentel et al., 1996). One point yet to be clarified is the presence of small exposures of medium- to high-grade rocks (migmatites, enderbites, and mafic-ultramafic bodies), dated between 560 Ma to 520 Ma, along the TB in Goiás and Tocantins (e.g., Lima et al., 2008; Motta-Araujo et 
al., 2003). The tectonic significance of these local occurrences is poorly understood, but they might represent exposures of lower crustal sections related to the emplacement of mafic magmas and subsequent crustal melting during Late Neoproterozoic to Cambrian times.

At the time of the intrusion of these granites or afterwards, a series of small extensional intracratonic sedimentary basins formed in graben troughs, such as the Jaibaras, Monte do Carmo, Água Bonita, and Piranhas basins, along the TB in Ceará, Tocantins, Goiás, and Mato Grosso States (Brito-Neves et al., 1984). Most of them were rift basins formed between the Cambrian and the Silurian by brittle reactivation processes that affected older shear zones of the TB. They were mainly formed by fault-scarp-related paraconglomerates at the base, followed laterally and vertically by fluvial-lacustrine sandstones interbedded with shales.

The Jaibaras rift, located at the northwest corner of the Borborema Province (Ja in figure 3), is the best representative of these extensional structures (Oliveira and Mohriak, 2003; Aguiar et al., 2011). Its age is wellcontrolled by the Mucambo (530 Ma) and Meruoca (510 Ma) granitic plutons. The graben trough continues to the southwest, beneath the sedimentary rocks of the Parnaiba basin, where it represents a precursor intracratonic rift for the thermal subsidence of the cratonic basin, which started in the Silurian with the deposition of the Serra Grande Formation. The main depocenters for this formation and younger sedimentary sequences until the Carboniferous were located along the TB (Brito-Neves and others, 1984), demonstrating that the successive extensional tectonic reactivations occurred in the Paleozoic. Brito-Neves et al. (1984) suggested the presence of a cratonic nucleous, herein named as the "Parnaiba block" (see figures 10.2 and 10.3), within the basement of the Parnaiba Basin, to the west of the TB trend.

Within the Tocantins Province in central Brazil, the TB maintains a northeast-southwest trend and is located over the Goiás Magmatic Arc. Immediately to the southwest of the Parnaiba Basin, the Monte do Carmo rift (Mo in figure 10.3) seems to have had a very similar tectonic evolution to the Jaibaras rift. The Agua Bonita graben, also located along the TB (Ag in figure 3), is filled with Paleozoic sediments (Brito Neves et al., 1984). The Piranhas basin, filled with Cambrian and Ordovician sediments, is located right next to the border of the Paraná cratonic basin.

To the southwest, the TB disappears below the northeastern corner of the Paraná Basin. As suggested by Cordani et al. (1984) and as inferred by Mantovani and Brito-Neves (2005) from geophysical evidence, within the basement of this basin, the megashear separates the supracrustal rocks of the Paraguay Belt to the west from a cratonic fragment (the Paranapanema block) to the east (figures 10.4 and 10.5). Along the western boundary of the Paraná Basin, not far from the influence of the TB megashear, Ferreira et al. (2008) dated a few practically undeformed granitic plutons, which yielded ages between $550 \mathrm{Ma}$ and $520 \mathrm{Ma}$ and will be discussed later. These plutons are filling spaces related to extensional features. They intrude deformed metasediments belonging to the older lithostratigraphic system of the Paraguay Belt. Continuing into Paraguay and Argentina, the TB is present within the basement of the Chaco-Paraná cratonic basin. Here, the $\mathrm{TB}$ has affected the tectonic evolution of the sedimentary systems, as shown by the more prominent depocenters of the linear basins of Pilar in Paraguay (Wiens, 1985) and Las Breñas in Argentina (LB in figure 10.4), where a total thickness of more than 6000 meters can be found. 
Carlos E. Ganade de Araujo - Tese de Doutorado - Universidade de São Paulo Capítulo 10 - Was there a Clymene Ocean?

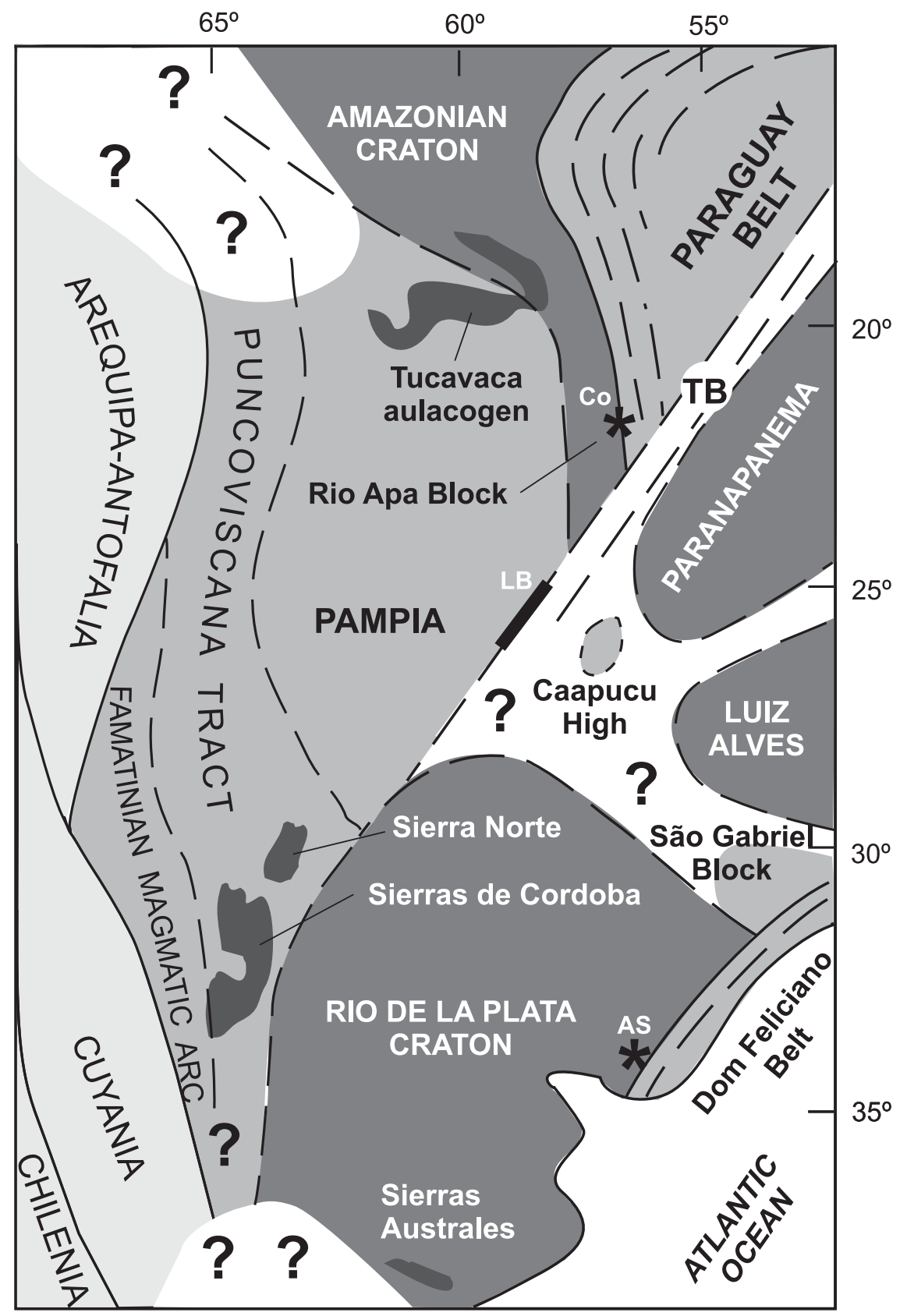

Figure 10.4 - Geotectonic interpretation of the south-eastern part of South America. It includes cratonic units (Amazonian, Rio de La Plata, Paranapanema and Luiz Alves), allochthonous terranes (ArequipaAntofalla, Famatina, Cuyania South America during the Paleozoic and the tectonic units of the Pampean orogeny: the eastern Pampean ranges and the Puncoviscana Tract. Phanerozoic covers are omitted. Tectonic features related to the Transbrasiliano Lineament.

In summary, the Goiás-Pharusian Ocean was already closed at $600 \mathrm{Ma}$. Therefore, later events, most of which located within or near the TB, were of an extensional character. This overall extensional tectonic scenario in central Brazil clearly contrasts with that of the coeval Pampean Orogen in Argentina. In this latter area, the period between ca. $560 \mathrm{Ma}$ and $520 \mathrm{Ma}$ was marked by the subduction of the Pacific oceanic lithosphere, 
including tectonic compression and regional high-to medium-grade metamorphism, associated with voluminous granite magmatism of an orogenic and subduction-related nature (Ramos 1988; Rapela et al., 1998).

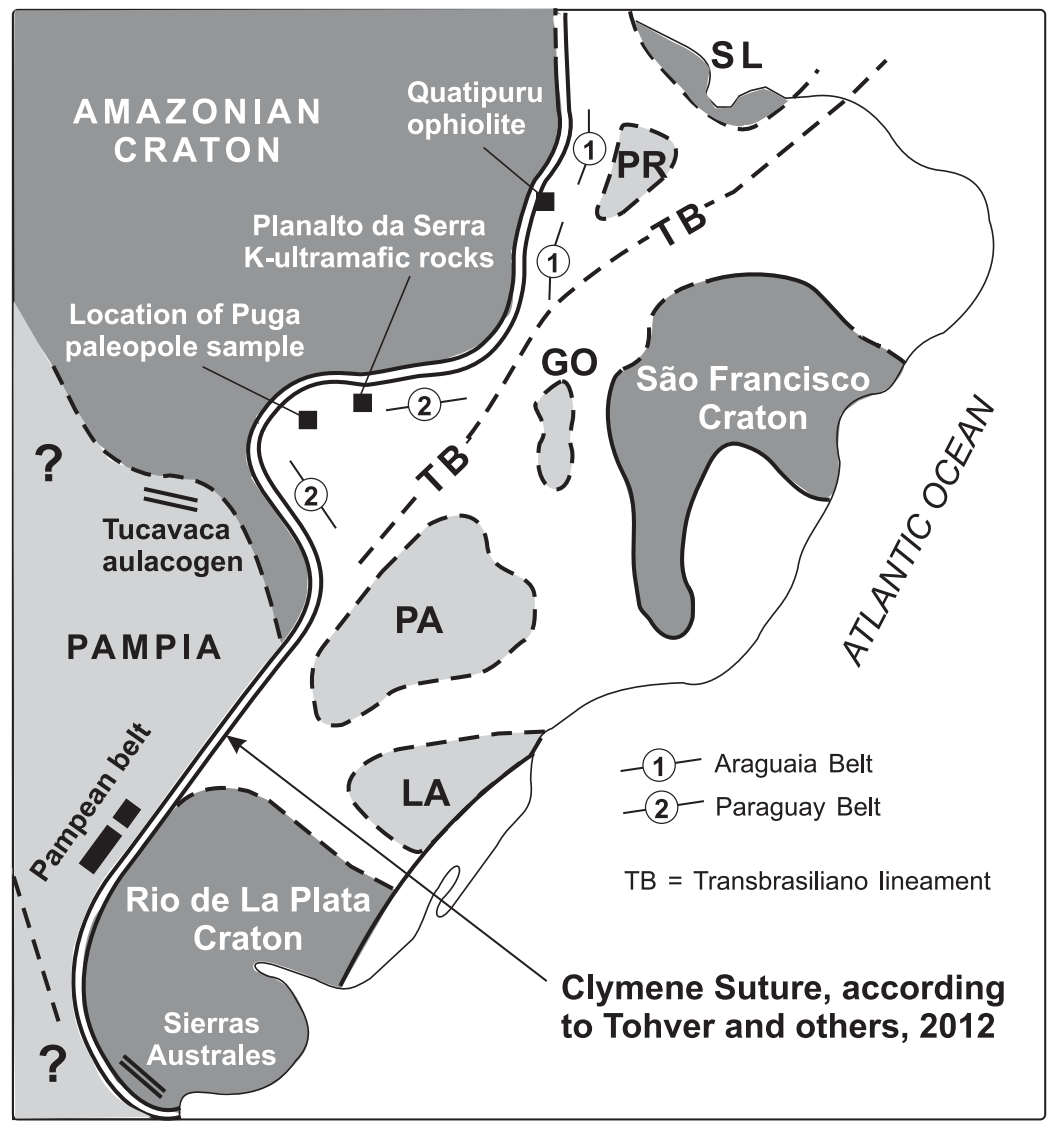

Figure 10.5 - Late Neoproterozoic geotectonic features of eastern South America. The location of the proposed suture resulting from the closure of a supposed Ediacaran/Cambrian Clymene Ocean is indicated.

\subsection{Was there an Ediacaran Clymene Ocean in Central South America?}

In this chapter, we present some arguments showing that a Cambrian oceanic closure, as suggested by Trindade et al. (2006) and Tohver et al. (2012) and depicted in figure 10.5, is untenable on the grounds of the available evidence.

\subsubsection{Age of the Amazonian-São Francisco-Congo collision along the region of the Transbrasiliano Megashear}

As we showed in the previous chapters, the amalgamation of Gondwana involved a long process of plate convergence. In South America, it started at ca. 900 Ma, during the earliest magmatic phases of the juvenile, intraoceanic, and accretionary Goiás Magmatic Arc. Evidence suggests that the main collisional episodes of the Brasiliano-Pan African orogens occurred at the end of the Neoproterozoic. Several recent articles with robust geochronological control (mainly by means of $\mathrm{U}-\mathrm{Pb}$ zircon ages) demonstrated that the tectonic 
Carlos E. Ganade de Araujo - Tese de Doutorado - Universidade de São Paulo

Capítulo 10 - Was there a Clymene Ocean?

evolution of the region dominated by the TB was developed roughly between $650 \mathrm{Ma}$ and $600 \mathrm{Ma}$. Considering the possible high-grade metamorphic events that could be related to Himalayan-type collisions as tracers for the main episodes related to the convergence between the Amazonian and São Francisco-Congo Cratons, we find that these events are restricted to the oldest phase of the process at ca. $650 \mathrm{Ma}$ (Baldwin and Brown, 2008; Della Giustina et al., 2009). Younger tectono-magmatic episodes have been registered until ca. 600 Ma. However, within the Ediacaran to Cambrian time-period, the few magmatic episodes observed in the area have been related to either posttectonic or anorogenic granitic plutons associated with an extensional tectonic regime.

In summary, the assembly of West Gondwana was completed by $600 \mathrm{Ma}$, when the convergence between the Amazon-West African and the Central African blocks had already been terminated. Therefore, there is no geological evidence of a possible Ediacaran Clymene Ocean in Central Brazil.

\subsubsection{The Bassarides, Rokelides, Araguaia, AND Gurupi belts}

Figure 10.3 shows a possible Neoproterozoic tectonic scenario related to the process of plate interaction and convergence between the Amazonian and West African Cratons. This figure shows the position of the Brasiliano-Pan African orogenic belts, such as the Bassarides, Rokelides, Gurupi, and Araguaia, formed by the interplay and consequent collisions between the mentioned cratonic elements. It also accounts for the São Luis cratonic fragment and the possible Parnaiba Block microcontinent, which is concealed below the sediments of the Parnaiba basin and was envisioned by Brito-Neves et al. (1984). The shape of this cratonic fragment is based on the geophysical interpretation of Nunes (1993) and is taken from Klein and Moura (2008).

Villeneuve (2008) extensively reviewed the orogenic belts on the western side of the West African Craton. The oldest is the Bassaride belt, which is cut to the north by the Paleozoic Mauritanide belt and to the south by the Rokelide belt, although parts of it are incorporated within the two younger belts. It is comprised of three lithostratigraphic units, the oldest of which is a volcano-sedimentary sequence formed within a rift-related basin. According to Villeneuve (2008), a few rhyolites stratigraphically below the oldest sequence of the unit yielded ages between $1050 \mathrm{Ma}$ and $1000 \mathrm{Ma}$. A range of ages between $700 \mathrm{Ma}$ and $650 \mathrm{Ma}$ were obtained for the volcanic and plutonic rocks of the Niokolo-Koba Group, affected by compression and crustal thickening around $660 \mathrm{Ma}$. These were followed by the deposition of the flyschoid sedimentation of the Mali and Batapa Groups, whose final metamorphism has been dated at ca. 555 Ma (Villeneuve and Dallmeyer, 1987; Dallmayer, 1989). A molassic phase consisting of reddish sandstones concluded the sedimentary history of the belt.

According to the same author (Villeneuve, 2008), the younger Rokelide Belt consists of the high-grade basement gneisses of the Kasila thrust belt in the west, extensively mobilized during the Pan-African tectonothermal event, and the Rokelide trough to the east, filled with the low-grade and weakly deformed metasediments of the Rokel River Group and interpreted as a foreland system. Rocks of the Kasila thrust belt (Ka in figure 10.3) present Archean ages, similar to those encountered in the nearby Kénéba-Man domain of the West African Craton (Hurley et al., 1971; Williams, 1988). The Rokel River Group (Ro in figure 3) comprises glaciogenic deposits in the lower part and clastic rocks associated with different volcanic types at the 
top. Delor et al. (2002) reported U-Pb zircon ages of ca. $570 \mathrm{Ma}$ from the high-grade rocks, interpreted to be the timing of the granulitization. K-Ar and Ar-Ar ages on hornblendes were obtained by Dallmayer (1989), who reported that the range (580-550 Ma) constrained the entire tectonic evolution of the belt to a preEdiacaran time.

Since the article by Hurley et al. (1967), the São Luis Craton (figures 10.3 and 10.5) has been considered to be a small cratonic fragment that was separated from the much larger West African Craton and remained in South America when the Atlantic Ocean was formed in Mesozoic time. The Neoproterozoic Gurupi belt, which occurs on the western side of the craton, displays structural transport and metamorphic polarity towards the cratonic area. Klein and Moura (2008) analyzed the tectonic development of the belt, suggesting a direct continuation of the Rokelide Belt. The predominant rocks exposed in the outcropping area were basement gneisses with Paleoproterozoic ages of ca. 2200 Ma. These rocks, affected by the Brasiliano-Pan African orogeny, included granitoids that were correlative of similar Tromaí calc-alkaline bodies belonging to the São Luis Craton. They formed the continental basement over which a Neoproterozoic belt was developed, starting with a rifting phase at ca. $730 \mathrm{Ma}$ (Klein et al., 2005). At the southeastern part of the belt, the medium-grade metasedimentary rocks of the Marajupema Formation were found, thrust over the basement rocks. Klein and Moura (2008) suggested that the Neoproterozoic tectonic event was due to a collision between the São Luis Craton with the concealed Parnaiba cratonic block, located below the sedimentary rocks of the Parnaiba Basin.

In pre-drift Brazil-Africa reconstructions, the Araguaia Belt in Brazil has been routinely correlated with the Rokelides; both belts exhibit similar north-northwestern trends (see figure 10.3) and virtually the same age for the tectonothermal event responsible for their final tectonic configuration (Trompette, 1994; Moura et al., 2008). However, these belts have opposite structural vergence. The Araguaia Belt shows tectonic transport to the west, in the direction of the Amazonian Craton, whereas the Rokelide Belt is transported easterly, against the West African Craton. The Araguaia Belt (Alvarenga et al., 2000) comprises two main tectonic units: the low-grade metasediments and associated mafic and ultramafic bodies of the Tocantins Group to the west (To in figure 10.3), and the medium- to high-grade gneisses of the Estrondo Group to the east (Es in figure 10.3), thrust over the former tectonic unit. The Tocantins Group exhibits north-south structural trends that cut through the west-northwest-east-southeast trends of the Archean and Paleoproterozoic rocks of the Carajás domain of the Amazonian Craton. Its mafic-ultramafic rocks are included within tectonic slices and are interpreted to be remnants of ophiolitic complexes. One of these, the Quatipuru ophiolite, was dated at ca. $750 \mathrm{Ma}$ by Paixão et al. (2008) with the Sm-Nd method. Moura et al. (2008) reported one very precise $\mathrm{Pb}$ evaporation zircon age of $817 \pm 5 \mathrm{Ma}$ for an intrusion of metagabbro. A rather imprecise $\mathrm{Pb}-\mathrm{Pb}$ evaporation age of ca. $1000 \mathrm{Ma}$ for the Serra da Estrela alkaline syenitic gneiss has been interpreted as indicating a major event of crustal rifting and formation of the Araguaia basin (Alvarenga et al., 2000).

Within the Estrondo Group, several basement inliers occupying mantled gneissic dome-like structures have been recognized (Hasui et al., 1984; Herz et al., 1989), yielding Archean and Paleoproterozoic ages. Four of them were located in figure 10.3. This finding led Moura and Gaudette (1999) to suggest that they could be extensions of the Amazonian Craton. Some zircon Pb evaporation ages ranging from $650 \mathrm{Ma}$ to $550 \mathrm{Ma}$ were obtained for a few syntectonic granitoid rocks, constraining the timing of structural development within the 
belt (Alves et al., 2006). Radiometric ages between $560 \mathrm{Ma}$ and $530 \mathrm{Ma}$ obtained by the K-Ar method in a few micas and amphiboles (Moura et al., 2008) indicated that the region of the Araguaia belt was already below ca. $300{ }^{\circ} \mathrm{C}$ in the Cambrian. Although a more robust geochronological control is needed for the Araguaia belt, from the perspective of regional cooling, these K-Ar mica ages alone preclude the onset of major regional thermo-tectonic episodes, such as a major continental collision, in Cambrian times.

The Bassarides, Rokelides, Gurupi, and Araguaia belts have been regarded as originating within an intraplatelike tectonic setting (Brito-Neves and Cordani, 1991; Villeneuve and Cornée, 1994; Alvarenga et al., 2000; Villeneuve, 2008, among many others). In this work they will be considered as members of a few activated aulacogens, located between the West African and Amazonian Cratons. Although some of these Neoproterozoic belts may have given birth to a poorly evolved oceanic rift where the ocean floor was formed in restricted areas, such as the Serra do Quatipuru within the Araguaia Belt (Kotschoubey et al., 2005: Paixão et al., 2002), the lack of arc-related magmatic rocks along all them strongly indicates the possibility of an intracontinental tectonic evolution. Finally, the close correlation in age between the basement rocks encountered in the orogenic belts and their respective cratonic areas (see figure 10.3) reinforces this reasoning. For the Gurupi belt, the basement granitoid gneisses are a direct continuation of the Tronai granites of Paleoproterozoic age of the São Luis Craton. For the Rokelides, the allochthonous Kasila highgrade gneisses show Archean ages of the same order as those encountered in the adjacent Kénéba-Man domain of the West African Craton. For the Araguaia belt, the granitoid rocks occupying the mantled gneissic domes, basement of the medium-grade rocks of the Estrondo Group, display either Archean or Paleoproterozoic ages, similar to the ages obtained from the Carajás domain of the Amazonian Craton.

The possibility of the existence of a concealed Parnaiba Block is strengthened when several U-Pb dates from detrital zircons ages of Neoproterozoic formations of the Gurupi and Araguaia belts are considered. Based on results obtained from a quartzite belonging to the Estrondo Group in the southern part of the Araguaia belt, Moura et al. (2008) demonstrated a derivation from predominant Neoproterozoic to Mesoproterozoic sources, with ages between $1200 \mathrm{Ma}$ to $800 \mathrm{Ma}$. Possible source rocks were not observed within the neighboring regions of the Amazonian Craton. These authors postulated a possible eastern provenance, from sources now below the sediments of the Parnaiba basin. Similarly, the presence of detrital zircon crystals as young as 1100 Ma from the Marajupema Formation (Klein and Moura, 2008) was taken to indicate the presence of source rocks from the south because provinces from the Mesoproterozoic age were not found on the São Luis Craton, within the southern part of the West African Craton, or from the eastern part of the Amazonian Craton.

In conclusion, we consider that the Bassarides, Rokelides, Gurupi, and Araguaia are intracontinental belts formed by the tectonic evolution of aulacogenic-type systems. Consequently, their tectonic history would precede the collision between the Amazonian and São Francisco-Congo Cratons along the Transbrasiliano corridor. This conclusion is supported by the evidence that the linear structures of the TB megashear truncate the north-south structural trends of the Araguaia Belt (see figure 10.3). The origin of the stresses related to the basin inversion within these belts is poorly understood. As a tentative speculation, we attribute these events, at least partially, to distant plate adjustments accompanying the successive stages of the closing of the Goiás-Pharusian Ocean along the Transbrasiliano-Kandi tectonic corridor. 
Carlos E. Ganade de Araujo - Tese de Doutorado - Universidade de São Paulo

Capítulo 10 - Was there a Clymene Ocean?

\subsubsection{The Corumbá - Arroyo del Soldado Epicontinental Sea}

The Paraguay belt is a typical thrust-and-fold belt located along the southeastern margin of the Amazonian Craton (Alvarenga et al., 2000; Campanha et al., 2011; see location in figures 10.4 and 10.5). It comprises the older Cuiabá Group, which includes the glacial sediments of the Puga Formation, and the younger Corumbá Group, which comprises carbonates and pelites with Ediacaran-age fossils (Boggiani et al., 2010). According to Babinski et al. (2006), some "cap carbonates" of the Araras Group, which directly overlie diamictites of the Puga Formation, were dated at ca. $630 \mathrm{Ma}$ (by $\mathrm{Pb}-\mathrm{Pb}$ whole-rock isochron method). In general, the sedimentary environment indicates a restricted marine shelf with shallow marine waters. This situation could be related to an epicontinental sea overlying a continental basement that corresponds to the extension of the Amazonian Craton. The sediments of the Corumbá Group are mainly marine and correlate with the sedimentary filling of the nearby Tucavaca aulacogen in Bolivia (see figures 10.4 and 10.5). Moreover, Gaucher et al. (2003) demonstrated the existence of a close correlation between the Corumbá Group of the Paraguay Belt and the Arroyo del Soldado Group in Uruguay (Go and AS in figure 10.4). They observed that these sedimentary sequences, which belonged to the same continental shelf that comprised virtually the same succession with the same Ediacaran age, deepened to the east along the eastern edge of the Rio de La Plata and Amazonian Cratons (e.g. Gaucher et al., 2003, 2008 and 2009). This finding is a powerful paleogeographic indicator for the Ediacaran connection of both cratonic units, which precludes the existence of a wide ocean (e.g., the Clymene) between them.

The rocks of the Paraguay belt are affected by low-grade metamorphism up to the biotite zone of the greenschist facies. They are also affected by tectonic deformation, which is almost imperceptible on the border of the craton but increases up to tight isoclinal folds towards its inner areas (Alvarenga et al., 2000). A detailed regional study by Campanha et al. (2011) in the southern part of the region demonstrated the presence of different structural domains. In particular, rocks of the Cuiabá Group (named Agachi schists by these authors) were affected by deformation and low-grade metamorphism while the sedimentary rocks of the upper part of the Corumbá Group (Tamengo and Guaicurus formations of Ediacaran age) were virtually undeformed and unconformably deposited over the sialic basement of the Rio Apa Block (figure 10.4). De Min et al. (2012) provided an important piece of evidence regarding the tectonic evolution of the area. In the northern sector of the Paraguay belt, they studied a series of K-rich, undeformed ultramafic bodies and associated carbonatites that intruded the low-grade metamorphic rocks belonging to the Puga Formation of the Cuiabá Group. The intrusions were plugs and dykes affecting an area about $30 \mathrm{~km}$ long, not far from Planalto da Serra, Mato Grosso. A few of these rocks were dated by Ar-Ar, Rb-Sr, and Sm-Nd methods, which revealed high-quality radiometric ages of ca. $600 \mathrm{Ma}$, placing a lower limit for the deformation of the Cuiabá Group. Moreover, the extensional tectonics of Planalto da Serra could be coeval with the one that produced the Tucavaca aulacogen. We believe that such late Neoproterozoic regional tectonics may indicate the starting point for the separation of Laurentia from West Gondwana.

A final regional deformational phase of very low intensity, extensional in character and related to a few intrusions of granitic bodies, took place during the Cambrian or even later. Within the area of the Paraguay belt in the vicinity of the TB megashear, Ferreira et al. (2008) and McGee et al. (2012) dated some 
undeformed granitic bodies, such as the São Vicente (521 \pm 8 Ma), Coxim (542 \pm 4 Ma), Rio Negro (549 \pm 4 $\mathrm{Ma})$, Sonora $(549 \pm 5 \mathrm{Ma})$ and Taboco $(546 \pm 4 \mathrm{Ma})$, which intruded the deformed supracrustal rocks of the Cuiabá Group. These plutons were coeval with felsic tuffs interlayered with sedimentary rocks of the much younger Tamengo Formation, recently dated at $543 \pm 4 \mathrm{Ma}$ (Boggiani et al., 2010). In the Cambrian, the Pampean Orogeny was in action at the southern margin of Gondwana, but no evidence for an oceanic lithosphere has been found in the vicinity of the Paraguay belt. Moreover, the possible suture envisioned by Tohver et al. (2012) along the edge of the main thrust front of the Paraguay Belt (see figure 10.5) cannot be defended, because the sedimentary sequences are autochthonous marginal basins located at the border of the Amazonian Craton.

\subsection{4 - Significance of the Puga Paleomagnetic Pole}

Several large-scale models based on paleomagnetic measurements have been proposed for the assembly of Gondwana. The oldest such model showed the final collision of two large continental masses, West Gondwana (formed of South America and Africa) and East Gondwana (formed of Antarctica, Australia, India and Madagascar), during the period from late Neoproterozoic to early Paleozoic along the Mozambique belt (see, for example, original works by Kroener, 1980 or McWilliams, 1981). In recent years, the mechanism for Gondwana assembly has become more precisely constrained, due to a better understanding of the tectonic evolution and timing of the successive collisions between continental building blocks. However, the Ediacarian interval is notorious for its difficulty in paleomagnetic interpretation, and different models for the assembly of Gondwana have been suggested, such as those by Meert, (2003); Cordani et al. (2003); Yoshida et al. (2003); Collins and Pisarevski, (2005); Pisarevski et al. (2008); Meert and Lieberman, (2008), among many others.

Paleomagnetic measurements were obtained by Trindade et al. (2003) for dolomites of the Puga cap carbonate of the Araras Formation within the Paraguay Belt (location in figure 10.5), whose age has been supposed to be very late Neoproterozoic or early Ediacaran. Because this apparent pole plotted quite far from the other poles of Gondwana of the same age, the authors proposed that the Amazonian Craton and the rest of Gondwana were not united, and a large ocean existed between them during the Ediacarian. In their figure 10, they named this ocean as "Clymene".

The Puga paleopole is the most important and, perhaps, the sole evidence to which the hypothesis of the Cambrian Clymene Ocean is dependent. This finding is considered to be of high quality because of internal coherence. However, Trindade et al. (2006) recognized that the age of 630 to $600 \mathrm{Ma}$ for this paleopole, taken on the basis of $\mathrm{Sr}$ and $\mathrm{C}$ isotopes, is loosely constrained. Moreover, as emphasized by Pisarevski et al. (2008), this Puga paleopole is located at high latitude, not far from the present-day pole; thus, it could be related to a recent remagnetization.

At present, no other reliable paleomagnetic poles are available for the Amazonian Craton for the Neoproterozoic-early Paleozoic time interval. In our view, there is currently no evidence to show definitively that the Amazonian Craton was far away from the São Francisco-Congo Craton at the time when the Iapetus Ocean started to form. New paleomagnetic measurements from Neoproterozoic to Cambrian rocks, located within the Amazonian Craton, are needed. Specifically for the Paraguay belt, it will be very important to 
Carlos E. Ganade de Araujo - Tese de Doutorado - Universidade de São Paulo

Capítulo 10 - Was there a Clymene Ocean?

obtain significant paleomagnetic results from the undeformed magmatic rocks of Planalto da Serra, which exhibit robust radiometric ages close to $600 \mathrm{Ma}$.

\subsubsection{The Pampean Ocean and its northern continuation}

Figure 10.4 approximately follows the model of Escayola et al. (2011), in which their Ediacaran oceanic opening (called the Puncoviscana tract) runs along the proto-Andean active margin of West Gondwana, with a north-south trend. The Pampean Orogen, whose medium- to high-grade metamorphic rocks would be coeval with the less metamorphic meta-sediments of the Puncoviscana Formation, is constrained in time between 560 Ma and $520 \mathrm{Ma}$. Therefore, it was tectonically active during most of the Cambrian. The Amazonian, São Francisco-Congo, and Rio de La Plata Cratons were already together after the collisions related to the Brasiliano-Pan African orogeny; thus, extensional processes, instead of convergence, are observed along the possible sutures, close to the TB megashear zone. In our view, the active margin represented by the Pampean Orogen, with its northern continuation, is the first evidence of the subduction of the Pacific oceanic plate under the southwestern margin of Gondwana. The closure of the Puncoviscana tract may have been the result of an interaction between the Rio de La Plata Craton and either the Pampean terrane of Rapela and others (1998), the Pampia terrane of Ramos et al. (2010), or the Arequipa-Antofalla microcontinent of Escayola et al. (2011). In any case, the subducted oceanic lithosphere would have disappeared below the Rio de La Plata Craton. The Pampean Orogeny, being coeval with the comparable Phanerozoic orogenic systems of the Southern Hemisphere, would be one of the oldest evidences for the onset of the Terra Australis Orogen, as proposed by Cawood (2005). Finally, the Puncoviscana Formation is younger than $570 \mathrm{Ma}$, as demonstrated by the age of the detrital zircons (Escayola et al., 2011). Thus, at the time of the Pampean orogeny, the Puncoviscana Ocean could not have reached central South America because the collisional sutures related to the Brasiliano orogenic cycle were already closed by this time.

Trindade et al. (2006) did not provide conclusive arguments to prove the existence of an oceanic domain north of the Pampean ranges in Ediacaran to Cambrian times. Tohver et al. (2012) tried to find a possible model to justify the existence of a Clymene Ocean of that age and suggested the location of a Clymene suture as represented in figure 10.5. First, they envisioned an Ediacaran link between the rocks of the Sierras de Cordoba with those within the basement of the Paleozoic sedimentary rocks of the Sierras Australes (see figures 10.4 and 10.5). Second, they suggested a correlation of these systems with the Paraguay Belt. lthough we have some difficulties in correlating the collisional rocks of the Sierras de Cordoba with the granitic rocks of the Sierra de La Ventana, we could consider an Ediacaran to Cambrian link between these regions, maintaining an unconfined position for them, while surrounding the Rio de La Plata Craton. This composite belt, extending to the northern Sierras Pampeanas as in figure 10.4, would be typically accretionary and related to the subduction of the proto-Andean Pacific oceanic lithosphere. However, we cannot accept the tentative correlation between the Sierras de Cordoba and the Paraguay Belt, for several reasons. First, the localities are very far apart $(>500 \mathrm{~km})$. Second, there is not any similarity of lithology, metamorphism, or structural trends. Third, and most importantly, there was no oceanic connection in the Ediacaran between the Pampean and Paraguay belts, as was mentioned above when referring to the Corumbá-Arroyo del Soldado epicontinental shelf. 
Carlos E. Ganade de Araujo - Tese de Doutorado - Universidade de São Paulo

Capítulo 10 - Was there a Clymene Ocean?

\subsection{Conclusions}

From the discussion presented in the previous chapters, the tectonic history of West Gondwana can be summarized as follows:

1. The orogenic belts observed along the margins of the West African, Amazonian, São Francisco-Congo, and Kalahari Cratons and the Saharan Metacraton were formed during the Brasiliano-Pan African orogenic cycle through the closing of the Goiás-Pharusian Ocean, the only large domain with an oceanic lithosphere occurring among them. After a long-lived convergence, starting ca. $900 \mathrm{Ma}$, the main collisional episodes of Himalayan type that formed West Gondwana were dated roughly ca. $650 \mathrm{Ma}$ and $620 \mathrm{Ma}$, when Laurentia and Baltica were still attached to the supercontinent.

2. In Ediacaran time, Gondwana was already formed as a coherent continental block with a continental crust. Laurentia and Baltica started to separate from it, as the final stage of Rodinia fragmentation, ca. $600 \mathrm{Ma}$ or a little later, with the onset of a major spreading center and the formation of the Iapetus Ocean. This development was concomitant with the tectono-magmatic evolution in the Brasiliano-Pan African belts, especially along the region of the Transbrasiliano-Kandi megashear.

3. At the beginning of the Paleozoic when major plate reorganization was necessary, the subduction of the oceanic lithosphere started along the Pacific margin of the supercontinent. The accretionary Pampean Orogen in Argentina was developed in the Cambrian between $550 \mathrm{Ma}$ and $520 \mathrm{Ma}$. It showed tectonic shortening and regional high- to medium-grade metamorphism, associated with voluminous subduction-related granite magmatism.

In conclusion, the Ediacaran to Cambrian timeframe (see itens 2 and 3 above) is critical for the assessment of the possible existence of a Clymene Ocean in South America. At that time, southern Gondwana was surrounded by marginal accretionary orogens. Early Paleozoic subduction and consequent accretionary tectonics were also occurring, which provided the kinematic framework for distant plate adjustments, such as local collisions and minor tectonic adjustments in the interior of the supercontinent. Most of these changes were of an extensional character and were along the Transbrasiliano-Kandi megashear, which was established on the continental crust. Therefore, from the Ediacaran to early Cambrian time in the central region of South America, there is no geological evidence of any area with an oceanic lithosphere, ruling out the possible existence of a Clymene Ocean in that age.

\section{Acknowledgements}

The authors wish to thank Claudio Gaucher, Cees Van Staal and an anonymous referee for their helpful comments and suggestions, which improved an earlier version of this paper. In a special way, the constructive review made by Associate Editor David Evans was greatly appreciated. MASB and UGC also acknowledge FAPESP (Foundation Agency for Research Support of the State of São Paulo) for its continued support through grant 05/58688-1). 
Carlos E. Ganade de Araujo - Tese de Doutorado - Universidade de São Paulo

Capítulo 10 - Was there a Clymene Ocean?

\subsection{References}

Abdelsalam, M. G., Liégeois, J. P., and Stern, R. J., 2002, The Saharan metacraton: Journal Afr. Earth Sci., v. 34, p. $119-136$.

Affaton, P., Kröner, A., and Seddoh, K. F., 2000, Pan-African granulite formation in the Kabye Massif of northern Togo (West Africa): $\mathrm{Pb}-\mathrm{Pb}$ zircon ages: International Journal of Earth Sciences, v. 88, p. 778-790.

Agbossoumondé, Y., Menot, R. P., and Guillot, S., 2001, Metamorphic evolution of Neo-proterozoic eclogites from south Togo (West Africa): Journal of African Earth Sciences, v. 33, p. 227-244.

Aguiar, M. P, Chamani, M. A. C., and Riccomini, C., 2011, O "Graben" de Água Bonita, TO-GO e seu significado tectônico. Anais do 13 Simpósio Nacional de Estudos Tectônicos e VII International Symposium on Tectonics. Campinas, SP, Sociedade Brasileira de Geologia, Núcleo São Paulo, p. 443-446.

Alvarenga, G. J. S., Moura, C. A. V., Gorayeb, P. S. S., and Abreu, F. A. M., 2000, Paraguay and Araguaia belts, in Cordani, U. G., Milani, E. J., Thomaz-Filho, A., Campos, D. A., editors, Tectonic Evolution of South America: 31 st International Geological Congress, Rio de Janeiro, p. 183-193.

Alves, G. L., ms, 2006, Petrologia, geoquímica e geocronologia do Granito Ramal do Lontra e sua relação com a tectônica e metamorfismo do Cinturão Araguaia, Xambioá (TO): Masters Dissertation, Universidade Federal do Para.

Amaral, W. S., Santos, T. J. S., Wernick, E., Matteini, M., Dantas, E. L., and Moreto, C. P. N., 2010, U-Pb, Lu-Hf and Sm-Nd geochronology of rocks from the Forquilha Eclogite Zone, Geará Central Domain, Borborema Province, NEBrazil, in VII SSAGI South American Symposium on Isotope Geology, Brasília.

Arthaud, M. H., Caby, R., Fuck, R. A., Dantas, E. L., and Parente, C. V., 2008, Geology of the Northern Borborema Province, NE Brazil and its correlation with Nigeria, NW Africa, in Pankhurst, R. J., Trouw, R. A. J., Brito Neves, B. B., and de Wit, M. J., editors, West Gondwana: Pre-Cenozoic Correlations Across the Atlantic Region: Geological Society of London Special Publications 294, p. 49-67.

Assumpção, M., An, M., Bianchi, M., Franca, G.S.L., Rocha, M., Barbosa, J.R., and Berrocal, J., 2004, Seismic studies of the Brasilia fold belt at the western border of the São Francisco Craton, central Brazil, using receiver function, surfacewave dispersion and teleseismic tomography: Tectonophysics, 388: 173-185.

Attoh, K., 1998, High-pressure granulite facies metamorphism in the Pan-African Dahomeyide orogen, West Africa: Journal of Geology, v. 106, p. 236-246.

Attoh, K.and Brown, L. D. 2008. The neoproterozoic Trans-Saharan/Trans-Brasiliano shear zones: suggested tibetan analogs. Eos Transactions AGU, $\mathbf{8 9}$ (23) (Joint Assembly Supplement) abstract S51A-04.

Babinski,M., Trindade,R.I., Alvarenga,C.J.S, Boggiani,P.C., Liu,D., Santos,R.V., and Brito Neves,B.B. 2006. Chronology of neoproterozoic ice ages in Central Brazil. In: SSAGI, VI South Am. Symposium on Isotope Geology, Abstracts, Mar del Plata, CD-ROM

Baldwin J.A. and Brown, M. - 2008 - Age and duration of ultrahigh-temperature metamorphism in the Anápolis-Itauçu Complex, Southern Brası́ lia Belt, central Brazil - constraints from U-Pb geochronology, mineral rare earth element chemistry and trace-element thermometry

Berger, J., Caby, R., Liégois, J. P., Mercier, J. C., and Demaiffe, D., 2011, Deep inside a neoproterozoic intra-oceanic arc: growth, differentiation and exhumation of the Amalaoulaou complex (Gourma, Mali): Contributions to Mineral Petrol., doi: 10.1007/s00410-011-0624.

Boggiani, P.G., Gaucher,G., Sial,A.N., Babinski,M., Simona, G., Riccomini, G., Ferreira,V.P., and Fairchild,T.R. 2010. Chemostratigraphy of the Tamengo Formation (Corumba Group, Brazil): A contribution to the calibration of the Ediacaran carbon-isotope curve. Precamb. Research, 182:382-401

Brito-Neves, B. B., Fuck, R. A., Cordani, U. G., and Thomaz-Filho, A., 1984, Influence of basement structures on the evolution of the major sedimentary basins of Brazil: a case of tectonic heritage: J. Geodynamics, v. 1, p. 495-510. 
Carlos E. Ganade de Araujo - Tese de Doutorado - Universidade de São Paulo

Capítulo 10 - Was there a Clymene Ocean?

Brito-Neves B.B. and Cordani, U.G., 1991. Tectonic evolution of South America during the Late Proterozoic. Precambrian Research, 53(1/2): 23-40.

Caby, R., 1989, Precambrian terranes of Benin Nigeria and Northeast Brazil and the late Proterozoic South Atlantic fit: Geological Society of America Special Paper 230: 145-158.

Caby, R., 1994, Precambrian coesite from northern Mali: first record and implications for plate tectonics in the TransSaharan segment of the Pan-African belt: Eur. J. Mineral., v. 6, p. 235-244.

Caby, R., 2003, Terrane assembly and geodynamic evolution of central-western Hoggar: a synthesis: Journal of African Earth Sciences, v. 37, p. 133-159.

Campanha, G.A.C., Boggiani, P.C., Sallun-Filho, W., de Sá, F.R., Zuquim, M.P.S., and Piacentini, T. - 2011 - A Faixa de Dobramento Paraguai na Serra da Bodoquena e Depressão do Rio Miranda, Mato Grosso do Sul -Geologia USP. Ser. Cient. 11 (3): 79-96.

Castro, N. A., Ganade de Araujo, G. E., Basei, M. A. S., Osako, L. S., Nutman, A., and Liu, D., 2012, Ordovician Atype granitoid magmatism on the Ceará Central Domain, Borborema Province, NE-Brazil: Journal of South American Earth Sciences, v. 36, p. 18-31.

Cawood, P. A., 2005, Terra Australis orogen: Rodinia breakup and development of the Pacific and Iapetus margins of Gondwana during the Neoproterozoic and Paleozoic: Earth-Science Reviews, v. 69, p. 249-279.

Collins, A. S., and Pisarevsky, S. A., 2005, Amalgamating eastern Gondwana: The evolution of the Circum-Indian Orogens: Earth-Science Reviews, v. 71, no. 3-4, p. 229-270, doi: 10.1016/j.earscirev.2005.02.004.

Cordani, U.G., Kawashita, K., Vancini, K.R.B., Boriani, A., Bigioggero, B., Cadoppi, P., and Sacchi, R. - 1993 Geochronology and Geochemistry of Upper Proterozoic Granites from Southern Benin. - An. Acad. Bras. Ci., 65 (4): 389-402.

Cordani, U. G., D'Agrella-Filho, M. S., Brito-Neves, B. B., and Trindade, R. I. F., 2003, Tearing up Rodinia: the Neoproterozoic palaeogeography of South American cratonic fragments: Terra Nova, v. 15, p. 350-359.

Cordani, U. G., Teixeira, W., D’Agrella-Filho, M. S., and Trindade, R. I., 2009, The position of the Amazonian Craton in supercontinents: Gondwana Research, v. 15, p. 396-407.

Cordani, U. G., Brito-Neves, B. B., Fuck, R. A., Porto, R., Thomaz-Filho, A., and Cunha, F. M. B. da, 1984, Estudo preliminar de integração do Pré-Cambriano com os eventos tectônicos das bacias sedimentares brasileiras: Ciência Técnica Petróleo, Seção Exploração Petróleo 15, p. 1-70.

Dallmeyer, R. D., 1989, A tectonic linkage between the Rokelide orogen (Sierra Leone) and the St Lucie metamorphic complex in the Florida subsurface: Journal of Geology, v. 89, p. 183-195.

Dallmayer, R.D. and Villeneuve, M. 1987 - 40Ar/39Ar mineral age record of polyphase tectonothermal evolution in the southern Mauritanide orogeny, southeastern Senegal. Bulletin Geol Soc America, 98: 602-61 1.

Delor, C., Lafon, J. M., Milesi, J. P., and Fanning, M., 2002, First evidence of 560 - 575 Ma granulites and syn-tectonic magmatism in the Rokelides belt: geology, geochronology and geodynamic implications: 19th Colloquium on African Geology, El Jadida, Morocco, El Jadida University Press, Abstracts, 58.

De Min A., Hendriks B., Slejko F., Comin-Chiaramonti P., Girardi V.A.V., Ruberti E., Gomes C., Neder R. D., and Pinho, F. G. 2013. Age of ultramafic-K rocks from Planalto da Serra, Mato Grosso, Brazil. Alkaline magmatism and lithospheric mantle, Eds. L. G. Gwalani, P. Comin-Chiaramonti, P. J. Downes. Journal of South American Earth Science, Special Issue, vol. 41, 57-64.

Della Giustina, M. E. S., Oliveira, C. G., Pimentel, M., and Buhn, B., 2009, Neoproterozoic magmatism and high-grade metamorphism in the Goiás Massif: new LA-MC-ICMPS U-Pb and $\mathrm{Sm}-\mathrm{Nd}$ data and implications for collisional history of the Brasília Belt: Precambrian Research, v. 172, p. 67-79. 
Carlos E. Ganade de Araujo - Tese de Doutorado - Universidade de São Paulo

Capítulo 10 - Was there a Clymene Ocean?

Dostal, J., Dupuy, C., and Caby, R., 1994, Geochemistry of the neoproterozoic tilemsi belt of Iforas (Mali, Sahara) - a crustal section of an oceanic island-arc: Precambrian Research, v. 65, p. 55-69.

Duclaux, G., Ménot, R. P., Guillot, S., Agbossoumondé, Y., and Hilairet, N., 2006, The mafic layered complex of the Kabyé massif (north Togo and north Benin): Evidence of a Pan-African granulitic continental arc root: Precambrian Research, v. 151, p. 101-118.

Escayola, M.P., Pimentel, M.M. and Armstrong, R. 2007. A Neoproterozoic Back-Arc Basin: SHRIMP U-Pb and SmNd isotopic evidence from the Eastern Pampean Ranges, Argentina. Geology, 35, (6): 495-498.

Escayola, M.P., Van Staal, G.R., and Davis, W.J. - 2011 - The age and tectonic setting of the Puncoviscana Formation in northwestern Argentina: An accretionary complex related to Early Cambrian closure of the Puncoviscana Ocean and accretion of the Arequipa-Antofalla block. - Journal of South American Earth Sciences, 32: 438-459.

Fairhead, J. D. and Maus, S. 2003. CHAMP satellite and terrestrial magnetic data help define the tectonic model for South America and resolve the lingering problem of the pre-break-up fit of the South Atlantic Ocean. The Leading Edge, 22(8): 779-783.

Feng, M.; Van der Lee, S.; and Assumpção, M. 2007. Upper mantle structure of South America from joint inversion of waveforms and fundamental mode group velocities of Rayleigh waves. Journal of Geophysical Research, 112 doi: 10.1029/2006JB004449.

Ferreira G., Dantas E., Pimentel M., Buhn B., and Ruiz A.S. 2008. Nd isotopic signature and U-Pb LA-ICPMS ages of Cambrian intrusive granites in the boundaries between Brasília Belt and Paraguay Belt. In: South American Symposium on Isotope Geology, 6, Bariloche, Abstracts, CD-ROM.

Fetter, A. H., Santos, T. J. S., Van Schumus, W. R., Hackspacher, P. C., Brito Neves, B. B., Arthaud, M. H., Nogueira Neto, J. A., and Wernick, E., 2003, Evidence for Neoproterozoic continental arc magmatism in the Santa Quitéria Batholith of Ceará State, NW Borborema Province, NE Brazil: implications for the assembly of west Gondwana: Gondwana Research, v. 6, p. 265-273.

Gaucher, C., Boggiani, P. C., Sprechmann, P., Sial, A. N., and Fairchild, T. R., 2003, Integrated correlation of the Vendian to Cambrian Arroyo del Soldado and Corumbá Groups (Uruguay and Brazil): palaeogeographic, palaeoclimatic and palaeobiologic implications: Precambrian Research, v. 120, p. 241-278.

Gaucher, G., Finney, S. G., Poiré, D. G., Valencia, V. A., Grove, M., Blanco, G., Pamoukaghlián, K., Gómez Peral, L., 2008, Detrital zircon ages of Neoproterozoic sedimentary successions in Uruguay and Argentina: insights into the geological evolution of the Río de la Plata Craton: Precambrian Research, v. 167, p. 150-170.

Gaucher, G., Frimmel, H. E., and Germs, G. J. B., 2009, Tectonic events and palaeogeographic evolution of Southwestern Gondwana in the Neoproterozoic and Cambrian. In: Gaucher, C., Sial, A. N., Halverson, G. P., and Frimmel, H. E., editors, Neoproterozoic-Cambrian tectonics, global change and evolution: a focus on southwestern Gondwana: Developments in Precambrian Geology, v. 16, p. 295-316.

Hasui, Y., Costa, J. B. S., and Abreu, F. A. M., 1984, Província Tocantins Setor setentrional. In: Almeida, F. F. A., and Hasui, Y., editors, O Precambriano no Brasil. Edgard Blucher, São Paulo, p. 137-204.

Herz, N., Hasui, Y., Costa, J. B. S., and Matto, M. A. S., 1989, The Araguaia Fold Belt, Brazil: a reactivated BrasilianoPan-Africano cycle (550 Ma) geosuture: Precambrian Research, v. 42, p. 371-386.

Hurley, P. M., Almeida, F. F. M., Melcher, G. G., Cordani, U. G., Rand, J., Kawashita, K., Vandoros, P., Pinson, W. H., and Fairbarn, H. W., 1967, Test of continental drift by means of radiometric ages: Science, v. 144, p. 495-500.

Hurley, P. M., Leo, G. W., White, R. W., and Fairbairn, H. W., 1971, Liberian age province (about 2700 Ma) and adjacent provinces in Liberia and Sierra Leone: Geological Society of America Bulletin, v. 82, p. 1004-1005.

Jahn, B., Caby, R., and Monié, P., 2001, The oldest UHP eclogites of the World: age of UHP metamorphism, nature of protoliths and tectonic implications: Chemical Geology, v. 178, p. 143-158. 
Carlos E. Ganade de Araujo - Tese de Doutorado - Universidade de São Paulo

Capítulo 10 - Was there a Clymene Ocean?

Junges, S.L., Pimentel, M.M. and Moraes, R., 2002, Nd isotopic study of the Neoproterozoic Mara Rosa Arc, central Brazil: implications for the evolution of the Brasilia Belt, Precambrian Research, v. 117: 101-118.

Klein E.L., Moura, C.A. V., Krymsky, R. S., and Griffin, W.L., 2005, The Gurupi Belt, northern Brazil: Lithostratigraphy, geochronology and geodynamic evolution: Precambrian Research, v. 141, p. 83-105.

Klein, E. L., and Moura, C. A. V., 2008, São Luiz Craton and Gurupi Belt (Brazil): possible links with the West African Craton and surrounding Pan-African belts. In: Pankhurst, R. J., Trouw, R. A. J., Brito Neves, B. B., and De Wit, M., editors, West Gondwana: Pre-Cenozoic Correlations Across the South Atlantic region: Geological Society, London, Special Publications, v. 294, p. 137-151.

Kotschoubey, B., Hieronymous, B., and Albuquerque, C. A. R., 2005, Disrupted peridotites and basalts from Neoproterozoic Araguaia belt (northern Brazil): remnants of a poorly evolved oceanic crust?: Journal of South American Earth Sciences, v. 20, p. 211-230.

Kröner, A. - 1980 - Pan African Crustal Evolution - Episodes, 2: 3-8.

Kröner, A., and Cordani, U., 2003, African, southern Indian and South American cratons were not part of the Rodinia supercontinent: evidence from field relationships and geochronology: Tectonophysics, v. 375, p. 325-352.

Li, Z. X., Bogdanova, S. V., Collins, A. S., Davidson, A., De Waele, B., Ernst, R. E., Fitzsimons, I. C. W., Fuck, R. A., Gladkochub, D. P., Jacobs, J., Karlstrom, K. E., Lu, S., Natapov, L. M., Pease, V., Pisarevsky, S. A., Thrane, K., and Vernikovsky, V., 2008, Assembly, configuration, and break-up history of Rodinia: a synthesis: Precambrian Research, v. 67, no.1-2, p. 179-210.

Liégeois, J.P., Latouche, L., Navez,J., and Black, R. , 2000, Pan African collision, collapse ans escape tectonicsin the Tuareg Shield:relations with the East Sharan Ghost craton and the West African craton. In: 18 ${ }^{\text {th }}$ Colloquium of African Geology, Graz, Austria. Journal of African Earth Science, 30: 53-54.

Lima, H. A. F., Ferreira Filho, G. F., Pimentel, M. M., Dantas, E. L., and Araujo, S. M., 2008, Geology, petrology and geochronology of the layered mafic-ultramafic intrusions in the Porto Nacional area, central Brazil: Journal South of American Earth Sciences, v. 26, p. 300-317.

Mantovani, M. S. M., and Brito-Neves, B. B., 2005, The Paranapanema Lithospheric Block: Its importance for Proterozoic (Rodinia, Gondwana) supercontinent theories: Gondwana Research, v. 8, p. 303-315.

McGee, B., Collins, A., and Trindade, R. I., 2012, G'Day Gondwana the final accretion of a supercontinent: U-Pb ages from the post-orogenic São Vicente Granite, northern Paraguay Belt, Brazil: Gondwana Research, v. 21, p. $316-322$.

McWilliams, M. O., 1981, Paleomagnetism and Precambrian Tectonic Evolution of Gondwana. In: Kröner, A., editor, Precambrian Plate Tectonics, Developments in Precambrian Geology 4, chapter 26, p. 649-687.

Meert, J. G., 2003, A synopsis of events related to the assembly of eastern Gondwana: Tectonophysics, v. 362, no. 1-4, p. 1-40, doi: 10.1016/S0040-1951(02)00629-7.

Meert, J. G., and Lieberman, B. S., 2008, The Neoproterozoic assembly of Gondwana and its relationship to EdiacaranCambrian radiation: Gondwana Research, v. 14, p. 5-21.

Motta-Araújo, J. G. M., Pimentel, M. M., and Armstrong, R., 2003, U-Pb ages, Sm-Nd isotopes and structural analysis of the Moiporá-Novo Brasil shear zone system: the limits between Neoproterozoic Goiás Magmatic Arc and the Archean Uvá Complex, Tocantins Province, Central Brazil. In: IV South American Symposium on Isotope Geology, 2003, Salvador - Bahia.

Moura, G.A.V. and Gaudette, H.E., 1993 - Evidence of Brasiliano-Pan African deformation in the Araguaia belt: Implication for Gondwana evolution. Revista Brasileira de Geociências, 23: 117-123.

Moura, C. A. V., Pinheiro, B. L. G., Nogueira A. G. R, Gorayeb, P. S. S., and Galarza, M. A., 2008, Sedimentary provenance and paleoenvironment of the Baixo Araguaia Supergroup: constraints on the paleogeographical evolution of the Araguaia Belt and Assembly of West Gondwana. In: 
Carlos E. Ganade de Araujo - Tese de Doutorado - Universidade de São Paulo

Capítulo 10 - Was there a Clymene Ocean?

Pankhurst, R. J., Trouw, R. A. J., Brito Neves, B. B., De Wit, M., editors, West Gondwana: Pre-Cenozoic Correlations Across the South Atlantic region: Geological Society, London, Special Publications 294, p. 173-196.

Nunes, K. C., 1993, Interpretação integrada da Bacia do Parnaiba com ênfase nos dados aeromagnéticos. In: Congresso Internacional da Sociedade Brasileira de Geofísica, 2. Resumos expandidos, v. 1, p. 152-157.

Oliveira, D. G., and Mohriak, W. U., 2003, Jaibaras trough: an important element in the early tectonic evolution of the Parnaíba interior sag basin, Northern Brazil: Marine and Petroleum Geology, v. 20, p. 351-383.

Paixão, M. A. P., and Nilson, A. A., 2002, Fragmentos ofiolíticos da Faixa Araguaia: caracterização geológica e implicações tectônicas. In: Klein, E. L., Vasquez, M. L., and Rosa-Costa, L. T., editors, Contribuições à Geologia da Amazônia, 3. Sociedade Brasileira de Geologia-Núcleo Norte, Belém, p. 85-103.

Paixão, M. A., Nilson, A. A., and Dantas, E. L., 2008, The Neoproterozoic Quatipuru ophiolite and the Araguaia fold belt, central-northern Brazil, compared with correlatives in NW Africa, in Pankhurst, R.J., et al. (Ed.), West Gondwana: Pre-Cenozoic Correlations Across the South Atlantic Region: Geological Society of London Special Publication, 294, p. 297-318.

Pimentel, M. M., and Fuck, R. A., 1992. Neoproterozoic crustal accretion in central Brazil: Geology, v. 20, p. 375-379.

Pimentel, M.M., Fuck, R.A. and Alvarenga, G.J.S., 1996. Post-Brasiliano (Pan African) high-K granitic magmatism in central Brazil: late Precambrian/early Paleozoic extension. Precambrian Research, 80: 217-238.

Pimentel, M. M., Fuck, R. A., Jost, H., Ferreira-Filho, C. F., and Araújo, S. M., 2000, The basement of the Brasília Fold Belt and the Goiás Magmatic Arc, in Cordani, U. G., Milani, E. J., Thomaz Filho, A., and Campos, D. A., editors, Tectonic Evolution of South America: 31 ${ }^{\text {st }}$ International Geological Congress, Rio de Janeiro, Brazil, p. $195-229$.

Pisarevsky, S. A., Murphy, J. B., Cawood, P. A., and Collins, A. S., 2008, Late Neoproterozoic and Early Cambrian palaeogeography: models and problems, in Pankhurst, R. J., Trouw, R. A. J., de Brito-Neves, B. B., and de Wit, M. J., editors, West Gondwana: Pre-Cenozoic Correlations Across the South Atlantic Region: Geological Society of London Special Publications 294,p. 9-31.

Ramos, V. A., 1988, Late Proterozoic - Early Proterozoic of South America - A collisional history: Episodes, v. 11, p. $168-174$

Ramos, V. A., Vujovich, G., Artino, R., and Otamendi, J., 2010, Pampia: A large cratonic block missing in the Rodinia supercontinent: Journal of Geodynamics, v. 50, p. 243-255.

Rapalini, A. E., 2006, New late Proterozoic paleomagnetic pole for the Rio de la Plata craton: Implications for Gondwana: Precambrian Research, v. 47, no. 3-4, p. 223-233, doi: 10.1016/j.precamres.2006.01.016.

Rapela, C. W., Pankhurst, R. J., Casquet, C., Baldo, E., Saavedra, J., Galindo, C., and Fanning, C. M., 1998, The Pampean Orogeny of the southern proto-Andes: evidence for Cambrian continental collision in the Sierras de Córdoba, in Pankhurst, R. J., Rapela, C. W., editors, The Proto-Andean Margin of Gondwana: Geological Society Special Publication 142, p. 181-217.

Schwartz, J. J., Gromet, L. P., and Miró, R., 2008, Timing and duration of the calc-alkaline arc of the Pampean Orogeny: implication for the Late-Neoproterozoic to Cambrian evolution of Western Gondwana: Journal of Geology, v. 116 , p. 39-61.

Soares, J. E. P., Berrocal, J. A., Fuck, R. A., Mooney, W. D., and Ventura, D. B. R., 2006, Seismic characteristics of central Brazil crust and upper mantle: a deep seismic refraction study: Journal of Geophysical Research, v. 111, B12302, doi.10.1-1060.

Tohver, E., D'Agrella-Filho, M.S., and Trindade, R.I.F., 2006, Paleomagnetic record of Africa and South America for the 1200-500 Ma interval, and evaluation of Rodinia and Gondwana assemblies: Precambrian Research, v. 147, no. 3, p. 193-222. 
Tohver, E., Cawood, P. A., Rossello, E. A., and Jourdan, F., 2012, Closure of the Clymene Ocean and formation of West Gondwana in the Cambrian: Evidence from the Sierras Australes of the southernmost Rio de la Plata Craton, Argentina: Gondwana Research, v. 21, n. 2-3, p. 394-405.

Tohver, E., Trindade, R. I. F., Solum, J. G., Hall, G. M., Riccomini, G., and Nogueira, A. C., 2010, Closing the Clymene Ocean and bending a Brasiliano belt: evidence for the Cambrian formation of Gondwana from SE Amazon craton: Geology v.38, p. 267-270.

Trindade, R. I. F., Font, E., D'Agrella-Filho, M. S., Nogueira, A. C. R., and Riccomini, G., 2003, Low latitude and multiple geomagnetic reversals in the Neoproterozoic Puga cap carbonate, Amazon craton: Terra Nova, v. 15, p. 441446.

Trindade, R.I.F., D’Agrella-Filho, M.S., Epof, I., and Brito-Neves, B.B., 2006, Paleomagnetism of Early Cambrian Itabaiana mafic dikes (NE Brazil) and the final assembly of Gondwana. - Earth Plan. Science Letters, 244: 361-377.

Trompette, R., 1994, Geology of Western Gondwana, Pan-African - Brasiliano aggregation of South America and Africa: A. A. Balkema, Rotterdam, Brookfield, 350 p.

Ventura, D. B. R., Soares, J. E. P., Fuck, R. A., Caridade, L. G., 2011, Garacterização sísmica e gravimétrica da litosfera sob a linha de refração sísmica profunda de Porangatu, Província Tocantins, Brasil central: Revista Brasileira de Geociências, v. 41, p. 130-140.

Villeneuve, M., and Dallmeyer, R. D., 1987, Geo- dynamic evolution of the Mauritanides, Bassarides and Rokelides orogens (West Africa): Precambrian Research, v. 37, p. 19-28.

Villeneuve, M., and Cornée, J. J., 1994, Structure, evolution and paleogeography of the West African craton and bordering belt during the Neoproterozoic: Precambrian Research, v. 69, p. 307-326.

Villeneuve, M., 2008, Review of the orogenic belts on the western side of the West African craton: the Bassarides, Rokelides and Mauritanides. In: Enninh, N., and Liégeois, J. P., editors, The Boundaries of the West African Craton: Geological Society, London, Special Publications 297, p. 169-201.

Wiens, F., 1985, Phanerozoic Tectonics and Sedimentation in the Chaco Basin of Paraguay, with Comments on Hydrocarbon Potential. In: Tankard, A. J., Suarez Soruco, R., and Welsink, H. J., editors, Petroleum basins in South America: AAPG Memoir 62, p. 185-205.

Williams, H. R., 1988, The Archean Kasila group of Western Sierra Leone: Geology and relations with adjacent granitegreenstone terrane: Precambrian Research, v. 38, p. 201-213.

Yoshida, M., Jacobs, J., Santosh, M., and Rajesh, H.M., 2003, Role of pan African events in the Circum-East Antarctic Orogen of East Gondwana: a critical overview. - In: Yoshida, M., Windley, B.F., Dasgupta, S. (Eds) - Proterozoic East Gondwana: Supercontinent Assembly and Breakup. - Geological Society, London. Special Publication 206: 57-75. 


\section{Conclusões}

Os dados produzidos nesta Tese, em conjunto com aqueles mais relevantes já existentes na literatura geológica, referenciados ao longo dos capítulos anteriores, permitiram apresentar algumas conclusões tectônicas em escalas que vão do nível regional a supra-continental, envolvendo o Domínio Ceará Central, a Província Borborema e o supercontinente Gondwana. Grande parte dessas conclusões referem-se aos produtos (p.e. sedimentação, magmatismo e metamorfismo) derivados do consumo e fechamento do Oceano Goiás-Farusiano (OGF).

Dentro do Domínio Ceará Central, o estudo de proveniência de zircões detríticos nas rochas metassedimentares do Complexo Ceará, permitiu o reconhecimento de bacias sin-orogênicas relacionadas com o sistema de subducção do OGF. Além disso, as idades obtidas nesses zircões permitiram indiretamente reconhecer um importante e longo período de magmatismo entre 900-650 Ma, interpretado como indicativo do magmatismo de arco resultante do consumo da litosfera oceânica do OGF. No Domínio Médio Coreaú, a oeste do Domínio Ceará Central, as sequencias quartzíticas de margem passiva da Formação São Joaquim revelaram somente a presença de zircões antigos, derivados de crosta Arqueana e Paleoproterozóica, provavelmente derivadas do craton Oeste-Africano. Os zircões detríticos da Formação Goiabeira, no Domínio Médio Coreaú, forneceram idades similares às rochas metassedimentares do Complexo Ceará, o que poderia indicar um contexto similar para a deposição dos sedimentos associados a estas unidades estratigráficas em um mesmo ambiente orogênico.

Com relação ao magmatismo relacionado ao consumo do OGF as investigações isotópicas e geocronológicas do Complexo Tamboril-Santa Quitéria, no Domínio Ceará Central, permitiram o reconhecimento de três estágios magmáticos principais. O estágio inicial condiz com a colocação de granitóides juvenis da unidade Lagoa Caíçara em um arco magmático instalado na borda oeste do continente que constituí hoje o embasamento antigo da Província Borborema Norte, durante 890-800 Ma. Esse estágio foi seguido por um aparente período de ausência de magmatismo no Domínio Ceará Central. Contudo, como colocado acima, evidencias indiretas para a continuidade do magmatismo de arco ente 800-650 Ma são observadas nas idades dos zircões detríticos de bacias sin-orogênicas (bacias de fore-arc e back-arc) a leste e a oeste do Complexo Tamboril-Santa Quitéria. Isótopos de ${ }^{18} \mathrm{O} /{ }^{16} \mathrm{O}$ nesses zircões detríticos indicaram que fontes juvenis e crustais contribuíram para o magmatismo neste intervalo de tempo. O estágio de arco juvenil é seguido por um estágio de arco maturo com assinaturas híbridas entre crosta e manto, representados pelas unidades Boi e Santa Quitéria além de ortognaisses da unidade Lagoa Caíçara, entre 660-630 Ma. O ultimo estágio é representado pelo magmatismo essencialmente crustal, que gerou os diatexitos da unidade Tamboril entre 625-618 Ma. Este magmatismo é temporalmente associado ao início da colisão continental, evidenciado pela idade do metamorfismo eclogítico entre 624-616 Ma.

O metamorfismo associado a subducção de longa duração descrito acima foi obliterado pelo metamorfismo associado a colisão continental subsequente. Sobrecrescimentos metamórficos datados entre 650-630 Ma nos zircões detríticos do Complexo Ceará poderiam estar relacionados com o metamorfismo de subducção, contudo, o erro das análises individuais não permitem conclusões sólidas. Idades precisas para o metamorfismo colisional foram obtidas em eclogitos da Zona eclogítica de Forquilha, a oeste do Complexo 
Carlos E. Ganade de Araujo - Tese de Doutorado - Universidade de São Paulo Capítulo 11 - Conclusões

Tamboril-Santa Quitéria. Idades U-Pb de domínios metamórficos distintos em combinação com a química dos zircões analisados permitiram datar o início do metamorfismo colisional em $624 \pm 7,0 \mathrm{Ma}$, com pico em $616 \pm 6,1 \mathrm{Ma}$. Essas idades estão em conformidade com idades de outros eclogitos que afloram no ao longo OGO no Togo $(608,7 \pm 5,8 \mathrm{Ma})$ na região de Lato e Mali $(611,3 \pm 3,6 \mathrm{Ma})$ no sul do Hoggar, na região de Gourma.

No âmbito da Província Borborema, os novos dados apresentados aqui, aliados aos dados geocronológicos já existentes, permitiram a construção de um modelo de evolução tectônica entre 620-550 Ma envolvendo a hipótese de interferência entre duas colisões distintas ao longo da borda oeste e sul da Província. O modelo propõe que a interação dos esforços gerados por estes dois eventos colisionais foi responsável pela geração do feixe de zonas de cisalhamento que caracterizam a Província, e por sua subsequente extrusão em direção nordeste. No modelo, o importante Lineamento Transbrasiliano é interpretado como uma zona de transferência que operou como um limite de placa transformante permitindo a aproximação e colisão da Província com o cráton São Francisco.

A história de convergência tectônica e geração dos elementos relacionados a esta convergência (p.e. sedimentação, magmatismo e metamorfismo) associada ao consumo e fechamento do OGF é similar ao longo do Lineamento Transbrasiliano-Kandi que se estende por mais de $5000 \mathrm{~km}$ da Algéria ao Brasil Central. Este corredor tectônico abrange diversos blocos, províncias e áreas orogênicas Neoproterozóicas que possuem diferentes nomes regionais. Nesta Tese, todas essas regiões alinhadas ao longo deste corredor tectônico foram agrupadas em um só orógeno: o Orogéno Gondwana Oeste (OGO). O sincronismo do metamorfismo eclogítico de ultra-alta pressão ao longo do OGO sugere que a colisão continental entre as massas continentais envolvidas na construção desse Orógeno foi simultânea por mais de $2500 \mathrm{~km}$ entre 610-615 Ma. Este seria o primeiro registro de uma colisão continental de magnitude similar ao Orógeno Himalaiano $(\approx 2500 \mathrm{~km})$ envolvendo subduç̧ão continental profunda em pressões superiores a 2,7 GPa ( $>90 \mathrm{~km}$ de profundidade). A edificação e erosão dessas Megamontanhas, com elevações superiores a 8000 km (em analogia com o Orógeno Himalaiano) podem ter contribuído para a elevada taxa de sedimentação na transição entre os períodos Ediacariano-Cambriano, e consequentemente para o aumento da $p \mathrm{O}^{2}$ na atmosfera e oceanos e dos nutrientes (sedimentos) bio-disponíveis necessários para a radiação e manutenção da Vida.

Por fim, a colisão simultânea entre as massas continentais (crátons) responsáveis para a formação deste extenso orógeno sugerem que o supercontinente Gondwana já estava consolidado ao longo do OGO no final do período Ediacariano. Esta perspectiva contrasta com outras que sugerem a presença de um amplo oceano Cambriano na América do Sul. A ocorrência de bacias marinhas Cambrianas (e.g. Faixa Paraguai) nas proximidades do OGO é um fato inegável, contudo e deposição das mesmas devem ter ocorrido, em um sentido amplo, como forelands associados ao desmonte OGO. A deformação destas sequencias ocorreu em consequência da compressão final ao longo do OGO no Cambriano.

A geração de novos dados estimula a pesquisa científica e abre espaço para novas interpretações. Muitas lacunas ainda estão por serem preenchidas e a reprodutibilidade das interpretações geradas nesta Tese precisam ser testadas em suas diversas escalas. Dentro do Domínio Ceará Central, a estrutura e evolução tectônica associada a exumação das rochas eclogíticas devem ser investigadas em detalhe. O posicionamento 
Carlos E. Ganade de Araujo - Tese de Doutorado - Universidade de São Paulo Capítulo 11 - Conclusões

temporal das diversas gerações de leucossomas relacionados ao estágio colisional ainda estão por serem definidas e carecem de melhor investigação. A validade do modelo proposto para Província Borborema com base na interferência entre duas colisões ainda carece de melhores dados acerca do período em que as diversas zonas de cisalhamentos foram operantes. Por fim, dentro do contexto do OGO, o timing dos eclogitos expostos no extremo norte na região do Hoggar ainda esbarra em certa deficiência de dados, bem como a extensão do mesmo a sul do Brasil Central. Essas, entre outras, fazem parte de uma gama de questões que ainda necessitam de uma resposta mais sólida. 


\section{ANEXO I \\ (análises U-Th-Pb LA-ICP-MS em zircões detríticos)}




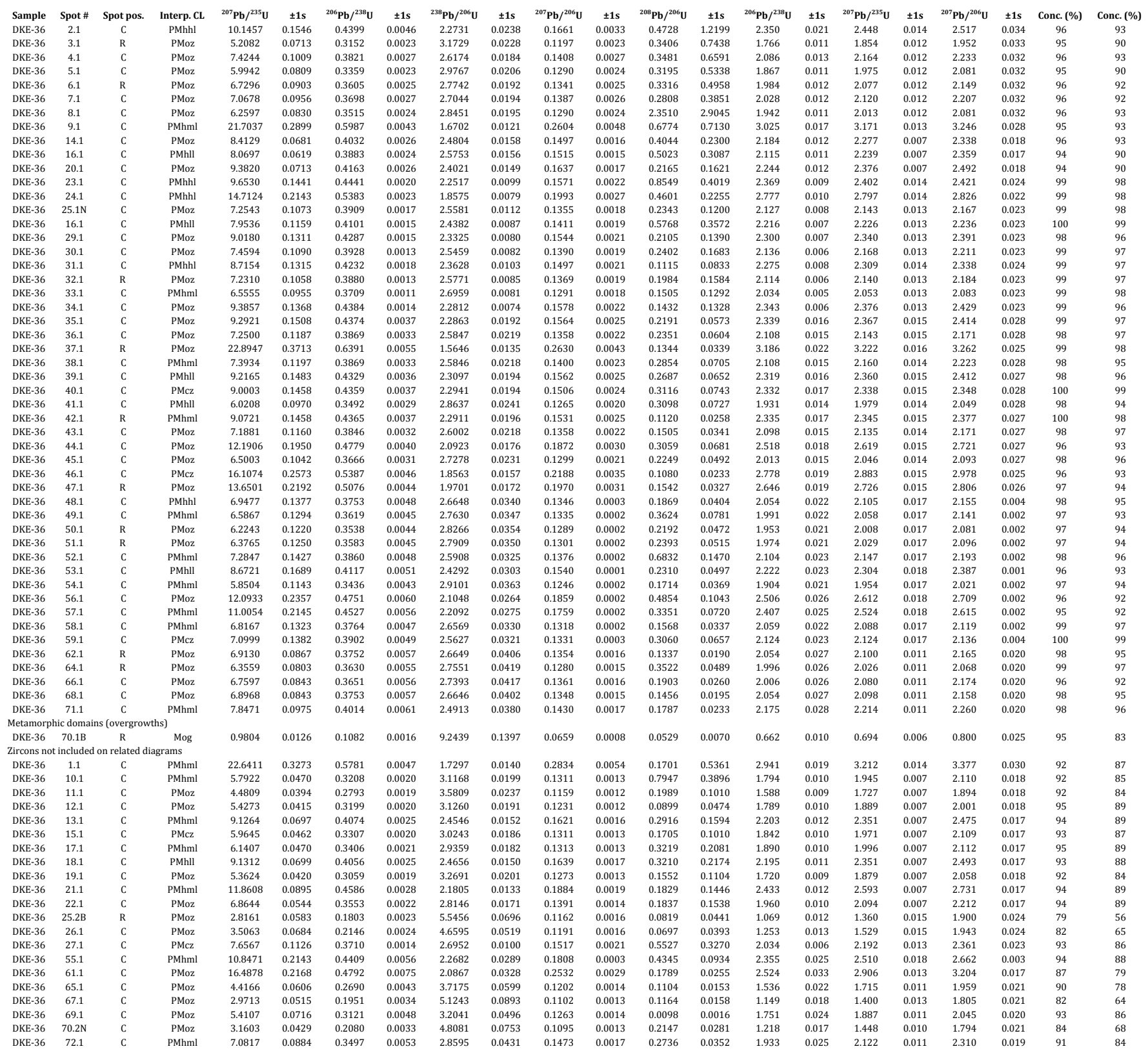




\begin{tabular}{|c|c|c|c|c|c|c|c|c|c|c|c|c|c|c|c|c|c|c|c|c|c|}
\hline ample & Spot \# & Spot pos. & Interp. CL & ${ }^{207} \mathbf{P b} /{ }^{235} \mathbf{U}$ & $\pm 1 s$ & ${ }^{206} \mathrm{~Pb} /{ }^{238} \mathrm{U}$ & $\pm 1 \mathrm{~s}$ & ${ }^{238} \mathbf{P b} / /^{206} \mathrm{U}$ & $\pm 1 \mathrm{~s}$ & ${ }^{207} \mathrm{~Pb} /{ }^{206} \mathrm{U}$ & $\pm 1 \mathrm{~s}$ & ${ }^{208} \mathrm{~Pb} /{ }^{206} \mathrm{U}$ & $\pm 1 \mathrm{~s}$ & ${ }^{206} \mathrm{~Pb} /{ }^{238} \mathrm{U}$ & $1 s$ & ${ }^{207} \mathbf{P b} /{ }^{235} \mathbf{U}$ & $\pm 1 \mathrm{~s}$ & ${ }^{207} \mathbf{P b} /{ }^{206} \mathbf{U}$ & $1 \mathrm{~s}$ & Conc. (\%) & Conc. \\
\hline DKE-39 & 1.1 & C & PMoz & 7.8151 & 0.0576 & 0.4057 & 0.0024 & 2.4650 & 0.0146 & 0.1408 & 0.0006 & 0.4847 & 0.1794 & 2.195 & 0.011 & 2.210 & 0.007 & 2.232 & 0.008 & $99^{\circ}$ & 98 \\
\hline DKE-39 & 2.1 & C & PMoz & 9.5278 & 0.0711 & 0.4373 & 0.0028 & 2.2870 & 0.0145 & 0.1600 & 0.0008 & 0.3445 & 0.1309 & 2.338 & 0.012 & 2.390 & 0.007 & 2.453 & 0.009 & 98 & 95 \\
\hline DKE-39 & 3.1 & C & PMoz & 7.4750 & 0.0563 & 0.3873 & 0.0023 & 2.5822 & 0.0152 & 0.1399 & 0.0007 & 0.3078 & 0.1198 & 2.110 & 0.011 & 2.170 & 0.007 & 2.222 & 0.008 & 97 & 95 \\
\hline DKE-39 & 4.1 & C & PMhml & 6.4733 & 0.0734 & 0.3716 & 0.0046 & 2.6908 & 0.0335 & 0.1275 & 0.0006 & 0.1833 & 0.0689 & 2.037 & 0.022 & 2.042 & 0.010 & 2.061 & 0.008 & 100 & 99 \\
\hline DKE-39 & 6.1 & C & PMhml & 9.8507 & 0.1132 & 0.4577 & 0.0057 & 2.1847 & 0.0271 & 0.1572 & 0.0009 & 0.3086 & 0.1077 & 2.430 & 0.025 & 2.421 & 0.011 & 2.422 & 0.010 & 100 & 100 \\
\hline DKE-39 & 7.1 & C & PMhhl & 6.6072 & 0.0877 & 0.3696 & 0.0052 & 2.7057 & 0.0380 & 0.1306 & 0.0012 & 0.3786 & 0.1278 & 2.027 & 0.024 & 2.060 & 0.012 & 2.104 & 0.016 & 98 & 96 \\
\hline DKE-39 & 8.1 & c & PMhhl & 9.8078 & 0.1209 & 0.4511 & 0.0060 & 2.2170 & 0.0296 & 0.1604 & 0.0012 & 0.2290 & 0.0749 & 2.400 & 0.027 & 2.417 & 0.011 & 2.456 & 0.013 & 99 & 98 \\
\hline DKE-39 & 9.1 & C & PMhhl & 5.7417 & 0.0734 & 0.3351 & 0.0046 & 2.9843 & 0.0408 & 0.1258 & 0.0010 & 0.3417 & 0.1077 & 1.863 & 0.022 & 1.938 & 0.011 & 2.038 & 0.014 & 96 & 91 \\
\hline DKE-39 & 12.1 & C & PMoz & 7.4342 & 0.0838 & 0.3965 & 0.0049 & 2.5223 & 0.0314 & 0.1367 & 0.0007 & 0.2905 & 0.0834 & 2.153 & 0.023 & 2.165 & 0.010 & 2.183 & 0.009 & 99 & 99 \\
\hline DKE-39 & 13.1 & C & PMoz & 7.3505 & 0.0859 & 4014 & 0.0050 & 4912 & 0.0311 & 0.1335 & 0.0007 & 0.2302 & 0.0642 & 2.176 & 0.023 & 2.155 & 0.010 & 2.140 & 0.009 & 101 & 102 \\
\hline DKE-39 & 14.1 & C & PMoz & 6.7924 & 0.0790 & 0.3711 & 0.0047 & 2.6946 & 0.0342 & 0.1337 & 0.0008 & 0.0777 & 0.0214 & 2.035 & 0.022 & 2.085 & 0.010 & 2.144 & 0.010 & 98 & 95 \\
\hline DKE-39 & 15.1 & C & PMhml & 9.1477 & 0.1024 & 0.4170 & 0.0052 & 2.3983 & 0.0298 & 0.1591 & 0.0008 & 0.3910 & 0.1030 & 2.247 & 0.024 & 2.353 & 0.010 & 2.443 & 0.008 & 95 & 92 \\
\hline DKE-39 & 17.1 & C & PMoz & 7.2822 & 0.0941 & 0.3971 & 0.0041 & 2.5182 & 0.0257 & 0.1342 & 0.0017 & 0.4190 & 0.3716 & 2.156 & 0.019 & 2.147 & 0.011 & 2.151 & 0.022 & 100 & 100 \\
\hline DKE-39 & 18.1 & C & PMoz & 6.2535 & 0.0814 & 0.3473 & 0.0034 & 2.8795 & 0.0283 & 0.1321 & 0.0017 & 0.4461 & 0.4051 & 1.922 & 0.016 & 2.012 & 0.011 & 2.123 & 0.022 & 96 & 90 \\
\hline DKE-39 & 19.1 & C & PMoz & 7.0608 & 0.0878 & 0.3821 & 0.0036 & 2.6169 & 0.0248 & 0.1345 & 0.0016 & 0.5728 & 0.5330 & 2.086 & 0.017 & 2.119 & 0.011 & 2.154 & 0.020 & 98 & 97 \\
\hline DKE-39 & 20.1 & C & PMoz & 6.7407 & 0.0836 & 0.3685 & 0.0035 & 2.7137 & 0.0255 & 0.1351 & 0.0016 & 1.7326 & 1.6537 & 2.022 & 0.016 & 2.078 & 0.011 & 2.162 & 0.020 & $9 /$ & 94 \\
\hline DKE-39 & 21.1 & $\mathrm{R}$ & PMoz & 6.8463 & 0.0846 & 0.3665 & 0.0034 & 2.7283 & 0.0254 & 0.1359 & 0.0016 & 0.7831 & 0.7672 & 2.013 & 0.016 & 2.092 & 0.011 & 2.172 & 0.020 & 96 & 93 \\
\hline DKE-39 & 24.1 & c & PMoz & 8.3184 & 0.1053 & 0.4116 & 0.0040 & 2.4294 & 0.0234 & 0.1487 & 0.0017 & 0.5111 & 0.5437 & 2.222 & 0.018 & 2.266 & 0.011 & 2.327 & 0.020 & 08 & 95 \\
\hline DKE-39 & 26.1 & C & PMoz & 9.4631 & 0.1172 & 0.4268 & 0.0040 & 2.3428 & 0.0222 & 0.1641 & 0.0019 & 0.4860 & 0.5484 & 2.291 & 0.018 & 2.384 & 0.011 & 2.496 & 0.020 & 96 & 92 \\
\hline DKE-39 & 30.1 & C & PMcz & 7.3867 & 0.0685 & 0.3788 & 0.0042 & 2.6398 & 0.0291 & 0.1436 & 0.0008 & 1.2884 & 0.4423 & 2.071 & 0.019 & 2.159 & 0.008 & 2.267 & 0.010 & 96 & 91 \\
\hline DKE-39 & 33.1 & C & PMoz & & 0.0851 & 4064 & 0.0046 & 2.4604 & 0.0281 & 0.1585 & 0.0008 & 0.6917 & 0.2618 & 2.1 & 00 & 2.2 & 000 & 2.4 & 0.0 & & 90 \\
\hline DKE-39 & 34.1 & C & PMoz & 4.7094 & 0.0465 & 0.3067 & 0.0034 & 3.2607 & 0.0362 & 0.1118 & 0.0007 & 0.9415 & 0.3690 & 1.724 & 0.017 & 1.769 & .008 & .831 & 0.012 & 97 & 94 \\
\hline DKE-39 & 36.1 & C & PMoz & 7.5884 & 0.0680 & 0.3924 & 0.0043 & 2.5484 & 0.0278 & 0.1416 & 0.0007 & 0.3128 & 0.1313 & 2.134 & 0.020 & 2.183 & 0.008 & 2.242 & 0.009 & 98 & 95 \\
\hline DKE-39 & 37.1 & $c$ & PMoz & 8. & 328 & .4214 & 0.0048 & 2.3728 & 0.0270 & 0.1436 & 0.0008 & 0.3539 & 0.1 & 2.267 & 0.02 & 2.267 & 0.00 & 2.2 & 0.009 & 100 & 100 \\
\hline DKE-39 & 38.1 & C & PMoz & 12.8425 & 0.1158 & 5057 & 0.0055 & 1.9777 & 0.0217 & 0.1887 & 0.0011 & 0.7399 & 0.3377 & 2.638 & .024 & 2.668 & 0.008 & 2.734 & 0.009 & 99 & 96 \\
\hline DKE-39 & 40.1 & C & PMoz & 7.7245 & 0.0698 & 0.3835 & 0.0043 & 2.6078 & 0.0291 & 0.1473 & 0.0009 & 0.3797 & 0.1891 & 2.092 & 0.020 & 2.199 & 0.008 & 2.310 & 0.010 & 95 & 91 \\
\hline \multicolumn{22}{|c|}{ rcons not inclue } \\
\hline DKE-39 & 11.1 & R & PMoz & & 0.0391 & 3145 & 0.0017 & 1794 & 0.0175 & 0.128 & 0.0005 & 0.3038 & 0.1484 & 1.7 & 0.00 & 1.899 & 0.006 & 2.077 & 0.007 & 93 & 85 \\
\hline DKE-39 & 5.1 & C & PMoz & 6.2390 & 0.0692 & 0.3442 & 0.0042 & 2.9055 & 0.0357 & 0.1333 & 0.0006 & 0.2142 & 0.0776 & 1.907 & 0.020 & 2.010 & 0.010 & 2.138 & 0.008 & 95 & 89 \\
\hline DKE-39 & 10.1 & $c$ & Moz & 4.4744 & 0.0533 & 2612 & 0.0033 & .8282 & 0.0487 & 1245 & 0.0006 & 0.1416 & 0.0434 & 1.496 & 0.017 & 1.726 & 0.010 & 21 & 0.009 & 8 & 74 \\
\hline DKE-39 & 16.1 & C & PMoz & 6.8901 & 0.0816 & 0.3509 & 0.0044 & 2.8497 & 0.0360 & 0.1426 & 0.0008 & 0.3688 & 0.0946 & 1.939 & .021 & 2.097 & 010 & 2.255 & 0.010 & 92 & 86 \\
\hline DKE-39 & 22.1 & C & PM & & & 0.2280 & 0.0022 & 4.3857 & 0.0428 & & 15 & & & 1.3 & & 1.5 & 0.010 & 1.975 & 0.021 & 84 & 67 \\
\hline DKE-39 & 23.1 & $f$ & noz & 366 & 67 & .3174 & 3 & 1503 & 0.0331 & 61 & 0.0016 & 0.4639 & 0.4 & 1.777 & 0.016 & 1.959 & 0.011 & 1.174 & 0.020 & 91 & 82 \\
\hline DKE-39 & 25.1 & C & PMoz & 8. & & 3928 & 0. & 55 & 0. & & 18 & 79 & & 2. & & & & 8 & 0 & 3 & 8 \\
\hline DKE-39 & 27.1 & $c$ & & & & & & & 0.0339 & & & & & 1.6 & & 1.7 & & 1.882 & 0.021 & 94 & 88 \\
\hline DKE-39 & 28.1 & $f_{-1} \rightarrow$ & Moz & 4.5745 & 0.0593 & 2647 & 0.0027 & .7784 & 0.0378 & 0.1265 & 0.0015 & 0.3824 & 0.4595 & 1.514 & 014 & 1.745 & 011 & 2.048 & 0.020 & 87 & 74 \\
\hline DKE-39 & 29.1 & 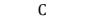 & Me & 4. & 0.0568 & 253 & & 3.9529 & 0.0387 & & & 0.4653 & & 1.4 & & & & (5) & & 4 & 70 \\
\hline DKE-39 & 31.1 & $f$ & PI & & & 0. & & 3.7542 & 0. & & & & & 1.522 & & 1.8 & 08 & 2.323 & 0.009 & 80 & 66 \\
\hline DKE & 32.1 & C & Moz & 31 & 0.0564 & 37 & 32 & 5.1633 & .0854 & 11119 & 17 & 0.5233 & 0.1 & 1.141 & 017 & 30 & 15 & 832 & 027 & 83 & 2 \\
\hline DKE-39 & 35.1 & 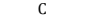 & & & 0. & 0.40 & & 2.4 & 0.02 & & & & & 2.1 & & & & & 0.011 & 94 & 8 \\
\hline DKE-39 & 39.1 & C & PMhhl & & & 0.3 & 0.0040 & & 0.0358 & 0.1358 & & 0.6318 & 0.3014 & 1.866 & 0.019 & 2.004 & 0.013 & 2.170 & 0.025 & 93 & 86 \\
\hline DKE- & 42.1 & $c$ & Moz & 4.1320 & 0393 & . 2779 & 0.0031 & 3.5988 & 0.0396 & 0.1092 & .0007 & 0.5416 & 0.2961 & 1.581 & 0.015 & 1.661 & 0.008 & 1.790 & 0.011 & 95 & 88 \\
\hline DKE-39 & 41.1 & c & PMoz & 2.5789 & 0.0277 & 0.1621 & 0.0018 & 6.1706 & 0.0696 & 0.1169 & 0.0007 & 0.2135 & 0.1113 & 0.968 & 0.010 & 1.295 & 0.008 & 1.910 & 0.010 & 75 & 51 \\
\hline
\end{tabular}




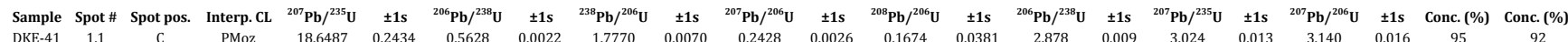

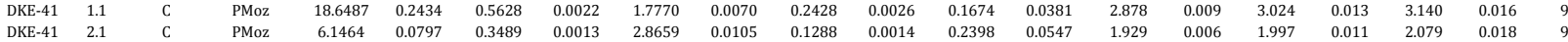

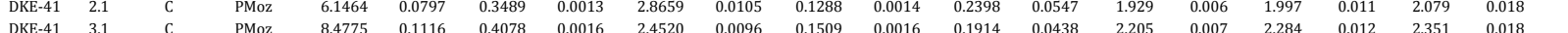

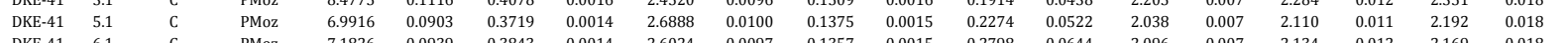

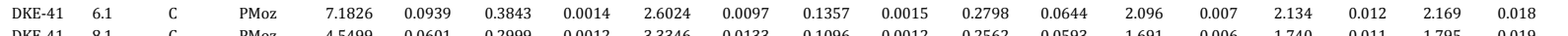

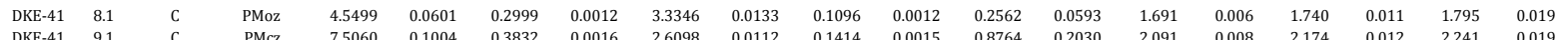

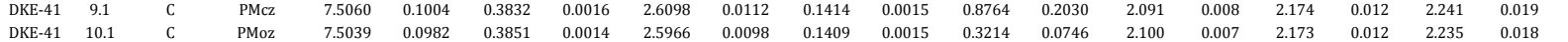

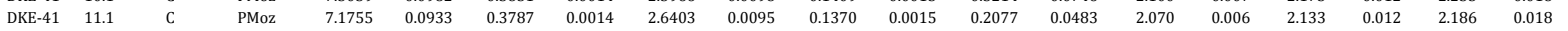
DKE-41 13.1 $\begin{array}{ll}\text { DKE-41 } & 14.1 \\ \text { DKE-41 } & 18.1\end{array}$ DKE-41 20.1 DKE-41 21.1 DKE-41 22.1 DKE-41 24.1 DKE-41 25. DKE-41 26.1 DKE-41 27.1 DKE-41 29.1 DKE-41 30.1 DKE-41 31.1 DKE-41 32.1 DKE-41 33.1 DKE-41 34.1 DKE-41 35.1 DKE-41 36.1 DKE-41 38.1 DKE-41 39.1 $\begin{array}{ll}\text { DKE-41 } & 41.1 \\ \text { DKE- } 41 & 42.1\end{array}$ $\begin{array}{ll}\text { DKE-41 } & 42.1 \\ \text { DKE-41 } & 43.1\end{array}$ DKE-41 44.1 DKE-41 46.1 \begin{tabular}{ll} 
DKE-41 & 48.1 \\
DKE-41 & 49.1 \\
\hline
\end{tabular} $\begin{array}{ll}\text { DKE-41 } & 49.1 \\ \text { DKE-41 } & 50.1\end{array}$ DKE-41 51.1 DKE-41 52.1 DKE-41 53.1 DKE-41 54.1 DKE-41 55.1 DKE-41 56.1 $\begin{array}{ll}\text { DKE-41 } & 57.1 \\ \text { DKE-41 } & 58.1\end{array}$ $\begin{array}{lr}\text { DKE-41 } & 58.1 \\ \text { DKE-41 } & 59.1\end{array}$ DKE-41 59. DKE-41 60.1 DKE 41

$\begin{array}{ll}\text { DKE-41 } & 63.1 \\ \text { DKE-41 } & 64.1\end{array}$

$\begin{array}{ll}\text { DKE-41 } & 64.1 \\ \text { DKE-41 } & 65.1\end{array}$ Zircons not used Zircons not used on the related diagram
DKE-41 4.1 DKE 41 $\begin{array}{llll}\text { DKE-41 } & 7.1 & \text { C } & \text { PM }\end{array}$ $\begin{array}{llll}\text { DKE-41 } & 15.1 & \text { C } & \text { PMoz }\end{array}$ DKE-41 171 DKE-41 19.1
DKE $\begin{array}{lll}D & \text { DKE } 41 & 231\end{array}$ DKE-41 37.1 DKE-41 40.1 DKE-41 45.1 DKE-41 47.1 DKE-41 61.1 


\begin{tabular}{|c|c|c|c|c|c|c|c|c|c|c|c|c|c|c|c|c|c|c|c|c|c|}
\hline Sample & Spot\# & Spot pos. & Interp. CL & ${ }^{207} \mathbf{P b} /{ }^{235} \mathbf{U}$ & $\pm 1 \mathrm{~s}$ & ${ }^{206} \mathbf{P b} /{ }^{238} \mathrm{U}$ & $\pm 1 s$ & ${ }^{238} \mathbf{P b} /{ }^{206} \mathbf{U}$ & $\pm 1 s$ & ${ }^{207} \mathrm{~Pb} /{ }^{206} \mathrm{U}$ & $\pm 1 s$ & ${ }^{208} \mathbf{P b} /{ }^{206} \mathbf{U}$ & $\pm 1 \mathrm{~s}$ & ${ }^{206} \mathbf{P b} /{ }^{238} \mathrm{U}$ & $\pm 1 s$ & ${ }^{207} \mathbf{P b} /{ }^{235} \mathbf{U}$ & $\pm 1 \mathrm{~s}$ & ${ }^{207} \mathbf{P b} /{ }^{206} \mathbf{U}$ & $\pm 1 \mathrm{~s}$ & Conc. (\%) & Conc. (\% \\
\hline DKE-30 & 1.1 & C & PMoz & 1.7891 & 0.0350 & 0.1749 & 0.0037 & 5.7174 & 0.1224 & 0.0742 & 0.0007 & 0.6221 & 0.5947 & 1.039 & 0.021 & 1.041 & 0.013 & 1.049 & 0.019 & 100 & $99^{\circ}$ \\
\hline DKE-30 & 2.1 & c & PMzc & 1.2550 & 0.0255 & 0.1366 & 0.0031 & 7.3194 & 0.1680 & 0.0679 & 0.0007 & 1.0473 & 0.9417 & 0.826 & 0.018 & 0.826 & 0.011 & 0.862 & 0.021 & 100 & 96 \\
\hline DKE-30 & 3.1 & C & PMoz & 6.7753 & 0.1266 & 0.3879 & 0.0082 & 2.5779 & 0.0548 & 0.1279 & 0.0010 & 0.4908 & 0.4164 & 2.113 & 0.038 & 2.083 & 0.016 & 2.067 & 0.014 & 101 & 102 \\
\hline DKE-30 & 4.1 & c & PMcz & 10.6234 & 1990 & 0.4840 & 0.0103 & 2.0661 & 0.0439 & 0.1612 & 0.0013 & 0.8270 & 0.6643 & 2.545 & 0.045 & 2.491 & 0.017 & 2.465 & 0.014 & 102 & 103 \\
\hline DKE-30 & 5.1 & c & PMoz & 2.1247 & 0.0408 & 0.1906 & 0.0041 & 5.2477 & 0.1133 & 0.0791 & 0.0008 & 0.4828 & 0.3683 & 1.124 & 0.022 & 1.157 & 0.013 & 1.177 & 0.021 & 97 & 96 \\
\hline DKE-30 & 6.1 & C & PMoz & 6.9900 & 0.1304 & 0.3879 & 0.0082 & 2.5781 & 0.0548 & 0.1317 & 0.0011 & 0.4850 & 3522 & 2.113 & 0.038 & 2.110 & 0.016 & 2.118 & 0.014 & 100 & 100 \\
\hline DKE-30 & 7.1 & C & PMhhl & 1.3806 & 0.0341 & 0.1468 & 0.0039 & 6.8139 & 0.1822 & 0.0662 & 0.0012 & 0.9776 & 0.6847 & 0.883 & 0.022 & 0.881 & 0.014 & 0.809 & 0.039 & 100 & 109 \\
\hline DKE-30 & 8.1 & C & PMoz & 1.1550 & 0.0218 & 0.1291 & 0.0027 & 7.7476 & 0.1647 & 0.0658 & 0.0005 & 0.6942 & 0.4600 & 0.783 & 0.016 & 0.780 & 0.010 & 0.795 & 0.017 & 100 & 98 \\
\hline DKE-30 & 9.1 & c & PMoz & 1.0476 & 0.0202 & 0.1214 & 0.0026 & 8.2394 & 0.1758 & 0.0633 & 0.0006 & 0.3881 & 0.2465 & 0.738 & 0.015 & 0.728 & 0.010 & 0.715 & 0.020 & 101 & 103 \\
\hline DKE-30 & 10.1 & C & PMoz & 1.0464 & 0196 & 0.1198 & 0025 & 8.3503 & 0.1756 & 0.0641 & 0.0005 & 0.1734 & 0.1056 & 0.729 & 0.014 & 0.727 & 0.010 & 0.741 & 0.017 & 100 & \\
\hline DKE-30 & 11.1 & C & PMoz & 1.3015 & 0.0243 & 0.1423 & 0.0030 & 7.0270 & 0.1483 & 0.0673 & 0.0006 & 0.5242 & 0.3071 & 0.858 & 0.017 & 0.846 & 0.011 & 0.843 & 0.018 & 101 & 102 \\
\hline DKE-30 & 13.1 & c & PMoz & 1.1870 & 0.0220 & 0.1323 & 0.0008 & 7.5568 & 0.0470 & 0.0658 & 0.0009 & 0.7795 & 0.4534 & 0.801 & 0.005 & 0.795 & 0.010 & 0.795 & 0.030 & 101 & 101 \\
\hline DKE-30 & 14.1 & C & PMhml & 5.3101 & 0.0959 & 0.3368 & 0.0014 & 2.9694 & 0.0126 & 0.1157 & 0.0016 & 1.3487 & 0.7787 & 1.871 & 0.007 & 1.870 & 0.015 & 1.892 & 0.024 & 100 & \\
\hline DKE-30 & 16.1 & C & PMhhl & 1.2417 & 0.0260 & 0.1352 & 0.0017 & 7.3986 & 0.0954 & 0.0659 & 0.0011 & 0.5725 & 0.3271 & 0.817 & 0.010 & 0.820 & 0.012 & 0.801 & 0.034 & 100 & 102 \\
\hline DKE-30 & 17.1 & C & Moz & 2.0642 & 0.0373 & 0.1933 & 0.0008 & 5.1731 & 0.0225 & 0.0778 & 0.0011 & 0.4649 & 0.2630 & 1.139 & 0.005 & 1.137 & 0.012 & 1.144 & 0.028 & 100 & 100 \\
\hline DKE-30 & 19.1 & c & PMoz & 4.9371 & 0.0934 & 0.3249 & 0.0024 & 3.0781 & 0.0223 & 0.1109 & 0.0017 & 1.2513 & 0.6983 & 1.813 & 0.011 & 1.809 & 0.016 & 1.817 & 0.027 & 100 & 100 \\
\hline DKE-30 & 21.1 & C & PMoz & 1.5473 & 0.0287 & 0.1552 & 0.0006 & 6.4435 & 0.0267 & 0.0728 & 0.0010 & 0.3651 & 0.1994 & 0.930 & 0.004 & 0.949 & 0.011 & 1.009 & 0.029 & 98 & 92 \\
\hline DKE-30 & 22.1 & C & PMhlll & 1.7597 & 319 & 0.1716 & 0008 & 5.8272 & 0270 & 0.0736 & 0.0010 & 0.5459 & 2961 & 1021 & 0.004 & 1.031 & 0.012 & 1.030 & 0.029 & & 99 \\
\hline DKE-30 & 23.1 & c & PMcz & 1.2176 & 0.0225 & 0.1325 & 0.0007 & 7.5464 & 0.0378 & 0.0664 & 0.0010 & 0.6959 & 0.3751 & 802 & 004 & .809 & 010 & 0.814 & 032 & 99 & 99 \\
\hline DKE-30 & 25.1 & C & PMoz & 12.6921 & 0.1467 & 0.4866 & 0.0051 & 2.0551 & 0.0214 & 0.1913 & 0.0015 & -0.2616 & 2.6875 & 2.556 & 0.022 & 2.657 & 0.011 & 2.757 & 0.013 & 96 & 93 \\
\hline DKE-30 & 27.1 & C & PMCZ & 1.1876 & 213 & 0.1323 & 015 & 7.5610 & 0.0849 & 0.0663 & 0.0010 & -1.0112 & 3776 & 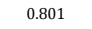 & 0.008 & 0.795 & 0.010 & 0.812 & 0030 & & 9 \\
\hline DKE-30 & 28.1 & c & PMoz & 1.1712 & 0.0152 & 0.1326 & 0.0014 & 7.5437 & 0.0825 & 0.0647 & 0.0006 & -1.1951 & 4.0127 & 0.802 & 0.008 & 0.787 & 0.007 & 0.760 & 0.020 & 102 & 106 \\
\hline DKE-30 & 30.1 & C & PMoz & 1.2929 & 0.0155 & 0.1396 & 0.0014 & 7.1650 & 0.0742 & 0.0686 & 0.0006 & -1.4000 & 3.2446 & 0.842 & 0.008 & 0.843 & 0.007 & 0.884 & 0.018 & 100 & 95 \\
\hline DKE-30 & 31.1 & C & & & & 0.1 & & 7.5592 & & 0.0685 & 0.0006 & -2.5900 & & & 8 & 0.824 & 17 & & 8 & & 91 \\
\hline DKE-30 & 32.1 & c & PMoz & 1.3237 & 0.0223 & 0.1382 & 0015 & 7.2335 & 0.0789 & 0.0698 & 0.0009 & -1.2831 & 2.2707 & 0.835 & 0.009 & 0.856 & 0.010 & .921 & 0.026 & 98 & 91 \\
\hline DKE-30 & 33.1 & c & PMoz & 3371 & 0.0169 & 1443 & 0015 & 6.9308 & 0.0741 & 0.0667 & 0.0006 & -2.9932 & 4.7364 & 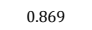 & 0.009 & 0.862 & 0.007 & 0.824 & 0.020 & 101 & 106 \\
\hline DKE-30 & 34.1 & C & PMoz & 1.5959 & 0.0198 & 0.1655 & 0.0018 & 6.0426 & 0.0644 & 0.0702 & 0.0007 & -3.7261 & 5.3324 & 0.987 & 0.010 & 0.969 & 0.008 & 0.932 & 0.021 & 102 & 106 \\
\hline DKE-30 & 35.1 & C & PMoz & 1.3066 & 0.0184 & 0.1428 & 0.0016 & 7.0016 & 0.0762 & 0.0668 & 0.0007 & -4.1944 & 5.4786 & 0.861 & 0.009 & 0.849 & 0.008 & .827 & 0.021 & 101 & 104 \\
\hline DKE-30 & 36.1 & c & & 13.5998 & 0. & 5148 & 052 & 1.9424 & 0.0198 & 0.1923 & 0.0015 & -3.0206 & 3.6287 & 2.6 & 0.022 & 2.722 & 0.011 & 2.766 & 0.013 & 98 & 97 \\
\hline DKE-30 & 37.1 & C & PMoz & 11.7090 & 0.1440 & 0.4971 & 0056 & 2.0117 & 0225 & 0.1717 & 0.0014 & -1.0554 & 1737 & 2.601 & 0.024 & 2.581 & 0.011 & .574 & .013 & 101 & 101 \\
\hline DKE-30 & 38.1 & c & $\mathrm{P}$ & 10.7364 & 0. & 0.4625 & 0 & 2.1622 & 25 & 0.1716 & 0.0015 & 0.4631 & 56 & 1 & 0.021 & 2.501 & 014 & .573 & .015 & 98 & 95 \\
\hline DKE-30 & 39.1 & 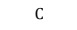 & & & & 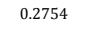 & & 3.6 & & 982 & 0.0009 & 0.9052 & & 1.5 & 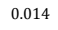 & 1.5 & ? & 1.59 & .017 & & 98 \\
\hline DKE-30 & 40.1 & C & PMoz & 0972 & 68 & 1240 & 3 & 8.0632 & 17 & 0.0645 & 0.0006 & 0.4442 & 03 & 0.754 & 0.007 & 0.752 & 8 & 754 & 0.021 & 100 & 100 \\
\hline DKE-30 & 41.1 & c & Pmoz/Mez & ה290 & & 0.1440 & & 6.9438 & & 0.0663 & 0.0006 & 0.7423 & & 08 & & 0862 & 9 & 811 & 0.020 & 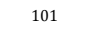 & 107 \\
\hline DKE-30 & 43.1 & c & & & & & & & & 150 & 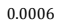 & 19 & & & & & & & 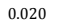 & & 105 \\
\hline DKE-30 & 45.1 & c & $\begin{array}{l}\mathrm{P} \\
\mathrm{P}\end{array}$ & 1.2438 & 0 & 0.1308 & & 7.6458 & 6 & 0.0679 & 0.0006 & 0.1936 & 6 & 0.7 & 0.008 & .821 & 009 & 862 & 0.019 & 97 & 92 \\
\hline DKE-30 & 46.1 & $c$ & & 327 & & 0.1265 & & 7.9059 & & 0.0651 & م0007 & 0.3247 & & 0.76 & 0 & .769 & 8 & 774 & 21 & 100 & 99 \\
\hline DKE-30 & 47.1 & c & & 701 & & 0.1 & & 8.4855 & & 0.0656 & 0.0006 & 33 & & & 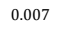 & 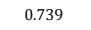 & 8 & .78 & 0.020 & & 91 \\
\hline DKE-30 & 48.1 & 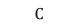 & & & & & & & & & & & & & & 806 & 9 & 0.762 & & 1 & 107 \\
\hline DKE-30 & 49.1 & c & & 241 & & 0.1155 & & 8.6558 & & 0.0635 & 0006 & 0.1577 & 1407 & 0.105 & .007 & 0.716 & 007 & 0.721 & 019 & 98 & 98 \\
\hline DKE-30 & 50.1 & C & 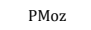 & 4865 & (2) & 150 & 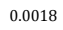 & 6.3222 & 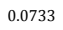 & 0.0689 & 0013 & - & 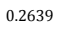 & & 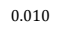 & 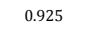 & 015 & 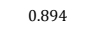 & .038 & 102 & 106 \\
\hline \multicolumn{22}{|c|}{ Zircons not included on rel: } \\
\hline DKE-30 & 12.1 & C & PMoz & 1.0611 & 0.0219 & 0.115 & 0. & 8.6536 & 42 & 0.0669 & 0.0007 & 1.5288 & 8306 & 0.705 & 0.014 & 0.734 & 011 & 0.831 & 0.022 & 96 & 85 \\
\hline DKE-30 & 15 & 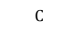 & & & & & & & & & & & & & & & & 177 & & 95 & 84 \\
\hline DKE-30 & 18.1 & D & Mc & 415 & 330 & 0.1134 & & 8.8165 & 0.10 & 0.0855 & 0.0016 & 0.5873 & 299 & 0.693 & 0.008 & 0.864 & 014 & 1.333 & 037 & 80 & 52 \\
\hline DKE-30 & 20.1 & 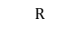 & & 1 & & 0 & & 675 & & & & 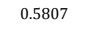 & & & & & & & & & , \\
\hline DKE-30 & $20.2 \mathrm{~N}$ & - & & & & 0.1042 & & 9.5999 & & & 0.0012 & & & & & 0.110 & 112 & 896 & 037 & 90 & 71 \\
\hline DKE-30 & 24.1 & 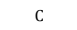 & $\mathrm{Pl}$ & 1.2043 & 23 & 0.1371 & & 7.2961 & & 0.0632 & 0.0010 & 0.5093 & 2733 & 0.82 & 0.006 & 803 & 010 & 711 & 035 & 103 & 117 \\
\hline DKE-30 & 26. & $\mathrm{R}$ & & & & & & & & & & -0.8581 & & & & & & & & & \\
\hline DKE-30 & 29.1 & r & PMhml & 2.7431 & 0.0387 & 0.2221 & & 4.5029 & .04t & 0.0953 & 0.0008 & -2.4944 & 6.8404 & $1.2 \mathrm{~s}^{2}$ & 0.013 & 1.340 & 0.010 & 1.540 & 0.016 & 96 & 84 \\
\hline DKE-30 & 42.1 & C & $\mathrm{PI}$ & 50 & & 26 & & 8.8791 & & 0.0702 & & 0.6093 & & 0. & $0 . c$ & 0.756 & 34 & 0.932 & 00 & 91 & 74 \\
\hline DKE-30 & 44.1 & $f$ & PMoz & 3.4404 & 0.0609 & 0.2121 & 0.0023 & 4.7145 & 0508 & 0.1171 & 0.0012 & 0.7992 & 5899 & 1.240 & 0.012 & .514 & 0.014 & 1.913 & 0.018 & 82 & 65 \\
\hline
\end{tabular}




\begin{tabular}{|c|c|c|c|c|c|c|c|c|c|c|c|c|c|c|c|c|c|c|c|c|c|}
\hline le & Spot\# & Spot pos. & Interp. CL & ${ }^{207} \mathbf{P b} / /^{235} \mathbf{U}$ & $\pm 1 \mathrm{~s}$ & ${ }^{206} \mathrm{~Pb} b{ }^{238} \mathrm{U}$ & $\pm 1 \mathrm{~s}$ & ${ }^{238} \mathrm{~Pb} / /^{206} \mathbf{U}$ & $\pm 1 s$ & ${ }^{207} \mathbf{P b} / /^{206} \mathbf{U}$ & $\pm 1 s$ & ${ }^{208} \mathrm{~Pb} / /^{206} \mathbf{U}$ & is & ${ }^{206} \mathbf{P b} \mathbf{2}{ }^{238} \mathbf{U}$ & $\pm 1 s$ & ${ }^{207} \mathrm{~Pb}$ b ${ }^{235} \mathrm{U}$ & $\pm 1 s$ & ${ }^{207} \mathrm{~Pb} /{ }^{206} \mathbf{U}$ & $\pm 1 s$ & Con & Conc. \\
\hline DKE-25 & 2.1 & $\mathrm{R}$ & PMoz & 0.7318 & 0.0089 & 0.0895 & 0.0012 & 11.1742 & 0.1499 & 0.0603 & 0.0004 & 0.6043 & 0.0797 & 0.553 & 0.007 & 0.558 & 0.005 & 0.609 & 0.014 & 99 & 91 \\
\hline DKE-25 & 3.1 & C & PMhml & 0.7987 & 0.0097 & 0.0972 & 0.0013 & 10.2842 & 0.1386 & 0.0598 & 0.0004 & 0.3713 & 0.0497 & 0.598 & 0.008 & 0.596 & 0.005 & 0.591 & 0.015 & 100 & 101 \\
\hline DKE-25 & 4.1 & c & PMcz & 6.8196 & 0.0791 & 0.3598 & 0.0046 & 2.7796 & 0.0358 & 0.1385 & 0.0007 & 0.2366 & 0.0316 & 1.981 & 0.022 & 2.088 & 0.010 & 2.204 & 0.009 & 95 & 90 \\
\hline DKE-25 & 7.1 & $\mathrm{R}$ & PMoz & 0.7954 & 0.0098 & 0.0966 & 0.0013 & 10.3550 & 0.1371 & 0.0604 & 0.0004 & 0.7668 & 0.1047 & 0.594 & 0.008 & 0.594 & 0.006 & 0.613 & 0.013 & 100 & 97 \\
\hline DKE-25 & 8.1 & C & PMcz & 0.7751 & 0.0092 & 0.0932 & 0.0012 & 10.7261 & 0.1391 & 0.0606 & 0.0003 & 0.0344 & 0.0049 & 0.575 & 0.007 & 0.583 & 0.005 & 0.618 & 0.012 & 99 & 93 \\
\hline DKE-25 & 9.1 & C & PMhml & 0.7647 & 0.0093 & 0.0939 & 0.0013 & 10.6493 & 0.1495 & 0.0609 & 0.0005 & 0.4595 & 0.0642 & 0.579 & 0.008 & 0.577 & 0.005 & 0.629 & 0.017 & 100 & 92 \\
\hline DKE-25 & 11.1 & C & PMoz & 6.8697 & 0.0815 & 0.3644 & 0.0048 & 2.7442 & 0.0360 & 0.1382 & 0.0007 & 0.2175 & 0.0306 & 2.003 & 0.023 & 2.095 & 0.010 & 2.201 & 0.009 & 96 & 91 \\
\hline DKE-25 & 13.1 & C & PMoz & 0.7430 & 0.0095 & 0.0911 & 0.0012 & 10.9744 & 0.1467 & 0.0602 & 0.0004 & 0.6770 & 0.0967 & 0.562 & 0.007 & 0.564 & 0.006 & 0.603 & 0.015 & 100 & 93 \\
\hline DKE-25 & 14.1 & C & PMoz & 20.6682 & 0.2518 & 0.5775 & 0.0065 & 1.7315 & 0.0195 & 0.2615 & 0.0019 & 0.2160 & 0.0486 & 2.939 & 0.027 & 3.123 & 0.012 & 3.253 & 0.011 & 94 & 90 \\
\hline DKE-25 & 15.1 & C & PMoz & 6.7844 & 0.0822 & 0.3679 & 0.0041 & 2.7183 & 0.0304 & 0.1347 & 0.0010 & 0.3191 & 0.0735 & 2.019 & 0.019 & 2.084 & 0.011 & 2.157 & 0.012 & 97 & 94 \\
\hline DKE-25 & 17.1 & C & PMoz & 4.1248 & 0.0521 & 0.2833 & 0.0034 & 3.5294 & 0.0417 & 0.1064 & 0.0008 & 0.4141 & 0.1000 & 1.608 & 0.017 & 1.659 & 0.010 & 1.742 & 0.014 & 97 & 92 \\
\hline DKE-25 & 18.1 & C & PMoz & 0.7876 & 0.0131 & 0.0937 & 0.0014 & 10.6676 & 0.1625 & 0.0606 & 0.0008 & 0.7109 & 0.1766 & 0.578 & 0.008 & 0.590 & 0.007 & 0.621 & 0.029 & 98 & 93 \\
\hline DKE-25 & 19.1 & C & PMoz & 6.7037 & 0.0816 & 0.3602 & 0.0041 & 2.7763 & 0.0313 & 0.1358 & 0.0010 & 0.1357 & 0.0344 & 1.983 & 0.019 & 2.073 & 0.011 & 2.170 & 0.013 & 96 & 91 \\
\hline DKE-25 & 21.1 & C & PMoz & 6.7657 & 0.0843 & 0.3658 & 0.0042 & 2.7338 & 0.0317 & 0.1357 & 0.0010 & 0.2184 & 0.0581 & 2.010 & 0.020 & 2.081 & 0.011 & 2.169 & 0.012 & 97 & 93 \\
\hline DKE-25 & 24.1 & C & PMhml & 7.5759 & 0.0907 & 0.3909 & 0.0043 & 2.5582 & 0.0283 & 0.1421 & 0.0010 & 0.1448 & 0.0418 & 2.127 & 0.020 & 2.182 & 0.011 & 2.249 & 0.012 & 97 & 95 \\
\hline DKE-25 & 28.1 & C & PMhl & 6.4139 & 0.0835 & 0.3572 & 0.0047 & 2.7997 & 0.0370 & 0.1313 & 0.0014 & 0.3311 & 2.0055 & 1.969 & 0.022 & 2.034 & 0.011 & 2.113 & 0.018 & 97 & 93 \\
\hline DKE-25 & 29.1 & c & PMoz & 0.8073 & 0.0123 & 0.0963 & 0.0014 & 10.3840 & 0.1552 & 0.0613 & 0.0007 & 0.2628 & 1.4678 & 0.593 & 0.008 & 0.601 & 0.007 & 0.643 & 0.024 & 99 & 92 \\
\hline DKE-25 & 30.1 & C & PMhhl & 0.6947 & 0.0151 & 0.0857 & 0.0014 & 11.6654 & 0.1884 & 0.0585 & 0.0010 & 0.3309 & 1.7149 & 0.530 & 0.008 & 0.536 & 0.009 & 0.543 & 0.038 & 99 & 98 \\
\hline DKE-25 & 31.1 & C & PMhhl & 6.9949 & 0.0910 & 0.3724 & 0.0049 & 2.6852 & 0.0352 & 0.1376 & 0.0014 & 0.2025 & 0.9788 & 2.041 & 0.023 & 2.111 & 0.011 & 2.193 & 0.018 & 97 & 93 \\
\hline DKE-25 & 32.1 & C & PMoz & 6.6572 & 0.0859 & 0.3552 & 0.0046 & 2.8152 & 0.0365 & 0.1370 & 0.0014 & 0.3115 & 1.4104 & 1.959 & 0.022 & 2.067 & 0.011 & 2.186 & 0.017 & 95 & 90 \\
\hline DKE-25 & 34.1 & C & PMoz & 0.8046 & 0.0112 & 0.0953 & 0.0013 & 10.4946 & 0.1407 & 0.0608 & 0.0007 & 0.3851 & 1.5482 & 0.587 & 0.008 & 0.599 & 0.006 & 0.626 & 0.025 & 98 & 94 \\
\hline DKE-25 & 38.1 & $\mathrm{R}$ & PMoz & 0.7700 & 0.0114 & 0.0944 & 0.0013 & 10.5931 & 0.1426 & 0.0589 & 0.0007 & 1.0409 & 3.4185 & 0.582 & 0.007 & 0.580 & 0.006 & 0.557 & 0.027 & 100 & 104 \\
\hline DKE-25 & 39.1 & C & PMoz & 0.8414 & 0.0123 & 0.1005 & 0.0014 & 9.9474 & 0.1337 & 0.0601 & 0.0007 & 0.4161 & 1.3069 & 0.618 & 0.008 & 0.620 & 0.007 & 0.602 & 0.026 & 100 & 103 \\
\hline DKE-25 & 40.1 & C & PMoz & 0.7978 & 0.0113 & 0.0964 & 0.0009 & 10.3762 & 0.1020 & 0.0610 & 0.0005 & 0.2988 & 0.0398 & 0.593 & 0.006 & 0.596 & 0.006 & 0.633 & 0.019 & 100 & 94 \\
\hline DKE-25 & 41.1 & c & PMoz & 6.5370 & 0.0908 & 0.3660 & 0.0036 & 2.7321 & 0.0266 & 0.1311 & 0.0011 & 0.2099 & 0.0281 & 2011 & 0.017 & 2051 & 0.012 & 2.110 & 0.014 & & 95 \\
\hline $\begin{array}{l}\text { DKE-25 } \\
\text { D }\end{array}$ & 42.1 & $\mathrm{R}$ & PMoz & 0.7952 & 0.0115 & 0.0954 & 0.0009 & 10.4817 & 0.1026 & 0.0610 & 0.0005 & 0.0885 & 0.0129 & 0.587 & 0.005 & 0.594 & 0.006 & 0.634 & 0.019 & 99 & 93 \\
\hline DKE-25 & 43.1 & C & PMoz & 0.7255 & 0.0108 & 0.0893 & 0.0009 & 11.1974 & 0.1155 & 0.0593 & 0.0005 & 0.9326 & 0.1226 & 0.551 & 0.005 & 0.554 & 0.006 & 0.571 & 0.020 & 100 & 97 \\
\hline DKE-25 & 44.1 & C & PMoz & 0.8157 & 0.0115 & 0.0976 & 0.0010 & 10.2415 & 0.1013 & 0.0607 & 0.0005 & 0.4208 & 0.0554 & 0.601 & 0.006 & 0.606 & 0.006 & 0.622 & 0.019 & 99 & 97 \\
\hline DKE-25 & 45.1 & C & PMcz & 0.8365 & 0.0120 & 0.1003 & 0.0010 & 9.9707 & 0.1003 & 0.0614 & 0.0005 & 0.1185 & 0.0159 & 0.616 & 0.006 & 0.617 & 0.007 & 0.646 & 0.018 & 100 & 95 \\
\hline DKE-25 & 46.1 & C & PMoz & 0.7882 & 0.0115 & 0.0964 & 0.0010 & 10.3690 & 0.1082 & 0.0600 & 0.0005 & 0.3796 & 0.0551 & 0.594 & 0.006 & 0.590 & 0.007 & 0.597 & 0.018 & 101 & 99 \\
\hline DKE-25 & 48.1 & C & & 6.8118 & 0.0924 & 0.3661 & 0.0035 & 2.7316 & 0.0264 & 0.1366 & 0.0011 & 0.2942 & 0.0382 & 2.011 & 0.017 & 2.087 & 0.012 & 2.181 & 0.013 & & 92 \\
\hline DKE-25 & 50.1 & c & PMoz & 4.3386 & 0.0603 & 0.2950 & 0.0029 & 3.3898 & 0.0338 & 0.1081 & 0.0009 & $\begin{array}{l}1.0720 \\
\text {. }\end{array}$ & 0.1388 & 1.666 & 0.015 & 1.701 & 0.011 & 1.771 & 0.014 & 98 & 94 \\
\hline DKE-25 & 51.1 & C & PMcz & 7.8652 & 0.1068 & 0.3884 & 0.0037 & 2.5747 & 0.0246 & 0.1485 & 0.0012 & 0.3500 & 0.0452 & 2.115 & 0.017 & 2.216 & 0.012 & 2.325 & 0.013 & 95 & 91 \\
\hline DKE-25 & 52.1 & C & PMhhl & 0.8485 & 0.0181 & 0.1027 & 0.0016 & 9.7348 & 0.1511 & 0.0613 & 0.0011 & 1.1978 & 0.1552 & 0.630 & 0.009 & 0.624 & 0.010 & 0.646 & 0.039 & 101 & 98 \\
\hline DKE-25 & 53.1 & C & PMhml & 0.7560 & 0.0140 & 0.0941 & 0.0016 & 10.6219 & 0.1845 & 0.0588 & 0.0008 & 0.6990 & 0.1948 & 0.580 & 0.010 & 0.572 & 0.008 & 0.552 & 0.028 & 101 & 105 \\
\hline DKE-25 & 55.1 & C & PMoz & 13.0451 & 0.1940 & 0.4902 & 0.0061 & 2.0399 & 0.0252 & 0.1947 & 0.0020 & 0.2495 & 0.0737 & 2.572 & 0.026 & 83 & 0.014 & 2.787 & 0.017 & 96 & 92 \\
\hline DKE-25 & 56.1 & C & PMhml & 0.8110 & 0.0128 & 0.0998 & 0.0013 & 10.0237 & 0.1280 & 0.0594 & 0.0006 & 0.5267 & 0.1606 & 0.613 & 0.007 & 0.603 & 0.007 & 0.575 & 0.024 & 102 & 107 \\
\hline DKE-25 & 57.1 & C & PMoz & 0.7823 & 0.0125 & 0.0963 & 0.0013 & 10.3821 & 0.1401 & 0.0598 & 0.0007 & 1.0232 & 0.3228 & 0.593 & 0.008 & 0.587 & 0.007 & 0.589 & 0.024 & 101 & 101 \\
\hline DKE-25 & 58.1 & D & $\mathrm{PN}$ & 0.8166 & 0.0132 & 0.1017 & 0.0014 & 9.8325 & 0.1326 & 0.0591 & 0.0007 & 0.3517 & . & 0.624 & 0.008 & 606 & 0.007 & 0.563 & 0.026 & 103 & 111 \\
\hline DKE-25 & 59.1 & $\mathrm{R}$ & $\mathrm{P}$ & 114 & 0.0130 & 0.0971 & 0.0012 & 10.2982 & 0.1314 & 0.0613 & 0.0007 & 0.3712 & 0.1248 & 0.597 & 0.007 & 603 & 0.007 & 0.643 & 0.024 & 99 & 93 \\
\hline DKE-25 & 61.1 & C & & 245 & 0.0127 & 0.0981 & 0.0012 & 10.1951 & 0. & 0.0613 & 0.0007 & 0.3660 & 0.1333 & 0.603 & 0.007 & 0.611 & 0.007 & 0.642 & 0.023 & 99 & 94 \\
\hline DKE-25 & 62.1 & 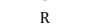 & 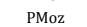 & 0.8613 & 0.0140 & 0.1020 & 0.0014 & 9.8023 & 0.13 & 0.0618 & 0.0007 & 0.2755 & 44 & 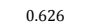 & 008 & 631 & 0.008 & 0.663 & 0.025 & 99 & 94 \\
\hline DKE-25 & 63.1 & $\mathrm{c}$ & $\mathrm{oz}$ & 0.8256 & 0.0129 & 0.0975 & 0.0012 & 10.2550 & 0.1284 & 0.0619 & 0.0007 & 0.2828 & 0.1116 & 0.600 & 0.007 & 0.611 & 0.007 & 0.664 & 0.023 & 98 & 90 \\
\hline DKE-25 & 64.1 & , & & 0.7463 & 0 & 0.0894 & 0.000 & 11.1844 & 0.174 & 0.0605 & 0.0007 & 0.9888 & 0.4075 & 0.552 & 0.008 & 0.566 & 0.008 & 0.616 & 0.026 & 98 & 90 \\
\hline DKE-25 & 65.1 & $\mathrm{c}$ & PMoz & 0.7726 & 0.0119 & 0.0946 & 0.0012 & 10.5763 & 0.1336 & 0.0599 & 0.0006 & 0.2968 & 0.1279 & 0.582 & 0.007 & 581 & 0.007 & 0.594 & 0.023 & 100 & 98 \\
\hline \multicolumn{22}{|c|}{ Zircons not included on rel } \\
\hline DKE-25 & 1.1 & $\mathrm{R}$ & PMoz & 0.8023 & 0.0109 & 0.0946 & 0. & 10.5684 & 0.1446 & 0.0619 & 0.0005 & 0.23 & 18 & .583 & 0.008 & 0.598 & 0.006 & 0.665 & 0.017 & 97 & 88 \\
\hline DKE-25 & 5.1 & $\mathrm{R}$ & & 0.9080 & 0.0111 & 0.0992 & 0.0013 & 10.0821 & 0.1325 & 0.0665 & 0.0004 & 0.3533 & 0.0477 & 0.610 & 0.008 & 656 & 0.006 & 0.817 & 0.014 & 93 & 75 \\
\hline DKE-25 & 6.1 & c & PI & & 0.0106 & 0.1020 & 0.0 & 9.8059 & 0.1 & 38 & 0.0004 & 0.6453 & 0.0876 & 0.626 & 0.008 & 647 & 0.006 & 0.730 & 0.013 & 97 & 86 \\
\hline KE-25 & 10.1 & 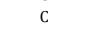 & . & 355 & 0.0842 & 562 & & & 0. & & & 0. & & & 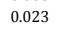 & .071 & 1 & 198 & 0.009 & & 89 \\
\hline DKE-25 & 12.1 & c & & & 0. & 062 & 0 & & 0. & & & 0. & & 0 & 0.0 & 5 & 0.010 & 0.899 & 0.017 & 9 & 72 \\
\hline DKE-25 & 16.1 & 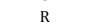 & PMhml & 34 & 0.0107 & 0.0959 & 0. & 10.4228 & 0.1194 & & & 0.4305 & 0.1014 & 0.591 & 0.006 & 616 & 0.006 & 0.710 & .016 & 96 & 83 \\
\hline DKE-25 & 20.1 & $\mathrm{R}$ & & & 0.0154 & 0.0937 & & 10.6669 & & & & & & & & & 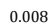 & . & & & 53 \\
\hline DKE-25 & 22.1 & c & & & 0.0 & 0.1123 & & 8.9 & 0.1 & & & 0. & 0.1 & 0 & 88 & 0.712 & 0.007 & 0.798 & 0 & 96 & 86 \\
\hline DKE-25 & 23.1 & 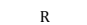 & PM & 0.7950 & 0.0105 & 0.0941 & 0.0011 & 10.6235 & 0.1249 & 0.0615 & 0.0005 & 0.5798 & 0.1629 & 0.580 & 0.007 & 594 & .006 & 0.649 & 0.019 & 98 & 89 \\
\hline DKE-25 & 25.1 & $\mathrm{c}$ & PMhm & 0.7762 & 0.0106 & 0.0930 & 0.0011 & 10.7472 & 0.1318 & 00 & 0.0005 & 085 & 0.2528 & . & 07 & 583 & 006 & 646 & 019 & & - \\
\hline DKE-25 & 26.1 & . & & 6 & 0.0731 & 0.3388 & & 2.9 & 0.0 & 0. & 0. & 0. & 0.0 & 1 & 0.018 & 1.996 & 010 & 2.128 & 12 & 94 & 88 \\
\hline DKE-25 & 27.1 & c & PMoz & 6.7406 & 0.0877 & 0.3544 & 0.0046 & 2.8215 & 0.0368 & 0.1384 & 0.0014 & 0.1208 & 0.7991 & 1.956 & 0.022 & 2.078 & 011 & 2.203 & 0.017 & 94 & 89 \\
\hline DKE-25 & 33.1 & R & & 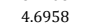 & 0.06 & & & & & & & & & & & 1.766 & 0.012 & 1.962 & 0.018 & 91 & 82 \\
\hline KE-25 & 35.1 & C & PMoz & 4.0781 & 0.0536 & 0.2459 & 0.0032 & 4.0673 & 0.0534 & 0.1221 & 0.00 & 0.4139 & 1.5756 & 1.417 & 0.017 & 1.650 & 0.011 & 1.986 & 017 & 86 & 71 \\
\hline 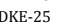 & 36.1 & C & & 07077 & 0.0104 & 0.0853 & & 11.7198 & & & & & & & & & & 0.612 & 23 & 97 & 86 \\
\hline DKE-25 & 37.1 & c & & & 0.0271 & & & & 0.0 & 0.0818 & 0.0008 & 0.0627 & 0.2160 & 1.098 & 0.013 & 1.144 & 0.009 & 1.244 & 0.020 & 96 & 88 \\
\hline KE-25 & 47.1 & $\mathrm{R}$ & PMoz & 5.3790 & 0.0734 & 0.3203 & 0.0031 & 3.1224 & 0.0301 & 0.1235 & 0.0010 & 0.3455 & 0.0450 & 1.791 & 0.015 & 1.882 & 0.012 & 2.007 & 0.014 & 95 & 89 \\
\hline & 49.1 & C & & 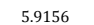 & 0 & . & & & 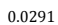 & & & & & & & & & 7 & 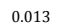 & & 88 \\
\hline DKE- & 54.1 & C & PMoz & 0.7597 & 0.0130 & 0.0880 & 0.0012 & $\begin{array}{l}11.3580 \\
11.350\end{array}$ & 0.1567 & 0.0622 & 0.0007 & 0.4783 & 0.1 & 0.5 & 0.007 & 0.574 & 0.007 & 0.674 & 0.024 & 95 & 81 \\
\hline DKE-25 & 60.1 & C & PMoz & 0.7469 & 0.0131 & 0.0889 & 0.0012 & 11.2529 & 0.1563 & 0.0616 & 0.0007 & 0.7177 & 0.2515 & 0.549 & 0.007 & 0.566 & 0.008 & 0.653 & 0.025 & 97 & 84 \\
\hline
\end{tabular}




\begin{tabular}{|c|c|c|c|c|c|c|c|c|c|c|c|c|c|c|c|c|c|c|c|c|c|}
\hline Sample & Spot\# & Spot pos. & Interp. CL & ${ }^{207} \mathrm{~Pb} /{ }^{235} \mathrm{U}$ & $\pm 1 \mathrm{~s}$ & ${ }^{206} \mathrm{~Pb} /{ }^{238} \mathrm{U}$ & $\pm 1 \mathrm{~s}$ & ${ }^{238} \mathbf{P b} /{ }^{206} \mathbf{U}$ & $\pm 1 \mathrm{~s}$ & ${ }^{207} \mathrm{~Pb} /{ }^{206} \mathrm{U}$ & $\pm 1 \mathrm{~s}$ & ${ }^{208} \mathbf{P b} /{ }^{206} \mathbf{U}$ & $\pm 1 \mathrm{~s}$ & ${ }^{206} \mathbf{P b} /{ }^{238} \mathbf{U}$ & $\pm 1 \mathrm{~s}$ & ${ }^{207} \mathrm{~Pb} /{ }^{235} \mathbf{U}$ & $\pm 1 \mathrm{~s}$ & ${ }^{207} \mathrm{~Pb} /{ }^{206} \mathrm{U}$ & $\pm 1 \mathrm{~s}$ & Conc. (\%) & Conc. \\
\hline DKE-45 & 1.1 & $\mathrm{R}$ & MR/Mog & 0.9853 & 0.0082 & 0.1152 & 0.0009 & 8.6772 & 0.0644 & 0.0627 & 0.0003 & 0.2160 & 0.0690 & 0.703 & 0.005 & 0.696 & 0.004 & 0.692 & 0.009 & 101 & 102 \\
\hline DKE-45 & 3.1 & $\mathrm{R}$ & PMoz & 1.0137 & 0.0087 & 0.1159 & 0.0010 & 8.6318 & 0.0757 & 0.0639 & 0.0004 & 0.2772 & 0.0911 & 0.707 & 0.006 & 0.711 & 0.004 & 0.734 & 0.012 & 99 & 96 \\
\hline DKE-45 & 4.1 & C & PMhml & 1.2316 & 0.0103 & 0.1369 & 0.0010 & 7.3040 & 0.0536 & 0.0660 & 0.0004 & 0.3667 & 0.1217 & 0.827 & 0.006 & 0.815 & 0.005 & 0.804 & 0.014 & 101 & 103 \\
\hline DKE-45 & 6.1 & c & PMoz & 1.3282 & 0.0221 & 0.1453 & 0.0024 & 6.8813 & 0.1154 & 0.0671 & 0.0003 & 0.2848 & 0.0903 & 0.875 & 0.014 & 0.858 & 0.010 & 0.838 & 0.011 & 102 & 104 \\
\hline DKE-45 & 7.1 & C & PMoz & 1.2619 & 0.0214 & 0.1395 & 0.0024 & 7.1701 & 0.1233 & 0.0659 & 0.0004 & 0.5119 & 0.1596 & 0.842 & 0.014 & 0.829 & 0.010 & 0.798 & 0.013 & 102 & 105 \\
\hline DKE-45 & 9.1 & C & PMzc & 5.5552 & 0.0911 & 0.3461 & 0.0058 & 2.8894 & 0.0482 & 0.1180 & 0.0005 & 0.0832 & 0.0251 & 1.916 & 0.028 & 1.909 & 0.014 & 1.926 & 0.008 & 100 & 99 \\
\hline DKE-45 & 10.1 & C & PMoz & 1.4140 & 0.0234 & 0.1483 & 0.0025 & 6.7414 & 0.1130 & 0.0696 & 0.0004 & 0.6568 & 0.1954 & 0.892 & 0.014 & 0.895 & 0.010 & 0.915 & 0.011 & 100 & 97 \\
\hline DKE-45 & 11.1 & $\mathrm{R}$ & PMhml & 1.1447 & 0.0192 & 0.1222 & 0.0021 & 8.1859 & 0.1377 & 0.0683 & 0.0005 & 0.0688 & 0.0215 & 0.743 & 0.012 & 0.775 & 0.009 & 0.876 & 0.014 & 96 & 85 \\
\hline DKE-45 & 12.1 & $\mathrm{R}$ & PMoz & 1.2646 & 0.0208 & 0.1404 & 0.0023 & 7.1206 & 0.1182 & 0.0662 & 0.0003 & 0.3169 & 0.0914 & 0.847 & 0.013 & 0.830 & 0.009 & 0.809 & 0.011 & 102 & 105 \\
\hline DKE-45 & 13.1 & C & PMoz & 2302 & 0.0201 & 0.1360 & 0.0023 & 7.3553 & 0.1221 & 0.0665 & 0.0003 & 0.5301 & 0.1503 & 0.822 & 0.013 & 0.814 & 0.009 & 0.818 & 0.010 & 101 & 100 \\
\hline DKE-45 & 14.1 & $\mathrm{R}$ & PMoz & 3644 & 0.0229 & 0.1515 & 0.0025 & 6.6022 & 0.1097 & 0.0660 & 0.0004 & 0.2159 & 0.0603 & 0.909 & 0.014 & 0.874 & 0.010 & 0.803 & 0.013 & 104 & 113 \\
\hline DKE-45 & 15.1 & C & PMoz & 1.2237 & 0.0211 & 0.1367 & 0.0023 & 7.3137 & 0.1229 & 0.0659 & 0.0004 & 0.8721 & 0.2401 & 0.826 & 0.013 & 0.811 & 0.010 & 0.798 & 0.012 & 102 & 104 \\
\hline DKE-45 & 16.1 & C & PMoz & 3520 & 0.0223 & 0.1494 & 0.0025 & 6.6916 & 0.1115 & 0.0669 & 0.0004 & 0.3469 & 0.0941 & 0.898 & 0.014 & 0.868 & 0.010 & 0.831 & 0.011 & 103 & 108 \\
\hline DKE-45 & 17.1 & c & PMoz & 1.1431 & 0.0207 & 0.1278 & 0.0022 & 7.8219 & 0.1327 & 0.0653 & 0.0006 & 0.6963 & 0.1863 & 0.776 & 0.012 & 0.774 & 0.010 & 0.781 & 0.018 & 100 & 99 \\
\hline DKE-45 & 18.1 & c & PMoz & .5874 & 0.0278 & 0.1603 & 0.0026 & 6.2380 & 0.1028 & 0.0697 & 0.0005 & 0.1528 & 0.0403 & 0.958 & 0.015 & 0.965 & 0.011 & 0.917 & 0.014 & 99 & 105 \\
\hline DKE-45 & 18.2 & $\mathrm{R}$ & PMoz & 3551 & 0.0111 & 0.1465 & 0.0005 & 6.8243 & 0.0212 & 0.0683 & 0.0005 & 0.0144 & 0.0059 & 0.882 & 0.003 & 0.870 & 0.005 & 0.876 & 0.016 & & 101 \\
\hline DKE-45 & 19.1 & $\mathrm{R}$ & PMoz & 1.2314 & 0.0065 & 0.1351 & 0.0003 & 7.4024 & 0.0166 & 0.0669 & 0.0004 & 0.5194 & 0.1614 & 0.817 & 0.002 & 0.815 & 0.003 & 0.830 & 0.013 & 100 & 98 \\
\hline DKE-45 & 20.1 & C & PMoz & 257 & 0.0060 & 0.1375 & 0.0002 & 7.2709 & 0.0125 & 0.0657 & 0.0003 & 0.6201 & 0.1915 & 0.831 & 0.001 & 0.812 & 0.003 & 0.792 & 0.011 & 102 & 105 \\
\hline DKE-45 & 21.1 & C & PMoz & 166 & 0.0074 & 0.1539 & 0.0004 & 6.4958 & 0.0149 & 0.0675 & 0.0004 & 0.3330 & 0.1023 & 0.923 & 0.002 & 0.896 & 0.003 & 0.850 & 0.012 & 103 & 109 \\
\hline DKE-45 & 24.1 & C & PMoz & 063 & 0.0081 & 0.1357 & 0.0003 & 7.3666 & 0.0173 & 0.0650 & 0.0004 & 0.2350 & 0.0710 & 0.821 & 0.002 & 0.803 & 0.004 & 0.769 & 0.014 & 102 & 107 \\
\hline DKE-45 & 26.1 & $\mathrm{R}$ & PMoz & 177 & 0.0056 & 0.1172 & 0.0003 & 8.5332 & 0.0201 & 0.0639 & 0.0004 & 0.2339 & 0.0702 & 0.714 & 0.002 & 0.71 & 0.003 & 0.732 & 0.014 & & 98 \\
\hline DKE-45 & 27.1 & $\mathrm{R}$ & PMoz & 0081 & 0.0069 & 0.1154 & 0.0004 & 8.6682 & 0.0318 & 0.0643 & 0.0004 & 0.4231 & 0.1259 & 0.704 & 0.002 & 0.708 & 0.004 & 0.748 & 0.013 & 99 & 94 \\
\hline DKE-45 & 29.1 & C & PMhml & 5030 & 0.0144 & 0.1585 & 0.0007 & 6.3080 & 0.0275 & 0.0699 & 0.0007 & 0.4769 & 0.1407 & 0.949 & 0.004 & 0.932 & 0.006 & 0.925 & 0.020 & 102 & 103 \\
\hline DKE-45 & 30.1 & C & PMoz & 759 & & 0.1133 & 0.0019 & 8.8224 & 0.1507 & 0.0604 & 0.0008 & 0.2306 & 0.3230 & 0.692 & 0.011 & 0.6 & 0.013 & 0.613 & 0.027 & & 113 \\
\hline DKE-45 & 31.1 & C & PMhml & 2264 & 0.0285 & 0.1366 & 0.0022 & 7.3187 & 0.1201 & 0.0652 & 0.0005 & 0.8182 & 1.0458 & 0.826 & 0.013 & 0.813 & 0.013 & 0.777 & 0.017 & 102 & 106 \\
\hline DKE-45 & 33.1 & C & PMor & 3699 & 0.0309 & 0.1495 & 0.0024 & 6.6888 & 0.1089 & 0.0673 & 0.0005 & 1.0279 & 1.1187 & 0.898 & 0.014 & 0.876 & 0.013 & 0.842 & 0.015 & 103 & 107 \\
\hline DKE-45 & 34.1 & C & PN & 2867 & 0.0289 & 0.1412 & 0.0023 & 7.0799 & 0.1154 & 0.0669 & 0.0005 & 0.6438 & 0.6523 & 0.852 & 0.013 & 0.840 & 0.013 & 0.832 & 0.016 & 101 & 102 \\
\hline DKE-45 & 35.1 & $c$ & PMoz & 683 & 0.0287 & 0.1425 & 0.0023 & 7.0170 & 0.1152 & 0.0655 & 0.0005 & 1.8059 & 1.7113 & 0.859 & 0.013 & 0.832 & 0.013 & 0.786 & 0.015 & 103 & 109 \\
\hline DKE-45 & 36.1 & C & & 112 & 0.0281 & 0.1399 & 0.0023 & 7.1469 & 0.1155 & 0.0662 & 0.0005 & 2.1515 & 1.9313 & 0.844 & 0.013 & 0.828 & 0.013 & 0.808 & 0.015 & 10 & 104 \\
\hline DKE-45 & 37.1 & $\mathrm{C}$ & PMzc & 532 & 0.0312 & 0.1483 & 0.0024 & 6.7448 & 0.1100 & 0.0669 & 0.0005 & 0.9296 & 0.7801 & 0.891 & 0.014 & 0.869 & 0.013 & 0.832 & 0.016 & 103 & 107 \\
\hline DKE-45 & 38.1 & $\mathrm{R}$ & PI & 297 & 0.0232 & 0.1168 & 0.0019 & 8.5603 & 0.1391 & 0.0645 & 0.0005 & 1.4828 & 1.1770 & 0.712 & 0.011 & 0.719 & 0.012 & 0.754 & 0.016 & 99 & 94 \\
\hline DKE-45 & 39.1 & C & & & & 0.1 & & 6.8591 & 0.1118 & 665 & 7 & 0.9903 & & & 0.0 & 0.8 & 0.014 & 0.819 & $0 . c$ & 102 & 107 \\
\hline DKE-45 & 40.1 & $\mathrm{R}$ & PMoz & 158 & 0. & 0.1233 & 0020 & 8.1088 & 0.1324 & 0.0677 & 0.0006 & 1.1256 & 0.8063 & 0.750 & 0.012 & 0.775 & 0.012 & 0.857 & 0.019 & 97 & 87 \\
\hline DKE-45 & 42.1 & 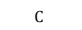 & & & & 01459 & & 6.8552 & C & 0.0668 & 0.0007 & 1.3753 & 0.9984 & 0.878 & 0.014 & 0.847 & 0.011 & 0.829 & 0.023 & . & 106 \\
\hline DKE-45 & 43.1 & C & & 1 & 0. & 0.1. & 0.0023 & 6.6029 & 04 & 657 & 0.0004 & 7468 & 1.2 & 0.909 & 0.01 & 0.8 & 0.009 & 0.792 & 0.011 & 104 & 115 \\
\hline DKE-45 & 44.1 & C & & & & & & & & 654 & & 9985 & & 0.866 & 0.012 & 0.8 & 0.009 & 0.78 & 0.014 & & 111 \\
\hline DKE-45 & 45.1 & $\mathrm{C}$ & & & & & & 6.9876 & & 0.0658 & 0.0003 & 2.7116 & 1.8 & 0.862 & 0.012 & 0.837 & 0.009 & 0.796 & 0.009 & 103 & 108 \\
\hline DKE-45 & 46.1 & C & & 34 & 0. & & 22 & 7.0540 & & 0.0657 & & 3.1432 & 2.1876 & 0.855 & 0.012 & 0.834 & 0.009 & 0.793 & 0.014 & & 108 \\
\hline DKE-45 & 47.1 & C & & & & & & 6.6771 & & & & 14 & 0.8 & 0.9 & 0.0 & 0.8 & 0.010 & 0.788 & 0.016 & 104 & 114 \\
\hline DKE-45 & 48.1 & C & & 08 & & 6 & & 8.5061 & & 643 & 003 & 1.8974 & 1. & 0.717 & 0.010 & 0.719 & 0.008 & 0.746 & 0.011 & 100 & 96 \\
\hline DKE-45 & 49.1 & C & & & & & & 66 & & 0.0657 & 0.0 & 1.2147 & & 0.886 & 0.013 & 0.853 & 0.011 & 0.794 & 0.020 & 104 & 112 \\
\hline DKE-45 & 50.1 & C & PMoz & 1.1315 & 0.0196 & 0.1217 & 0.0019 & 8.2173 & 0.1270 & 0.0676 & 0.0005 & 1.1587 & 0.7844 & 0.740 & 0.011 & 0.768 & 0.009 & 0.853 & 0.017 & 96 & 87 \\
\hline \multicolumn{22}{|c|}{ 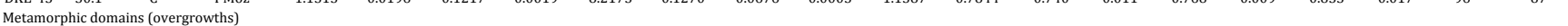 } \\
\hline DKE-45 & 5.1 & $\mathrm{R}$ & Mc & 8752 & 0.006 & 0.104 & 0.0007 & 9.6196 & 0.066 & 0.061 & 0.0002 & 0.0792 & 0.0 & 0.638 & 0.004 & 0.638 & 0.004 & 0.648 & 0.007 & 100 & 98 \\
\hline DKE-45 & 8.1 & $\mathrm{R}$ & $\mathrm{M}$ & 272 & & 0.0993 & 17 & 10.0733 & 0.1703 & 0.0608 & 0.0003 & 0073 & 0.0035 & 0.610 & 0.010 & 0.612 & 0.008 & 0.626 & 0.011 & 00 & 97 \\
\hline DKE- & $22.1 \mathrm{~B}$ & $\mathrm{R}$ & & & & 政 & & 9.46 & & 603 & & 0707 & & & & & & & 0.016 & & 06 \\
\hline DKE-45 & $23.1 \mathrm{~B}$ & R & & 0.8021 & 0. & 0. & & 10.2809 & 0. & & & 76 & 0. & 0. & 0.0 & 0.5 & 0. & 542 & 0.015 & 100 & 93 \\
\hline DKE-45 & 42.2 & $\mathrm{R}$ & Mog & 919 & 0.0137 & 0.0947 & 0.0015 & 10.5612 & 0.1675 & 0.0608 & 0.0004 & 0.1393 & 0.1017 & 0.583 & 0.009 & 0.592 & 0.008 & 0.626 & 0.015 & 98 & 93 \\
\hline DKE-4 & 28. & 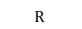 & Mos & & 0 & 0.1 & 000 & 9.43 & 04 & 0.0620 & 0.00 & 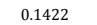 & 0.04 & 0.64 & 0.0 & 0.6 & 0.00 & 0.667 & 0.023 & 100 & 97 \\
\hline \multicolumn{22}{|c|}{ Zircons not included on rela } \\
\hline DKE-45 & 32.1 & $\mathrm{C}$ & $\mathrm{Mz} / \mathrm{Mez}$ & .9018 & 0.0202 & 1092 & 0.0018 & 1593 & 0.1484 & .0606 & 0.0004 & .0332 & 0.0391 & 0.668 & 0.010 & 0.653 & 0.011 & 0.618 & 0.015 & 106 & 109 \\
\hline
\end{tabular}




\begin{tabular}{|c|c|c|c|c|c|c|c|c|c|c|c|c|c|c|c|c|c|c|c|c|c|}
\hline Sample & Spot \# & Spot pos. & Interp. CL & ${ }^{207} \mathrm{~Pb} / /^{235} \mathrm{U}$ & $\pm 1 \mathrm{~s}$ & 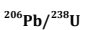 & $1 \mathrm{~s}$ & ${ }^{238} \mathrm{~Pb} / /^{206} \mathbf{U}$ & $\pm 1 \mathrm{~s}$ & ${ }^{7} \mathbf{P b} /{ }^{206} \mathbf{U}$ & $\pm 1 \mathrm{~s}$ & ${ }^{208} \mathrm{~Pb}$ b ${ }^{206} \mathrm{U}$ & $\pm 1 \mathrm{~s}$ & ${ }^{206} \mathbf{P b} \mathbf{2}{ }^{238} \mathbf{U}$ & $\pm 1 s$ & ${ }^{207} \mathbf{P b} /^{235} \mathbf{U}$ & $\pm 1 \mathrm{~s}$ & ${ }^{207} \mathbf{P b} / /^{206} \mathbf{U}$ & $\pm 1 \mathrm{~s}$ & Conc. (\%) & nc. \\
\hline DKE 43 & 1.1 & $\mathrm{C}$ & PMhml & 1.3165 & 0.0293 & 0.1438 & 0.0039 & 6.9529 & 0.1887 & 0.0690 & 0.0008 & 0.4714 & 0.2072 & 0.866 & 0.022 & 0.853 & 0.013 & 0.896 & 0.023 & 102 & 97 \\
\hline DKE 43 & 2.1 & C & PMhml & 1.1329 & 0.0251 & 0.1267 & 0.0032 & 7.8927 & 0.1993 & 0.0655 & 0.0007 & 0.3320 & 0.1484 & 0.769 & 0.018 & 0.769 & 0.012 & 0.785 & 0.023 & 100 & 98 \\
\hline DKE 43 & 3.1 & C & PMhml & 4.0272 & 0.0869 & 0.2841 & 0.0071 & 3.5202 & 0.0879 & 0.1054 & 0.0008 & 0.3360 & 0.1531 & 1.612 & 0.036 & 1.640 & 0.017 & 1.725 & 0.014 & 98 & 93 \\
\hline DKE 43 & 4.1 & c & PMoz & 11.3385 & 0.2285 & 0.4724 & 0.0117 & 2.1166 & 0.0522 & 0.1763 & 0.0006 & 0.4493 & 0.2085 & 2.494 & 0.051 & 2.551 & 0.019 & 2.619 & 0.006 & 98 & 95 \\
\hline DKE 43 & 5.1 & C & PMoz & 1.1367 & 0.0231 & 0.1251 & 0.0031 & 7.9943 & 0.1976 & 0.0668 & 0.0003 & 0.1344 & 0.0637 & 0.760 & 0.018 & 0.771 & 0.011 & 0.829 & 0.008 & 99 & 92 \\
\hline DKE 43 & 6.1 & C & PMoz & 0.8896 & 0.0182 & 0.1058 & 0.0026 & 9.4531 & 0.2356 & 0.0621 & 0.0002 & 0.1750 & 0.0848 & 0.648 & 0.015 & 0.646 & 0.010 & 0.672 & 0.009 & 100 & 97 \\
\hline DKE 43 & 9.1 & C & PMhml & 5.9773 & 0.1217 & 0.3575 & 0.0089 & 2.7971 & 0.0699 & 0.1234 & 0.0004 & 0.6563 & 0.3383 & 1.970 & 0.042 & 1.973 & 0.018 & 2.005 & 0.006 & 100 & 98 \\
\hline DKE 43 & 10.1 & C & PMoz & 10.0554 & 0.2046 & 0.4522 & 0.0113 & 2.2112 & 0.0553 & 0.1633 & 0.0005 & 0.2645 & 0.1394 & 2.405 & 0.050 & 2.440 & 0.019 & 2.488 & 0.005 & 99 & 97 \\
\hline DKE 43 & 11.1 & C & PMoz & 1.0881 & 0.0223 & 0.1201 & 0.0030 & 8.3247 & 0.2096 & 0.0662 & 0.0002 & 0.1140 & 0.0615 & 0.731 & 0.017 & 0.748 & 0.011 & 0.810 & 0.008 & 98 & 90 \\
\hline DKE 43 & 12.1 & c & PMoz & 1.0263 & 0.0213 & 0.1198 & 0.0030 & 8.3452 & 0.2101 & 0.0634 & 0.0003 & 0.2314 & 0.1278 & 0.730 & 0.017 & 0.717 & 0.011 & 0.715 & 0.010 & 102 & 102 \\
\hline DKE 43 & $14.2 \mathrm{~N}$ & C & PMoz & 1.2265 & 0.0163 & 0.1383 & 0.0013 & 7.2295 & 0.0661 & 0.0657 & 0.0003 & 0.4257 & 0.0837 & 0.835 & 0.007 & 0.813 & 0.007 & 0.792 & 0.011 & 103 & 105 \\
\hline DKE 43 & 15.1 & C & PMoz & 5.0199 & 0.0611 & 0.3258 & 0.0023 & 3.0695 & 0.0215 & 0.1130 & 0.0005 & 2.1140 & 0.4135 & 1.818 & 0.011 & 1.823 & 0.010 & 1.850 & 0.008 & 100 & 98 \\
\hline DKE 43 & 16.1 & C & PMoz & 1.1525 & 0.0135 & 0.1286 & 0.0008 & 7.7790 & 0.0483 & 0.0660 & 0.0003 & 0.4367 & 0.0850 & 0.780 & 0.005 & 0.778 & 0.006 & 0.801 & 0.008 & 100 & 97 \\
\hline DKE 43 & 17.1 & C & PMoz & 1.1487 & 0.0136 & 0.1288 & 0.0009 & 7.7659 & 0.0517 & 0.0656 & 0.0002 & 0.2931 & 0.0568 & 0.781 & 0.005 & 0.777 & 0.006 & 0.790 & 0.008 & 101 & 99 \\
\hline DKE 43 & 18.1 & C & PMoz & 0.9584 & 0.0121 & 0.1082 & 0.0008 & 9.2387 & 0.0681 & 0.0654 & 0.0004 & 0.3687 & 0.0713 & 0.663 & 0.005 & 0.682 & 0.006 & 0.784 & 0.015 & 97 & 85 \\
\hline DKE 43 & 19.1 & C & PMcz & 1.0087 & 0.0117 & 0.1181 & 0.0008 & 8.4689 & 0.0559 & 0.0629 & 0.0003 & 0.3050 & 0.0587 & 0.720 & 0.004 & 0.708 & 0.006 & 0.698 & 0.009 & 102 & 103 \\
\hline DKE 43 & 20.1 & C & PMhll & $\begin{array}{l}1.7465 \\
\end{array}$ & 0.0197 & 0.1723 & 0.0010 & 5.8044 & 0.0349 & 0.0742 & 0.0003 & 0.3500 & 0.0669 & $\begin{array}{l}1.025 \\
\end{array}$ & 0.006 & 1.026 & 0.007 & $\begin{array}{l}1.049 \\
\end{array}$ & 0.007 & 100 & 98 \\
\hline DKE 43 & 22.1 & $\mathrm{R}$ & PMoz & 1.0639 & 0.0124 & 0.1212 & 0.0008 & 8.2486 & 0.0530 & 0.0645 & 0.0003 & 0.1888 & 0.0358 & 0.738 & 0.004 & 0.736 & 0.006 & 0.755 & 0.009 & 100 & 98 \\
\hline DKE 43 & $23.2 \mathrm{~N}$ & C & PMoz & 0.9214 & 0.0109 & 0.1093 & 0.0007 & 9.1466 & 0.0565 & 0.0618 & 0.0003 & 0.3266 & 0.0616 & 0.669 & 0.004 & 0.663 & 0.006 & 0.663 & 0.011 & 101 & 101 \\
\hline DKE 43 & 24.1 & C & PMhml & 6.5430 & 0.0738 & 0.3787 & 0.0023 & 2.6403 & 0.0157 & 0.1269 & 0.0005 & 0.5230 & 0.0979 & 2.070 & 0.011 & 2.052 & 0.010 & 2.054 & 0.006 & 01 & 101 \\
\hline DKE 43 & $24.2 \mathrm{~B}$ & $\mathrm{R}$ & PMhhl & 5.4399 & 0.0562 & 0.3389 & 0.0039 & 2.9506 & 0.0339 & 0.1174 & 0.0005 & 0.6414 & 0.0864 & 1.881 & 0.019 & 1.891 & 0.009 & 1.918 & 0.008 & 99 & 98 \\
\hline DKE 43 & 25.1 & C & PMoz & 1.2760 & 0.0161 & 0.1426 & 0.0018 & 7.0121 & 0.0868 & 0.0656 & 0.0004 & 0.3001 & 0.0406 & 0.859 & 010 & 0.835 & 0.007 & 0.791 & 0.013 & - & 109 \\
\hline DKE 43 & 26.1 & C & PMhhl & 1.2507 & 0.0134 & 0.1390 & 0.0018 & 7.1950 & 0.0930 & 0.0646 & 0.0006 & 0.3036 & 0.0417 & 0.839 & 0.010 & 0.824 & 0.006 & 0.758 & 0.020 & 02 & 111 \\
\hline DKE 43 & $28.2 \mathrm{~N}$ & C & PMCZ & 1.0949 & 0.0132 & 0.1231 & 0.0015 & 8.1234 & 0.0962 & 0.0650 & 0.0004 & 0.3556 & 0.0481 & 0.748 & 0.008 & 0.751 & 0.006 & 0.770 & 0.012 & 100 & 97 \\
\hline DKE 43 & $28.1 \mathrm{~B}$ & $\mathrm{R}$ & PMoz & 1.0847 & 0.0111 & 0.1214 & 0.0014 & 8.2354 & 0.0944 & 0.0651 & 0.0003 & 0.2751 & 0372 & 0.7 & 00 & . & 0.005 & 0.774 & 0.010 & & 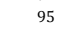 \\
\hline DKE 43 & 29.1 & $\mathrm{R}$ & PMoz & 1.2375 & 0.0121 & 0.1372 & 0.0016 & 7.2865 & 0.0830 & 0.0661 & 0.0003 & 0.0707 & 0.0097 & 0.829 & 0.009 & 0.818 & 0.005 & 0.804 & 0.008 & 101 & 103 \\
\hline DKE 43 & 30.1 & C & PMoz & 0.9659 & 0.0116 & 0.1105 & 0.0015 & 9.0526 & 0.1192 & 0.0639 & 0.0003 & 0.1999 & 0.0271 & 0.675 & 0.008 & 0.686 & 0.006 & 0.733 & 0.009 & 98 & 92 \\
\hline DKE 43 & 31.1 & C & PMhml & 5.7240 & 0.0581 & 0.3449 & 0.0040 & 2.8997 & 0.0335 & 0.1213 & 0.0005 & 0.5070 & 0.0689 & 1.910 & 0.019 & 1.935 & 0.009 & 1.974 & 0.007 & 99 & 97 \\
\hline DKE 43 & 32.1 & C & PMhml & 6.2108 & 0.0757 & 0.3605 & 0.0045 & 2.7742 & 0.0346 & 0.1262 & 0.0006 & 0.3365 & 0.0460 & 1.984 & 0.021 & 2.006 & 0.011 & 2.044 & 0.009 & 99 & 97 \\
\hline DKE 43 & 33.1 & $\mathrm{R}$ & PMoz & 1.5268 & 0.0154 & 0.1568 & 0.0018 & 6.3785 & 0.0746 & 0.0713 & 0.0003 & 0.3117 & 0.0424 & 0.93 & 010 & 0.941 & 006 & 0.964 & 0.009 & 100 & 97 \\
\hline DKE 43 & 34.1 & C & PMoz & 1.2533 & 0.0129 & 0.1361 & 0.0016 & 7.3477 & 0.0855 & 0.0666 & 0.0003 & 0.7382 & 0.1009 & 0.823 & 0.009 & 0.825 & 0.006 & 0.822 & 0.009 & 100 & 100 \\
\hline DKE 43 & 35.1 & C & PMhml & 1.0129 & 0.0105 & 0.1166 & 0.0014 & 8.5783 & 0.1009 & 0.0636 & 0.0003 & 0.0673 & 0.0094 & 0.711 & 0.008 & 0.710 & 0.005 & 0.723 & 0.009 & 100 & 98 \\
\hline DKE 43 & 36.1 & C & PMg & 9.3926 & 0.2183 & 0.4264 & 0.0104 & 2.3452 & 0.0572 & 0.1611 & 0.0002 & 0.4574 & 0737 & 2.290 & 0.047 & 2. & & 2.464 & 0.002 & 96 & 93 \\
\hline DKE 43 & 37.1 & c & PMoz & 1.0286 & 0.0245 & 0.1183 & 0.0029 & 8.4534 & 0.2081 & 0.0640 & 0.0003 & 0.1596 & 0.0258 & 0.721 & .017 & 0.718 & .012 & 0.736 & 0.009 & 100 & 98 \\
\hline DKE 43 & 38.1 & C & PMoz & 0.9372 & 0.0225 & 0.1103 & 0.0028 & 9.0621 & 0.2262 & 0.0622 & 0.0001 & 0.5933 & 0.0961 & 0.675 & 0.016 & 0.671 & 0.012 & 0.676 & 0.004 & 100 & 100 \\
\hline DKE 43 & 39.1 & $\rho$ & & 52 & 0.0222 & 0.1108 & 0.0027 & 9.0277 & 0. & 0.0629 & 0.0002 & 1.2896 & 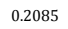 & 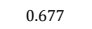 & 16 & 89 & 11 & 0.700 & 0.006 & & 97 \\
\hline DKE 43 & 40.1 & C & PMhml & 1.1375 & 0.0267 & 0.1280 & 0.0032 & 7.8112 & 0.1924 & 0.0657 & 0.0004 & 0.5686 & 0.0922 & 0.777 & 0.018 & 0.771 & 0.013 & 0.792 & 0.012 & 101 & 98 \\
\hline DKE 43 & 41.1 & C & DMA & 10485 & 0.0243 & 0.1184 & 00029 & 8.4434 & 0.2040 & 0.0649 & 0.0002 & 0.1854 & 0.0301 & 0.722 & 0.016 & 0.728 & 0.012 & 0.767 & 0.006 & 99 & 94 \\
\hline DKE 43 & $42.2 \mathrm{~N}$ & 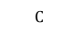 & & 0.9237 & c & 0.1089 & 0.002 & 9.1810 & & 0.0632 & 0005 & 0.2060 & & 0.6 & 15 & 0.66 & .01 & 0.71 & 0.016 & & 94 \\
\hline DKE 43 & 43.1 & C & $\mathrm{P}$ & 1.1647 & 0.0284 & 0.1304 & 0.0033 & 7.6658 & 0.1919 & 0.0650 & 0.0003 & 0.2916 & 0.0477 & 0.790 & 0.019 & 0.784 & 0.013 & 0.768 & 0.009 & 101 & 103 \\
\hline DKE 43 & 59.1 & 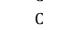 & & . & 0.0837 & 0.2851 & 0.0050 & 3.5079 & 0.0613 & 0.1036 & 0.0006 & 0.1885 & 0.0898 & 1.617 & 0.025 & 1.604 & 0.017 & 1.693 & 0.010 & 101 & 95 \\
\hline DKE 43 & 45.1 & c & PMhll & 9.8090 & 0.2241 & 0.4496 & 0.0107 & 2.2242 & 0.0531 & 0.1607 & 0.0002 & 0.1898 & 0.0310 & 2.393 & 0.048 & 2.417 & 0.021 & 2.460 & 0.003 & 99 & 97 \\
\hline DKE 43 & 46.1 & $\mathrm{R}$ & & 1.0558 & 0.0241 & 0.1203 & 0.0029 & 8.3149 & 0.1984 & 0.0643 & 0.0002 & 0.1951 & 00319 & 0.732 & 0.016 & 0.732 & 0.012 & 0.748 & 0.006 & 100 & 98 \\
\hline DKE 43 & 47.1 & C & PMoz & 1.0873 & 0.0250 & 0.1230 & 0.0030 & 8.1323 & 0.1955 & 0.0643 & 0.0001 & 0.1051 & 0.0172 & 0.748 & 017 & 0.747 & 012 & 0.745 & 0.004 & 00 & 100 \\
\hline DKE 43 & 48.1 & c & PMoz & 1.0941 & 0.0243 & 0.1253 & 0.0023 & 7.9840 & 0 & 0.0640 & 0.0003 & 0.4468 & 1707 & 0.761 & 13 & 751 & 112 & 0.737 & 0.010 & 1 & 103 \\
\hline DKE 43 & 49.1 & $\mathrm{R}$ & & & 0.0245 & & 0.0 & 7.9302 & 0.1410 & 0.0 & 0. & 0. & 0 & 0 & 013 & 761 & 12 & 0.762 & 0.011 & 01 & 101 \\
\hline DKE 43 & 51.1 & c & & 92 & c & 82 & 0. & 9. & 0. & 0. & & & & & & 0.662 & 011 & 0.681 & 11 & & 97 \\
\hline DKE 43 & 52.1 & c & & & & & & & & & & & 58 & & & & & 0 & 0.010 & & 100 \\
\hline DKE 43 & 53.1 & $c$ & & & 0 & & 0 & 7.1 & 0 & & 04 & 0. & 93 & 848 & 15 & 37 & 13 & 0.798 & 0.014 & 11 & 106 \\
\hline DKE 43 & 55.1 & c & & & & & & & & & & & & & & & & & & & 100 \\
\hline DKE 43 & 56.1 & c & & & & & & 7. & & & & & & & & 20 & & 69 & 0.011 & 99 & 93 \\
\hline DKE 43 & 57.1 & 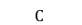 & PI & 64 & 0 & 95 & 24 & 7.1695 & 0.1248 & 0.0675 & 04 & 0. & 0.1880 & 0.842 & 14 & 844 & 012 & 0.849 & 0.011 & 100 & 99 \\
\hline DKE 43 & 58.1 & c & PM & & & & & & & & & & & & & 408 & & 2.447 & & & 97 \\
\hline DKE 43 & 44.1 & & & 0.83 & 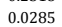 & 5 & 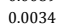 & 9.7062 & .32 & 0.0627 & & & 0113 & 0 & 0.020 & 18 & 16 & 2 & .027 & 02 & 91 \\
\hline \multicolumn{22}{|c|}{ Zircons not included on related diagrams } \\
\hline DKE 43 & 7.1 & $\mathrm{c}$ & PMoz & & & & & 9 & & & & & & $\sigma_{0}$ & & 0.669 & 10 & 0.7 & 08 & 99 & 88 \\
\hline DKE 43 & 8.1 & c & $\mathrm{P}$ & 8.4566 & 0.17 & 0.3883 & 0.00 & 2.5755 & 0.0641 & 0.1 & 0. & 0.3907 & 0.1970 & 2 & 0 & 2.281 & 018 & 2.448 & 0.005 & 93 & 86 \\
\hline DK & 13.1 & C & PM & 10.8753 & & & & 2.2580 & 0.0571 & & & & & & & & 19 & 2.664 & 0.006 & 94 & 89 \\
\hline & 21.1 & $c^{\circ}$ & & & & & & & & & & & & & & & & 0.629 & 0.011 & 0 & ( \\
\hline DKE 43 & $42.1 \mathrm{~B}$ & $\mathrm{R}$ & Mo & 0.7308 & 0.0182 & 0.0894 & 0.0022 & 11.1888 & 0.2741 & 0.0606 & 0.0005 & 0.0041 & 0.0030 & 0.552 & 0.013 & 0.557 & 0.011 & 0.620 & 0.017 & 99 & 89 \\
\hline & $50.1 \mathrm{~B}$ & $\mathrm{R}$ & 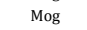 & & c & 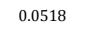 & & & 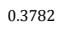 & & & & & & & & & 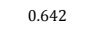 & 15 & 90 & 51 \\
\hline DKE 43 & 54.1 & ${ }^{C}$ & PM & & & 0.0929 & & 10.7652 & & & & 0.1723 & & 0.573 & 0.010 & 0.616 & 0.013 & 0.760 & 0.033 & 93 & 75 \\
\hline DKE 43 & 14.1B & $\mathrm{R}$ & $\mathbb{N}$ & 0.6684 & .0147 & 0.0780 & 0.0016 & 12.8124 & 0.2580 & 0.0622 & 0.0005 & 0.0318 & 0.0075 & 0.484 & 0.009 & 0.520 & 0.009 & 0.675 & 0.018 & 93 & 72 \\
\hline - & 77 & 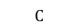 & PMoz & 1.0131 & 06 & 1226 & 0.0015 & 8.1561 & 0.0994 & .0610 & 0.0004 & .3215 & 0442 & 746 & 0.009 & 710 & 0.005 & .635 & 0.015 & 105 & 118 \\
\hline
\end{tabular}




\begin{tabular}{|c|c|c|c|c|c|c|c|c|c|c|c|c|c|c|c|c|c|c|c|c|c|}
\hline Sample & Spot \# & Spot pos. & Interp. CL & ${ }^{207} \mathbf{P b} /{ }^{235} \mathbf{U}$ & $\pm 1 \mathrm{~s}$ & ${ }^{206} \mathrm{~Pb} /{ }^{238} \mathrm{U}$ & $\pm 1 \mathrm{~s}$ & ${ }^{238} \mathbf{P b} /{ }^{206} \mathrm{U}$ & $\pm 1 \mathrm{~s}$ & ${ }^{207} \mathrm{~Pb} /{ }^{206} \mathrm{U}$ & $\pm 1 \mathrm{~s}$ & ${ }^{208} \mathrm{~Pb} /{ }^{206} \mathrm{U}$ & $\pm 1 \mathrm{~s}$ & ${ }^{206} \mathrm{~Pb} /{ }^{238} \mathrm{U}$ & $\pm 1 \mathrm{~s}$ & ${ }^{207} \mathrm{~Pb} /{ }^{235} \mathbf{U}$ & $\pm 1 \mathrm{~s}$ & ${ }^{207} \mathrm{~Pb} /{ }^{206} \mathbf{U}$ & $\pm 1 \mathrm{~s}$ & Conc. (\%)* & onc. (\%)* \\
\hline DKE-19 & 1.1 & $\mathrm{C}$ & PMoz & 6.1047 & 0.1000 & 0.3574 & 0.0044 & 2.7979 & 0.0344 & 0.1247 & 0.0009 & 0.5132 & 0.3111 & 1.970 & 0.021 & 1.991 & 0.014 & 2.023 & 0.012 & 99 & 97 \\
\hline DKE-19 & 2.1 & C & PMhll & 5.3999 & 0.0885 & 0.3301 & 0.0041 & 3.0295 & 0.0372 & 0.1199 & 0.0008 & 0.4622 & 0.2690 & 1.839 & 0.020 & 1.885 & 0.014 & 1.955 & 0.012 & 98 & 94 \\
\hline DKE-19 & 3.1 & C & PMcz & 3.3006 & 0.0544 & 0.2510 & 0.0031 & 3.9843 & 0.0492 & 0.0963 & 0.0007 & 0.2012 & 0.1126 & 1.444 & 0.016 & 1.481 & 0.013 & 1.560 & 0.013 & 97 & 93 \\
\hline DKE-19 & 4.1 & C & PMoz & 2.2962 & 0.0380 & 0.2037 & 0.0025 & 4.9083 & 0.0607 & 0.0826 & 0.0006 & 0.7501 & 0.4043 & 1.195 & 0.013 & 1.211 & 0.012 & 1.266 & 0.014 & 99 & 94 \\
\hline DKE-19 & 5.1 & c & PMoz & 6.7065 & 0.1101 & 0.3662 & 0.0045 & 2.7308 & 0.0336 & 0.1341 & 0.0010 & 0.1346 & 0.0700 & 2.011 & 0.021 & 2.073 & 0.014 & 2.149 & 0.012 & 97 & 94 \\
\hline DKE-19 & 7.1 & C & PMoz & 5.0059 & 0.0826 & 0.3150 & 0.0039 & 3.1745 & 0.0392 & 0.1162 & 0.0008 & 0.7460 & 0.3635 & 1.765 & 0.019 & 1.820 & 0.014 & 1.899 & 0.013 & 97 & 93 \\
\hline DKE-19 & 8.1 & $\mathrm{C}$ & PMoz & 5.4497 & 0.0904 & 0.3321 & 0.0041 & 3.0114 & 0.0376 & 0.1207 & 0.0009 & 2.3005 & 1.0800 & 1.848 & 0.020 & 1.893 & 0.014 & 1.967 & 0.013 & 98 & 94 \\
\hline DKE-19 & 9.1 & C & PMhml & 5.1493 & 0.0846 & 0.3321 & 0.0041 & 3.0109 & 0.0372 & 0.1144 & 0.0008 & 1.5002 & 0.6822 & 1.849 & 0.020 & 1.844 & 0.014 & 1.873 & 0.012 & 100 & 99 \\
\hline DKE-19 & 10.1 & C & PMhll & 2.6891 & 0.0441 & 0.2256 & 0.0028 & 4.4335 & 0.0545 & 0.0873 & 0.0006 & 0.2350 & 0.1036 & 1.311 & 0.015 & 1.325 & 0.012 & 1.373 & 0.014 & 99 & 95 \\
\hline DKE-19 & 12.1 & C & PMoz & 2.1773 & 0.0361 & 0.1993 & 0.0025 & 5.0177 & 0.0625 & 0.0804 & 0.0006 & 0.2578 & 0.1072 & 1.172 & 0.013 & 1.174 & 0.011 & 1.210 & 0.015 & 100 & 97 \\
\hline DKE-19 & 13.1 & C & PMoz & 2.2617 & 0.0372 & 0.1986 & 0.0024 & 5.0362 & 0.0621 & 0.0839 & 0.0006 & 0.1836 & 0.0742 & 1.168 & 0.013 & 1.200 & 0.012 & 1.295 & 0.014 & 97 & 90 \\
\hline DKE-19 & 14.1 & C & PMoz & 6.5989 & 0.1063 & 0.3757 & 0.0047 & 2.6616 & 0.0331 & 0.1290 & 0.0008 & 0.5491 & 0.2405 & 2.056 & 0.022 & 2.059 & 0.014 & 2.082 & 0.011 & 100 & 99 \\
\hline DKE-19 & 16.1 & C & PMoz & 2.0560 & 0.0331 & 0.1873 & 0.0023 & 5.3404 & 0.0663 & 0.0806 & 0.0005 & 0.2687 & 0.1222 & 1.106 & 0.013 & 1.134 & 0.011 & 1.216 & 0.013 & 98 & 91 \\
\hline DKE-19 & 17.1 & C & PMoz & 3.2661 & 0.0524 & 0.2524 & 0.0031 & 3.9613 & 0.0490 & 0.0948 & 0.0006 & 0.1839 & 0.0853 & 1.451 & 0.016 & $\begin{array}{l}1.473 \\
1.473\end{array}$ & $\begin{array}{l}0.011 \\
0.012\end{array}$ & $\begin{array}{l}1.531 \\
1.531\end{array}$ & $\begin{array}{l}0.012 \\
0.012\end{array}$ & $\begin{array}{l}30 \\
99\end{array}$ & 95 \\
\hline DKE-19 & 18.1 & C & PMoz & 3.2491 & 0.0521 & 0.2483 & 0.0031 & 4.0270 & 0.0498 & 0.0958 & 0.0006 & 0.2964 & 0.1401 & 1.430 & 0.016 & 1.469 & 0.012 & 1.549 & 0.012 & 97 & 92 \\
\hline DKE-19 & 19.1 & C & PMoz & 1.5327 & 0.0264 & 0.1594 & 0.0021 & 6.2718 & 0.0833 & 0.0712 & 0.0005 & 1.1278 & 0.5440 & 0.954 & 0.012 & 0.944 & 0.011 & 0.963 & 0.016 & 101 & 99 \\
\hline DKE-19 & 20.1 & C & PMoz & 2.3451 & 0.0379 & 0.2039 & 0.0026 & 4.9039 & 0.0615 & 0.0847 & 0.0005 & 0.3161 & 0.1551 & 1.196 & 0.014 & 1.226 & 0.011 & 1.314 & 0.012 & 98 & 91 \\
\hline DKE-19 & 21.1 & C & PMoz & 4.7827 & 0.0771 & 0.3101 & 0.0039 & 3.2247 & 0.0402 & 0.1134 & 0.0007 & 0.3911 & 0.1966 & 1.741 & 0.019 & 1.782 & 0.013 & 1.856 & 0.011 & 98 & 94 \\
\hline DKE-19 & 22.1 & C & PMoz & 2.2151 & 0.0359 & 0.2004 & 0.0025 & 4.9912 & 0.0620 & 0.0813 & 0.0005 & 0.2286 & 0.1174 & 1.177 & 0.013 & 1.186 & 0.011 & 1.232 & 0.013 & 99 & 96 \\
\hline DKE-19 & 23.1 & C & PMhhl & 4.3562 & 0.0723 & 0.3000 & 0.0040 & 3.3339 & 0.0444 & 0.1070 & 0.0009 & 0.2863 & 0.1505 & 1.691 & 0.020 & 1.704 & 0.014 & $\begin{array}{l}1.252 \\
1.752\end{array}$ & 0.014 & 99 & 97 \\
\hline DKE-19 & 24.1 & C & PMoz & 2.1722 & 0.0350 & 0.1989 & 0.0025 & 5.0284 & 0.0624 & 0.0805 & 0.0005 & 0.1870 & 0.1004 & 1.169 & 0.013 & 1.172 & 0.011 & 1.213 & 0.013 & 100 & 96 \\
\hline DKE-19 & 25.1 & C & PMoz & 3.3103 & 0.0531 & 0.2566 & 0.0032 & 3.8972 & 0.0482 & 0.0950 & 0.0006 & 0.0784 & 0.0431 & 1.472 & 0.016 & 1.483 & 0.012 & 1.534 & 0.012 & & 96 \\
\hline $\begin{array}{l}\text { DKE-19 } \\
\text { D }\end{array}$ & 27.1 & c & $\begin{array}{l}\text { PMoz } \\
\text { Pons }\end{array}$ & 1.6104 & 0.0132 & 0.1608 & 0.0011 & $\begin{array}{l}6.2172 \\
6\end{array}$ & 0.0440 & 0.0735 & 0.0003 & 0.2980 & 0.1729 & 0.961 & 0.006 & 0.974 & 0.005 & $\begin{array}{l}1.029 \\
1.029\end{array}$ & 0.009 & 99 & 93 \\
\hline DKE-19 & 28.1 & $\mathrm{C}$ & PMoz & 2.1823 & 0.0175 & 0.1977 & 0.0014 & 5.0579 & 0.0355 & 0.0810 & 0.0003 & 0.3183 & 0.1750 & 1.163 & 0.007 & 1.175 & 0.006 & 1.227 & 0.008 & 99 & 95 \\
\hline DKE-19 & 29.1 & C & PMoz & 1.8163 & 0.0167 & 0.1726 & 0.0014 & 5.7929 & 0.0474 & 0.0769 & 0.0004 & 0.2245 & 0.1174 & 1.027 & 0.008 & 1.051 & 0.006 & 1.122 & 0.010 & 98 & 92 \\
\hline $\begin{array}{l}\text { DKE-19 } \\
\text { D }\end{array}$ & 30.1 & C & $\begin{array}{l}\text { PMoz } \\
\text { Pons }\end{array}$ & 5.5520 & 0.0453 & 0.3333 & 0.0025 & 3.0007 & 0.0227 & 0.1220 & 0.0006 & 0.4102 & 0.2041 & $\begin{array}{l}1.854 \\
\end{array}$ & 0.012 & $\begin{array}{l}1.909 \\
1.909\end{array}$ & 0.007 & 1.985 & 0.008 & 97 & 93 \\
\hline DKE-19 & 31.1 & $\mathrm{R}$ & PMoz & 4.5651 & 0.0365 & 0.3056 & 0.0022 & 3.2726 & 0.0235 & 0.1099 & 0.0005 & 0.9102 & 0.4321 & 1.719 & 0.011 & 1.743 & 0.007 & 1.801 & 0.007 & 99 & 95 \\
\hline DKE-19 & 33.1 & C & PMoz & 4.7841 & 0.0397 & 0.3081 & 0.0023 & 3.2453 & 0.0239 & 0.1152 & 0.0005 & 1.4057 & 0.6154 & 1.732 & 0.011 & 1.782 & 0.007 & 1.884 & 0.008 & 97 & 92 \\
\hline $\begin{array}{l}\text { DKE-19 } \\
\text { D }\end{array}$ & $\begin{array}{l}35.1 \\
34.1\end{array}$ & c & PMoz & 4.3473 & 0.0335 & 0.2931 & 0.0020 & $\begin{array}{l}3.4725 \\
3.4122\end{array}$ & 0.0236 & 0.1083 & 0.0004 & 0.6942 & 0.2901 & $\begin{array}{l}1.657 \\
\end{array}$ & 0.010 & $\begin{array}{l}1.702 \\
1.72\end{array}$ & 0.006 & $\begin{array}{l}1.775 \\
1.775\end{array}$ & 0.007 & 97 & 93 \\
\hline DKE-19 & 37.1 & C & PMoz & 6.9645 & 0.0551 & 0.3735 & 0.0027 & 2.6777 & 0.0191 & 0.1367 & 0.0005 & 0.3467 & 0.1294 & 2.046 & 0.013 & 2.107 & 0.007 & 2.182 & 0.006 & 97 & 94 \\
\hline DKE-19 & 38.1 & c & PMoz & 3.0539 & 0.0242 & 0.2359 & 0.0017 & 4.2382 & 0.0305 & 0.0946 & 0.0004 & 0.2683 & 0.0967 & 1.3 & 0.0 & 1.42 & 0.006 & 1.526 & 0.008 & 96 & 0 \\
\hline $\begin{array}{l}\text { DKE-19 } \\
\text { D }\end{array}$ & $\begin{array}{l}30.1 \\
39.1\end{array}$ & c & $\begin{array}{l}\text { PMoz } \\
\text { Pons }\end{array}$ & $\begin{array}{l}1.6226 \\
\end{array}$ & 0.0136 & $\begin{array}{l}0.1630 \\
0\end{array}$ & 0.0012 & 6.1350 & 0.0460 & 0.0724 & 0.0003 & 0.5609 & 0.1954 & 0.973 & 0.007 & $\begin{array}{l}0.979 \\
0\end{array}$ & 0.005 & 0.996 & 0.009 & 99 & 98 \\
\hline DKE-19 & 40.1 & C & PMoz & 14.4862 & 0.1392 & 0.5066 & 0.0070 & 1.9738 & 0.0274 & 0.2109 & 0.0015 & 0.4917 & 0.3253 & 2.642 & 0.030 & 2.782 & 0.009 & 2.919 & 0.012 & 95 & 91 \\
\hline DKE-19 & 41.1 & c & PMoz & 1.4078 & 0.0174 & 0.1503 & 0.0024 & 6.6523 & 0.1058 & 0.0705 & 0.0010 & 1.1808 & 0.7628 & 0.903 & 0.0 & 0.892 & 0.007 & 0.942 & 0.028 & 101 & 96 \\
\hline DKE-19 & 43.1 & C & PMoz & 5.3967 & 0.0508 & 0.3253 & 0.0045 & 3.0744 & 0.0427 & 0.1217 & 0.0009 & 0.5853 & 0.3583 & 1.815 & 0.022 & 1.884 & 0.008 & 1.981 & 0.013 & 96 & 92 \\
\hline DKE-19 & 46.1 & C & PMcz & 14.4760 & 0.1394 & 0.5162 & 0.0073 & 1.9372 & 0.0274 & 0.2064 & 0.0015 & 0.8566 & 0.4894 & 2.683 & 0.031 & 2.781 & 0.009 & 2.883 & 0.012 & 96 & 93 \\
\hline DKE-19 & 47.8 & c & PMhml & 9.9408 & 0.0939 & 0.4411 & 0.0061 & 2.2668 & 0.0316 & 0.1653 & 0.0012 & 0.3733 & 0.2078 & 2.356 & 0.0 & 2.42 & 0.009 & 2.508 & 0.012 & & 94 \\
\hline $\begin{array}{l}\text { DKE-19 } \\
\text { D }\end{array}$ & 48.8 & c & PMoz & 1.5708 & 0.0161 & 0.1567 & 0.0022 & $\begin{array}{l}6.3799 \\
6\end{array}$ & 0.0907 & 0.0735 & 0.0005 & 0.2653 & 0.1444 & 0.939 & 0.0 & 0.959 & 0.006 & $\begin{array}{l}1.029 \\
\end{array}$ & 0.015 & 98 & 91 \\
\hline DKE-19 & 49.1 & C & PMoz & 5.8437 & 52 & 0.3346 & 0.0047 & 2.9888 & 0.0419 & 0.1280 & 0.0009 & 0.8536 & 0.4545 & 1.861 & 0.023 & 1.953 & 0.008 & 2.068 & 0.013 & 95 & 90 \\
\hline DKE-19 & 50.1 & C & PMoz & 2.4120 & 0.0235 & 0.2084 & 0.0029 & 4.7984 & 0.0675 & 0.0849 & 0.0006 & 0.7025 & 0.3661 & 1.220 & 0.016 & 1.246 & 0.007 & 1.318 & 0.014 & 98 & 93 \\
\hline DKE-19 & 52.1 & 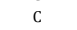 & PMoz & 2.0991 & 0.0198 & 0.1895 & 0.0027 & 5.2770 & 0.0739 & 0.0813 & 0.0006 & 0.3542 & 0.1771 & 1.1 & 0.0 & 1.14 & 0.00 & 1.232 & 0.014 & 97 & 91 \\
\hline \multicolumn{22}{|c|}{ Metamorphic domains (overgrowths) } \\
\hline DKE-19 & $32.1 \mathrm{~B}$ & $\mathrm{R}$ & Mog & 0.8116 & 0.0080 & 0.098 & 0.0009 & 10.1813 & 0.0914 & 0.060 & 0.0004 & 0.030 & 0.0173 & 0.6 & 0.00 & 0.6 & 0.004 & 617 & 0.014 & 10 & 90 \\
\hline \multicolumn{22}{|c|}{ Zircons not included on related diagrams } \\
\hline DKE-19 & 6.1 & C & PMoz & 4.6723 & 0.0770 & 02740 & 0.0034 & 3.6387 & .0452 & 0.1242 & 0.00 & 0.20 & 0.1052 & 1.565 & 0.0 & 1.762 & 0.014 & 2.016 & 0.012 & 89 & 78 \\
\hline DKE-19 & 11.1 & $\mathrm{c}$ & PMoz & 5.5435 & 0.0907 & 0.3228 & 0.0040 & 3.0976 & 0.0380 & 0.1264 & 0.0009 & 0.3095 & 0.1325 & 1.804 & 0.0 & $1.9 \mathrm{c}$ & 0.014 & .046 & 0.012 & 95 & 38 \\
\hline DKE-19 & 15.1 & c & $\mathrm{Pl}$ & 2.1040 & 0.0363 & 0.1880 & 0.0 & 5.3203 & 0.0692 & 0.0820 & 0.0008 & 0. & 0.1821 & 1.110 & 0.013 & 1.150 & 0.012 & 1.249 & 0.019 & 97 & 89 \\
\hline DKE-19 & 26.1 & c & PMcz & 1.4847 & 0.0248 & 0.1486 & 0.0019 & 6.7289 & 0.0846 & 0.0732 & 0.0005 & 0.3742 & 0.2103 & 0.893 & 0.010 & 0.924 & 0.010 & 1.021 & 0.015 & 97 & 88 \\
\hline DKE-19 & 35.1 & C & PMoz & 1.4806 & 0.0191 & 0.1498 & 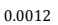 & 6.6738 & 0.0551 & 0.0733 & 0.0007 & 0.5617 & 0.2259 & 0.900 & 0.0 & 0.922 & 0.008 & 022 & 020 & 98 & 38 \\
\hline DKE-19 & $36.1 \mathrm{~B}$ & $\mathrm{R}$ & Mo & & & & & & 0.0791 & & & & 0.0112 & 0.568 & & 0.585 & 0.004 & 0.668 & 0.009 & 97 & 85 \\
\hline DKE-19 & $42.1 \mathrm{~B}$ & $\mathrm{R}$ & Mog & 0.7240 & 0.0072 & 0.0871 & 0.0012 & 11.4745 & 0.1631 & 0.0608 & 0.0005 & 0.0182 & 0.0117 & 0.539 & 0.007 & 0.553 & 0.004 & 0.626 & 0.016 & 97 & 86 \\
\hline DKE-19 & $44.1 \mathrm{~B}$ & $\mathrm{R}$ & Mog & 0.9804 & 0.0102 & 0.0981 & 0.0014 & 10.1947 & 0.1461 & 0.0736 & 0.0006 & 0.0922 & 0.0553 & 0.603 & 0.008 & 0.694 & 0.005 & 1.032 & 0.016 & 87 & 58 \\
\hline DKE-19 & $45.1 \mathrm{~B}$ & $\mathrm{R}$ & PMc & 1.3539 & 0.0127 & 0.1409 & 0.0020 & 7.0983 & 0.0983 & 0.0708 & 0.0005 & 0.0396 & 0.0231 & 0.850 & 0.011 & 869 & 0.005 & 0.950 & 0.015 & 98 & 89 \\
\hline DKE 19 & 51.1 & $\mathrm{R}$ & PMoz & 11.6195 & 0.1099 & 0.4285 & 0.0060 & 2.3335 & 0.0328 & 0.1986 & 0.0014 & 0.5548 & 0.2831 & 2.299 & 0.027 & 2.574 & 0.009 & 2.820 & 0.012 & 89 & 82 \\
\hline
\end{tabular}




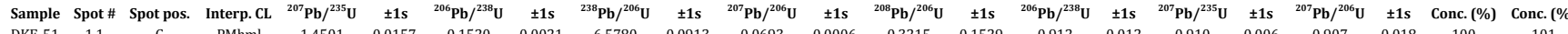

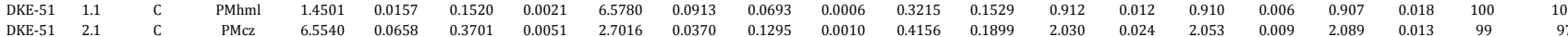
\begin{tabular}{lllllllllllllllllllllllll} 
DKE-51 & 3.1 & $C$ & PMoz & 3.4790 & 0.0370 & 0.2664 & 0.0037 & 3.7538 & 0.0519 & 0.0949 & 0.0008 & 0.2088 & 0.0919 & 1.523 & 0.019 & 1.522 & 0.008 & 1.533 & 0.015 & 100 & 99 & 99 \\
\hline
\end{tabular} \begin{tabular}{rrllllllllllllllllllll} 
DKE-51 & 4.1 & $\mathrm{C}$ & PMoz & 4.0888 & 0.0442 & 0.2918 & 0.0041 & 3.4270 & 0.0478 & 0.1011 & 0.0009 & 0.4415 & 0.1873 & 1.651 & 0.020 & 1.652 & 0.009 & 1.649 & 0.016 & 100 & 100 \\
\hline
\end{tabular}

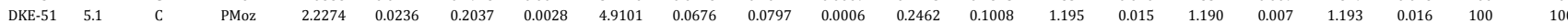

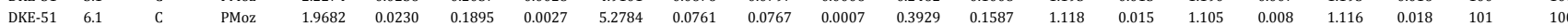

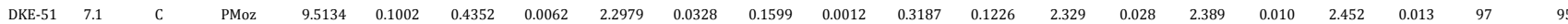

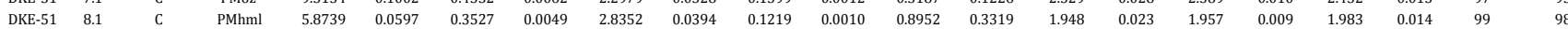

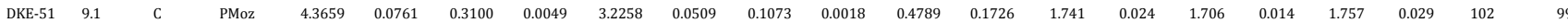

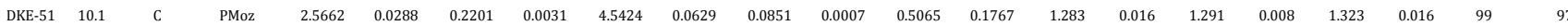

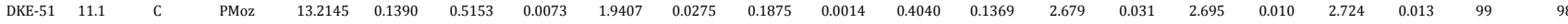

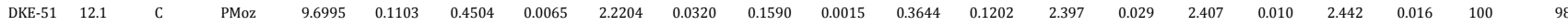

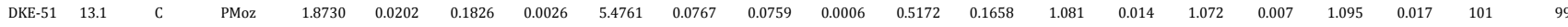

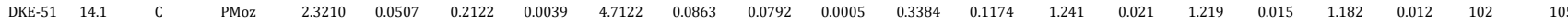

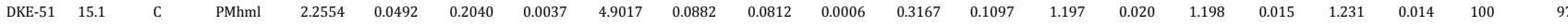

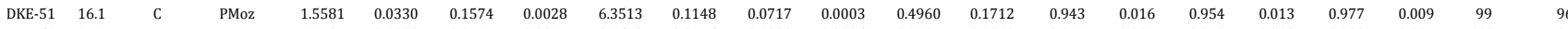
$\begin{array}{llllllllllllllllllllll}\text { DKE-51 } & 17.1 & \mathrm{R} & \text { PMoz } & 6.6784 & 0.1398 & 0.3767 & 0.0067 & 2.6548 & 0.0475 & 0.1290 & 0.0005 & 0.3684 & 0.1269 & 2.061 & 0.031 & 2.070 & 0.018 & 2.082 & 0.007 & 100 & 99\end{array}$

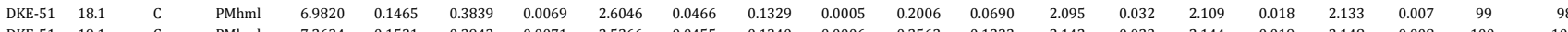

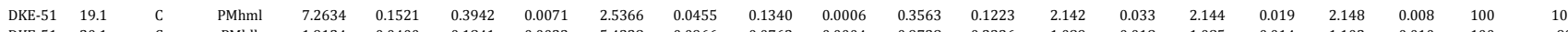

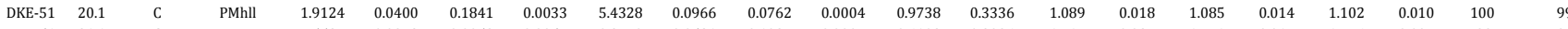

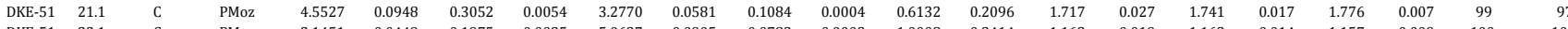

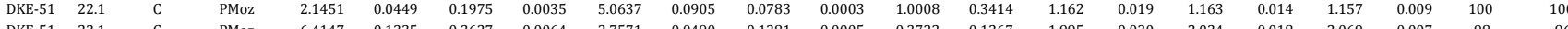

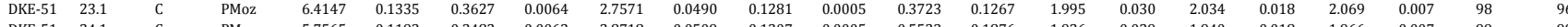

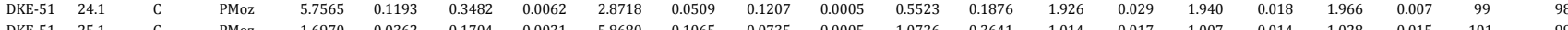

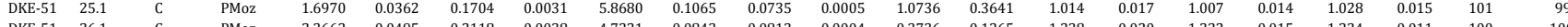
$\begin{array}{llllllllllllllllllllll}\text { DKE-51 } & 26.1 & \mathrm{C} & \text { PMoz } & 2.3662 & 0.0495 & 0.2118 & 0.0038 & 4.7221 & 0.0843 & 0.0813 & 0.0004 & 0.3736 & 0.1265 & 1.238 & 0.020 & 1.232 & 0.015 & 1.234 & 0.011 & 100 & 100\end{array}$

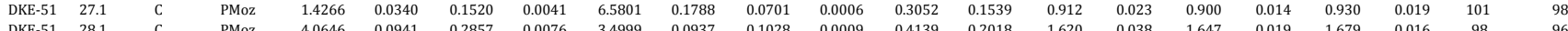

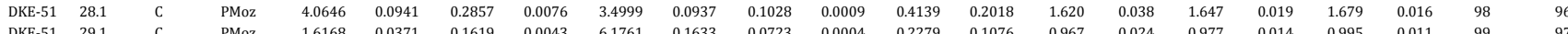

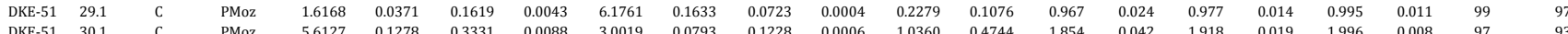

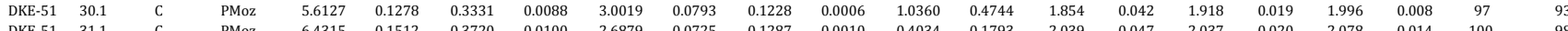

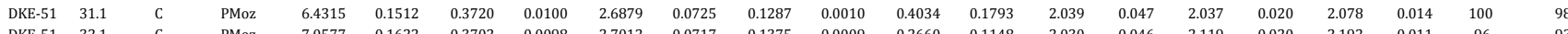

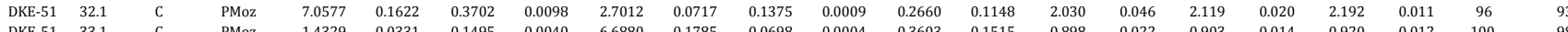

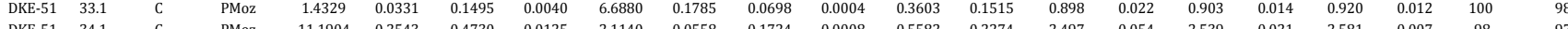

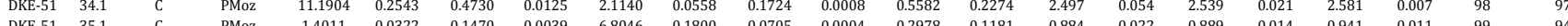
$\begin{array}{llllllllllllllllllllll}\text { DKE-51 } & 35.1 & \mathrm{C} & \text { PMoz } & 1.4011 & 0.0322 & 0.1470 & 0.0039 & 6.8046 & 0.1800 & 0.0705 & 0.0004 & 0.2978 & 0.1181 & 0.884 & 0.022 & 0.889 & 0.014 & 0.941 & 0.011 & 99 & 94\end{array}$

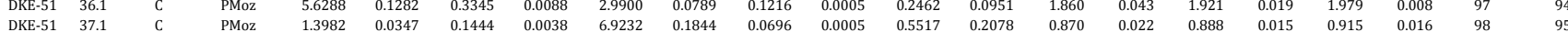

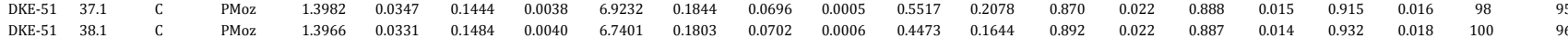
DKE-51 38.1

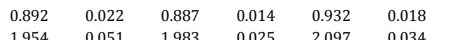




\begin{tabular}{|c|c|c|c|c|c|c|c|c|c|c|c|c|c|c|c|c|c|c|}
\hline Sample & Spot\# & Spot pos. & Spot pos. & ${ }^{207} \mathbf{P b} /{ }^{235} \mathbf{U}$ & $\pm 1 \mathrm{~s}$ & ${ }^{206} \mathbf{P b} /{ }^{238} \mathbf{U}$ & $\pm 1 \mathrm{~s}$ & ${ }^{238} \mathrm{~Pb} / /^{206} \mathrm{U}$ & $\pm 1 s$ & ${ }^{207} \mathbf{P b} /{ }^{206} \mathbf{U}$ & $\pm 1 \mathrm{~s}$ & ${ }^{208} \mathbf{P b} /{ }^{206} \mathbf{U}$ & $\pm 1 \mathrm{~s}$ & ${ }^{206} \mathbf{P b} /{ }^{238} \mathbf{U}$ & $\pm 1 \mathrm{~s}$ & ${ }^{207} \mathbf{P b} /{ }^{235} \mathbf{U}$ & $\pm 1 \mathrm{~s}$ & ${ }^{207} \mathrm{~Pb} /{ }^{206} \mathrm{U}$ \\
\hline DKE-53 & 1.1 & c & PMhml & 2.1297 & 0.0658 & 0.2004 & 0.0040 & 4.9900 & 0.0996 & 0.0776 & 0.0015 & -0.1514 & 0.4199 & 1.177 & 0.021 & 1.158 & 0.021 & 1.139 \\
\hline DKE-53 & 2.1 & C & PMoz & 1.1335 & 0.0346 & 0.1271 & 0.0025 & 7.8688 & 0.1548 & 0.0651 & 0.0012 & -0.0639 & 0.2029 & 0.771 & 0.014 & 0.769 & 0.016 & 0.774 \\
\hline DKE-53 & 3.1 & $\mathrm{R}$ & PMoz & 1.1198 & 0.0341 & 0.1269 & 0.0025 & 7.8833 & 0.1549 & 0.0648 & 0.0012 & -0.0749 & 0.2780 & 0.770 & 0.014 & 0.763 & 0.016 & 0.762 \\
\hline DKE-53 & 4.1 & $\mathrm{R}$ & PMoz & 1.1402 & 0.0347 & 0.1266 & 0.0025 & 7.8981 & 0.1552 & 0.0656 & 0.0012 & -0.0650 & 0.2906 & 0.769 & 0.014 & 0.773 & 0.016 & 0.789 \\
\hline DKE-53 & 5.1 & $\mathrm{R}$ & PMhhl & 5.4228 & 0.1669 & 0.3409 & 0.0068 & 2.9335 & 0.0588 & 0.1171 & 0.0023 & -0.4722 & 2.6513 & 1.891 & 0.033 & 1.888 & 0.026 & 1.914 \\
\hline DKE-53 & 6.1 & $\mathrm{R}$ & PMoz & 2.1949 & 0.0664 & 0.1961 & 0.0039 & 5.0989 & 0.1003 & 0.0817 & 0.0015 & -0.0256 & 0.1935 & 1.154 & 0.021 & 1.179 & 0.021 & 1.242 \\
\hline DKE-53 & 8.1 & C & PMoz & 4.5147 & 0.1355 & 0.3059 & 0.0060 & 3.2690 & 0.0637 & 0.1079 & 0.0020 & -0.0711 & 1.7259 & 1.721 & 0.029 & 1.734 & 0.025 & 1.768 \\
\hline DKE-53 & 9.1 & C & PMcz & 1.8866 & 0.0568 & 0.1723 & 0.0034 & 5.8031 & 0.1134 & 0.0809 & 0.0015 & 0.0026 & 0.5955 & 1.025 & 0.018 & 1.076 & 0.020 & 1.224 \\
\hline DKE-53 & 10.1 & c & PMoz & 2.1682 & 0.0648 & 0.2014 & 0.0039 & 4.9641 & 0.0969 & 0.0787 & 0.0015 & 0.0408 & 0.8148 & 1.183 & 0.021 & 1.171 & 0.021 & 1.169 \\
\hline DKE-53 & 11.1 & C & PMoz & 1.0758 & 0.0324 & 0.1227 & 0.0024 & 8.1497 & 0.1599 & 0.0644 & 0.0012 & 0.0387 & 0.4041 & 0.746 & 0.014 & 0.742 & 0.016 & 0.750 \\
\hline DKE-53 & 12.1 & $\mathrm{R}$ & PMoz & 1.1225 & 0.0334 & 0.1256 & 0.0024 & 7.9594 & 0.1537 & 0.0658 & 0.0012 & 0.0467 & 0.3303 & 0.763 & 0.014 & 0.764 & 0.016 & 0.795 \\
\hline DKE-53 & 13.1 & C & PMoz & 1.1202 & 0.0332 & 0.1246 & 0.0024 & 8.0273 & 0.1547 & 0.0662 & 0.0012 & 0.0503 & 0.2690 & 0.757 & 0.014 & 0.763 & 0.016 & 0.810 \\
\hline DKE-53 & 14.1 & C & PMhml & 1.5071 & 0.0123 & 0.1549 & 0.0016 & 6.4577 & 0.0648 & 0.0717 & 0.0005 & 0.0234 & 0.0058 & 0.928 & 0.009 & 0.933 & 0.005 & 0.978 \\
\hline DKE-53 & 15.1 & c & PMoz & 3.3168 & 0.0239 & 0.2556 & 0.0025 & 3.9119 & 0.0382 & 0.0954 & 0.0006 & 0.1531 & 0.0316 & 1.467 & 0.013 & 1.485 & 0.006 & 1.541 \\
\hline DKE-53 & 16.1 & C & PMhml & 1.1311 & 0.0088 & 0.1247 & 0.0012 & 8.0195 & 0.0796 & 0.0667 & 0.0005 & 0.1077 & 0.0220 & 0.758 & 0.007 & 0.768 & 0.004 & 0.825 \\
\hline DKE-53 & 17.1 & C & PMhhl & 4.1376 & 0.0401 & 0.2908 & 0.0030 & 3.4383 & 0.0354 & 0.1048 & 0.0010 & 0.6211 & 0.1250 & 1.646 & 0.015 & 1.662 & 0.008 & 1.714 \\
\hline DKE-53 & 18.1 & c & PMhhl & 4.3375 & 0.0752 & 0.2986 & 0.0057 & 3.3490 & 0.0636 & 0.1078 & 0.0019 & 0.7375 & 0.1481 & 1.684 & 0.028 & 1.701 & 0.014 & 1.766 \\
\hline DKE-53 & 19.1 & C & PMoz & 1.1345 & 0.0088 & 0.1285 & 0.0013 & 7.7827 & 0.0780 & 0.0651 & 0.0004 & 0.0833 & 0.0165 & 0.779 & 0.007 & 0.770 & 0.004 & 0.772 \\
\hline DKE-53 & 20.1 & C & PMoz & 4.4502 & 0.0335 & 0.2989 & 0.0030 & 3.3455 & 0.0332 & 0.1094 & 0.0007 & 0.4468 & 0.0867 & 1.686 & 0.015 & 1.722 & 0.006 & 1.792 \\
\hline DKE-53 & 21.1 & c & PMoz & 4.1729 & 0.0326 & 0.2801 & 0.0028 & 3.5699 & 0.0358 & 0.1089 & 0.0007 & 0.4333 & 0.0829 & 1.592 & 0.014 & 1.669 & 0.006 & 1.784 \\
\hline DKE-53 & 22.1 & C & PMhhl & 2.6032 & 0.0333 & 0.2271 & 0.0027 & 4.4036 & 0.0522 & 0.0846 & 0.0011 & 0.2614 & 0.0510 & 1.319 & 0.014 & 1.302 & 0.009 & 1.312 \\
\hline DKE-53 & 23.1 & $\mathrm{R}$ & PMoz & 1.9781 & 0.0146 & 0.1825 & 0.0018 & 5.4800 & 0.0538 & 0.0793 & 0.0005 & 0.2663 & 0.0497 & 1.081 & 0.010 & 1.108 & 0.005 & 1.183 \\
\hline DKE-53 & 24.1 & c & PMhml & 7.3549 & 0.0557 & 0.3888 & 0.0039 & 2.5721 & 0.0256 & 0.1386 & 0.0009 & 0.2911 & 0.0537 & 2.117 & 0.018 & 2.156 & 0.007 & 2.205 \\
\hline DKE-53 & 25.1 & C & PMoz & 1.5348 & 0.0115 & 0.1590 & 0.0016 & 6.2912 & 0.0627 & 0.0711 & 0.0005 & 0.3199 & 0.0584 & 0.951 & 0.009 & 0.944 & 0.005 & 0.958 \\
\hline DKE-53 & 26.1 & C & PMoz & 1.1538 & 0.0092 & 0.1241 & 0.0012 & 8.0556 & 0.0796 & 0.0674 & 0.0005 & 0.1280 & 0.0231 & 0.754 & 0.007 & 0.779 & 0.004 & 0.846 \\
\hline DKE-53 & 27.1 & c & PMhml & 1.0693 & 0.0250 & 0.1196 & 0.0019 & 8.3603 & 0.1358 & 0.0657 & 0.0006 & 0.1213 & 0.0467 & 0.728 & 0.011 & 0.738 & 0.012 & 0.794 \\
\hline DKE-53 & 28.1 & C & PMoz & 2.0244 & 0.0460 & 0.1878 & 0.0030 & 5.3237 & 0.0858 & 0.0778 & 0.0006 & 0.5126 & 0.1979 & 1.110 & 0.016 & 1.124 & 0.015 & 1.145 \\
\hline DKE-53 & 29.1 & C & PMhhl & 13.5378 & 0.3070 & 0.5069 & 0.0083 & 1.9728 & 0.0322 & 0.1958 & 0.0015 & 0.5565 & 0.2162 & 2.643 & 0.035 & 2.718 & 0.021 & 2.797 \\
\hline DKE-53 & 30.1 & c & PMoz & 2.0537 & 0.0461 & 0.1872 & 0.0030 & 5.3412 & 0.0857 & 0.0801 & 0.0006 & 0.1539 & 0.0601 & 1.106 & 0.016 & 1.134 & 0.015 & 1.204 \\
\hline DKE-53 & 31.1 & C & PMoz & 5.0986 & 0.1144 & 0.3209 & 0.0051 & 3.1160 & 0.0500 & 0.1157 & 0.0008 & 0.6529 & 0.2569 & 1.794 & 0.025 & 1.836 & 0.019 & 1.892 \\
\hline DKE-53 & 32.1 & C & PMoz & 1.1599 & 0.0262 & 0.1269 & 0.0020 & 7.8785 & 0.1271 & 0.0667 & 0.0005 & 0.1452 & 0.0575 & 0.770 & 0.012 & 0.782 & 0.012 & 0.825 \\
\hline DKE-53 & 33.1 & C & PMoz & 5.2069 & 0.1163 & 0.3185 & 0.0051 & 3.1392 & 0.0504 & 0.1200 & 0.0009 & 1.1612 & 0.4624 & 1.783 & 0.025 & 1.854 & 0.019 & 1.956 \\
\hline DKE-53 & 34.1 & c & PMhml & 1.1840 & 0.0267 & 0.1304 & 0.0021 & 7.6712 & 0.1231 & 0.0663 & 0.0005 & 0.1146 & 0.0463 & 0.790 & 0.012 & 0.793 & 0.012 & 0.811 \\
\hline DKE-53 & 35.1 & C & PMoz & 1.9895 & 0.0457 & 0.1781 & 0.0029 & 5.6157 & 0.0925 & 0.0822 & 0.0006 & 0.1350 & 0.0546 & 1.056 & 0.016 & 1.112 & 0.015 & 1.255 \\
\hline DKE-53 & 36.1 & C & PMoz & 4.4880 & 0.1019 & 0.3004 & 0.0049 & 3.3289 & 0.0545 & 0.1086 & 0.0008 & 0.7338 & 0.2984 & 1.693 & 0.024 & 1.729 & 0.019 & 1.778 \\
\hline DKE-53 & 37.1 & c & PMhhl & 1.7498 & 0.0440 & 0.1710 & 0.0029 & 5.8482 & 0.0993 & 0.0786 & 0.0007 & 0.3031 & 0.1245 & 1.018 & 0.016 & 1.027 & 0.016 & 1.164 \\
\hline DKE-53 & 38.1 & C & PMhhl & 2.2636 & 0.0516 & 0.2033 & 0.0033 & 4.9179 & 0.0789 & 0.0802 & 0.0007 & 0.5199 & 0.2143 & 1.193 & 0.017 & 1.201 & 0.016 & 1.207 \\
\hline DKE-53 & 39.1 & $\mathrm{R}$ & PMoz & 1.6153 & 0.0359 & 0.1626 & 0.0026 & 6.1499 & 0.0984 & 0.0721 & 0.0005 & 0.4563 & 0.1893 & 0.971 & 0.014 & 0.976 & 0.014 & 0.988 \\
\hline DKE-53 & 40.1 & C & PMhhl & 18.3685 & 0.3756 & 0.5848 & 0.0065 & 1.7099 & 0.0191 & 0.2275 & 0.0031 & -0.9813 & 6.9650 & 2.968 & 0.027 & 3.009 & 0.020 & 3.039 \\
\hline DKE-53 & 42.1 & C & PMoz & 12.2847 & 0.2497 & 0.4827 & 0.0053 & 2.0717 & 0.0228 & 0.1853 & 0.0025 & -3.4912 & 13.2764 & 2.539 & 0.023 & 2.626 & 0.019 & 2.704 \\
\hline DKE-53 & 43.1 & C & PMoz & 5.4768 & 0.1111 & 0.3492 & 0.0038 & 2.8636 & 0.0314 & 0.1144 & 0.0015 & -2.8656 & 8.8444 & 1.931 & 0.018 & 1.897 & 0.017 & 1.873 \\
\hline DKE-53 & 44.1 & c & PMoz & 3.9909 & 0.0808 & 0.2928 & 0.0032 & 3.4159 & 0.0378 & 0.0992 & 0.0013 & -6.0982 & 15.8379 & 1.655 & 0.016 & 1.632 & 0.016 & 1.615 \\
\hline DKE-53 & 45.1 & c & PMoz & 1.4512 & 0.0303 & 0.1472 & 0.0016 & 6.7939 & 0.0757 & 0.0721 & 0.0010 & $\begin{array}{l}-4.7922 \\
\end{array}$ & 10.7429 & 0.885 & 0.009 & 0.910 & 0.012 & 0.988 \\
\hline DKE-53 & 46.1 & c & PMoz & 2.4193 & 0.0491 & 0.2149 & 0.0024 & 4.6541 & 0.0519 & 0.0820 & 0.0011 & -2.3963 & 4.8056 & 1.255 & 0.013 & 1.248 & 0.014 & 1.249 \\
\hline DKE-53 & 47.1 & C & PMoz & 3.4897 & 0.0706 & 0.2615 & 0.0029 & 3.8248 & 0.0425 & 0.0973 & 0.0013 & -2.8301 & 4.9813 & 1.497 & 0.015 & 1.525 & 0.016 & 1.578 \\
\hline DKE-53 & 48.1 & C & PMoz & 5.5854 & 0.1121 & 0.3444 & 0.0038 & 2.9040 & 0.0317 & 0.1187 & 0.0016 & -6.0150 & 9.5599 & 1.908 & 0.018 & 1.914 & 0.017 & 1.938 \\
\hline DKE-53 & 49.1 & C & PMhml & 2.0281 & 0.0409 & 0.1859 & 0.0020 & 5.3799 & 0.0590 & 0.0793 & 0.0011 & -3.3002 & 4.7814 & 1.099 & 0.011 & 1.125 & 0.014 & 1.183 \\
\hline DKE-53 & 50.1 & c & PMhml & 2.5808 & 0.0517 & 0.2175 & 0.0024 & 4.5984 & 0.0503 & 0.0864 & 0.0011 & -4.4705 & 5.9506 & 1.268 & 0.013 & 1.295 & 0.015 & 1.353 \\
\hline DKE-53 & 51.1 & C & PMhml & 6.5427 & 0.1308 & 0.3655 & 0.0040 & 2.7356 & 0.0300 & 0.1306 & 0.0017 & -5.7890 & 7.1267 & 2.008 & 0.019 & 2.052 & 0.017 & 2.103 \\
\hline DKE-53 & 52.1 & C & PMoz & 1.4632 & 0.0320 & 0.1427 & 0.0016 & 7.0081 & 0.0807 & 0.0786 & 0.0011 & -2.0083 & 2.2998 & 0.860 & 0.009 & 0.91 & 0.013 & 1.1 \\
\hline $\begin{array}{l}\text { DKE-53 } \\
\text { D }\end{array}$ & 53.1 & C & PMhml & 3.3320 & 0.0962 & 0.2649 & 0.0084 & 3.7757 & 0.1193 & 0.0923 & 0.0010 & 0.2686 & 0.3522 & 1.515 & 0.043 & $\begin{array}{l}1.489 \\
\text { nat }\end{array}$ & 0.022 & 1.479 \\
\hline DKE-53 & 54.1 & $\mathrm{R}$ & PMoz & 3.3527 & 0.0962 & 0.2420 & 0.0076 & 4.1323 & 0.1305 & 0.0988 & 0.0010 & 0.4283 & 0.5056 & 1.397 & 0.040 & 1.493 & 0.022 & 1.607 \\
\hline DKE-53 & 55.1 & C & PMoz & 1.9970 & 0.0591 & 0.1901 & 0.0060 & 5.2610 & 0.1663 & 0.0778 & 0.0010 & 0.5841 & 0.6269 & 1.122 & 0.032 & 1.114 & 0.020 & 1.145 \\
\hline DKE-53 & 58.1 & c & PMoz & 1.6835 & 0.0478 & 0.1618 & 0.0051 & 6.1823 & 0.1936 & 0.0762 & 0.0008 & 0.2018 & 0.1703 & 0.967 & 0.028 & 1.002 & 0.018 & 1.104 \\
\hline DKE-53 & 59.1 & C & PMoz & 3.8808 & 0.1102 & 0.2669 & 0.0084 & 3.7468 & 0.1173 & 0.1078 & 0.0011 & 0.6609 & 0.5254 & 1.525 & 0.042 & 1.610 & 0.023 & 1.766 \\
\hline DKE-53 & 60.1 & C & PMo & 1.7265 & 0.049 & 0.1648 & 0.0051 & 6.0692 & 1893 & 0.0776 & .0008 & 0.3730 & 0. & 0.983 & 0.028 & & 0.018 & \\
\hline DKE-53 & 61.1 & C & PMoz & 1.4651 & 0.0481 & 0.1555 & 0.0054 & 6.4296 & 0.2246 & 0.0703 & 0.0011 & 1.2815 & 0.89 & 0.932 & 0.030 & 0.916 & 0.020 & 0.936 \\
\hline DKE-53 & 62.1 & C & PMoz & 5.3101 & 0.1503 & 0.3196 & 0.0100 & 3.1292 & 0.0975 & 0.1226 & 0.0012 & 0.9241 & 0.6067 & 1.788 & 0.048 & 1.870 & 0.024 & 1.993 \\
\hline DKE-53 & 63.1 & c & PMor & 3.6209 & 0.104 & 0.2604 & 0.0081 & 3.8401 & 01201 & 0.1012 & 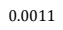 & 0.8135 & 0.5061 & 14 & 0.042 & 1 & 0.02 & 1. \\
\hline DKE-53 & 64.1 & c & PMoz & 1.5630 & 0.0437 & 0.1531 & 0.0047 & 6.5324 & 0.20 & 0.0751 & 0.0007 & 0.7193 & 0.4251 & 0.918 & 0.02 & 0.956 & 0.017 & 1.073 \\
\hline DKE-53 & 65.1 & s & PMoz & 2.7275 & 0.0763 & 0.2235 & 0.0069 & 4.4744 & 0.1383 & 0.0899 & 0.0009 & 0.7340 & 0.4131 & 1.300 & 0.036 & 336 & 0.021 & 1.430 \\
\hline DKE-53 & 66.1 & 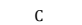 & $\mathrm{PMo}$ & 3.1945 & 0.0604 & 0.2442 & 0.0074 & 4.0944 & & 0.0958 & 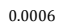 & 0. & & 1.40 & 0.038 & & 0.015 & - \\
\hline DKE-53 & 67.1 & c & PMo & 2 & 0.0492 & 97 & 0 & 4.5510 & & 0.0864 & 5 & 0. & 0. & 1.2 & 0.035 & 1.294 & 0.014 & 1.352 \\
\hline DKE-53 & 68.1 & s & PMoz & 3.3675 & 0.0645 & 0.2617 & 0.0 & 3.8210 & 0.1157 & 0.0944 & 0.0 & 0.1227 & 0.0 & 1.49 & 0.040 & 1. & 0.015 & 1.522 \\
\hline DKE-53 & 69.1 & C & PMhhl & 5.0561 & 0.0968 & 0.3197 & 0.0097 & 3.1281 & 0.0947 & 0.1164 & & 0.8206 & 0. & 1.788 & 047 & 829 & 0.016 & 1.903 \\
\hline DKE-53 & 70.1 & c & PMhml & 1.7782 & 0.033 & 0.1741 & 0.0053 & 5.7431 & 0. & 0.0750 & 005 & 0.3719 & 0. & 1.035 & 029 & 038 & 0.012 & 1.071 \\
\hline DKE-53 & 71.1 & C & PMhml & 2.3102 & 0.0442 & 0.2079 & 0.0063 & 4.8107 & 0.1453 & 0.0815 & 0.0006 & 0.2829 & 0.0546 & 1.21 & 0.033 & 1.215 & 0.013 & 1.238 \\
\hline DKE-53 & 73.1 & c & PMo & 4.6075 & 0.08 & 0.3026 & 0.0091 & 3.3050 & & 0. & & 0.7208 & & 1.7 & & & & \\
\hline DKE-53 & 74 & 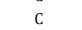 & & & 0. & & & 2.9914 & & & & & & 1.85 & 0.048 & & 0.016 & 1.994 \\
\hline DKE-53 & 75.1 & C & PMoz & 6.4577 & 0.124 & 0.371 & 0.0 & 2.689 & 0.0815 & 0.1280 & 0.0 & 0.5889 & 0.1062 & 2.03 & 0.053 & 2.04 & 0.017 & 2.068 \\
\hline DKE-53 & 76.1 & c & PMo & 1.1089 & 0.02 & 0.1233 & 0.0037 & 8.1085 & & 0.0659 & 04 & 0.1150 & 0. & 0.750 & .021 & 0.758 & 0.010 & 0.800 \\
\hline DKE-53 & 77. & 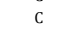 & PM & & 0.09 & & & 3.265 & & 0.11 & & & & 1. & & 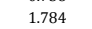 & 0.016 & 1.883 \\
\hline DKE-53 & 78.1 & C & PMoz & 1.9715 & 0.0371 & 0.1846 & 0.0056 & 5.4172 & 0.1630 & 0.0782 & 0.0005 & 0.2397 & 0.0413 & 1.092 & 0.030 & 1.106 & 0.013 & 1.155 \\
\hline & & & & & & & & & & & & & & & & & & \\
\hline DKE-53 & 41.1 & c & $\mathrm{PN}$ & 1. & 0.0408 & 0. & 0. & 6. & & 0.092 & & -0 . & & 0.880 & 0.009 & 1.070 & $0 . c$ & 1.483 \\
\hline DKE-53 & 7.1 & c & PM & 5.0769 & 0.15 & 0.3054 & 0.0060 & 3.2740 & 0.0646 & 0.1196 & 0.0023 & -0.0747 & 0.8022 & 1.71 & 0.030 & 1.832 & 0.026 & 1.951 \\
\hline DKE-53 & 56.1 & C & PMC & 5.2343 & 0.14 & 0.3050 & 0.0096 & 3.2792 & 0.1034 & 0.1256 & 0.0012 & 0.8680 & 0.8541 & 1.71 & 0.047 & 1.858 & 0.024 & 2.036 \\
\hline DKE-53 & 57.1 & R & & & & & & & & & & & & 0. & 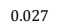 & & 0.019 & 1.284 \\
\hline DKE-53 & 72.1 & C & PMoz & 1.9031 & 0.0374 & 0.1701 & 0.0052 & 5.8804 & 0.1803 & 0.0817 & 0.0005 & 0.2494 & 0.0473 & 1.012 & 0.029 & 1.082 & 0.013 & 1.242 \\
\hline
\end{tabular}




\begin{tabular}{|c|c|c|c|c|c|c|c|c|c|c|c|c|c|c|c|c|c|c|c|c|c|}
\hline DKE-06 & 14.1 & C & PMhml & 6.4379 & 0.0483 & 0.3565 & 0.0029 & 2.8052 & 0.0230 & 0.1308 & 0.0015 & 0.5898 & 0.2382 & 1.965 & 0.014 & 2.037 & 0.007 & 2.106 & 0.019 & 96 & 93 \\
\hline DKE-06 & 16.1 & C & PMhml & 6.8832 & 0.0477 & 0.3730 & 0.0032 & 2.6810 & 0.0229 & 0.1360 & 0.0015 & 0.3828 & 0.1642 & 2.043 & 0.015 & 2.096 & 0.006 & 2.173 & 0.019 & 97 & 94 \\
\hline DKE-06 & 19.1 & C & PMoz & 6.0673 & 0.0791 & 0.3428 & 0.0047 & 2.9174 & 0.0397 & 0.1299 & 0.0014 & 0.3823 & 0.1807 & 1.900 & 0.022 & 1.986 & 0.011 & 2.094 & 0.019 & 96 & 91 \\
\hline DKE-06 & 23.1 & C & PMoz & 5.7762 & 0.0400 & 0.3312 & 0.0027 & 3.0195 & 0.0245 & 0.1271 & 0.0014 & 0.2715 & 0.1547 & 1.844 & 0.013 & 1.943 & 0.006 & 2.057 & 0.019 & 95 & 90 \\
\hline DKE-06 & 24.1 & C & PMhml & 6.7770 & 0.1150 & 0.3835 & 0.0064 & 2.6076 & 0.0438 & 0.1328 & 0.0016 & 0.2083 & 0.1239 & 2.093 & 0.030 & 2.083 & 0.015 & 2.132 & 0.020 & 100 & 98 \\
\hline DKE-06 & 25.1 & C & PMoz & 6.8990 & 0.0545 & 0.3675 & 0.0033 & 2.7208 & 0.0243 & 0.1350 & 0.0015 & 0.2222 & 0.1379 & 2.018 & 0.015 & 2.099 & 0.007 & 2.161 & 0.019 & 96 & 93 \\
\hline DKE-06 & 26.1 & C & PMoz & 7.0756 & 0.1647 & 0.4008 & 0.0076 & 2.4951 & 0.0473 & 0.1327 & 0.0019 & 0.0917 & 0.0881 & 2.173 & 0.035 & 2.121 & 0.021 & 2.131 & 0.024 & 102 & 102 \\
\hline DKE-06 & 27.1 & C & PMoz & 6.2043 & 0.0946 & 0.3465 & 0.0032 & 2.8862 & 0.0263 & 0.1304 & 0.0017 & 0.4806 & 0.4345 & 1.918 & 0.015 & 2.005 & 0.013 & 2.101 & 0.022 & 96 & 91 \\
\hline DKE-06 & $28.2 \mathrm{~N}$ & C & PMoz & 9.2539 & 0.1428 & 0.4245 & 0.0041 & 2.3558 & 0.0229 & 0.1587 & 0.0020 & 0.4292 & 0.3496 & 2.281 & 0.019 & 2.363 & 0.014 & 2.439 & 0.022 & 97 & 94 \\
\hline DKE-06 & 29.1 & C & PMoz & 6.5338 & 0.1041 & 0.3612 & 0.0038 & 2.7688 & 0.0291 & 0.1338 & 0.0017 & 0.2747 & 0.2132 & 1.988 & 0.018 & 2.050 & 0.014 & 2.145 & 0.022 & 97 & 93 \\
\hline DKE-06 & 32.1 & C & PMoz & 7.1723 & 0.2413 & 0.3875 & 0.0118 & 2.5807 & 0.0784 & 0.1415 & 0.0020 & 0.4934 & 0.3357 & 2.111 & 0.054 & 2.133 & 0.030 & 2.241 & 0.024 & 99 & 94 \\
\hline DKE-06 & 33.1 & C & PMoz & 7.4754 & 0.1108 & 0.3986 & 0.0036 & 2.5086 & 0.0227 & 0.1368 & 0.0017 & 0.2988 & 0.1951 & 2.163 & 0.017 & 2.170 & 0.013 & 2.183 & 0.022 & 100 & 99 \\
\hline DKE-06 & 34.1 & C & PMoz & 6.6818 & 0.1051 & 0.3735 & 0.0039 & 2.6773 & 0.0277 & 0.1317 & 0.0017 & 0.9333 & 0.5860 & 2.046 & 0.018 & 2.070 & 0.014 & 2.117 & 0.022 & 99 & 97 \\
\hline DKE-06 & 35.1 & C & PMoz & 5.9921 & 0.0901 & 0.3486 & 0.0032 & 2.8684 & 0.0263 & 0.1262 & 0.0016 & 0.0742 & 0.0449 & 1.928 & 0.015 & 1.975 & 0.013 & 2.044 & 0.022 & 98 & 94 \\
\hline DKE-06 & 40.1 & C & PMoz & 7.0304 & 0.1025 & 0.3839 & 0.0044 & 2.6048 & 0.0297 & 0.1348 & 0.0009 & 0.4515 & 0.2993 & 2.095 & 0.020 & 2.115 & 0.013 & 2.158 & 0.011 & 99 & 97 \\
\hline DKE-06 & 42.1 & C & PMoz & 6.3441 & 0.0866 & 0.3554 & 0.0035 & 2.8138 & 0.0273 & 0.1299 & 0.0009 & 0.5730 & 0.4115 & 1.960 & 0.016 & 2.025 & 0.012 & 2.094 & 0.012 & 97 & 94 \\
\hline DKE-06 & 44.1 & C & PMoz & 7.0995 & 0.0962 & 0.3790 & 0.0037 & 2.6383 & 0.0261 & 0.1373 & 0.0009 & 0.2778 & 0.2162 & 2.072 & 0.018 & 2.124 & 0.012 & 2.190 & 0.011 & 98 & 95 \\
\hline DKE-06 & 45.1 & C & PMhml & 6.8089 & 0.0939 & 0.3684 & 0.0036 & 2.7142 & 0.0262 & 0.1347 & 0.0010 & 0.5157 & 0.4232 & 2.022 & 0.017 & 2.087 & 0.012 & 2.156 & 0.013 & 97 & 94 \\
\hline DKE-06 & 46.1 & C & PMhml & 6.4206 & 0.0850 & 0.3587 & 0.0034 & 2.7875 & 0.0261 & 0.1304 & 0.0009 & 1.1054 & 0.9523 & 1.976 & 0.016 & 2.035 & 0.012 & 2.101 & 0.011 & 97 & 94 \\
\hline DKE-06 & 47.1 & C & PMoz & 6.0778 & 0.1560 & 0.3440 & 0.0088 & 2.9073 & 0.0744 & 0.1286 & 0.0011 & 0.2025 & 0.1842 & 1.906 & 0.042 & 1.987 & 0.022 & 2.077 & 0.015 & 96 & 92 \\
\hline DKE-06 & 48.1 & C & PMoz & 6.2306 & 0.0849 & 0.3549 & 0.0035 & 2.8176 & 0.0276 & 0.1290 & 0.0010 & 0.3407 & 0.3261 & 1.958 & 0.017 & 2.009 & 0.012 & 2.082 & 0.013 & 97 & 94 \\
\hline DKE-06 & 49.1 & C & PMoz & 6.6097 & 0.0875 & 0.3587 & 0.0034 & 2.7875 & 0.0267 & 0.1351 & 0.0009 & 0.1338 & 0.1356 & 1.976 & 0.016 & 2.061 & 0.012 & 2.161 & 0.012 & 96 & 91 \\
\hline DKE-06 & 50.1 & C & PMoz & 6.6165 & 0.0875 & 0.3589 & 0.0034 & 2.7866 & 0.0266 & 0.1351 & 0.0009 & 0.1260 & 0.1357 & 1.977 & 0.016 & 2.062 & 0.012 & 2.162 & 0.012 & 96 & 91 \\
\hline DKE-06 & 51.1 & C & PMoz & 6.6088 & 0.1482 & 0.3697 & 0.0076 & 2.7050 & 0.0555 & 0.1318 & 0.0011 & 0.3615 & 0.0853 & 2.028 & 0.036 & 2.061 & 0.020 & 2.119 & 0.015 & 98 & 96 \\
\hline DKE-06 & 52.1 & C & PMoz & 7.3742 & 0.1657 & 0.3880 & 0.0080 & 2.5771 & 0.0529 & 0.1387 & 0.0011 & 0.1821 & 0.0431 & 2.114 & 0.037 & 2.158 & 0.020 & 2.207 & 0.014 & 98 & 96 \\
\hline DKE-06 & 53.1 & C & PMhml & 6.8720 & 0.1528 & 0.3701 & 0.0075 & 2.7023 & 0.0550 & 0.1362 & 0.0011 & 0.2575 & 0.0613 & 2.030 & 0.035 & 2.095 & 0.020 & 2.175 & 0.014 & 97 & 93 \\
\hline DKE-06 & 55.1 & C & PMhml & 7.1835 & 0.1602 & 0.3785 & 0.0077 & 2.6420 & 0.0537 & 0.1383 & 0.0011 & 0.0643 & 0.0155 & 2.069 & 0.036 & 2.134 & 0.020 & 2.202 & 0.014 & 97 & 94 \\
\hline DKE-06 & 56.1 & C & PMoz & 6.7787 & 0.1517 & 0.3770 & 0.0077 & 2.6523 & 0.0542 & 0.1309 & 0.0011 & 0.5009 & 0.1206 & 2.062 & 0.036 & 2.083 & 0.020 & 2.107 & 0.014 & 99 & 98 \\
\hline DKE-06 & 57.1 & C & PMoz & 6.2954 & 0.1389 & 0.3648 & 0.0074 & 2.7414 & 0.0554 & 0.1271 & 0.0010 & 0.3419 & 0.0825 & 2.005 & 0.035 & 2.018 & 0.019 & 2.056 & 0.014 & 99 & 98 \\
\hline DKE-06 & 58.1 & C & PMoz & 8.9769 & 0.1977 & 0.4316 & 0.0087 & 2.3172 & 0.0468 & 0.1529 & 0.0013 & 0.2214 & 0.0537 & 2.313 & 0.039 & 2.336 & 0.020 & 2.375 & 0.014 & 99 & 97 \\
\hline DKE-06 & 59.1 & C & PMoz & 7.2614 & 0.1598 & 0.3830 & 0.0077 & 2.6108 & 0.0526 & 0.1385 & 0.0011 & 0.1888 & 0.0459 & 2.090 & 0.036 & 2.144 & 0.019 & 2.205 & 0.014 & 97 & 95 \\
\hline DKE-06 & 60.1 & C & PMoz & 6.4293 & 0.1421 & 0.3522 & 0.0071 & 2.8397 & 0.0572 & 0.1333 & 0.0011 & 0.2645 & 0.0646 & 1.945 & 0.034 & 2.036 & 0.019 & 2.139 & 0.014 & 96 & 91 \\
\hline DKE-06 & 61.1 & C & PMoz & 6.2870 & 0.1376 & 0.3586 & 0.0072 & 2.7889 & 0.0560 & 0.1295 & 0.0011 & 0.2074 & 0.0509 & 1.975 & 0.034 & 2.017 & 0.019 & 2.089 & 0.014 & 98 & 95 \\
\hline DKE-06 & 62.1 & C & PMoz & 6.5704 & 0.1437 & 0.3703 & 0.0074 & 2.7008 & 0.0542 & 0.1307 & 0.0011 & 0.4443 & 0.1095 & 2.031 & 0.035 & 2.055 & 0.019 & 2.104 & 0.014 & 99 & 96 \\
\hline \multicolumn{22}{|c|}{ Metamorphic domains (overgrowths) } \\
\hline DKE-06 & 15.1B & $\mathrm{R}$ & Mog & 0.7701 & 0.0073 & 0.0939 & 0.0008 & 10.6529 & 0.0921 & 0.0601 & 0.0008 & 0.0180 & 0.0076 & 0.578 & 0.005 & 0.580 & 0.004 & 0.601 & 0.027 & 100 & 96 \\
\hline DKE-06 & $21.1 \mathrm{~B} 1$ & $\mathrm{R}$ & Mog & 0.7615 & 0.0074 & 0.0920 & 0.0008 & 10.8654 & 0.0904 & 0.0608 & 0.0008 & 0.0729 & 0.0371 & 0.568 & 0.005 & 0.575 & 0.004 & 0.627 & 0.027 & 99 & 91 \\
\hline DKE-06 & $21.2 \mathrm{~B} 2$ & $\mathrm{R}$ & Mog & 0.7024 & 0.0077 & 0.0878 & 0.0008 & 11.3897 & 0.1066 & 0.0587 & 0.0008 & 0.0114 & 0.0076 & 0.543 & 0.005 & 0.540 & 0.005 & 0.549 & 0.031 & 100 & 99 \\
\hline \multicolumn{22}{|c|}{ Zircons not included on related diagrams } \\
\hline DKE-06 & 1.1 & C & PMoz & 5.0196 & 0.0690 & 0.3005 & 0.0013 & 3.3276 & 0.0149 & 0.1236 & 0.0009 & 0.4468 & 0.0839 & 1.694 & 0.007 & 1.823 & 0.012 & 2.007 & 0.013 & 93 & 84 \\
\hline DKE-06 & 13.1 & c & PMoz & 4.7904 & 0.0683 & 0.2857 & 0.0016 & 3.5006 & 0.0191 & 0.1239 & 0.0010 & 0.3189 & 0.0539 & 1.620 & 0.008 & 1.783 & 0.012 & 2.012 & 0.014 & 91 & 81 \\
\hline DKE-06 & 17.1 & C & PMoz & 5.2650 & 0.0443 & 0.3027 & 0.0026 & 3.3031 & 0.0288 & 0.1286 & 0.0015 & 0.1036 & 0.0459 & 1.705 & 0.013 & 1.863 & 0.007 & 2.077 & 0.020 & 92 & 82 \\
\hline DKE-06 & 18.1 & C & PMoz & 4.9585 & 0.0330 & 0.2850 & 0.0023 & 3.5089 & 0.0287 & 0.1280 & 0.0014 & 0.1994 & 0.0911 & 1.616 & 0.012 & 1.812 & 0.006 & 2.068 & 0.019 & 89 & 78 \\
\hline DKE-06 & 20.1 & C & PMoz & 4.7369 & 0.0366 & 0.2750 & 0.0024 & 3.6366 & 0.0311 & 0.1258 & 0.0014 & 0.3081 & 0.1501 & 1.566 & 0.012 & 1.774 & 0.006 & 2.038 & 0.019 & 88 & 77 \\
\hline DKE-06 & 22.1 & C & PMoz & 4.2217 & 0.0337 & 0.2610 & 0.0024 & 3.8309 & 0.0350 & 0.1238 & 0.0014 & 0.1758 & 0.0962 & 1.495 & 0.012 & 1.678 & 0.007 & 2.010 & 0.020 & 89 & 74 \\
\hline DKE-06 & 28.1B & $\mathrm{R}$ & Mog & 0.6457 & 0.0139 & 0.0787 & 0.0009 & 12.7017 & 0.1430 & 0.0613 & 0.0012 & 0.0859 & 0.0750 & 0.489 & 0.005 & 0.506 & 0.009 & 0.644 & 0.043 & 97 & 76 \\
\hline DKE-06 & 30.1 & C & PMoz & 5.2915 & 0.0818 & 0.3054 & 0.0030 & 3.2743 & 0.0318 & 0.1269 & 0.0016 & 0.6252 & 0.4635 & 1.718 & 0.015 & 1.867 & 0.013 & 2.053 & 0.022 & 92 & 84 \\
\hline DKE-06 & 31.1 & C & PMoz & 6.3863 & 0.1718 & 0.3320 & 0.0060 & 3.0120 & 0.0548 & 0.1354 & 0.0019 & 0.4188 & 0.2988 & 1.848 & 0.029 & 2.030 & 0.023 & 2.165 & 0.024 & 91 & 85 \\
\hline DKE-06 & 36.1 & C & PMoz & 2.1921 & 0.0390 & 0.1546 & 0.0019 & 6.4681 & 0.0804 & 0.1020 & 0.0013 & 0.7185 & 0.4192 & 0.927 & 0.011 & 1.179 & 0.012 & 1.666 & 0.024 & 79 & 56 \\
\hline DKE-06 & 37.1 & C & PMoz & 6.0924 & 0.1039 & 0.3423 & 0.0039 & 2.9212 & 0.0331 & 0.1325 & 0.0017 & 0.2316 & 0.1305 & 1.898 & 0.019 & 1.989 & 0.015 & 2.128 & 0.022 & 95 & 89 \\
\hline DKE-06 & 38.1 & C & PMoz & 6.2518 & 0.0960 & 0.3404 & 0.0038 & 2.9378 & 0.0324 & 0.1362 & 0.0014 & 0.9243 & 0.5693 & 1.889 & 0.018 & 2.012 & 0.013 & 2.176 & 0.017 & 94 & 87 \\
\hline DKE-06 & 39.1 & C & PMoz & 3.9238 & 0.0536 & 0.2696 & 0.0026 & 3.7095 & 0.0359 & 0.1058 & 0.0008 & 0.8682 & 0.5542 & 1.539 & 0.013 & 1.619 & 0.011 & 1.733 & 0.013 & 95 & 89 \\
\hline DKE-06 & 41.1 & C & PMoz & 4.3305 & 0.0621 & 0.2659 & 0.0027 & 3.7615 & 0.0387 & 0.1188 & 0.0008 & 0.6252 & 0.4310 & 1.520 & 0.014 & 1.699 & 0.012 & 1.939 & 0.012 & 89 & 78 \\
\hline DKE-06 & 43.1 & C & PMoz & 6.5065 & 0.0886 & 0.3502 & 0.0035 & 2.8554 & 0.0281 & 0.1356 & 0.0009 & 0.5419 & 0.4060 & 1.936 & 0.016 & 2.047 & 0.012 & 2.168 & 0.012 & 95 & 89 \\
\hline DKE-06 & 54.1 & C & PMoz & 5.2497 & 0.1175 & 0.3118 & 0.0063 & 3.2074 & 0.0653 & 0.1240 & 0.0011 & 0.1208 & 0.0289 & 1.749 & 0.031 & 1.861 & 0.019 & 2.013 & 0.015 & 94 & 87 \\
\hline DKE-06 & 63.1 & C & PMoz & 5.0830 & 0.1123 & 0.3098 & 0.0063 & 3.2282 & 0.0652 & 0.1203 & 0.0010 & 0.1333 & 0.0330 & 1.740 & 0.031 & 1.833 & 0.019 & 1.960 & 0.014 & 95 & 89 \\
\hline
\end{tabular}




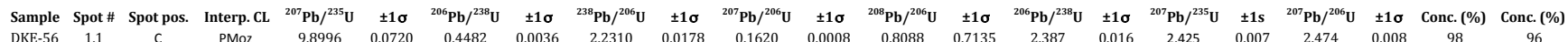

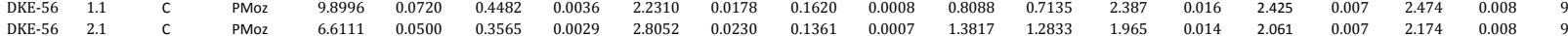

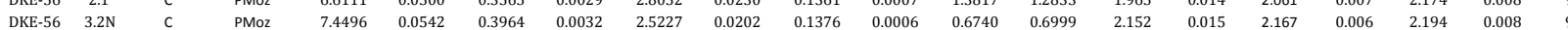

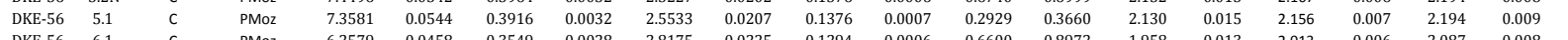

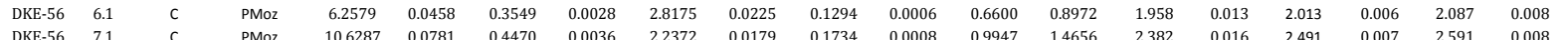

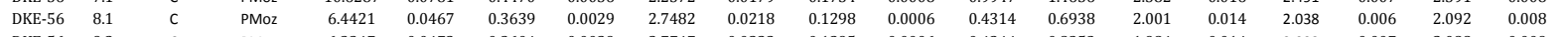

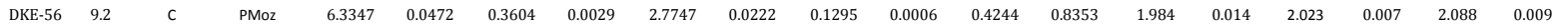

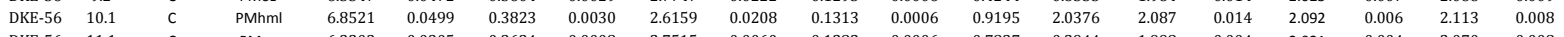

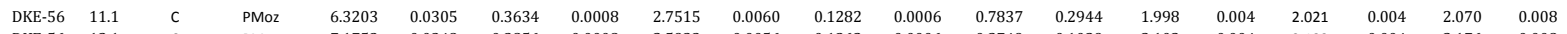
DKE-56 12.1 DKE-56 13.1 DKE-56 14.1 DKE-56 15.1 $\begin{array}{ll}\text { DKE-56 } & 16.1 \\ \text { DRE-56 } & 17.1\end{array}$ \begin{tabular}{ll} 
DKE-56 & 17.1 \\
\hline
\end{tabular} DKE-56 18.1 \begin{tabular}{ll} 
DKE-56 & 19.1 \\
\hline
\end{tabular} DKE-56 20.1 $\begin{array}{ll}\text { DKE-56 } & 21.1 \\ \text { DKE-56 } & 22.1\end{array}$ $\begin{array}{ll}\text { DKE-56 } & 22.1 \\ \text { DKE-56 } & 23.1\end{array}$ $\begin{array}{ll}\text { DKE-56 } & 23.1 \\ \text { DKE-56 } & 24.1\end{array}$ \begin{tabular}{ll} 
DKE-56 & 24.1 \\
\hline
\end{tabular} $\begin{array}{ll}\text { DKE-56 } & 25.1 \\ \text { DKE-56 } & 271\end{array}$ $\begin{array}{ll}\text { DKE-56 } & 27.1 \\ \text { DKE-56 } & 282\end{array}$ $\begin{array}{ll}\text { DKE-56 } & 28.2 \\ \text { DKE-56 } & 29.18\end{array}$ $\begin{array}{cc}\text { DKE-56 } & 29.1 \mathrm{~B} \\ \text { DKE-56 } & 29.2\end{array}$ \begin{tabular}{ll} 
DKE-56 & 29.2 \\
\hline DKE-56 & 30.1
\end{tabular} $\begin{array}{ll}\text { DKE-56 } & 30.1 \\ \text { DKE-56 } & 31.1\end{array}$ $\begin{array}{ll}\text { DKE-56 } & 32.1\end{array}$ DKE-56 33.1 $\begin{array}{ll}\text { DKE-56 } & 34.1 \\ \text { DKE-56 } & 46.1\end{array}$ DKE-56 47.1 DKE-56 48.1 DKE-56 49.1 \begin{tabular}{ll} 
DKE-56 & $50.1 \mathrm{~N}$ \\
\hline
\end{tabular} DKE-56 50.2B $\begin{array}{ll}\text { DKE-56 } & 51.1 \\ \text { DKE-56 } & 52.1 \\ \text { DKE-56 } & 53.1\end{array}$ DKE-56 53.1 \begin{tabular}{ll} 
DKE-56 & 54.1 \\
\hline
\end{tabular} DKE-56 55.1 DKE-56 56.1 DKE-56 57.1 DKE-56 60.1 DKE-56 62.1 DKE-56 63.1 DKE-56 64.1

\begin{tabular}{ll} 
DKE-56 & 65.1 \\
\hline
\end{tabular}

$\begin{array}{ll}\text { DKE-56 } & 66.1 \\ \text { DKE-56 } & 68.1\end{array}$

$\begin{array}{ll}\text { DKE-56 } & 68.1 \\ \text { DKE-56 } & 69.1\end{array}$

$\begin{array}{ll}\text { DKE-56 } & 69.1 \\ \text { DKE-56 } & 70.2 \mathrm{~N}\end{array}$ DKE-56 $70.2 \mathrm{~N} \quad \mathrm{C} \quad$ PM DKE-56 $70.1 \mathrm{~B} \quad \mathrm{R}$ (overgrowths) $\begin{array}{llll}\text { DKE-56 } & 70.1 \mathrm{~B} & \mathrm{R} & \mathrm{Mog} \\ \text { Zircons not included on related diagrams } & \end{array}$ $\begin{array}{llll}\text { Zircons not included on related diagrams } \\ \text { DKE-56 } & 3.1 \mathrm{~B} & \mathrm{R} & \text { Mog } \\ \text { DKE-56 } & 4.1 \mathrm{~N} & \mathrm{C} & \text { PMoz }\end{array}$ $\begin{array}{ll}\text { DKE-56 } & 4.1 \mathrm{~N} \\ \text { DKE-56 } & 4.2 \mathrm{~B}\end{array}$ $\begin{array}{cc}\text { DKE-56 } & 4.2 \mathrm{~B} \\ \text { DKE-56 } & 9.1\end{array}$ $\begin{array}{ll}\text { DKE-56 } & 9.1 \\ \text { DKE } & 26.1\end{array}$ DKE-56 28.1B DKE-56 59.1 $\begin{array}{ll}\text { DKE-56 } & 58.1 \\ \text { DKE-56 } & 61.1 \\ \text { DKE-56 } & 67.1\end{array}$ DKE-56 67.1 


\begin{tabular}{|c|c|c|c|c|c|c|c|c|c|c|c|c|c|c|c|c|c|c|c|c|c|}
\hline Sample & Spot\# & pot pos. & Interp. CL & ${ }^{207} \mathbf{P b} /{ }^{235} \mathrm{U}$ & $\pm 1 \mathrm{~s}$ & ${ }^{206} \mathbf{P b} /^{238} \mathrm{U}$ & $\pm 1 \mathrm{~s}$ & ${ }^{238} \mathrm{~Pb} /{ }^{206} \mathrm{U}$ & $\pm 1 s$ & ${ }^{207} \mathbf{P b} / /^{206} \mathrm{U}$ & $\pm 1 \mathrm{~s}$ & ${ }^{208} \mathrm{~Pb} / /^{206} \mathrm{U}$ & $\pm 1 \mathrm{~s}$ & ${ }^{206} \mathbf{P b} \mathbf{~}^{23 \mathbf{S}^{-}}$ & $\pm 1 \mathrm{~s}$ & ${ }^{207} \mathbf{P b} /{ }^{235} \mathbf{U}$ & $\pm 1 \mathrm{~s}$ & ${ }^{207} \mathrm{~Pb} /{ }^{206} \mathrm{U}$ & $\pm 1 \mathrm{~s}$ & Conc. (\%) & Conc. (\%) \\
\hline NCEB-351 & 1.1 & c & PMoz & 7.1395 & 0.0772 & 0.3919 & 0.0027 & 2.5514 & 0.0174 & 0.1343 & 0.0013 & 0.2107 & 0.0305 & 2.132 & 0.012 & 2.129 & 0.010 & 2.152 & 0.016 & 101 & \\
\hline NCEB-351 & 2.1 & C & PMoz & 7.1007 & 0.0868 & 0.3841 & 0.0032 & 2.6033 & 0.0219 & 0.1358 & 0.0013 & 0.2435 & 0.0352 & 2.096 & 0.015 & 2.124 & 0.011 & 2.171 & 0.017 & 104 & 97 \\
\hline NCEB-351 & 3.1 & c & PMoz & 6.3539 & 0.0707 & 0.3643 & .0026 & 2.7450 & 0.0192 & 0.1283 & 0.0012 & 0.2117 & 0.0309 & 2.002 & 0.012 & 2.026 & 0.010 & 2.072 & 0.016 & 103 & 97 \\
\hline NCEB-351 & 4.1 & c & PMoz & 6.8435 & 0.0732 & 0.3961 & 0.0026 & 2.5248 & 0.0166 & 0.1260 & 0.0012 & 0.5965 & 0.0885 & 2.151 & 0.012 & 2.091 & 0.009 & 2.040 & 0.017 & 95 & 105 \\
\hline NCEB-351 & 5.1 & c & PMoz & 14.5873 & 0.1563 & 0.5286 & 0.0035 & 1.8917 & 0.0127 & 0.2025 & 0.0019 & 0.4016 & 0.0601 & 2.736 & 0.015 & 2.789 & 0.010 & 2.852 & 0.015 & 104 & 96 \\
\hline NCEB-351 & 6.1 & c & PMoz & 6.7503 & 0.0723 & 0.3810 & 0.0026 & 2.6247 & 0.0177 & 0.1302 & 0.0012 & 0.3432 & 0.0521 & 2.081 & 0.012 & 2.079 & 0.009 & 2.098 & 0.016 & 101 & 99 \\
\hline NCEB-351 & 7.1 & c & PMhml & 6.2465 & 0.0704 & 0.3604 & 0.0026 & 2.7745 & 0.0197 & 0.1283 & 0.0012 & 0.5203 & 0.0800 & 1.984 & 0.012 & 2.011 & 0.010 & 2.073 & 0.016 & 104 & 96 \\
\hline NCEB-351 & 9.1 & c & PMhml & 11.7793 & 0.1258 & 0.4832 & 0.0032 & 2.0696 & 0.0137 & 0.1803 & 0.0017 & 0.8096 & 0.1278 & 2.541 & 0.014 & 2.587 & 0.010 & 2.658 & 0.016 & 105 & 96 \\
\hline NCEB-351 & 12.1 & $\mathrm{R}$ & PMoz & 6.8251 & 0.0736 & 0.3759 & 0.0025 & 2.6601 & 0.0176 & 0.1325 & 0.0012 & 0.3211 & 0.0529 & 2.057 & 0.012 & 2.089 & 0.010 & 2.128 & 0.016 & 103 & 97 \\
\hline NCEB-351 & 17.1 & c & PMOZ & 6.6866 & 0.1378 & 0.3638 & 0.0095 & 2.7484 & 0.0714 & 0.1353 & 0.0008 & 0.2945 & 0.1512 & 2.000 & 0.045 & 2.071 & 0.018 & 2.164 & 0.010 & 108 & 92 \\
\hline NCEB-351 & 20.1 & c & PMhml & 6.4281 & 0.1348 & 0.3572 & 0.0094 & 2.7992 & 0.0738 & 0.1289 & 0.0008 & 0.0687 & 0.0307 & 1.969 & 0.045 & 2.036 & 0.018 & 2.081 & 0.011 & 106 & 95 \\
\hline NCEB-351 & 21.1 & c & PMhml & 6.5267 & 0.1347 & 0.3677 & .0096 & 2.7195 & 0.0713 & 0.1300 & 0.0007 & 0.6466 & 0.2724 & 2.019 & 0.045 & 2.050 & 0.018 & 2.095 & 0.010 & 104 & 96 \\
\hline NCEB-351 & 23.1 & c & PMoz & 6.9835 & 0.1485 & 0.3764 & 0.0100 & 2.6569 & 0.0708 & 0.1346 & 0.0008 & 0.3556 & 0.1376 & 2.059 & 0.047 & 2.109 & 0.019 & 2.156 & 0.011 & 105 & 96 \\
\hline NCEB-351 & 24.1 & c & PMoz & 4.7001 & 0.0984 & 0.3149 & 0.0083 & 3.1758 & 0.0841 & 0.1094 & 0.0007 & 0.5066 & 0.1883 & 1.765 & 0.041 & 1.767 & 0.017 & 1.792 & 0.012 & 102 & 98 \\
\hline NCEB-351 & 27.1 & c & PMoz & 6.3908 & 0.1079 & 0.3629 & 0.0049 & 2.7559 & 0.0371 & 0.1272 & 0.0008 & 0.1689 & 0.0448 & 1.996 & 0.023 & 2.031 & 0.015 & 2.057 & 0.010 & 103 & 97 \\
\hline NCEB-351 & 28.1 & c & PMoz & 19.7208 & 0.3351 & 0.5952 & 0.0082 & 1.6800 & 0.0231 & 0.2418 & 0.0014 & 0.3051 & 0.0803 & 3.011 & 0.033 & 3.078 & 0.016 & 3.134 & 0.009 & 104 & 96 \\
\hline NCEB-351 & 30.1 & c & PMOZ & 6.3193 & 0.1042 & 0.3587 & 0.0048 & 2.7876 & 0.0374 & 0.1272 & 0.0007 & 0.1602 & 0.0415 & 1.976 & 0.023 & 2.021 & 0.014 & 2.057 & 0.010 & 104 & 96 \\
\hline NCEB-351 & 33.1 & $\mathrm{R}$ & PMoz & 6.1044 & 0.0997 & 0.3503 & 0.0047 & 2.8550 & 0.0379 & 0.1270 & 0.0007 & 0.1616 & 0.0410 & 1.936 & 0.022 & 1.991 & 0.014 & 2.054 & 0.010 & 106 & 94 \\
\hline NCEB-351 & 37.1 & c & PMOZ & 3.6932 & 0.0618 & 0.2719 & 0.0036 & 3.6773 & 0.0493 & 0.0973 & 0.0006 & 0.6608 & 0.1622 & 1.551 & 0.018 & 1.5 & 0.013 & 1.579 & 0.012 & 102 & 98 \\
\hline NCEB-351 & 38.1 & c & PMoz & 6.5024 & 0.1075 & 0.3569 & 0.0048 & 2.8015 & 0.0380 & 0.1311 & 0.0008 & 0.2539 & 0.0619 & 1.968 & 3 & 2.0 & 0.01 & 2.110 & 0.010 & 10 & 93 \\
\hline СЕВ-351 & 41.1 & c & PMOZ & 6.8454 & 0.1139 & 0.3758 & 0.0039 & 2.6607 & 0.0275 & 0.1331 & 0.0015 & 0.2906 & 0.0530 & 2.057 & 8 & 2.0 & 0.0 & 2.136 & 0.019 & & 96 \\
\hline NCEB-351 & 50.1 & c & PMzC & 6.3193 & 0.0791 & 0.3535 & 0.0031 & 2.8291 & 0.0246 & 0.1310 & 0.0009 & 0.2249 & 0.0269 & 1.951 & 0.015 & 2.021 & 0.011 & 2.108 & 0.011 & 08 & 93 \\
\hline NCEB-351 & 59.1 & c & PMoz & 12.2677 & 0.1414 & 0.4876 & 0.0038 & 2.0507 & 0.0160 & 0.1870 & 0.0012 & 0.2284 & 0.0272 & 2.560 & 0.016 & 2.625 & 0.011 & 2.719 & 0.011 & 106 & 94 \\
\hline NCEB-351 & 60.1 & c & PMoz & 6.9354 & 0.0843 & 0.3738 & 0.0032 & 2.6754 & 0.0232 & 0.1345 & 0.0008 & 0.2665 & 0.0317 & 2.047 & 0.015 & 2.103 & 0.011 & 2.155 & 0.011 & 105 & 95 \\
\hline NCEB-351 & 61.1 & c & PMoz & 7.1994 & 0.0835 & 0.3788 & 0.0030 & 2.6399 & 0.0207 & 0.1378 & 0.0009 & 0.3614 & 0.0431 & 2.071 & 0.014 & 2.136 & 0.010 & 2.196 & 0.011 & 106 & 94 \\
\hline NCEB-351 & $43.2 \mathrm{~N}$ & c & PMoz & 6.7874 & 0.1094 & 0.3619 & 0.0036 & 2.7632 & 0.0273 & 0.1354 & 0.0015 & 0.2878 & 0.0527 & 1.991 & 0.017 & 2.084 & 0.014 & 2.165 & 0.019 & 109 & 92 \\
\hline NCEB-351 & $45.2 \mathrm{~N}$ & c & PMoz & 13.4201 & 0.2114 & 0.4899 & 0.0047 & 2.0412 & 0.0197 & 0.2002 & 0.0022 & 0.6457 & 0.1190 & 2.570 & 0.020 & 2.710 & 0.015 & 2.833 & 0.018 & 110 & 91 \\
\hline \multirow{2}{*}{\multicolumn{22}{|c|}{ 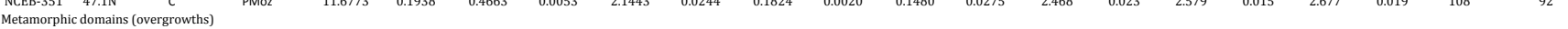 }} \\
\hline & & & & & & & & & & & & & & & & & & & & & \\
\hline NCEB-351 & 8.1 & $\mathrm{R}$ & Mog & 52 & 10 & 0 & 0008 & 10.45 & 34 & t & 06 & 0.0135 & 0025 & 89 & 04 & 0.5 & 106 & 12 & 0.022 & 04 & 96 \\
\hline NCEB-351 & 13.1 & $\mathrm{R}$ & Mog & 0.8210 & 0.0087 & 0.0999 & 0.0007 & 10.0144 & 0.0668 & 0.0603 & 0.0006 & 0.0082 & 0.0016 & 0.614 & 0.004 & 0.609 & 0.005 & 0.609 & 0.020 & 99 & 101 \\
\hline NCEB-351 & 14.1 & $\mathrm{R}$ & Mog & 0.8308 & 0.0170 & 0.1004 & 0.0026 & 9.9579 & 0.2566 & 0.0606 & 0.0004 & 0.0166 & 0.0103 & 0.617 & 0.015 & 0.614 & 0.009 & 0.619 & 0.013 & 100 & 100 \\
\hline NCEB-351 & 16.1 & $\mathrm{R}$ & Mog & 0.7729 & 0.0165 & 0.0936 & 0.0024 & 10.6782 & 0.2769 & 0.0598 & 0.0005 & 0.0108 & 0.0060 & 0.577 & 0.014 & 0.581 & 0.009 & 0.589 & 0.018 & 102 & 98 \\
\hline NCEB-351 & 35.1 & $\mathrm{R}$ & Mog & 0.7390 & 0.0134 & 0.0887 & 0.0012 & 11.2735 & 0.1562 & 0.0596 & 0.0004 & 0.0137 & 0.0038 & 0.548 & 0.007 & 0.562 & 0.008 & 0.581 & 0.014 & 106 & 94 \\
\hline NCEB-351 & 36.1 & $\mathrm{R}$ & Mog & 0.8542 & 0.0143 & 0.1028 & 0.0014 & 9.7250 & 0.1310 & 0.0596 & 0.0004 & 0.0004 & 0.0026 & 0.631 & 0.008 & 0.627 & 0.008 & 0.582 & 0.015 & 92 & 108 \\
\hline NCEB-351 & 39.1 & $\mathrm{R}$ & Mog & 0.8868 & 0.0151 & 0.1052 & 0.0015 & 9.5063 & 0.1331 & 0.0613 & 0.0005 & 0.0085 & 0.0030 & 0.645 & 0.009 & 0.645 & 0.008 & 0.642 & 0.017 & 100 & 100 \\
\hline EB-351 & 40.1 & $\mathrm{R}$ & Mog & 0.8189 & 0.0138 & 0.1002 & 0.0011 & 9.9818 & 0.1109 & 0.0600 & 0.0007 & 0.0096 & 0.0018 & 0.615 & 0.007 & 0.607 & 0.008 & & 0.024 & 97 & 103 \\
\hline EB-351 & 42.1 & $\mathrm{R}$ & M & 0.7649 & & 0.09 & 0.0011 & 10.7081 & 0.1236 & 0.0595 & 0.0007 & 0.0091 & 0.0017 & & 0.006 & 0.5 & 0.008 & & 0.024 & & 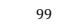 \\
\hline NCEB-351 & 44.1 & $\mathrm{R}$ & Mog & 0.7643 & 133 & 0.0943 & 0.0009 & 10.6073 & 0.106 & 0.0596 & 0.0008 & 0.0023 & 0.0028 & 0.5 & 0.006 & 0.5 & $0 . c$ & & 0.028 & 10 & 100 \\
\hline NCEB-351 & 47.2 & $\mathrm{R}$ & Mog & 0.7492 & 0.0131 & 0.0928 & 0.0011 & 10.7713 & 0.1226 & 0.0595 & 0.0007 & 0.0093 & 0.0020 & 0.572 & 0.006 & 0.568 & 0.008 & 0.579 & 0.025 & 10 & 99 \\
\hline NCEB-351 & 48.1 & $\mathrm{R}$ & Mog & 0.8226 & 0.0133 & 0.0976 & 0.0010 & 10.2470 & 0.1012 & 0.0616 & 0.0007 & 0.0069 & 0.0015 & 0.600 & 0.006 & 0.609 & 0.007 & 0.655 & 0.025 & 109 & 92 \\
\hline NCEB-351 & 49.1 & $\mathrm{R}$ & Mog & 0.7662 & 0.0107 & 0.0912 & 0.0007 & 10.9657 & 0.0847 & 0.0604 & 0.0005 & 0.0020 & 0.0019 & 0.563 & 0.004 & 0.578 & 0.006 & 0.613 & 0.019 & 109 & 92 \\
\hline NCEB-351 & 51.1 & $\mathrm{R}$ & M & 0.7015 & 0.0088 & 0.0877 & 0.0007 & 11.4075 & 0.0976 & 0.0587 & 0.0004 & 0.0044 & 0.0007 & 0.542 & 0.004 & 0.540 & 0.005 & 0.548 & 0.015 & 101 & 99 \\
\hline NCEB-351 & 52.1 & $\mathrm{R}$ & Mog & 0.8417 & 0.0104 & 0.0999 & 0.0007 & 10.0136 & 0.0741 & 0.0605 & 0.0005 & 0.0006 & 0.0015 & 0.614 & 0.004 & 0.620 & 0.006 & 0.616 & 0.017 & 100 & 100 \\
\hline NCEB-351 & 56.1 & $\mathrm{R}$ & Mog & 0.8064 & 0.0096 & 0.0965 & 0.0008 & 10.3663 & 0.0826 & 0.0608 & 0.0004 & 0.0069 & 0.0013 & 0.594 & 0.005 & 0.600 & 0.005 & & 0.014 & & 95 \\
\hline B-351 & $45.1 \mathrm{~B}$ & $\mathrm{p}$ & $M$ & 0. & & 0.0966 & .0009 & 10.3538 & 0.0 & r & 0.0007 & 0.0112 & 0.0024 & 0.594 & 0.005 & 0.5 & 0.007 & 0.6 & 0.025 & & 97 \\
\hline NCEB-351 & $43.1 \mathrm{~B}$ & $\mathrm{R}$ & & 0 & & 0.1028 & 0 & 9.7 & 0.09 & 0. & & 0 & 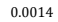 & & & 0.62 & & & 0. & & 101 \\
\hline \multirow{2}{*}{\multicolumn{22}{|c|}{$\begin{array}{l}\text { NCEB-351 } 45.3 B \\
\text { Zircons not included }\end{array}$}} \\
\hline & & & & & & & & & & & & & & & & & & & & & \\
\hline NCEB-351 & 18.1 & C & PMoz & 5.6601 & 0.1165 & 0.3296 & 0.0086 & 3.0338 & 0.0790 & 0.1257 & 0.0007 & 0.7843 & 0.3815 & 1.837 & 0.042 & 1.925 & 0.018 & 2.037 & 0.010 & 111 & 90 \\
\hline NCEB-351 & 10.1 & c & & & & 0.2 & 0.0021 & 3.7894 & 0.0298 & & $0 . c$ & 0.3015 & 0.0483 & 1.510 & 0.011 & 1.7 & 0.010 & 2.007 & 0.016 & 133 & 75 \\
\hline NCEB-351 & 11.1 & c & & 3.6565 & & 0.235 & 0.0020 & 4.2491 & 0.0 & 0.1175 & 0. & 0.1221 & 0.0199 & 1.362 & 0.010 & 1.5 & 0.010 & 1.918 & 0.017 & 141 & 71 \\
\hline NCEB-351 & 15.1 & R & PMOZ & 5.0353 & & 0.3049 & 0.0079 & 3.2803 & 0.0847 & 0.1223 & 0 & 0.1776 & 0.1022 & 1.715 & 0.039 & $\begin{array}{l}1.825 \\
\end{array}$ & 0.017 & 1.989 & 0.010 & 11 & 86 \\
\hline NCEB-351 & 19.1 & c & PMOZ & 3.1637 & 0.0717 & 0.2006 & 0.0054 & 4.9849 & 0.1345 & & 0.0008 & 0.0514 & 0.0240 & & & 1.448 & 0 & & 0.011 & & 60 \\
\hline NCEB-351 & 22.1 & c & PMOZ & & & 0.20 & 0.0054 & 4.9398 & 01 & & & 年 & 0.0757 & & & 1.4 & & & 0. & & 65 \\
\hline & 32. & c & & & & & & 6.3 & & & & & & & & & & & & & 60 \\
\hline & 25. & c & & & & & & & & & & & & & & 2.3 & & & & & 86 \\
\hline $\mathrm{NC}$ & 34.1 & R & $\mathrm{M}$ & & & & & 12 . & & & & & & & & 0.5 & & 0. & 0.014 & 116 & 87 \\
\hline NCEB-351 & 31.1 & $\mathrm{R}$ & & & & 0.0 & 0.0 & 10.5 & & 0.0 & & 0.0080 & 0.0022 & 0. & & 0.5 & 0.0 & 0.416 & 0.015 & 74 & 135 \\
\hline NCEB-351 & 46.1 & R & & 6.0440 & & 0.33 & 0.0032 & 2.9587 & 0.0279 & 0.1 & 0.0014 & 0.1041 & 0.0193 & 1.8 & 0.015 & 1.9 & 0.014 & 2.096 & 0.019 & 112 & 90 \\
\hline NCEB-351 & 53.1 & c & PN & 1.2779 & 0.0 & 0.1231 & 0.0010 & 8.12 & 0.0674 & 0.0 & 0.0005 & 0.0234 & 0.0032 & 0.749 & 0.006 & 0.836 & 0.007 & 1.104 & 0.014 & 147 & 68 \\
\hline NCEB-351 & 54.1 & c & PMoz & 1.3360 & 0.0158 & 0.1212 & 0.0009 & 8.2479 & 0.0627 & 0.0811 & 0.0006 & 0.0278 & 0.0035 & 0.738 & 0.005 & 0.861 & 0.007 & 1.228 & 0.014 & 166 & 60 \\
\hline NCEB-351 & 55.1 & c & PMoz & 2.9847 & 0.0378 & 0.2002 & .0018 & 4.9957 & 0.0449 & 0.1096 & 0.0007 & 0.2414 & 00287 & 1176 & 0.010 & 1.404 & 0.010 & 1706 & 0.011 & 153 & 65 \\
\hline & 57. & c & & & & ד7ר? & & 2. & & & & & & & & 1.960 & 然 & & 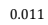 & & 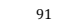 \\
\hline & 58. & c & & & & & & & & & & & & & & & & & & & 3 \\
\hline & 29 & $\mathrm{R}$ & & & & & & & & & & & & & & & & & & & 79 \\
\hline B-351 & 26.1 & $\mathrm{R}$ & M & 0.7689 & 0.0164 & 0.0893 & 0.0024 & 1.1942 & 0.3019 & 0.0610 & 0.0004 & .0203 & 0.0071 & 0.552 & 0.014 & 0.579 & 0.009 & 0.634 & 0.013 & 115 & 87 \\
\hline
\end{tabular}




\begin{tabular}{|c|c|c|c|c|c|c|c|c|c|c|c|c|c|c|c|c|c|c|c|c|c|}
\hline Sample & Spot & Spot pos. & Interp. CL & ${ }^{207} \mathbf{P b} /{ }^{235} \mathbf{U}$ & $\pm 1 \mathrm{~s}$ & ${ }^{206} \mathrm{~Pb} /{ }^{238} \mathrm{U}$ & $\pm 1 \mathrm{~s}$ & ${ }^{238} \mathrm{~Pb} /{ }^{206} \mathrm{U}$ & $\pm 1 \mathrm{~s}$ & ${ }^{207} \mathrm{~Pb} /{ }^{206} \mathrm{U}$ & \pm & ${ }^{208} \mathbf{P b} /{ }^{206} \mathbf{U}$ & $\pm 1 s$ & ${ }^{206} \mathrm{~Pb} /{ }^{238} \mathrm{U}$ & $\pm 1 \mathrm{~s}$ & ${ }^{207} \mathrm{~Pb} /{ }^{235} \mathrm{U}$ & \pm & ${ }^{207} \mathbf{P b} /{ }^{206} \mathbf{U}$ & $\pm 1 \mathrm{~s}$ & Conc. (\%) & Conc. (\%) \\
\hline NCEB-427 & 2.1 & $\mathrm{R}$ & Mog & 1.9366 & 0.0284 & 0.1803 & 0.0015 & 5.5465 & 0.0456 & 0.0776 & 0.0004 & 0.0474 & 0.0168 & 1.069 & 0.008 & 1.094 & 0.010 & 1.139 & 0.011 & 98 & 107 \\
\hline NCEB-427 & 3.1 & C & PMoz & 7.6458 & 0.1073 & 0.3901 & 0.0026 & 2.5635 & 0.0171 & 0.1412 & 0.0008 & 0.3808 & 0.1328 & 2.123 & 0.012 & 2.190 & 0.013 & 2.238 & 0.010 & 97 & 105 \\
\hline NCEB-427 & 4.1 & C & PMoz & 6.9282 & 0.0962 & 0.3687 & 0.0024 & 2.7125 & 0.0178 & 0.1363 & 0.0008 & 0.2593 & 0.0894 & 2.023 & 0.011 & 2.102 & 0.012 & 2.177 & 0.010 & 96 & 108 \\
\hline NCEB-427 & 6.1 & C & PMoz & 12.2458 & 0.1730 & 0.4686 & 0.0032 & 2.1339 & 0.0146 & 0.1881 & 0.0011 & 0.5891 & 0.1983 & 2.477 & 0.014 & 2.623 & 0.013 & 2.729 & 0.010 & 94 & 110 \\
\hline NCEB-427 & 8.1 & C & PMoz & 2.1134 & 0.0367 & 0.1895 & 0.0015 & 5.2779 & 0.0412 & 0.0814 & 0.0009 & 1.7581 & 0.5719 & 1.119 & 0.008 & 1.153 & 0.012 & 1.236 & 0.022 & 97 & 110 \\
\hline NCEB-427 & 9.1 & C & PMoz & 4.3024 & 0.0647 & 0.2940 & 0.0022 & 3.4016 & 0.0250 & 0.1083 & 0.0009 & 0.5332 & 0.1721 & 1.661 & 0.011 & 1.694 & 0.012 & 1.774 & 0.015 & 98 & 107 \\
\hline NCEB-427 & 10.1 & C & PMoz & 7.3895 & 0.1045 & 0.3865 & 0.0027 & 2.5871 & 0.0179 & 0.1407 & 0.0008 & 0.4000 & 0.1273 & 2.107 & 0.012 & 2.160 & 0.013 & 2.232 & 0.010 & 98 & 106 \\
\hline NCEB-427 & 11.1 & C & PMoz & 7.2381 & 0.1155 & 0.3911 & 0.0036 & 2.5568 & 0.0239 & 0.1352 & 0.0013 & 0.3485 & 0.1101 & 2.128 & 0.017 & 2.141 & 0.014 & 2.163 & 0.016 & 99 & 102 \\
\hline NCEB-427 & 12.1 & c & PMoz & 2.5889 & 0.0366 & 0.2213 & 0.0015 & 4.5181 & 0.0302 & 0.0863 & 0.0005 & 0.2509 & 0.0782 & 1.289 & 0.008 & 1.29 & 0.010 & 1. & 0.012 & 99 & 105 \\
\hline NCEB-427 & 13.1 & c & PMoz & 6.6553 & 0.0730 & 0.3658 & 0.0025 & 2.7336 & 0.0188 & 0.1336 & 0.0006 & 0.2017 & 0.0601 & 2.010 & 0.012 & 2.067 & 0.010 & 2.143 & 0.007 & 97 & 107 \\
\hline NCEB-427 & 15.1 & $\mathrm{R}$ & PMoz & 6.6997 & 0.0650 & 0.3743 & 0.0019 & 2.6714 & 0.0135 & 0.1320 & 0.0005 & 0.3308 & 0.1002 & 2.050 & 0.009 & 2.073 & 0.009 & 2.121 & 0.007 & 99 & 103 \\
\hline NCEB-427 & 16.1 & C & PMhhl & 5.5123 & 0.0560 & 0.3282 & 0.0019 & 3.0474 & 0.0173 & 0.1242 & 0.0007 & 0.3939 & 0.1205 & 1.829 & 0.009 & 1.903 & 0.009 & 2.016 & 0.009 & 96 & 110 \\
\hline NCEB- 427 & 17.1 & C & PMoz & 7.1572 & 0.0723 & 0.3866 & 0.0021 & 2.5866 & 0.0139 & 0.1353 & 0.0007 & 0.4423 & 0.1364 & 2.107 & 0.010 & 2.131 & 0.009 & 2.164 & 0.008 & 99 & 103 \\
\hline NCEB-427 & 18.1 & c & PMoz & 5.2824 & 0.0533 & 0.3303 & 0.0017 & 3.0272 & 0.0160 & 0.1176 & 0.0006 & 0.3568 & 0.1110 & 1.840 & 0.008 & 1.866 & 0.009 & 1.921 & 0.008 & 99 & 104 \\
\hline NCEB- 427 & 19.1 & $\mathrm{R}$ & PMoz & 7.5735 & 0.0740 & 0.3919 & 0.0020 & 2.5519 & 0.0132 & 0.1424 & 0.0006 & 0.3285 & 0.1029 & 2.131 & 0.009 & 2.182 & 0.009 & 2.252 & 0.007 & 98 & 106 \\
\hline NCEB-427 & 20.1 & C & PMoz & 8.2213 & 0.0836 & 0.4105 & 0.0023 & 2.4360 & 0.0138 & 0.1457 & 0.0006 & 0.3901 & 0.1234 & 2.2 & 0.011 & 2.2 & 0.009 & 2.2 & 0.008 & & 103 \\
\hline NCEB-427 & 22.1 & C & PMoz & 2.6812 & 0.0263 & 0.2282 & 0.0012 & 4.3827 & 0.0232 & 0.0857 & 0.0003 & 0.1471 & 0.0474 & 1. & 0.006 & 1.3 & 0.007 & 1. & 0.008 & 100 & 101 \\
\hline NCEB-427 & 23.1 & $\mathrm{R}$ & PMoz & 5.8449 & 0.0575 & 0.3378 & 0.0017 & 2.9604 & 0.0153 & 0.1264 & 0.0005 & 0.3903 & 0.1268 & 1.876 & 0.008 & 1.953 & 0.008 & 2.047 & 0.007 & & 109 \\
\hline NCEB-427 & 24.1 & $\mathrm{R}$ & PMhhl & 5.7130 & 0.0569 & 0.3418 & 0.0020 & 2.9254 & 0.0167 & 0.1223 & 0.0006 & 2.3513 & 0.7715 & 1.895 & 0.009 & 1.933 & 0.009 & 1.990 & 0.008 & 98 & 105 \\
\hline NCEB-427 & 26.1 & $\mathrm{R}$ & PMoz & 7.9167 & 0.1427 & 0.4007 & 0.0042 & 2.4954 & 0.0265 & 0.1429 & 0.0014 & 0.1477 & 0.0336 & 2.172 & 0.020 & 2.222 & 0.016 & 2.258 & 0.017 & 98 & 104 \\
\hline NCEB-427 & 27.1 & c & PMoz & 4.2301 & 0.0775 & 0.2936 & 0.0033 & 3.4064 & 0.0386 & 0.1052 & 0.0011 & 0.5408 & 0.1208 & 1.659 & 0.017 & 1.680 & 0.015 & 1.721 & 0.019 & 99 & 104 \\
\hline NCEB-427 & 28.1 & $\mathrm{R}$ & PMoz & 4.5742 & 0.0825 & 0.3109 & 0.0033 & 3.2163 & 0.0343 & 0.1071 & 0.0011 & 0.4279 & 0.0942 & 1.745 & 0.016 & 1.745 & 0.015 & 1.754 & 0.018 & 100 & 101 \\
\hline NCEB-427 & 29.1 & $\mathrm{R}$ & PMoz & 4.6577 & 0.0844 & 0.3165 & 0.0034 & 3.1598 & 0.0341 & 0.1057 & 0.0011 & 0.4184 & 0.0901 & 1.773 & 0.017 & 1.760 & 0.015 & 1.731 & 0.019 & 101 & 98 \\
\hline NCEB-427 & 30.1 & c & PMoz & 6.5957 & 0.1161 & 0.3709 & 0.0038 & 2.6958 & 0.0277 & 0.1293 & 0.0012 & 0.3721 & 0.0787 & 2.034 & 0.018 & 2.059 & 0.015 & 2.086 & 0.016 & 99 & 103 \\
\hline NCEB-427 & 31.1 & $\mathrm{R}$ & PMoz & 4.4300 & 0.0794 & 0.3004 & 0.0032 & 3.3294 & 0.0356 & 0.1064 & 0.0011 & 0.4596 & 0.0963 & 1.693 & 0.016 & 1.718 & 0.015 & 1.743 & 0.018 & 19 & 103 \\
\hline CEB-427 & 33.1 & C & PMhll & 6.6263 & 0.1175 & 0.3684 & 0.0038 & 2.7148 & 0.0283 & 0.1311 & 0.0012 & 0.2486 & .0507 & 2. & $0 . c$ & 2.0 & 0.0 & & 0.016 & & 104 \\
\hline NCEB-427 & 34.1 & c & PMoz & 1.8620 & 0.0335 & 0.1797 & 0.0020 & 5.5649 & 0.0628 & 0.0754 & 0.0008 & 0.6539 & 0.1317 & 1.065 & 0.011 & 1.068 & 0.012 & 1.081 & 0.022 & 100 & 101 \\
\hline NCEB-427 & 35.1 & c & PMoz & 3.4570 & 0.0624 & 0.2644 & 0.0028 & 3.7817 & 0.0400 & 0.0953 & 0.0009 & 0.3815 & 0.0760 & 1.512 & 0.014 & 1.517 & 0.014 & 1.540 & 0.018 & 100 & 102 \\
\hline NCEB-427 & 36.1 & C & PMoz & 8.2675 & 0.1447 & 0.4005 & 0.0041 & 2.4966 & 0.0257 & 0.1501 & 0.0014 & 0.2980 & 0.0586 & 2.172 & 0.019 & 2.261 & 0.016 & 2.343 & 0.016 & 96 & 108 \\
\hline NCEB-427 & 37.1 & c & PMoz & 7.8321 & 0.1405 & 0.4013 & 0.0044 & 2.4921 & 0.0273 & 0.1419 & 0.0013 & 0.2880 & 0.0560 & 2.175 & 0.020 & 2.212 & 0.016 & 2.247 & 0.016 & 98 & 103 \\
\hline NCEB-427 & 38.1 & C & PMoz & 8.0319 & 0.2116 & 0.4028 & 0.0051 & 2.4829 & 0.0315 & 0.1452 & 0.0024 & 0.1783 & 0.0385 & 2.182 & 0.023 & 2.235 & 0.024 & 2.286 & 0.028 & 98 & 105 \\
\hline NCEB-427 & 39.1 & c & PMoz & 14.0576 & 0.3716 & 0.5255 & 0.0069 & 1.9029 & 0.0251 & 0.1963 & 0.0031 & 0.2250 & 0.0493 & 2.722 & 0.029 & 2.754 & 0.025 & 2.801 & 0.026 & 99 & 103 \\
\hline NCEB-427 & 44.1 & c & PMoz & 14.0840 & 0.3638 & 0.5128 & 0.0065 & 1.9502 & 0.0247 & 0.2003 & 0.0031 & 0.0951 & 0.0231 & 2.668 & 0.028 & 2.755 & 0.024 & 2.834 & 0.026 & 97 & 106 \\
\hline NCEB-427 & 45.1 & c & PMoz & 7.8761 & 0.2028 & 0.4005 & 0.0050 & 2.4968 & 0.0314 & 0.1426 & 0.0023 & 0.1465 & 0.0367 & 2.171 & 0.023 & 2.217 & 0.023 & & 0.027 & 98 & 104 \\
\hline NCEB-427 & 46.1 & c & PMhhl & 7.1455 & 0.1854 & 0.3883 & 0.0049 & 2.5751 & 0.0326 & 0.1355 & 0.0022 & 0.1121 & 0.0288 & 2.115 & 0.023 & 2.130 & 0.023 & 2.167 & 0.028 & 99 & 102 \\
\hline NCEB-427 & 48.1 & $\mathrm{R}$ & PMoz & 4.3578 & 0.1118 & 0.2986 & 0.0038 & 3.3490 & 0.0425 & 0.1067 & 0.0017 & 0.3192 & 0.0855 & 1.684 & 0.019 & 1.704 & 0.021 & 1.747 & 0.028 & 99 & 104 \\
\hline NCEB-427 & 50.1 & c & PMoz & 7.4471 & 0.0519 & 0.3980 & 0.0039 & 2.5123 & 0.0247 & 0.1374 & 0.0012 & 0.2893 & 0.0841 & 2.160 & 0.018 & 2.167 & 0.006 & 2.191 & 0.014 & 100 & 101 \\
\hline NCEB-427 & 51.1 & $\mathrm{R}$ & PMoz & 4.8426 & 0.0315 & 0.3169 & 0.0031 & 3.1554 & 0.0304 & 0.1120 & 0.0009 & 0.3229 & 0.0927 & 1.775 & 0.015 & 1.792 & 0.005 & 1.834 & 0.014 & 99 & 103 \\
\hline NCEB-427 & 53.1 & C & PMoz & 2.0827 & 0.0153 & 0.1948 & 0.0019 & 5.1334 & 0.0505 & 0.0787 & 0.0007 & 0.3518 & 0.0975 & 1.147 & 0.010 & 1.143 & 0.005 & 1.167 & 0.017 & 100 & 102 \\
\hline NCEB-427 & 54.1 & C & PMoz & 2.7707 & 0.0194 & 0.2298 & 0.0022 & 4.3509 & 0.0423 & 0.0885 & 0.0007 & 0.3418 & 0.0936 & 1.334 & 0.012 & 1.348 & 0.005 & 1.400 & 0.016 & 99 & 105 \\
\hline NCEB-427 & 55.1 & C & PMoz & 1.5936 & 0.0110 & 0.1611 & 0.0016 & 6.2078 & 0.0604 & 0.0719 & 0.0006 & 0.1770 & 0.0480 & 0.963 & 0.009 & 0.968 & 0.004 & 0.984 & 0.017 & 99 & 102 \\
\hline NCEB-427 & 56.1 & c & PMoz & 2.280 & 0.0163 & 0.2046 & 0.0020 & 4.8872 & 0.0474 & & 0.0007 & 0.4595 & 0.1230 & & 0.011 & 1.2 & 0.005 & & 0.017 & & 103 \\
\hline NCEB-427 & 57.2 & c & $\mathrm{Pl}$ & 12.6929 & 0.0839 & 0.45 & 0. & 2.0 & 0.01 & & & 0.2 & 0.06 & 2.5 & $0 . c$ & 2.6 & & 2.7 & 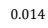 & & 105 \\
\hline NCEB-427 & 58.1 & c & PMoz & 1.6484 & 0.0112 & 0.1626 & & 6.149 & . & & & 0.3640 & 5 & 0. & 0.009 & 0.9 & 0.004 & 1. & 0.017 & 98 & 105 \\
\hline NCEB-427 & $49.2 \mathrm{~N}$ & c & PMhml & 2.1384 & 0.0548 & 0.1924 & 0.0 & 5.1970 & 0.0666 & $0 . c$ & 0 & 0.2744 & 0.0780 & 1.1 & 0.013 & 1.16 & $0 . c$ & 1. & 0.031 & 98 & 108 \\
\hline NCEB-427 & $52.2 \mathrm{~N}$ & C & PMoz & 6.7916 & 0.0470 & 0.3733 & 0.0 & 2.6792 & 0.0265 & & & 0.1128 & 0.0319 & 2.0 & 0.017 & 2.085 & $0 . c$ & 2.1 & 0.014 & 98 & 105 \\
\hline NCEB-427 & $60.1 \mathrm{~N}$ & c & PMoz & 2.5531 & 0.0166 & 0.2147 & 0.0021 & 4.6575 & 0.0450 & 0.0867 & 0.0007 & 0.1717 & 0.0436 & 1.254 & 0.011 & 1.287 & 0.005 & 1.360 & 0.016 & 97 & 108 \\
\hline \multirow{2}{*}{\multicolumn{22}{|c|}{ Metamorphic domains (overgrowt }} \\
\hline & & & & & & & & & & & & & & & & & & & & & \\
\hline NCEB-427 & 1.1 & $\mathrm{R}$ & M & & 0.012 & 0.0 & & & & & & 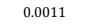 & 0.00 & & & 0.5 & 0.008 & & 0.0 & & 102 \\
\hline$N C F$ - $_{-}$ & $52.1 \mathrm{~B}$ & $\mathrm{R}$ & & & & 0.0 & & & & & & & & & 00 & & & & & & 101 \\
\hline $\mathrm{NC}$ & 41. & $\mathrm{r}$ & M & & & 0.0928 & & 10.7 & & & & 0.00 & & & & & & & & & 104 \\
\hline NCEB-427 & 21.1 & 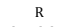 & Mog & 0.7980 & 0.0078 & 0.0956 & 0.0005 & 10.4601 & 0.0552 & 0.0606 & 0.0002 & 0.0112 & 0.0037 & 0.589 & 0.003 & 0.596 & 0.004 & 0.620 & 0.009 & 99 & 105 \\
\hline \multicolumn{22}{|c|}{ Zircons not included on related diagran } \\
\hline NCEB-427 & 16.1 & c & PMhhl & 5.6629 & 0.1012 & 0.328 & 0.0035 & 3.04 & 0.0325 & 0.12 & 0.00 & 0.25 & 0.0545 & 1.8 & 0.017 & 1.9 & 0.015 & 2.4 & 0.017 & 95 & 111 \\
\hline 27 & 59.1 & $\mathrm{R}$ & $\mathrm{M}$ & 0. & 0.0083 & 0.09 & 0.0011 & 10.3106 & 0.1217 & $0 . c$ & 0. & 0.0386 & 0.0099 & 0. & 0.007 & 0.638 & 0.004 & 0.794 & 0.018 & 93 & 133 \\
\hline NCEB-427 & 57.1 & $\mathrm{R}$ & & 0.5634 & 0.0066 & 0.0711 & 0.0008 & 14.0582 & & & & 0.0133 & 0.0036 & & 0.005 & 0.454 & 0.004 & 0.592 & 0.019 & 88 & 134 \\
\hline NCEB-427 & 5.1 & $\mathrm{R}$ & PMhhl & 1.7852 & 0.0279 & 0.1525 & 0.0013 & 6.5595 & 0.0575 & 0.0854 & 0.0007 & 0.3706 & 0.1263 & 0.915 & 0.007 & 1.040 & 0.010 & 1. & 0.016 & 38 & 145 \\
\hline NCEB-4 & 49.1B & $\mathrm{D}$ & Mc & 0.5457 & 0.01 & 006 & $0.0 c$ & 14.9940 & 02 & & & & & & n & 04 & & & 0.034 & 34 & 35 \\
\hline & 47. & R & & & & & & 9.6 & & & & & & & & & & & & & 193 \\
\hline & 42 & c & & & & & & & & & & & & & & & & & & 95 & - \\
\hline NCEB-427 & 43.1 & $\mathrm{R}$ & $\mathrm{M}$ & & 0.0 & & & & & & & 0. & & 1. & & 1.1 & 0. & 1.367 & 0.030 & 92 & 129 \\
\hline NCEB-427 & 40.1 & c & PMoz & 5.7 & 0.1511 & 0.32 & 0.0 & 3.0 & 0.0389 & & & 0.0 & 0.0 & 1. & 0.020 & 1.9 & 0.022 & 2. & 0.027 & 93 & 115 \\
\hline NCEB-427 & 25.1 & $\mathrm{R}$ & Mog & 0.9107 & 0.0099 & 0.1025 & 0.0007 & 9.7586 & 0.0650 & 0.0 & 0.0003 & 0.0088 & 0.0031 & 0.6 & 0.004 & 0.65 & 0.005 & 0.786 & 0.010 & 96 & 125 \\
\hline NCEB-427 & 20.1 & c & PMoz & 0.61 & 0.0116 & 0.07 & 0.0009 & 13.3569 & 0.1564 & 0.0 & 0.0006 & 0.0441 & 0.0091 & 0. & 0.005 & 0.490 & 0.007 & 0.612 & 0.021 & 95 & 131 \\
\hline NCEB-427 & $7.2 \mathrm{~B}$ & $\mathrm{R}$ & Mog & 0.3956 & 0.0078 & 0.0464 & 0.0005 & 21.5471 & 0.2528 & 0.0621 & 0.0006 & 0.1013 & 0.0334 & 0.292 & 0.003 & 0.338 & .006 & 0.673 & 0.020 & 86 & 230 \\
\hline $\mathrm{N}$ & 14.1 & R & PMoz & 3.8124 & 0.0387 & 0.2436 & 0.0014 & 4.1055 & 0.0236 & .1158 & 0.0005 & 4440 & 1334 & 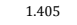 & 0.007 & .595 & .008 & 1.893 & 0.007 & 88 & 135 \\
\hline
\end{tabular}




\section{ANEXO II}

(análises SHRIMP U-Th-Pb em zircões ígneos) 


\begin{tabular}{|c|c|c|c|c|c|c|c|c|c|c|c|c|c|}
\hline sample/zircon & ${ }^{206} \mathrm{~Pb}_{\mathrm{c}}(\%)$ & U (ppm) & Th (ppm) & Th/U & ${ }^{206} \mathrm{~Pb}^{*}(\mathrm{ppm})$ & ${ }^{207} \mathrm{~Pb}^{*} /{ }^{206} \mathrm{~Pb}^{*}$ & $\pm(\%)$ & ${ }^{207} \mathrm{~Pb}^{*} /{ }^{235} \mathbf{U}$ & $\pm(\%)$ & ${ }^{206} \mathrm{~Pb}^{*} /{ }^{238} \mathrm{U}$ & $\pm(\%)$ & ${ }^{206} \mathrm{~Pb}^{*} /{ }^{238} \mathrm{U}$ (Ma) & $1 \mathrm{~s}$ \\
\hline 273A-1.1 & 4.33 & 214 & 74 & 0.36 & 28.07 & 0.0695 & 17.8 & 1.3945 & 18.2 & 0.1456 & 2.7 & 876.0 & 21.6 \\
\hline $273 \mathrm{~A}-2.1$ & 8.20 & 106 & 69 & 0.67 & 15.27 & 0.0714 & 31.1 & 1.5000 & 31.8 & 0.1525 & 3.3 & 914.8 & 27.6 \\
\hline 273A-3.1 & 1.80 & 969 & 63 & 0.07 & 87.07 & 0.0601 & 6.8 & 0.8497 & 7.3 & 0.1026 & 2.3 & 629.8 & 13.8 \\
\hline $273 \mathrm{~A}-4.1$ & 3.07 & 776 & 66 & 0.09 & 69.66 & 0.0647 & 10.1 & 0.9013 & 10.5 & 0.1011 & 2.3 & 620.6 & 13.7 \\
\hline $273 \mathrm{~A}-5.1$ & 6.05 & 155 & 54 & 0.36 & 20.88 & 0.0709 & 21.3 & 1.4318 & 21.8 & 0.1465 & 2.8 & 881.6 & 22.8 \\
\hline $273 A-5.2$ & 1.17 & 1044 & 226 & 0.22 & 94.57 & 0.0634 & 5.2 & 0.9109 & 5.8 & 0.1042 & 2.3 & 638.9 & 14.0 \\
\hline $273 A-6.1$ & 5.23 & 136 & 81 & 0.62 & 18.31 & 0.0653 & 19.5 & 1.3341 & 20.1 & 0.1482 & 2.9 & 891.0 & 23.8 \\
\hline 273A-7.1 & 8.80 & 86 & 25 & 0.30 & 12.31 & 0.0693 & 27.9 & 1.4370 & 28.8 & 0.1505 & 3.3 & 904.0 & 27.6 \\
\hline 273A-7.2 & 1.25 & 1184 & 265 & 0.23 & 104.53 & 0.0591 & 4.7 & 0.8266 & 5.3 & 0.1014 & 2.3 & 622.9 & 13.5 \\
\hline $273 A-8.1$ & 8.05 & 77 & 26 & 0.35 & 10.99 & 0.0974 & 24.3 & 2.0416 & 24.9 & 0.1518 & 3.4 & 911.2 & 28.6 \\
\hline $273 \mathrm{~A}-8.2$ & 3.79 & 328 & 195 & 0.61 & 41.28 & 0.0636 & 15.3 & 1.2290 & 15.7 & 0.1403 & 2.5 & 846.2 & 20.0 \\
\hline $273 A-9.1$ & 1.81 & 927 & 75 & 0.08 & 85.25 & 0.0607 & 6.7 & 0.8781 & 7.2 & 0.1050 & 2.4 & 643.4 & 15.0 \\
\hline $273 \mathrm{~A}-10.1$ & 4.99 & 154 & 95 & 0.63 & 20.32 & 0.0704 & 17.5 & 1.4088 & 18.0 & 0.1451 & 2.7 & 873.3 & 22.3 \\
\hline 273A-11.1 & 5.40 & 144 & 55 & 0.39 & 19.60 & 0.0651 & 23.8 & 1.3356 & 24.3 & 0.1489 & 3.0 & 894.8 & 24.8 \\
\hline $273 \mathrm{~A}-11.2$ & 2.91 & 688 & 149 & 0.22 & 57.51 & 0.0604 & 10.1 & 0.7852 & 10.5 & 0.0943 & 2.4 & 581.1 & 13.2 \\
\hline $273 \mathrm{~A}-12.1$ & 5.24 & 198 & 81 & 0.43 & 25.27 & 0.0758 & 15.5 & 1.4657 & 16.0 & 0.1403 & 2.7 & 846.4 & 21.1 \\
\hline $273 \mathrm{~A}-12.2$ & 2.55 & 655 & 155 & 0.24 & 57.57 & 0.0582 & 13.0 & 0.7979 & 13.3 & 0.0995 & 2.4 & 611.6 & 14.0 \\
\hline $273 \mathrm{~A}-12.3$ & 9.63 & 122 & 59 & 0.50 & 11.88 & 0.0636 & 42.5 & 0.8953 & 43.2 & 0.1021 & 3.7 & 626.7 & 21.7 \\
\hline 273A-13.1 & 7.39 & 76 & 31 & 0.43 & 10.68 & 0.0908 & 24.2 & 1.8921 & 24.8 & 0.1509 & 3.4 & 906.1 & 27.9 \\
\hline $273 \mathrm{~A}-14.1$ & 4.33 & 191 & 77 & 0.42 & 25.57 & 0.0697 & 19.1 & 1.4237 & 19.5 & 0.1483 & 2.8 & 891.3 & 22.6 \\
\hline 273A-15.1 & 7.00 & 119 & 44 & 0.38 & 16.60 & 0.0721 & 24.0 & 1.4863 & 24.7 & 0.1495 & 3.1 & 898.2 & 25.8 \\
\hline $273 \mathrm{~A}-16.1$ & 8.35 & 96 & 30 & 0.32 & 14.56 & 0.0735 & 36.9 & 1.6274 & 37.7 & 0.1606 & 3.6 & 959.8 & 31.0 \\
\hline $273 \mathrm{~A}-17.1$ & 9.54 & 94 & 26 & 0.28 & 12.70 & 0.0692 & 37.5 & 1.3402 & 38.4 & 0.1405 & 3.5 & 847.4 & 27.3 \\
\hline sample/zircon & ${ }^{206} \mathrm{~Pb}_{\mathrm{c}}$ (\%) & U (ppm) & Th (ppm) & Th/U & ${ }^{206} \mathrm{~Pb}^{*}$ (ppm) & ${ }^{207} \mathrm{~Pb}^{*} /{ }^{206} \mathrm{~Pb}^{*}$ & $\pm(\%)$ & ${ }^{207} \mathrm{~Pb}^{*} /{ }^{2355} \mathrm{U}$ & $\pm(\%)$ & ${ }^{206} \mathrm{~Pb}^{*} / /^{238} \mathrm{U}$ & $\pm(\%)$ & ${ }^{206} \mathrm{~Pb}^{*} /{ }^{238} \mathrm{U}$ (Ma) & $1 \mathrm{~s}$ \\
\hline $125 \mathrm{~A}-1.1$ & 4.15 & 376 & 193 & 0.53 & 35.09 & 0.0629 & 16.6 & 0.9008 & 17.0 & 0.1039 & 2.5 & 637.2 & 15.4 \\
\hline $125 \mathrm{~A}-2.1$ & 2.21 & 664 & 485 & 0.76 & 62.35 & 0.0601 & 13.6 & 0.8853 & 13.9 & 0.1068 & 2.5 & 654.3 & 15.2 \\
\hline $125 \mathrm{~A}-3.1$ & 1.57 & 742 & 477 & 0.66 & 67.65 & 0.0634 & 6.9 & 0.9126 & 7.4 & 0.1044 & 2.3 & 640.0 & 14.1 \\
\hline $125 \mathrm{~A}-4.1$ & 3.58 & 354 & 189 & 0.55 & 32.92 & 0.0671 & 14.4 & 0.9632 & 14.8 & 0.1041 & 2.4 & 638.6 & 14.9 \\
\hline 125A-5.1 & 2.30 & 549 & 348 & 0.66 & 50.80 & 0.0629 & 9.9 & 0.9119 & 10.3 & 0.1051 & 2.6 & 644.3 & 15.9 \\
\hline $125 \mathrm{~A}-6.1$ & 3.16 & 390 & 226 & 0.60 & 37.12 & 0.0640 & 14.7 & 0.9458 & 15.0 & 0.1071 & 2.4 & 656.1 & 15.2 \\
\hline $125 \mathrm{~A}-7.1$ & 3.93 & 364 & 189 & 0.54 & 33.91 & 0.0625 & 18.3 & 0.8950 & 18.6 & 0.1038 & 2.6 & 636.9 & 15.4 \\
\hline $125 \mathrm{~A}-8.1$ & 5.54 & 224 & 117 & 0.54 & 21.85 & 0.0674 & 26.9 & 0.9945 & 27.3 & 0.1070 & 3.0 & 655.5 & 18.4 \\
\hline $125 \mathrm{~A}-9.1$ & 2.83 & 490 & 378 & 0.80 & 45.83 & 0.0620 & 12.0 & 0.9020 & 12.3 & 0.1055 & 2.4 & 646.7 & 14.6 \\
\hline $125 \mathrm{~A}-10.1$ & 3.21 & 439 & 307 & 0.72 & 41.65 & 0.0649 & 14.8 & 0.9538 & 15.2 & 0.1067 & 3.1 & 653.4 & 19.5 \\
\hline $125 \mathrm{~A}-11.1$ & 2.00 & 610 & 349 & 0.59 & 56.26 & 0.0628 & 9.5 & 0.9106 & 9.9 & 0.1051 & 2.4 & 644.2 & 14.4 \\
\hline $125 \mathrm{~A}-12.1$ & 2.26 & 604 & 443 & 0.76 & 57.01 & 0.0618 & 10.4 & 0.9128 & 10.7 & 0.1072 & 2.4 & 656.2 & 14.8 \\
\hline sample/zircon & ${ }^{206} \mathrm{~Pb}_{\mathrm{c}}$ (\%) & U (ppm) & Th (ppm) & Th/U & ${ }^{206} \mathrm{~Pb}^{*}$ (ppm) & ${ }^{207} \mathrm{~Pb}^{*} /{ }^{206} \mathrm{~Pb}^{*}$ & $\pm(\%)$ & ${ }^{207} \mathrm{~Pb}^{*} / /^{235} \mathrm{U}$ & $\pm(\%)$ & ${ }^{206} \mathrm{~Pb}^{*} /{ }^{238} \mathrm{U}$ & $\pm(\%)$ & ${ }^{206} \mathrm{~Pb}^{*} /{ }^{238} \mathrm{U}$ (Ma) & $1 \mathrm{~s}$ \\
\hline 273B-1.2 & 3.96 & 514 & 88 & 0.18 & 47.66 & 0.0678 & 18.5 & 0.9665 & 18.8 & 0.1034 & 2.9 & 634.1 & 17.5 \\
\hline 273B-2.1 & 8.96 & 116 & 21 & 0.19 & 14.36 & 0.0684 & 33.0 & 1.2305 & 33.8 & 0.1305 & 3.3 & 790.6 & 24.4 \\
\hline $273 \mathrm{~B}-2.2$ & 2.06 & 872 & 219 & 0.26 & 74.17 & 0.0598 & 6.9 & 0.7983 & 7.3 & 0.0969 & 2.3 & 596.2 & 13.1 \\
\hline 273B-3.1 & 6.66 & 258 & 78 & 0.31 & 23.56 & 0.0622 & 22.0 & 0.8477 & 22.5 & 0.0988 & 2.7 & 607.4 & 15.7 \\
\hline 273B-4.1 & 4.75 & 111 & 26 & 0.24 & 12.44 & 0.0973 & 18.4 & 1.6641 & 18.7 & 0.1239 & 3.1 & 752.8 & 21.5 \\
\hline 273B-5.1 & 10.28 & 88 & 32 & 0.37 & 12.15 & 0.0807 & 32.1 & 1.5995 & 33.0 & 0.1436 & 3.8 & 865.0 & 29.7 \\
\hline 273B-6.1 & 9.59 & 175 & 42 & 0.25 & 18.44 & 0.0791 & 35.4 & 1.2034 & 36.1 & 0.1102 & 4.1 & 674.1 & 25.5 \\
\hline 273B-7.1 & 2.26 & 632 & 118 & 0.19 & 56.22 & 0.0583 & 8.5 & 0.8133 & 9.0 & 0.1011 & 2.6 & 621.0 & 15.5 \\
\hline 273B-8.1 & 2.04 & 681 & 142 & 0.22 & 60.49 & 0.0591 & 7.1 & 0.8247 & 7.6 & 0.1012 & 2.3 & 621.3 & 13.7 \\
\hline 273B-9.1 & 2.70 & 630 & 125 & 0.20 & 55.37 & 0.0592 & 9.2 & 0.8109 & 9.7 & 0.0994 & 2.3 & 610.6 & 13.6 \\
\hline 273B-10.1 & 2.59 & 554 & 153 & 0.29 & 49.03 & 0.0575 & 10.9 & 0.7951 & 11.3 & 0.1003 & 2.4 & 616.0 & 13.9 \\
\hline 273B-11.1 & 7.45 & 152 & 35 & 0.24 & 16.94 & 0.0674 & 36.3 & 1.1117 & 36.9 & 0.1197 & 4.0 & 728.7 & 26.9 \\
\hline 273B-11.2 & 2.77 & 799 & 102 & 0.13 & 66.05 & 0.0623 & 8.1 & 0.8020 & 8.6 & 0.0934 & 2.3 & 575.5 & 12.9 \\
\hline 273B-12.1 & 8.15 & 151 & 39 & 0.26 & 17.42 & 0.0662 & 29.9 & 1.1165 & 30.6 & 0.1225 & 3.3 & 744.7 & 22.6 \\
\hline 273B-13.1 & 1.66 & 933 & 136 & 0.15 & 83.31 & 0.0607 & 6.9 & 0.8547 & 7.4 & 0.1021 & 2.3 & 626.8 & 13.7 \\
\hline 273B-14.1 & 1.99 & 714 & 122 & 0.18 & 65.18 & 0.0601 & 7.3 & 0.8610 & 7.8 & 0.1040 & 2.3 & 637.6 & 14.1 \\
\hline 273B-15.1 & 0.68 & 1765 & 591 & 0.35 & 152.30 & 0.0596 & 2.9 & 0.8188 & 3.7 & 0.0997 & 2.2 & 612.8 & 13.1 \\
\hline 273B-16.1 & 3.01 & 535 & 85 & 0.17 & 49.46 & 0.0629 & 14.2 & 0.9039 & 14.5 & 0.1042 & 2.5 & 639.0 & 15.0 \\
\hline 273B-17.1 & 3.01 & 381 & 242 & 0.66 & 49.49 & 0.0728 & 13.2 & 1.4682 & 13.6 & 0.1462 & 2.5 & 879.6 & 20.4 \\
\hline 273B-18.1 & 3.79 & 500 & 60 & 0.12 & 44.62 & 0.0632 & 17.9 & 0.8688 & 18.3 & 0.0998 & 2.6 & 613.0 & 14.9 \\
\hline sample/zircon & ${ }^{206} \mathrm{~Pb}_{\mathrm{c}}$ (\%) & U (ppm) & Th (ppm) & Th/U & ${ }^{206} \mathrm{~Pb}^{*}$ (ppm) & ${ }^{207} \mathrm{~Pb}^{*} /{ }^{206} \mathrm{~Pb}^{*}$ & $\pm(\%)$ & ${ }^{77} \mathbf{P b}^{*} / /^{235} \mathbf{U}$ & $\pm(\%)$ & ${ }^{16} \mathrm{~Pb}^{*} /{ }^{238} \mathrm{U}$ & $\pm(\%)$ & ${ }^{206} \mathrm{~Pb}^{*} /{ }^{238} \mathrm{U}$ (Ma) & $1 \mathrm{~s}$ \\
\hline $211-1.1$ & 0.69 & 552 & 377 & 0.71 & 47.80 & 0.0594 & 4.3 & 0.8202 & 5.1 & 0.1003 & 2.8 & 614.9 & 16.6 \\
\hline $211-2.1$ & 1.66 & 308 & 255 & 0.85 & 28.64 & 0.0620 & 7.3 & 0.9075 & 7.8 & 0.1065 & 2.4 & 650.7 & 15.2 \\
\hline $211-3.1$ & 4.44 & 336 & 228 & 0.70 & 31.81 & 0.0624 & 19.1 & 0.9014 & 19.5 & 0.1058 & 2.6 & 642.9 & 17.3 \\
\hline $211-4.1$ & 5.55 & 283 & 181 & 0.66 & 26.59 & 0.0612 & 28.1 & 0.8692 & 28.5 & 0.1036 & 2.4 & 632.5 & 18.0 \\
\hline $211-5.1$ & 6.12 & 218 & 96 & 0.45 & 21.30 & 0.0660 & 24.6 & 0.9684 & 25.1 & 0.1062 & 2.5 & 652.2 & 16.8 \\
\hline $211-6.1$ & 4.48 & 314 & 322 & 1.06 & 30.76 & 0.0604 & 21.5 & 0.9048 & 21.9 & 0.1101 & 2.4 & 664.7 & 16.9 \\
\hline $211-8.1$ & 2.87 & 649 & 421 & 0.67 & 57.56 & 0.0597 & 19.2 & 0.8237 & 19.5 & 0.1010 & 2.4 & 615.4 & 15.7 \\
\hline $211-9.1$ & 3.53 & 408 & 228 & 0.58 & 36.98 & 0.0599 & 14.1 & 0.8387 & 14.5 & 0.1029 & 2.3 & 623.6 & 14.7 \\
\hline $211-10.1$ & 4.25 & 327 & 182 & 0.58 & 30.51 & 0.0592 & 20.5 & 0.8471 & 20.8 & 0.1040 & 2.4 & 636.9 & 15.5 \\
\hline $211-11.1$ & 3.03 & 421 & 357 & 0.88 & 39.52 & 0.0608 & 13.4 & 0.8864 & 13.7 & 0.1065 & 2.3 & 648.0 & 14.9 \\
\hline 211-12.1 & 3.62 & 362 & 295 & 0.84 & 33.69 & 0.0591 & 12.2 & 0.8501 & 12.7 & 0.1057 & 2.4 & 639.4 & 15.0 \\
\hline sample/zircon & ${ }^{206} \mathrm{~Pb}_{\mathrm{c}}$ (\%) & U (ppm) & Th (ppm) & $\mathrm{Th} / \mathrm{U}$ & ${ }^{206} \mathrm{~Pb}^{*}$ (ppm) & ${ }^{207} \mathrm{~Pb}^{*} /{ }^{206} \mathrm{~Pb}^{*}$ & $\pm(\%)$ & ${ }^{207} \mathbf{P b}^{*} / /^{235} \mathbf{U}$ & $\pm(\%)$ & ${ }^{206} \mathrm{~Pb}^{*} / /^{238} \mathrm{U}$ & $\pm(\%)$ & ${ }^{206} \mathrm{~Pb}^{*} /{ }^{238} \mathrm{U}$ (Ma) & $1 \mathrm{~s}$ \\
\hline $277-1.1$ & 3.05 & 481 & 451 & 0.97 & 44.66 & 0.0662 & 11.1 & 0.9601 & 11.3 & 0.1051 & 2.3 & 641.7 & 14.6 \\
\hline $277-2.1$ & 2.20 & 550 & 443 & 0.83 & 50.87 & 0.0666 & 4.2 & 0.9723 & 4.9 & 0.1059 & 2.3 & 645.0 & 14.8 \\
\hline $277-3.1$ & 1.27 & 707 & 588 & 0.86 & 65.51 & 0.0654 & 4.0 & 0.9602 & 4.6 & 0.1064 & 2.3 & 651.4 & 14.3 \\
\hline $277-4.1$ & 1.66 & 895 & 557 & 0.64 & 82.70 & 0.0668 & 2.5 & 0.9827 & 3.4 & 0.1067 & 2.3 & 647.8 & 14.2 \\
\hline $277-5.1$ & 1.79 & 502 & 274 & 0.56 & 47.09 & 0.0610 & 6.2 & 0.8970 & 6.6 & 0.1066 & 2.3 & 655.4 & 14.7 \\
\hline $277-6.1$ & 2.28 & 619 & 515 & 0.86 & 56.76 & 0.0648 & 6.6 & 0.9322 & 7.0 & 0.1043 & 2.3 & 638.3 & 14.3 \\
\hline $277-7.1$ & 1.17 & 1519 & 1169 & 0.79 & 140.04 & 0.0673 & 1.8 & 0.9934 & 2.9 & 0.1070 & 2.2 & 649.2 & 13.9 \\
\hline $277-8.1$ & 2.10 & 620 & 376 & 0.63 & 58.06 & 0.0654 & 5.4 & 0.9662 & 5.9 & 0.1071 & 2.3 & 653.3 & 14.5 \\
\hline $277-9.1$ & 2.02 & 684 & 559 & 0.84 & 62.49 & 0.0691 & 3.5 & 1.0020 & 4.2 & 0.1051 & 2.3 & 638.6 & 14.1 \\
\hline $277-10.1$ & 1.36 & 930 & 776 & 0.86 & 85.57 & 0.0660 & 3.8 & 0.9670 & 4.4 & 0.1063 & 2.3 & 646.8 & 14.1 \\
\hline $277-11.1$ & 3.34 & 464 & 273 & 0.61 & 43.77 & 0.0678 & 9.8 & 0.9999 & 10.1 & 0.1070 & 2.3 & 649.0 & 14.8 \\
\hline $277-12.1$ & 2.62 & 564 & 325 & 0.59 & 54.13 & 0.0630 & 7.0 & 0.9466 & 7.4 & 0.1090 & 2.3 & 664.3 & 14.9 \\
\hline
\end{tabular}




\begin{tabular}{|c|c|c|c|c|c|c|c|c|c|c|c|c|c|}
\hline sample/zircon & ${ }^{206} \mathrm{~Pb}_{\mathrm{c}}(\%)$ & U (ppm) & Th (ppm) & Th/U & ${ }^{206} \mathrm{~Pb}^{*}(\mathrm{ppm})$ & ${ }^{207} \mathrm{~Pb}^{*} /{ }^{206} \mathrm{~Pb}^{*}$ & $\pm(\%)$ & ${ }^{207} \mathbf{P b}^{*} /{ }^{235} \mathbf{U}$ & $\pm(\%)$ & ${ }^{206} \mathrm{~Pb}^{*} /{ }^{238} \mathbf{U}$ & $\pm(\%)$ & ${ }^{206} \mathrm{~Pb}^{*} /{ }^{238} \mathrm{U}$ (Ma) & $1 \mathrm{~s}$ \\
\hline $269-1.1$ & 0.36 & 176 & 99 & 0.59 & 20.63 & 0.0705 & 2.5 & 1.2856 & 4.1 & 0.1363 & 3.0 & 823.5 & 23.2 \\
\hline $269-1.2$ & 1.13 & 176 & 47 & 0.28 & 15.81 & 0.0636 & 3.0 & 0.8180 & 7.9 & 0.1036 & 2.8 & 635.5 & 17.2 \\
\hline $269-3.1$ & 2.34 & 393 & 68 & 0.18 & 43.38 & 0.0623 & 11.0 & 1.0775 & 15.8 & 0.1254 & 2.8 & 761.5 & 19.9 \\
\hline $269-3.2$ & 0.59 & 243 & 41 & 0.18 & 22.08 & 0.0584 & 3.0 & 0.8393 & 4.8 & 0.1049 & 2.7 & 643.0 & 16.6 \\
\hline $269-4.1$ & 0.49 & 297 & 185 & 0.64 & 26.00 & 0.0656 & 2.3 & 0.8399 & 5.0 & 0.1014 & 2.7 & 622.4 & 15.9 \\
\hline $269-5.1$ & 0.94 & 147 & 66 & 0.47 & 13.73 & 0.0653 & 3.4 & 0.8862 & 7.2 & 0.1076 & 3.0 & 658.5 & 18.5 \\
\hline $269-6.1$ & 0.67 & 180 & 156 & 0.90 & 15.97 & 0.0646 & 3.0 & 0.7854 & 8.5 & 0.1025 & 2.8 & 628.9 & 16.9 \\
\hline $269-7.1$ & 1.84 & 38 & 56 & 1.52 & 3.43 & 0.0675 & 8.0 & 0.9569 & 13.4 & 0.1023 & 4.7 & 627.8 & 27.9 \\
\hline $269-8.1$ & 1.03 & 618 & 184 & 0.31 & 70.61 & 0.0670 & 1.7 & 1.1506 & 5.0 & 0.1315 & 2.6 & 796.3 & 19.5 \\
\hline 269-9.1 & 0.97 & 175 & 41 & 0.24 & 15.66 & 0.0608 & 3.4 & 0.8107 & 7.4 & 0.1028 & 2.8 & 630.8 & 16.9 \\
\hline $269-10.1$ & 0.60 & 177 & 166 & 0.97 & 15.79 & 0.0667 & 3.3 & 0.8762 & 5.3 & 0.1029 & 2.8 & 631.5 & 16.7 \\
\hline $269-11.1$ & 0.11 & 278 & 195 & 0.72 & 24.37 & 0.0621 & 2.5 & 0.8841 & 3.8 & 0.1018 & 2.7 & 625.0 & 16.0 \\
\hline 269-12.1 & 0.35 & 291 & 66 & 0.23 & 25.44 & 0.0622 & 2.5 & 0.8502 & 3.9 & 0.1015 & 2.7 & 623.1 & 16.2 \\
\hline $269-13.1$ & 2.17 & 146 & 25 & 0.18 & 12.24 & 0.0635 & 5.8 & 0.7023 & 14.0 & 0.0956 & 3.0 & 588.4 & 17.0 \\
\hline $269-14.1$ & 0.87 & 124 & 77 & 0.64 & 11.05 & 0.0607 & 4.3 & 0.8626 & 7.7 & 0.1030 & 2.9 & 632.1 & 17.7 \\
\hline $269-15.1$ & 0.69 & 222 & 184 & 0.86 & 18.68 & 0.0579 & 3.7 & 0.8087 & 5.8 & 0.0974 & 2.8 & 599.1 & 15.8 \\
\hline sample/zircon & ${ }^{206} \mathrm{~Pb}_{\mathrm{c}}(\%)$ & U (ppm) & Th (ppm) & $\mathrm{Th} / \mathrm{U}$ & ${ }^{206} \mathrm{~Pb}^{*}(\mathrm{ppm})$ & ${ }^{207} \mathrm{~Pb}^{*} /{ }^{206} \mathrm{~Pb}^{*}$ & $\pm(\%)$ & ${ }^{207} \mathrm{~Pb}^{*} /{ }^{235} \mathrm{U}$ & $\pm(\%)$ & ${ }^{206} \mathrm{~Pb}^{*} /{ }^{238} \mathrm{U}$ & $\pm(\%)$ & ${ }^{206} \mathrm{~Pb}^{*} /{ }^{238} \mathrm{U}$ (Ma) & $1 s$ \\
\hline $200 \mathrm{~A}-1.1$ & 0.62 & 380 & 314 & 0.85 & 34.39 & 0.0687 & 2.0 & 0.9064 & 4.0 & 0.1047 & 2.7 & 642.0 & 16.2 \\
\hline $200 \mathrm{~A}-2.1$ & 0.13 & 969 & 651 & 0.69 & 88.55 & 0.0645 & 1.4 & 0.8785 & 3.0 & 0.1062 & 2.6 & 650.8 & 15.9 \\
\hline $200 \mathrm{~A}-3.1$ & 0.05 & 648 & 460 & 0.73 & 59.91 & 0.0645 & 1.7 & 0.9083 & 3.1 & 0.1076 & 2.6 & 658.6 & 16.3 \\
\hline $200 \mathrm{~A}-4.1$ & 0.29 & 380 & 254 & 0.69 & 37.07 & 0.0608 & 2.4 & 0.9163 & 4.0 & 0.1131 & 2.7 & 690.8 & 17.5 \\
\hline 200A-5.1 & 0.63 & 364 & 276 & 0.78 & 35.19 & 0.0641 & 2.8 & 0.9163 & 4.7 & 0.1118 & 2.7 & 683.0 & 17.7 \\
\hline $200 \mathrm{~A}-6.1$ & 0.65 & 285 & 212 & 0.77 & 26.77 & 0.0657 & 2.5 & 0.8938 & 4.3 & 0.1086 & 2.7 & 664.4 & 17.1 \\
\hline $200 \mathrm{~A}-7.1$ & 0.22 & 604 & 419 & 0.72 & 56.44 & 0.0655 & 1.6 & 0.9215 & 3.4 & 0.1085 & 2.6 & 664.0 & 16.4 \\
\hline $200 \mathrm{~A}-7.2$ & 1.67 & 596 & 314 & 0.55 & 37.63 & 0.0442 & 7.9 & 0.5464 & 7.7 & 0.0723 & 2.7 & 449.8 & 11.6 \\
\hline 200A-8.1 & 0.78 & 337 & 210 & 0.64 & 30.76 & 0.0643 & 2.3 & 0.8714 & 5.3 & 0.1054 & 2.7 & 646.2 & 16.5 \\
\hline 200A-9.1 & 0.27 & 457 & 259 & 0.59 & 41.90 & 0.0638 & 2.2 & 0.9157 & 3.8 & 0.1065 & 2.6 & 652.3 & 16.3 \\
\hline $200 \mathrm{~A}-10.1$ & 0.34 & 663 & 501 & 0.78 & 60.61 & 0.0662 & 1.7 & 0.8720 & 3.6 & 0.1060 & 2.6 & 649.3 & 16.0 \\
\hline $200 \mathrm{~A}-11.1$ & 0.19 & 694 & 479 & 0.71 & 63.84 & 0.0632 & 1.6 & 0.8720 & 3.4 & 0.1069 & 2.7 & 654.7 & 16.6 \\
\hline sample/zircon & ${ }^{206} \mathrm{~Pb}_{\mathrm{c}}(\%)$ & U (ppm) & Th (ppm) & $\mathrm{Th} / \mathrm{U}$ & ${ }^{206} \mathrm{~Pb}^{*}(\mathrm{ppm})$ & ${ }^{207} \mathrm{~Pb}^{*} /{ }^{206} \mathrm{~Pb}^{*}$ & $\pm(\%)$ & ${ }^{207} \mathrm{~Pb}^{*} /{ }^{235} \mathrm{U}$ & $\pm(\%)$ & ${ }^{206} \mathrm{~Pb}^{*} /{ }^{238} \mathrm{U}$ & $\pm(\%)$ & ${ }^{206} \mathrm{~Pb}^{*} /{ }^{238} \mathrm{U}$ (Ma) & $1 \mathrm{~s}$ \\
\hline 221-1.1 & 0.98 & 86 & 61 & 0.74 & 10.21 & 0.0800 & 3.5 & 1.2591 & 7.3 & 0.1366 & 4.1 & 825.6 & 31.7 \\
\hline $221-2.1$ & 1.27 & 94 & 70 & 0.78 & 11.22 & 0.0659 & 4.0 & 1.1800 & 9.5 & 0.1375 & 3.0 & 830.6 & 23.2 \\
\hline 221-3.1 & 0.57 & 100 & 48 & 0.50 & 11.78 & 0.0642 & 3.7 & 1.2020 & 6.2 & 0.1361 & 2.9 & 822.4 & 22.5 \\
\hline $221-4.1$ & 0.98 & 80 & 41 & 0.52 & 9.82 & 0.0718 & 3.6 & 1.2499 & 6.5 & 0.1410 & 3.0 & 850.3 & 23.7 \\
\hline 221-5.1 & 0.74 & 92 & 50 & 0.56 & 11.08 & 0.0692 & 5.9 & 1.3918 & 6.6 & 0.1398 & 3.1 & 843.5 & 24.2 \\
\hline $221-6.1$ & 1.07 & 164 & 108 & 0.68 & 19.58 & 0.0720 & 2.7 & 1.2323 & 7.0 & 0.1373 & 3.0 & 829.6 & 23.3 \\
\hline $221-7.1$ & 0.71 & 210 & 140 & 0.69 & 25.33 & 0.0740 & 3.2 & 1.2083 & 5.8 & 0.1391 & 2.7 & 839.8 & 21.5 \\
\hline 221-8.1 & 1.60 & 87 & 52 & 0.62 & 10.01 & 0.0751 & 3.9 & 1.1706 & 11.5 & 0.1314 & 3.1 & 795.6 & 23.0 \\
\hline 221-9.1 & 0.67 & 136 & 88 & 0.67 & 16.60 & 0.0706 & 2.9 & 1.3122 & 5.0 & 0.1409 & 2.9 & 850.0 & 22.8 \\
\hline $221-10.1$ & 1.03 & 72 & 45 & 0.65 & 8.79 & 0.0709 & 3.9 & 1.2381 & 10.9 & 0.1410 & 3.1 & 850.2 & 24.7 \\
\hline $221-11.1$ & 0.86 & 94 & 51 & 0.56 & 11.90 & 0.0724 & 3.4 & 1.3634 & 6.4 & 0.1463 & 2.9 & 880.1 & 24.1 \\
\hline $221-12.1$ & 1.15 & 75 & 42 & 0.57 & 8.97 & 0.0665 & 4.6 & 1.2347 & 8.0 & 0.1366 & 3.1 & 825.2 & 23.6 \\
\hline $221-13.1$ & 0.71 & 256 & 149 & 0.60 & 29.79 & 0.0722 & 3.4 & 1.2252 & 5.6 & 0.1344 & 2.7 & 812.7 & 20.9 \\
\hline $221-14.1$ & 2.23 & 108 & 55 & 0.53 & 13.03 & 0.0689 & 6.8 & 1.0809 & 15.3 & 0.1377 & 3.1 & 831.6 & 24.1 \\
\hline sample/zircon & ${ }^{206} \mathrm{~Pb}_{\mathrm{c}}(\%)$ & U (ppm) & Th (ppm) & $\mathrm{Th} / \mathrm{U}$ & ${ }^{106} \mathrm{~Pb}^{*}$ (ppm) & ${ }^{207} \mathbf{P b}^{*} /{ }^{206} \mathbf{P b}^{*}$ & $\pm(\%)$ & ${ }^{207} \mathbf{P b}^{*} /{ }^{235} \mathrm{U}$ & $\pm(\%)$ & ${ }^{206} \mathbf{P b}^{*} J^{238} \mathbf{U}$ & $\pm(\%)$ & ${ }^{206} \mathrm{~Pb}^{*} /{ }^{238} \mathrm{U}$ (Ma) & $1 \mathrm{~s}$ \\
\hline $231-1.1$ & 0.37 & 172 & 76 & 0.45 & 14.40 & 0.0618 & 3.6 & 0.8719 & 5.7 & 0.0972 & 2.8 & 597.7 & 16.0 \\
\hline $231-2.1$ & 3.96 & 164 & 96 & 0.60 & 14.84 & 0.0584 & 11.8 & 0.9190 & 15.7 & 0.1009 & 3.3 & 619.9 & 19.4 \\
\hline $231-3.1$ & 1.40 & 117 & 52 & 0.46 & 10.08 & 0.0669 & 4.1 & 0.8511 & 12.8 & 0.0984 & 3.0 & 605.2 & 17.5 \\
\hline $231-4.1$ & 1.60 & 95 & 42 & 0.46 & 8.53 & 0.0746 & 3.8 & 0.8636 & 8.3 & 0.1022 & 3.0 & 627.6 & 18.0 \\
\hline 231-5.1 & 0.50 & 147 & 39 & 0.27 & 14.41 & 0.0606 & 3.6 & 0.9510 & 5.6 & 0.1132 & 2.8 & 691.1 & 18.6 \\
\hline $231-6.1$ & 0.23 & 527 & 5 & 0.01 & 46.70 & 0.0599 & 1.8 & 0.8463 & 3.4 & 0.1028 & 2.8 & 631.0 & 16.7 \\
\hline $231-6.2$ & 1.16 & 154 & 57 & 0.39 & 14.33 & 0.0648 & 3.5 & 0.8877 & 8.3 & 0.1070 & 2.9 & 655.1 & 18.2 \\
\hline $231-7.1$ & 0.26 & 199 & 98 & 0.51 & 17.76 & 0.0643 & 2.7 & 0.8783 & 5.0 & 0.1038 & 2.7 & 636.9 & 16.7 \\
\hline $231-8.1$ & 0.60 & 290 & 104 & 0.37 & 25.74 & 0.0613 & 2.5 & 0.8289 & 5.6 & 0.1026 & 2.7 & 629.6 & 16.2 \\
\hline 231-9.1 & 1.22 & 108 & 41 & 0.40 & 10.10 & 0.0681 & 4.0 & 0.9237 & 8.7 & 0.1073 & 3.1 & 657.3 & 19.1 \\
\hline 231-10.1 & 0.37 & 259 & 145 & 0.58 & 22.54 & 0.0620 & 3.9 & 0.8197 & 5.5 & 0.1009 & 2.7 & 620.0 & 16.1 \\
\hline $231-11.1$ & 0.83 & 175 & 66 & 0.39 & 15.65 & 0.0614 & 3.3 & 0.8276 & 6.2 & 0.1030 & 2.8 & 631.9 & 16.9 \\
\hline $231-12.1$ & 0.86 & 92 & 36 & 0.41 & 8.20 & 0.0583 & 5.6 & 0.8923 & 7.1 & 0.1028 & 3.0 & 630.8 & 18.1 \\
\hline sample/zircon & ${ }^{206} \mathrm{~Pb}_{\mathrm{c}}(\%)$ & U (ppm) & Th (ppm) & $\mathrm{Th} / \mathrm{U}$ & ${ }^{206} \mathrm{~Pb}^{*}$ (ppm) & ${ }^{207} \mathrm{~Pb}^{*} /{ }^{206} \mathrm{~Pb}^{*}$ & $\pm(\%)$ & ${ }^{207} \mathrm{~Pb}^{*} /{ }^{235} \mathrm{U}$ & $\pm(\%)$ & ${ }^{206} \mathrm{~Pb}^{*} /{ }^{238} \mathrm{U}$ & $\pm(\%)$ & ${ }^{206} \mathrm{~Pb}^{*} /{ }^{238} \mathrm{U}$ (Ma) & $1 \mathrm{~s}$ \\
\hline $125 \mathrm{E}-1.1$ & 0.68 & 186 & 151 & 0.84 & 16.30 & 0.0669 & 2.8 & 0.9453 & 3.9 & 0.1025 & 2.8 & 623.6 & 16.5 \\
\hline $125 \mathrm{E}-2.1$ & 0.70 & 937 & 288 & 0.32 & 81.18 & 0.0625 & 1.5 & 0.8655 & 3.0 & 0.1004 & 2.6 & 614.9 & 15.2 \\
\hline $125 \mathrm{E}-3.1$ & 0.17 & 1073 & 206 & 0.20 & 95.07 & 0.0606 & 1.2 & 0.8615 & 2.8 & 0.1031 & 2.6 & 631.8 & 15.4 \\
\hline $125 \mathrm{E}-4.1$ & 2.32 & 905 & 201 & 0.23 & 81.79 & 0.0604 & 4.7 & 0.8533 & 5.3 & 0.1025 & 2.6 & 629.9 & 15.6 \\
\hline $125 \mathrm{E}-5.1$ & 2.94 & 817 & 116 & 0.15 & 69.81 & 0.0612 & 5.0 & 0.8173 & 5.6 & 0.0969 & 2.6 & 593.2 & 14.9 \\
\hline $125 \mathrm{E}-6.1$ & 0.39 & 808 & 174 & 0.22 & 71.26 & 0.0620 & 1.5 & 0.8766 & 3.0 & 0.1025 & 2.6 & 627.4 & 15.5 \\
\hline $125 \mathrm{E}-7.1$ & 2.35 & 274 & 64 & 0.24 & 24.84 & 0.0620 & 5.0 & 0.8822 & 5.7 & 0.1032 & 2.7 & 632.1 & 16.6 \\
\hline $125 \mathrm{E}-8.1$ & 0.26 & 654 & 81 & 0.13 & 58.63 & 0.0616 & 2.1 & 0.8853 & 3.4 & 0.1042 & 2.6 & 638.6 & 15.9 \\
\hline $125 \mathrm{E}-9.1$ & 1.22 & 628 & 93 & 0.15 & 55.61 & 0.0640 & 2.5 & 0.8998 & 3.6 & 0.1020 & 2.6 & 624.9 & 15.6 \\
\hline $125 \mathrm{E}-10.1$ & 0.45 & 821 & 184 & 0.23 & 72.10 & 0.0637 & 1.5 & 0.8981 & 3.0 & 0.1023 & 2.6 & 624.4 & 15.4 \\
\hline $125 \mathrm{E}-11.1$ & 6.19 & 781 & 177 & 0.23 & 72.86 & 0.0612 & 13.3 & 0.8545 & 13.6 & 0.1013 & 2.6 & 623.0 & 15.9 \\
\hline $125 \mathrm{E}-12.1$ & 2.11 & 1088 & 212 & 0.20 & 98.58 & 0.0614 & 3.8 & 0.8747 & 4.6 & 0.1033 & 2.6 & 632.5 & 15.6 \\
\hline sample/zircon & ${ }^{206} \mathrm{~Pb}_{\mathrm{c}}(\%)$ & U (ppm) & Th (ppm) & $\mathrm{Th} / \mathrm{U}$ & ${ }^{206} \mathrm{~Pb}^{*}(\mathrm{ppm})$ & ${ }^{207} \mathrm{~Pb}^{*} /{ }^{206} \mathrm{~Pb}^{*}$ & $\pm(\%)$ & ${ }^{207} \mathrm{~Pb}^{*} /{ }^{235} \mathrm{U}$ & $\pm(\%)$ & ${ }^{206} \mathrm{~Pb}^{*} /{ }^{238} \mathrm{U}$ & $\pm(\%)$ & ${ }^{206} \mathrm{~Pb}^{*} /{ }^{238} \mathrm{U}$ (Ma) & $1 \mathrm{~s}$ \\
\hline $170 \mathrm{~A}-1.1$ & 0.90 & 109 & 52 & 0.49 & 9.73 & 0.0537 & 6.6 & 0.8971 & 6.1 & 0.1019 & 3.0 & 633.1 & 17.9 \\
\hline $170 \mathrm{~A}-2.1$ & 0.43 & 222 & 93 & 0.43 & 21.59 & 0.0608 & 2.9 & 0.9263 & 4.2 & 0.1127 & 2.7 & 687.7 & 17.8 \\
\hline 170A-3.1 & 1.66 & 427 & 36 & 0.09 & 37.56 & 0.0645 & 3.8 & 0.9127 & 6.8 & 0.1005 & 2.7 & 618.2 & 16.0 \\
\hline $170 \mathrm{~A}-4.1$ & 0.59 & 285 & 41 & 0.15 & 26.06 & 0.0612 & 2.8 & 0.8780 & 4.2 & 0.1061 & 3.0 & 649.1 & 18.4 \\
\hline $170 \mathrm{~A}-5.1$ & 0.50 & 266 & 131 & 0.51 & 25.23 & 0.0611 & 2.9 & 0.9160 & 4.5 & 0.1099 & 2.7 & 671.6 & 17.2 \\
\hline $170 \mathrm{~A}-6.1$ & 0.97 & 73 & 42 & 0.60 & 6.48 & 0.0694 & 5.7 & 1.0345 & 7.7 & 0.1023 & 3.2 & 630.9 & 19.2 \\
\hline 170A-7.1 & 2.19 & 88 & 85 & 1.00 & 7.83 & 0.0754 & 4.6 & 0.8888 & 12.6 & 0.1030 & 3.0 & 622.6 & 18.7 \\
\hline 170A-8.1 & 0.19 & 486 & 201 & 0.43 & 46.48 & 0.0647 & 2.3 & 0.9699 & 4.2 & 0.1112 & 3.3 & 678.8 & 21.3 \\
\hline 170A-9.1 & 1.24 & 146 & 15 & 0.10 & 13.47 & 0.0591 & 4.1 & 0.8209 & 9.4 & 0.1064 & 2.8 & 649.6 & 17.9 \\
\hline 170A-10.1 & 1.49 & 151 & 90 & 0.61 & 14.09 & 0.0661 & 3.6 & 0.8621 & 9.9 & 0.1082 & 2.8 & 656.2 & 18.1 \\
\hline 170A-11.1 & 0.67 & 180 & 123 & 0.70 & 16.68 & 0.0631 & 3.4 & 0.9060 & 5.9 & 0.1073 & 2.8 & 655.6 & 17.6 \\
\hline 170A-12.1 & 0.72 & 418 & 66 & 0.16 & 40.02 & 0.0651 & 2.6 & 0.9220 & 5.1 & 0.1113 & 2.6 & 676.2 & 17.0 \\
\hline
\end{tabular}


ANEXO III

(análises SHRIMP U-Th-Pb em zircões metamórficos) 


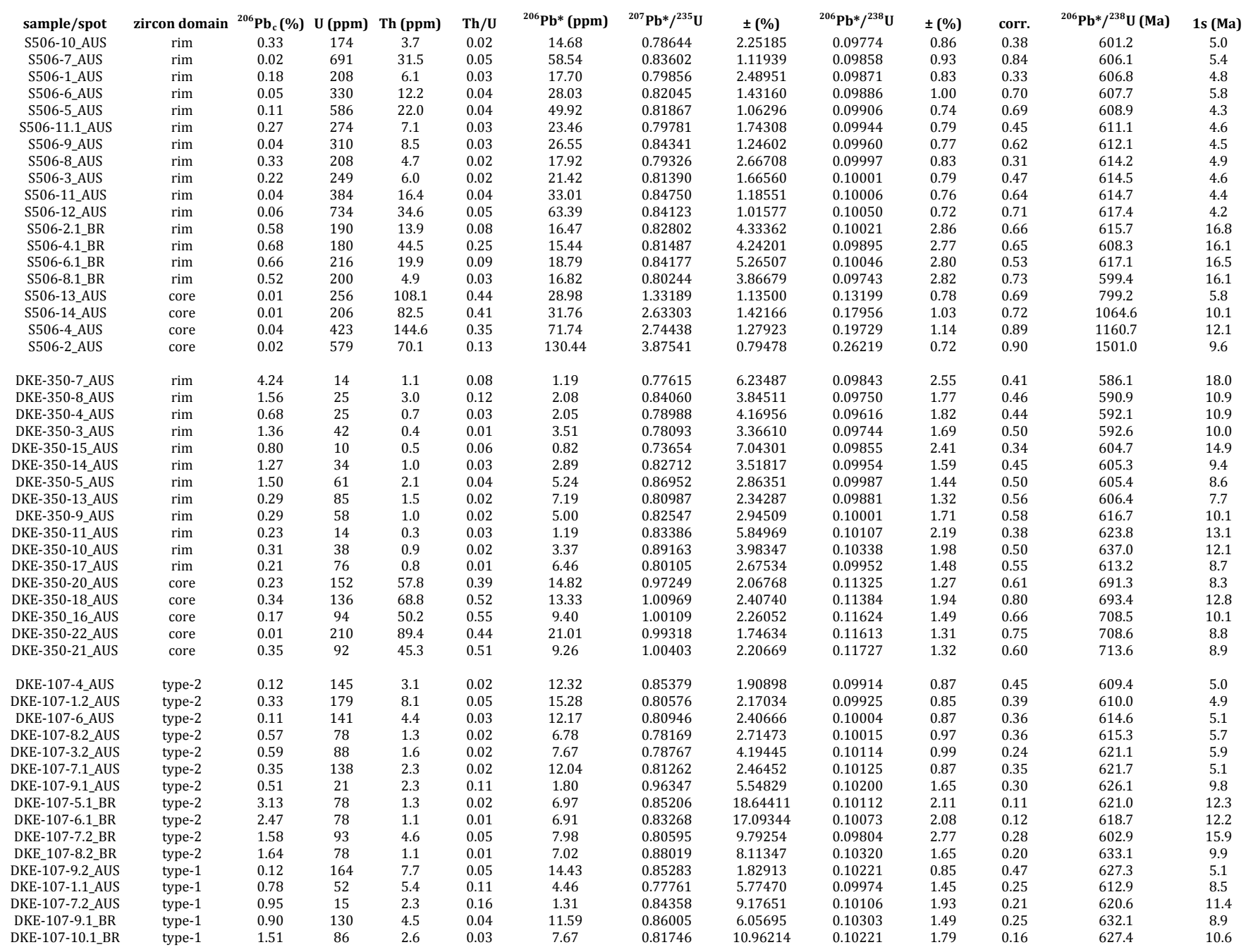




\section{ANEXO IV}

(análises LA-ICP-MS Lu-Hf em zircões ígneos) 


\begin{tabular}{|c|c|c|c|c|c|c|c|}
\hline sample & ${ }^{176} \mathrm{Hf} /{ }^{177} \mathrm{Hf}$ & $\pm(2 s)$ & ${ }^{176} \mathrm{Lu} /{ }^{177} \mathrm{Hf}$ & $\pm(2 s)$ & Age (Ma) & eHf (t) & $\mathrm{T}_{\mathrm{DM} 1}$ (Ga) \\
\hline DKE-125E 1.1 & 0.282622 & 0.000046 & 0.000883 & 0.000013 & 623 & 8.1 & 0.99 \\
\hline DKE-125E 2.1 & 0.282666 & 0.000044 & 0.000921 & 0.000005 & 614 & 9.4 & 0.90 \\
\hline DKE-125E 3.1 & 0.282563 & 0.000034 & 0.001583 & 0.000014 & 631 & 5.9 & 1.14 \\
\hline DKE-125E 4.1 & 0.282583 & 0.000035 & 0.001189 & 0.000012 & 629 & 6.7 & 1.09 \\
\hline DKE-125E 5.1 & 0.282678 & 0.000035 & 0.000901 & 0.000024 & 593 & 9.4 & 0.89 \\
\hline DKE-125E 6.1 & 0.282656 & 0.000023 & 0.000966 & 0.000004 & 627 & 9.3 & 0.92 \\
\hline DKE-125E 7.1 & 0.282588 & 0.000027 & 0.001649 & 0.000025 & 632 & 6.7 & 1.09 \\
\hline DKE-125E 10.1 & 0.282495 & 0.000045 & 0.001162 & 0.000002 & 624 & 3.5 & 1.29 \\
\hline DKE-125E 11.1 & 0.282555 & 0.000033 & 0.001026 & 0.000006 & 623 & 5.6 & 1.15 \\
\hline DKE-125E 12.1 & 0.282623 & 0.000033 & 0.001231 & 0.000014 & 632 & 8.1 & 1.00 \\
\hline DKE-125E 8.1 & 0.282674 & 0.000034 & 0.001065 & 0.000025 & 638 & 10.2 & 0.87 \\
\hline DKE-125E 9.1 & 0.282692 & 0.000030 & 0.001006 & 0.000003 & 624 & 10.5 & 0.84 \\
\hline sample/zircon & ${ }^{176} \mathrm{Hf} /{ }^{177} \mathrm{Hf}$ & $\pm(2 s)$ & ${ }^{176} \mathrm{Lu} /{ }^{177} \mathrm{Hf}$ & $\pm(2 s)$ & Age (Ma) & eHf (t) & $\mathrm{T}_{\mathrm{DM} 1}(\mathrm{Ga})$ \\
\hline DKE-125A 4.1 & 0.282241 & 0.000028 & 0.001715 & 0.000016 & 638 & -5.5 & 1.87 \\
\hline DKE-125A 5.1 & 0.282195 & 0.000038 & 0.002080 & 0.000016 & 644 & -7.1 & 1.98 \\
\hline DKE-125A 6.1 & 0.282234 & 0.000037 & 0.001911 & 0.000023 & 656 & -5.4 & 1.88 \\
\hline DKE-125A 7.1 & 0.282202 & 0.000045 & 0.001677 & 0.000046 & 636 & -6.9 & 1.95 \\
\hline DKE-125A 8.1 & 0.282251 & 0.000048 & 0.001809 & 0.000018 & 655 & -4.8 & 1.84 \\
\hline DKE-125A 11.1 & 0.282161 & 0.000039 & 0.002055 & 0.000022 & 644 & -8.3 & 2.05 \\
\hline DKE-125A 12.1 & 0.282112 & 0.000043 & 0.002235 & 0.000036 & 656 & -9.9 & 2.16 \\
\hline DKE-125A 1.1 & 0.282347 & 0.000033 & 0.001946 & 0.000026 & 637 & -1.8 & 1.64 \\
\hline DKE-125A 10.1 & 0.282150 & 0.000039 & 0.002201 & 0.000016 & 653 & -8.6 & 2.07 \\
\hline DKE-125A 2.1 & 0.282266 & 0.000031 & 0.001971 & 0.000035 & 654 & -4.3 & 1.81 \\
\hline DKE-125A 3.1 & 0.282078 & 0.000037 & 0.002674 & 0.000017 & 640 & -11.6 & 2.25 \\
\hline DKE-125A 9.1 & 0.282140 & 0.000039 & 0.002354 & 0.000025 & 646 & -9.1 & 2.10 \\
\hline sample/zircon & ${ }^{176} \mathrm{Hf} /{ }^{177} \mathrm{Hf}$ & $\pm(2 s)$ & ${ }^{176} \mathrm{Lu} /{ }^{177} \mathrm{Hf}$ & $\pm(2 s)$ & Age (Ma) & eHf (t) & $\mathrm{T}_{\mathrm{DM} 1}$ (Ga) \\
\hline DKE-170 1.1 & 0.282526 & 0.000050 & 0.001803 & 0.000043 & 633 & 4.5 & 1.23 \\
\hline DKE-170 2.1 & 0.282639 & 0.000036 & 0.000627 & 0.000015 & 687 & 10.2 & 0.91 \\
\hline DKE-170 3.1 & 0.282495 & 0.000050 & 0.001390 & 0.000054 & 618 & 3.3 & 1.30 \\
\hline DKE-170 4.1 & 0.282590 & 0.000033 & 0.000941 & 0.000017 & 649 & 7.5 & 1.05 \\
\hline DKE-170 9.1 & 0.282535 & 0.000033 & 0.000676 & 0.000007 & 649 & 5.7 & 1.17 \\
\hline DKE-170 10.1 & 0.282741 & 0.000048 & 0.000482 & 0.000001 & 656 & 13.2 & 0.69 \\
\hline DKE-170 11.1 & 0.282548 & 0.000057 & 0.001731 & 0.000021 & 655 & 5.8 & 1.17 \\
\hline DKE-170 12.1 & 0.282563 & 0.000041 & 0.000695 & 0.000032 & 676 & 7.2 & 1.09 \\
\hline DKE-170 5.1 & 0.282471 & 0.000052 & 0.001134 & 0.000008 & 671 & 3.7 & 1.31 \\
\hline DKE-170 6.1 & 0.282507 & 0.000031 & 0.000824 & 0.000010 & 630 & 4.2 & 1.25 \\
\hline DKE-170 7.1 & 0.282598 & 0.000036 & 0.000806 & 0.000002 & 622 & 7.2 & 1.05 \\
\hline DKE-170 8.1 & 0.282504 & 0.000034 & 0.000787 & 0.000030 & 678 & 5.1 & 1.23 \\
\hline sample/zircon & ${ }^{176} \mathrm{Hf} /{ }^{177} \mathrm{Hf}$ & $\pm(2 s)$ & ${ }^{176} \mathrm{Lu} /{ }^{177} \mathrm{Hf}$ & $\pm(2 s)$ & Age (Ma) & eHf $(t)$ & $\mathrm{T}_{\mathrm{DM} 1}$ (Ga) \\
\hline DKE-200A 1.1 & 0.282291 & 0.000054 & 0.000289 & 0.000007 & 642 & -3.0 & 1.71 \\
\hline DKE-200A 2.1 & 0.282389 & 0.000040 & 0.000301 & 0.000006 & 650 & 0.7 & 1.49 \\
\hline DKE-200A 3.1 & 0.282349 & 0.000044 & 0.000218 & 0.000001 & 658 & -0.5 & 1.57 \\
\hline DKE-200A 4.1 & 0.282262 & 0.000029 & 0.000246 & 0.000002 & 690 & -2.9 & 1.75 \\
\hline DKE-200A 5.1 & 0.282413 & 0.000056 & 0.000188 & 0.000002 & 683 & 2.3 & 1.41 \\
\hline DKE-200A 6.1 & 0.282397 & 0.000034 & 0.000187 & 0.000001 & 664 & 1.3 & 1.46 \\
\hline DKE-200A 7.1 & 0.282226 & 0.000041 & 0.000246 & 0.000001 & 664 & -4.8 & 1.85 \\
\hline DKE-200A 10.1 & 0.282251 & 0.000027 & 0.000216 & 0.000000 & 649 & -4.2 & 1.80 \\
\hline DKE-200A 11.1 & 0.282428 & 0.000044 & 0.000245 & 0.000001 & 654 & 2.2 & 1.40 \\
\hline DKE-200A 8.1 & 0.282289 & 0.000040 & 0.000227 & 0.000001 & 646 & -2.9 & 1.71 \\
\hline DKE-200A 9.1 & 0.282288 & 0.000044 & 0.000195 & 0.000001 & 652 & -2.8 & 1.71 \\
\hline
\end{tabular}




\begin{tabular}{|c|c|c|c|c|c|c|c|}
\hline sample/zircon & ${ }^{176} \mathrm{Hf} /{ }^{177} \mathrm{Hf}$ & $\pm(2 s)$ & ${ }^{176} \mathrm{Lu} /{ }^{177} \mathrm{Hf}$ & $\pm(2 s)$ & Age (Ma) & eHf (t) & $\mathrm{T}_{\text {DM1 }}$ (Ga) \\
\hline DKE-211 1.1 & 0.282103 & 0.000037 & 0.000553 & 0.000001 & 614 & -10.4 & 2.16 \\
\hline DKE-211 2.1 & 0.282028 & 0.000038 & 0.000491 & 0.000005 & 650 & -12.2 & 2.30 \\
\hline DKE-211 3.1 & 0.281794 & 0.000040 & 0.000478 & 0.000002 & 642 & -20.7 & 2.82 \\
\hline DKE-211 5.1 & 0.281080 & 0.000035 & 0.001189 & 0.000012 & 652 & -46.1 & 4.38 \\
\hline DKE-211 9.1 & 0.282131 & 0.000041 & 0.000542 & 0.000005 & 623 & -9.2 & 2.09 \\
\hline DKE-211 10.1 & 0.282209 & 0.000040 & 0.000587 & 0.000002 & 636 & -6.2 & 1.91 \\
\hline DKE-211 12.1 & 0.282214 & 0.000043 & 0.000520 & 0.000001 & 639 & -5.9 & 1.89 \\
\hline DKE-211 11.1 & 0.282149 & 0.000032 & 0.000623 & 0.000002 & 648 & -8.0 & 2.04 \\
\hline DKE-211 4.1 & 0.282091 & 0.000039 & 0.000523 & 0.000001 & 632 & -10.4 & 2.17 \\
\hline DKE-211 6.1 & 0.282044 & 0.000048 & 0.001026 & 0.000051 & 664 & -11.6 & 2.27 \\
\hline DKE-211 8.1 & 0.282314 & 0.000038 & 0.000549 & 0.000003 & 615 & -2.9 & 1.69 \\
\hline sample/zircon & ${ }^{176} \mathrm{Hf} /{ }^{177} \mathrm{Hf}$ & $\pm(2 s)$ & ${ }^{176} \mathrm{Lu} /{ }^{177} \mathrm{Hf}$ & $\pm(2 s)$ & Age (Ma) & eHf $(t)$ & $\mathrm{T}_{\mathrm{DM} 1}(\mathrm{Ga})$ \\
\hline DKE-221 1.1 & 0.282807 & 0.000237 & 0.000454 & 0.000005 & 825 & 19.3 & 0.43 \\
\hline DKE-221 2.1 & 0.282617 & 0.000098 & 0.001325 & 0.000014 & 830 & 12.1 & 0.89 \\
\hline DKE-221 3.1 & 0.281580 & 0.000171 & 0.000881 & 0.000008 & 822 & -24.5 & 3.20 \\
\hline DKE-221 9.1 & 0.282455 & 0.000099 & 0.001714 & 0.000022 & 850 & 6.6 & 1.26 \\
\hline DKE-221 10.1 & 0.282502 & 0.000099 & 0.001403 & 0.000005 & 850 & 8.5 & 1.15 \\
\hline DKE-221 13.1 & 0.282561 & 0.000121 & 0.001986 & 0.000020 & 812 & 9.4 & 1.05 \\
\hline DKE-221 14.1 & 0.282614 & 0.000070 & 0.001134 & 0.000035 & 831 & 12.2 & 0.89 \\
\hline DKE-221 11.1 & 0.282650 & 0.000078 & 0.001230 & 0.000006 & 880 & 14.4 & 0.78 \\
\hline DKE-221 12.1 & 0.282413 & 0.000064 & 0.001445 & 0.000037 & 825 & 4.8 & 1.36 \\
\hline DKE-221 5.1 & 0.282280 & 0.000350 & 0.001176 & 0.000014 & 843 & 0.5 & 1.65 \\
\hline DKE-221 7.1 & 0.282455 & 0.000078 & 0.001033 & 0.000010 & 839 & 6.8 & 1.25 \\
\hline DKE-221 8.1 & 0.282729 & 0.000100 & 0.001052 & 0.000012 & 795 & 15.5 & 0.65 \\
\hline sample/zircon & ${ }^{176} \mathrm{Hf} /{ }^{177} \mathrm{Hf}$ & $\pm(2 s)$ & ${ }^{176} \mathrm{Lu} /{ }^{177} \mathrm{Hf}$ & $\pm(2 s)$ & Age (Ma) & eHf (t) & $\mathrm{T}_{\mathrm{DM} 1}(\mathrm{Ga})$ \\
\hline DKE-231 1.1 & 0.282110 & 0.000045 & 0.000000 & 0.000000 & 597 & -10.3 & 2.14 \\
\hline DKE-231 2.1 & 0.281979 & 0.000065 & 0.000004 & 0.000001 & 619 & -14.4 & 2.42 \\
\hline DKE-231 3.1 & 0.282154 & 0.000054 & 0.000009 & 0.000001 & 605 & -8.5 & 2.03 \\
\hline DKE-231 4.1 & 0.282097 & 0.000083 & 0.000006 & 0.000001 & 627 & -10.1 & 2.15 \\
\hline DKE-231 5.1 & 0.281515 & 0.000338 & 0.000000 & 0.000000 & 691 & -29.3 & 3.39 \\
\hline DKE-231 8.1 & 0.282073 & 0.000169 & 0.000002 & 0.000001 & 629 & -10.9 & 2.20 \\
\hline DKE-231 11.1 & 0.281982 & 0.000082 & 0.000003 & 0.000000 & 631 & -14.0 & 2.40 \\
\hline DKE-231 10.1 & 0.282192 & 0.000056 & 0.000016 & 0.000002 & 620 & -6.9 & 1.94 \\
\hline DKE-231 12.1 & 0.282207 & 0.000087 & 0.000005 & 0.000001 & 630 & -6.1 & 1.90 \\
\hline DKE-231 6.2 & 0.282641 & 0.000053 & 0.000006 & 0.000001 & 655 & 9.8 & 0.91 \\
\hline DKE-231 7.1 & 0.281848 & 0.000162 & 0.000004 & 0.000001 & 636 & -18.7 & 2.70 \\
\hline DKE-231 9.1 & 0.282151 & 0.000041 & 0.000000 & 0.000001 & 657 & -7.5 & 2.01 \\
\hline sample/zircon & ${ }^{176} \mathrm{Hf} /{ }^{177} \mathrm{Hf}$ & $\pm(2 s)$ & ${ }^{176} \mathrm{Lu} /{ }^{177} \mathrm{Hf}$ & $\pm(2 s)$ & Age (Ma) & eHf (t) & $\mathrm{T}_{\mathrm{DM} 1}(\mathrm{Ga})$ \\
\hline DKE-269 1.1 & 0.282685 & 0.000064 & 0.001128 & 0.000009 & 823 & 14.5 & 0.73 \\
\hline DKE-269 3.1 & 0.282020 & 0.000044 & 0.001300 & 0.000029 & 761 & -10.5 & 2.28 \\
\hline DKE-269 3.2 & 0.282523 & 0.000030 & 0.000071 & 0.000000 & 643 & 5.4 & 1.18 \\
\hline DKE-269 5.1 & 0.282323 & 0.000051 & 0.000043 & 0.000001 & 658 & -1.4 & 1.63 \\
\hline DKE-269 6.1 & 0.282461 & 0.000047 & 0.000119 & 0.000002 & 628 & 2.8 & 1.33 \\
\hline DKE-269 14.1 & 0.282406 & 0.000033 & 0.000068 & 0.000008 & 632 & 1.0 & 1.46 \\
\hline DKE-269 15.1 & 0.282385 & 0.000032 & 0.000146 & 0.000013 & 599 & -0.5 & 1.53 \\
\hline DKE-269 1.2 & 0.282428 & 0.000042 & 0.000161 & 0.000001 & 635 & 1.8 & 1.41 \\
\hline DKE-269 10.1 & 0.282375 & 0.000033 & 0.000065 & 0.000001 & 631 & -0.1 & 1.53 \\
\hline DKE-269 4.1 & 0.282486 & 0.000038 & 0.000143 & 0.000008 & 622 & 3.5 & 1.28 \\
\hline DKE-269 8.1 & 0.281805 & 0.000060 & 0.002386 & 0.000075 & 796 & -17.9 & 2.77 \\
\hline DKE-269 9.1 & 0.282360 & 0.000036 & 0.000093 & 0.000001 & 630 & -0.7 & 1.56 \\
\hline
\end{tabular}




\begin{tabular}{|c|c|c|c|c|c|c|c|}
\hline sample/zircon & ${ }^{176} \mathrm{Hf} /{ }^{177} \mathrm{Hf}$ & $\pm(2 s)$ & ${ }^{176} \mathrm{Lu} /{ }^{177} \mathrm{Hf}$ & $\pm(2 s)$ & Age (Ma) & eHf (t) & $\mathbf{T}_{\text {DM1 }}$ (Ga) \\
\hline DKE-273A 6.1 & 0.282192 & 0.000061 & 0.002460 & 0.000039 & 891 & -2.3 & 1.86 \\
\hline DKE-273A 8.1 & 0.282237 & 0.000043 & 0.002115 & 0.000028 & 911 & -0.1 & 1.74 \\
\hline DKE-273A 10.1 & 0.282248 & 0.000048 & 0.002089 & 0.000038 & 873 & -0.5 & 1.73 \\
\hline DKE-273A 13.1 & 0.282147 & 0.000045 & 0.002482 & 0.000010 & 906 & -3.6 & 1.96 \\
\hline DKE-273A 14.1 & 0.282160 & 0.000046 & 0.003188 & 0.000054 & 891 & -3.8 & 1.96 \\
\hline DKE-273A 15.1 & 0.282272 & 0.000049 & 0.002589 & 0.000016 & 898 & 0.6 & 1.68 \\
\hline DKE-273A 16.1 & 0.282384 & 0.000041 & 0.001974 & 0.000046 & 959 & 6.2 & 1.37 \\
\hline DKE-273A 12.1 & 0.282145 & 0.000037 & 0.002442 & 0.000063 & 846 & -4.9 & 1.99 \\
\hline DKE-273A 5.1 & 0.282262 & 0.000047 & 0.002218 & 0.000005 & 881 & 0.1 & 1.70 \\
\hline DKE-273A 5.2 & 0.282357 & 0.000025 & 0.000680 & 0.000007 & 638 & -0.9 & 1.58 \\
\hline DKE-273A 7.1 & 0.282280 & 0.000045 & 0.001867 & 0.000059 & 904 & 1.5 & 1.63 \\
\hline DKE-273A 7.2 & 0.282393 & 0.000027 & 0.000547 & 0.000010 & 622 & 0.1 & 1.50 \\
\hline sample/zircon & ${ }^{176} \mathrm{Hf} /{ }^{177} \mathrm{Hf}$ & $\pm(2 s)$ & ${ }^{176} \mathrm{Lu} /{ }^{177} \mathrm{Hf}$ & $\pm(2 s)$ & Age (Ma) & eHf (t) & $\mathrm{T}_{\mathrm{DM} 1}(\mathrm{Ga})$ \\
\hline DKE-273B 2.1 & 0.282333 & 0.000045 & 0.002326 & 0.000005 & 790 & 14.5 & 0.73 \\
\hline DKE-273B 2.2 & 0.282501 & 0.000018 & 0.000612 & 0.000014 & 596 & -10.5 & 2.28 \\
\hline DKE-273B 3.1 & 0.282173 & 0.000046 & 0.001811 & 0.000025 & 607 & 5.4 & 1.18 \\
\hline DKE-273B 8.1 & 0.282422 & 0.000030 & 0.000549 & 0.000015 & 621 & -1.4 & 1.63 \\
\hline DKE-273B 9.1 & 0.282403 & 0.000027 & 0.000435 & 0.000011 & 610 & 2.8 & 1.33 \\
\hline DKE-273B 10.1 & 0.282590 & 0.000035 & 0.000911 & 0.000025 & 610 & 1.0 & 1.46 \\
\hline DKE-273B 12.1 & 0.282166 & 0.000056 & 0.002696 & 0.000042 & 744 & -0.5 & 1.53 \\
\hline DKE-273B 14.1 & 0.282697 & 0.000036 & 0.000894 & 0.000015 & 637 & 1.8 & 1.41 \\
\hline DKE-273B 15.1 & 0.282538 & 0.000028 & 0.000751 & 0.000021 & 612 & -0.1 & 1.53 \\
\hline DKE-273B16.1 & 0.282595 & 0.000029 & 0.000581 & 0.000013 & 639 & 3.5 & 1.28 \\
\hline DKE-273B 4.1 & 0.282437 & 0.000056 & 0.002244 & 0.000012 & 752 & -17.9 & 2.77 \\
\hline DKE-273B 7.1 & 0.282635 & 0.000031 & 0.000542 & 0.000007 & 621 & -0.7 & 1.56 \\
\hline sample/zircon & ${ }^{176} \mathrm{Hf} /{ }^{177} \mathrm{Hf}$ & $\pm(2 s)$ & ${ }^{176} \mathrm{Lu} /{ }^{177} \mathrm{Hf}$ & $\pm(2 s)$ & Age (Ma) & eHf (t) & $\mathrm{T}_{\mathrm{DM} 1}(\mathrm{Ga})$ \\
\hline DKE-277 1.1 & 0.282348 & 0.000028 & 0.000775 & 0.000006 & 641 & -1.2 & 1.60 \\
\hline DKE-277 2.1 & 0.282309 & 0.000034 & 0.000432 & 0.000002 & 645 & -2.3 & 1.67 \\
\hline DKE-277 8.1 & 0.282322 & 0.000031 & 0.000513 & 0.000003 & 653 & -1.7 & 1.64 \\
\hline DKE-277 9.1 & 0.282201 & 0.000039 & 0.001151 & 0.000017 & 638 & -6.6 & 1.94 \\
\hline DKE-277 10.1 & 0.282274 & 0.000027 & 0.000700 & 0.000001 & 646 & -3.7 & 1.76 \\
\hline DKE-277 11.1 & 0.282275 & 0.000032 & 0.000440 & 0.000002 & 649 & -3.5 & 1.75 \\
\hline DKE-277 12.1 & 0.282331 & 0.000031 & 0.000473 & 0.000003 & 664 & -1.2 & 1.62 \\
\hline DKE-277 3.1 & 0.282269 & 0.000040 & 0.000700 & 0.000002 & 651 & -3.7 & 1.77 \\
\hline DKE-277 4.1 & 0.282328 & 0.000031 & 0.000627 & 0.000004 & 647 & -1.7 & 1.64 \\
\hline DKE-277 5.1 & 0.282348 & 0.000032 & 0.000528 & 0.000003 & 655 & -0.8 & 1.58 \\
\hline DKE-277 6.1 & 0.282342 & 0.000034 & 0.000608 & 0.000012 & 638 & -1.4 & 1.61 \\
\hline DKE-277 7.1 & 0.282345 & 0.000030 & 0.000668 & 0.000006 & 649 & -1.1 & 1.60 \\
\hline
\end{tabular}


(análises SHRIMP Oxigênio ${ }^{18} \mathrm{O} /{ }^{16} \mathrm{O}$ em zircões ígneos) 
Sample DKE-43 ratio (\%o) error (\%o) Sample DKE-45 ratio (\%o) error (\%o) Sample DKE-221 ratio (\%o) error (\%o)

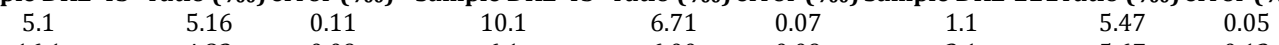

$\begin{array}{lllllllll}5.1 & 5.16 & 0.11 & 10.1 & 6.71 & 0.07 & 1.1 & 5.47 & 0.12 \\ 16.1 & 4.83 & 0.09 & 6.1 & 6.00 & 0.09 & 3.1 & 6.15 & 0.07\end{array}$

$\begin{array}{lllcccccc}17.1 & 4.48 & 0.08 & 7.1 & 7.27 & 0.06 & 3.1 & 6.15 & 0.07 \\ 18.1 & 5.25 & 0.07 & 11.1 & 12.50 & 0.07 & 9.1 & 6.21 & 0.06\end{array}$

$\begin{array}{lllllllll}22.1 & 7.25 & 0.11 & 12.1 & 5.72 & 0.09 & 10.1 & 5.45 & 0.09\end{array}$

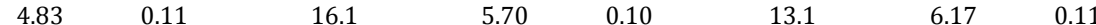

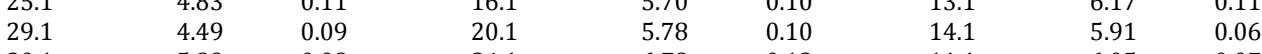

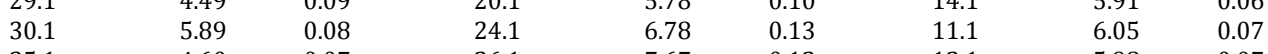

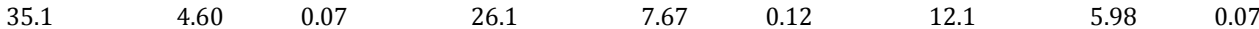

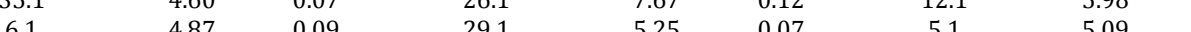

$\begin{array}{ccccccccc}6.1 & 4.87 & 0.09 & 29.1 & 5.25 & 0.07 & 5.1 & 5.09 & 0.1 \\ 56.1 & 4.40 & 0.07 & 30.1 & 7.73 & 0.10 & 7.1 & 5.84 & 0.1 \\ 52.2 & 7.24 & 0.07 & 31.1 & 6.26 & 0.06 & 8.1 & 6.24 & 0.09\end{array}$

$\begin{array}{lllllllll}52.2 & 7.24 & 0.07 & 31.1 & 6.26 & 0.06 & 8.1 & 6.24 & 0.09\end{array}$

$\begin{array}{lllllllll}47.1 & 8.11 & 0.07 & 37.1 & 6.46 & 0.11 & 4.1 & 6.04 & 0.08 \\ 38.1 & 5.84 & 0.11 & 38.1 & 7.12 & 0.09 & 6.1 & 5.67 & 0.11\end{array}$

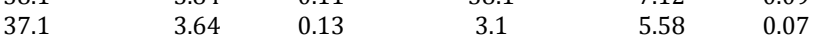

$\begin{array}{llllll}34.1 & 5.30 & 0.06 & 34.1 & 6.90 & 0.14\end{array}$

$\begin{array}{llllll}26.1 & 4.22 & 0.08 & 35.1 & 7.49 & 0.11 \\ 19.1 & 5.24 & 0.14 & 36.1 & 6.28 & 0.06\end{array}$

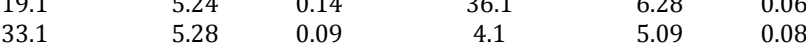

$41.1 \quad 4.68 \quad 0.05$

$48.1 \quad 4.78 \quad 0.12$

$\begin{array}{lll}51.1 & 6.82 & 0.07\end{array}$

Sample DKE-273Aratio (\%o) error (\%o) Sample DKE-273Bratio (\%o) error (\%o) Sample DKE-211ratio (\%o) error (\%o)

\begin{tabular}{|c|c|c|c|c|c|c|c|c|}
\hline 6.1 & 6.07 & 0.10 & 2.1 & 5.45 & 0.10 & 1.1 & 7.92 & 0.05 \\
\hline 8.1 & 6.44 & 0.09 & 2.2 & 8.05 & 0.11 & 2.1 & 8.23 & 0.09 \\
\hline 10.1 & 5.25 & 0.06 & 3.1 & 9.10 & 0.08 & 3.1 & 7.78 & 0.11 \\
\hline 13.1 & 5.57 & 0.09 & 8.1 & 7.65 & 0.10 & 5.1 & 7.75 & 0.10 \\
\hline 14.1 & 6.15 & 0.08 & 9.1 & 7.42 & 0.09 & 9.1 & 8.00 & 0.07 \\
\hline 15.1 & 5.80 & 0.11 & 10.1 & 7.87 & 0.08 & 10.1 & 7.40 & 0.11 \\
\hline 16.1 & 6.00 & 0.11 & 12.1 & 5.01 & 0.08 & 12.1 & 8.07 & 0.12 \\
\hline 12.1 & 6.31 & 0.04 & 14.1 & 6.72 & 0.04 & 11.1 & 8.58 & 0.07 \\
\hline 5.1 & 5.59 & 0.08 & 15.1 & 7.06 & 0.08 & 4.1 & 7.07 & 0.09 \\
\hline 5.2 & 7.59 & 0.06 & 16.1 & 6.93 & 0.06 & 6.1 & 7.73 & 0.11 \\
\hline 7.1 & 5.85 & 0.08 & 4.1 & 7.27 & 0.09 & 8.1 & 8.03 & 0.06 \\
\hline 7.2 & 7.69 & 0.06 & 7.1 & 7.15 & 0.09 & 7.1 & 8.18 & 0.07 \\
\hline 1.1 & 5.60 & 0.08 & 1.1 & 5.06 & 0.07 & & & \\
\hline 3.1 & 8.12 & 0.08 & 1.2 & 6.70 & 0.08 & Sample DKE-277 & & \\
\hline 4.1 & 7.87 & 0.08 & 5.1 & 4.89 & 0.06 & 2.1 & 5.92 & 0.09 \\
\hline 8.2 & 5.71 & 0.09 & 6.1 & 6.41 & 0.15 & 8.1 & 6.24 & 0.07 \\
\hline 9.1 & 8.17 & 0.05 & 11.1 & 5.53 & 0.10 & 9.1 & 5.48 & 0.08 \\
\hline 11.1 & 5.85 & 0.08 & 11.2 & 6.51 & 0.03 & 10.1 & 5.61 & 0.14 \\
\hline 11.2 & 7.69 & 0.06 & 12.2 & 5.45 & 0.10 & 11.1 & 6.25 & 0.10 \\
\hline 12.2 & 7.57 & 0.08 & 13.1 & 7.61 & 0.08 & 12.1 & 5.90 & 0.09 \\
\hline 12.3 & 7.88 & 0.07 & 17.1 & 4.64 & 0.07 & 3.1 & 5.79 & 0.11 \\
\hline 2.1 & 5.96 & 0.12 & 18.1 & 5.94 & 0.08 & 4.1 & 5.54 & 0.16 \\
\hline 20.1 & 5.20 & 0.04 & & & & 5.1 & 6.01 & 0.09 \\
\hline \multirow[t]{2}{*}{20.2} & 5.84 & 0.09 & & & & 6.1 & 5.72 & 0.09 \\
\hline & & & & & & 7.1 & 5.79 & 0.08 \\
\hline
\end{tabular}

Sample DKE-170 ratio (\%o) error (\%o) Sample DKE-200Aratio (\%o) error (\%o) Sample DKE-269ratio (\%o) error (\%o)

\begin{tabular}{|c|c|c|c|c|c|c|c|c|}
\hline 1.1 & 8.27 & 0.15 & 1.1 & 7.8 & 0.11 & 1.1 & 6.24 & 0.08 \\
\hline 2.1 & 6.85 & 0.06 & 2.1 & 7.27 & 0.1 & 3.1 & 10.34 & 0.05 \\
\hline 3.1 & 7.65 & 0.06 & 3.1 & 7.81 & 0.06 & 3.2 & 9.44 & 0.08 \\
\hline 4.1 & 8.02 & 0.08 & 4.1 & 8.19 & 0.08 & 5.1 & 8.74 & 0.07 \\
\hline 9.1 & 7.3 & 0.07 & 5.1 & 6.79 & 0.07 & 6.1 & 10.82 & 0.08 \\
\hline 10.1 & 5.94 & 0.1 & 6.1 & 6.73 & 0.06 & 14.1 & 10.33 & 0.06 \\
\hline 11.1 & 7.88 & 0.07 & 7.1 & 6.93 & 0.09 & 15.1 & 10.27 & 0.07 \\
\hline 12.1 & 7.86 & 0.05 & 10.1 & 7.55 & 0.08 & 10.1 & 9.66 & 0.07 \\
\hline 5.1 & 9.06 & 0.07 & 11.1 & 7.63 & 0.09 & 4.1 & 9.91 & 0.1 \\
\hline 6.1 & 7.86 & 0.05 & 8.1 & 7.51 & 0.07 & 8.1 & 10 & 0.11 \\
\hline 7.1 & 7.39 & 0.06 & 9.1 & 7.93 & 0.09 & 9.1 & 10.01 & 0.1 \\
\hline \multirow[t]{5}{*}{8.1} & 7.95 & 0.05 & & & & 11.1 & 9.58 & 0.1 \\
\hline & & & & & & 12.1 & 8.81 & 0.06 \\
\hline & & & & & & 13.1 & 9.3 & 0.11 \\
\hline & & & & & & 2.1 & 8.9 & 0.1 \\
\hline & & & & & & 7.1 & 8.69 & 0.11 \\
\hline
\end{tabular}




\section{ANEXO VI}

(análises LA-ICP-MS ETR em zircões) 


\begin{tabular}{|c|c|c|c|c|c|c|c|c|c|c|c|c|c|c|c|c|c|c|c|c|c|c|}
\hline Sample & Zircon type & $\mathbf{Y}$ & $\mathrm{Nb}$ & La & $\mathrm{Ce}$ & $\mathrm{Pr}$ & Nd & $\mathrm{Sm}$ & $\mathrm{Eu}$ & Gd & Tb & Dy & но & $\mathrm{Er}$ & $\mathrm{Tm}$ & $\mathbf{Y b}$ & Lu & $\mathrm{Ta}$ & $\mathbf{P b}$ & Th & u & $\mathrm{Ti}$ \\
\hline $510-1$ & igneous core & 1662 & 2.95 & $<0.01$ & 4.36 & 0.06 & 1.41 & 5.83 & 0.57 & 39.9 & 13.4 & 171 & 60.8 & 271 & 53.5 & 467 & 81.9 & 1.50 & 2.93 & 41.1 & 116 & 28.0 \\
\hline $510-2$ & igneous core & 1329 & 2.50 & $<0.01$ & 4.01 & 0.06 & 1.59 & 5.31 & 0.63 & 33.8 & 11.0 & 137 & 47.9 & 211 & 43.0 & 367 & 64.3 & 1.32 & 2.91 & 33.5 & 106 & 24.4 \\
\hline $510-3$ & igneous core & 1300 & 1.97 & $<0.01$ & 3.43 & 0.03 & 0.81 & 3.46 & 0.50 & 26.4 & 9.26 & 126 & 46.4 & 214 & 44.3 & 385 & 68.1 & 1.32 & 2.07 & 34.0 & 99.4 & 32.2 \\
\hline $510-4$ & igneous core & 1084 & 1.63 & $<0.01$ & 4.26 & 0.04 & 1.06 & 3.04 & 0.29 & 22.1 & 7.60 & 97 & 35.8 & 169 & 34.1 & 301 & 52.4 & 1.01 & 4.56 & 65.1 & 165 & 24.1 \\
\hline $510-5$ & igneous core & 1520 & 3.15 & $<0.01$ & 4.70 & 0.08 & 2.14 & 6.17 & 0.72 & 38.7 & 12.9 & 158 & 55.8 & 245 & 49.7 & 433 & 72.9 & 1.34 & 3.36 & 40.3 & 111 & 26.7 \\
\hline $510-6$ & igneous core & 709 & 2.39 & $<0.01$ & 3.04 & 0.03 & 0.63 & 2.01 & 0.24 & 14.4 & 5.02 & 66 & 24.3 & 114 & 24.8 & 228 & 40.8 & 3.30 & 2.00 & 24.5 & 73.3 & $\begin{array}{l}16.7 \\
204\end{array}$ \\
\hline $\begin{array}{l}510-24 \\
510-25\end{array}$ & $\begin{array}{l}\text { igneous core } \\
\text { igneous core }\end{array}$ & $\begin{array}{l}722 \\
1187\end{array}$ & $\begin{array}{l}1.32 \\
3.91\end{array}$ & $\begin{array}{l}<0.01 \\
<0.01\end{array}$ & $\begin{array}{l}3.54 \\
8.50\end{array}$ & $\begin{array}{l}0.04 \\
0.04\end{array}$ & $\begin{array}{l}0.92 \\
125\end{array}$ & 3.15 & $\begin{array}{l}0.47 \\
0.49\end{array}$ & 18.3 & 5.81 & 71 & 25.3 & 112 & 23.0 & 196 & 33.5 & 0.70 & $\begin{array}{l}1.67 \\
585\end{array}$ & $\begin{array}{l}23.2 \\
77.7\end{array}$ & 94.5 & $\begin{array}{l}20.4 \\
19.1\end{array}$ \\
\hline $\begin{array}{l}510-25 \\
510-26\end{array}$ & $\begin{array}{l}\text { igneous core } \\
\text { rim }\end{array}$ & $\begin{array}{l}1487 \\
234\end{array}$ & $\begin{array}{l}3.91 \\
0.30\end{array}$ & $\begin{array}{l}<0.01 \\
20.3\end{array}$ & $\begin{array}{l}8.50 \\
4.76\end{array}$ & $\begin{array}{l}0.04 \\
8.77\end{array}$ & $\begin{array}{l}1.25 \\
51.7\end{array}$ & $\begin{array}{l}4.69 \\
17.8\end{array}$ & $\begin{array}{l}0.99 \\
6.14\end{array}$ & $\begin{array}{l}31.6 \\
36.1\end{array}$ & $\begin{array}{l}10.9 \\
5.93\end{array}$ & $\begin{array}{l}140 \\
42.7\end{array}$ & $\begin{array}{l}51.2 \\
8.73\end{array}$ & $\begin{array}{l}234 \\
21.2\end{array}$ & $\begin{array}{l}48.1 \\
2.26\end{array}$ & $\begin{array}{l}418 \\
967\end{array}$ & $\begin{array}{l}70.7 \\
1.24\end{array}$ & $\begin{array}{l}2.47 \\
0.05\end{array}$ & $\begin{array}{l}5.85 \\
0.08\end{array}$ & $\begin{array}{l}79.7 \\
0.52\end{array}$ & $\begin{array}{l}152 \\
40.1\end{array}$ & $\begin{array}{l}19.1 \\
13.0\end{array}$ \\
\hline $\begin{array}{l}510-26 \\
510-27\end{array}$ & rim & 21.6 & 0.26 & $\begin{array}{l}20.3 \\
0.09\end{array}$ & $\begin{array}{l}4.10 \\
3.46\end{array}$ & $\begin{array}{l}0.7 / 7 \\
0.08\end{array}$ & $\begin{array}{l}15.7 \\
0.97\end{array}$ & $\begin{array}{l}1.8 \\
0.68\end{array}$ & $\begin{array}{l}6.14 \\
0.41\end{array}$ & 2.06 & $\begin{array}{l}5.93 \\
0.42\end{array}$ & $\begin{array}{l}42.7 \\
3.60\end{array}$ & $\begin{array}{l}8 . / 3 \\
0.90\end{array}$ & $\begin{array}{l}12.2 \\
2.80\end{array}$ & $\begin{array}{l}2.26 \\
0.46\end{array}$ & $\begin{array}{l}\text {. } \\
3.37\end{array}$ & $\begin{array}{l}1.24 \\
0.44\end{array}$ & $\begin{array}{l}.05 \\
0.04\end{array}$ & $\begin{array}{l}0.08 \\
0.18\end{array}$ & $\begin{array}{l}0.52 \\
2.96\end{array}$ & $\begin{array}{l}40.1 \\
45.9\end{array}$ & $\begin{array}{l}13.0 \\
12.4\end{array}$ \\
\hline $510-28$ & rim & 14.2 & 0.23 & $<0.01$ & 1.12 & 0.00 & 0.09 & 0.44 & 0.27 & 1.25 & 0.21 & 1.92 & 0.40 & 1.47 & 0.24 & 2.10 & 0.26 & 0.04 & $<0.01$ & 0.26 & 24.9 & $\begin{array}{l}7.45 \\
7.83\end{array}$ \\
\hline $510-12$ & rim & 15.9 & 0.23 & 0.15 & 0.75 & 0.04 & 0.28 & 0.44 & 0.31 & 1.48 & 0.25 & $\begin{array}{l}2.24 \\
\end{array}$ & 0.51 & 1.66 & 0.24 & 1.98 & 0.30 & 0.04 & 0.03 & 0.41 & 83.0 & 7.90 \\
\hline $510-13$ & rim & 10.6 & 0.27 & $<0.01$ & 0.63 & $<0.01$ & 0.08 & 0.25 & 0.14 & 0.81 & 0.16 & 1.41 & 0.34 & 1.18 & 0.15 & 1.29 & 0.21 & 0.04 & 0.03 & 0.28 & 33.2 & 7.20 \\
\hline $510-14$ & rim & 18.5 & 0.30 & $<0.01$ & 0.01 & $<0.01$ & 0.00 & 0.00 & 0.01 & 0.12 & 0.08 & 1.26 & 0.54 & 2.80 & 0.77 & 8.55 & 2.26 & 0.12 & $<0.01$ & 0.04 & 4.01 & 5.01 \\
\hline $510-21$ & rim & 14.5 & 0.30 & $<0.01$ & 0.18 & $<0.01$ & 0.00 & 0.02 & 0.09 & 0.67 & 0.18 & 1.78 & 0.45 & 1.54 & 0.32 & 3.19 & 0.67 & 0.06 & $<0.01$ & 0.16 & 5.63 & $\begin{array}{l}6.48 \\
8.70\end{array}$ \\
\hline $510-19$ & rim & 13.5 & 0.24 & 0.03 & 0.53 & 0.01 & 0.10 & 0.26 & 0.18 & 1.10 & 0.23 & 1.92 & 0.42 & 1.32 & 0.22 & 1.65 & 0.25 & 0.04 & 0.06 & 0.57 & $\begin{array}{r}78.4 \\
7101\end{array}$ & 10.8 \\
\hline $510-8$ & rim & 11.5 & 0.29 & 0.10 & 0.88 & 0.01 & 0.12 & 0.21 & 0.17 & 0.88 & 0.18 & 1.58 & 0.34 & 1.20 & 0.19 & 1.46 & 0.26 & 0.05 & 0.04 & 0.71 & 101 & 8.26 \\
\hline $510-22$ & rim & 30.3 & 0.26 & $<0.01$ & 1.00 & 0.02 & 0.44 & 0.77 & 0.45 & 2.61 & 0.54 & 4.17 & 1.02 & 3.23 & 0.51 & 4.09 & 0.60 & 0.05 & 0.10 & 1.72 & 169 & 17.6 \\
\hline $510-23$ & rim & 15.1 & 0.25 & 0.02 & 0.83 & 0.02 & 0.23 & 0.40 & 0.25 & 1.20 & 0.24 & 1.81 & 0.50 & 1.52 & 0.22 & 1.84 & 0.27 & 0.05 & 0.09 & 1.30 & 147 & 10.3 \\
\hline $510-10$ & rim & 25.9 & 0.30 & $\begin{array}{l}0.01 \\
<0.01\end{array}$ & $\begin{array}{l}1.10 \\
1.78\end{array}$ & 0.01 & 0.14 & 0.53 & 0.35 & 2.04 & 0.40 & $\begin{array}{l}3.38 \\
3.38\end{array}$ & 0.81 & 2.5 & 0.4 & 3.02 & 0.46 & 0.05 & 0.06 & 1.03 & 119 & 10.7 \\
\hline $510-7$ & rim & $\begin{array}{l}15.6 \\
187\end{array}$ & 0.28 & $<0.01$ & $\begin{array}{l}1.78 \\
1.45\end{array}$ & $\begin{array}{r}0.01 \\
\end{array}$ & 0.22 & 0.37 & 0.25 & 1.22 & $\begin{array}{l}0.27 \\
0.18\end{array}$ & $\begin{array}{r}2.03 \\
1.81\end{array}$ & $\begin{array}{l}0.50 \\
0.56\end{array}$ & $\begin{array}{l}1.5 \\
3.3\end{array}$ & 0.2 & 2.06 & 0.35 & 0.04 & 0.16 & 2.84 & 33.3 & $\begin{array}{l}11.2 \\
0.55\end{array}$ \\
\hline $\begin{array}{c}510-9 \\
510-16\end{array}$ & rim & $\begin{array}{l}18.7 \\
152\end{array}$ & $\begin{array}{l}0.30 \\
0.27\end{array}$ & $<0.01$ & $\begin{array}{l}1.45 \\
0.64\end{array}$ & $\begin{array}{l}<0.01 \\
0.02\end{array}$ & $\begin{array}{l}0.08 \\
0.07\end{array}$ & $\begin{array}{l}0.23 \\
0.21\end{array}$ & $\begin{array}{l}0.16 \\
0.13\end{array}$ & $\begin{array}{l}0.80 \\
0.92\end{array}$ & $\begin{array}{l}0.18 \\
0.24\end{array}$ & $\begin{array}{l}1.81 \\
1.90\end{array}$ & $\begin{array}{l}0.56 \\
0.50\end{array}$ & $\begin{array}{l}3.3 \\
1.6\end{array}$ & $\begin{array}{l}1.0 \\
0.3\end{array}$ & $\begin{array}{l}20.1 \\
2.59\end{array}$ & $\begin{array}{l}4.50 \\
0.51\end{array}$ & $\begin{array}{l}0.04 \\
0.04\end{array}$ & $\begin{array}{l}0.14 \\
0.05\end{array}$ & $\begin{array}{l}2.17 \\
0.86\end{array}$ & $\begin{array}{l}28.9 \\
18.3\end{array}$ & $\begin{array}{l}9.55 \\
14.7\end{array}$ \\
\hline $\begin{array}{l}510-16 \\
510-17\end{array}$ & $\begin{array}{l}\text { rim } \\
\text { rim }\end{array}$ & $\begin{array}{l}15.2 \\
29.6\end{array}$ & $\begin{array}{l}0.27 \\
0.25\end{array}$ & $\begin{array}{c}0.04 \\
<0.01\end{array}$ & $\begin{array}{l}0.64 \\
1.73\end{array}$ & $\begin{array}{l}0.02 \\
0.02\end{array}$ & $\begin{array}{l}0.07 \\
0.54\end{array}$ & $\begin{array}{l}0.21 \\
0.89\end{array}$ & $\begin{array}{l}0.13 \\
0.54\end{array}$ & $\begin{array}{l}0.92 \\
2.44\end{array}$ & $\begin{array}{l}0.24 \\
0.54\end{array}$ & $\begin{array}{l}1.90 \\
4.61\end{array}$ & $\begin{array}{l}0.5 \\
1.0\end{array}$ & $\begin{array}{l}1.61 \\
2.98\end{array}$ & $\begin{array}{l}0.32 \\
0.51\end{array}$ & $\begin{array}{l}\begin{array}{r}2.59 \\
3.49\end{array} \\
3.49\end{array}$ & $\begin{array}{l}0.51 \\
0.53\end{array}$ & $\begin{array}{l}0.04 \\
0.03\end{array}$ & $\begin{array}{l}0.05 \\
0.36\end{array}$ & $\begin{array}{l}0.86 \\
5332\end{array}$ & $\begin{array}{l}18.3 \\
40.5\end{array}$ & $\begin{array}{l}14.7 \\
10.6\end{array}$ \\
\hline $510-29$ & rim & 25.6 & 0.23 & $<0.01$ & $\begin{array}{l}1.73 \\
1.08\end{array}$ & $\begin{array}{l}0.02 \\
<0.01\end{array}$ & 0.25 & $\begin{array}{l}0.99 \\
0.77\end{array}$ & $\begin{array}{l}0.54 \\
0.43\end{array}$ & $\begin{array}{l}2.44 \\
2.18\end{array}$ & 0.43 & 3.45 & 0.84 & 2.61 & 0.4 & 3.32 & 0.47 & 0.04 & 0.06 & 1.26 & 116 & 12.1 \\
\hline $510-30$ & rim & 23.1 & 0.25 & $<0.01$ & 0.60 & $<0.01$ & 0.11 & 0.32 & 0.30 & 1.73 & 0.36 & 2.94 & 0.8 & 2.3 & 0.4 & 3.3 & 0.45 & 0.05 & 0.03 & 0.31 & 72.1 & 9.81 \\
\hline $510-11$ & homg rounded & 13.2 & 0.28 & $<0.01$ & 3.05 & 0.03 & 0.71 & 0.91 & 0.46 & 1.57 & 0.25 & 1.83 & 0.40 & 1.28 & 0.21 & 1.47 & 0.22 & 0.04 & 0.14 & 2.80 & 29.1 & 14.9 \\
\hline $510-15$ & homg rounded & 13.6 & 0.28 & $<0.01$ & 4.09 & 0.03 & 0.32 & 0.55 & 0.29 & 1.30 & 0.21 & 2.01 & 0.41 & 1.35 & 0.21 & 1.71 & 0.24 & 0.04 & 0.26 & 4.70 & 33.8 & 10.2 \\
\hline $510-20$ & homg. rounded & 13.2 & 0.29 & $<0.01$ & 3.94 & 0.02 & 0.28 & 0.37 & 0.23 & 1.03 & 0.22 & 1.82 & 0.38 & 1.39 & 0.23 & 1.77 & 0.27 & 0.05 & 0.37 & 6.94 & 33.0 & 12.8 \\
\hline 350 & igneous core & 117 & 0.44 & $<0.01$ & 1.61 & 0.01 & 0.29 & 2.16 & 1.73 & 17.2 & 3.8 & 24 & 3.6 & 8. & 1.2 & 9 & 1.31 & 0.14 & 0.03 & 0.79 & 73.1 & 5.15 \\
\hline $350-$ & igneous core & 2099 & 8.15 & $<0.01$ & 6.0 & 0.07 & 1.7 & 5.22 & 1.03 & 35.2 & 13. & 189 & 74. & $35 \%$ & 76 & 700 & $\begin{array}{l}124 \\
184\end{array}$ & $\begin{array}{l}3.08 \\
2.31\end{array}$ & $\begin{array}{l}2.77 \\
280\end{array}$ & $\begin{array}{l}41.3 \\
41.7\end{array}$ & $\begin{array}{l}79.6 \\
787\end{array}$ & $\begin{array}{l}4.86 \\
4.94\end{array}$ \\
\hline $350-17$ & igneous core & 3564 & 5.63 & 0.01 & 5.4 & 0.21 & 4.02 & 9.92 & 2.00 & 67.4 & 24. & 341 & 12 & 59 & 12 & 10 & $\begin{array}{l}184 \\
154\end{array}$ & $\begin{array}{l}2.31 \\
7.05\end{array}$ & $\begin{array}{l}2.80 \\
3.31\end{array}$ & $\begin{array}{l}41.7 \\
49.4\end{array}$ & $\begin{array}{l}78.7 \\
124\end{array}$ & $\begin{array}{l}4.94 \\
4.75\end{array}$ \\
\hline $350-18$ & $\begin{array}{l}\text { igneous core } \\
\text { jingeouscrore }\end{array}$ & 2688 & 17.8 & $<0.01$ & 13.3 & 0.08 & 1.87 & $\begin{array}{l}6.20 \\
0.56\end{array}$ & 0.9 & 45.2 & $\begin{array}{l}17.94 \\
2253\end{array}$ & 252 & 97.5 & 46 & 98. & 88 & 154 & 7.05 & $\begin{array}{l}3.31 \\
3.30\end{array}$ & 49.4 & 124 & 4.75 \\
\hline $350-19$ & $\begin{array}{l}\text { igneous core } \\
\text { igneouscrore }\end{array}$ & 3372 & $\begin{array}{l}8.00 \\
565\end{array}$ & $<0.01$ & 6.41 & 0.16 & 3.68 & 9.56 & 1.64 & 61.2 & 22.53 & 317 & 122 & 578 & 119 & 1075 & 182 & 3.22 & 3.20 & 48.2 & 102 & 6.19 \\
\hline $\begin{array}{l}\begin{array}{l}350-20 \\
350-21\end{array} \\
3\end{array}$ & $\begin{array}{l}\text { igneous core } \\
\text { igneous core }\end{array}$ & $\begin{array}{l}2485 \\
1013\end{array}$ & $\begin{array}{l}5.65 \\
3.28 \\
\end{array}$ & $\begin{array}{l}<0.01 \\
<0.01\end{array}$ & $\begin{array}{l}5.62 \\
3.06\end{array}$ & $\begin{array}{l}0.11 \\
0.03\end{array}$ & $\begin{array}{l}2.83 \\
0.71\end{array}$ & $\begin{array}{l}8.00 \\
2.51\end{array}$ & $\begin{array}{l}1.27 \\
0.67\end{array}$ & $\begin{array}{l}47.3 \\
18.5\end{array}$ & $\begin{array}{l}17.10 \\
6.71\end{array}$ & $\begin{array}{l}{ }^{236} \\
91\end{array}$ & $\begin{array}{l}89.0 \\
35.1\end{array}$ & $\begin{array}{l}428 \\
169\end{array}$ & $\begin{array}{l}91.2 \\
36.4\end{array}$ & $\begin{array}{l}832 \\
343\end{array}$ & $\begin{array}{l}140 \\
61.2\end{array}$ & $\begin{array}{l}2.57 \\
1.29\end{array}$ & $\begin{array}{l}2.62 \\
0.64\end{array}$ & $\begin{array}{l}39.6 \\
10.8\end{array}$ & $\begin{array}{l}97.3 \\
49.4\end{array}$ & $\begin{array}{l}8.30 \\
19.3\end{array}$ \\
\hline
\end{tabular}


(análises LA-ICP-MS em rutilo) 


\begin{tabular}{|c|c|c|c|c|c|c|c|c|c|c|c|c|c|c|c|c|c|}
\hline Sample & $\mathrm{Al}(\mathrm{ppm})$ & P (ppm) & Sc (ppm) & $\mathrm{V}$ (ppm) & $\operatorname{Cr}(p p m)$ & Mn (ppm) & $\mathrm{Fe}(\mathrm{ppm})$ & $\mathrm{Cu}(\mathrm{ppm})$ & Zn (ppm) & $\mathrm{Y}(\mathrm{ppm})$ & $\mathrm{Zr}$ (ppm) & $\mathrm{Nb}(\mathrm{ppm})$ & Mo (ppm) & Hf (ppm) & Ta (ppm) & w (ppm) & $\mathrm{Zr}-\mathrm{in} \mathrm{T}\left({ }^{\circ} \mathrm{C}\right)$ \\
\hline RT506-01 & 35.40 & 18.60 & 1.58 & 3153 & 81.30 & 0.02 & 1979 & 16.09 & 9.28 & 0.05 & 355.2 & 297.1 & 10.45 & 16.92 & 17.60 & 5.19 & 751 \\
\hline RT506-04 & 43.80 & 18.30 & 1.28 & 3890 & 56.50 & 6.40 & 1710 & 15.38 & 9.00 & 0.05 & 263.0 & 249.5 & 9.48 & 13.78 & 13.47 & 4.99 & 724 \\
\hline RT506-05 & 75.80 & 14.80 & 2.36 & 4400 & 117.90 & 12.10 & 2570 & 15.40 & 10.21 & 0.07 & 297.5 & 228.2 & 10.36 & 14.03 & 10.26 & 5.42 & 735 \\
\hline RT506-06 & 27.67 & 20.10 & 2.24 & 2308 & 196.60 & 0.04 & 1635 & 14.68 & 9.22 & 0.06 & 574.7 & 384.3 & 11.12 & 20.86 & 20.89 & 20.64 & 796 \\
\hline RT506-07 & 18.78 & 16.30 & 2.20 & 1315 & 548.00 & 0.02 & 1717 & 15.11 & 8.06 & 0.06 & 292.9 & 591.0 & 13.31 & 15.42 & 37.92 & 40.96 & 734 \\
\hline RT506-09 & 28.26 & 17.60 & 2.14 & 1135 & 1120.00 & 0.04 & 980 & 14.26 & 7.89 & 0.06 & 347.6 & 415.8 & 12.82 & 15.90 & 20.26 & 47.90 & 749 \\
\hline RT506-10 & 19.37 & 23.50 & 2.00 & 1499 & 337.70 & 1.86 & 1588 & 15.21 & 9.16 & 0.06 & 203.4 & 443.6 & 11.39 & 12.17 & 35.43 & 32.58 & 703 \\
\hline RT506-11 & 22.20 & 17.10 & 1008.00 & 3114 & 169.10 & 0.12 & 1013 & 14.58 & 8.37 & 0.07 & 224.6 & 311.3 & 11.21 & 13.05 & 15.55 & 5.52 & 711 \\
\hline RT506-12 & 18.50 & 15.20 & 2.39 & 1412 & 1375.00 & 0.00 & 1680 & 15.29 & 9.30 & 0.06 & 419.9 & 1494.0 & 14.03 & 18.92 & 151.60 & 82.40 & 766 \\
\hline RT506-13 & 53.30 & 15.80 & 1.88 & 3150 & 68.80 & 0.96 & 1787 & 15.94 & 7.62 & 0.14 & 321.2 & 272.0 & 9.39 & 15.84 & 13.03 & 5.23 & 742 \\
\hline RT506-14 & 14.95 & 16.30 & 2.64 & 1424 & 735.00 & 64.90 & 2679 & 13.10 & $\begin{array}{l}1.02 \\
17.80\end{array}$ & 0.07 & 115.8 & 426.5 & 9.58 & 10.48 & 26.25 & $\begin{array}{l}5.23 \\
47.30\end{array}$ & 658 \\
\hline RT506-15 & 28.08 & 19.30 & 1.55 & 3089 & 63.60 & 0.11 & 1553 & 13.89 & 7.62 & 0.06 & 415.8 & 252.2 & 9.51 & 18.00 & 19.90 & 5.42 & 765 \\
\hline RT514-01 & 130.00 & 19.80 & 1625.00 & 1894 & 101.00 & 24.27 & 2384 & 13.76 & 9.06 & 0.06 & 212.8 & 397.3 & 8.74 & 11.55 & 32.14 & 10.68 & 706 \\
\hline RT514-02 & 17.02 & 17.90 & 1.54 & 2118 & 75.50 & 0.00 & 1604 & 14.28 & 8.07 & 0.06 & 274.8 & 371.8 & 8.43 & 13.48 & 23.23 & 9.15 & 728 \\
\hline RT514-03 & 114.20 & 19.60 & 2.06 & 1840 & 112.60 & 0.01 & 1655 & 13.55 & 7.99 & 0.05 & 304.0 & 385.5 & 8.19 & 13.40 & 20.50 & 8.58 & 737 \\
\hline RT514-04 & 95.00 & 19.00 & 2.25 & 2247 & 138.80 & 0.00 & 1858 & 13.97 & 7.90 & 0.06 & 535.8 & 344.0 & 8.53 & 21.10 & 25.95 & 7.29 & 789 \\
\hline RT514-05 & 53.50 & 14.30 & 2.09 & 2076 & 101.70 & 0.06 & 1557 & 13.78 & 8.34 & 0.07 & 298.4 & 396.8 & 8.95 & 15.15 & 26.64 & 8.60 & 735 \\
\hline RT514-06 & 239.00 & 15.90 & 1.79 & 1855 & 115.30 & 0.11 & 1616 & 12.55 & 8.27 & 0.06 & 242.9 & 381.6 & 8.65 & 12.37 & 20.47 & 8.30 & 717 \\
\hline RT514-07 & 88.90 & 17.90 & 1.59 & 1998 & 105.30 & 0.02 & 1912 & 13.16 & 7.34 & 0.06 & 234.5 & 459.3 & 8.54 & 12.87 & 26.88 & 9.73 & 714 \\
\hline RT514-08 & 49.00 & 16.70 & 1.85 & 2034 & 105.20 & 0.11 & 1484 & 14.00 & 18.20 & 0.06 & 248.7 & 346.7 & 8.73 & 13.85 & 19.25 & 8.78 & 719 \\
\hline RT514-09 & 65.30 & 18.00 & 1.73 & 1886 & 101.90 & 0.03 & 1722 & 350.00 & 7.40 & 0.06 & 243.6 & 418.2 & 8.76 & 15.37 & 33.00 & 8.48 & 718 \\
\hline RT514-10 & 290.00 & 18.30 & 2111.00 & 1809 & 105.70 & 0.00 & 1957 & 13.76 & 8.02 & 0.06 & 250.0 & 342.3 & 7.99 & 12.36 & 15.75 & 9.43 & 720 \\
\hline RT514-11 & 332.00 & 19.10 & 2.63 & 1667 & 183.20 & 0.03 & 1741 & 13.96 & 8.11 & 0.07 & 279.9 & 430.4 & 8.44 & 13.68 & 19.11 & 10.53 & 730 \\
\hline RT514-12 & 19.55 & 15.50 & 2.31 & 1804 & 97.30 & 0.00 & 1589 & 12.48 & 7.45 & 0.07 & 325.0 & 370.3 & 8.29 & 16.38 & 17.10 & 7.87 & 743 \\
\hline RT514-14 & 26.86 & 17.30 & 1.19 & 1878 & 107.80 & 0.21 & 1688 & 12.87 & 8.40 & 0.05 & 148.3 & 377.0 & 8.93 & 11.60 & 19.64 & 8.37 & 677 \\
\hline RT514-15 & 74.20 & 17.90 & 2.41 & 1894 & 143.90 & 0.00 & 1750 & 12.67 & 9.24 & 0.04 & 248.0 & 415.8 & 9.06 & 13.93 & 20.12 & 9.19 & 719 \\
\hline RT350-1 & 78.80 & 13.80 & 1.95 & 1957 & 88.40 & -0.05 & 1769 & 9.01 & 9.00 & 0.06 & 222.5 & 405.7 & 7.99 & 12.29 & 27.60 & 8.59 & 722 \\
\hline RT350-2 & 78.30 & 13.40 & 2.22 & 1972 & 95.80 & 0.10 & 1787 & 9.10 & 6.29 & 0.04 & 202.6 & 391.3 & 8.33 & 11.21 & 26.87 & 9.97 & 715 \\
\hline RT350-3 & 48.00 & 17.50 & 1.78 & 2146 & 96.30 & 0.07 & 1838 & 8.92 & 6.90 & 0.04 & 300.8 & 406.4 & 8.26 & 14.50 & 23.75 & 9.05 & 748 \\
\hline RT350-4 & 135.30 & 17.50 & 1.31 & 2156 & 56.80 & 0.13 & 1520 & 9.27 & 8.30 & 0.05 & 250.1 & 352.6 & 8.07 & 14.80 & 23.47 & 8.79 & 732 \\
\hline RT350-5 & $\begin{array}{l}73.00 \\
73.00\end{array}$ & 18.80 & 2.36 & 1861 & 85.50 & 0.07 & 1801 & 9.97 & 6.01 & 0.05 & 198.7 & 387.4 & 8.28 & 11.65 & 25.24 & 9.18 & 713 \\
\hline RT350-6 & 245.30 & 15.10 & 1.68 & 1953 & 55.90 & 0.13 & 1639 & 9.04 & 6.57 & 0.05 & 268.5 & 366.0 & 8.15 & 13.57 & 25.60 & 9.66 & 738 \\
\hline RT350-7 & 77.20 & 15.10 & 1.96 & 1962 & 65.40 & 3.18 & 1997 & 9.64 & 9.42 & 0.05 & 211.9 & 324.3 & 7.93 & 11.92 & 15.94 & 9.36 & 718 \\
\hline RT350-8 & 139.20 & 16.90 & 2.16 & 1986 & 94.90 & 0.08 & 2021 & 9.18 & 6.86 & 0.05 & 174.3 & 392.3 & 8.34 & 11.07 & 21.25 & 10.12 & 703 \\
\hline RT350-9 & 176.30 & 17.50 & 1.98 & 1738 & 494.00 & $\begin{array}{l}-0.01 \\
-0.01\end{array}$ & 1937 & 9.99 & $\begin{array}{l}.00 \\
9.10\end{array}$ & 0.17 & 160.0 & 1192.0 & $\begin{array}{l}0.04 \\
10.41\end{array}$ & 6.10 & 65.61 & 11.38 & 696 \\
\hline RT350-10 & 60.90 & 17.60 & 1.34 & 1853 & 81.00 & 0.72 & 1547 & 9.74 & 7.77 & 0.26 & 179.6 & 342.3 & 8.50 & 10.98 & 23.72 & 9.62 & 705 \\
\hline RT350-11 & 23.18 & 20.50 & 2.27 & 2020 & 76.10 & 0.03 & 1494 & 8.97 & 5.90 & 0.05 & 263.2 & 352.7 & 8.82 & 14.28 & 21.77 & 8.59 & 736 \\
\hline RT350-12 & 400.00 & 15.00 & 1.26 & 1606 & 564.20 & 3.40 & 2384 & 9.27 & 8.13 & 0.13 & 53.8 & 919.0 & 9.94 & 2.99 & 53.09 & 9.05 & 618 \\
\hline RT350-13 & 86.10 & 14.70 & 1.75 & 2120 & 63.80 & 0.34 & 2062 & 9.19 & 11.63 & 0.06 & 282.9 & 371.2 & 7.65 & 13.95 & 20.36 & 7.90 & 743 \\
\hline
\end{tabular}




\section{ANEXO VIII}

(análises de microssonda em onfacita, granada e fengita) 


\begin{tabular}{|c|c|c|c|c|c|c|c|c|c|}
\hline \multirow{2}{*}{$\begin{array}{l}\text { Sample } \\
\text { Garnet } \\
\mathrm{SiO}_{2}\end{array}$} & \multirow{2}{*}{$\begin{array}{c}\text { S-514A } \\
38.81\end{array}$} & \multirow{2}{*}{$\begin{array}{c}\text { S514A' }^{\prime} \\
38.73\end{array}$} & \multirow{2}{*}{$\begin{array}{c}\text { S-514B } \\
37.69\end{array}$} & \multirow{2}{*}{$\begin{array}{c}\text { S-514C } \\
37.58\end{array}$} & \multicolumn{5}{|c|}{ DKE-350ADKE-350BDKE-350C DKE-350DDKE-350E } \\
\hline & & & & & 39.23 & 38.40 & 39.83 & 39.12 & 38.70 \\
\hline $\mathrm{TiO}_{2}$ & 0.20 & 0.34 & 0.20 & 0.05 & 0.03 & 0.21 & 0.05 & 0.09 & 0.14 \\
\hline $\mathrm{Al} 203$ & 22.11 & 21.95 & 21.68 & 21.88 & 22.66 & 21.37 & 22.73 & 21.67 & 21.57 \\
\hline $\mathrm{FeO}$ & 22.84 & 22.86 & 23.25 & 22.29 & 24.32 & 25.31 & 21.22 & 25.18 & 24.85 \\
\hline Mno & 0.24 & 0.24 & 0.22 & 0.24 & 0.46 & 0.64 & 0.29 & 0.92 & 0.69 \\
\hline MgO & 8.83 & 8.63 & 9.04 & 8.67 & 7.10 & 5.16 & 8.40 & 5.48 & 6.85 \\
\hline $\mathrm{CaO}$ & 7.54 & 8.16 & 7.57 & 8.41 & 7.96 & 10.11 & 9.36 & 9.56 & 8.21 \\
\hline $\mathrm{Cr}_{2} \mathrm{O}_{3}$ & 0.08 & 0.04 & 0.00 & 0.02 & 0.00 & 0.03 & 0.05 & 0.03 & 0.07 \\
\hline Total & 100.65 & 100.96 & 99.64 & 99.14 & 101.76 & 101.24 & 101.93 & 102.04 & 101.09 \\
\hline Si & 2.95 & 2.95 & 2.91 & 2.91 & 2.97 & 2.97 & 2.98 & 2.99 & 2.97 \\
\hline Al & 1.98 & 1.97 & 1.98 & 2.00 & 2.02 & 1.95 & 2.00 & 1.95 & 1.95 \\
\hline $\mathrm{Ti}$ & 0.01 & 0.02 & 0.01 & 0.00 & 0.00 & 0.01 & 0.00 & 0.01 & 0.01 \\
\hline $\mathrm{Fe}^{2+}$ & 1.45 & 1.45 & 1.50 & 1.45 & 1.54 & 1.64 & 1.33 & 1.61 & 1.60 \\
\hline Mn & 0.02 & 0.02 & 0.02 & 0.02 & 0.03 & 0.04 & 0.02 & 0.06 & 0.05 \\
\hline $\mathrm{Mg}$ & 1.00 & 0.98 & 1.04 & 1.00 & 0.80 & 0.59 & 0.94 & 0.62 & 0.78 \\
\hline $\mathrm{Ca}$ & 0.62 & 0.67 & 0.63 & 0.70 & 0.65 & 0.84 & 0.75 & 0.78 & 0.68 \\
\hline $\mathrm{Cr}$ & 0.01 & 0.00 & 0.00 & 0.00 & 0.00 & 0.00 & 0.00 & 0.00 & 0.00 \\
\hline Cations & 8.04 & 8.05 & 8.09 & 8.08 & 8.01 & 8.04 & 8.02 & 8.03 & 8.04 \\
\hline $\mathbf{X}_{\text {Alm }}$ & 0.47 & 0.47 & 0.47 & 0.46 & 0.51 & 0.53 & 0.44 & 0.52 & 0.51 \\
\hline $\mathbf{X}_{\mathrm{Sps}}$ & 0.01 & 0.00 & 0.01 & 0.00 & 0.01 & 0.01 & 0.01 & 0.02 & 0.01 \\
\hline $\mathbf{X}_{\mathrm{Prp}}$ & 0.33 & 0.31 & 0.33 & 0.32 & 0.27 & 0.19 & 0.31 & 0.20 & 0.25 \\
\hline $\mathbf{X}_{\mathrm{Grs}}$ & 0.20 & 0.21 & 0.20 & 0.22 & 0.21 & 0.27 & 0.25 & 0.25 & 0.22 \\
\hline \multicolumn{10}{|c|}{ Omphacite } \\
\hline $\mathrm{SiO}_{2}$ & 57.61 & 55.33 & 54.32 & 53.96 & 56.99 & 55.97 & 56.44 & 56.38 & 54.70 \\
\hline $\mathrm{TiO}_{2}$ & 0.13 & 0.13 & 0.10 & 0.12 & 0.05 & 0.04 & 0.05 & 0.05 & 0.04 \\
\hline $\mathrm{Al}_{2} \mathbf{O}_{3}$ & 15.63 & 14.89 & 15.10 & 14.26 & 9.84 & 8.00 & 10.86 & 8.75 & 8.23 \\
\hline $\mathrm{Cr}_{2} \mathrm{O}_{3}$ & 0.03 & 0.03 & 0.03 & 0.03 & 0.05 & 0.25 & 0.06 & 0.14 & 0.38 \\
\hline $\mathrm{FeO}$ & 2.59 & 2.67 & 2.42 & 2.46 & 3.55 & 6.12 & 4.11 & 5.54 & 4.78 \\
\hline Mno & 0.00 & 0.02 & 0.02 & 0.02 & 0.01 & 0.01 & 0.01 & 0.01 & 0.01 \\
\hline MgO & 7.15 & 6.93 & 6.74 & 7.21 & 10.25 & 9.81 & 8.79 & 9.54 & 9.91 \\
\hline $\mathrm{CaO}$ & 10.91 & 11.13 & 10.53 & 11.22 & 15.41 & 15.28 & 14.23 & 14.78 & 15.16 \\
\hline $\mathrm{Na}_{2} \mathrm{O}$ & 8.36 & 8.02 & 8.12 & 7.73 & 5.54 & 5.50 & 6.53 & 5.84 & 5.38 \\
\hline Total & 102.41 & 99.15 & 97.39 & 97.00 & 101.69 & 100.99 & 101.07 & 101.03 & 98.61 \\
\hline $\mathrm{Si}$ & 1.97 & 1.96 & 1.95 & 1.95 & 2.00 & 1.99 & 1.98 & 2.00 & 1.99 \\
\hline Al(IV) & 0.03 & 0.04 & 0.05 & 0.05 & 0.00 & 0.01 & 0.02 & 0.00 & 0.01 \\
\hline Al(VI) & 0.60 & 0.58 & 0.59 & 0.56 & 0.40 & 0.33 & 0.43 & 0.36 & 0.34 \\
\hline $\mathrm{Ti}$ & 0.00 & 0.00 & 0.00 & 0.00 & 0.00 & 0.00 & 0.00 & 0.00 & 0.00 \\
\hline $\mathrm{Fe}^{3+}$ & 0.00 & 0.01 & 0.02 & 0.03 & 0.00 & 0.05 & 0.02 & 0.03 & 0.04 \\
\hline $\mathrm{Fe}^{2+}$ & 0.07 & 0.07 & 0.06 & 0.05 & 0.10 & 0.13 & 0.10 & 0.13 & 0.10 \\
\hline Mn & 0.00 & 0.00 & 0.00 & 0.00 & 0.00 & 0.00 & 0.00 & 0.00 & 0.00 \\
\hline $\mathrm{Mg}$ & 0.37 & 0.37 & 0.36 & 0.39 & 0.54 & 0.52 & 0.46 & 0.50 & 0.54 \\
\hline $\mathrm{Ca}$ & 0.40 & 0.42 & 0.41 & 0.43 & 0.58 & 0.58 & 0.54 & 0.56 & 0.59 \\
\hline $\mathrm{Na}$ & 0.56 & 0.55 & 0.57 & 0.54 & 0.38 & 0.38 & 0.45 & 0.40 & 0.38 \\
\hline $\mathrm{Cr}$ & 0.00 & 0.00 & 0.00 & 0.00 & 0.00 & 0.01 & 0.00 & 0.00 & 0.01 \\
\hline $\begin{array}{l}\text { Cations } \\
\text { Phengite }\end{array}$ & 4.00 & 4.00 & 4.00 & 4.00 & 4.00 & 4.00 & 4.00 & 4.00 & 4.00 \\
\hline $\mathrm{SiO}_{2}$ & 53.03 & 53.04 & 50.17 & 50.18 & 53.86 & 53.29 & 51.01 & 51.99 & 51.14 \\
\hline $\mathrm{TiO}_{2}$ & 0.54 & 0.54 & 0.77 & 0.79 & 0.24 & 0.28 & 0.24 & 0.26 & 0.23 \\
\hline $\mathrm{Al}_{20}$ & 27.15 & 27.16 & 26.41 & 26.64 & 26.47 & 26.26 & 27.68 & 25.97 & 25.42 \\
\hline $\mathrm{Cr}_{2} \mathrm{O}_{3}$ & 0.02 & 0.03 & 0.03 & 0.05 & 0.05 & 0.05 & 0.06 & 0.07 & 0.08 \\
\hline $\mathrm{FeO}$ & 1.18 & 1.18 & 1.08 & 1.18 & 1.76 & 1.44 & 1.55 & 1.55 & 1.72 \\
\hline MnO & 0.00 & 0.00 & 0.00 & 0.01 & 0.00 & 0.02 & 0.00 & 0.00 & 0.01 \\
\hline Mg0 & 4.66 & 4.67 & 4.14 & 4.19 & 4.58 & 4.41 & 3.64 & 4.29 & 4.18 \\
\hline $\mathrm{CaO}$ & 0.02 & 0.02 & 0.01 & 0.00 & 0.00 & 0.04 & 0.01 & 0.05 & 0.11 \\
\hline $\mathrm{Na}_{2} \mathrm{O}$ & 0.36 & 0.36 & 0.42 & 0.40 & 0.41 & 0.65 & 0.72 & 0.63 & 0.75 \\
\hline $\mathbf{K}_{2} \mathbf{O}$ & 10.19 & 10.20 & 10.49 & 10.50 & 10.35 & 10.71 & 9.84 & 10.81 & 9.88 \\
\hline BaO & 0.00 & 0.00 & 0.00 & 0.00 & 0.00 & 0.00 & 0.00 & 0.00 & 0.00 \\
\hline Total & 97.15 & 97.20 & 93.51 & 93.95 & 9772 & 97.14 & 94.75 & 95.63 & 93.52 \\
\hline $\mathrm{Si}$ & 6.88 & 6.87 & 6.80 & 6.77 & 6.96 & 6.95 & 6.80 & 6.91 & 6.92 \\
\hline Al(IV) & $\begin{array}{l}0.00 \\
1.13\end{array}$ & 1.13 & $\begin{array}{l}.00 \\
1.20\end{array}$ & 1.23 & 1.04 & 1.05 & 1.20 & 1.09 & 1.08 \\
\hline $\mathrm{Al}(\mathrm{VI})$ & 3.02 & 3.02 & 3.01 & 3.01 & 2.99 & 2.98 & 3.14 & 2.97 & 2.98 \\
\hline $\mathrm{Ti}$ & 0.05 & 0.05 & 0.08 & 0.08 & 0.02 & 0.03 & 0.02 & 0.03 & 0.02 \\
\hline $\mathrm{Cr}$ & 0.00 & 0.00 & 0.00 & 0.00 & 0.01 & 0.00 & 0.01 & 0.01 & 0.01 \\
\hline $\mathrm{Fe}^{2+}$ & 0.13 & 0.13 & 0.12 & 0.13 & 0.19 & 0.16 & 0.17 & 0.17 & 0.20 \\
\hline Mn & 0.00 & 0.00 & 0.00 & 0.00 & 0.00 & 0.00 & 0.00 & 0.00 & 0.00 \\
\hline Mg & 0.90 & 0.90 & 0.84 & 0.84 & 0.88 & 0.86 & 0.72 & 0.85 & 0.84 \\
\hline $\mathrm{Ca}$ & 0.00 & 0.00 & 0.00 & 0.00 & 0.00 & 0.01 & 0.00 & 0.01 & 0.02 \\
\hline $\mathrm{Na}$ & 0.09 & 0.09 & 0.11 & 0.11 & 0.10 & 0.16 & 0.19 & 0.16 & 0.20 \\
\hline $\mathbf{K}$ & 1.69 & 1.69 & 1.81 & 1.81 & 1.71 & 1.78 & 1.67 & 1.83 & 1.71 \\
\hline Cations & 13.89 & 13.89 & 13.98 & 13.98 & 13.90 & 13.98 & 13.93 & 14.03 & 13.97 \\
\hline $\mathrm{T}\left({ }^{\circ} \mathrm{C}\right)$ & 715.17 & 721.28 & 631.00 & 578.69 & 621.14 & 667.28 & 754.19 & 686.59 & 622.35 \\
\hline P (Kbar) & 32.84 & 32.84 & 29.46 & 28.72 & 28.35 & 29.75 & 29.28 & 29.46 & 27.76 \\
\hline
\end{tabular}





\section{ANEXO IX}

(análises ICP-MS Sr-Nd em rochas ígneas) 


\begin{tabular}{|c|c|c|c|c|c|c|c|c|c|c|c|c|}
\hline Sample & Rb (ppm) & $\operatorname{Sr}(p p m)$ & Sm (ppm) & Nd (ppm) & ${ }^{87} \mathrm{Rb} /{ }^{86} \mathrm{Sr}$ & ${ }^{87} \mathrm{Sr} /{ }^{86} \mathrm{Sr}$ & ${ }^{147} \mathrm{Sm} /{ }^{144} \mathrm{Nd}$ & ${ }^{43} \mathrm{Nd} /{ }^{144} \mathbf{N d}$ & $\left.{ }^{\left({ }^{87}\right.} \mathrm{Sr} /{ }^{86} \mathrm{Sr}\right) \mathrm{i}$ & $\mathrm{eSr}_{\text {(T1) }}$ & $\mathbf{e N d}_{(\mathrm{T} 1)}$ & $\mathrm{T}_{1}$ (Ma) \\
\hline DKE-170 & 148.0 & 131.8 & 6.0 & 30.8 & 3.2583 & 0.7331 & 0.1169 & 0.5124 & 0.7028 & -13.19 & 1.70 & 663 \\
\hline DKE-200 & 322.5 & 397.6 & 8.9 & 52.0 & 2.3530 & 0.7325 & 0.1034 & 0.5120 & 0.7106 & 97.19 & -5.45 & 654 \\
\hline DKE-211 & 134.6 & 688.1 & 11.8 & 65.8 & 0.5662 & 0.7108 & 0.1083 & 0.5121 & 0.7056 & 26.61 & -4.25 & 637 \\
\hline DKE-221 & 49.2 & 203.1 & 2.6 & 14.8 & 0.7018 & 0.7109 & 0.1084 & 0.5124 & 0.7026 & -13.63 & 4.98 & 831 \\
\hline DKE-269 & 186.7 & 1493.8 & 20.7 & 155.4 & 0.3619 & 0.7141 & 0.0806 & 0.5116 & 0.7109 & 100.88 & -10.75 & 628 \\
\hline DKE-231 & 258.9 & 598.4 & 6.9 & 42.1 & 1.2544 & 0.7256 & 0.0995 & 0.5117 & 0.7144 & 150.99 & -9.65 & 627 \\
\hline DKE-273A & 73.6 & 211.7 & 2.6 & 12.6 & 1.0075 & 0.7148 & 0.1265 & 0.5124 & 0.7020 & -20.80 & 3.84 & 892 \\
\hline DKE-273B & 107.8 & 369.3 & 3.8 & 23.6 & 0.8458 & 0.7154 & 0.0979 & 0.5121 & 0.7079 & 58.83 & -3.55 & 618 \\
\hline DKE-277 & 65.8 & 503.5 & 4.7 & 24.6 & 0.3784 & 0.7091 & 0.1153 & 0.5120 & 0.7056 & 27.01 & -5.87 & 648 \\
\hline
\end{tabular}


(análises geoquímicas - granitóides) 


\begin{tabular}{|c|c|c|c|c|c|c|c|c|c|c|c|c|c|c|}
\hline Sample & KE-267 & KE-273A & KE-233A & KE-263B & KE-270 & KE-254 & KE-221 & KE-170A & KE-171A & KE-200A & KE-259 & KE-276 & KE-277 & KE-278 \\
\hline Unit & LC & LC & LC & LC & LC & LC & LC & LC & LC & LC & BO & BO & BO & BO \\
\hline $\mathrm{SiO}_{2}(\mathrm{wt} \%)$ & 67.68 & 68.2 & 65.21 & 67.61 & 67.97 & 66.17 & 65.38 & 55.4 & 55.5 & 62.21 & 67.07 & 68.56 & 69 & 69.05 \\
\hline $\mathrm{Al}_{2} \mathrm{O}_{3}(\mathrm{wt} \%)$ & 13.82 & 14.33 & 15.04 & 14.28 & 15.33 & 16.32 & 15.24 & 16.01 & 17.44 & 17.12 & 15.78 & 15.01 & 15.46 & 14.99 \\
\hline $\mathrm{CaO}(\mathrm{wt} \%)$ & 2.13 & 1.96 & 2.81 & 2.35 & 1.73 & 2.92 & 2.55 & 5.22 & 7.67 & 3.47 & 2.03 & 2.18 & 2.45 & 1.98 \\
\hline K2O (wt\%) & 5.33 & 5.17 & 4.14 & 3.99 & 5.98 & 3.42 & 2.94 & 3.71 & 1.77 & 4.86 & 7.39 & 2.41 & 3.7 & 4.91 \\
\hline $\mathrm{Na}_{2} \mathrm{O}(w t \%)$ & 3.13 & 3.68 & 3.78 & 3.93 & 3.85 & 4.18 & 3.84 & 3.89 & 3.99 & 4.22 & 2.61 & 4.75 & 4.03 & 3.29 \\
\hline $\mathrm{FeO}(w t \%)$ & 2.43 & 2.91 & 3 & 1.89 & 1.62 & 2.46 & 3.48 & 3.51 & 3.52 & 3.5 & 2.31 & 3.15 & 1.99 & 2.32 \\
\hline $\mathrm{Fe}_{2} \mathrm{O}_{3}(\mathrm{wt} \%)$ & 3.76 & 4.64 & 4.84 & 3.39 & 3.73 & 4.04 & 5.8 & 8.52 & 9.77 & 6.01 & 4.05 & 4.99 & 3.19 & 2.99 \\
\hline MgO (wt\%) & 1.36 & 0.76 & 0.95 & 1.16 & 0.07 & 1.12 & 1.23 & 3.05 & 4.41 & 1.78 & 0.79 & 0.93 & 0.9 & 1.05 \\
\hline $\mathrm{MnO}(\mathrm{wt} \%)$ & 0.09 & 0.1 & 0.12 & 0.06 & 0.06 & 0.06 & 0.06 & 0.12 & 0.16 & 0.12 & 0.03 & 0.17 & 0.08 & 0.07 \\
\hline $\mathrm{TiO}_{2}(w t \%)$ & 0.66 & 0.73 & 0.77 & 0.48 & 0.19 & 0.45 & 0.75 & 1.58 & 1.2 & 1.1 & 1.09 & 0.8 & 0.37 & 0.39 \\
\hline $\mathrm{P}_{2} \mathrm{O}_{5}(\mathrm{wt} \%)$ & 0.21 & 0.21 & 0.2 & 0.15 & 0.19 & 0.16 & 0.24 & 0.62 & 0.35 & 0.37 & 0.28 & 0.24 & 0.18 & 0.07 \\
\hline LOI & 0.31 & 0.1 & 0.08 & 0.89 & 0.24 & 0.31 & 0.22 & 0.32 & 0.35 & 0.37 & 0.83 & 0.21 & 0.3 & 0.16 \\
\hline Sum & 98.51 & 99.88 & 97.94 & 98.28 & 99.34 & 99.16 & 98.26 & 98.46 & 102.6 & 101.63 & 101.96 & 100.28 & 99.67 & 98.95 \\
\hline $\mathrm{Ba}(p p m)$ & 836 & 1384 & 1782 & 892 & 1230 & 860 & 1091 & 1158 & 862 & 1865 & 3141 & 479 & 868 & 741 \\
\hline $\mathrm{Be}(\mathrm{ppm})$ & 4.5 & 1.7 & 2.5 & 3.4 & 1.4 & 3.9 & 1.5 & 3.2 & 0.8 & 4 & 1.3 & 4 & 3.6 & 0.8 \\
\hline Cs (ppm) & 3.61 & 1.22 & 2.62 & 1.68 & 1.04 & 3.82 & 1.55 & 3.05 & 1.49 & 3.65 & 0.32 & 7.72 & 4.62 & 2.65 \\
\hline $\mathrm{Ga}(\mathrm{ppm})$ & 23.5 & 26.7 & 26 & 25.6 & 23.2 & 25.2 & 19.7 & 17.9 & 17.9 & 31.9 & 20.9 & 28.7 & 19 & 22.1 \\
\hline Hf (ppm) & 5.89 & 10.33 & 8.97 & 2.92 & 14.34 & 4.9 & 9.09 & 6.58 & 2.86 & 5.39 & 19.04 & 9.63 & 2.47 & 3.75 \\
\hline $\mathrm{Nb}(\mathrm{ppm})$ & 14.25 & 21.65 & 20.13 & 8.26 & 2.11 & 3.44 & 6.48 & 11.63 & 6.7 & 19.39 & 4.23 & 29.97 & 3.67 & 5.95 \\
\hline $\mathrm{Rb}(\mathrm{ppm})$ & 184.4 & 127.7 & 127.2 & 115.1 & 126 & 144.9 & 84.4 & 124.6 & 56.8 & 187.4 & 160.7 & 133.5 & 92.4 & 159.3 \\
\hline Sn (ppm) & 1.4 & 0.5 & 1.6 & 1.7 & 4.6 & 1.1 & 3.5 & 5.7 & 4 & 4.6 & 3.3 & 2.6 & 2.7 & 2.1 \\
\hline $\mathrm{Sr}(\mathrm{ppm})$ & 399.7 & 221.2 & 318.9 & 587 & 272.7 & 404.9 & 535.9 & 675.1 & 536.8 & 745.3 & 1472.2 & 175.8 & 239.9 & 152 \\
\hline Ta (ppm) & 0.89 & 2.42 & 0.98 & 2.05 & 0.05 & 0.05 & 0.05 & 1.47 & 0.05 & 8.55 & 0.05 & 2.27 & 0.33 & 0.23 \\
\hline Th (ppm) & 12.6 & 9.3 & 6.3 & 10.1 & 2.7 & 13.9 & 13.4 & 4.2 & 0.1 & 5.1 & 31.8 & 9.7 & 3.6 & 5.7 \\
\hline $\mathrm{U}(\mathrm{ppm})$ & 2.84 & 1 & 0.95 & 2.22 & 1.04 & 1.74 & 1.11 & 2.16 & 0.86 & 2.73 & 1.75 & 3.49 & 1.31 & 0.85 \\
\hline W (ppm) & 0.1 & 0.2 & 0.1 & 0.5 & 2 & 0.1 & 0.1 & 0.1 & 0.1 & 8 & 0.1 & 0.1 & 0.7 & 0.1 \\
\hline$Y(p p m)$ & 25.8 & 43.87 & 37.77 & 11.34 & 9.7 & 7.01 & 14.76 & 20.08 & 18.92 & 20.18 & 11.02 & 48.84 & 10.95 & 27.4 \\
\hline $\mathrm{Zr}$ (ppm) & 216.8 & 506.1 & 465.7 & 116.9 & 677 & 191.9 & 314.5 & 259 & 100.3 & 345.8 & 884.2 & 471.8 & 93.8 & 148.4 \\
\hline Co (ppm) & 10.9 & 6.3 & 5.1 & 8.8 & 1.9 & 7.7 & 9.4 & 15.6 & 15.1 & 14 & 4.4 & 5.1 & 5.2 & 6.7 \\
\hline $\mathrm{Cr}(\mathrm{ppm})$ & 43 & 9 & 9 & 18 & 5 & 15 & 26 & 36 & 26 & 24 & 6 & 10 & 4 & 41 \\
\hline Cs (ppm) & 3.55 & 1.13 & 2.38 & 1.59 & 0.24 & 3.67 & 1.33 & 3.2 & 1.56 & 3.73 & 0.27 & 7.98 & 4.27 & 2.48 \\
\hline $\mathrm{Cu}(\mathrm{ppm})$ & 22.1 & 18 & 9.7 & 6.7 & 2.2 & 17.4 & 36.7 & 19.3 & 8.9 & 29.4 & 22.4 & 7.8 & 3.1 & 7 \\
\hline $\mathrm{Ga}(\mathrm{ppm})$ & 7.8 & 7.9 & 7 & 5.9 & 3.6 & 6.8 & 9.2 & 8.2 & 5.9 & 10.1 & 7 & 8.7 & 4.4 & 6.3 \\
\hline $\mathrm{Hf}(\mathrm{ppm})$ & 0.31 & 0.17 & 0.19 & 0.1 & 0.06 & 0.14 & 0.09 & 0.21 & 0.18 & 0.24 & 0.12 & 0.09 & 0.05 & 0.07 \\
\hline La (ppm) & 49.8 & 66.5 & 53.5 & 29.4 & 6.3 & 38.6 & 22.3 & 45 & 13.8 & 52 & 141.4 & 40.4 & 18.4 & 17.8 \\
\hline $\mathrm{Li}(\mathrm{ppm})$ & 30 & 24 & 25 & 38 & 1 & 38 & 20 & 33 & 41 & 46 & 26 & 89 & 38 & 31 \\
\hline $\mathrm{Nb}(\mathrm{ppm})$ & 1.46 & 1.38 & 1.53 & 0.65 & 0.25 & 0.5 & 0.87 & 0.75 & 0.28 & 1.24 & 0.97 & 2.52 & 0.73 & 1.22 \\
\hline $\mathrm{Ni}$ (ppm) & 23.3 & 8.1 & 5.4 & 17 & 2.7 & 7.5 & 13.3 & 19.4 & 17.1 & 15.9 & 2.3 & 6.1 & 2.3 & 19.2 \\
\hline $\mathrm{Pb}(\mathrm{ppm})$ & 3.5 & 2.2 & 2.5 & 4.3 & 2.6 & 2.9 & 4.6 & 2.1 & 2.3 & 4.2 & 5.7 & 2.8 & 1.1 & 1.5 \\
\hline $\mathbf{R b}(\mathrm{ppm})$ & 137.8 & 60.6 & 71.5 & 81.3 & 9.7 & 101.2 & 74.9 & 134 & 67.6 & 141.6 & 64 & 123.7 & 61.5 & 100.4 \\
\hline Sc (ppm) & 6 & 10.7 & 8.1 & 3.1 & 0.6 & 1.5 & 4.6 & 4 & 5.9 & 6.7 & 1.3 & 11 & 2.4 & 5.6 \\
\hline Sn (ppm) & 2.2 & 2.8 & 3.6 & 1.2 & 0.6 & 0.8 & 1.7 & 1.3 & 1 & 1.5 & 9.9 & 3.4 & 1.1 & 3.4 \\
\hline $\mathrm{Sr}(\mathrm{ppm})$ & 33.8 & 12.4 & 15.6 & 44.7 & 10.2 & 13.9 & 21.6 & 24.8 & 28.6 & 48.2 & 78 & 7.1 & 9.3 & 7.2 \\
\hline Th (ppm) & 22.9 & 13.9 & 9.8 & 16.2 & 1.5 & 19.2 & 13.1 & 9.3 & 2.1 & 9.9 & 51.6 & 9 & 4.9 & 4.5 \\
\hline$U$ (ppm) & 2.03 & 0.37 & 0.49 & 1.79 & 0.15 & 0.77 & 0.31 & 1.87 & 0.61 & 1.47 & 0.91 & 1.85 & 1 & 0.2 \\
\hline V (ppm) & 38 & 27 & 23 & 31 & 35 & 36 & 48 & 66 & 88 & 77 & 28 & 17 & 21 & 32 \\
\hline$Y(p p m)$ & 17.9 & 29.28 & 31.17 & 7.33 & 7.95 & 5.6 & 10.32 & 14.13 & 10.78 & 11.09 & 6.3 & 24.37 & 7.36 & 6.39 \\
\hline $\mathrm{Zn}(\mathrm{ppm})$ & 65 & 66 & 62 & 45 & 20 & 50 & 71 & 63 & 41 & 84 & 70 & 91 & 38 & 32 \\
\hline $\mathrm{Zr}(\mathrm{ppm})$ & 6.2 & 3.3 & 4.1 & 2.2 & 3 & 5 & 1.1 & 1.7 & 2.3 & 5.6 & 1 & 1.8 & 0.7 & 1.7 \\
\hline $\mathrm{Ce}(\mathrm{ppm})$ & 96.2 & 133.9 & 96.6 & 54.4 & 15.6 & 93.7 & 116.5 & 142.3 & 54.1 & 118.9 & 345.9 & 124.2 & 33.9 & 72.2 \\
\hline Dy (ppm) & 5.09 & 7.87 & 7.23 & 2.11 & 1.66 & 1.8 & 3.83 & 6.43 & 4.41 & 3.86 & 3.8 & 9.31 & 1.85 & 5.62 \\
\hline $\operatorname{Er}(p p m)$ & 2.33 & 4.21 & 3.71 & 0.95 & 1.24 & 0.71 & 1.98 & 2.95 & 2.43 & 1.64 & 0.92 & 4.79 & 1.19 & 2.72 \\
\hline Eu (ppm) & 1.88 & 2.17 & 2.66 & 0.97 & 1.82 & 0.62 & 1.43 & 2.74 & 1.46 & 2.52 & 2.11 & 1.94 & 0.88 & 0.77 \\
\hline Gd (ppm) & 6.87 & 10.16 & 8.67 & 2.59 & 2.06 & 2.72 & 5.69 & 8.36 & 4.67 & 6.48 & 8.21 & 10.51 & 2.46 & 5.67 \\
\hline Ho (ppm) & 0.88 & 1.56 & 1.4 & 0.34 & 0.34 & 0.19 & 0.66 & 1.09 & 0.8 & 0.63 & 0.45 & 1.57 & 0.33 & 1 \\
\hline La (ppm) & 46.6 & 66 & 52 & 30.7 & 7.9 & 51.5 & 62 & 71.8 & 31.4 & 62.5 & 206.3 & 62.7 & 23.8 & 32.6 \\
\hline Lu (ppm) & 0.15 & 0.7 & 0.58 & 0.19 & 0.26 & 0.27 & 0.43 & 0.58 & 0.62 & 0.2 & 0.17 & 0.57 & 0.09 & 0.4 \\
\hline $\mathrm{Nd}(\mathrm{ppm})$ & 47 & 57.6 & 46.6 & 21.6 & 8.6 & 34.8 & 49.9 & 72.7 & 27.3 & 54.1 & 132.8 & 55.9 & 15 & 33.2 \\
\hline $\operatorname{Pr}(\mathrm{ppm})$ & 12.1 & 15.08 & 11.64 & 5.46 & 1.84 & 10.19 & 13.5 & 18.83 & 6.95 & 14.66 & 37.12 & 15.57 & 3.8 & 8.46 \\
\hline Sm (ppm) & 9 & 11.1 & 8.9 & 3.5 & 2.2 & 4.3 & 8.9 & 12.4 & 5.1 & 8.6 & 17.6 & 11.3 & 2.6 & 6.3 \\
\hline Tb (ppm) & 0.92 & 1.48 & 1.13 & 0.39 & 0.26 & 0.21 & 0.62 & 0.94 & 0.6 & 0.96 & 0.62 & 1.53 & 0.37 & 0.96 \\
\hline Tm (ppm) & 0.28 & 0.55 & 0.47 & 0.13 & 0.18 & 0.05 & 0.19 & 0.34 & 0.3 & 0.29 & 0.06 & 0.64 & 0.13 & 0.34 \\
\hline $\mathrm{Yb}$ (ppm) & 2 & 3.5 & 3.9 & 1 & 1.1 & 0.7 & 1.5 & 2.4 & 2.4 & 1.9 & 0.5 & 4.1 & 1 & 2.4 \\
\hline $\mathrm{Eu} / \mathrm{Eu}^{*}$ & 0.74 & 0.63 & 0.93 & 0.99 & 2.63 & 0.56 & 0.62 & 0.83 & 0.92 & 1.04 & 0.72 & 0.55 & 1.07 & 0.4 \\
\hline$(\mathrm{La} / \mathrm{Sm})_{\mathrm{n}}$ & 2.84 & 3.26 & 3.2 & 4.81 & 1.97 & 6.57 & 3.82 & 3.18 & 3.38 & 3.99 & 3.94 & 3.04 & 5.02 & 2.84 \\
\hline$(\mathrm{La} / \mathrm{Yb})_{\mathrm{n}}$ & 14.12 & 11.43 & 8.08 & 18.61 & 4.35 & 44.59 & 25.05 & 18.13 & 7.93 & 19.94 & 91.52 & 9.27 & 14.42 & 8.23 \\
\hline$(\mathrm{Tb} / \mathrm{Yb})_{\mathrm{n}}$ & 1.96 & 1.8 & 1.23 & 1.66 & 1.01 & 1.28 & 1.76 & 1.67 & 1.06 & 2.15 & 5.11 & 1.59 & 1.57 & 1.7 \\
\hline Tot REE & 231.3 & 315.88 & 245.49 & 124.33 & 45.06 & 201.76 & 267.13 & 343.86 & 142.54 & 277.24 & 125.63 & 304.63 & 87.4 & 172.64 \\
\hline ASI & 0.93 & 0.94 & 0.95 & 0.95 & 0.96 & 1.03 & 1.08 & 0.8 & 0.78 & 0.92 & 1.06 & 1.04 & 1.02 & 1.05 \\
\hline
\end{tabular}




\begin{tabular}{|c|c|c|c|c|c|c|c|c|c|c|c|c|c|c|c|}
\hline Sample & KE-279 & KE-176B & KE-180 & KE-191A & KE-191B & KE-194A & KE-195 & KE-205A & KE-208 & KE-209 & KE-211 & KE-212 & KE-213 & KE-214 & KE-2 \\
\hline Unit & BO & ST & ST & ST & ST & ST & ST & ST & ST & ST & ST & ST & ST & ST & ST \\
\hline $\mathrm{SiO}_{2}(w t \%)$ & 69.45 & 58.76 & 60 & 61 & 61.09 & 61.67 & 61.96 & 62.68 & 62.97 & 62.98 & 63.02 & 63.27 & 63.33 & 63.45 & 65.77 \\
\hline $\mathrm{Al}_{2} \mathrm{O}_{3}(\mathrm{wt} \%)$ & 15.08 & 17.47 & 14.88 & 13.45 & 14.85 & 16.56 & 14.89 & 15.65 & 14.78 & 16.7 & 16.53 & 15.84 & 15.98 & 15.97 & 16.95 \\
\hline $\mathrm{CaO}(w t \%)$ & 1.91 & 5.29 & 4.12 & 3.41 & 3.84 & 4.27 & 3.37 & 3.25 & 3.3 & 2.89 & 4.25 & 3.87 & 3.56 & 3.2 & 2.39 \\
\hline 20 (wt\%) & 3.77 & 3.06 & 4.32 & 6.66 & 4.76 & 3.45 & 5.35 & 5.56 & 4.7 & 3.09 & 2.44 & 3.73 & 5.17 & 4.57 & 4.94 \\
\hline $\mathrm{a}_{2} \mathrm{O}(w t \%)$ & 4.09 & 5.17 & 4.21 & 2.99 & 3.28 & 3.62 & 3.23 & 3.44 & 3.12 & 4.66 & 4.08 & 3.62 & 3.75 & 3.71 & 4.46 \\
\hline $\mathrm{FeO}$ (wt\%) & 1.51 & 3.47 & 3.34 & 2.84 & 3.07 & 3.97 & 2.68 & 3.83 & 3.36 & 4.08 & 3.25 & 2.87 & 3.06 & 3.88 & 2.33 \\
\hline $\mathrm{e}_{2} \mathrm{O}_{3}(\mathrm{wt} \%)$ & 2.1 & 6.72 & 7.35 & 5.48 & 5.63 & 5.87 & 5.48 & 5.6 & 5.34 & 6.64 & 5.6 & 6.11 & 5.96 & 5.59 & 3.69 \\
\hline MgO (wt\%) & 0.63 & 3.35 & 2.62 & 4.21 & 2.81 & 1.89 & 2.26 & 2.27 & 2.2 & 1.38 & 1.55 & 1.63 & 2.62 & 1.63 & 0.99 \\
\hline MnO (wt\%) & 0.03 & 0.15 & 0.14 & 0.08 & 0.12 & 0.08 & 0.09 & 0.09 & 0.13 & 0.2 & 0.11 & 0.09 & 0.1 & 0.11 & 0.05 \\
\hline $\mathrm{TiO}_{2}(\mathrm{wt} \%)$ & 0.27 & 1.05 & 1.51 & 0.83 & 1.1 & 0.83 & 0.98 & 1.02 & 0.96 & 1.18 & 0.63 & 0.93 & 1.06 & 1.05 & 0.5 \\
\hline $\mathrm{P}_{2} \mathrm{O}_{5}(\mathrm{wt} \%)$ & 0.08 & 0.35 & 0.58 & 0.51 & 0.46 & 0.35 & 0.35 & 0.34 & 0.36 & 0.35 & 0.16 & 0.24 & 0.41 & 0.36 & 0.18 \\
\hline LOI & 0.28 & 0.87 & 0.5 & 0.3 & 0.36 & 0.6 & 0.33 & 0.54 & 0.71 & 0.23 & 0.47 & 0.2 & 0.36 & 0.34 & 0.51 \\
\hline Sum & 98.68 & 102.26 & 100.24 & 98.96 & 98.31 & 99.19 & 98.31 & 100.44 & 98.58 & 100.28 & 98.84 & 99.54 & 102.31 & 99.99 & 100.42 \\
\hline $\mathrm{Ba}(\mathrm{ppm})$ & 745 & 1374 & 1223 & 2307 & 1120 & 1963 & 1189 & 1071 & 1195 & 608 & 809 & 1630 & 1028 & 1584 & 1735 \\
\hline $\mathrm{Be}(\mathrm{ppm})$ & 2 & 3.1 & 3.4 & 9.8 & 4.9 & 2.7 & 5.6 & 5.7 & 3.9 & 4.1 & 2 & 2.2 & 5.1 & 3.8 & 2.1 \\
\hline Cs (ppm) & 1.35 & 2.16 & 1.45 & 16.81 & 5.44 & 1.41 & 4.47 & 5.88 & 1.51 & 5.76 & 1.44 & 1.03 & 3.21 & 2.36 & 2.12 \\
\hline Ga (ppm) & 19.3 & 29.6 & 29.9 & 24.8 & 20.3 & 28.8 & 19.8 & 27.8 & 26.4 & 31.9 & 22.2 & 19.3 & 27.8 & 29.3 & 26.4 \\
\hline Hf (ppr & 3.04 & 3.65 & 6.14 & 13.54 & 8.9 & 4.81 & 10.98 & 7.88 & 7.2 & 10.87 & 4.33 & 10.46 & 8.83 & 8.06 & 6.7 \\
\hline $\mathrm{Nb}($ & 6.87 & 17 & 25.66 & 17.58 & 10.93 & 5.82 & 12.55 & 16.74 & 14.5 & 25.76 & 6.33 & 3.87 & 10.54 & 21.64 & 4.94 \\
\hline $\mathrm{Rb}$ (ppm) & 106.5 & 70.6 & 150.6 & 318.7 & 195.7 & 109.8 & 271.9 & 246.7 & 140.1 & 160 & 81 & 90.3 & 195.2 & 140.1 & 7.1 \\
\hline Sn (ppm) & 2 & & 5.7 & 6 & 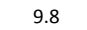 & 1.5 & 6.5 & 4.3 & 2.8 & 2.2 & 2.3 & 2.8 & 6 & 2.3 & 1.3 \\
\hline $\mathrm{Sr}$ (ppm) & 329.6 & 1118.8 & 638.4 & 702.9 & 501.8 & 916.7 & 560.4 & 505.7 & 541.6 & 224.7 & 436.1 & 419.3 & 452.2 & 666.7 & 604.4 \\
\hline $\mathrm{Ta}(\mathrm{ppm})$ & 0.22 & 0.39 & 7.68 & 0.42 & 1.49 & 2.82 & 0.79 & 1.48 & 0.73 & 0.99 & 0.05 & 0.05 & 0.05 & 2.18 & 0.05 \\
\hline Th $(p$ & 6.5 & 2 & 17.7 & 52.4 & 22.9 & 5.8 & 22.9 & 15.1 & 13.3 & 9.1 & 0.9 & 0.1 & 8.1 & 7.9 & 3.2 \\
\hline$U(p$ & 1.06 & 0.51 & 1.58 & 63 & 5.54 & 0.81 & 4.03 & 3.22 & 0.95 & 1.84 & 0.61 & 0.89 & 1.55 & 2.34 & 0.76 \\
\hline$W(p$ & 0.1 & & 0. & & 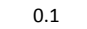 & 16 & 0.1 & 01 & 01 & 0.2 & 0.1 & 0.1 & 0.1 & 0.1 & 0.1 \\
\hline$Y(p p m)$ & 5.53 & 15.55 & 27.32 & 25.57 & 22.33 & 17.18 & 21.8 & 17.8 & 32.89 & 40.13 & 18.13 & 18.37 & 18.76 & 35.32 & 5.99 \\
\hline $\mathrm{Zr}(\mathrm{ppr}$ & 115 & 181.4 & 298 & 540.4 & 316.5 & 257.2 & 349.5 & 321.8 & 277.5 & 628.1 & 155.7 & 472.4 & 328.2 & 383.1 & 273.7 \\
\hline Co ( & 2.7 & 15.7 & 17.3 & 14.2 & 12.3 & 11.1 & 10.1 & 15.6 & 12.2 & 8.1 & 10.9 & 8.4 & 15.1 & 14.1 & 6.9 \\
\hline $\mathrm{Cr}(\mathrm{p}$ & 8 & 39 & 39 & 1 & 60 & 15 & 50 & 47 & 58 & & 11 & 1 & 48 & 18 & 7 \\
\hline Cs ( & 1.08 & 2.17 & 1.46 & 19.06 & 5.63 & 1.53 & 3.38 & 5.44 & 1.47 & & 1.63 & 1.09 & 3.24 & 2.53 & 2.07 \\
\hline $\mathrm{Cu}($ & 26 & & 68.4 & 7 & 112 & 123 & 9.9 & 45.1 & 14.1 & 102 & 16.2 & 22.4 & 19.4 & 19.8 & 7.4 \\
\hline Ga & 4 & & 9 & & 8 & & 7.2 & & 9.2 & 0.4 & 7.3 & 5.5 & 9.8 & .9 & 7.3 \\
\hline $\mathrm{Hf}($ & 0.12 & 0.11 & 0 & 0 & 0.42 & & 0.3 & 0.35 & 0.25 & 0.19 & 0.08 & 0.08 & 0.18 & 0.33 & 0.09 \\
\hline $\mathrm{La}($ & 15.5 & & 43.4 & 90.3 & 46.5 & 55.6 & 52 & 53.1 & 93.6 & 49.9 & 6.2 & 10.4 & 53.7 & 42.2 & 23.8 \\
\hline $\mathrm{Li}(\mathrm{pp}$ & 11 & 32 & 24 & 55 & 38 & 24 & 31 & 37 & 21 & 66 & 29 & 23 & 28 & 45 & 24 \\
\hline $\mathrm{Nb}$ (ppm) & 0.52 & 03 & 1.96 & 178 & 117 & 0.34 & 1.8 & 13 & 0.8 & 1.55 & 0.65 & 0.63 & 0.78 & 0.98 & 0.39 \\
\hline $\mathrm{Ni}($ & 28 & 3 & 26.5 & & 30.7 & 5 & 25.7 & 29.9 & 27.9 & 9.5 & 4 & 5.8 & 32.7 & 12.8 & 5.6 \\
\hline $\mathrm{Pb}($ & 3.7 & 1 & 3 & 3.9 & 4 & & 4.5 & 5.9 & 2.9 & 2.3 & 3.4 & 3 & 4 & 3 & 2.2 \\
\hline Rb ( & 58.2 & 79.3 & 120.4 & 194.6 & 168.2 & 08.5 & 153.8 & 203.2 & 109 & 156.1 & 75.3 & 64.8 & 143.4 & 124.4 & 61.8 \\
\hline $\mathrm{Sc}(\mathrm{r}$ & 1.9 & & 6. & 2 & (1) & 6.6 & 4 & 6 & 9.2 & 11.4 & 5.6 & 4.2 & 7.4 & 7.4 & 3.9 \\
\hline Sn (ppm) & 1.8 & & 2.6 & 2.4 & 2.7 & 32 & 2.5 & 3 & 2.9 & 2.6 & 1.4 & 1.3 & .5 & 1.9 & 1.2 \\
\hline $\mathrm{Sr}(\mathrm{r}$ & 11.5 & & & 5 & & 49 & 30.5 & & 17 & 0 & 19.1 & & & 55.4 & 21.1 \\
\hline Th 1 & 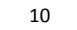 & & & 2 & 28 & 9.6 & 38.6 & 19. & 16.4 & & 1. & 1.1 & .5 .2 & 7.2 & 4.3 \\
\hline U ( & 0.42 & 0 & 0.64 & .73 & 3.55 & 0.37 & 3.06 & 2.14 & 0.44 & 1.18 & 0.19 & 0.34 & 0.41 & 0.95 & 0.2 \\
\hline$V(p$ & 16 & 1 & 8 & 41 & 3 & 4 & 4 & 0 & 60 & 32 & 54 & 39 & 65 & 75 & 30 \\
\hline$Y(p p m)$ & 3.88 & 7.66 & 17.48 & 14.4 & 11.88 & 7.72 & 11.97 & 11.76 & 19.72 & 36.78 & 12.47 & 11.09 & 9.82 & 15.91 & 5.55 \\
\hline $\mathrm{Zn}($ & 39 & 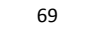 & 74 & 35 & 64 & 77 & 50 & 67 & 62 & 101 & 49 & 44 & 71 & 86 & 55 \\
\hline $\operatorname{Zr}($ & 2 & & & & 7 & & & & 5 & & & & & 8 & 2.7 \\
\hline $\mathrm{Ce}$ & 53.9 & & 119.3 & .80 & & 3.1 & 146.9 & 117.4 & 188.7 & 120.1 & 47 & 69.8 & 151.4 & 150.4 & 49.2 \\
\hline Dy ( & 1.24 & & 5.32 & 6.17 & 0.39 & & 4.86 & 3.91 & 6.95 & 7.83 & 3.78 & 4.48 & 5.31 & 7.46 & 1.55 \\
\hline $\operatorname{Er}(p$ & 0.49 & 1.25 & 2.72 & & & 15 & 2.74 & 169 & 3.25 & 4.14 & 2.01 & 2.18 & 2.24 & 3.6 & 0.46 \\
\hline Eu & 0.82 & & & & & & 1.57 & 1. & 2.21 & 1.74 & 0 & .11 & 1.45 & 2.7 & 1.61 \\
\hline Gd & 01 & & & & & & 8.12 & & 08 & 210 & & 5.28 & 7.52 & 10.35 & 2.62 \\
\hline Ho & 0.26 & & & & & & 1 & & 11 & 1.43 & & 89 & 0.89 & 1.3 & 18 \\
\hline La ( & 30.2 & & 57.2 & 107.5 & 79.3 & 56 & 78.2 & 62.1 & 95.8 & 58 & 27.7 & 38.5 & 85.5 & 63.6 & 28.1 \\
\hline Lu ( $p$ & 0.13 & 0.32 & 0.5 & 0.49 & 0.4 & .26 & 0.61 & 0.31 & 0.41 & 0.37 & 0.35 & 0.5 & 0.5 & 0.29 & 0.08 \\
\hline Nd（ & 24.2 & & & 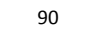 & & & 63.8 & 45.8 & 77.2 & 57.3 & 23.4 & 5.2 & 69.8 & 73.9 & 20.1 \\
\hline & 6. & 6 & 1 & $2 \pi$ & & 11. & 16.85 & 12.79 & 21.15 & 13.79 & 5.75 & 8.75 & 18.07 & 19.12 & 5.2 \\
\hline & 4.2 & $\epsilon$ & & & & & & & & 11 & 4 & 5.6 & 114 & 12 & 3.3 \\
\hline Tb (ppm) & 0.24 & & & 1.06 & 0.9 & & .81 & 0.66 & 1.36 & 1.5 & 0.41 & 0.69 & 0.77 & 1.34 & 0.3 \\
\hline $\mathrm{Tm}$ (ppm) & 0.05 & 0.18 & 0.43 & 0.3 & 0.31 & 0.19 & 0.35 & 0.25 & 0.45 & 0.47 & 0.2 & 0.32 & 0.21 & 0.49 & 0.06 \\
\hline $\mathrm{Yb}$ (ppm) & 0.2 & & 2 & & 2.2 & 1 & 2.5 & 1.4 & 2. & 3.3 & 1.8 & 2.1 & 1.7 & 2.9 & 0.4 \\
\hline $\mathrm{Eu} / \mathrm{Eu}^{*}$ & 0.54 & 0.85 & 0.78 & 0.53 & 0.58 & 0.83 & 0.52 & 0.78 & 0.0 & 0.5 & 0.68 & 0.63 & 0.48 & 0.72 & 1.68 \\
\hline$(\mathrm{La} / \mathrm{Sm})_{\mathrm{n}}$ & 6.43 & 2.5 & 3.05 & 4.12 & 3.66 & 4.33 & 4.05 & 4.6 & 3.98 & 2.84 & 3.3 & 3.77 & 4.11 & 2.68 & 4.67 \\
\hline$(\mathrm{La} / \mathrm{Yb})_{\mathrm{n}}$ & 250.06 & 12.73 & 12.84 & 29.61 & 21.85 & 24.24 & 18.96 & 26.88 & 20.74 & 10.65 & 9.33 & 11.11 & 30.48 & 13.29 & 42.58 \\
\hline$(T b / Y b)_{n}$ & 5.28 & 2.03 & 1.43 & 2.05 & 1.74 & 2.04 & 1.38 & 2.01 & 2.07 & 1.93 & 0.97 & 1.4 & 1.93 & 1.97 & 3.19 \\
\hline Tot REE & 756.56 & 136.44 & 281.57 & 452.71 & 352.71 & 238 & 338.91 & 261.39 & 424.53 & 291.37 & 122.45 & 175.4 & 356.76 & 350.45 & 113.16 \\
\hline ASI & 0.99 & 0.82 & 0.78 & 0.73 & 0.85 & 0.95 & 0.86 & 0.89 & 0.91 & 1.03 & 0.97 & 0.93 & 0.88 & 0.95 & 1 \\
\hline
\end{tabular}




\begin{tabular}{|c|c|c|c|c|c|c|c|c|c|c|c|c|c|c|c|}
\hline Sample & KE-244A & KE-246 & KE-282 & KE-283 & KE-292 & KE-294 & KE-313 & KE-315 & KE-317 & KE-318 & KE-319 & KE-199 & KE-203 & KE-205B & KE-215A \\
\hline Unit & ST & ST & ST & ST & ST & ST & ST & ST & ST & ST & ST & TB & TB & TB & TB \\
\hline $\mathrm{SiO}_{2}(w t \%)$ & 65.77 & 66.12 & 69.65 & 70.05 & 70.51 & 70.53 & 71.46 & 71.7 & 72.46 & 74.13 & 75.43 & 62.04 & 62.6 & 62.74 & 63.53 \\
\hline $\mathrm{Al}_{2} \mathrm{O}_{3}(\mathrm{wt} \%)$ & 16.95 & 16.87 & 14.32 & 14.08 & 14.89 & 15.83 & 15.54 & 14.13 & 14.45 & 13.36 & 14.51 & 16.22 & 16.33 & 15.41 & 14.93 \\
\hline $\mathrm{CaO}(w t \%)$ & 2.39 & 3.25 & 3.59 & 1.83 & 1.99 & 1.81 & 0.76 & 2.55 & 1.38 & 1.2 & 0.92 & 3.29 & 5.58 & 3.31 & 2.96 \\
\hline K2O (wt\%) & 4.94 & 3.79 & 1.89 & 4.45 & 3.66 & 5.38 & 7.42 & 1.99 & 6.19 & 4.09 & 6.41 & 4.65 & 2.09 & 5.84 & 4.88 \\
\hline $\mathrm{Na}_{2} \mathrm{O}(\mathrm{wt} \%)$ & 4.46 & 4.19 & 3.73 & 3.47 & 3.9 & 4.16 & 3.43 & 4.24 & 3.16 & 4.15 & 2.98 & 3.79 & 3.47 & 3.13 & 4.15 \\
\hline $\mathrm{FeO}(w t \%)$ & 2.33 & 3.47 & 3.44 & 2.38 & 2.37 & 0.98 & 0.66 & 2.3 & 1.77 & 1.81 & 0.93 & 3.16 & 3.43 & 3.65 & 2.27 \\
\hline $\mathrm{Fe}_{2} \mathrm{O}_{3}(\mathrm{wt} \%)$ & 3.69 & 4.78 & 5.74 & 2.91 & 3.31 & 1.37 & 0.97 & 3.01 & 2.62 & 2.41 & 1.38 & 5.17 & 6.92 & 5.54 & 5.16 \\
\hline MgO (wt\%) & 0.99 & 1.2 & 1.67 & 0.78 & 1.05 & 0.18 & 0.09 & 0.96 & 0.35 & 0.28 & 0.16 & 1.58 & 3.26 & 2.73 & 1.5 \\
\hline MnO (wt\%) & 0.05 & 0.11 & 0.13 & 0.08 & 0.06 & 0.02 & 0.03 & 0.07 & 0.04 & 0.04 & 0.02 & 0.08 & 0.11 & 0.09 & 0.09 \\
\hline $\mathrm{TiO}_{2}(w t \%)$ & 0.5 & 0.61 & 0.45 & 0.63 & 0.48 & 0.09 & 0.05 & 0.38 & 0.31 & 0.17 & 0.08 & 1.03 & 0.73 & 0.93 & 1.01 \\
\hline $\mathrm{P}_{2} \mathrm{O}_{5}(\mathrm{wt} \%)$ & 0.18 & 0.16 & 0.11 & 0.19 & 0.12 & 0.03 & 0.03 & 0.1 & 0.09 & 0.04 & 0.04 & 0.38 & 0.13 & 0.33 & 0.34 \\
\hline LOI & 0.51 & 0.22 & 0.24 & 0.49 & 0.18 & 0.21 & 0.24 & 0.19 & 0.14 & 0.07 & 0.1 & 0.49 & 0.27 & 0.4 & 0.27 \\
\hline Sum & 100.42 & 101.31 & 101.53 & 99.19 & 100.16 & 99.61 & 100.04 & 99.34 & 101.19 & 99.95 & 102.03 & 98.71 & 101.5 & 100.45 & 98.82 \\
\hline $\mathrm{Ba}(\mathrm{ppm})$ & 1735 & 1522 & 478 & 1099 & 1128 & 1437 & 823 & 457 & 860 & 589 & 1326 & 1828 & 628 & 1102 & 1635 \\
\hline $\mathrm{Be}(\mathrm{ppm})$ & 2.1 & 2.8 & 0.2 & 1.4 & 1.7 & 2.5 & 1.9 & 0.7 & 1.5 & 1.6 & 0.9 & 2.9 & 1.3 & 3.4 & 2 \\
\hline Cs (ppm) & 2.12 & 2.38 & 2.87 & 2.05 & 1.73 & 1.34 & 4.5 & 1.26 & 1.58 & 1.98 & 1.5 & 1.83 & 2.12 & 20.41 & 2.9 \\
\hline $\mathrm{Ga}(\mathrm{ppm})$ & 26.4 & 21.4 & 12 & 23.6 & 23.6 & 18.3 & 25.4 & 17.5 & 19.4 & 22.6 & 9.6 & 20.7 & 20.3 & 24.7 & 29.4 \\
\hline Hf (ppm) & 6.7 & 4.64 & 2.19 & 8.32 & 4.4 & 2.42 & 1.29 & 3.34 & 6.51 & 4.91 & 2.68 & 8.31 & 5.63 & 8.32 & 6.7 \\
\hline $\mathrm{Nb}(\mathrm{ppm})$ & 4.94 & 12.14 & 1.87 & 12.04 & 3.81 & 0.54 & 0.78 & 6.37 & 4.91 & 9.97 & 0.05 & 7.28 & 2.93 & 16.46 & 22.54 \\
\hline $\mathrm{Rb}(\mathrm{ppm})$ & 87.1 & 118.4 & 60.8 & 104.8 & 84.2 & 138.3 & 234.7 & 48.5 & 221.1 & 100.9 & 121.5 & 152.3 & 73 & 319.4 & 146.2 \\
\hline Sn (ppm) & 1.3 & 0.6 & 1.8 & 0.3 & 0.3 & 3.9 & 0.3 & 1.1 & 7.9 & 2.7 & 9.5 & 6.4 & 2.8 & 4.3 & 6.7 \\
\hline $\mathrm{Sr}(\mathrm{ppm})$ & 604.4 & 189.6 & 274.4 & 230.2 & 523 & 311.9 & 172.9 & 217.8 & 223.1 & 105.6 & 253.1 & 606.3 & 284 & 421 & 654.7 \\
\hline Ta (ppm) & 0.05 & 0.53 & 0.05 & 0.05 & 0.05 & 0.05 & 0.06 & 2.74 & 2.14 & 0.66 & 0.05 & 1.21 & 0.05 & 1.89 & 6.28 \\
\hline Th (ppm) & 3.2 & 8 & 0.1 & 8.3 & 7.1 & 0.1 & 5.5 & 3.3 & 15.3 & 6.3 & 0.1 & 4.1 & 6.1 & 14.7 & 9.2 \\
\hline U (ppm) & 0.76 & 1.43 & 0.62 & 1.03 & 0.79 & 0.71 & 2.8 & 0.87 & 2.73 & 1.42 & 0.62 & 1.19 & 1.24 & 5.71 & 1.92 \\
\hline W (ppm) & 0.1 & 0.1 & 0.1 & 0.1 & 0.1 & 0.1 & 0.1 & 0.7 & 0.1 & 0.1 & 0.1 & 0.1 & 0.1 & 1.1 & 0.1 \\
\hline$Y(\mathrm{ppm})$ & 5.99 & 13.83 & 19.15 & 18.3 & 8.04 & 2.86 & 14.75 & 12.69 & 15.11 & 53.52 & 2.2 & 23.08 & 21.12 & 20.74 & 39.49 \\
\hline $\mathrm{Zr}(\mathrm{ppm})$ & 273.7 & 197.7 & 82.6 & 431.3 & 178.3 & 60.3 & 26.6 & 153.8 & 276.7 & 143.6 & 81.9 & 344.9 & 211.4 & 358.4 & 320.2 \\
\hline Co (ppm) & 6.9 & 8.5 & 8.4 & 4.5 & 7.7 & 1.4 & 0.6 & 6.9 & 2.6 & 2.3 & 1.1 & 10.3 & 12.3 & 15.1 & 10.3 \\
\hline $\mathrm{Cr}(\mathrm{ppm})$ & 7 & 5 & 15 & 9 & 24 & 13 & 3 & 17 & 5 & 8 & 7 & 18 & 40 & 78 & 13 \\
\hline Cs (ppm) & 2.07 & 2.63 & 2.98 & 1.99 & 1.91 & 0.57 & 0.65 & 1.33 & 1.14 & 1.7 & 0.57 & 1.67 & 2.25 & 21.16 & 2.4 \\
\hline $\mathrm{Cu}(\mathrm{ppm})$ & 7.4 & 20.4 & 2.9 & 5.2 & 6.1 & 4.1 & 1.4 & 3.3 & 3.4 & 2.4 & 3.2 & 16.8 & 25.2 & 31.9 & 17.6 \\
\hline $\mathrm{Ga}(\mathrm{ppm})$ & 7.3 & 7.4 & 5.9 & 7 & 6.6 & 1.9 & 1.5 & 5.3 & 4 & 4.6 & 1.7 & 9.3 & 5.6 & 10.3 & 7.5 \\
\hline Hf (ppm) & 0.09 & 0.2 & 0.09 & 0.07 & 0.11 & 0.18 & 0.05 & 0.05 & 0.32 & 0.05 & 0.08 & 0.23 & 0.15 & 0.39 & 0.3 \\
\hline La (ppm) & 23.8 & 51 & 7.4 & 101.6 & 48 & 5 & 11 & 19.7 & 32.5 & 17.8 & 3.1 & 53.9 & 22.6 & 51.9 & 63.6 \\
\hline Li (ppm) & 24 & 27 & 32 & 24 & 28 & 7 & 10 & 47 & 14 & 31 & 2 & 30 & 18 & 47 & 29 \\
\hline $\mathrm{Nb}$ (ppm) & 0.39 & 1.07 & 0.39 & 0.83 & 0.43 & 1.08 & 0.52 & 0.66 & 1.93 & 3.98 & 0.56 & 1.06 & 0.63 & 1.54 & 2.41 \\
\hline $\mathrm{Ni}$ (ppm) & 5.6 & 2.4 & 4 & 3.9 & 17.1 & 1.4 & 1.4 & 10.7 & 2.4 & 3.4 & 1.8 & 10.2 & 21.7 & 37.8 & 10 \\
\hline $\mathrm{Pb}(\mathrm{ppm})$ & 2.2 & 2.1 & 2 & 2.3 & 3 & 4 & 5.6 & 2.3 & 1.8 & 1.2 & 6.1 & 8.5 & 2 & 7.2 & 2.4 \\
\hline $\mathbf{R b}(\mathrm{ppm})$ & 61.8 & 115.6 & 75.6 & 63.4 & 73.6 & 16.4 & 10.8 & 51.7 & 52.8 & 37.7 & 19.1 & 119.8 & 76.5 & 281.4 & 77.4 \\
\hline Sc (ppm) & 3.9 & 8.9 & 7.8 & 7.7 & 4.9 & 0.4 & 0.6 & 4 & 1.9 & 6.1 & 0.8 & 5.8 & 4.3 & 5.9 & 3.9 \\
\hline Sn (ppm) & 1.2 & 1.2 & 1.5 & 1 & 1.2 & 2.1 & 1.6 & 0.9 & 2 & 3 & 1.3 & 1.9 & 1.4 & 5.3 & 2.2 \\
\hline $\mathrm{Sr}(\mathrm{ppm})$ & 21.1 & 9.6 & 10.4 & 15.1 & 19.1 & 9.4 & 5.6 & 7.8 & 12.3 & 4.9 & 7.1 & 32.8 & 13.9 & 38.8 & 32.2 \\
\hline Th (ppm) & 4.3 & 14.3 & 2.9 & 14.3 & 10.8 & 2.5 & 8.5 & 4.7 & 21.4 & 5.1 & 2.8 & 11 & 12.1 & 24.1 & 10.3 \\
\hline $\mathrm{U}(\mathrm{ppm})$ & 0.2 & 0.66 & 0.26 & 0.42 & 0.33 & 0.19 & 1.92 & 0.63 & 0.98 & 0.31 & 0.33 & 0.5 & 0.73 & 4.13 & 0.82 \\
\hline$V(p p m)$ & 30 & 44 & 61 & 17 & 31 & 11 & $<1$ & 28 & 12 & 6 & 7 & 62 & 77 & 64 & 52 \\
\hline$Y(p p m)$ & 5.55 & 9.41 & 8.54 & 19.47 & 8.29 & 2.21 & 3.71 & 7.6 & 8.99 & 8.04 & 1.83 & 11.37 & 7.65 & 14.21 & 22.48 \\
\hline $\mathrm{Zn}(\mathrm{ppm})$ & 55 & 55 & 53 & 50 & 54 & 11 & 9 & 33 & 28 & 53 & 14 & 77 & 40 & 56 & 66 \\
\hline $\mathrm{Zr}(\mathrm{ppm})$ & 2.7 & 5.6 & 0.6 & 1.9 & 3.2 & 2.7 & 1 & 0.7 & 9.2 & 0.7 & 1.6 & 4.6 & 1.3 & 5.1 & 5.9 \\
\hline $\mathrm{Ce}(\mathrm{ppm})$ & 49.2 & 78.6 & 23.2 & 187.8 & 85.9 & 16.9 & 22.9 & 33.5 & 109.7 & 59.4 & 11.6 & 168.1 & 58.4 & 103.7 & 166.3 \\
\hline Dy (ppm) & 1.55 & 2.58 & 3.57 & 4.24 & 1.78 & 0.55 & 2.84 & 2.39 & 4.18 & 9.86 & 0.37 & 6.58 & 4.08 & 4.39 & 7.6 \\
\hline $\mathrm{Er}(\mathrm{ppm})$ & 0.46 & 1.1 & 2.71 & 1.96 & 0.81 & 0.32 & 1.14 & 1.28 & 1.7 & 5.46 & 0.12 & 2.72 & 2.51 & 2.05 & 3.96 \\
\hline $\mathrm{Eu}(\mathrm{ppm})$ & 1.61 & 1.38 & 0.79 & 2.29 & 1.15 & 0.32 & 0.97 & 0.64 & 0.76 & 0.71 & 0.27 & 2.39 & 0.86 & 1.55 & 2.53 \\
\hline Gd (ppm) & 2.62 & 3.22 & 3.73 & 8.02 & 3.42 & 0.71 & 2.76 & 2.07 & 4.87 & 9.3 & 0.52 & 9.26 & 4.59 & 6.06 & 10.23 \\
\hline Ho (ppm) & 0.18 & 0.45 & 0.83 & 0.68 & 0.32 & 0.1 & 0.48 & 0.36 & 0.78 & 1.89 & 0.05 & 1.07 & 0.94 & 0.77 & 1.39 \\
\hline La (ppm) & 28.1 & 43 & 15.4 & 98.9 & 47.2 & 11.2 & 11 & 18.6 & 58.4 & 27.6 & 8 & 77.6 & 32.8 & 49.1 & 68.3 \\
\hline Lu (ppm) & 0.08 & 0.19 & 0.58 & 0.21 & 0.05 & 0.22 & 0.05 & 0.1 & 0.4 & 0.73 & 0.05 & 0.36 & 0.65 & 0.32 & 0.5 \\
\hline Nd (ppm) & 20.1 & 30.1 & 12.4 & 69.9 & 31.8 & 6.1 & 9.6 & 12.6 & 39.8 & 32.5 & 4.6 & 89.5 & 26.3 & 47.2 & 79.2 \\
\hline $\operatorname{Pr}(p p m)$ & 5.2 & 8.33 & 3.74 & 19.67 & 8.82 & 1.85 & 2.6 & 3.48 & 13.28 & 7.51 & 0.98 & 23.96 & 6.81 & 12.19 & 20.56 \\
\hline Sm (ppm) & 3.3 & 4.8 & 3.4 & 10.4 & 4.8 & 0.9 & 2.5 & 2.5 & 8.3 & 8.7 & 0.7 & 15.1 & 5.9 & 8.6 & 13.6 \\
\hline Tb (ppm) & 0.3 & 0.5 & 0.5 & 1.05 & 0.45 & 0.05 & 0.46 & 0.36 & 0.76 & 1.5 & 0.05 & 0.99 & 0.61 & 0.79 & 1.37 \\
\hline $\operatorname{Tm}(\mathrm{ppm})$ & 0.06 & 0.16 & 0.33 & 0.17 & 0.13 & 0.05 & 0.13 & 0.23 & 0.23 & 0.75 & 0.05 & 0.36 & 0.31 & 0.23 & 0.5 \\
\hline $\mathrm{Yb}$ (ppm) & 0.4 & 0.9 & 2.8 & 1.4 & 0.7 & 0.1 & 1.2 & 1.3 & 1.4 & 4.5 & 0.1 & 2.6 & 2.3 & 1.7 & 3.1 \\
\hline $\mathrm{Eu} / \mathrm{Eu}^{*}$ & 1.68 & 1.08 & 0.68 & 0.77 & 0.87 & 1.23 & 1.14 & 0.87 & 0.37 & 0.24 & 1.38 & 0.62 & 0.51 & 0.66 & 0.66 \\
\hline$(\mathrm{La} / \mathrm{Sm})_{\mathrm{n}}$ & 4.67 & 4.91 & 2.48 & 5.22 & 5.39 & 6.83 & 2.41 & 4.08 & 3.86 & 1.74 & 6.27 & 2.82 & 3.05 & 3.13 & 2.75 \\
\hline$(\mathrm{La} / \mathrm{Yb})_{\mathrm{n}}$ & 42.58 & 28.96 & 3.33 & 42.81 & 40.87 & 67.88 & 5.56 & 8.67 & 25.28 & 3.72 & 48.48 & 18.09 & 8.64 & 17.5 & 13.35 \\
\hline$(\mathrm{Tb} / \mathrm{Yb})_{\mathrm{n}}$ & 3.19 & 2.36 & 0.76 & 3.19 & 2.74 & 2.13 & 1.63 & 1.18 & 2.31 & 1.42 & 2.13 & 1.62 & 1.13 & 1.98 & 1.88 \\
\hline Tot REE & 113.16 & 175.31 & 73.98 & 406.69 & 187.33 & 39.37 & 58.63 & 79.41 & 244.56 & 170.41 & 27.46 & 400.59 & 147.06 & 238.65 & 379.14 \\
\hline ASI & 1 & 1 & 0.97 & 1 & 1.06 & 0.99 & 1.03 & 1.03 & 1 & 0.99 & 1.07 & 0.94 & 0.9 & 0.88 & 0.85 \\
\hline
\end{tabular}




\begin{tabular}{|c|c|c|c|c|c|c|c|c|c|c|c|c|c|c|}
\hline Sample & KE-218 & KE-222B & KE-230 & KE-232 & KE-233B & KE-235 & KE-236 & KE-237A & KE-258A & KE-261 & KE-263A & KE-262 & KE-272 & $E-273$ \\
\hline Unit & TB & TB & TB & TB & TB & TB & TB & TB & TB & TB & TB & TB & TB & TB \\
\hline $\mathrm{SiO}_{2}(w t \%)$ & 64.1 & 64.71 & 64.94 & 65.13 & 65.28 & 65.64 & 65.64 & 65.68 & 66.27 & 67.39 & 67.4 & 67.4 & 68.11 & 68.36 \\
\hline $\mathrm{Al}_{2} \mathrm{O}_{3}(\mathrm{wt} \%)$ & 15.92 & 15.87 & 16.73 & 14.81 & 16.81 & 15.39 & 15.39 & 15.66 & 16.73 & 16.98 & 15.58 & 14.86 & 13.66 & 16 \\
\hline $\mathrm{CaO}$ (wt\%) & 2.61 & 3.66 & 3.23 & 2.22 & 3.04 & 2.69 & 2.69 & 2.36 & 3.08 & 2.83 & 2.74 & 2.64 & 1.82 & 2.1 \\
\hline K2O (wt\%) & 4.65 & 1.69 & 5.12 & 4.78 & 6.52 & 5.05 & 5.05 & 5.01 & 3.98 & 6.37 & 3.4 & 2.97 & 5.34 & 5.64 \\
\hline $\mathrm{Na}_{2} \mathrm{O}(w t \%)$ & 4.06 & 4.31 & 4.54 & 3.54 & 4.46 & 3.61 & 3.61 & 3.8 & 4.68 & 3.89 & 4.09 & 3.87 & 3.09 & 4.02 \\
\hline $\mathrm{FeO}(w t \%)$ & 2.41 & 3.78 & 2.63 & 2.7 & 2.69 & 2.66 & 2.66 & 2.79 & 2.74 & 2.44 & 2.22 & 2.8 & 2.07 & 2.46 \\
\hline $\mathrm{Fe}_{2} \mathrm{O}_{3}(\mathrm{wt} \%)$ & 3.93 & 5.46 & 4.76 & 4.08 & 4.7 & 4.27 & 4.27 & 4.53 & 4.22 & 3.08 & 3.43 & 3.84 & 3.16 & 3.24 \\
\hline MgO (wt\%) & 0.97 & 1.27 & 1.64 & 1.32 & 1.58 & 1.29 & 1.29 & 1.15 & 1.2 & 0.68 & 0.91 & 1.35 & 0.93 & 1.21 \\
\hline MnO (wt\%) & 0.07 & 0.1 & 0.1 & 0.05 & 0.08 & 0.07 & 0.07 & 0.07 & 0.1 & 0.04 & 0.1 & 0.07 & 0.05 & 0.07 \\
\hline $\mathrm{TiO}_{2}$ (wt\%) & 0.63 & 0.49 & 0.77 & 0.82 & 0.83 & 0.8 & 0.8 & 0.85 & 0.64 & 0.76 & 0.41 & 0.52 & 0.46 & 0.56 \\
\hline $\mathrm{P}_{2} \mathrm{O}_{5}(\mathrm{wt} \%)$ & 0.18 & 0.14 & 0.21 & 0.27 & 0.39 & 0.33 & 0.33 & 0.28 & 0.22 & 0.19 & 0.18 & 0.14 & 0.15 & 0.19 \\
\hline LOI & 0.07 & 0.21 & 0.4 & 0.67 & 0.4 & 0.54 & 0.54 & 0.21 & 0.36 & 0.68 & 0.4 & 0.36 & 0.31 & 0.45 \\
\hline Sum & 97.2 & 97.91 & 102.44 & 97.69 & 104.09 & 99.67 & 99.67 & 99.6 & 101.48 & 102.89 & 98.63 & 98.03 & 97.08 & 101.85 \\
\hline Ba (ppm) & 1968 & 438 & 1001 & 1033 & 2027 & 1342 & 1342 & 1343 & 911 & 1016 & 702 & 1025 & 841 & 1154 \\
\hline Be (ppm) & 3 & 1.3 & 2.5 & 1.3 & 2.8 & 3.4 & 3.4 & 1.2 & 5.5 & 6.5 & 4.9 & 1.5 & 2.8 & 4.6 \\
\hline Cs (ppm) & 1 & 1.93 & 1.4 & 1.83 & 2.59 & 1.07 & 1.07 & 1.39 & 5.04 & 5.5 & 5.86 & 2.87 & 1.57 & 3.73 \\
\hline Ga (ppm) & 20.3 & 18.6 & 23.4 & 20.2 & 20.7 & 23.8 & 23.8 & 22.8 & 23.2 & 30.7 & 22.1 & 25 & 23.4 & 25.5 \\
\hline Hf (ppm) & 7.01 & 2.5 & 4.58 & 9.69 & 8.35 & 6.88 & 6.88 & 11.06 & 4.97 & 5.14 & 2.68 & 3.44 & 4.75 & 3.75 \\
\hline $\mathrm{Nb}$ (ppm) & 8.34 & 6.44 & 9.05 & 4.74 & 8.01 & 4.34 & 4.34 & 9.98 & 10.24 & 19.76 & 4.53 & 6.9 & 9.75 & 15.94 \\
\hline Rb (ppm) & 129.8 & 85.2 & 95.9 & 128.7 & 167.2 & 151.8 & 151.8 & 172.8 & 137.3 & 266.2 & 101.5 & 103.5 & 208.1 & 158.6 \\
\hline Sn (ppm) & 3.9 & 3.7 & 2.3 & 3.6 & 3.8 & 3.5 & 3.5 & 2.8 & 1.4 & 2.5 & 1.8 & 0.3 & 1.7 & 4.8 \\
\hline $\mathrm{Sr}(\mathrm{ppm})$ & 735.2 & 231.9 & 501.5 & 435.8 & 579.8 & 463.4 & 463.4 & 489.5 & 423.2 & 684.1 & 245.2 & 682.8 & 383.3 & 505 \\
\hline Ta (ppm) & 0.05 & 0.07 & 0.5 & 0.05 & 0.71 & 0.05 & 0.05 & 1.43 & 1.5 & 2.1 & 1.6 & 0.11 & 0.05 & 2.81 \\
\hline Th (ppm) & 7.5 & 1.6 & 8.6 & 5.1 & 7.2 & 17 & 17 & 10.8 & 21.8 & 10.7 & 0.5 & 7.3 & 25.6 & 10.1 \\
\hline$U$ (ppm) & 1.21 & 0.89 & 0.61 & 0.75 & 3.87 & 1.3 & 1.3 & 1.53 & 3.13 & 5.07 & 0.96 & 0.79 & 2.01 & 1.57 \\
\hline W (ppm) & 0.1 & 0.1 & 0.1 & 0.1 & 0.1 & 0.1 & 0.1 & 0.1 & 0.5 & 0.2 & 0.1 & 0.1 & 0.1 & 1.5 \\
\hline$Y(p p m)$ & 16.61 & 21.33 & 15.13 & 12.47 & 18.54 & 19.66 & 19.66 & 30.01 & 15.27 & 9.18 & 9.65 & 5.67 & 15.59 & 21.84 \\
\hline $\mathrm{Zr}(\mathrm{ppm})$ & 246.4 & 76.9 & 237.1 & 365.2 & 276.7 & 284.4 & 284.4 & 424.9 & 305.9 & 281.1 & 134.9 & 133.3 & 163.4 & 163.4 \\
\hline Co (ppm) & 5.6 & 7.3 & 8.9 & 8.9 & 8.8 & 8.4 & 8.4 & 7.7 & 6.8 & 5.5 & 6.8 & 12 & 6.3 & 9.1 \\
\hline $\mathrm{Cr}(\mathrm{ppm})$ & 10 & 5 & 20 & 19 & 16 & 17 & 17 & 14 & 14 & 6 & 5 & 27 & 30 & 39 \\
\hline Cs (ppm) & 0.85 & 1.84 & 1.42 & 1.48 & 2.66 & 1.09 & 1.09 & 1.28 & 5.66 & 5.09 & 6.22 & 3.18 & 1.26 & 3.7 \\
\hline $\mathrm{Cu}(\mathrm{ppm})$ & 5 & 3.7 & 5.6 & 2.9 & 4.9 & 10.3 & 10.3 & 15.2 & 2.3 & 5.6 & 4.9 & 94.6 & 4.8 & 6.1 \\
\hline $\mathrm{Ga}(\mathrm{ppm})$ & 5.3 & 6.1 & 6.7 & 8.7 & 8.7 & 8.4 & 8.4 & 7.8 & 6.6 & 8.1 & 5.3 & 8.5 & 5.5 & 7.5 \\
\hline Hf (ppm) & 0.16 & 0.12 & 0.14 & 0.11 & 0.3 & 0.2 & 0.2 & 0.23 & 0.23 & 0.2 & 0.06 & 0.1 & 0.24 & 0.12 \\
\hline La (ppm) & 67 & 6.6 & 43.2 & 65.3 & 60 & 95.3 & 95.3 & 58.2 & 43.1 & 64.3 & 6.1 & 57.2 & 69.1 & 48.3 \\
\hline Li (ppm) & 23 & 29 & 18 & 20 & 28 & 21 & 21 & 30 & 26 & 35 & 48 & 31 & 17 & 34 \\
\hline Nb (ppm) & 1.21 & 0.34 & 0.55 & 0.59 & 0.93 & 0.87 & 0.87 & 1.75 & 1.14 & 1.83 & 0.27 & 0.58 & 1.13 & 1.07 \\
\hline $\mathrm{Ni}(\mathrm{ppm})$ & 5 & 1.8 & 12.9 & 13.1 & 9.1 & 8.9 & 8.9 & 7.3 & 10.2 & 3.7 & 3.1 & 22.5 & 13.1 & 20.6 \\
\hline $\mathrm{Pb}$ (ppm) & 3.9 & 1.8 & 1.8 & 3 & 6.8 & 4.9 & 4.9 & 4.4 & 2.6 & 5.3 & 1.6 & 1.8 & 3.3 & 2.7 \\
\hline Rb (ppm) & 56.1 & 94.5 & 73.2 & 70.6 & 113.2 & 91.1 & 91.1 & 108.8 & 112.9 & 151.9 & 81.4 & 112.3 & 98.3 & 105.7 \\
\hline Sc (ppm) & 2 & 7.3 & 4.1 & 5.6 & 5.9 & 6.4 & 6.4 & 4.6 & 4.5 & 1.7 & 4.6 & 2.8 & 3.5 & 2.6 \\
\hline Sn (ppm) & 1.6 & 1.3 & 2.2 & 1.9 & 2.1 & 1.7 & 1.7 & 2.3 & 3.6 & 2.1 & 3.4 & 1.2 & 2.1 & 1.7 \\
\hline $\mathrm{Sr}$ (ppm) & 23.2 & 8.8 & 22.6 & 19.8 & 30.5 & 29.5 & 29.5 & 28.2 & 18.9 & 28.3 & 10 & 52.1 & 31.3 & 24.7 \\
\hline Th (ppm) & 17.2 & 2.5 & 13.7 & 13.3 & 15.6 & 28.7 & 28.7 & 18.3 & 40.1 & 23.1 & 1.6 & 13.7 & 44.3 & 13.9 \\
\hline$U(p$ & 0.58 & 0.6 & 0.22 & 0.21 & 2.75 & 0.56 & 0.56 & 0.57 & 2.49 & 2.78 & 0.73 & 0.38 & 1.09 & 0.9 \\
\hline$V(p p m)$ & 35 & 42 & 44 & 41 & 51 & 52 & 52 & 48 & 32 & 7 & 29 & 48 & 27 & 31 \\
\hline$Y(p p m)$ & 9.81 & 15.13 & 11.06 & 11.23 & 12.34 & 10.27 & 10.27 & 16.39 & 15.35 & 4.9 & 7.98 & 6.02 & 10.72 & 13.66 \\
\hline $\mathrm{Zn}(\mathrm{ppm})$ & 48 & 51 & 47 & 57 & 66 & 63 & 63 & 68 & 41 & 81 & 43 & 53 & 33 & 48 \\
\hline $\mathrm{Zr}$ (ppm) & 4.2 & 0.8 & 4.7 & 2.4 & 5.8 & 4.4 & 4.4 & 3.7 & 8.5 & 5.3 & 1.2 & 3.7 & 6.9 & 3 \\
\hline $\mathrm{Ce}(\mathrm{ppm})$ & 138.7 & 22.7 & 85.5 & 169.8 & 171.5 & 275.2 & 275.2 & 177.1 & 69.3 & 99.3 & 9.9 & 87.5 & 102.6 & 78 \\
\hline Dy (ppm) & 4.06 & 3.96 & 3.03 & 3.47 & 5.99 & 4.8 & 4.8 & 7.16 & 2.98 & 2.19 & 2.11 & 1.15 & 2.92 & 3.77 \\
\hline $\mathrm{Er}(\mathrm{ppm})$ & 2.15 & 2.92 & 1.59 & 0.99 & 2.18 & 1.92 & 1.92 & 3.7 & 1.53 & 0.85 & 0.93 & 0.43 & 1.33 & 2.11 \\
\hline Eu (ppm) & 1.49 & 0.95 & 1.02 & 1.4 & 2.09 & 1.78 & 1.78 & 1.87 & 0.99 & 1.23 & 0.72 & 0.98 & 1.01 & 1.22 \\
\hline Gd (ppm) & 5.69 & 3.37 & 3.89 & 6.15 & 6.38 & 6.72 & 6.72 & 8.96 & 3.38 & 4.03 & 1.96 & 2.21 & 3.88 & 4.1 \\
\hline Ho (ppm) & 0.57 & 0.88 & 0.51 & 0.53 & 0.9 & 0.87 & 0.87 & 1.23 & 0.52 & 0.28 & 0.35 & 0.19 & 0.41 & 0.75 \\
\hline La (ppm) & 85.5 & 13 & 43.9 & 89.4 & 88 & 152.4 & 152.4 & 84.3 & 36.9 & 56.9 & 5.5 & 47.2 & 62.3 & 49.5 \\
\hline Lu (ppm) & 0.44 & 0.64 & 0.31 & 0.26 & 0.32 & 0.22 & 0.22 & 0.68 & 0.31 & 0.07 & 0.07 & 0.05 & 0.25 & 0.33 \\
\hline Nd (ppm) & 56.7 & 13.1 & 31.5 & 73.2 & 82.9 & 94.1 & 94.1 & 84.6 & 25.8 & 38.2 & 5.3 & 28.6 & 34.1 & 28 \\
\hline $\operatorname{Pr}(p p m)$ & 15.9 & 2.92 & 8.79 & 19.51 & 21.06 & 30.1 & 30.1 & 22.21 & 6.95 & 10.55 & 1.08 & 8.39 & 10.36 & 8.19 \\
\hline Sm (ppm) & 8.4 & 3.6 & 5.3 & 10 & 10.1 & 12.7 & 12.7 & 13.3 & 4.8 & 6.1 & 1.4 & 3.6 & 5.6 & 4.9 \\
\hline Tb (ppm) & 0.63 & 0.53 & 0.59 & 0.51 & 0.84 & 0.67 & 0.67 & 1.19 & 0.52 & 0.49 & 0.28 & 0.26 & 0.51 & 0.65 \\
\hline $\operatorname{Tm}(p p m)$ & 0.17 & 0.4 & 0.17 & 0.12 & 0.28 & 0.22 & 0.22 & 0.46 & 0.19 & 0.13 & 0.13 & 0.06 & 0.19 & 0.27 \\
\hline Yb (ppm) & 1.6 & 2.7 & 1.3 & 1 & 2.2 & 1.6 & 1.6 & 3.3 & 1.5 & 0.5 & 0.9 & 0.4 & 1.3 & 1.8 \\
\hline $\mathrm{Eu} / \mathrm{Eu}^{*}$ & 0.66 & 0.84 & 0.69 & 0.55 & 0.8 & 0.59 & 0.59 & 0.53 & 0.76 & 0.76 & 1.34 & 1.07 & 0.67 & 0.84 \\
\hline$(\mathrm{La} / \mathrm{Sm})_{\mathrm{n}}$ & 5.58 & 1.98 & 4.54 & 4.9 & 4.78 & 6.58 & 6.58 & 3.48 & 4.22 & 5.12 & 2.15 & 7.19 & 6.1 & 5.54 \\
\hline$(\mathrm{La} / \mathrm{Yb})_{\mathrm{n}}$ & 32.39 & 2.92 & 20.47 & 54.18 & 24.24 & 57.73 & 57.73 & 15.48 & 14.91 & 68.97 & 3.7 & 71.52 & 29.04 & 16.67 \\
\hline$(\mathrm{Tb} / \mathrm{Yb})_{\mathrm{n}}$ & 1.68 & 0.84 & 1.93 & 2.17 & 1.62 & 1.78 & 1.78 & 1.53 & 1.48 & 4.17 & 1.32 & 2.77 & 1.67 & 1.54 \\
\hline Tot REE & 322 & 71.67 & 187.4 & 376.34 & 394.74 & 583.3 & 583.3 & 410.06 & 155.67 & 220.82 & 30.63 & 181.02 & 226.76 & 183.59 \\
\hline ASI & 0.97 & 1.02 & 0.89 & 0.99 & 0.84 & 0.94 & 0.94 & 0.98 & 0.95 & 0.92 & 1.01 & 1.03 & 0.96 & 0.97 \\
\hline
\end{tabular}

